MARÍA JOSÉ CALVO SAN JOSÉ

\title{
LA FUNCIÓN SOCIAL DE LA PROPIEDAD Y SU PROYECCIÓN EN EL SISTEMA DE COMPENSACIÓN URBANÍSTICA
}

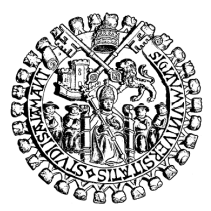

EDICIONES UNIVERSIDAD DE SALAMANCA 


\title{
COLECCIÓN VITOR
}

\author{
58
}

c

Ediciones Universidad de Salamanca

María José Calvo San José

$1^{a}$ edición: Noviembre, 2000

I.S.B.N. : $84-7800-904-3$

Depósito Legal : S. 1368 - 2000

Ediciones Universidad de Salamanca

Apartado postal 325

E - 37080 Salamanca (España )

Impreso en España - Printed in Spain

Realizacion:

Nematica, S.L.

Todos los derechos reservados. Ni la totalidad ni parte de este libro puede reproducirse ni transmitirse sin permiso escrito de

Ediciones Universidad de Salamanca

$\kappa$

CEP. Servicio de Bibliotecas

CALVO SAN JOSÉ, María José

La función social de la propiedad y su proyección en el sistema de compensación urbanística [Archivo de ordenador] / María José Calvo San José.

$--1^{\text {a }}$ ed.--Salamanca : Ediciones Universidad de Salamanca, 2000

1 disco compacto.-- (Colección Vítor ; 58)

Tesis-Universidad de Salamanca, 1997

1. Propiedad- Derecho- Historia. 2. Propiedad- Aspecto social

3. Propiedad- Derecho- España. 4. Urbanismo- Derecho- España.

5.Universidad de Salamanca (España)- Tesis y disertaciones académicas.

$347.23(043.2)$ 


\section{RESUMEN}

La problemática abordada por el presente trabajo gira, básicamente, en torno a la noción de propiedad, planteada desde la perspectiva jurídica del derecho Civil, en el ámbito del urbanismo. En él se analiza una nueva etapa del derecho de propiedad, dominada por el elemento social, tratando de demostrar a través del análisis de diferentes leyes especiales (si bien poniendo especial énfasis en la Ley del Suelo), la profunda transformación que la propiedad privada ha experimentado.

El propietario va a ir adquiriendo las distintas y escalonadas facultades que integran el derecho de la propiedad urbana, siempre que cumpla con los correlativos deberes inherentes a cada una de las fases de adquisición de aquéllas.

El contenido esencial del derecho de propiedad del suelo es un límite a la regulación legal de este derecho impuesto por la Constitución. Este contenido esencial está compuesto por todas las facultades potenciales de goce (cultivar, cazar, edificar, etc.) facultades que son anteriores a la Ley e inherentes a la propiedad del suelo. El contenido esencial es delimitado según la Constitución por la función social de la propiedad que se traduce en la imposición de límites generales y de deberes o cargas para el ejercicio de determinadas facultades.

En este sentido, contenido esencial y contenido del derecho de propiedad no coinciden. El primero es un límite constitucional a respetar por el legislador estatal y por el autonómico, que deben tener en cuenta también y de manera primordial que en el contenido esencial se asienta la función social de la propiedad.

Dando un paso más, nos centramos especialmente en el estudio de la función social de la propiedad y su incidencia en el sistema de compensación urbanística, como sistema de ejecución privada en el que la distribución equitativa de las cargas y beneficios del planeamiento se lleva a sus últimas consecuencia. $Y$ es este equilibrio entre cargas y beneficios el que va a resolver la integración del binomio derecho de propiedad y función social.

Así pues, se aborda por un lado el estudio de la función social, y por otro el del sistema de compensación, tratando de analizar la proyección que ha tenido aquélla en el mencionado sistema de ejecución privada, con el consiguiente análisis de su evolución histórica. 
Ha de decirse al respecto, que lo que legitima el estudio (desde el punto de vista civil) de la configuración del sistema de compensación como límite del derecho de propiedad, es la amplitud de su ámbito civil precisamente, ya que, a parte de incidir en la propiedad, se asienta en conceptos de naturaleza civil como son: adjudicación, transmisión, carácter fiduciario, poder de disposición, aportación, subrogación etc. ; sin dejar de ser conscientes de que en todo caso existe una importante carga de Derecho Administrativo o en general de Derecho Público en esta materia. Lo que pone de manifiesto, que ante la indiferencia, en muchas ocasiones, de los civilistas, se ha ido produciendo una invasión del derecho público en instituciones de marcado carácter civil, como es el caso que nos ocupa.

La particularidad de este sistema radica en el protagonismo de la gestión urbanística, que no es administrativa sino privada, atribuyendo al propietario una función conferida a los poderes públicos, confiando en él su ejecución, su gestión, si bien no en solitario, siendo, el sistema, un exponente más de la primacía del interés general sobre el particular, y de la idea de control y equilibrio que persigue la concreción de esa función social de un Derecho privado. Todo ello se traduce en una intervención pública en la propiedad privada, delimitando el contenido normal del derecho de propiedad, donde el término compensación es utilizado en el sentido de igualar las cargas con los beneficios derivados del planeamiento. Para que el reparto equitativo de beneficios y cargas sea proporcional a los terrenos aportados para el bien común, la comunidad de propietarios se constituye en Junta de Compensación.

En consecuencia, otro apartado importante al que era necesario dedicar nuestra atención es el que se refiere a los aspectos civiles de la Junta de compensación, ya que en ellas están implicadas diversas instituciones de indiscutible naturaleza civil, como son: las aportaciones de los terrenos, las adjudicaciones de los mismos, la expedición de títulos de propiedad a los adjudicatarios que adquieren las parcelas resultantes etc., así como la problemática suscitada en orden: a la existencia o no del instituto de la transmisión, o el de la subrogación, o el poder fiduciario de la Junta o el poder de disposición de ésta o el de los propietarios, o si la Junta es un representante o un servidor de la posesión, entre otras figuras de indudable carácter civil.

En líneas generales, estos han sido los aspectos, que nos han parecido más relevantes desde el punto de vista del derecho civil. 


\section{ABSTRACT}

The set of problems approached in this piece of work, deal basically with the notion of property, posed from the juridical perspective of Civil Law, on a Town-planning basis.

In it, a new stage in propietorship is analyzed which is sominated by the social element. By means of the analysis of different special Laws (i.e. Law of Urban Land, Law of Agrarian Amendment and Development, Law of Costs, etc...), but laying special emphasis on the Urban Land Law, it tries to provide an insight into the deep transformation which private property has experienced.

The property owner will acquire the different and progressive faculties which make up the right to urban property, provided the property owner observers the correlative duties inherent in each one of the phases of the acquisition of them.

The new Urban Land law develops the régime of property through the mechanism of the social functin, stating that intention of conditioning the faculties which derive from the right of property to the property owner, thus complementing that which is established in sectgion 33.2 of the E.C..

The essential content of the right to land property is a limit to the legal regulation of this right imposed by the Constitution. This essential content is made up of all the potential faculties of possession (i.e. cultivating, hunting, building, etc.), all of which are prior to the Law and inherent to property of land. The essential content is delimited, according to the Constitution by the social function of the property which results in the imposition of general limits and of requirements or encumbrances for the practise of determinate faculties.

In this sense, the essential content and the content of propietorship do not coincide. The former is a constitutional limit, which is to be regarded by both the state and the autonomy law-maker. They must also take into account, and make it their fundamental concern that this essetial content is the basis for the social function of property.

On the other hand, we must also point up that the new Land law controls the social function of urban property, through the setting-up of charges, duties, restraints, assessments, rights and faculties which the property owner is charged with their accomplishment and practise in the legal established form, constitute and make the social function of urban property effective.

Moving one step forward, we specially focus on the study of the social function of property and its effect on the compensation system urban development, as a system of private application in which the equitable distribution of charges and benefits of the posing is taken to its last consequences. And it is this balance between charges and benefits the one which is to solve the integration of the binomial - right to property and social function.

Therefore, we approach the study of social function on the one hand, and the system of compensation on the other hand, trying to analyze the proyection which it has had in the previously mentioned system of private performance with the consequent analysis of its historical evolution.

With regard to the subject, we must add that which legitimates the study (from a civil point of view) of the configuration of the compensation system as a limit to the right of 
property, is precisely the extent within the Civil scape as, apart from having an incidence in property, it is based on comcepts of Civil nature as: adjudication, transmission, power of disposition, contribution, subrogation etc., bearing in mind that in any case there is an important of Administrative Law or Public Law in general in this issue.

This clearly points out that, given the indifference, in many cases of Civil Lawyers, an encroachment on public rights in institutions which have a marked civil character, he's taken place, as in this particular case.

The special feature of this system is the leading role of urban management, which is not administrative but private, thus attributing to the owner a function bestoned on public authorities, entrusting its application and management to him, although not unaided, being the system one more exponent of the priority of general interest over particular one, and the idea of control and equilibrum which aims at the concretion of that social function of a Private Law. All this results in public intervention in private property, delimiting the normal content of the right of property, where the term compensation is used in its sense of equalizing charges and benefits derived from the approach or int the terms of section 3.1.b. from T.R. 92, its purpose is to avoid the unequal function of benefits and charges in the approach among the owners afected by urban management, so that the equal share of benefits and charges is proportional to the Land contriguted for common well-being, the owners' association establishes itself as a Compensation Board.

Consequently, another important aspect to which it was necessary to pay our attention is the one which refers to Civil aspects of the Compensation Board, as in them several institutions of undeniable civil nature are implicated, such as are: the contribution of land, their alloment, the issue of full legal ownership for the adjudicatee who purchase the resultant land, etc., as the problems arising from: the existence or non-existence of the regulation of transmission, or of the subrogation, or of the power of the Board or the power of its regulation or of that of the owners, or if the board acts as a representant or at the service of the property, among other things of an undoubtable civil character.

In general terms, these have been the issues which we have considered more relevat from a civil law point of view. 


\section{Capítulo Primero}

Análisis de la Propiedad Quiritaria y su carácter absoluto

Capítulo Segundo

Limitaciones de la Propiedad Quiritaria en el Derecho Común.

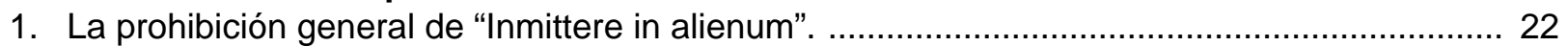

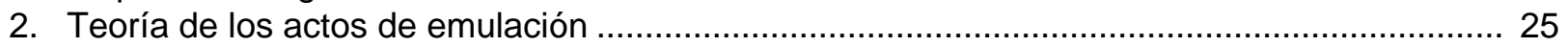

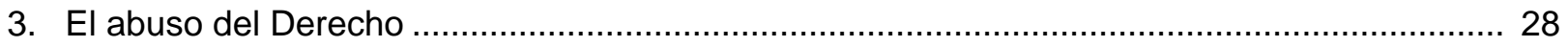

4. Propiedad función: Propuesta de Duguit .............................................................................. 36

5. La doctrina de la iglesia. Otras manifestaciones ............................................................. 43

\section{Capítulo Tercero}

La propiedad privada en la Codificación francesa: Antecedentes e influencia ejercitada ... 47

\section{Capítulo Cuarto}

La propiedad y sus límites en el Código Civil español......................................................... 59

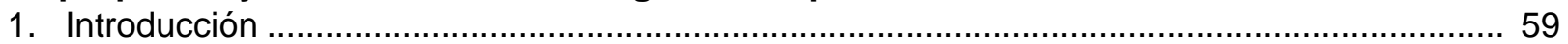

2. Antecedentes históricos que han influido en la formación del concepto de dominio................ 63

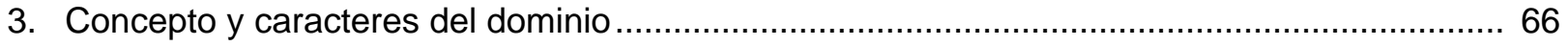

3.1 La valoración del dominio como poder general, abstracto y elástico................................ 71

3.2 Caracterización Jurisprudencial del dominio ................................................................ 74

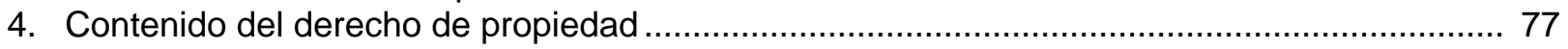

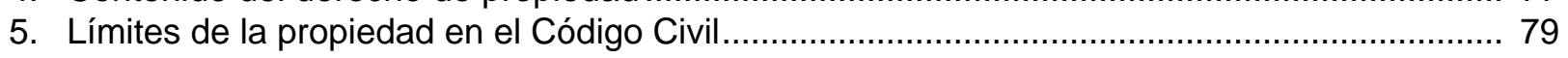

5.1. Concepto de límites y limitaciones ............................................................................. 82

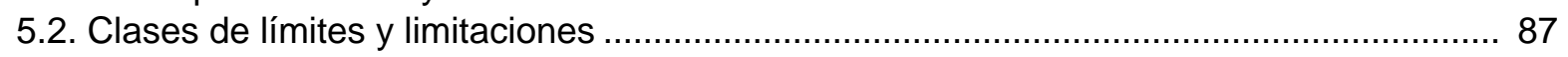

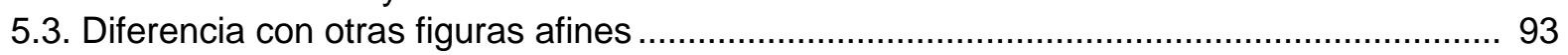

6. Limitación y expropiación del derecho de propiedad........................................................... 103

\section{Capítulo Quinto}

La función social de la propiedad. Su consagración en la Constitución Española de 1978111

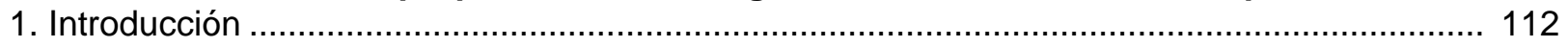

2. El "Derecho a la propiedad". Reconocimiento constitucional ............................................... 113

2.1. Discutible carácter de Derecho fundamental de la propiedad ...................................... 117

3. Significado y alcance de la función social de la propiedad .................................................... 120

3.1. El carácter objetivo de la función social de la propiedad............................................ 127

3.2. Incidencia de la función social en el concepto y contenido del derecho de propiedad..... 135

\section{Capítulo Sexto}

La propiedad urbanística: Su función social

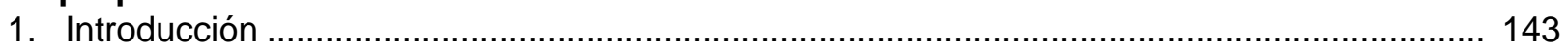

2. La propiedad urbanística ............................................................................................... 146

3. El concepto de plan y su incidencia en el Derecho de propiedad ........................................ 154

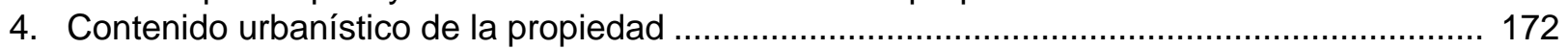


4.1. Contenido urbanístico de la propiedad en las Leyes Autonómicas

4.1.1. Los deberes de los propietarios de suelo urbano en la legislación de las Comunidades Autónomas

4.1.2. Derechos de propietarios de suelo urbanizable en las Comunidades Autónomas.

4.1.3. Los deberes de los propietarios de suelo urbanizable en las diferentes Comunidades Autónomas

\section{Capítulo Séptimo}

La Gestión Urbanística: Urbanización y ejecución

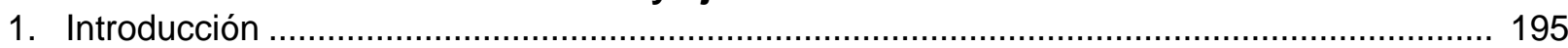

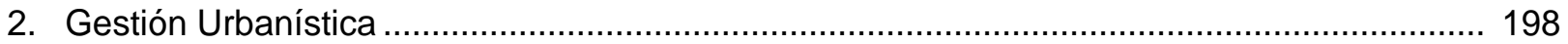

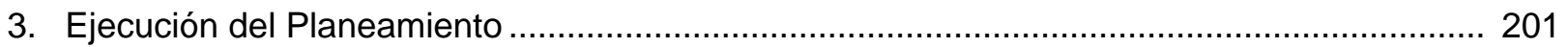

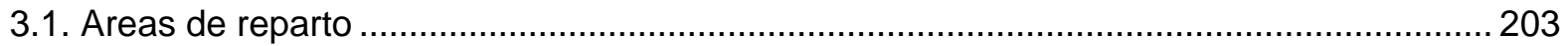

3.2. La unidad de ejecución: Concepto, procedimiento y requisitos .................................... 206

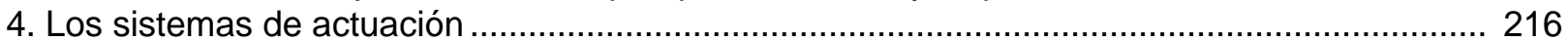

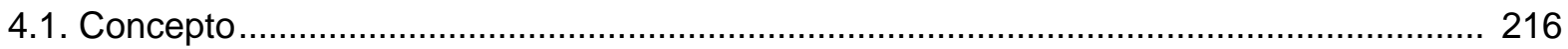

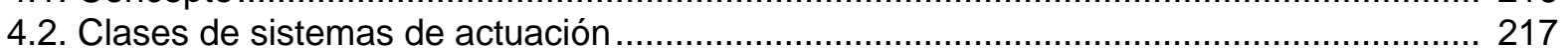

4.3. Elección del sistema de actuación urbanística ............................................................... 219

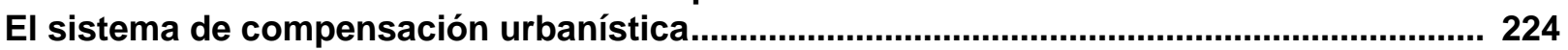

Capítulo Octavo

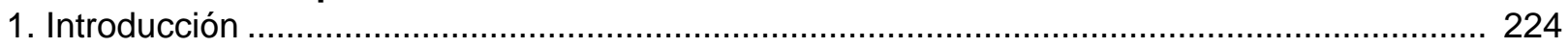

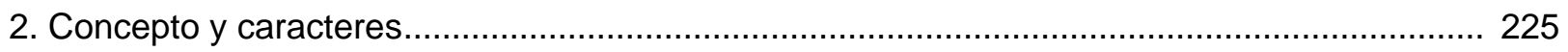

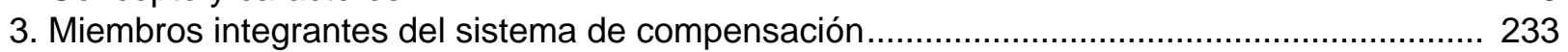

3.1. Los propietarios de terrenos que hayan aceptado el sistema ...................................... 234

3.2. Los propietarios de suelo destinado a sistemas generales .......................................... 236

3.3. Las entidades públicas como titulares de bienes incluidos en la unidad de ejecución..... 238

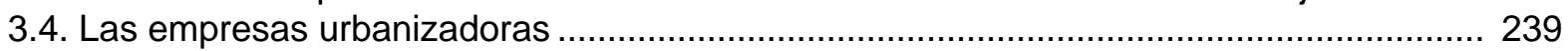

4. Contenido del sistema de compensación: las cargas y derechos de los propietarios............. 241

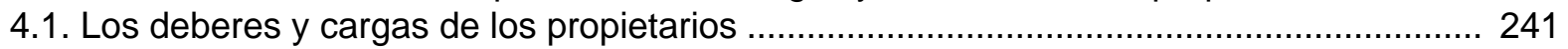

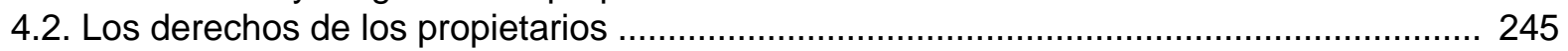

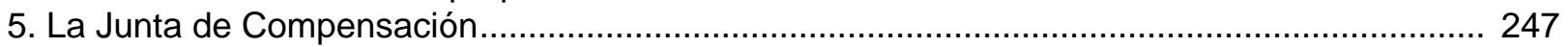

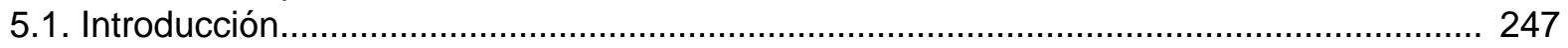

5.2. Naturaleza jurídica de la Junta de Compensación ...................................................... 249

5.3. Derecho a formar parte de la Junta de Compensación ................................................ 256

5.4. Constitución de la Junta de Compensación..................................................................... 263

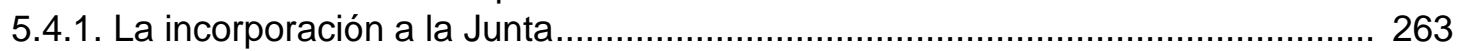

5.4.2. Procedimiento de constitución de la Junta.................................................... 264

5.5. Organos rectores de la Junta de Compensación.......................................................... 270

5.6. Responsabilidad de la Junta de Compensación .......................................................... 271

5.7. Responsabilidad de los miembros de la Junta de compensación..................................... 275

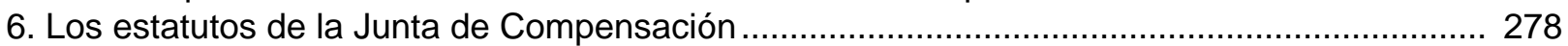

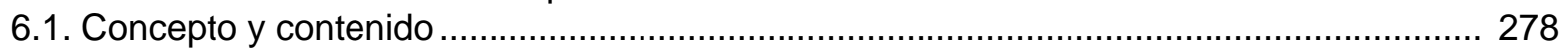

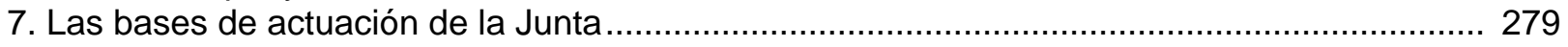

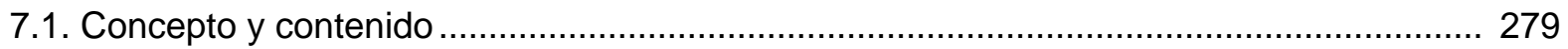

\section{Capítulo noveno}

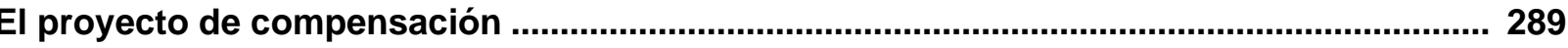

1. Concepto y naturaleza del proyecto de compensación........................................................ 289

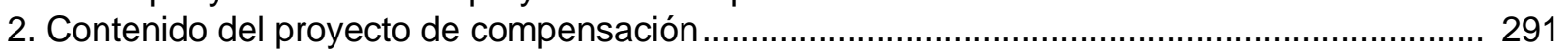

3. Tramitación y aprobación del proyecto de compensación .................................................... 293

4. Efectos de la aprobación definitiva del proyecto de compensación.......................................... 299

4.1. Efectos jurídico-económicos: Cesiones obligatorias y gratuitas de suelo.......................... 301 
4.2. Efectos de carácter jurídico-registral: Inscripción del proyecto de compensación en el registro de la propiedad y en el libro registro del Ayuntamiento

\section{Capítulo Décimo}

El poder de disposición como mecanismo de actuación de la Junta .................................. 319

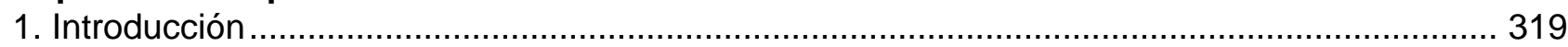

2. Negocio fiduciario: La superación de la teoría del doble efecto ......................................... 323

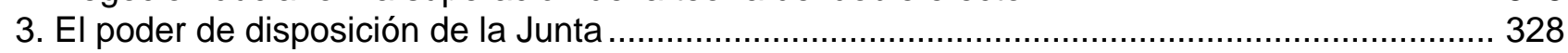

3.1. Concepto de poder de disposición............................................................................... 328

4. Alcance de facultades que integran el poder de disposición de la Junta de Compensación.... 331

5. La actuación de la Junta de Compensación como "fiduciaria................................................... 336

6. Transmisión de la propiedad de las fincas a la Junta ............................................................. 340

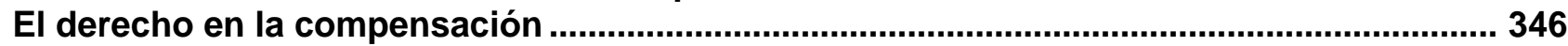

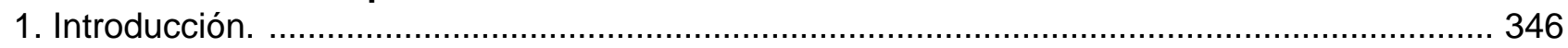

2. Contenido del derecho en la compensación. ....................................................................... 348

3. Inscripción en el Registro del derecho en la compensación .................................................. 349

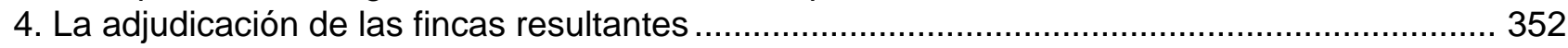

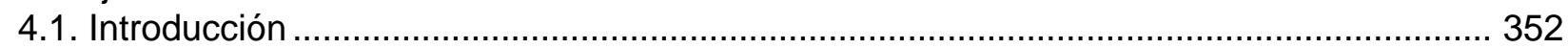

4.2. Sujetos adjudicatarios de las fincas resultantes......................................................... 353

4.3. Adjudicación de las fincas resultantes a los propietarios de fincas incluidas en la unidad

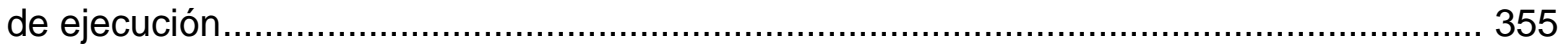

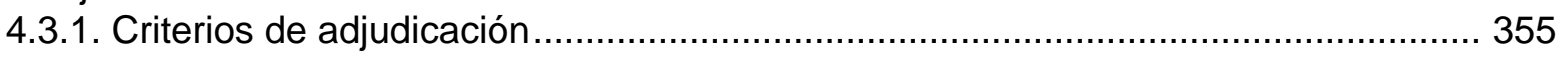

4.4. Efectos del acuerdo aprobatorio de compensación ....................................................... 358

4.4.1. La subrogación real como institución de Derecho Civil y su conexión con el sistema de compensación urbanística

4.4.2. Efectos de la aprobación definitiva del proyecto de compensación respecto de las situaciones jurídicas de carácter real....

4.4.3. La afección real de las fincas de resultado al cumplimiento de las cargas y pago de los gastos

4.4.4. Diferencia y afinidades de la garantía real con otras figuras jurídicas .................... 373

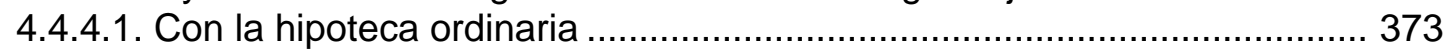

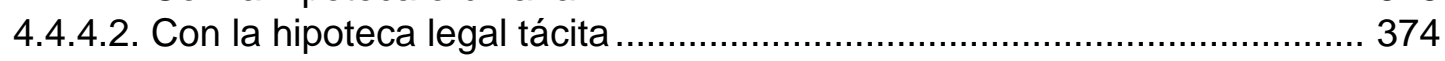

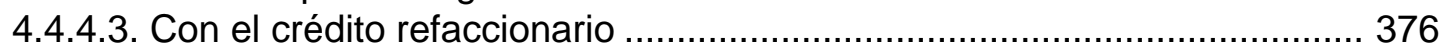

4.4.5. La preferencia de la garantía y la alteración del rango hipotecario ......................... 377

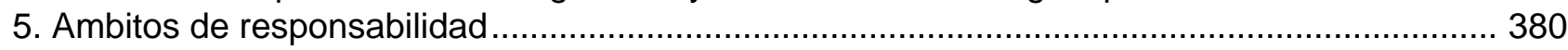

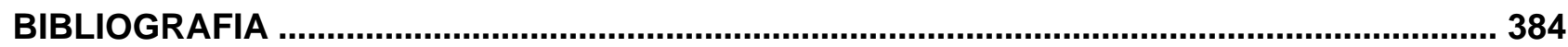


A mi padre

(In memoriam) 


\section{Prólogo}

Afrontar el espinoso tema de la propiedad inmobiliaria, en el tránsito hacia un nuevo milenio, ha sido el reto planteado a los juristas y al que hemos respondido con dispersión e irregularidad. El desmoronamiento de lo establecido, de los elaborados y tradicionales conceptos jurídicos vinculados a la idea de propiedad, ha provocado transformaciones de tal naturaleza que no siempre han venido acompañadas de un proceso de reflexión teórica suficiente para la superación de los antiguos dogmas

El legislador español de los últimos 30 años y, especialmente, de las dos décadas precedentes, ha proporcionado grandes quebraderos de cabeza para tratar de reconstruir, no sólo el nuevo régimen jurídico de la propiedad, sino incluso para intentar comprender los objetivos que provocaban dicho cambio.

Muchas de las alteraciones de derecho positivo venían a responder a auténticas necesidades surgidas en la práctica, e incluso consolidadas en ella, que no encontraban correspondencia en el acervo de normas dirigidas a tal fin ; en otros casos, el cambio político, la modificación de principios básicos inspiradores en un Estado concreto y, en general, en los Estados de nuestro entorno, de valorar como motor de cambio la exaltación del interés social prevaleciendo frente a egoístas intereses individuales de ámbito ilimitado y sin control en el disfrute de las facultades dominicales, como en el ejercicio de otro tipo de derecho patrimoniales, sentaba pautas de obligada mutación.

Con particular fuerza se manifiestan esos cambios en el contexto de la propiedad urbana. Y, a la par de la publicación de una emblemática Ley en el devenir de rápidas e incontroladas modificaciones legislativas, se asienta el inicio de la andadura investigadora de la Prof ${ }^{a}$ Calvo San José , autora de este trabajo. La Ley de reforma y valoraciones del suelo de 1990 supuso el reconocimiento directo de un modelo de estatuto de la propiedad urbana radicalmente alejada de la propiedad absoluta e individualista del pasado siglo, plasmada como institución emblemática de nuestro Código civil que ahora, a partir de breves cláusulas de remisión a la legislación especial, sufría un giro copernicano claramente apreciable en la aplicación e interpretación de preceptos formalmente inmodificados. Pocos datos hacían suponer a una recién licenciada, muy interesada por estos temas y, en particular, por el concepto constitucional de función social de la propiedad, que a nuestros ojos se prestaba a tomar forma un cambio de tal envergadura, más allá de aquellas conocidas construcciones que la vieron surgir en la dogmática jurídica y que, ahora, por impulso 
del legislador y acentuadas de la propia mano del intérprete por excelencia de la Constitución en nuestro Ordenamiento, trataban de ofrecer un modelo en transformación, lleno de contradicciones, "liderando" una renovación necesaria, aunque no siempre a través de las vías o por medio de los instrumentos más adecuados.

Iniciado un trabajo no exento de obstáculos y retos, y una vez alcanzados los primeros resultados, se delimita el objeto de su memoria de tesis doctoral que, en lo esencial, constituye el trabajo que ahora presentamos y que mereció la máxima calificación para un tribunal compuesto por los Profesores Dr. Mariano Alonso Pérez (Presidente), Dr. Carlos Maluquer de Motes, Drāe, Carmen Gómez Laplaza, Drạ̄ Ma José Herrero García, y Dr. Javier Hualde Sánchez. Así, el análisis de la compensación, uno de los sistemas de actuación urbanística, y principal método de actuación privada en ese ámbito, suscitaba en el marco del Derecho civil grandes cuestiones de índole teórico y práctico, en una materia de una doble complejidad al tener que situarla en el devenir de nuevos conceptos, y en la colisión de otros principios y derechos de naturaliza privatística junto con mecanismos de corte publicista y en el aparente "campo de nadie" del urbanismo y de la normativa de gestión urbanística.

No resultaba fácil desentrañar los problemas suscitados, y mucho menos cuando el cambio legislativo en la materia ha sido continuo. Los avatares de la Ley del suelo en nuestro país, de todos conocidos, han afectado a esta materia a lo largo de distintos textos y por impulso, primero del legislador, y más tarde del Tribunal Constitucional.

Como no podía ser menos, tan tortuosa historia ha incidido y dejado huella en el proceso de esta obra que, tratando de sistematizar y clarificar una larga y profusa evolución histórica de la propiedad inmobiliaria, busca situar en ese continuo proceso de transformaciones, con una doble y contrapuesta carga ideológica en las algunas de las más importantes modificaciones legislativas (Texto refundido de 26 de junio de 1992 y de 13 de abril de 1998), el desarrollo y conflictividad del sistema de compensación, atendiendo especialmente a la regulación general, pero poniendo de manifiesto la pluralidad normativa surgida en ciertos aspectos por mor del diseño autonómico de nuestro Estado y con causa inmediata en la STC de 20 de marzo de 1997 artífice del consiguiente caos que derivado del vacío legislativo que generó medidas excepcionales y de carácter provisional que sólo provocaron confusión en muchas comunidades autónomas y que sirvió de excusa en el ámbito estatal para auspiciar un nuevo giro en el modelo de propiedad urbana, en esta ocasión, de corte 
más liberal que social, por el que, manteniendo el viejo objetivo de contribuir a la disminución del precio del suelo y a reducir la especulación, antes al contrario, ofrece para su consecución una "inyección" de suelo urbanizable que en ningún caso ha supuesto reducción de precio y sí actuaciones de gestión incontrolada bajo una aparente vuelta a la defensa de un concepto de propiedad urbana pleno de contenido por lo que a los poderes del propietario se refiere. En una suerte de materialización de un desagravio hacia aquella otra actitud que en algunos momentos llegó a sonar drástica como el contundente interrogante de Cicerón en las Catilinarias: "¿juzgas que tus posesiones han de ser sacrosantas en medio de la devastación de todas?", el derecho a edificar, entre otros, deja en gran medida de formar parte del conjunto de facultades, ajenas al contenido natural del derecho, que el propietario del suelo estaba en condiciones de alcanzar sólo tras el cumplimiento de obligaciones y cargas derivadas de la función social de la propiedad, aunque ello no suponga un retorno radical al viejo sistema.

Si duro fue el camino de la investigación en razón del tema, el calendario de avatares legislativos han venido a complicarlo hasta el extremo obligando a una larga y continua revisión de la propia construcción hasta llegar a este momento en el que por la Prof ${ }^{a}$ Calvo se pone un punto y aparte en esta investigación. Rememorando nuevamente la obra clásica antes citada, creo escuchar un lamento de la autora: " $\mathrm{OOh}$ tiempos, oh costumbres!". La tarea fue dura, quizá más de lo que nunca pudo preverse, y el trabajo realizado ha de valorarse en esa prueba a la que nos han sometido los tiempos y...... en la comprensión y desarrollo de la moderna propiedad.

Maㅡ Jesús Moro Almaraz

Prof ${ }^{\mathrm{a}}$ Titular de Derecho Civil

Universidad de Salamanca 


\section{ABREVIATURAS}

ADC

AAMN

A.r

BOE

C.C

CCAA

CE

CCJC

CT

DA

DF

DT

DJ

DGRN

DL

DSC

LEF

LRJAPPAC

$\mathrm{LH}$

LRRU
Anuario de Derecho Civil.

Anales de la Academia Matritense del Notariado.

Repertorio de Jurisprudencia Aranzadi.

Boletín Oficial del Estado.

Código Civil.

Comunidades Autónomas.

Constitución Española.

Cuadernos Civitas de Jurisprudencia Civil.

Ciudad y Territorio.

Disposición Adicional.

Diposición Final.

Disposición Transitoria.

Documentación Jurídica.

Dirección General de los Registros y del Notariado.

Decreto Ley.

Diario de Sesiones de las Cortes.

Ley de Expropiación Forzosa de 16 diciembre 1954.

Ley 30/ 1992, de 26 noviembre, de régimen jurídico de las Administraciones públicas y de procedimiento administrativo común.

Ley Hipotecaria , Texto Refundido aprobado por Decreto de 8 de febrero de 1946

Ley de Reforma del régimen urbanístico y valoraciones del suelo $8 / 1990$, de 15 julio. 


$\begin{array}{ll}\text { PAU } & \begin{array}{l}\text { Programa de Actuación Urbanística } \\ \text { RDP }\end{array} \\ \text { RGLJ } & \text { Revista de Derecho Privado. } \\ \text { RCDI } & \text { Revista General de Legislación y Jurisprudencia. } \\ \text { RDN } & \text { Revista Crítica de Derecho Inmobiliario. } \\ \text { RDU } & \text { Revista de Derecho Urbanístico. } \\ \text { RPA } & \text { Revista de Administración Pública. } \\ \text { REDA } & \text { Revista Española de Derecho Administrativo. } \\ \text { REVL } & \text { Revista de Estudios de la Vida Local. } \\ \text { Riv.Trim.Dir.Proc.Civ. } & \text { Rivista Trimestrale di Diritto e Procedura Civile. } \\ \text { Riv.Dir.Civ. } & \text { Rivista di Diritto Civile. } \\ \text { RPU } & \text { Reglamento de Planeamiento Urbanístico } \\ \text { RGU } & \text { Reglamento de Gestión Urbanística } \\ \text { S.S } & \text { Siguientes. } \\ \text { STC } & \text { Sentencia del Tribunal Constitucional. } \\ \text { STS } & \text { Sentencia del Tribunal Supremo. } \\ \text { TC } & \text { Tribunal Constitucional. } \\ \text { TAU } & \text { Transferencias de Aprovechamiento Urbanístico. }\end{array}$




\section{CAPITULO PRIMERO}

\section{ANALISIS DE LA PROPIEDAD QUIRITARIA Y SU CARACTER ABSOLUTO.}

La concepción romana de la propiedad (dominium, condominium, debitum...) constituye un punto de partida imprescindible para comprender el sentido de la propiedad moderna ${ }^{1}$. No obstante, hay que tener en cuenta que la propiedad romana puede ser enjuiciada desde dos puntos de vista:

-Como señala Kaser², en primer lugar se podría contemplar la propiedad como fenómeno social, en este sentido se trataría de analizar su contenido, los vínculos y límites que sirvieron para acomodar la propiedad, a las exigencias y necesidades de los individuos a lo largo de las diversas épocas de la evolución de Roma.

Estas limitaciones que conformaron el concepto de propiedad, cambiaron y fueron adaptándose a la realidad social del momento, a las circunstancias históricas concretas de pueblos y épocas 3 .

\footnotetext{
1 Vid. LOBATO GOMEZ, Propiedad privada del suelo y derecho a edificar, Madrid, 1989,p. 32.

2 Cfr. KASER, M., "El concepto romano de la propiedad", AA MM, T. XVI, 1968, p. 6 y ss.

OURLIAC, P. y MALAFOSSE, J., Histoire du Droit privé. Paris, 1968-1971. Vol. II, Les Biens, 2e. ed. 1971, p. 18 y ss.

3 Como referencia a la configuración jurídica de la propiedad en el Derecho Romano puede verse entre otros: BRASSIELLO, V., La Propietá Nella Sua Esenza e Nella Sua Estensione, Milano, 1952; Propietá (Diritto romano), Novisimo Digento Italiano, XIV, Torino, 1957 p. 111 y ss.; BONFANTE, P., Corso di Diritto Romano, T. II, La Propietá, 1a parte, Milano, 1966, (reedición), p. 227 y ss.; CAPOGROSSI COLOGNESI, L., La struttura della propietá e la formazione del "iurapraediorum" nell etá repubblicana, Milano, vol. I, 1969, vol. II, 1974; BETTI, E., Instituzioni di diritto_romano, Padova, 1947, vol. I, p. 361 y ss.; MONIER, R., Manuel élèmentaire de droit romain, Paris, 1947 (6a. ed.), T. I, p. 354 y ss.; SCHULZ, F., Derecho romano clásico, Barcelona, 1960 (trad. esp.), p. 325 y ss.; OURLIAC, P., y MALAFOSSE, J., Derecho romano y Francés hisórico, T. II, Los bienes, Barcelona, 1963, (trad. esp.), p. 231 y ss. ; BIONDI, B., Instituzioni di diritto romano, Milano, 1972 (reimpresión de la 4a. ed.) p. 223 y ss.; ARIAS RAMOS, J., Derecho Romano, Madrid 1972 (12a. ed.) T. I, p. 221 y ss.; ARANGO RUIZ, V., Instituzioni di diritto romano, Napoli, 1974 (14 ed.) p. 180 y ss.; GAUDEMET, J., Le droit privé romain, París 1974, p. 71 y ss.; D'ORS, A., Derecho Privado Romano, Pamplona, 1974 (4a. ed.), p. 189 y ss.; FUENTESECA, P., Derecho Privado Romano, Madrid, 1978, p. 101 y ss.; GARCIA GARRIDO, J.M., Derecho Privado Romano, I. Instituciones, Madrid, 1979, p. 173 y ss.; GUARINO, A., Diritto privato romano, Napoli, 1981 (6a. ed.), p. 547 y ss.; IGLESIAS, J., Derecho Romano. Instituciones de Derecho Privado, Barcelona, 1982, (7a. ed.), p. 257 y ss.; asímismo vid. la Enciclopedia Giuridica Italiana, Vol. XIII Parte IV, p. 63 y ss.
} 
Pero al lado de este enfoque, la propiedad romana ofrece también un segundo aspecto mucho más útil para destacar las relaciones entre el antiguo Derecho romano y los ordenamientos jurídicos modernos. Esta faceta se refiere al concepto de la propiedad, es decir, a "la forma jurídica que se ha ido llenando de contenido social a lo largo de los tiempos"4. Se puede afirmar que la configuración del concepto jurídico de propiedad en los sistemas continentales del Derecho privado, es aún la romana. El concepto de propiedad de las modernas codificaciones se remonta, mediante la brillante aportación del ius commune, al Derecho romano justinianeo, que condensó el pensamiento de los grandes jurístas clásicos. Este concepto clásico de propiedad designa el señorio pleno de la persona sobre la cosa 5 .

Para el ordenamiento romano no importa tanto la actividad del propietario, como que el propietario puede disponer de cierta cosa exclusivamente, para lo cual se le concede un poder amplísimo que puede calificarse de ilimitado.

Desde este punto de vista se ha definido el dominium clásico como "el máximo derecho real o como la relación jurídica de pertenencia que confiere a la persona sobre la cosa, el señorio de contenido pleno y de carácter independiente por excelencia ${ }^{6}$. Esta subjetivación de la propiedad romana como derecho, ius, poder o señorio que pertenece plenamente a un sujeto ,dominium o, en la medida en que la cosa pertenece al individuo, iura in re aliena, implica el tránsito de la propiedad basada en la familia y en la autoridad originaria y absoluta del pater-familias, a un derecho del sujeto dominado por una finalidad económica propia7.

\footnotetext{
${ }^{4}$ KASER, M., "El concepto romano...", cit., p. 7.

5 IBIDEM, P. 8.; Instituciones de Justiniano, Libro II Título 4, IV, aparece definida como "plena in re potestas".

6 Cfr. BETTI, Instituzioni de Diritto romano, cit. p. 371. Vid. también las conocidas definiciones de BONFANTE, P., La propietá, I, cit., p. 241, "La propietá é la signoria piú generales, in atto o in poteza, sulla cosa"; y de BRASSIELLO, V., "Propietá (Diritto romano)", cit, p. 11 y ss. que define el dominio como "una signoria sulla cosa, esplincanteri in una serie di facoltá, potenzialmente illimitate. p. 112.

7 LONGO, G., Corso di Diritto Romano. I diritti reali, Padova, 1962, p. 28. ARCHI, G., "Il concetto della propietá nei diritti del mondo antico". Rvta. trimestale di Diritto e Procedura Civile, 1958, p. 1205 a 1208.
} 
A partir de aquí, el derecho de propiedad puede describirse como el más amplio y el único derecho real autónomo ${ }^{8}$ En esta concepción la "función pública" de la propiedad romana habría que plantearla como una relación entre el interés del propietario y el de la colectividad.

Por lo tanto, deberiamos decir que la propiedad romana no fue absoluta9 ${ }^{9}$, sino que teóricamente se concibió como absoluta e ilimitada, pues era el derecho real por excelencia (el señorio más amplio, como decía BONFANTE), las limitaciones aparecen en el Derecho romano justinianeo, y reaparecen en cada momento histórico durante la larga historia del Derecho común, tal como aún lo vemos en los estudios de los Pandectistas, reflejados muy bien en WINDSCHEID.

Esto nos pone de relieve que en la práctica había límites pero fueron límites externos, a diferencia de los actuales, como explicaremos oportunamente; pero la base del concepto de propiedad continuó siendo la misma hasta el final de la etapa antigua del Derecho romano.

A partir de la época tardo republicana en que aparece formado el concepto de dominio ex iure quiritium ${ }^{10}$, se produce un ensanchamiento y

\footnotetext{
8 LONGO CARLO, citado por LONGO G., en Corso di Diritto Romano..., cit., p. 31 a 32.

${ }^{9}$ ARCHI, G., II concetto della propietá..., cit., p. 1215. Rvta. trimestrale di Diritto e Procedeira Civile, señala al respecto que en el ámbito del sistema romano el instituto del dominium no mira a garantizar al titular del derecho la mayor suma de poderes sobre la cosa. Su función principal es la de resolver el problema de la pertenencia de una cosa a un individuo con exclusión de cualquier otro.

10 La opinión que ha dominado durante largo tiempo en la doctrina, y que todavía hoy es seguida por muchos, considera la antigua propiedad quiritaria como expresión de la soberanía del paterfamilias sobre las cosas pertenecientes colectivamente al grupo de la familia, es decir, sobre las res mancipi. Para demostrar su tesis, BONFANTE, en Historia del Derecho romano, 4 vols., traducción de la ed. italiana (1934), por SANTA CRUZ TEIJEIRO, Madrid, 1944, establece un paralelismo entre los que él llama los caracteres del dominio del paterfamilias sobre los fundos itálicos y los caracteres de la soberanía del Estado sobre el territorio sometido a él, destacando los puntos siguientes:

$1^{\circ}$ Los límites del fundo romano son sacros, como los del territorio del Estado, y son establecidos con la solemne ceremonia religiosa de la limitatio. $2^{\circ}$ La propiedad romana es absoluta e ilimitada internamente; no admite ninguna ingerencia o influencia extraña en su esfera. Según BONFANTE, las cuatro antiguas servidumbres sobre el fundo (via, iter, actus, aquaeductus) no habrían sido concebidas originariamente como derechos sobre las cosas que estaban en propiedad de otro, sino que habrían sido porciones de territorio destintas del territorio que atraviesan. 3ㄴ La propiedad inmobiliaria romana es absorbente, en el sentido de que cualquier cosa que entre en su esfera se encuentra sometida al derecho del dominus, de igual modo que toda cosa que entra en territorio de un Estado está sometida a la soberanía de éste. $4^{\circ}$ El fundo itálico está inmune y libre de todo tributo o carga, ya sea en relación con los particulares o con el Estado. La
} 
una generalización del mismo, así, junto a la propiedad quiritaria que era conforme al Derecho del pueblo romano (ius civile), aparece la bonitaria y la peregrina, por obra del pretor.

Al final del período clásico se mantiene vivo el concepto de propiedad quiritaria . El dominium clásico aparece como la proyección en el plano objetivo, de la personalidad del pater; constituye la afirmación y la exteriorización misma de su libertad ${ }^{11}$.

Lo que sucede después, con el Derecho postclásico( Derecho romano justinianeo), es distinto. La aparición masiva de las limitaciones del dominio, en distintos ámbitos, hace que se produzca un derrumbamiento parcial del concepto de dominio . Justiniano, restaura los principios clásicos. Dominium y propietás ${ }^{12}$ pasan a designar de nuevo únicamente el señorio pleno sobre la cosa, "la plena in re potestas"13, vinculado a ciertos modos de adquirir. En definitiva en la época postclásica el dominium conserva los caracteres clásicos, representa el poder jurídico total sobre la cosa conceptualmente separado de la apropiación económica de la misma a través del goce o de la posesión ${ }^{14}$.

Resumiendo, se puede decir, siguiendo a KASER, que "el concepto romano de propiedad del derecho clásico y justinianeo, que ofrece perfiles muy acusados y conserva su vigencia en la actualidad, sólo pudo surgir cuando los juristas romanos llegaron a la madurez que supone pensar en categorías abstractas. Este concepto de propiedad, tan exquisitamente

diferencia entre él y los fundos provinciales estaría caracterizada precisamente por el hecho de que estos últimos están sometidos a tributo. 5늘 La propiedad romana es perpetua, en el sentido de que no se la puede concebir sometida a término.

Estos caracteres originarios, siempre según BONFANTE, se habrían ido transformando de forma progresiva a lo largo de la evolución de la sociedad y de la economía romanas.

11 Cfr. KASER, M., Römisches Recht als Gemeinschaftsorduung, Tübingen, 1939, cit. por GROSSI, P., Le situazioni_reali nell'esperienza giuridica medievale, Padova, 1968, p. 1., si bien es cierto que no es opinión unánime que pueda hablarse de la existencia en Roma de "derecho subjetivo" de propiedad.

12 Cfr. BONFANTE, La propietá..., cit., p. 232.

13 Instituciones de Justiniano, libro I, título, 4.4.

14 GROSSI, P., Le situazioni reali nell'esperienzagiuridica medievale, ${ }_{2}$ Padova, 1968, p. 31-32. 
elaborado, se pierde de nuevo con la caida de lo clásico, es ajeno al derecho vulgar de la época postclásica y renace de nuevo con la doctrina clasicista de las escuelas orientales, a la que sigue la codificación justinianea en el "Corpus luris" ${ }^{15}$ en él, solamente se recoge una mínima parte del régimen de la propiedad que había regido en los inmensos territorios de lo que fuera el imperio romano. Sin embargo estos materiales son suficientes para que la especulación posterior, durante el Derecho común, y con la recepción del Derecho romano, la doctrina de glosadores, comentaristas, humanistas y sistemáticos, tenga elementos con que elaborar el concepto moderno de propiedad 16 . Hoy, este concepto sigue latiendo en los ordenamientos jurídicos continentales. Constituyó el modelo a seguir por los codificadores franceses, para definir el concepto de propiedad contenido en el artículo 544 del Código Civil frances.

Sin embargo, a pesar de todo lo dicho hasta ahora, hay autores que mantienen que el Derecho Romano no dejó ninguna definición del derecho de propiedad17.

En Roma advertimos varios períodos en que la propiedad se nos presenta con peculiares características. En un principio predomina determinada inclinación colectivista: las tierras pertenecen y están al servicio de la familia o del grupo de familias. No existe una propiedad individualizada. Sin embargo, conforme avanza el tiempo va aflorando un nuevo pensamiento;

\footnotetext{
15 Cfr. KASER, “El concepto de propiedad... cit., p. 8.

16 Vid. CAPOGROSSI COLOGNESI, en el artículo "Proprietà ( Diritto romano) “, en Enciclopedia del diritto , t. XXXVII, num.32 y ss.

17 Para DUSI, Institucioni di Diritto privato. Vol. 5. 7a. ed. Torino 1977, p. 523 "el Derecho Romano no ha dejado ninguna verdadera definición del derecho de propiedad, probablemente porque, reconociendo de ella dos formas distintas, el dominio quiritario y el bonitario, le era muy difícil reunirlas en una definición única, simple y breve".

FAIREN, M., en las anotaciones a la obra de OURLIAC, P., y MALAFOSSE, J., Derecho romano y francés histórico, Tomo II. Los bienes, Barcelona 1963, p. 522, quien afirma que el "ius utendi, et abutendi re sua quatenur iuris ratio patitur", si bien tiene base romana, está referida a una idea del todo ajena al derecho de propiedad. DI MARZO, G., Le base_romanistiche del Codice Civile. Turín, 1950 pp. 158 y ss., donde además de la definición citada del Codex mandati, cita la del Digesto 1, 5, 4, pr: "Est naturalis facultas e ius quod cuique facere libet, nisi si quid vi aut iure prohibeatur", la cual no se refiere a la propiedad sino a la libertad.
} 
aquel sentimiento familiar de la propiedad va quedando desplazado, la propiedad toma un nuevo rumbo. Una vez lograda su máxima expresión se va notando un declive, una tendencia a dotar a la propiedad de un cierto sentido social.

Pero, aunque, la propiedad romana se desenvuelve en sucesivos y diversos estadios, es corriente presentarla como una propiedad de tipo absoluto y excluyente. El primitivo dominium ex iure Quiritium (propiedad privada del civis romanus ) tiene los caracteres de absoluto, absorbente y exclusivo. Consecuencia de ello es la impenetrabilidad absoluta de sus confines materiales por parte de los extraños ${ }^{18}$.

A medida que evoluciona la sociedad, se hace más necesario establecer unas limitaciones a ese derecho y se pasa de un estado de absoluta independencia a otro de coordinación de los respectivos derechos, e incluso en algunos casos de subordinación; esta evolución que encontramos ya en las XII Tablas será desarrollada por el Edicto del Pretor así como por las decisiones de los jurisconsultos de finales de la época republicana y sobre todo de la época clásica, pues a medida que la vida se fue haciendo más compleja, el triunfo del derecho, para que la convivencia fuera posible, se hizo inevitable ${ }^{19}$. Justiniano no hizo más que llevar a su máximo desarrollo estas ideas, restringiendo esa característica de "exclusividad" en función de las necesidades de aquel momento 20 .

18 Vid. GARCIA SANCHEZ, J. , en Teoría de la immissio (Caracteres de las relaciones de vecindad predial en Roma), Madrid, 1975, p. 7. En el mismo sentido vid. GIRAUD, CH., Recherches sur le droit de proprietè chez les Romains sous_la Republique et sous l'empire, Aix 1838, p. 230 y ss.; LUSIGNANI, L., Le limitazioni della proprietà in Diritto Romano, en Filangieri 23 (1898) 497 y ss. , especialmente en la p. 586.; SORGE VADALA, G., Sui rapporti di vicinato, Torino, 1909, p. 33-34; GROSSO, G., Problemi Generali del Diritto atraverso il Diritto Romano, $2^{\circ}$ ed., ampl., Torino, 1967, p. 145 y ss.; IGLESIAS SANTOS, J., Orden jurídico y orden extrajurídico, en Estudios de Historia de Roma. Derecho Romano. Derecho Moderno, Madrid, 1968, p. 99; Appunti di Istituzioni di Diritto Romano, Redatti a cura degli assistenti. Parte speciale, Milano, 1969, p. 27 y 29.

19 Vid. MUHLENBRUCH, C.F., Doctrina Pandectarum, Bruxelles, 1838, p. 239; RODGER, A., Owners and Neighbours in Roman Law, Oxford, 1972, p. 3-6.

20 Vid. GARCIA SANCHEZ, J., Teoria de la Immissio, ob.cit., p. 9; CHARRIN, A., Extensión del Derecho de propiedad, en RGLJ 128, 1916, p. 268; GROSSO, G., Schemi giuridici e società nella storia del Diritto Privato Romano. Dall'epoca arcaica alla giurisprudenza classica: diritti reali e obligazioni, Torino, 1970, p. 228-239. 


\title{
CAPITULO SEGUNDO
}

\author{
LIMITACIONES DE LA PROPIEDAD QUIRITARIA EN EL DERECHO \\ COMUN.
}

\section{LA PROHIBICION GENERAL DE IMMITTERE IN ALIENUM}

La interferencia de intereses, y la posibilidad de conflictos entre los propietarios vecinos es un tema cuya regulación jurídica preocupó ya desde los primeros tiempos al pueblo romano.

El objetivo era la necesaria coexistencia y pacífica convivencia, para lo cual fue preciso establecer una serie de criterios directivos al respecto, los cuales por un lado responden al carácter casuista de la jurisprudencia romana y por otro están en íntima conexión con la mentalidad y necesidades del monento histórico en que los supuestos se plantean y fue preciso regular ${ }^{21}$

De acuerdo con el carácter absorbente de la primitiva propiedad romana, dominium ex uire Quiritium ${ }^{22}$, no es de extrañar que el primer criterio rector de las opiniones jurisprudenciales fuera el de la prohibición de invadir la esfera interna de la propiedad del vecino, es decir, se prohibió toda actividad

\footnotetext{
${ }^{21}$ Vid. GARCIA SANCHEZ, J., Teoria de la Immissio. Caracteres de las relaciones de vecindad predial en Roma. Madrid, 1975. p. 53 y ss.

22 Vid. ARCHI, G.," II concetto della proprietà nei diritti del mondo antico", en Rev. Inter. de Dr. de L' Ant. 6 (1959), p. 235; L'aspetto funzionale del "dominium" romano, en BIDR 61(1958) p. 67; BETTI, E., Istituzioni di Diritto Romano,vol. I , rist. della sec. ed., Padova, 1947, pp.374-375; GROSSO,G., Lezioni di Storia del Diritto Romano, 5o ed. , Torino, 1965, pp132-133; SQUITTI, B.,Proprietá, en Enc. Giur. Ital. vol. XIII - IV, Milano 1901, pp. 95-293; BRUGI, B., "'L'inmisione di rumore prodotto da uno stabilimento e la limitazioni della proprietà", en Riv. Dir. Comm. 5,2 (1907), p. 168-173; RUIZ DEL CASTILLO, C., "Concepto jurídico-social de la propiedad y sus limitaciones", en RGLJ, 149 (1926), pp. 576-600; RUBINO, D.,"Odierne tendenze sui limiti del diritto de proprietà", en Annali Macereta 17 (1948) 75-87; RAHOLA, F., "De la evolución del Derecho de propiedad privada", en RJC 17 (1911), pp. 5- 49 ; MOLITOR, E.,"Nueva problemática de la propiedad", en RAP 38 (1954), pp. 168-183; GALLARDO RUEDA , A., "Limitaciones del dominio”, en BIMJ 209 (1952) , PP. 3 4 , resumiendo una conferencia del profesor Vasalli.
} 
que ejercitándose en el fundo propio llevaba consigo una injerencia dentro de los confines del fundo vecino 23 .

Para Biondi24 se trata de un criterio ciertamente rígido y riguroso, que pervive en toda la época clásica, no impuesto por ley alguna, sino deducido lógicamente por la Jurisprudencia de la esencia misma del dominio. Para garantizar la plena independencia fundiaria se prohibe categóricamente que el propietario, obrando in suo, pueda realizar tales innovaciones que impliquen una immissio en el fundo vecino.

ALBERTARIO observa que el Derecho Romano, al regular las relaciones de vecindad, procediendo siempre según la lógica jurídica, se mueve desde un punto de vista individualísta. Por ello, al propietario le es lícito, dentro de los confines del fundo, hacer todo cuanto quiera, sin importar que ello no le sea útil y dañe gravemente al vecino. El único límite es la immisión. En su opinión, es en la legislación justinianea, donde comienza a inspirar su regulación el principio de la utilidad pública y de la equidad25.

En el derecho más antiguo ciertamente rigió una concepción neta y rigidamente individualista de la propiedad ${ }^{26}$, el propietario puede hacer todo lo que quiera dentro de los confines de su fundo, sin consideración alguna a los intereses del vecino, pero, al mismo tiempo, no puede sobrepasar la línea

23 Son importantes en materia de inmisiones los trabajos del profesor ALONSO PEREZ,"La tutela del Derecho Civil frente a imnisiones molestas y nocivas" en Estudios Jurídicos en homenaje al profesor Aurelio Mendez,Madrid, 1996 pp.4783 - 4784. Hace un análisis de la configuración jurídica y de los medios de defensa en el Código Civil de las inmisiones. Después de analizar multiples supuesto, llega a la conclusión de que la inmisión supone injerencia en la esfera jurídica ajena mediante la propagación de sustancias nocivas o perturbadoras, y comprende también la realización de actos que tienen lugar en el imnueble propio, pero que repercuten negativamente en el del vecino; en "Las relaciones de vecindad", ADC, 1983,p.367 y ss. "a cada cual le está permitido proceder como guste en su esfera jurídica, con tal de que no invada de forma intolerable la ajena"; o en "La lucha contra las inmisiones molestas y nocivas: Especial consideración de los medios jurídico-civiles. ( En defensa de los consumidores de medio ambiente, de salud y de bienestar ), Recopilación de Ponencias y Comunicaciones. Consejo General del Poder Judicial, Vol. II, Madrid, 1993, pp. 1049-1505. Asimismo, hace un comentario detenido a la St. del TS de 3 de diciembre de 1987 sobre el tema de inmisiones, Cuadernos Civitas de jurisprudencia civil, septiembre-diciembre 1987, pp. 5255-5269.

24 Vid. BIONDI,B., "Influssi Cristiani sulla legislazione agraria romana", en BIDR 61 (1958), p. 87.

25 Vid. ALBERTARIO, E., Le valutazione quantitative nel Diritto Giustinianeo e nelle legislazioni moderne, en Studi di Diritto Romano, vol. V, Milano, 1937, pp. 305 - 306, entre los principales defensores de esta teoría vid. BEKKER, Die Gesetzlichen Eigentunsschränkungen, en Jährbücher fur Gemeinrecht, V, pp. 166-167.

26 Vid. CAPOGROSSI COLOGNESI, L., La struttura della proprietá e la formazione dei "iura praediorum" nell' etá republicana, Milano, 1969, pp. 404 - 405. 
de sus confines, puesto que entonces invadiría la esfera interna de la propiedad del vecino y dicha invasión constituye una lesión de su derecho ${ }^{27}$.

A pesar de lo dicho anteriormente en ocasiones hay inmisiones que no están prohibidas, sino que son lícitas, y por lo mismo han de tolerarse para el uso normal del fundo, a fin de que el derecho del propietario no se vea privado, en gran parte, de muchas facultades que en teoría le corresponden.

Entre immisiones lícitas e ilícitas, algunos autores consideran que la raíz de esta separación radica no en el uso normal o anormal del derecho de propiedad sino en la necesidad social, que, en cuanto hace prevalecer el interés general, obliga a soportar las injerencias derivadas de los actos comunes que se ejercitan sobre los inmuebles por parte de sus titulares, viniendo prohibidos todos aquellos actos del ejercicio del derecho de propiedad que, siendo resultado de un uso normal de los fundos, responden a una actividad especial.

El principal impulsor de esta teoría es Bonfante 28 quien estima que, además de ser el más humano y a pesar de no estar expresamente formulado en las fuentes, aparece inspirando gran parte de las decisiones de los jurisconsultos clásicos, presentando la fundamentación más sólida en los textos. Formula el criterio de la necesidad social del siguiente modo: "no existe un immittere y un facere ilícitos cuando se permanece dentro de la esfera de las necesidades sociales, generales y absolutas, por lo cual el propietario vecino debe tolerar las inmisiones derivadas bien de la naturaleza de las cosas bien de la necesidad absoluta y general, que se equipara a la naturaleza" 29 .

27 Vid. GARCIA SANCHEZ, J., Teoria de la Immissio, ob.cit., p. 73.

28 Vid. BONFANTE, P., "Criterio fondamentale dei rapporti di vicinanza", en Riv. Dir. Civ. 3 (1911) pp. 517561; Las relaciones de vecindad. Trad. prólogo, concordancias y apéndice de A. García Valdecasas, 1a. ed., Madrid,1932, p. 57 y 63 y ss.

29 En la , misma dirección vid. entre otros DEGNI, F.," I limiti del diritto di proprietá", en Filangieri 26 (1901), p. 734.; FERRINI, C., Delle servitú stabilite dalla legge, 3 vols. Torino, 1923,pp. 133- 135; S.v. Dominium, en 
Si bien es cierto que el criterio de la necesidad social está vigente, al menos, en Derecho justineaneo respecto de algunas materias y supuestos aislados así, en el régimen jurídico concerniente a la agricultura, en conexión con el ejercicio de la actio aquae pluviae arcendae, y en lo referente al oscurecimiento de las luces del vecino; el principio más importante que guió a los jurisconsultos clásicos fue el del uso normal en el ejercicio del derecho propio, el cual, a su vez, implica una cierta tolerabilidad por parte de los sujetos afectados.

En base a este criterio se declaran lícitas, entre otras, las imnisiones de humo provenientes del fuego del hogar, el vapor o la humedad que proceden del baño vecino, a consecuencia de lo cual se calienta o humedece la pared ajena, etc. Por el contrario, son ilícitas esas mismas inmisiones cuando el vapor quema la pared o la humedad es permanente, pues entonces se ha sobrepasado el uso normal del derecho propio.

Uno de los criterios limitativos del derecho de propiedad por razón de vecindad, que los jurisconsutos de la Edad Media apoyaron en fragmentos de las fuentes romanas, es el de la "prohibición de los actos de emulación"30

\section{TEORIA DE LOS ACTOS DE EMULACION}

El promotor de esta teoría fue Cino de Pistoya (a. 1271- 1336), al cual siguieron, contribuyendo a concretar su contenido, Baldo de Ubaldis (1327-

Dig. Ital. Vol. IX-3. Torino, 1927, p. 787.; PASQUERA, F., S.V. Immissioni, en Nuovo Digesto Italiano, vol. VI, Torino, 1938, pp.725- 726 .

30 Vid. entre otros BONFANTE, P., "Criterio fondamentale..."ob.cit.,p. 521 y ss.; Las relaciones de vecindad...ob.cit., pp. 23 - 29; SCIALOJA,V., Teoria de la proprietá nel Diritto Romno. Lezioni ordinate, curate, edite da P. Bonfante. Vol. I. Parte II. Roma, 1933, pp. 414- 420; FERRARA, F.,"Lecciones. Extracto de J. Dalmases". RDP XV (1928), pp. 138- 140; cfr.J. González. "Las conferencias del Dr. Ferrara", en RCDI, 45 (1928) pp. 682-688 y 46 (1928)pp. 768- 777; D’ELIMIA, A., Una sentencia sul problema dell'abuso del Diritto, en SDHI 11(1945), pp. 279- 300; SEGRE, G., Corso di Diritto Romano, Le cose, la proprietá, gli altri diritti reali ed il possesso, Torino 1930, pp. 181- 201; NICOLINI, U., La proprietá, il principe e l'espropiazione per publica utilitá . Studi sulla dottrina giuridica intermedia, rist. , Milano 1952, pp. 62- 81. 
1400), Pablo de Castro (m. 1411), Bartolomé de Saliceto ( $m .1417)$, Alejandro de Imola (1424-1519) y otros muchos juristas ${ }^{31}$.

La negación más radical de esta teoría, la aporta Scialoja ${ }^{32}$, para él , un acto es de por sí lícito no se puede hacer ilícito por la intención del que lo realiza. Las acciones humanas, afirma, están reguladas por normas de diverso tipo por ejemplo jurídicas, morales, de religión, de las costumbres, etc. Ahora bien, estos actos pueden estar prohibidos por dichas normas, pero no por las jurídicas, ya que en juicio el perjudicado debe demostrar que se ha lesionado un derecho propio y reclamar ese derecho. Por lo cual, concluye, admitir en Derecho Romano un límite semejante es tanto como ir contra la interpretación lógica de todo el sistema.

Bonfante ${ }^{33}$ señala que el gran defecto de esta teoría consiste en insinuar elementos éticos y psicológicos en el campo de las relaciones de vecindad, en el cual, con toda seguridad, puede afirmarse que el Derecho Romano, al menos en el período clásico, no los admitía.

Pernice $^{34}$ indica que la existencia de la prohibición de los actos realizados con intención de perjudicar se encuentra perfectamente desarrollada en el derecho Justinianeo, y, tiene apoyo en algunas decisiones de juristas republicanos y clásicos por ejemplo el dolo es siempre contrario al derecho, y, por tanto, el ejercicio doloso de un derecho es siempre una transgresión del mismo, por lo cual es ilícito.

De entre las muchas formulaciones dadas al concepto de "acto emulativo"35, la opinión más común lo entiende como "aquel acto que

\footnotetext{
31 Vid. GARCIA SANCHEZ,J., Teoria de la immissio, ob. cit., p.212.

32 Vid. SCIALOJA, V., Teoria della proprietá nel Diritto Romano. Lezioni ordinate, curate, edite da P.Bonfante, vol. I,parte II. Roma, 1933pp. 596 y ss.; Degli atti d'emulazione nell' esercizio dei diritti, en Studi Giuridici. Vol.III-1a parte, Roma, 1932,pp. 199- 201.

33 Vid. BONFANTE,P., Criterio fondamentale..., ob.cit., p. 780; Las relaciones de vecindad...ob.cit., p. 25.

34 Vid. PERNICE,A., Labeo. Römisches Priatrecht im ersten Jahrunderte der Kaiserzeit. Neudruck der ausgabe,vol. III, Halle 1895, pp. 57 y ss.

35 Vid. SCIALOJA, V., Aemulatio, en Studi Giuridici. Vol. III, 1era. parte,1932,pp. 216- 259 y en Enciclopedia Giuridica Italiana, Vol. I - II a, 1892, pp. 426- 452.; ANCONA, E., "Degli atti ad emulazione nell'esercizio del 
respondiendo al contenido del propio derecho subjetivo, se realiza sin ninguna utilidad propia y con la exclusiva finalidad de perjudicar a otro".

Pacchioni36 señala cinco elementos para que se pueda hablar de acto emulativo: 1) Que sea un acto de ejercicio del derecho propio, es decir, un acto que el agente tenga la facultad de realizarlo como titular de un derecho cualquiera, y especialmente como propietario. 2) Se debe realizar sin ninguna ventaja para el agente, ya que si éste obtuviese alguna ventaja al realizarlo ya no se podría considerar ilícito, aún cuando tuviera consecuencias desagradables o dañosas para terceras personas. 3) Que el acto se haya realizado con intención de dañar a otro, animus nocendi, habiéndose de demostrar dicha intención en cada caso concreto. La simple ausencia de un interés propio no es más que una presunción de animus nocendi, pero no una prueba segura. 4) Que el acto haya causado un daño real a otro. 5) Que el daño consista en la lesión de un interés, no de un derecho, pues en este último caso no puede hablarse de ejercicio del derecho propio.

Resumiendo se puede decir que la doctrina no es unánime a la hora de dar un significado al término aemulatio, mientras un sector ${ }^{37}$ mantiene el significado de competencia y no el de intención de perjudicar o animus nocendi, los justinianeos le dieron otro matiz ${ }^{38}$, aludiendo al acto realizado

diritto di proprietá", en A.G. 54 (1894) pp. 299- 300; BONFANTE, P., Corso di Diritto Romano, Vol. III, Diritti reali, Roma, 1933, p. 290; STELLA MARANCA, F, In tema di divieto dell"aemulatio", en Studi in memoria di A. Albertoni, vol. II, Padova, 1938,p. 454; ROTONDI, M., L'àbuso di Diritto, en Riv. Dir. Civ. 15 (1923)p. 211; BARTOSEK, M., Sul concettodi atto emulativo specialmente in Diritto Romano e di Storia del Diritto Romano, Verona 1948, Vol. III, Milano, 1951, pp.194- 195; RICCOBONO, S.,voz aemulatio, en Nuovo Digesto Italiano, vol.I, p. 208; FRISOLI, E., "La dottrina della 'chicane' o del doloso abuso del diritto secondo il diritto romano e il diritto odierno", en Filangieri 19 (1904)pp. 484- 485; PAES DA SILVA, A.,"Os actos emulativos no direito romano", en Bol. da Fac. de Dir. Univ. de Coimbra 10 (1926- 1928),p. 531; ATZERI VACCA,F., Sulla dottrina degli atti ad emulazione, Cagliari, 1886,p. 7.

36 vid. PACCHIONI, G., Corso di Diritto Romano. Vol. II, Torino, 1920, p. 320.

37 Vid. SCIALOJA,V., Teoria della proprietá...ob. cit. p.415; La proprietá...ob.cit., pp. 598- 599; BRUGI,B., Della Proprietá, vol. I, Napoli, 1923,p. 299.; FRISOLI,E., La dottrina della "chicane"...ob.cit.,p.494; STELLA MARANCA, F., In tema di divieto...ob.cit., p. 472.; BONFANTE,P., Corso...ob.cit.,p. 296; CARAVELLA, R., Le limitazioni del dominio per regioni di vicinanza in Diritto Romano, Roma, 1971,p. 17.;PAES DA SILVA, A., Os actos emulativos...ob.cit., p. 533.; VOLTERRA, E., Istituzioni di Diritto Privato Romano, Roma, 1961, p.300 entre otros.

38 Vid. RICCOBONO, S., Voz aemulatio, en Nuovo Digesto Italiano, vol. I, Torino, 1937, p. 208.; SORGE VADALA, G., Sui rapporti di vicinato, Torino,1909,pp. 127- 128.; ROTONDI, M., "L'abuso di “, en Riv. Dir. Civ., p. 222. 
maliciosamente en relación con el ejercicio del poder por el dueño dentro de su esfera jurídica, está presente el matiz subjetivo intencional.

La teoría, elaborada en el Medioevo, de los actos de emulación tiene algunas manifestaciones en textos clásicos alterados por los Compiladores, y, por tanto, vigentes en esta época. Se trata de supuestos aislados en los cuales se da primacía, para juzgar la licitud e ilicitud en el ejercicio del derecho de propiedad al principio de la "intención", ocupando un lugar secundario, a este respecto, los confines del fundo.

El hecho de declarar lícitos e ilícitos los actos según cual haya sido la intención del agente, hace que las limitaciones al ejercicio del derecho de propiedad adquieran un marcado carácter subjetivo, mientras que, en las épocas republicana y clásica, las mismas presentan siempre un claro matiz objetivo.

Esta teoría, desarrollada en la Edad Media para solucionar los conflictos de derecho a que daba lugar la coexistencia de fundos vecinos, constituye el antecedente de la doctrina del abuso del derecho.

\section{EL ABUSO DEL DERECHO.}

Las primeras correcciones que se formularon al derecho de propiedad liberal fueron canalizadas a través de la doctrina del Abuso del Derecho39.

39 Ciertamente, la función social de la propiedad y la doctrina del abuso del derecho son dos categorías jurídicas que van íntimamente unidas vid. sobre este particular, MONTES,V., Comentario a los artículos 348 y 344 del Código civil en Comentarios al Código civil y Compilaciones forales, Albadalejo, Madrid, 1985, T.V., p. 121. 
El abuso del derecho, como ha puesto de manifiesto la doctrina ${ }^{40}$, representa, una teoría antiindividualista, en cuanto que viene a recortar el poder absoluto que se le otorga al propietario en el liberalismo individualista.

El abuso del derecho' en esta primera época, quedó configurado, por la intención de dañar por parte de quien ejercita su derecho, sin que ella le reporte ninguna utilidad ${ }^{41}$.

La consideración del daño como factor determinante de la causa del abuso no está ausente en la época liberal, ya que la Declaración de los Derechos del hombre y del ciudadano de 16 de agosto de 1789 se preocupa de la fijación, como límite natural, del respeto hacia los derechos ajenos. Sin embargo, este respeto a los derechos de los demás es una fórmula poco precisa, ya que dentro de ella tenían cabida no solo las limitaciones legales a que hace expresa referencia el artículo 544 del Código Napoleón, sino también determinados supuestos de responsabilidad sin culpa, que debían considerarse como auténticas limitaciones al ejercicio del derecho de propiedad. Dentro de estas ideas se enmarca, en principio, el abuso del derecho "como sistema idóneo para extender los supuestos de responsabilidad extracontractural a aquellos casos en que no mediaba culpa o negligencia por parte del propietario y sin que ello supusiera, en ningún caso, el reconocimiento de un régimen de responsabilidad objetiva"42.

40 WALINE, M., L'individualisme et le Droit. Paris, 1945, p. 412; CALVO SOTELO, J., La doctrina del abuso del derecho como limitación del derecho subjetivo. Madrid, 1917, p. 21; ROTONDI "(L'abuso del Diritto" en Rev. Dir. Civ., 1923, p. 105 y ss.) dice: nació la teoría del abuso del derecho como freno a ciertas formas de ejercicio del derecho de propiedad, de contenido tan amplio que, dañosamente repercuten en terceros, merecedores de protección no inferior.

${ }^{41}$ Sobre los antecedentes romanos del abuso del derecho, puede verse RODRIGUEZ ARIAS-BUSTAMANTE, L., "El abuso del derecho de la historia y en la legislación comparada", en Revista de Derecho Inmobiliario (marzo-abril), 1955, pp. 133 y ss.

FAIREN MARTINEZ, "El abuso del derecho", R.D.N. 1960, p. 113; JORDANO, Dictamen sobre el abuso de derecho y fraude a la ley, ADC, 1960, p. 7.

RODRIGUEZ ARIAS, “El abuso de derecho", RDP 1971.

Entre los autores que comentan la reforma del Título Preliminar del Código Civil, vid.: Comentarios a las reformas del Código Civil, vol. I, 1975, Art. 7 por MONTES, p. 356 y ss; CASTAN VAZQUEZ, Notas para la historia de la reforma del Título Preliminar del Código Civil, en D.J., 1974, no 4, p. 15; IDEM, "El abuso de derecho en el nuevo título Preliminar del Código Civil”. Estudio reforma Título Preliminarl. Madrid, 1977, p. 57. DIEZ PICAZO, "El abuso de derecho y el fraude a la ley en el nuevo Título Preliminar del Código Civil y el problema de sus recíprocas relaciones". D.J., 1974, p. 30; MARTIN BERNAL, "Nuevas consideraciones valorativas en la teoría del abuso del derecho", ADC 1979; IDEM, El abuso de derecho, Madrid, 1982, p. 160 y SS..

42 ESCRIBANO COLLADO, P., Propiedad privada urbana, Madrid,1979, p. 84 y ss. 
Según CALVO SOTELO43, "como precursores de la teoría del abuso del derecho cabe citar principalmente a TOULLIER, que afirmaba que no puede incurrirse en falta cuando se hace lo que se tiene derecho a hacer pero añadía, "a menos que se excedan los justos límites de su derecho y se observe claramente que, entre varias maneras de ejercitarlo, se haya escogido, con propósito de dañar a otro, la que podría serle perjudicial”.

Se recoge aquí la teoría subjetiva del abuso del derecho, tal y como había sido desarrollada entorno a la aemulatio en el Derecho romano justineaneo, según la cual el acto es abusivo porque el ejercicio ha sido ejercitado con la intención de dañar a otro o sin verdadero interés individual para ejercitarlo.

La cuestión más controvertida se centra en la determinación de en qué casos el ejercicio del derecho de propiedad podía entenderse abusivo, de forma que el sujeto o sujetos afectados no tuvieran que soportar sus consecuencias. En este punto hay una evolución interesante, que viene a ampliar el concepto de ejercicio abusivo del derecho.

La evolución mencionada viene determinada por la objetivación de la causa del abuso, aunque el valor jurídico que la figura del abuso del derecho pretende satisfacer sigue siendo el mismo, es decir, se trata de impedir que el ejercicio de los derechos pueda ser la causa de los perjuicios ajenos. Esta objetivación de la causa supone un paso más respecto a su consideración en el Derecho Romano. Mientras en un primer momento el abuso del derecho se delimitaba por la realización de perjuicios individuales, en una etapa posterior va a sancionar aquellas actividades del propietario susceptibles de producir un perjuicio para la colectividad es decir, "hay abuso del derecho cuando su ejercicio legal es antisocial" 44.

43 CALVO SOTELO, J., La doctrina del abuso del derecho....,ob. cit, p. 21.

44 GITRAMA GONZALEZ, M.," La corrección del automatismo jurídico mediante las condenas del fraude a la ley y del abuso del derecho", en Curso Monográfico sobre la Ley de Bases para la Modificación del Título 
En el origen de esta nueva teoría del abuso del derecho, según la cual ya no es decisiva la intención de dañar en el agente para la determinación del acto como abusivo, sino que éste se asimila a todo ejercicio antisocial de un Derecho subjetivo, están toda una serie de transformaciones en la ciencia jurídica, que da lugar a un cambio de perspectiva respecto al Derecho. Por lo tanto el origen real de los derechos del hombre se encuentra en lo social, no teniendo razón de existir aquéllos, más que para asegurar el funcionamiento de la vida colectiva.

No puede hablarse de derechos absolutos, sino relativos ${ }^{45}$, pues los derechos tienen una misión social que cumplir. En la finalidad del Derecho se encuentra la regla de utilización del bien, el acto de ejercicio debe orientarse según aquella finalidad 46 .

De todas formas, esta nueva orientación no ha supuesto, en tema de propiedad, el abandono de su concepción individual, sino que ha venido a suavizar su alcance. Es decir, el abuso del derecho no puede considerarse sino como un criterio social, limitador de los derechos subjetivos, pero respetando en todo su naturaleza individual ${ }^{47}$.

Nuestro Código Civil, hasta la Reforma del Título Preliminar por Decreto 1388/1974, de 31 de julio, no contenía en su articulado una regulación expresa del abuso del derecho, aunque no puede pensarse que la

Preliminar del Código Civil. Publicaciones del llustre Colegio de Abogados de Valencia y Legislación. Valencia, 1975, p. 144.

45 La idea de la relatividad de los derechos subjetivos es expresada también por IRTI, N., en "Dal diritto civile al diritto agrario", Revista di Diritto Agrario, 1961, p. 266.

46 JOSSERAND, L., Derecho Civil. Tomo I, vol. I. Teorías generales del derecho y de los derechos. Las personas. Traducción española de CUNCHILLOS Y MANTEROLA, Buenos Aires, 1952, quien considera la existencia de derechos absolutos que escapan a la disciplina del abuso, a los que llama derechos incausados

47 DE VITA., La propietá nell'esperienza giuridica contemporanea. Analisi comparativa del diritto francese, Milán, 1969, p. 191, quien añade que el concepto de abuso del derecho es, "desde este ángulo, mucho más ambiguo que el de la función social que califica teleológicamente el ejercicio del derecho según una proposición positivamente identificable. La propiedad-función social debe desarrollarse según un determinado iter, la desviación del cual se concreta en un defecto de legitimación del derecho mismo. El ejercicio abusivo, reprimible sólo cuando se concreta en un daño para los demás, indica que las prerrogativas, cuyos límites no han sido prefijados explícitamente por el legislador, no se deben usar infringiendo el principio general de solidaridad. 
falta de aquella diera pie para la permisividad del ejercicio abusivo; y ello porque, si bien faltaba un texto que, con carácter general lo prohibiera, el ejercicio abusivo constituía ya un principio general de nuestro Derecho ${ }^{48}$, además del pronunciamiento de la Jurisprudencia sobre el tema.

Antes de la Reforma de 1974, cabría la prohibición del ejercicio abusivo en base al artículo 1902 del Código Civil, que obliga a reparar el daño causado, al que por acción u omisión causa daño a otro interviniendo culpa o negligencia49. Por su parte la Ley de Arrendamientos Urbanos en su artículo 9, apartado 2, rechazaba ${ }^{50}$, en su ámbito, el abuso del derecho al afirmar que "los Jueces y Tribunales rechazarán las pretensiones que impliquen manifiesto abuso o ejercicio anormal de un derecho...".

También la jurisprudencia ha sido abundante en el tema del abuso del derecho. No sólo se ha pronunciado el T.S. para el caso concreto del artículo 9 de la L.A.U., sino que han sido numerosas las sentencias ${ }^{51}$ que se han dado fuera del contexto del referido artículo.

48 GITRAMA en su ob. ult. cit, p. 140, afirma que la "teoría del abuso del derecho constituye un instrumento técnico jurídico que viene a alinearse junto a aquellos otros principios de la buena fe, la equidad, el orden público, las buenas costumbres; en suma, un standard de que el juez se vale para corregir el automatismo de las normas, para completar éstas y para a veces limitar sus lamentables efectos, indagando el fin perseguido por los litigantes tras la apariencia de las situaciones que configura. Precisamente por esta misma elasticidad, puede pensarse que se hallaba justificada la ausencia del Código Civil de un precepto general obstaculizante del abuso del derecho.

49 Opinión doctrinal representada entre otros, por CALVO SOTELO, ob. cit. p. 32; ROTONDI, ob. cit. p. 107 y ss.

50 Esta Ley de Arrendamientos Urbanos de 1964 (Texto Refundido aprobado por Decreto de 24 de diciembre de 1964 ha sido posteriormente modificada y derogada por la Ley 29/1994, de 24 de noviembre de 1994.

${ }^{51}$ Así, cabria mencionar las Sentencias de 27 de enero de 1959 (R.446) en materia de Arrendamientos Urbanos, de 6 de febrero de 1959 (R.460) en materia de desahucio en precario, de 24 de febrero de 1959 (R.1080) en materia de compraventa, de 22 de septiembre de 1959(R.3359)en materia de liquidación de cuentas de crédito en establecimiento bancario, de 25 de noviembre de 1960(R.3766) en materia de compraventa, de 3 de mayo de 1961(R.1853) en materia de arrendamientos urbanos, de 25 de mayo de 1961(R.2337) en materia de arrendamientos urbanos, de 18 de enero de 19649(R.205) en materia de arrendamientos urbanos, de 12 de febrero de 1966(R.1529) en materia de arrendamientos urbanos, de 31 de enero de 1969(R.428) en materia de servidumbre de luces y vistas en Cataluña, de 12 de enero de 1970(R.167) en materia de deslinde de fincas, de 5 de junio de 1972(R.2599) en materia de abuso de derecho, de 14 de febrero de 1976(R.616) en materia de arrendamientos urbanos, de 26 de abril de 1976(R.1926) en materia de aguas, de 22 de abril de 1978(R.1364)en materia de partición hereditaria.

Sentencia de 18 de mayo de 1981(R.2074) en materia de arrendamientos urbanos, de 24 de marzo de 1983(R.1612) en materia de deslinde, de 2 de febrero de 1984(R.571) en materia de compraventa de inmuebles, de 23 de junio de 1986(R.3791) en materia de arrendamientos urbanos, de 21 de abril de 1987(R.2720) en materia de partición hereditaria, de 5 de octubre de 1988(R.7381) en materia de cooperativas agrícolas, de 4 de enero de 1989(R.95)en materia de compraventa de inmuebles, de 2 de 
La primera sentencia en este tema, así como la más importante por la cantidad de estudios doctrinales que ha suscitado, es la sentencia de 14 de febrero de 1944 (R.293). El T.S en su considerando tercero afirmaba que.... "los derechos subjetivos, aparte de sus límites legales, con frecuencia defectuosamente precisados, tiene otros de origen moral, teológico y social, y que incurre en responsabilidad el que, obrando al amparo de una legalidad externa y de un aparente ejercicio de su derecho, traspasa en realidad los linderos impuestos al mismo por la equidad y la buena fe, con daño para terceros o para la sociedad; tesis ésta que ha sido también apoyada por la doctrina científica de nuestro país, que ha recogido y perfilado el concepto del abuso del derecho, considerándolo integrado por estos elementos esenciales: uso de un derecho, objetiva y externamente legal; daño a un interés no protegido por una específica prerrogativa jurídica; inmoralidad o antisocialidad de ese daño, manifestada en forma subjetiva (cuando el derecho se actúa con la intención de perjudicar o sencillamente sin un fin serio y legítimo) o bajo forma objetiva (cuando el daño proviene de exceso o anormalidad en el ejercicio del derecho)".

Como puede observarse en el considerando transcrito, en donde el T.S. especifica cuáles son los requisitos para poder hablarse de ejercicio abusivo, tanto vale para su determinación el criterio subjetivo como el objetivo. Así habrá abuso del derecho, tanto si el daño ocasionado a un interés no protegido por la norma jurídica se hace con la intención de perjudicar o sencillamente sin un fin serio o legítimo (criterio subjetivo) o por ejercicio

noviembre de 1990(R.8455) en materia de opción de compra, de 26 de diciembre de 1990(R.10374) en materia de cláusula penal, de 19 de noviembre de 1991(R.8411) en materia de compraventa, de 10 de marzo de 1992(R.2015) en materia de asociaciones, de 14 de marzo de 1992(R.2180)en materia de desahucio. En materia de Propiedad Horizontal, en conexión con el abuso del derecho vid. entre otras las siguientes sentencias :St. de la AP de Alicante de 6 de abril de 1992,Act.civil 365/ 1992 , marginal 830 ; St. de la AP de Alicante de 12 de mayo 1992, Act. civil 406/ 1992 , marginal 936 ; St. de la AP de Toledo de 13 de octubre de 1992, Act.civil 513/ 1993, marginal 820; St. de la AP de Málaga de 23 de julio de 1993, Act. civil 196/ 1994, marginal 325; St. de la AP de Málaga de 2 de marzo de 1994.Act. civil 1089/ 1994, marginal 1661; St. del TS de 6 de mayo de 1994, 90/ 1994, pag. 2300; St. de AP de Lleida de 13 de octubre de 1994, 315/ 1995, marginal 446; St. del TS de 13 de febrero de 1995, 448/1995, pag. 1093 y la St. de la AP de La Coruña de 21 de noviembre de 1995, 253/ 1996, marginal 386 entre otras. 
antisocial, es decir, de exceso o anormalidad en el ejercicio del derecho (interés objetivo).

A partir de la Reforma del Título Preliminar del Código Civil, el abuso del derecho se contempla expresamente en el artículo 7 del citado cuerpo legal. Según este precepto, el ejercicio de un derecho puede ser abusivo, bien porque se ejercite fuera de los límites normales ocasionando daño para un tercero, o bien porque suponga una utilización antisocial del mismo. En relación con esto cabe hacer una doble matización (o dos consideraciones): En primer lugar, será el Juez quien determine la existencia del abuso, es decir, el que decida en qué supuestos debe hablarse de ejercicio abusivo, en virtud de los standard52 "límites normales" y "ejercicio antisocial”; en segundo lugar, el diferente tratamiento jurídico a que es sometido el ejercicio ya sea abusivo, ya sea antisocial.

Si se trata de ejercicio antisocial, el precepto se limita a señalar que la ley no lo ampara, de tal forma que carece de protección jurídica. Si, por el contrario, el ejercicio es abusivo no sólo lo considera desprovisto de protección jurídica, sino que además lo declara ilícito y establece la obligación de indemnizar53 los daños causados, por entender que la actividad realizada constituye un supuesto de invasión de la esfera de intereses ajenos al propietario, en definitiva, porque el titular en su ejercicio ha sobrepasado los límites normales de su derecho. De aquí que, mientras en el segundo caso se prevea la adopción de las medidas judiciales o administrativas pertinentes para destruir la situación de abuso, en el primero el precepto se limita a incluir el ejercicio antisocial del derecho en el mundo de los hechos, desprovisto por lo tanto de protección jurídica. Aunque en este caso, cualquier persona

\footnotetext{
52 JOSSERAND, L., El espíritu de los derechos y su relatividad, México, 1946, p. 23 señala que los standard jurídicos constituyen límites autonómicos de la voluntad judicial en los que ésta ha de inspirarse siempre que no tenga precisa apoyatura legal.

53 Obligación de indemnizar que, al proceder de acto ilícito, ha de regirse por lo establecido en el artículo 1902 y concordaste del Código Civil: "El que por acción u omisión cause daño a otro interviniendo culpa o negligencia está obligado a reparar el daño causado".
} 
pudiera por vía de hecho impedir tal ejercicio antisocial, no cabe duda de que la solución dada por el Código Civil es muy limitada.

Resumiendo, podríamos afirmar que, mientras en un primer momento el abuso del derecho se delimitaba por la realización de perjuicios individuales, en una etapa posterior va a sancionar aquellas actividades del propietario susceptibles de producir un perjuicio para la colectividad, es decir, pasa a ser un criterio social de funcionalización del derecho54, o mejor, una cláusula general limitativa del derecho subjetivo ${ }^{55}$, pero que sigue respetando la naturaleza de "prerrogativa exquisitamente individual del dominio"56. El ejercicio abusivo del derecho, cuyos límites no han sido prefijados por el legislador, indica que las prerrogativas que atribuye a su titular no deben ser usadas infringiendo el principio general de solidaridad. Por tanto, aunque el abuso se manifieste como intención malévola, culpa en la ejecución, ausencia de interés legítimo, o desvío de su finalidad, el concepto viene a significar que en el momento en que el ejercicio del derecho se interfiere con intereses o derechos ajenos, individuales o colectivos, este límite, que el legislador no ha puesto de modo expreso, surge a través de la obra concreta del juez.

En este contexto, la función social de la propiedad, viene a ser, como una especialización en materia propietaria de dos viejas categorías: la del abuso del derecho y su ejercicio antisocial, como límite negativo al ejercicio de cualquier derecho subjetivo; y la de la buena fe como condición y, por ende, límite positivo del ejercicio de los derechos, recogidos en el mismo precepto 57

\footnotetext{
54 Cfr. ALPA, G., y BESSONE, M., Atipicitá dell'illecito, I, I profiti dottrinali, Milano, 1981, pp. 77 y ss.; ESCRIBANO COLLADO, La propiedad privada, ob.cit., pp. 91 y ss.; MARTIN BERNAL, J.M., El abuso del derecho, Madrid, 1982, pp. 160 y ss., con base en el vigente artículo 7º, párrafo segundo, del Título Preliminar del Código Civil.

55 Vid. DE VITA, La propietá, ob.cit., p. 191.

56 Cfr. IRTI, Dal Diritto Civile, ob. cit.,p. 46.

57 Vid. CONDE-PUMPIDO TOURON, C., "Derecho de Propiedad y Protección del Medio Ambiente. La acción negatoria ", Rev. Consejo General del Poder Judicial, Madrid, abril, 1994, p. 20.
} 


\section{PROPIEDAD FUNCION: PROPUESTA DE DUGUIT.}

A principios del siglo XX, LEON DUGUIT partiendo de la consideración de que el derecho de propiedad como derecho subjetivo es una idea metafísica ${ }^{58}$, imposible de mantener en una época de realismo y positivismo59, llega a proponer la sustitución del derecho subjetivo por la idea de función social, en el sentido de que sólo se le reconoce al individuo para la realización de una determinada función.

La propiedad afirma este autor "deja de ser un derecho subjetivo del individuo y tiende a convertirse en función social"60.

Ponía de manifiesto, que a pesar de la creencia generalizada de que el Code Civil y la ideología liberal constituían un sistema de derecho definitivo, lo cierto era que "apenas la construcción ha sido terminada, las grietas han aparecido. EI siglo XIX ha sido un período particularmente fecundo en todas las órdenes de la actividad humana. Un movimiento considerable se ha realizado en el dominio social. Pero este movimiento, en lugar de ser, como pensaban los hombres de la Revolución Francesa y la primera generación del siglo último, el desenvolvimiento normal de los principios formulados en 1789 , ha sido una reacción formidable contra ellos"61.

El choque entre ambas concepciones, suponía según el autor citado el paso de una concepción puramente individualista del derecho, basado sobre la idea del derecho subjetivo del individuo, a un sistema jurídico apoyado sobre una concepción esencialmente socialista, es decir, fundado sobre la idea de una regla social que se impone al individuo.

58 LEON DUGUIT., Las transformaciones del Derecho (Público y privado). Traducción española de G. POSADA. Buenos Aires, s. f., p. 174.

59 DUGUIT, L., ob.cit., p. 175.

60 DUGUIT, L., Manual de Derecho Constitucional. 2a. edic. Madrid, 1926, p. 285.

61 IDEM., Las transformaciones...,ob.cit., pp. 172 y 178. 
La superación de este antagonismo conceptual se había de conseguir, según Duguit, abandonando la idea de derecho subjetivo, que respondía a una concepción metafísica del derecho, imposible de mantener en una época de realismo y positivismo, y de esta forma llegaba a concluir lo siguiente:

"La propiedad no es ya en el derecho moderno el derecho intangible, absoluto, que el hombre que posee riqueza tiene sobre ella. Ella es y debe ser; es la condición indispensable de la prosperidad y la grandeza de las sociedades y las doctrinas colectivistas son una vuelta a la barbarie. Pero la propiedad no es un derecho, es una función social. El propietario, es decir, el poseedor de una riqueza tiene, por el hecho de poseer esta riqueza, una función social que cumplir; mientras cumple esta misión sus actos de propietario están protegidos. Si no la cumple o la cumple mal, si por ejemplo no cultiva la tierra, o deja arruinarse su casa, la intervención de los gobernantes es legítima para obligarle a cumplir su función social de propietario, que consiste en asegurar el empleo de las riquezas que posee conforme a su destino"62.

Este planteamiento es desarrollado por DUGUIT, en el que partiendo de algunas ideas del ideario positivista de A. COMPTE, concluye identificando el contenido de la propiedad función en dos proposiciones:

1. "El propietario tiene el deber, y por tanto el poder, de emplear la cosa que posee en la satisfacción de las necesidades individuales, y especialmente de las suyas propias, de emplear la cosa en el desenvolvimiento de su actividad física, intelectual y moral".

2. "El propietario tiene el deber, y por consiguiente el poder, de emplear su cosa en la satisfacción de necesidades comunes, de una colectividad nacional entera o de colectividades secundarias". 
Partiendo de estas premisas DUGUIT propone la siguiente idea: "la propiedad es, para todo poseedor de una riqueza, el deber, la obligación de orden subjetivo, de emplear la riqueza que posee en mantener y aumentar la interdependencia social”63.

Desde esta perspectiva es obvio que la "función" no determina una prioridad de fines que el propietario individual debe respetar usando el derecho en su beneficio, sino una verdadera carga funcional que ordena su actividad hacia la colectividad y que le despoja de prerrogativas personales.

De aquí se deduce que DUGUIT advierte como imprescindible, la vocación funcional de la propiedad, pero esta intuición, al estar desprovista de una adecuada formulación técnica, no fue bien acogida por la doctrina ${ }^{64}$.

Contra la teoría propugnada por DUGUIT se ha generado una serie de opiniones, queriendo resaltar las dificultades e inconvenientes que lleva implícita su aceptación. Así se ha dicho que la aceptación de la propiedadfunción llevaría consigo, la negación de los derechos subjetivos ${ }^{65}$, puesto que, como afirma el mismo DUGUIT66, "el detentador de una riqueza no tiene derecho sobre ella; se da una nueva situación de hecho que le obliga a realizar una cierta función social; y su apropiación es protegida en la medida, y solamente en la medida, en que él la cumple".

En este sentido la situación jurídica del poseedor de bienes no está incursa en el derecho subjetivo, ya que el detentador no tiene poder para decidir sobre las cosas que posee, pues sólo ha de limitarse a cumplir las

6363 IBIDEM, p. 340.

64 LANUERSIN, J., La propiedad ¿una nueva regla de juego?, Madrid, 1976 (trad.esp.) p. 60. "Estas proposiciones y estas señales de alerta "(La propiedad no es un derecho intangible y sagrado, sino un derecho continuamente cambiante que debe amoldarse a las necesidades sociales a las cuales debe responder. Si llegara un momento en el que la propiedad individual no respondiese ya a esa necesidad social, el legislador deberá intervenir para organizar otras formas de apropiación de la riqueza)", apenas iban a encontrar eco. El Repertorio Dalloz de 1924 ni siquiera menciona en su artículo sobre la propiedad, las teorías de León Duguit".

65 PICAR, M., en Tratado práctico de Derecho Civil francés, de PLANIOL y RIPERT. Habana, 1946, p. 20. PUGLIATTI, S., La propietá del nuovo diritto. Milano, 1964, p. 110.

66 DUGUIT, Le droit social, le droit individuel et la transformations de l'Etat. París, 1908, p. 148. 
directrices que le marque el contenido de la función social de aquellas. Posición, por otra parte, antagónica respecto al derecho subjetivo, pues éste, supone la concesión al propietario de una esfera de autonomía, a través de la cual puede controlar el objeto de su derecho con exclusión de las demás personas. En definitiva, función y derecho son dos entidades diversas que no es posible conciliar67.

De otra parte, y como consecuencia de lo anterior, el propietario se convierte en funcionario. Sí, como afirma DUGUIT, el propietario ha de cumplir una función social, y ésta tiene como objetivo un interés supraindividual, es decir, un interés general, resulta que la función social lleva necesariamente a una función pública, toda vez que el intérprete de ese interés general que el propietario ha de cumplir es el Estado. Se convierte así el propietario en un “órgano de actuación del interés público"68.

Conversión que sólo sería posible si existiera la obligación o el deber jurídico, por parte del propietario, de realizar una actividad encaminada exclusivamente a la realización de intereses públicos ${ }^{69}$, puesto que, como afirma PUGLIATTI70 "la función en sentido técnico existe cuando el sujeto actúa en interés ajeno (además de su propio interés). Y si se llegara a la existencia de ese deber jurídico, es decir, si el propietario es considerado como funcionario, "éste no podrá tomar ninguna iniciativa; no podrá sino seguir las vías que se le indican por su deber de funcionario"71. En este supuesto, el propietario ya no actúa libremente dado que la propiedad-función supone un régimen de propiedad inspirado en el interés público; que se caracteriza más por los deberes que impone que por los derechos que

\footnotetext{
67 PUGLIATTI, S., La propietá...,ob.cit., p. 141. BARASI, C., La propietá nel nuovo Códice Civile. Milano, 1943, p. 97.

68 PUGLIATTI, S., La propietá nel nuovo diritto. Milano, 1964. Ob.cit., p. 141.

${ }^{69}$ MESSINEO, F., Manual de Derecho Civil y Comercial. Vol. III, Personalidad. Familia. Derechos reales. Traducción española de SENTIS MELENDO. Buenos Aires, 1971.

70 MESSINEO, F., Ob. ult. cit., p. 141.

71 IBIDEM, p. 254.
} 
concede, y que queda fuera de la esfera del Derecho individual o privado, para entrar plenamente en la del Derecho social, si se admite esta figura, o en la más perfilada y actual del Derecho público 72.

Por tanto, parece claro, que el concepto de propiedad consagrado en el Code Civil francés de 1804, que incorporan, con más o menos matices, el resto de los Códigos decimonónicos, y cuyo esquema abstracto como "poder general e independiente de la persona sobre la cosa" continua prevaleciendo en la doctrina jurídica europea, va a ser objeto de transformación a lo largo del siglo XX, transformación por otra parte paralela a las profundas modificaciones que sufre el orden social.

En este sentido queremos resaltar la opinión de un conocido antropólogo francés, que resume con toda claridad la necesidad de replantear la organización del derecho de propiedad vigente a finales del siglo XIX. Dice LETOURNEAU: "Si la civilización europea quiere durar y progresar, le será preciso reformar su constitución de la propiedad, refrenar los abusos. Por su esencia misma el régimen de la propiedad es el gran resorte de toda la vida social. No se debe tocar más que, con extrema prudencia, pero no se deberá discutir en una sociedad el derecho a modificarlo a la medida de sus intereses generales"73.

En consecuencia, la situación de tensión social que nutre las actitudes críticas producidas frente a una imagen individualista del derecho de propiedad como un derecho natural del hombre absoluto y exclusivo a la que nos hemos referido, marca y define las características con que acaba un siglo y comienza otro.

Se suele afirmar así que en su "principio" la propiedad está dirigida hacia la satisfacción de fines individuales, mientras que en su "uso" debe

\footnotetext{
72 CASTAN, La propietá... ob.cit., p. 80.

73 LETOURNEAU, CH., L'evolution de la propieté, Paris, 1889, p. 487.
} 
plegarse a finalidades sociales ${ }^{74}$. Usando de su derecho el propietario no puede pretender satisfacer exclusivamente su interés; debe respetar el interés general; el elemento social traza el límite del elemento individual, pero al mismo tiempo supone su justificación. La "función social" completa la "función personal"75.

En definitiva, se parte de la distinción entre titularidad y ejercicio del derecho de propiedad; como las restricciones afectan exclusivamente al ejercicio del derecho sólo este puede quedar sujeto al interés social, y, en consecuencia, el interés colectivo contribuye únicamente a orientar el ejercicio del derecho, y no a plantear la cuestión de si debe admitirse o no la existencia del derecho subjetivo.

Por último, poner de manifiesto que la teoría de la propiedad-función no está exenta de influencias ideológicas. Prueba de ello es su utilización como vehículo apropiado por los regímenes totalitarios. En éstos, una de las bases fundamentales en la que se asienta todo el orden jurídico, está constituida por la preferencia de la autoridad del Estado sobre los derechos subjetivos de los particulares. Como consecuencia de ello se produce la desnaturalización de los derechos subjetivos, reduciendo al individuo a un mero punto de referencia con respecto al Estado.

Se recoge esta teoría en el Estado fascista italiano, que parte del hecho de que el "nuevo e imprescindible interés público constituye el aumento de la producción nacional. Si los derechos de propiedad constituyen un obstáculo al cumplimiento de tal fin, deben ser sacrificados, porque en el ordenamiento corporativo, la propiedad privada es instrumento dirigido a incrementar el producto social total"76.

\footnotetext{
74 Vid. TROTABAS, L., "La fonction sociale de la propiété privée: le point de vue technique”, en RENARDTROTABAS, La fonction sociale, cit., pp. 14, 18 y ss.

75 Cfr. COSTE-FLORET, P., La nature juridique du droit de propiété ..,ob.cit. pp. 235-236.

76 EINAUDI, L., Ordinamento corporativo e propietà privata, en Economía, 1935, p. 20.
} 
Lo importante, como afirma EINAUDI, era la producción nacional, de forma que la función social, estaba ligada a ella, como interés supremo de la nación.

En contraposición a este contenido de la función social en los estados fascistas, está la función social enmarcada dentro del principio de solidaridad, que trata de corregir la situación tradicional entre individuo y sociedad. Para ESCRIBANO77, "la distinción que media entre función social como productividad y función social como manifestación de la solidaridad social, lo representa sin duda alguna el régimen de la tierra. Mientras ésta última persigue el acceso del campesino, del que trabaja la tierra, a formas más estables de tenencia y aprovechamiento de tierras, aquélla persigue como única finalidad el incremento de la producción nacional"78.

De todo lo dicho hasta aquí, vamos a resumir en unas líneas la aportación de DUGUIT; si bien la teoría de concebir el derecho de propiedad como institución dirigida sólo y exclusivamente a cumplir una función social, no fue aceptada por la mayoría de la doctrina, dado que suponía la negación de la propiedad como derecho subjetivo, quedando reducido el propietario a un simple funcionario, supuso el hecho real de que, frente a la concepción liberal que concebía la propiedad como el derecho más absoluto, surgiera la idea de que la propiedad no es en sí misma una función social, pero sí es necesario que cumpla no sólo necesidades individuales sino también colectivas.

Esta nueva forma de concebir la función social de la propiedad que toma de DUGUIT su terminología, surge desde el primer momento ligada al

77 ESCRIBANO COLLADO, P., La propiedad privada urbana, Madrid, 1979, p. 106.

78 En nuestro Derecho, el Fuero del Trabajo expresaba de forma clara esta relación entre función social de la propiedad y productividad: "El Estado reconoce y ampara la propiedad privada como medio natural para el cumplimiento de las funciones individuales, familiares y sociales (Punto XII, 1ํ.). La producción nacional constituye una unidad económica al servicio de la Patria. Es deber de todo español defenderla, mejorarla e incrementarla. Todos los factores que en la producción intervienen quedan subordinados al interés supremo de la Nación". 
concepto de derecho subjetivo. La función se incorpora al derecho subjetivo que subsiste, y el fin social se combina con el fin individual que le es inherente. "La propiedad no es una función social, tiene una función social"79; es la fórmula que logrará alcanzar verdadero arraigo.

\section{LA DOCTRINA DE LA IGLESIA. OTRAS MANIFESTACIONES.}

Si bien es cierto que la teoría de la función social fue expresamente desarrollada por DUGUIT, inspirándose en algún momento en las reflexiones de AUGUSTO COMPTE ${ }^{80}$, los antecedentes pueden encontrarse ya en los grandes Padres de la Iglesia, en los teólogos escolásticos ${ }^{81}$ y en los grandes maestros de Teología y Derecho de la Escuela de Salamanca.

La doctrina social de la Iglesia Católica sentada por la patrística, en especial Santo Tomás de Aquino, y desarrollada posteriormente en las Encíclicas Pontificias, entre las que sobresalen la Rerum Novarum (León XIII, 1891), Quadragessimo Anno (Pio XI, 1931), Mater e Magistra (Juan XXIII, 1961), Centessimus annus, (Juan Pablo II, 1991), postulaba ya el cumplimiento de la función social de la propiedad privada con anterioridad temporal a que fuese recibida en el pensamiento jurídico. Esta corriente

\footnotetext{
79 Vid. MORIN, G., L'oeuvre de Duguit et le Droit privé. Archives de philosophie du droit, 1932, p. 158. Idéntica opinión MESTRE, A., "Remarques sur la notion de propiété d'aprés Duguit". Archives de philosophie du droit, 1932, p. 165.

80 COMPTE. Systeme de politique positive 1982, I, p. 156.

81 S. AMBROSIO, S. BASILIO, S. BUENAVENTURA, San Juan CRISOSTOMO Y STO. TOMAS. , "La tierra se hizo para ser disfrutada en común por ricos y pobres, ¿por qué, joh ricos!, os la apropiais para vosotros solos?. (Del libro de Nabott). Para GALAN, "El bonum conmune y el derecho de propiedad según el pensamiento aquinatense", en R.C.D.I. (mayo), 1940, pp. 285 y ss. en la propiedad privada tal y como Sto. Tomás la concibe, queda siempre destacado su sentido comunal, su f. s., en un sentido mucho más enérgico de lo que puedan admitirlo las teorías modernas que han tratado de corregir los excesos a que condujo el régimen de propiedad privada del capitalismo moderno. Es decir, continúa GALAN, que en el concepto tomista de la propiedad hay un sentido indudablemente solidarista... La propiedad de los bienes no destinados inmediatamente a la satisfacción de la propia subsistencia, no constituye un derecho absoluto y sin límites, sino que tiene que cumplir una función social indeclinable, que obliga al propietario a utilizar su propiedad en beneficio común.
} 
doctrinal estima que la función social es un mero límite externo que carece de virtualidad para integrar el contenido del derecho de propiedad 82.

La Iglesia postulaba ya el cumplimiento de la función social de la propiedad privada con gran anterioridad temporal a que fuese recibida en el pensamiento jurídico ${ }^{83}$. Las primeras obras técnico-jurídicas en las que se habla de la función social datan de principios del presente Siglo, mientras que del ejercicio social de la propiedad se trataba ya en la Encíclica Rerum Novarum, redactada por León XIII en $1891^{84}$.

En dicha encíclica, se sigue considerando la propiedad privada como un atributo natural de la persona humana y una condición para su libertad y se presenta, como un "elemento del orden social".

Al mismo tiempo se afirma en ella la existencia de una función social en la propiedad privada de los bienes que completa su función individual, ciertamente no se evita la admisión de la intervención del Estado para "prestar los debidos cuidados a la salvación y al bienestar de la clase proletaria".

La actual forma de concebir en el mundo jurídico el principio de la función social, nada tiene que ver con el sentido que inicialmente le fue otorgado y hoy en día es mantenido por la Iglesia Católica.

\footnotetext{
82 Para un estudio más amplio de la doctrina social de la Iglesia Católica en materia de propiedad privada, vid. entre otros SIERRA BRAVO,R., La propiedad privada en la doctrina social de la lglesia, Madrid, 1967, p. 17 y ss.; RUIZ JIMENEZ, J., La propiedad, sus problemas y su función social, Vol. II, Madrid, 1962, p. 161 y ss.; REY MARTINEZ, F., La propiedad privada en la Constitución española, Madrid, 1994, p. 92 y ss. Esta doctrina social, sucintamente expuesta, y hoy día mantenida por la Iglesia Católica, ha sido tomada como punto de referencia por algunos juristas para construir, en el ámbito estrictamente jurídico, sus teorías acerca de la función social de la propiedad privada. Se trata de autores que sitúan la acción de ese principio en el ámbito externo del derecho de propiedad, por considerar que no es un concepto jurídico en sentido estricto, sino una mera regla programática de carácter interpretativo, como es el caso, en nuestra doctrina, de DE LOS MOZOS, El derecho de propiedad: crisis y retorno a la tradición jurídica, Madrid, 1993, p. 201 y 202.

83 Vid. DUGUIT, L., en sus estudios Las transformaciones generales del Derecho Privado desde el Código de Napoleón. Trad. A. Posada. Valparaíso (Chile), 1987p. 139 y ss.; Las transformaciones generales del Derecho Público y Privado. Trad. A. Posada, R. Jaen y C. Posada, Buenos Aires, 1975, p. 241 y ss.

84 El texto completo de esta Encíclica puede verse en Doctrina-Pontífica -Documentos sociales, Madrid, 1959, pp. 311 y ss.
} 
Para la doctrina social reiterada en las distintas Encíclicas Pontificias, la propiedad privada es un derecho natural que tiene su origen no en los hombres, sino en Dios. La naturaleza divina ha dado a los particulares la propiedad y, por lo tanto, debe ser concebida como un derecho inviolable y absoluto anterior al Estado mismo85.

Los Papas que fueron sucediéndose hasta el Concilio Vaticano II consolidan esta doctrina que, aunque mantiene como postulado fundamental que la propiedad es un derecho natural que el poder debe respetar en todo caso, predica la idea de un individualismo que niegue el aspecto social y público del derecho de propiedad y admite estar reservadas a la colectividad.

Quienes son propietarios han de considerarse, privilegiados y, por esa misma razón, han de compartir sus bienes con los demás, porque son escasos. Si la Iglesia defiende la propiedad privada es debido a que con ella se persigue un alto fin ético-social. Su uso ha de servir siempre al bien común ${ }^{86}$. Aunque la propiedad es un derecho natural que ha sido dado por Dios a los hombres, se cree que corresponde al individuo, en cuanto que propietario, la labor de perseguir junto a su interés particular, el interés general y el bien común, compartiendo sus riquezas con aquellos que nada poseen ${ }^{87}$

De estos argumentos es posible concluir que para el pensamiento católico, la función social es una regla moral carente de valor jurídico que opera desde el ámbito externo de la propiedad privada, porque ésta se considera como un derecho natural e inviolable anterior al Estado y al Derecho mismo.

La doctrina social de la Iglesia expuesta parece haber sido tomada como punto de referencia por algunos juristas para construir, en el ámbito

\footnotetext{
85 Vid. en alusión a esta doctrina, COLINA GAREA, R., La función social de la propiedad privada en la Constitución española de 1978, Barcelona 1997, p. 196.

86 Vid. FUENMAYOR , A., La propiedad privada y su función social, Vol. I, Pamplona, 1992, p. 620 y 621.

87 Vid. CAMPUZANO Y HORMA, F., "El derecho de propiedad en la nueva Constitución española" en RDP, diciembre de 1931 y enero de 1932p. 360; CASTAN TOBEÑAS, J., Familia y propiedad. La propiedad familiar en la esfera Civil y en la del Derecho Agrario, Madrid, 1956, p. 46 y 47.
} 
estrictamente jurídico, sus teorías acerca de la función social de la propiedad privada. Nos referimos a los autores que sitúan este principio en el ámbito externo del derecho de propiedad, por considerar que no es un concepto jurídico en sentido estricto, sino una mera regla programática de carácter interpretativo 88

88 Vid. DE MARTINO, F., Commentario del Codice Civile, Bologna, 1976, p. 145; IANNELLI, A., La proprietà costituzionale, Napoli, 1980, pp. 238 y 239. En nuestra doctrina, DE LOS MOZOS, J., Voz "Propiedad". Nueva Enciclopedia Jurídica Seix. T. XX, Barcelona, 1993,p. 945; El derecho de propiedad: crisis y retorno a la tradición jurídica, Madrid, 1993, pp. 201 y 202 


\section{LA PROPIEDAD PRIVADA EN LA CODIFICACION FRANCESA: ANTECEDENTES E INFLUENCIA EJERCITADA.}

El triunfo de la Revolución de 1789 y el asentamiento de la burguesía en el poder establecen las bases políticas y sociales necesarias para la definitiva configuración del derecho de propiedad como un derecho subjetivo fundamentado en la naturaleza de la persona humana, y atribuido a la misma, perfilándose así un concepto de dominio que va a constituir el eje central sobre el que se desarrollarán las construcciones dogmáticas del llamado individualismo jurídico en el que confluyen y se condensan la influencia del pensamiento del iusnaturalismo racionalista, la visión económica de los fisiócratas y las aportaciones teóricas de los grandes juristas franceses de los siglos XVII y XVIII ${ }^{99}$.

La teoría individualista del derecho de propiedad corresponde a una etapa histórica, más o menos amplia, aunque, se considere como la teoría más representativa que haya existido, a nuestro entender, por dos razones fundamentales: en primer lugar, porque ha sido la construcción

${ }^{89}$ Sobre el tema de los orígenes doctrinales de la propiedad individual y su manifestación en el Code Napoleón vid., entre otros: ALPA, G., y BESSONE, M., Poteri dei privati e statuto della propietá. II. Storia, funzione sociale, publici interventi, Padova, 1980, pp. 1 y ss.; ARNAUD, A.J., Les origines doctrinales du Code civil français, Paris, 1969, p. 182 y ss.; IDEM, Essai dánalise estructurale du Code civil français. La régle du jeu dans la paix bourgoise ${ }_{2}$ Paris, 1973; VIOLLET, Histoire du droit civil francais, Paris, 1905, p.555 a 561; RODOTA, Il terribile diritto. Saggi sulla propietá pirvata, cit., en particular La definizione della propietá nella codificazione napoleonica, Bologna, 1981, p. 61 y ss.; TARELLO, G., La ideología della codificazione nel secolo XIX, Genova, 1971, p. 43 y ss.; IDEM, Storia della cultura giuridica moderna, I. Assolutismo e codificazione del diritto, Bologna, 1976; WIEACKER, F., Storia del Diritto privato moderno, Milano 1980 (trad. it.), vol. I., p. 518 y ss.

Además puede verse:

AZCARATE, Ensayo sobre la historia del derecho de propiedad..., cit., T. II, p. 269 y ss.; CASTAN TOBEÑAS, La propiedad y sus problemas actuales, 2a. ed., Madrid, 1982, p. 40 y ss.; GITRAMA, M., Nuevo sentido de la propiedad, Valencia, 1960, p. 10; MONTES, La propiedad privada, cit., p. 37 y ss. 
jurídica que más tiempo ha perdurado en el mundo occidental, y en segundo lugar, porque ha sido el soporte de la mayoría de los ordenamientos jurídicos hasta casi la entrada de la época actual, en la que algunos de ellos, tratan de corregir los excesos y dificultades a que ha dado lugar la teoría individualista del derecho de propiedad.

Esta concepción del Derecho de propiedad, cuyo nacimiento y configuración se encuentra en el derecho romano, va a aparecer con más vivacidad en el siglo XVIII. Son las escuelas filosóficas de la época quienes, partiendo de la estructura y caracteres del derecho de propiedad romano, van a acentuar aún más sus metas individualistas.

Para CASTAN, más que en el Derecho romano, el origen claro, directo y muy próximo de la concepción individualista de la propiedad se encuentra, de una parte en las escuelas filosóficas de signo iusnaturalista y racional, que partían del falso concepto de que la propiedad tiene por esencia su carácter ilimitado y que su ordenación típica la dicta la naturaleza y la razón, desligada de toda clase de factores históricos; y de otra, en los escritores políticos ingleses, con JOHN LOCKE al frente, y en la escuela llamada clásica, del liberalismo económico de signo individualista (ADAM SMITH, los Fisiócratas, etc.).

Las escuelas filosóficas van a reaccionar contra la centralización de la monarquía absoluta. Contra esta política de centralización que, como hemos visto anteriormente, afectaba al derecho de propiedad, se van a pronunciar los filósofos de la Escuela del Derecho Natural, exaltando el aspecto individual, y considerando los derechos como naturales y por tanto, innatos al individuo. 
Teniendo en cuenta esta ideología, la propiedad no puede considerarse subordinada al dominio del soberano, sino como un derecho individual innato, independiente de la voluntad del soberano, con el contenido más absoluto posible, y que no puede ser limitado en principio, salvo por causa de necesidad pública (expropiación).

De acuerdo con lo dicho anteriormente podemos resumir en cuatro los rasgos que caracterizan el liberalismo:

- Hegemonía excluyente del individuo.

- El individuo como clave de la sociedad atómicamente estructurada.

- El individuo como centro de protección jurídica.

- Valorar en él, sobre todo, el poder de la voluntad, única proyección de la personalidad 90 .

La cristalización técnico-jurídica de este concepto de dominio tendrá lugar, tras algunas vicisitudes ${ }^{91}$, en el Code Civil, constituyendo la «piedra angular» del mismo92, pues, como declaraba expresamente PORTALIS en la Exposición de Motivos del propio texto normativo, «el cuerpo entero del Code Civil está consagrado a definir todo aquello que incumbe al ejercicio del derecho de propiedad; derecho fundamental sobre

90 PEREZ GONZALEZ, B., «Ley de Régimen del Suelo». Discurso pronunciado ante el Pleno de las Cortes Españolas el día 12 de mayo de 1956, en Rev. de Estudios de la vida local (julioagosto), 1956, p. 446.

BALLARIN, refiriéndose al Código Civil español afirma que éste era también un código fisiócrata, inspirado en el «liberalismo económico templado». Por esa razón se centraba en el hombre visto como individuo o ciudadano, abstracción hecha de las circunstancias geográficas, familiares y profesionales» en Estudios de Derecho Agrario y Política Agraria. Madrid, 1975, p. 95.

91 Para un análisis de estas vicisitudes cfr. RODOTA, Poteri dei privati e disciplina della propietá. I/ diritto privato nella societá moderna. Bologna, 1977, pp. 356 y ss.

92 La expresión DE PAGE, H., Traité élémentaire de Droit civil Belga, Bruxelles, 1952, T. V, p. 784, que afirmará: «Se puede decir que el Derecho privado casi entero está presentado en el Código civil desde el solo punto de vista de la propiedad». 
el cual reposan todas las instituciones sociales y que para el individuo es tan precioso como la vida misma, pues le asegura el medio de conservarla»93.

Con este punto de partida, y a pesar de la poca extensión del título que el código dedica a regular la disciplina de la propiedad (solamente los artículos 544 a 577), la idea de la misma está presente en la regulación del resto de las instituciones. Además, el Código dedica una especial atención a las cuestiones pertenecientes a la propiedad inmobiliaria94. Con lo que se ha podido afirmar que más que el Código de las personas, el Code civil es el de las cosas y de la riqueza adquirida95.

Por lo tanto, mientras que en la Declaración de los Derechos del Hombre y del Ciudadano de 16 de agosto de 1789 reconoce el derecho de propiedad como derecho natural del hombre «sacre et inviolable»96 con ello «Se pretende en primer lugar, proteger la propiedad contra la arbitrariedad del absolutismo y garantizar, en segundo lugar, el nuevo orden económico creado por la propia Revolución»97; en el Code Civil de 1804 se va a consolidar el dominio como un derecho subjetivo absoluto, exclusivo y

93 PORTALIS, J.M.E., Presentation au Corps Législatif et exposé des motifs, no 35, FENET, P.A., Recueil complet des travaux prèparatoires du Code Civil, Paris, 1927 (reimpresión, 1970), en particular, T. XI, p. 115 a 134.

94 Cfr. SOREL, A., Introduction. Le Code Civil, 1804-1904. Libre du Centenaire, Paris, 1904, T. I, p. XXXI, «Par ce mot, il (le Code) entenal a peu prés exclusivement l'immeuble, la maison et sourtotut la terre».

También podemos citar entre otros SAVY, R., «La Constitution des juges», Dalloz, 1983, p. 107. PESET, M., «Acerca de la propiedad en el Code», RCDI, 1976, p. 884.

95 Cfr. MORIN, G., La révolte du droit contra le Code, Paris, 1954, p. 114.

96 Establece en su Art. 2o: «Le but de toute association politique est la conservatión des droits naturels et imprescriptibles de l'homme. Ces droits sont la liberté, la propieté, la sureté et la resistance á l'opression». En este Art. 2 se catalogan como «derechos naturales e imprescindibles del hombre la libertad, la propiedad, la seguridad y la resistencia a la opresión, al tiempo que se cataloga al derecho de propiedad en el Art. 17 con los atributos de «sagrada e inviolable»; el cual dispone que "la propieté étant un droit inviolable et sacre, nul ne peut en etre privé, si ce n'est lorsque le nècesité publique légalmente constaté, l'exige evidentement, et sons la condition d'une juste et preable indenmité».

97 Cfr. MOLITOR, E., «Nueva problemática de la propiedad», RDP, 1954, p. 172. 
perpetuo, según la opinión casi unánime de sus primeros comentaristas. Absoluta, en cuanto otorga a su titular un poder ilimitado sobre la cosa, ius utendi, ius fruendi, ius abutendi, exclusivo en cuanto que facilita el goce propio de la cosa y faculta para impedir el goce ajeno, y perpetuo en la medida en que no está sujeto a ninguna limitación temporal, puede durar tanto como la cosa sobre la que recae y no prescribe por falta de ejercicio con el paso del tiempo.

Esta noción de propiedad, que gozó de la favorable acogida de los comentaristas ${ }^{98}$, y que lleva a configurar el dominio como un derecho general y abstracto de un sujeto sobre un bien, alcanzó con POTHIER ${ }^{99}$ su maduración, y al ser identificada con aquella otra atribuida al Derecho romano, «dominium est ius utendi et abutendi quatenus iuris ratio patitur», va a dar origen al concepto del artículo 544 del Código francés: «La propieté est le droit de jouir et désposer des choses de la maniére la plus absolute, pour- vou q'on n'en fasse un usage prohibé par les lois ou les réglements» 100 .

El artículo citado precedentemente establece que «la propiedad es el derecho de gozar y disponer de las cosas de la manera más absoluta». Concepto que es acogido por el Código Civil español en el

98 Vid. PECINELLI, F., Studi e ricerche intorno alla definizione "dominius est ius utendi et abutendi», Firenze, 1886, reed Napoli, 1980 p. 42 y ss.; BRUGGI, B., Della propietá, NapoliTorino, 1923 (2a. ed.) T. I, p. 28 y ss.

99 Si DOMAT intuyó esta nación y el concepto del derecho subjetivo al tratar de unificar las variadas situaciones reales existentes en el Antiguo Régimen, Les lois civiles dans leur ordre naturel, Oeuvres de J. Domat, Paris, 1823, T. IV, p. 242, en POTHIER se produce la maduración jurídica del concepto. Traité du Droit de Domaine de Propieté, Oeuvres, Paris, 1825, p. 114. Vid. además GROSSI, P., «Un paradiso per Pothier (R.J. Pothier e la propietá moderna») Q.F., 1985, p. 401 y ss., donde se intenta precisar el papel jugado por este autor en la formación del concepto moderno de la propiedad.

100 Por lo que respecta a la influencia que la teoría de la propiedad elaborada por POTHIER ejerció en el Code, ARNAUD, Les origenes doctrinales du Code civil français, Paris, 1969, p. 187, allí se afirma que «tout le traité du Droit du Domaine du n. 150 au n. 192, se trouve, presque article per article, dans le titre de la propiété». 
artículo 348, si bien prescindiendo de la frase «de la manera más absoluta» a que hace referencia el Código Napoleón.

La incorporación al Código francés de este modelo conceptual de propiedad se lleva a cabo, mediante un esquema abstracto que parace adaptarse a las necesidades que tiene la sociedad francesa de principio del siglo XIX, en ese momento, el derecho de propiedad se configura como un poder del propietario, cuyo contenido se presenta como potencialmente ilimitado, y que se concreta y define mediante el libre ejercicio por su titular, ejercicio que no podrá ser perturbado por la actuación de los demás, o a lo sumo sólo como señala SAVATIER ${ }^{101}$, por las reservas que imponen las relaciones de vecindad.

Como contrapartida a este poder del propietario «el mismo art. 544 se ocupa de anunciar la existencia de restricciones de carácter extrínseco al propio derecho, mediante «leyes o reglamentos», a los cuales el Derecho de propiedad es susceptible de estar sometido. Intereses de orden superior, de orden general o público, de orden social, imponen a veces que se suavice un poco el absolutismo del derecho de propiedad, que se prohiba a los propietarios ciertos actos de ejercicio, incluso que se les obligue a hacer alguna cosa, a cumplir diversas obligaciones, por el solo hecho de ser detentadores de bienes colocados bajo ciertas condiciones.

El legislador, bajo la única reserva del respeto a la constitución y a los principios del derecho público, es libre de determinar la extensión del sacrificio que la propiedad debe sufrir en interés general ${ }^{102}$.

101 SAVATIER, R.,Du Droit Civil au Droit Public, 10a. ed. Paris, 1950, p. 41.

102 Vid. BAUDRY-LACANTINERIE, G., y CHAVEAU, M., Traité théorique et pratique de droit civil. Les biens, Paris, 1905 (3a. ed.), p. 159-160. 
Por eso estas limitaciones externas, generalmente de carácter negativo (usage prohibé), se van a configurar únicamente como meras restricciones impuestas por el legislador al poder del propietario. E incluso, las «leyes y reglamentos» servirán como instrumento para ulteriores refuerzos de los poderes del mismo103.

Este marco legal así definido prevé las posibles limitaciones del contenido de la propiedad, como una garantía legal del derecho, que va a encontrar su refrendo en el art. 545 del mismo Código, en el que se prevé la posibilidad de supuestos de expropiación forzosa por causa de utilidad pública ${ }^{104}$.

Este concepto del dominio establecido en el art. 544, es producto no sólo de una determinada formulación legislativa, sino también de una elaboración doctrinal rigurosa que de la misma va a hacer la Escuela de la Exégesis ${ }^{105}$.

Son los comentaristas de la Escuela de la Exégesis ${ }^{106}$, quienes van a predicar el carácter absoluto del derecho de propiedad, en principio como un poder sin límites, en este sentido, escribe DEMOLOMBE, «La propiedad confiere al señor sobre la cosa un poder soberano, un despotismo completo»107. Estas afirmaciones, bastante exageradas ${ }^{108}$,

103 Cfr. RODOTA, II terribile diritto, cit., p. 70.

104 «Nadie puede ser constreñido a ceder su propiedad, sino es por causa de utilidad pública y mediante una justa y previa indemnización».

Obsérvese la dulcificación producida respecto al artc. 17 de la Declaración de los Derechos del Hombre que exigía «necesidad pública» 1 , lo que ya implica por sí mismo un aumento de las prerrogativas de la Administración Pública. Son de gran interés al respecto las indicaciones que hace SACCO, R., La propietá, Torino, 1968, p. 123 y ss.

105 Sobre el particular vid. GENY, F.,_Méthode d'interpretation et sourcen en droit privé positif, Paris, 1899. BONNECASE, J., L'Ecole de l'Exégése en Droit civil, Paris, 1924 (2a. ed.)

106 Entre los más representativos DEMOLOMBE, TOULLIER, POTHIER, LAURENT.

107 DEMOLOMBRE, Cours de Code Napoleon, Paris, 1845, T. 9, p. 485. En un sentido similar se van a manifestar el resto de los comentaristas, cfr. VIDAL, M., La propiété dans L'Ecole de l'Exègese en France», Itinerari moderni della propietà, cit., T. I, p. 30-32. 
llevan a la necesidad de plantearse una cuestión clave para la adecuada compresión del modelo de propiedad consagrado por la codificación.

En este sentido aparecen manifiestas dos líneas de aproximación al concepto de propiedad bien diferenciadas.

De un lado se hace aparecer al artículo 544 como el símbolo más calificado del individualismo jurídico. De otro, por el contrario, se trata de dulcificar esta concepción individualista, y se afirma que el esquema formal que queda plasmado en dicho artículo debe ser entendido como un instrumento, que puede ser utilizado para cualquier operación que tenga por finalidad reducir los poderes del propietario en favor de la colectividad que le reconoce y garantiza su derecho, y que, por lo tanto, debe ser mantenido y conservado.

A pesar del desarrollo de la normativa que incide en materia de propiedad, restringiendo los poderes del dueño, la permanencia de la definición unitaria, no responde a «una obsesión monomaniática de estudiosos incapaces de abandonar los esquemas predilectos, y para ello estar dispuestos a violentar la misma realidad legislativa, sino más bien es reflejo fiel de una situación en la cual la Legislación, incluso habiendo introducido numerosas regulaciones de los poderes del propietario, no había abierto ninguna fractura real de la trama individualista del instituto»109.

Para ello confluyen una serie de factores que deben ser puestos de relieve.

108 REMY, PH.,Eloge de l'exégése, Droits, 1, 1985, p. 115 y ss.

109 Cfr. RODOTA, Scienza giuridica ufficiale e definizioni della propietá, I terribile diritto, cit., p. 124. 
En primer lugar, hay que tener en cuenta que la Codificación representaba «la actuación de la idea individualista en el orden de las relaciones civiles. Por eso, la Codificación responde, en el campo de los derechos privados, a lo que las declaraciones de derechos y las constituciones en el campo del Derecho público... como éstas estaban dirigidas a garantizar la libertad política de los ciudadanos en sus relaciones con el Estado, así los Códigos procuraban asegurar la libertad civil del individuo en su vida privada contra las indebidas injerencias del poder político» 110 .

Este valor «constitucional» del Código, impone un preciso límite al legislador:

el respeto del dominio, lo que lleva a la necesidad de que las leyes especiales dictadas sean coherentes con los principios del Código civil111, ya que la concepción individualista del derecho se presenta como aquella que representa mejor la eliminación formal de los privilegios y la liberación de las innumerables cargas feudales que recaían sobre la tierra, materializando así las ideas de igualdad y libertad 112 .

Teniendo en cuenta lo anterior, la ilimitada atribución de poderes al propietario individual, afirmada en las definiciones legislativas y científicas, debe de entenderse como una limitación al poder del Estado en

110 SOLARI, G., Individualismo e Diritto privato, Torino, 1957 p. 57. Sobre esta relación existente entre Código y Constitución vid. además PEREZ SERRANO, N., "Constitucionalismo y Codificación», RGLJ, 1953 (número extraordinario del centenario), p. 50 y ss.; DE CASTRO, F., Derecho Civil de España, Madrid, 1955, T. I, p. 194 y ss.; TARELLO, Storia della cultura giuridica moderna, I. Assolutismo e codificazione del diritto, Bologna, 1973, p. 22 y ss.; TORRALBA, V., «El Derecho civil desde la Codificación hasta el tiempo presente». RGLJ, 1975, I, p. 247 y ss.; DE LOS MOZOS, J.L., Derecho Civil español, I, Parte General vol. 1ํ, Introducción al Derecho Civil, Salamanca, 1977, p. 192 y ss.

111 Cfr. RODOTA, Scienza giuridica ufficiale... cit., 117 y ss.; en particular BARCELLONA, P., Diritto privato e processo económico, Napoli, 1973, p. 127 y ss.

112 IRTI, N., Dal Diritto civile al Diritto agrario, Milano, 1962, pp. 4 y ss. y el trabajo de RODOTA, "La definizione della propietà nella codificazione napoleónica», "I terribile diritto, cit., especialmente p. 92. 
la materia113 por lo que incluso las normas sobre expropiación van a representar, más que limitaciones a la propiedad, un conjunto de garantías legales de la situación propietaria114.

Teniendo presente estas consideraciones se puede afirmar que con el art. 544 se tiende a individualizar la esfera de acción de cada propietario, a marcar los criterios de resolución de conflictos inter privados, y a fijar la garantía de la propiedad frente al Estado, más que a crear instrumentos para armonizar el interés individual con el interés social115.

La concepción de la propiedad que se plasma en el artículo 544 del Code civil francés va a ser aceptada en la mayor parte de Europa. En general, los Códigos civiles del siglo XIX, van a seguir la línea marcada por su predecesor.

Tras estallar, en 1914, la I Guerra Europea, se produce un hito que marca definitivamente el comienzo de una nueva etapa en la configuración jurídica de la propiedad privada116. La llamada legislación de guerra comportó notables cambios en la disciplina de la propiedad, multiplicándose las intervenciones del Estado para una economía de guerra. En este sentido, el interés nacional obligó a un esfuerzo común de la sociedad, primero para contribuir a un satisfactorio desarrollo de la guerra y después para la posterior reconstrucción de los países que intervinieron en el conflicto bélico. Este esfuerzo llevaba ligada la necesidad

113 RODOTA, «La definizione... cit., p. 91; IDEM, «Scienza giuridica...», cit., p. 120

114 GARCIA DE ENTERRIA, E., «Potestad expropiatoria y garantía patrimonial en la nueva Ley de Expropiación Forzosa», ADC, 1955, p. 1023 y ss.

115 En este sentido vid., IRTI, Dal Diritto Civile, cit., p. 36; BARCELLONA, Diritto privatto..., cit., pp. 183 y ss.

116 Vid. entre otros VASALLI, «Della legislazione di guerra e dei nuovi confini del diritto privato», Studi, II, cit., pp. 359 y ss. ; FERRARA, «Influenza giuridica della guerra nei raporti civili» 1915, y «Diritto di guerra e diritto di pace» 1918, Scritti giuridici, Milano, 1954, T.I, pp. 33 y ss.., y 64 y ss.; CARBONNIER, J., Derecho Flexible, Madrid, 1972 (trad. esp) p. 216; ALPA-BESSONE, Poteri dei privati..., II, ob. cit. , pp. 87 y ss. ; PUGLIATTI, La proprietà nel nouvo Diritto, Milano, 1954, pp. 91 y ss. 
de introducir restricciones a la autonomía privada de los propietarios para hacer frente a las necesidades colectivas generadas por la guerra.

Esta actitud del Estado basada en una política intervencionista instrumentada a través de la legislación especial, y que se irá generalizando por todo Europa, penetró profundamente en el subsuelo de la organización económico-jurídica, surgiendo con fuerza en el período postbélico, manteniéndose después y revelándose idónea para cimentar las estructuras del Estado social moderno, tras enlazar con las concepciones jurídicas que propugnaban la prevalencia de la dimensión social de la propiedad privada ${ }^{117}$.

En Francia, como en otros países de la Europa Occidental, en torno a la I Guerra Mundial se abre un nuevo período en la evolución del derecho de propiedad ${ }^{118}$. Al amparo del artículo 544, in fine, del Código civil $^{119}$, se van multiplicando las escasas restricciones que el Código civil preveía en los poderes del propietario sobre el objeto de su dominio, especialmente en interés de otros propietarios vecinos, concretándose en limitaciones legales impuestas por razones de interés público a la libertad de acción del propietario ${ }^{120}$ y en razón a las diversas obligaciones legales que se ponen a su cargo ${ }^{121}$.

117 Vid. PUGLIATTI, La proprietà, ob. cit., p. 92.

118 Acerca del proceso de transformación del derecho de propiedad que se consolida en Francia tras la I Guerra Mundial pueden verse entre otros: CARBONNIER, J.,_Derecho Flexible, ob. cit., pp. 216 y ss.; DUGUIT, Les transformations générales du droit privé depuis le Code Napoleon, Paris, 1912 ( trad, esp. Transformaciones de Derecho público y privado, buenos Aires, s.f., pp. 235 y ss.; GILLI, J.P.,Redefinir le droit de propriété, Paris, 1975, pp. 121 y ss.; GONNARD, R., La propriété dans la doctrine et dans l'histoire, Paris, 1943.

119 Vid. VAREILLES-SOMMIERES, «La définition et la notion juridique de la propriété», Rev.Trim. Der.Civ., 1905p. 443, «el derecho en virtud del cual una persona puede, en principio, hacer de una cosa lo que quiera de ella»

120 Vid. BONNECASE, J., Elementos de Derecho civil, T. I, Puebla, 1945 (trad. esp.), 644 y ss. ; COLIN, A., y CAPITANT, H., Curso elemental de Derecho civil, T. II, vol. 2o, Madrid, 1961 (trad, y notas D. DE BUEN). pp. 152 y ss. ; PLANIOL, M., Y RIPERT, G., Traité pratique de Droit civil francais, T. III, Les biens, Paris, 1952, pp. 411 y ss.

121 Vid. JOSSERAND, «Configuration du droit de propriété...»,ob.cit., p. 107; MORIN, «Le sens de l'evolution contemporaine du droit de propriété», Etudes Ripert, pp. 6 y ss.; SAVATIER, R., Du Droit civil au Droit public, Paris, 1950, pp. 40 y ss. ; WEILL, «Les limitations apportées à la 
Por tanto, el proceso de adaptación del instituto de la propiedad a las exigencias de la nueva realidad social, se ha operado sin modificar la fórmula del artículo 544 del Código civil. La adecuación de la propiedad a los intereses sociales se articula, de este modo, actuando externamente mediante técnicas predominantemente publicistas, por lo que la fisonomía de la propiedad se verá progresivamente condicionada por una reglamentación de carácter preferentemente administrativo.

Es especialmente significativo que, en los trabajos de la mayor parte de los juristas franceses de la época, las controversias suscitadas en torno a la propiedad encuentran escaso eco. En general, prefieren atenerse a la estricta exposición del Derecho positivo, limitándose a dejar constancia de las cada vez más abundantes restricciones de los poderes del propietario en razón del interés público. Sin embargo, esta actitud encuentra su contrapunto a partir de 1905, año en el que comenzó a tomar cuerpo la teoría de la función social de la propiedad propuesta por Duguit, para tratar de corregir los desequilibrios producidos en la vida social por el cariz individualista que inspiraba el concepto de propiedad vigente en Francia122. 


\section{CAPITULO CUARTO.}

\section{LA PROPIEDAD Y SUS LIMITES EN EL CODIGO CIVIL}

ESPAÑOL.

\section{INTRODUCCION:}

A pesar de las particularidades que presenta el ordenamiento jurídico español, no hay que olvidar que en los países de Europa Occidental, que forman nuestro entorno cultural, existe una tradicción jurídica común-romanista consolidada por la Codificación Civil que aún pervive en la actualidad. Por ello no es extraño que en líneas generales la noción de apropiación exclusiva de las cosas, la idea de propiedad privada, y el modelo conceptual que la sustenta, sea el mismo que sigue latiendo en nuestra cultura jurídica. Así, como tendremos ocasión de comprobar, el artículo 348 párrafo primero, de nuestro Código Civil presenta un indudable parentesco con las fórmulas que utilizan los códigos vigentes en los países más importantes de la Europa continental al referirse a la propiedad.

Antes de entrar en un análisis, que no puede ser exhaustivo ya que excedería al objetivo de este capítulo, del material normativo que disciplina actualmente el derecho de propiedad (Código civil, Leyes especiales y Constitucionales españolas de 1978) consideramos de especial importancia deslindar lo más claramente posible cómo se incorpora este concepto a nuestro Derecho Codificado.

Debe tenerse en cuenta que el Código civil español no responde, como el Código civil francés, al intento de consagrar la propiedad individual desde una óptica revolucionaria, dado que no se trata de afirmar y 
garantizar la propiedad frente a las trabas, que procedentes de la Edad Media, recaían sobre la misma, sino más bien de completar un largo proceso de consolidación de los derechos adquiridos y de defender y reafirmar la propiedad privada frente a todos aquellos que la ponían en cuestión o prentendían negarla123.

Por eso, el Código civil va a responder a un individualismo moderado destinado a mantener el status quo de la propiedad que a lo largo del siglo XIX, ha quedado libre de las trabas señoriales, se ha visto desvinculada y desamortizada, consolidándose los derechos de propiedad adquiridos como consecuencia de la misma a través de la legislación hipotecaria que comienza a desarrollarse a partir de $1855^{124}$.

Por otra parte, en España, aunque no con la misma intensidad que en otros países de Europa, surge el interés por la cuestión social que nace de la falta de armonía existente entre el Derecho privado, fundamentado en principios individualistas, y los nuevos problemas a los que se va a enfrentar un derecho público desarrollado con criterios diferentes y con una preocupación cada vez mayor por el interés público. La inadecuación del Derecho privado para resolver las exigencias sociales que comienzan a

123 Vid. LACRUZ BERDEJO, J.L., Elementos de Derecho Civil. Tomo III, Derechos reales. Vol. 1‥ Posesión y Propiedad. Barcelona 1979 p. 172, quien afirma que la fórmula que utiliza el Código en el artículo 348 "es sustancialmente la misma fórmula que un siglo antes se presentaba como revolucionaria, repensada ahora en un contexto económico y social cambiado, en sentido conservador. Merced, más que al significado literal de las palabras, al que tienen en la mente del legislador y sus contemporáneos, la propiedad privada cuya liberación de los vínculos feudales era a principios de siglo una exigencia ineludible de la economía, se confirma aquí, en cuanto a derecho "sagrado", como instrumento de salvaguarda del status quo en favor de las clases posidentes, y más en particular de la nueva burguesía nacida al amparo de la desamortización y de las grandes obras públicas". También MONTES, U., La propiedad privada en el sistema de Derecho Civil Contemporáneo, Madrid, 1980, p. 37 y ss.

124 Vid. GALLEGO, G., "Ideología y progresismo en la legislación hipotecaria del XIX", RCDI, 1986, pp. 621 y ss.; MALUQUER DE MOTES, C.J., "La Codificación civil en España (síntesis de un proceso)", RDP, 1981, pp. 183 y ss., que pone de relieve cómo se consolida por la legislación hipotecaria la propiedad adquirida como consecuencia de la desamortización; OLIVER, Derecho inmobiliario español, Madrid, 1892; GONZALEZ, J.,Estudios de derecho Hipotecario y Derecho Civil, Madrid, 1948. 
surgir hace que el denominado problema social ${ }^{125}$ no esté completamente ausente del proceso de formación del Código Civil126, y que pueda surgir en la ciencia jurídica española una preocupación por el estudio del derecho de propiedad a lo largo de la 2a. mitad del siglo XIX ${ }^{127}$.

Como se ha puesto de manifiesto reiteradamente por la doctrina, definir el derecho de propiedad no es tarea fácil. Una de las causas de esta circunstancia, y quizás la más directa, es el hecho de que el concepto de la institución que examinamos se encuentra históricamente muy condicionado, como ya hemos visto anteriormente. Son las circunstancias socioeconómicas y políticas, las que en cada momento histórico, van a determinar las directrices para su configuración.

Antes de entrar en el tema de cuál sea el concepto que la doctrina ha dado sobre el derecho de propiedad, vamos a apuntar la diferente terminología que se ha usado para diferenciarla. Los jurisconsultos romanos usaban dos términos distintos al hablar de propiedad: dominium y propietas $^{128}$. Los autores han intentado dar explicación a esta diversa terminología, afirmando que el término dominio es más extenso que el de propiedad, pues el primero abarca no sólo el dominio directo, sino también el útil, mientras que el segundo (propiedad) sólo hace referencia al dominio

125 Significativo al respecto es AZCARATE, G., Resumen de un debate sobre el problema social, Madrid, 1877, recogido como apéndice de su importante obra Ensayo sobre la historia del Derecho de propiedad, cit., T. III, pp. 355 y ss.

126Vid., LASO GAITE, J., Codificación Civil_(Génesis e historia del Código). Crónicas de la Codificación española, T. $4^{\circ}$, vol. $1^{\circ}$., p. 444.

${ }^{127}$ Entre los más importantes destacaremos:

ATARD, R., "La propiedad del subsuelo", RGLJ, 1873, pp. 970 y ss.; ALONSO MARTINEZ, M., Estudios sobre el derecho de propiedad, Madrid, 1874; AZCARATE, G., Ensayo sobre la historia del Derecho de propiedad, ob.cit., Madrid, 1879-1883 (3 vols.); GUTIERREZ, B., Influencia que en todos los tiempos ha ejercido el derecho de propiedad, y fines importantes que hoy está llamado a cumplir, Madrid, 1884; PEREZ Y OLIVA, I., Transformación en el concepto del derecho de propiedad en los últimos veinticinco años, Madrid, 1889.

128 STOLFI, N., Diritto civile. Vol. II, 1a. II posseso e la propietà. Torino, 1926. Con el término dominio se "acentúa el concepto de señorío sobre la cosa", mientras que propiedad venía a significar "la pertenencia de la cosa a la persona". 
directo. Para otro sector más moderno de la doctrina, representado en España por AZCARATE, el término propiedad es más extenso que la voz dominio, por cuanto con la expresión propiedad se designa toda relación del hombre con la naturaleza y todo poder sobre ella, mientras que el dominio debe aplicarse únicamente al poder pleno, indiviso e ilimitado de la persona sobre una cosa del mundo exterior ${ }^{129}$.

\author{
Actualmente se descarta casi unánimamente la distinción, \\ considerándose dominio y propiedad como sinónimos, y existiendo entre \\ ellos a lo sumo diferencia no en cuanto a su contenido, sino de puntos de \\ vista, toda vez que la propiedad es un concepto económico-jurídico, \\ mientras que el dominio lo es sólo jurídico ${ }^{130}$.
}

129 Como representantes de nuestra doctrina, que han diferenciado propiedad y dominio SANCHEZ ROMAN Y DE DIEGO. Para éste último, aunque propiedad y dominio se tomen como sinónimos, "aquella representa el género, o sea, la relación total que el hombre mantiene con la naturaleza para satisfacer las necesidades corporales, y claro es que significa también cada una de las relaciones particulares en que aquélla se desdobla; y el dominio representa la especie, es decir, una de esas relaciones interiores, y, por cierto, la más extensa y compleja, la que más amplio poder atribuye al propietario". Instituciones de Derecho Civil. Tomo I. Introducción general. Propiedad -Derechos reales. Madrid, 1959, p. 310. SANCHEZ ROMAN, F., Estudios de Derecho Civil. Tomo III. Derechos reales. El Derecho de propiedad y sus modificaciones. 2a. ed. Madrid, 1900, pp. 77 y ss.;PUIG BRUTAU, Fundamentos de derecho civil, t. III, vol. I, Barcelona, 1971, p. 141, para quien el término propiedad tiene un sentido más amplio que el de dominio.

130 MANRESA, J.M., Comentarios al Código Civil Español. Tomo III. 8a. ed. revisada y puesta al día por RICO PEREZ. Madrid, 1960, p. 184; SCAEVOLA, M., Código Civil. Tomo VI. Artículo 333 y 383, 5a. ed. revisada por ORTEGA LORCA. Madrid, 1949, p. 451; ALBALADEJO, M., Derecho Civil. III. Derecho de bienes. Vol. I. Parte general y Derecho de la Propiedad. 3a. ed. Barcelona, 1977, pp. 243 y ss.; CASTAN TOBEÑAS, J., Derecho civil español, común y foral. Tomo II. Derechos de cosas. Vol. II. Los derechos reales restringidos. 13a. ed. Madrid, 1982, p. 85. Esta diferencia hace que, en el lenguaje corriente, se hable de la propiedad en un sentido muy genérico, que abarca muchas formas de señorío sobre toda clase de bienes (por ejemplo, propiedad de la herencia, propiedad de las marcas y patentes, propiedad literaria y hasta propiedad de los créditos y de las cargas), mientras que la palabra dominio se reserva, por lo general, en sentido técnico, para el señorío sobre las cosas corporales. Los autores más modernos no mencionan la distinción así, LACRUZ, Elementos de derecho civil, t. III, Vol.1ํㅡㄴ, Barcelona, 1990, p. 167; ALBALADEJO, Curso de derecho civil español, t. III, Derecho de bienes, Barcelona, 1985, p. 157. Nosotros utilizaremos ambos términos indistintamente. 


\section{ANTECEDENTES HISTORICOS QUE HAN INFLUIDO EN LA}

FORMACION DEL CONCEPTO DE DOMINIO.

El concepto de derecho de propiedad que se establece en el artículo 348 del Código civil no va a suponer ninguna ruptura con el concepto que se había consolidado en el Derecho histórico españo|131. Analizando las opiniones vertidas por la doctrina, se puede observar una perfecta continuidad en la comprensión de este concepto antes y después de la promulgación del Código, ya que las Partidas supusieron un punto de referencia importante para el legislador. Así, la referencia al concepto establecido por las Partidas es corriente entre los autores que se refieren al tema con anterioridad a la promulgación del Código Civil132. Tras el Código Civil la tendencia de sus comentaristas a referirse a las Partidas, como precedente inmediato del artículo en cuestión es también general133.

131 En la legislación de las Partidas, Ley 1a., Tit. XXVIII, Part. 3a., se dice: "Señorío es poder que me ha en su cosa fazer de ella e en ella lo que quisiere: segund Dios e segund fuero", concepto que GREGORIO LOPEZ glosa del siguiente modo: "Dominium est potestas faciendi quod quis vult de suis rebus ut ius permittit" y más adelante resume el concepto de dominio "in vera significatione et stricte, tunc dominium est ius de re corporati perfectore disponendi: nisi lege prohibeat", con expresa referencia a BARTOLO y a BALDO, lo que permite ver la diversidad de matiz que presenta su propia glosa con el concepto debido al magisterio de estos dos autores. Por su parte, la Ley 10, Tit. XXXIII, Part. 7a., se expresa en los términos siguientes: "Otrosí decimos que propiedad es el señorio de la cosa..." Debe notarse, además, que ya en Espéculo, Ley III, Tit. VIII, Libro $V_{2}$ definía el señorío como "aquel poder que ganan los ommesen las cosas... para ffazer dello lo que quissieran, que non ssea contra el derecho de las leyes deste nuestro Libro".

132 Vid. SALA, J., Ilustración del Derecho Real de España. Valencia 1803. T. I, p. 100; DOMINGO DE MORATO, D.R., Derecho Civil Español, Valladolid, 1868, T. I, pp.266-267; ELIAS, J.A., Derecho Civil General y Foral de España, Barcelona, 1876, T. II, p. 32; HERRERO, S., El Código Civil Español, Valladolid, 1872, p. 266; GOMEZ DE LA SERNA, P., y MONTALVAN, J.M., Elementos de Derecho Civil y Penal de España, Madrid, 1881 (13a. ed.) T. I, p. 571; GARCIA GOYENA, F., en sus Concordancias, motivos y comentarios al Código civil español, Madrid, 1852, conecta el concepto de propiedad que recoge el artículo 391 del Proyecto de 1851 con la legislación de las Partidas.

133 Entre otros, FALCON, M., Derecho civil español, común y foral, Barcelona, 1893, pp. $122-$ 123; ABELLA, J., Código civil español, Madrid, 1904 (5a. ed.), p. 171; PLANAS, J.M., Instituciones del Derecho civil español, Barcelona, 1913, pp. 308-309; MANRESA, J.M., Comentarios al Código civil español, Madrid, 1952, T. III, 17a. ed. , revisado por CALVILLO, J.J., p. 186. Por último MONTES, La propiedad privada, cit., pp. 18 y ss. 
La razón de esta continuidad es evidente, la Ley de Bases que sirve de cauce para la formación del Código, tanto de forma genérica como específicamente refiriéndose al derecho de propiedad, impone a los redactores del nuevo Código, el mantenimiento de los fundamentos capitales del Derecho histórico patrio ${ }^{134}$, mandato cuyo cumplimiento no se pone en duda, en ningún momento, en ninguna de las dos cámaras legislativas ${ }^{135}$. Lo que sí es cierto, es que los redactores del Código no pudieron sustraerse a la influencia dominante ejercida por el Code civil francés ${ }^{136}$.

Llegado el momento de la codificación, se ve la necesidad de establecer en los cuerpos legales la definición de la propiedad. La que establece el Código Napoleón ${ }^{137}$ de 1804 en su artículo 544, es transcrita

134 Así, la Base 1a. dispone: "El Código tomará por base el Proyecto de 1851 en cuanto se halla contenido en éste el sentido y capital pensamiento de las instituciones civiles del derecho histórico patrio....", y la Base 10a., por su parte, establece que "se mantendrá el concepto de propiedad y... con arreglo a los fundamentos capitales del Derecho patrio".

135 El senador ALDECOA, en su discurso ante el Senado en defensa del dictamen de la Comisión, vierte las siguientes afirmaciones, que no van a ser contradichas en ningún momento de los debates, "ninguno de los conceptos fundamentales de nuestro Derecho civil..., ni el concepto fundamental relativo a la propiead..., se separan en lo más mínimo, de nuestro Derecho tradicional, de los sentimientos del pueblo español y de todos los principios universales de derecho en relación con las necesidades verdaderamente sentidas en nuestra patria"; "Respecto a la propiedad, el concepto se desarrolla en consonancia con la Base 10 y en consonancia con nuestro Derecho tradicional, es un concepto esencialmente individualista, como que tiende a desarrollar la libertad y la personalidad humana, tal como hoy se entiende, y no como se entendía en el Derecho romano...". Diario de Sesiones, Senado, o 49, 19Febrero-1889, p. 788.

136 Vid. DE CASTRO. Derecho Civil de España. I, cit., pp. 219 y ss. que pone de relieve que "será esta forma afrancesada la que se imponga a la atención del espectador y la que hará que sin atender al contenido- se le clasifique como un Código más del grupo latino, imitador del Código de Napoleón. Juicio, intrínsecamente injusto, que desconoce su último sentido nacional...". DE LOS MOZOS, J.L., Derecho Civil español, vol. 1. Salamanca, 1977, p. 272273, quien recogiendo en términos generales, la opinión del anterior afirma que el Código civil "no es copia del Código civil francés, o a lo sumo lo es sólo, y para ello parcialmente, en la forma, no en el contenido"; GIBERT, R., La codificación civil en España (1752-1889), La formazione storica del Diritto moderno in Europa, Firenze, 1973, vol. II, pp. 907 y ss., para quien es inexacto considerarlo como una adaptación del Código francés. Es más bien una adaptación del Derecho español con el lenguaje francés, pues, "aunque aparente imitación del Código napoleónico, es más fiel a la tradición jurídica española que el Proyecto de 1851" p. 933.

137 Entre otros vid. CASTAN, Derecho Civil español, Tomo II, vol. 1ํ, cit., p. 139; COSSIO, A., Instituciones de Derecho civil, Madrid, 1975, vol. 2, p. 518; DIEZ PICAZO, L., y GULLON, A., Sistema de Derecho Civil, T. II, Madrid, 1981 (2a. ed.) p. 175; LASARTE, C., Consideraciones previas al estudio del derecho de edificación: pluralismo de la propiedad privada", RGCJ, 1976, p. 16; MONTES, V., La propiedad privada, cit., p. 20; IDEM., Comentarios al Código Civil y a las 
prácticamente en el artículo 348 de nuestro Código Civil, se puede decir por tanto que el citado precepto tiene su causa directa en el Art. 544 del Code Napoleón, si bien con dos variantes significativas, en el caso de nuestro precepto, en primer lugar se suprime la expresión "de la manera más absoluta", como forma de ejercicio del derecho, supresión que ha sido elogiada desde los primeros comentaristas ${ }^{138}$ y por otro lado no se citan expresamente los reglamentos como fuente de las limitaciones de las facultades del propietario ${ }^{139}$.

Por ello, puede decirse, que el concepto de derecho de propiedad que se desprende del artículo 348 del Código Civil introduce "matices", pero

Compilaciones Forales, dirigidos por M. Albaladejo, T.V., vol. 1, Madrid, 1980, p. 104; PESET REIG, M., "Propiedad y Legislación", "Dos ensayos sobre la historia de la propiedad de la tierra", R.D.P. 1982 , p. 150.

138 De esta forma, BONEL Y SANCHEZ, L., Código Civil Español, T. II, Barcelona, 1890, p. 58 que se expresa en los siguientes términos: "Aquí debemos exponer que la definición de nuestro Código,... nos parece más racional, más técnica y menos expuesta a errores, que la que de la propiedad da el Código francés, pues según éste, el propietario ha de gozar de las cosas de modo más absoluto, y es utópico en nuestro concepto, porque... lo absoluto no se compagina bien con la sujeción a las leyes, a que debe someterse el derecho de propiedad." En este mismo sentido aunque con distintos matices, puede verse ESCRIBANO, T., "La propiedad y el artículo 348 del Código Civil español", RDP, 1916, p. 70; CASTAN TOBEÑAS, ob. ult. cit., y en general toda la doctrina.

139 El alcance de la supresión del término "reglamentos", que se había incorporado por influencia del Code al Proyecto de 1851 no ha sido estudiado con mucho detenimiento debido a que, en general, la doctrina lo ha considerado intrascendente (entendiendo que el término "leyes" debe interpretarse "con una inteligencia extensiva comprendiendo no sólo las leyes propiamente tales, sino también otra clase de disposiciones mal llamadas legales, como Reales Decretos, Ordenes, Instrucciones y Reglamentos, dictados por la Administración en uso de sus facultades discrecionales, y de carácter general". Cfr. ESCRIBANO, ob. ult. cit., $p$. 70; MANRESA, J.M., Comentarios al Código civil español, Madrid, 1952, T. III (8a. ed. revisada por RICO PEREZ, p. 195); MUCIUS SCAEVOLA, Código civil, VI, Madrid, 1949, 15a. ed.), p. 460; CASTAN, ob. ult. cit., p. 147, etc., encontrándose la ratio de la supresión, más o menos explícitamente, "no por dar mayor o menor extensión a lo que en sí significa el derecho de propiedad, sino porque los eminentes hombres del foro que componían la Comisión de Códigos últimamente comprendieran bien que los reglamentos no pueden estar en contradicción con la ley..., cfr. BONEL Y SANCHEZ, ob. ult. cit., p. 60. Algún autor, sin embargo, encontraba acertada esta supresión porque "los reglamentos no pueden ser origen cierto y legal de las limitaciones de la propiedad". Cfr. DANVILA Y COLLADO, M., El libro del propietario, Madrid, 1901 (4a. ed.), p. 17.

Además, por otra parte, debe recordarse, que ya antes del Código civil era fórmula habitual en algunas definiciones al uso del derecho de propiedad la exclusiva referencia al término leyes. Cfr. DIEZ PICAZO, C., "Los procesos de urbanización y el marco del derecho de propiedad", Estudios, cit., p. 269, estima que la cuestión no es "intrascendente", pues la potestad reglamentaria sí lo podrá actuar como potestad de configuración dominical cuando exista una expresa delegación o autorización de la ley. 
no supone una mutación respecto a la configuración del dominio en el Derecho común $^{140}$.

\section{CONCEPTO Y CARACTERES DEL DOMINIO}

No se puede olvidar, las particularidades del largo proceso de formación del Código civil que, además de durar casi un siglo ${ }^{141}$ y estar marcado por una clara tendencia a la superación del Antiguo Régimen, con los consiguientes altibajos producidos por los vaivenes políticos del siglo XIX, va a culminar en un momento en el que la preocupación por el interés general, como algo distinto del interés del Estado, comienza ya a estar marcada y definida, incluso a nivel legislativo. En todo este proceso, nos encontramos con que el concepto de propiedad, su extensión y sus límites van a ir sufriendo una serie de transformaciones que, sin salirse de la órbita del individualismo jurídico y de la fuerte influencia ejercida por el Código francés, le van a alejar del mismo de forma importante.

Con el Código civil se cierra así un lento proceso de transformación de la propiedad, "que se ha ido produciendo, de forma lenta y progresiva a lo largo de casi todo el siglo XIX"142, y que va a enlazar con el comienzo de una nueva forma de entender este instituto, que se va a consolidar a lo largo del presente siglo.

140 Cfr. Idea avalada por LALINDE, J., "El concepto de propiedad en el derecho histórico español", Revista del Instituto de Derecho Comparado, 119, 1962, pp. 7 y ss.

141 Como es sabido, el proceso codificador comienza en España en las Cortes de Càdiz, que incluyen, tras alguna propuesta anterior en el mismo sentido, en el artículo 258 de la Constitución de 1812 esta idea: "El Código civil y el criminal y el de Comercio serán unos mismos para toda la Monarquía, sin perjuicio de las variaciones que por particulares circunstancias podrán hacer las Cortes". Vid. CASTAN, Derecho Civil, III, 1ำ, pp. 240-241; DE CASTRO, Derecho Civil en España, I, cit., pp. 205-206; DE LOS MOZOS, Derecho civil español, cit., p. 229.

142 MALUQUER DE MOTES, ob. cit. pp. 1087 y ss. En parecido sentido se manifiesta LACRUZ BERDEJO, J.L., "Los conceptos clásicos de propiedad y contrato, ante la legislación de arrendamientos urbanos", Estudios de Derecho Civil, Barcelona, 1958, p. 253. 
Las transformaciones sufridas por dicho concepto presentan como característica más notable un cierto respeto a los principios del Derecho patrio, una progresiva asimilación formal y sistemática del modelo francés, y una preocupación por el interés público o el bien común, que se va a desenvolver como límite a los poderes del propietario individual a través de leyes especiales.

Para la doctrina clásica el derecho de propiedad es un derecho subjetivo de naturaleza real, que se diferencia de los demás derechos reales por ser un derecho unitario, perpetuo, exclusivo, ilimitado ${ }^{143}$.

Por lo que a la unidad se refiere entendida como "la existencia de una sola categoría de dominio, que corresponde a una sola categoría de personas, el individuo"144, predicable del Código francés ${ }^{145}$, es difícil de admitir en el sistema de nuestro Código Civil, ya que, de una parte, prevé claramente, la existencia de las llamadas propiedades especiales, y de otra no duda en admitir la posibilidad de que las personas jurídicas sean titulares de este derecho tanto en los supuestos en que recae sobre bienes muebles como en aquellos otros que recaen sobre bienes inmuebles ${ }^{146}$.

Derecho perpetuo: La doctrina de la Exégesis proclamada esta característica como esencial al dominio, se consideraba como consecuencia lógica del carácter absoluto que para la doctrina tradicional,

143 Corresponden estos caracteres a las definiciones del dominio que se dan durante todo el siglo pasado y que como veremos hoy son difícilmente predicables del modelo de derecho de propiedad que consagra nuestro Código civil.

144 MONTES, La propiedad privada, cit., p. 68.

145 Vid. RODOTA, II terribile diritto, cit., p. 92; PESET, "Acerca de la propiedad en el Code", cit., pp. 884-885.

146 En este mismo sentido debe recordarse que uno de los criterios que sustentan el individualismo del Código en esta materia es precisamente, las deficiencias de la regulación de la propiedad corporativa. Vid. AZCARATE, Historia del derecho de propiedad, III, cit., p. 261; SANCHEZ ROMAN, Estudios, III, cit., p. 56. 
tenía la propiedad ${ }^{147}$.Lo es, con independencia de quienes en cada momento sean propietarios, mientras la cosa siga existiendo, física o jurídicamente, dado que siempre tendrá un titular.

Esta característica aparece en los comentaristas del Code como una nota esencial del dominio ${ }^{148}$, de forma que no cabe imaginar una propiedad temporal, un dominio cuya existencia esté en cierta forma condicionado por el transcurso del tiempo ${ }^{149}$. La propiedad dura tanto como la cosa sobre la que recae ${ }^{150}$.

En nuestro Derecho la discusión en torno al problema no ha alcanzado gran relieve CASTAN la admite con atenuaciones y aclaraciones ${ }^{151}$. LACRUZ, considera la perpetuidad como un atributo del dominio junto a la exclusividad, entendiendo que "el derecho de dominio está llamado a durar ilimitadamente entre las manos de los sucesivos dueños, hasta el infinito, sin perjuicio de que a un titular concreto se le atribuya tal derecho sólo por un tiempo cierto y limitado"152. Sin embargo, si

147 En el derecho francés, es donde surge la caracterización del derecho de propiedad como un derecho perpetuo sobre la base del artículo 544 del Code, la opinión dominante se decanta de forma generalizada a favor del carácter perpetuo del dominio.

148 La doctrina ha adoptado dos posturas sobre el carácter perpetuo del derecho de propiedad: mientras que, para unos, la perpetuidad es nota esencial al dominio, de forma que desapareciendo aquél desaparece el mismo derecho, para otros "la propiedad es perpetua normalmente, pero hay que reconocer ciertas excepciones en que deja de serlo, sin atacar por eso lo que constituye su contenido lógico". FUENMAYOR, A., La revocación de la propiedad. Madrid, 1942, pp. 62 y ss. y la bibliografía en él contenida.

149 DEMOLOMBE, C., Cours de Code de Napoleón. IX. Traité de la distintion des biens. Tome I, De la propieté. De l'usufruct. De l'usage et de l'habitation. Paris, 1881, p. 465: "El derecho de propiedad es perpetuo... En efecto, no se comprende cómo un derecho que consiste en poder disponer de una cosa de manera más absoluta, puede pertenecer a aquél que deberá, ciertamente, en un momento determinado, restituir la cosa".

150 BAUDRY-LACANTINERIE, G., Precis de Droit Civil. Tomo III, 2a. ed. Paris, 1922, p. 662, num. 1330 Gis: "La duración de la propiedad no está limitada por el tiempo: dura en principio tanto como la cosa sobre la que recae"; CARBONIER, J., Droit Civil. Tomo III. Les biens, 9a. ed. Paris, 1978, pp. 93 y ss. "El derecho de propiedad tiene vocación para durar tanto como su objeto".

151 CASTAN, Derecho Civil, T. II. Vol. 1ำ, p. 109, donde señala que el derecho de propiedad es "potencialmente o normalmente perpetuo, pero no irrevocable". En sentido parecido PUIG PEÑA, Compendio de Derecho Civil, Tomo II, Derechos reales, 2a. ed. Pamplona, 1972, p. 56. 152 LACRUZ, Elementos, Tomo III, Vol. I, p. 179-180, señalando también que "en otro sentido se habla igualmente de perpetuidad del dominio para explicar que éste no se pierde por prescripción extintiva". 
bien es cierto que se acepta y admite el carácter perpetuo del derecho de propiedad, no es menos cierto que cada vez se tiende hacia una relativización del mismo, consecuencia ineludible de la paulatina disolución de su carácter absoluto.

ESPIN niega expresamente, sin embargo, que pueda considerarse como nota esencial del dominio, pues entiende que cabe la propiedad temporal, como la derivada de la venta con pacto de rescate, o de los bienes sujetos a sustitución fideicomisaria ${ }^{153}$. Asímismo en el ambito de la multipropiedad ${ }^{154}$, referida a un particular tipo de propiedad, la peculiar característica,esto es, el goce periódico del bien, deriba de la particularidad del objeto del derecho; va a ser el factor tiempo uno de los elementos esenciales para la individualización de éste, "la cosa sobre la que incide el derecho de goce del multipropietario, deberá, por ello, ser definida, además de en sus características espaciales, en las temporales"155 Recientemente O'CALLAGHAN considera que el derecho de propiedad es potencialmente o normalmente perpetuo, pero no irrevocable ${ }^{156}$. Otros autores, antiguos y modernos, no hacen referencia expresa a la cuestión al estudiar la propiedad o, a lo sumo, señalan de pasada que ya no puede decirse que este derecho sea absoluto, exclusivo y perpetuo ${ }^{157}$.

\footnotetext{
153 Cfr. ESPIN, Manual, II, pp. 70-71.

${ }^{154}$ Tras la publicación de la Ley $42 / 1998$, de 15 de diciembre, en la actualidad no tiene sentido hablar de multipropiedad, sino de "Derechos de aprovechamiento por turno de bienes inmuebles de uso turístico"

155 Vid. HERRERO GARCIA, M.J , La Multipropiedad, Madrid, 1989.

156 Cfr. O'CALLAGHAN, X., Compendio de Derecho civil, III, Madrid, 1985, pp. 75-76. En sentido parecido se manifiesta ALVAREZ CAPEROCHIPI, J.A., Curso de Derechos Reales, I, Madrid, 1986, p. 39, calificándolo de "tendencialmente perpetuo".

157 En este último sentido pueden citarse SANTOS BRIZ, J., Derecho civil. Teoría y práctica. Tomo II, Derecho de cosas. Madrid, 1973, p. 114; PEÑA BERNARDO DE QUIROS, M., Derechos reales. Derecho hipotecario. Publicaciones de la Facultad de Derecho de la Universidad Complutense de Madrid, 1982, p. 101.
} 
Estos breves apuntes, que son un exponente de la poca atención dedicada al tema por la doctrina española ${ }^{158}$, unidos a la ausencia en el artículo 348 de una expresa referencia al carácter absoluto de la propiedad, que es de donde formalmente se hace derivar esta nota en el Derecho francés ${ }^{159}$, bastan para poner de relieve la dificultad de predicar el carácter perpetuo del derecho de propiedad en el Código civil español.

Del carácter absoluto de la propiedad, (en cuanto otorga un poder ilimitado soberano sobre la cosa) surge la exclusividad (en cuanto que facilita y faculta para impedir el goce por los demás) ${ }^{160}$ queriendo significar con ella la no posibilidad de que un tercero pudiese obtener beneficio 0 ventaja de la cosa, aún en el caso de que no exista perjuicio para el propietario.

Esta característica no constituye una nota esencial al derecho de propiedad, que pueda servir para diferenciarla de los demás derechos reales, ya que la exclusividad es nota común a todo derecho real, a través de la cual se trata de impedir el uso y disfrute de terceros.

Por último la pretendida ilimitación de facultades que se hace derivar del carácter "absoluto" del dominio. Se produce un cambio en el Código civil español (en la configuración del dominio) en relación con el Código francés, por lo que no puede afirmarse la ilimitación de la propiedad ${ }^{161}$ si no es para hacer referencia a la generalidad de los poderes

158 No obstante, vid. MONTES, La propiedad privada, cit., pp. 69 y ss., y p. 304, donde estudia el tema del carácter perpetuo del dominio de forma bastante pormenorizada y sugerente, ofreciendo abundantes datos acerca del estado de la cuestión.

159 Vid. VIDAL, "La propiété dans l'école d'exegese en France... cit., pp. 35-36.

160 Vid. LAURENT, F., Principes de Droit Cínil. Tomo VI, 2a. ed. Bruxelles, 1878, p. 153, para quien, si bien el carácter exclusivo del dominio le es esencial, ello no significa sino una forma nueva de traducir su carácter absoluto.

161 VALVERDE y VALVERDE, C., Tratado de Derecho Civil. Tomo II. Parte especial. Derechos reales. Valladolid, 1936, p. 64, que refiriéndose al artículo 348 del Código civil afirma que "no reconoce al derecho de propiedad como absoluto e ilimitado, sino limitado por lo que 
conferidos propietario, pues, prescindiendo aquí de la supresión del inciso "de la manera más absoluta", en el artículo 348, y de los problemas que pudiera plantear la regulación del censo enfiteútico, nuestro Código civil contempla supuestos como las llamadas propiedades especiales, en los que, en razón al objeto y al interés público del mismo, aparecen situaciones en las cuales los poderes del titular son indeterminados pero están claramente limitados ${ }^{162}$. Incluso, en el supuesto típico de la propiedad del suelo, no encuentran reflejo en nuestro Código aquellas formulaciones más individualistas que entienden que el derecho de propiedad se extiende más allá de los confines de la cosa, ya que la propiedad del inmueble se entiende hacia arriba y hacia abajo indefinidamente, pues el artículo 350 del Código civil planteó la situación en términos completamente distintos y mucho más realistas, relativizando en gran medida los poderes del propietario, tanto sobre el suelo como sobre el subsuelo.

\subsection{LA VALORACION DEL DOMINIO COMO PODER GENERAL,} ABSTRACTO Y ELASTICO.

Ante las dificultades expuestas para caracterizar el dominio a través de las notas estudiadas, parece conveniente acudir a otros caracteres que se acomoden mejor al concepto de propiedad entendido como el más amplio poder que el ordenamiento permite tener sobre una cosa ${ }^{163}$. En este sentido la calificación del dominio como un poder general,

dispongan en contra de su disfrute las leyes y reglamentos". En sentido parecido PUIG BRUTAU, Fundamentos, pp. 261 y ss.

162 Vid., por ejemplo, la postura del Tribunal Supremo en la Sentencia de 20 de octubre de 1941 (R. 1087) cuyo considerando primero señala: "Que, con arreglo a los principios que informan la Ley de 13 de junio de 1879 y el Código civil, los derechos reconocidos a los propietarios de terrenos sobre las aguas que en ellos nacen o por los mismos discurren no son absolutos, sino que su mayor o menor extensión depende de la existencia de otro derecho preferente que es obligado respetar, pues así lo exige la naturaleza especial de esta propiedad..."

163 Para un estudio mas detallado del tema vid.LOBATO GOMEZ, Propiedad Privada..., ob. cit.

p. 257 y ss.; SANCHEZ ROMAN,en su obra Estudios de Derecho Civil, III, cit.,p. 81, se refiere al 
abstracto y elástico que actualmente predomina en la doctrina española, se adapta mucho mejor al modelo de propiedad incorporado por nuestro Código civil, e incluso, al concepto de propiedad que en la actualidad se desprende del ordenamiento jurídico español globalmente considerado y que cada vez es mas dificil de mantener. De esta forma, como alternativa a una concepción tradicional e individualista del dominio, que responde a las notas de unidad, perpetuidad, exclusividad e ilimitación, se pasa a caracterizar al derecho de propiedad como general, abstracto y elástico:

a) Generalidad.

La propiedad es un derecho real, es el derecho real más completo que puede ser concebido sobre una cosa. El derecho consiste en utilizar todos los servicios de la cosa salvo las excepciones que dicte el interés público o la existencia de otros derechos, siempre dentro del marco del ordenamiento jurídico ${ }^{164}$.

Algunos autores ligan a esta nota la independencia ${ }^{165}$, puesto que el derecho de propiedad existe por sí, sin necesidad de ningún otro derecho. Los demás son iura in re aliena, es decir, especiales y

dominio como "el poder más pleno y absoluto de los reconocidos por las leyes" y como "el derecho de pleno poder del dueño sobre las cosas corporales para todos los mismos fines", aunque en la p. 98 lo defina como "un derecho real constituido en cosa corporal, que otorga a la persona del dueño, con sujección a las leyes, el poder de su libre disposición y de su libre aprovechamiento, para todos y los mismos fines". Por su parte CLEMENTE DE DIEGO, Curso, III, cit., p. 104, se refiere al dominio como "la unidad de los poderes más amplios concedidos.

164 ALBALADEJO, Derecho Civil. T. III, Derechos de bienes, vol. 1ํ., Parte General y derecho de propiedad, 3a. ed. Barcelona, 1977, p. 133; ALVAREZ CAPEROCHIPI, J.A., Curso de derechos reales,_, Madrid, 1986, p. 39; CASTAN, La propiedad, cit., p. 91; IDEM, Derecho civil, II-I, cit., p. 150; ESPIN, Manual, II, cit., p. 71; LACRUZ, Elementos, III-I, cit., p. 177; O'CALLAGHAN, Compendio, III, cit., p. 75; PEÑA, Derechos reales, cit., p. 115; PUIG PEÑA, Compendio, II, cit., pp. 54-56; SUSTAETA, Propiedad y urbanismo, Madrid, 1978, p. 50; VALVERDE, Tratado, II, cit., p. 61; ROCA SASTRE, "La concepción del usufructo como pars domini", RGLJ, 1942, II, p. 584.

165 CASTAN, La propiedad, cit., p. 91; ROCA SASTRE, ob. y loc. ult. cit.; VALVERDE, ob. y loc. ult. cit. 
dependientes, por cuanto tienen un nucleo propio de contenido y exigen un previo derecho de propiedad sobre el que recaen.

b) Abstracción.

Esta nota viene a significar, que el derecho es siempre separable de sus facultades y puede tener una existencia distinta y autónoma de cada una de ellas ${ }^{166}$.

Por tanto no debemos de confundir la propiedad con el conjunto de facultades. La propiedad es un señorio autónomo e independiente.

c) Elasticidad.

Se dice que el dominio es elástico, no ya porque puede ser despojado de algunas o muchas facultades, o sometido a vínculos 0 restricciones sin dejar de ser dominio, sino porque abarca todas las posibles influencias sobre la cosa, reabsorviéndolas en tanto no correspondan a otro titular. Es decir, el dominio de una cosa atrae y contiene necesariamente cuantas facultades dominicales no estén en poder de persona distinta del dueño ${ }^{167}$.

166 ALVAREZ CAPEROCHIPI, ob. y loc. ult. cit.; CASTAN, La propiedad, cit., p. 91; IDEM, Derecho civil, II-I, cit., p. 150; CLEMENTE DE DIEGO, Curso, III, cit., p. 104; ESPIN, ob. y loc. ult. cit.; LACRUZ, Elementos, III-I, cit., pp. 177-178; O'CALLAGHAN, ob. y loc. ult. cit.; PEÑA, Derechos reales, cit., p. 102; ROCA SASTRE, ob. y loc. ult. cit.; SANTOS BRIZ, Derecho Civil, II, cit., p. 116.

167 ALVAREZ CAPEROCHIPI, Ob. y loc. ult. cit.; CASTAN, La propiedad, cit., p. 91; IDEM., Derecho civil, II-I, cit., p. 151; CLEMENTE DE DIEGO, ob. y loc. ult. cit.; ESPIN, ob. y loc. ult. cit.; DIEZ PICAZO Y GULLON, Sistema de Derecho civil, Vol. III, Derecho de cosas, 2a. ed., Madrid, 1982, p. 106; LACRUZ, ob. y loc. ult. cit.; MONTES, La propiedad privada, cit., p. 78; O'CALLAGHAN, ob. y loc. ult. cit.; SANTOS BRIZ, ob. y loc. ult. cit.; ROCA SASTRE, ob. y loc. ult. cit.; VALLET DE GOYTISOLO, J., Panorama de Derecho Civil, Barcelona, 1973 (2a. ed.), p. 154; VATIER, C., "La elasticidad del derecho de propiedad en los planes de mejora ejecutados mediante arrendamiento forzoso en el Derecho Agrario Español", RCDI, 1976, pp. 833 y ss. 


\subsection{LA CARACTERIZACION JURISPRUDENCIAL DEL DOMINIO.}

De la jurisprudencia del Tribunal Supremo pueden extraerse conclusiones similares. Rechaza los poderes ilimitados del propietario derivados del carácter absoluto del dominio, y se pronuncia reiteradamente contra tal hipótesis.

En este sentido es muy significativa la Sentencia de 22 de enero de 1914 (Sala 1a.), que afirma en uno de sus considerandos: "Si bien es esencia y atributo peculiar del dominio que aquel a quien pertenece una cosa pueda disponer de ella libremente, esta facultad no reviste caracteres absolutos y omnímodos, en razón a que toda propiedad se subordina siempre a limitaciones determinadas, ya por las leyes, ya por pactos convenidos o por costumbres establecidas y aceptadas, en cuya virtud ha de amoldarse a una u otras el ejercicio de tal dominio ${ }^{168 .}$

La misma idea sigue presente en sucesivos pronunciamientos que ayudan a formar una cierta opinión acerca del alcance del artículo 348. Así, la Sentencia de 30 de mayo de 1925 afirma que "el artículo 348 del Código civil determina el concepto legal de propiedad consagrándola, con criterio individualista, como derecho a gozar y disponer de una cosa, sin otras limitaciones que las impuestas por el interés social, expresado y garantizado por las leyes"169; la Sentencia de 26 de marzo de 1928, que señala: "el artículo 348 del Código civil, que define y puntualiza el derecho de propiedad, lejos de otorgar omnímodas y absolutas facultades a la libre disposición de las cosas que la integran, condiciona y subordina

168 JURISPRUDENCIA CIVIL, T. 129, pp. 195 y ss. Como podemos observar en esta y en sucesivas sentencias el Tribunal Supremo incluye la costumbre como fuente de limitación del derecho de propiedad.

169JURISPRUDENCIA CIVIL, T. 166, pp. 591 y ss. Se aprecia claramente la referencia al interés social, concepto mucho más amplio que utilidad pública o interés público. 
expresamente su disfrute a las limitaciones establecidas por las leyes"170; la Sentencia de 30 de octubre de 1928171; la Sentencia de 21 de febrero de 1930 (R. 700), en cuyo primer considerando puede leerse: "los artículos del Código civil 348 y 349, que definen y regulan el derecho de propiedad, consideran que por muy individualistas que puedan ser los legisladores, el derecho no debe ser absoluto, sino que tiene que limitarse por las leyes y los reglamentos". La Sentencia de 17 de noviembre de 1930, en la que se afirma que "el derecho de propiedad no sólo tiene un fin de carácter individual basado en el interés privado del sujeto del mismo, que el artículo 10 de la Ley Fundamental del Estado declara un principio inviolable, sino que además integra un fin colectivo y social, fundado en la necesidad de mantener el orden jurídico y procurar el bien común fomentando la riqueza pública" (R. 1.265); la Sentencia de 30 de septiembre de 1931, en cuyo primer considerando se afirma que "si bien son disposiciones de los artículos 348 y 349 del Código civil, que la propiedad es el derecho de gozar y disponer de una cosa... no es menos cierto que esos mismos artículos reconocen que tales derechos pueden tener limitaciones" (R. 2.156); la Sentencia de 20 de octubre de 1941, en cuyo considerando tercero se afirma que el artículo 348 del Código civil no atribuye a la propiedad "carácter absoluto, antes bien, alude expresamente, al formular su concepto, a las limitaciones establecidas en las leyes" (R. 1087); o la Sentencia de 23 de diciembre de 1943 (R. 1323), en la que se mantiene la misma idea.

170 JURISPRUDENCIA CIVIL, T. 128, pp. 685 y ss. Desde subrayarse la idea de subordinación de las facultades del propietario a la ley.

171 JURISPRUDENCIA CIVIL, T. 185, pp. 671 y ss. De esta sentencia merece transcribir el siguiente considerando: "que si bien en los artículos 348 y 349 del Código Civil, establece que la propiedad es el derecho de gozar y disponer de una cosa sin más limitaciones que las señaladas en las leyes, y que nadie podrá ser privado de su propiedad sino por autoridad competente y por causa justificada de utilidad pública, previa siempre la correspondiente indemnización, y si no procediese este requisito, los jueces ampararán y, en su caso, reintegrarán en la posesión al expropiado, como en el artículo 350 del mismo Código se limitan estos derechos de propiedad en los dos aludidos artículos sancionados, tanto por las servidumbres cuanto en lo dispuesto en las Leyes sobre Minas y Aguas y los Reglamentos de policía, es evidente que las autoridades de todas las órdenes pueden dictar disposiciones que respecto de Sanidad y Policía, sin conculcarlo limiten el derecho de propiedad. 
Aunque alguna vez el Tribunal Supremo ha afirmado que el artículo 348 del Código civil "consagra un derecho de propiedad absoluto y exclusivo"172, lo hace únicamente en relación con otros poseedores refiriéndose a un supuesto de reivindicación, y nunca entendiendo el término absoluto como equivalente a ilimitado.

Por otro lado, es obligado señalar que esta línea jurisprudencial enriquecida por la mención expresa de la "función social" en los textos constitucionales, terminara por confluir con otra, que aceptando la opinión de que "el dominio es el señorío abstracto y unitario sobre la cosa, y no la suma de facultades de las que el propietario puede verse privado temporalmente, sin que por ello pierda la integridad potencial de su derecho, determinante de la posibilidad de recuperación efectiva de todas las facultades dominicales"173, leva al Tribunal Supremo a concluir, en Setencia de 23 de diciembre de 1946 (R. 1.413), que el derecho de propiedad "bien se define como un derecho unitario y abstracto, conforme a la concepción de la doctrina científica, ya se atienda al concepto puramente legal, no es exacto decir que revista caracteres de absoluto, como lo demuestra la circunstancia de que el legislador español suprimiera al redactar el artículo 348, la expresión "de la manera más absoluta" configurada en el artículo 544 del Código francés ${ }^{174 ;}$ y a reafirmar años

172 Sentencia de 18 de abril de 1929. JURISPRUDENCIA CIVIL, T. 188, pp. 1080 y ss., en uno de cuyos considerandos puede leerse que "el artículo 348 del Código civil, consagra un derecho de propiedad absoluto y exclusivo que por su naturaleza real representa el vínculo jurídico que une la cosa a su propietario, concediéndole facultad para reivindicarla contra el que la retenga o posea, lo cual presupone, como reiteradamente tiene declarado la jurisprudencia, que para el éxito de la acción dominical se justifique cumplidamente el legítimo a favor del dueño".

173 Cfr. Sentencia de 3 de diciembre de 1946 (R. 1229). También Sentencia de 12 de junio de 1958 (R. 837). En relación con ésta debe recordarse que pocos años antes, en Sentencia de 7 de junio de 1941 (R. 738), aún se aludía al concepto de dominio "como suma total o íntegra de los poderes que pueden tenerse sobre una cosa con carácter exclusivo y excluyente".

174 En esta sentencia, continúa diciendo el Tribunal: “... que si bien es esencial y peculiar atributo del dominio el poder disponer libremente de las cosas, tal facultad no es absoluta y omnímoda, en razón a que toda propiedad se subordina siempre a limitaciones determinadas, ya por las leyes, ya por pactos convenidos, o costumbres aceptadas a las que, en su ejercicio, se ha de acomodar; de todo lo que cabe inferir que el reconocimiento del dominio, en la forma 
después, en otra Sentencia de 30 de enero de 1964 (R. 439) que el dominio tiene un contenido "unitario, global y elástico, distinto de sus facultades" 175 .

En este sentido, si tenemos en cuenta lo anterior, es indudable, como se verá oportunamente, que el carácter y el ámbito de las limitaciones al derecho de propiedad irá adquiriendo mayor amplitud a medida que crece la importancia del interés público y social de determinados aprovechamientos, y en consonancia con la funciòn social de la propiedad, que poco a poco va tomando carta de naturaleza en nuestro ordenamiento jurídico.

\section{CONTENIDO DEL DERECHO DE PROPIEDAD}

La propiedad privada en su doble dimensión, como institución y como derecho individual, ha experimentado una transformación tan profunda en nuestro siglo que impide concebirla como una figura jurídica reconducible exclusivamente al tipo abstracto descrito en el art.348 del Código Civil. Sin embargo, por más que se haya insistido en el vaciamiento del art. 348 del C.c ${ }^{176}$ constituye un punto de referencia obligado para la recognoscibilidad del derecho de propiedad 177 .Por ello

que la Sala lo expresó, se hizo con justeza, y en aromonía con los dictados de la Ley, máxime teniendo en cuenta que se trata de un derecho de propiedad sobre las aguas, de especial naturaleza y regulado por disposiciones diversas, y susceptibles, por el uso y disfrute de tan variados aprovechamientos", con lo que viene a extender la noción del dominio como "derecho unitario y abstracto" a las propiedades especiales, precisamente en conexión con la ausencia del carácter absoluto del derecho.

175 Vid. Infra Capitulo III, donde queda recogida la Jurisprudencia más moderna sobre la cuestión analizada.

176 En este sentido , MONTES, Comentarios al Código Civil y Compilaciones forales ,dirigidos por Albaladejo, Tomo V, Vol.I. Edersa, Madrid, 1990, arts 348 y ss. ,p. 196 dice que el art. 348 se nos aparece como un precepto obsoleto, aislado, que rige de modo residual y para bienes no incorporados directamente al proceso productivo, sin embargo reconoce que para definir qué es "propiedad"como situación jurídica, como relación jurídica, como un derecho real, hay que acudir, desde luego, a este precepto, pero no esya la única referencia, ni acaso la más importante, porque ha de ser integrado con la Ley de Régimen de Suelo, Reforma y Desarrollo Agrario, etc.

177 Vid. MEDINA DE LEMUS, M. La propiedad urbana y el aprovechamiento urbanístico, Madrid, 1995, p. 82. 
compartimos la idea de LOPEZ y LOPEZ 178 al afirmar que un válido punto de partida, a la hora de determinar cúal es el tipo abstracto del derecho de propiedad, que nos encamine a ulteriores concreciones del contenido esencial del mismo, viene representado por la vetusta definición del Código. En ella están presentes tres elementos : la facultad de goce, la facultad de disposición y la posibilidad de limitaciones del derecho por obra de las leyes.

Estas facultades de goce y disposición que conforman el contenido del derecho de propiedad no podrán ser eliminadas al ser reguladas legalmente en virtud de la función social ${ }^{179}$, salvo el supuesto de expropiación.

El art. 33 de la Constitución Española al incidir sobre el art. 348 del Código Civil genera un nuevo concepto de propiedad 180 . La función social se predica del contenido del derecho es decir de las facultades de goce y disposición que ostenta el titular, el propietario ${ }^{181}$. Ahora bien, no puede decirse que sólo el goce y la disposición constituyan las facultades normales del domimio, pues el contenido del derecho de propiedad no se compone únicamente de poderes sino que habrá de tenerse encuenta tambien los deberes y las cargas que pesan sobre el mismo, mermando parcialmente sus facultades dominicales. Todas estas limitaciones que han

178 Vid. LOPEZ y LOPEZ , A. M.,La disciplina constitucional de la propiedad privada, Madrid, 1988, p. 148.

179 Vid. BARNES VAZQUEZ, J., La Propiedad Constitucional. El estatuto Jurídico del Suelo Agrário, Madrid, 1988, p. 315, quien entiende por facultad de goce, el uso o disfrute del bien objeto del derecho en definitiva su aprovechamiento o explotación. Habla del goce y disposición de un modo instrumental , como modo de comprender el poder funcional en que se sustancia la propiedad constitucional .

180 Vid. COCA PAYERAS, Tanteo y Retracto, Función social de la propiedad y Competencia autonómica, Bolonia 1988. p. 272, quien tratando de conciliar los artículos 348 del C.c y 33 de la C.E obtiene la siguiente definición: "La propiedad es el derecho de gozar y disponer de una cosa, hasta donde ese goce y disposición cumplan una función social, sin más limitaciones que las establecidas en las leyes".

181 Vid. GALGANO, F. Diritto privato, Padova, 1981, p. 114-115. En relación al artículo 42 de la C.I. sostiene que la función social va referida al objeto del derecho de propiedad, no al derecho subjetivo como tal, pues las ideas de derecho subjetivo y función social son auténticas. 
dado lugar a una nueva configuración del derecho de propiedad se han desarrollado fuera del Código Civil, concretamente en las leyes especiales.

Por tanto, el artículo 348 del C.c es susceptible de ser interpretado en cada momento histórico de una manera distinta, así mientras que la concepción liberal del derecho de propiedad concebia esas facultades de goce y disposición como absolutas e ilimitadas, tan sólo recortables ab externo, la propiedad constitucional determina, mediante la ley, el contenido estatutario y normal ab interno de las facultades de goce y disposición ${ }^{182}$.

Hoy día el art. 348 contiene una definición insuficiente que no se ha mejorado, la propia C.E. no define el Derecho de propiedad, hay que acudir a las diversas leyes que regulan las diferentes propiedades. Hoy la propiedad es un derecho limitado, sometido a obligaciones, cargas, deberes e incluso a la propia expropiación. Es un derecho real, subjetivo y constitucional.

\section{LIMITES DE LA PROPIEDAD EN EL CODIGO CIVIL}

Es el propio ordenamiento jurídico en su conjunto el que delimita el verdadero contenido de la propiedad. De iure conditio ${ }^{183}$, sólo las normas jurídicas se encuentran realmente habilitadas para establecer hasta dónde pueden llegar los poderes del propietario, fijando una serie de límites que, brevemente, vamos a analizar.

En primer térmimo, conviene hacer una referencia a los límites que afectan a la facultad de goce del propietario, impidiendo que tal facultad pueda ser considerada como absoluta o ilimitada. Estos límites pueden

182 Vid. BARNES VAZQUEZ, J., La propiedad constitucional. El estatuto juridico del suelo agrario. Madrid, 1988, p. 318.

183 Vid. LASARTE ALVAREZ, C., Curso de Derecho Civil Patrimonial, ob. cit., p. 178 y 179. 
encontrar su fundamento tanto en el interes privado como en el interes general.

La propiedad, no puede legitimar conductas socialmente perniciosas y, en este sentido, la legislación positiva ha procurado siempre exigir al propietario un uso normal de su derecho, estableciendo numerosos límites a la facultad de goce.

Los límites fundamentales establecidos en interés privado y recogidos por el Código Civil suelen ser agrupados bajo el nombre de relaciones de vecindad, en cuanto tratan de evitar que la colindancia de distintos propietarios origine problemas de extralimitación y abuso por parte de cualquiera.

Así, es lógico que la minuciosa regulación del Código civil se asiente en la regla general de que todo propietario no esté autorizado a realizar en su propia casa actos que originen al vecino inmisiones o molestias superiores a lo razonablemente tolerable ${ }^{184}$.

En otras ocasiones, las leyes restringen la capacidad dispositiva del propietario, negándole el ejercicio de la facultad de disponer. Se habla, de prohibiciones de disponer para identificar aquellos supuestos en que el propietario no es total y absolutamente libre para enajenar el bien de que es titular. Aunque si bien es verdad, realmente, las prohibiciones legales de disponer desempeñan un papel bastante marginal dentro de nuestro sistema jurídico. Por lo general, se limitan a establecer un determinado plazo temporal durante el cual el propietario no puede enajernar el bien, en atención a razones de muy diversa índole, como así se manifiesta, por ejemplo en el art. 196 del C.c.

184 Vid. en nuestro Código Civil, como supuestos más llamativos, los siguientes límites: a la facultad de exclusión en los arts. 569 y 612.1 ; a la libertad de abrir en las paredes maestras huecos para luces o vistas en los arts. 581.1, 582 y 584; a la libertad en el montaje de cubiertas o tejados en el art. 586; y a la libertad de construir, plantar y montar instalaciones en el terreno propio en los arts. 590 y 599. 
El papel marginal de las prohibiciones legales de disponer se funda principalmente en que el Derecho privado codificado reaccionó virulentamente contra la propiedad vinculada característica de anteriores épocas históricas (mayorazgos, vinculaciones perpetuas en favor de las manos muertas, etc.) con la finalidad de facilitar el tráfico económico, la transmisibilidad de la tierrra y el propio crédito territorial ${ }^{185}$.

Precisamente por dichas razones, nuestro Derecho vigente se caracteriza también por un notorio desapego a las prohibiciones voluntarias de disponer, ya tengan su origen en actos a título gratuito o a título oneroso.

Por cuanto se refiere a los límites en interés público son aún más numerosos y se encuentran contemplados en disposiciones administrativas, reguladoras de diversas materias: instalación y establecimiento de industrias, conducción de energía eléctrica, minas, montes, carreteras y líneas férreas, defensa nacioneal, etc.

Fuera ya del Código Civil, y siguiento la idea del abandono de la concepción absolutista de la propiedad privada, que históricamente, se ha ido produciendo de forma paulatina, el último estadio en dicho proceso viene representado por la idea de la función social de la propiedad, acogida ahora en el artículo 33.2 de nuestra Constitución: "la función de estos derechos delimitará su contenido, de acuerdo con las leyes".

Consecuencia de este fenómeno social del dominio, y con ánimo de compaginar los intereses individuales con los de la colectividad, surge la distinción entre límites y limitaciones.

185 Vid. LASARTE ALVAREZ, C., Curso de Derecho Civil Patrimonial, ob. cit., p. 179. 


\subsection{CONCEPTO DE LIMITES Y LIMITACIONES}

La distinción apuntada tiene sus raíces en la doctrina alemana, sobre todo a partir de GIERKE ${ }^{186}$. Para ellos era necesario distinguir entre aquellas restricciones impuestas al derecho de propiedad sobre un contenido normal y preexistente, de aquellas otras que vienen a fijar los confines de dicho contenido, determinando el campo donde pueden desenvolverse libremente los poderes dominicales. Utilizan para expresar esos dos conceptos, términos distintos: Eigentumsbegrenzunden (límite) y Eigentumsbeschränkungen (limitaciones).

A partir de este momento los autores han definido los límites y limitaciones, tratando de diferenciarlos. Así, BARBERO afirma que los límites son aquellos que definen la propiedad, mientras que las limitaciones comprimen el contenido de la propiedad ${ }^{187}$. En nuestra doctrina, ha sido acogida esta distinción por varios autores. LACRUZ ${ }^{188}$ afirma que una serie de normas de distinta procedencia aportan a la propiedad privada lo que se suele llamar, restricciones, límites y modalidades por motivos de interés público. En realidad, tales disposiciones son precisamente las que configuran la propiedad: los que trazan los límites a donde llega, en cada hipótesis, el poder del dueño de actuar sobre la propia cosa, de excluir a los demás, de disponer de ella, etc. Por el contrario, la limitación, comprime, pero no oprime, el contenido de la propiedad: lo reduce a un ámbito más estricto que el típico y normal, pero sin amputarle su potencial capacidad para extenderse de nuevo a los límites iniciales, cuando ese gravamen cese.

186 GIERKE, Otto Von., La función social del Derecho Privado, Madrid, 1906 (trad. J.M. Navarro de Palencia) p. 27.

187 BARBERO, D., Sistema de Derecho Privado. Vol. II. Derechos de la personalidad, Derecho de familia, Derechos reales, Traducción española de SANTIS MELENDO, Buenos Aires, 1967, p. 228 y ss.

188 Vid. LACRUZ, Manual de Derecho Civil, Barcelona, 1990, p. 360. 
Para ALBALADEJO ${ }^{189}$ los límites son las fronteras o el punto normal hasta donde llega el poder del dueño; o sea, el régimen ordinario a que está sometido tal poder. Y añade, otra cosa son las "limitaciones" que procediendo de muchas causas, pueden reducir, en casos singulares, el poder que normalmente tiene el dueño sobre la cosa.

Igualmente, MARTIN MATEO190, reconoce la distinción entre "límites-confines" y limitaciones siguiendo a la doctrina alemana, según se refieran los mismos a delimitaciones del contenido normal de la propiedad, o bien a medidas que le fijan saliéndose, por decirlo así, de esta normalidad de concepto dada.

Para GARCIA DE ENTERRIA ${ }^{191}$, la incidencia del Derecho urbanístico sobre la propiedad fundiaria no puede ya explicarse en los términos tradicionales de las limitaciones de la propiedad. La doctrina alemana juega con un doble concepto que puede ser oportuno traer aquí. No se trata, dice, de restriciones o limitaciones de la propiedad, sino de delimitación de la propiedad en su contenido normal; no es una limitación de algo positivo y plenario, sino un límite de extensión, de un confín, que según el artículo 70.1 L.S., define el contenido normal de la propiedad.

Por su parte, BONILLA ENCINA ${ }^{192}$, distingue entre delimitación y limitación. La delimitación es aquella que integrándose en el contenido del dominio, afecta a toda propiedad, si bien con diferente signo según su especial destino (luego límite). Por su parte la limitación no representa otra

189 ALBALADEJO, Derecho Civil, Tomo III, Derecho de bienes, Vol. 1ㅇ Parte general y derecho de propiedad, Barcelona, 1989, p. 203 y ss.

190 MARTIN MATEO, R., "El estatuto de la propiedad inmobiliaria", R.A.P., año 1967, pp. 101 y ss.

191 GARCIA DE ENTERRIA, E., "La Ley del Suelo y los principios del Urbanismo", A.D.C. 1958, p. 503.

192 BONILLA ENCINA, "Titularidades delimitadas, Delimitaciones en la propiedad urbana, en Revista Crítica de Derecho Inmobiliario. 
cosa que una anormalidad en el estatuto normal de la propiedad, afectando exclusivamente a diferencia de la delimitación, al dominio que restringe y no a otro.

No obstante, este planteamiento de límites y limitaciones ha sido posteriormente criticado por algún sector doctrinal, para quien la tesis expuesta tropieza con objeciones difíciles de superar.

Así, DIEZ-PICAZO193 afirma que "ante todo no puede dejarse de observar que la doctrina tradicional no configura la tarea de fijación del contenido del derecho de propiedad como una actividad de signo positivo, que se lleva a cabo mediante la enumeración de las facultades que encierra, sino como una actividad de signo negativo, que se realiza mediante la indicación de aquello a lo que no alcanza. Es claro- dice- que si el contenido del dominio resulta fijado sólo negativamente, la distinción entre límite y limitación se desdibuja completamente. La distinción sólo sería posible si un contenido previo del derecho estuviera fijado positivamente. En tal caso, cualquier reducción de dicho previo contenido positivo sería una limitación".

Por lo expuesto, el concepto de "limitación" se convierte en el de "límite", desapareciendo las fronteras entre ambas figuras cuando se priva a la propiedad de sus facultades tradicionales sin que tal medida se corresponda en la realidad con un debido reintegro, aunque sea tan sólo legal.

Por su parte, algunos autores dan una teoría superadora de la distinción entre límites y limitaciones, fundamentándose en la disgregación de la propiedad. Se dice que "si no existe la propiedad sino las propiedades, es posible formular un concepto estatutario de aquélla, Revista de Derecho Urbanístico (mayo-junio) 1971, p. 20 y ss. 
superador de la idea de límites normales; lo que existe, se afirma, son categorías de bienes con un estatuto dominical propio, constituido por todo el conjunto de obligaciones y cargas impuestas ope legis, para cada uno de estos grupos de bienes. Con ello se supera además la distinción entre limitaciones y límites, ya que, en definitiva, todo forma parte del contenido normal de la categoría dominical concreta"194.

De todo lo dicho hasta ahora, se podía llegar al siguiente razonamiento: la distinción entre límites y limitaciones nos sitúa ante la diferencia entre contenido genérico o unitario del derecho de propiedad, constitucionalmente recogido, y el contenido que ocasionalmente puede encerrar la posición jurídica de un propietario, en cuanto se ve interferida por otras instituciones que merman el ámbito de poder inherente a aquel contenido genérico o unitario. Sistemáticamente, podemos decir, "que los límites nos ofrecen la panorámica de hasta donde llega el poder "del" propietario, son internos, forman parte del contenido del derecho y las limitaciones, la de hasta donde llega el poder de "un" sujeto que es propietario, o el poder de un sujeto "a pesar de ser propietario"195. Los límites son internos, consisten en las fronteras o punto normal hasta donde el poder del dueño llega, forman parte del contenido del derecho. Las limitaciones o cargas son externas al derecho de propiedad y consisten en reducciones del ámbito de poder tipificado legalmente como propio del titular del derecho y fruto de la colisión con otras figuras jurídicas.

Partiendo de la validez de la distinción, podemos llegar a la siguiente consecuencia: mientras que existe una presunción de inexistencia de limitaciones en la posición jurídica de un propietario (argumento que se

194 PUGLIATTI, S., La propietà nel nuovo diritto ${ }_{2}$ Milano, 1964, p. 145 y ss.

195 COCA PAYERAS, M., Tanteo y Retracto, función social de la propiedad y competencia autonómica, Bolonia, 1988 p. 295. 
desprende del artículo 348 del C.c primer párrafo, "in fine": "sin más limitaciones que las establecidas en las leyes") por lo que deberán ser probadas en todo caso, los límites existen como atributo consustancial al derecho de propiedad, y en todos ellos.

Siguiendo con este razonamiento, la lectura conjunta del art. 33.2 C.E. y del 348 del C. c, nos revela que la función social actúa en este caso, como "límite", pues ella es la encargada de "delimitar" el contenido de las facultades de goce y disposición de todo derecho de propiedad (art. 33.2 dela C.E.) mientras que el inciso final del primer párrafo del artículo 348 del Código Civil alude a las "limitaciones". El resultado sería: "el derecho de propiedad, es la facultad de gozar y disponer de una cosa, limitada por la función social, y sin más limitaciones que las establecidas en las leyes".

Queda claro, por tanto, que la función social por mandato constitucional, opera en el campo de los límites del derecho de propiedad, y no en el de las limitaciones, como se podía entender con anterioridad a la Constitución. Estamos ante una importante mutación, operada por la Constitución, del planteamiento histórico del juego de la función social, a la que, o bien se la dotaba de contenido teórico y por ende de consecuencias jurídicas, o bien se la reconducía al campo de las limitaciones ${ }^{196}$.

La doctrina trata de diferenciar ambas figuras. Así se advierte que, mientras el límite, en cuanto que configura el contenido normal del derecho

196 Cfr. en este sentido, RUIZ DEL CASTILLO, Carlos, "El concepto jurídico social de la propiedad y sus limitaciones" en Rev. Gen. Leg. y Jurisp. 1926, Tomo 149, p. 573 a 600, en particular p. 589 a 594. Además ALVAREZ GENDIN, Sabino, "La teoría del interés mayor como causa limitativa de la prop. privada" en Rev. Gen. de Leg. y Jurisp., 1929, tomo 154 p. 6 a 8 , pone de relieve que las limitaciones de la propiedad, no siempre son por razones de derecho público.

Sin embargo, JESUS LEGUINA, en "Las facultades dominicales de la propiedad forestal" en REDA 1974 p. 446 a 472 concretamente en la p. 450 situaba, antes de la oposición de la Constitución, a la f. s. como límite del derecho de propiedad, junto a la prohibición de realizar actos de emulación. Para ello, se servía de las Leyes Fundamentales. 
de propiedad, es connatural a él, la limitación es efecto de una norma o de un acto especial relativo a la cosa de cuya propiedad se trata.

\subsection{CLASES DE LIMITES Y DE LIMITACIONES:}

Curiosamente, toda la evolución del derecho de propiedad se ha plasmado legislativamente fuera del Código Civil a través de las correspondiente leyes especiales (Ley sobre el Régimen del Suelo y Ordenación Urbana, Ley de Aguas, Ley de Costas, etc.), pero lo realmente importante es que estas leyes anuncian un cambio conceptual de la propiedad, dado que han ido estableciendo un sin número de limitaciones a ese derecho de gozar y disponer a que alude nuestro Código.

En las líneas que siguen vamos a tratar de sintetizar, a título ejemplificativo, algunos de los distintos tipos de límites y de limitaciones contenidos en el ambito de la propiedad privada regulada en el Código Civil. Según se infiere de propio art. 549, los límites pueden hallarse establecidos en interés público o por razones de interés privado.

Los límites por razones de interés privado son menos numerosos y el núcleo-principal de los mismos está constituido por las llamadas "relaciones de vecindad", y los actos abusivos o contrarios a la buena fé197.

Nuestro Código Civil no contiene un precepto general que regule las relaciones de vecindad, como sucede por ejemplo en el Derecho italiano

197 En materia de relaciones de vecindad, y prohibición de los actos de emulación vid. entre otros: Prof. ALONSO PEREZ, M., "Las relaciones de vecindad" en A.D.C. (abril-junio) 1983, p. 357 y ss.; GONZALEZ MARTINEZ, J., "Las relaciones de vecindad y la prohibición de los actos de emulación", en R.C.D.I. septiembre 1928, p. 682 y ss.; BONFANTE, Las relaciones_de vecindad. Traducciòn española de GARCIA VALDECASAS, A. Madrid, 1932; GARCIA SANCHEZ, Teoría de la immissio. Caracteres de las relaciones de vecindad predial en Roma, Madrid, 1975, pp. 207; LACRUZ, Elementos de Derecho Civil, III, Derechos Reales, I, Posesión y Propiedad, Barcelona, p. 203; DIEZ PICAZO, Fundamentos de Derecho civil patrimonial, II, Madrid 1978, cit., p. 114. 
y alemán ${ }^{198}$, sino sólo disposiciones concretas y sistemáticamente encuadradas dentro de las servidumbres legales, lo que ha sido criticado por la doctrina, ya que estas figuras no suponen el sacrificio del interés de un fundo en beneficio de otro, sino que tratan de coordinar los intereses de todos dirigidos al bien común (limitaciones legales).

Se ha afirmado la necesidad de distinguir entre servidumbres y relaciones de vecindad, toda vez que mientras éstos constituyen el régimen normal de la propiedad, aquellas vienen a restringir el poder concedido al titular. De ahí, defiende textualmente el profesor ALONSO PEREZ, se derivan una serie de consecuencias que nos permiten diferenciar mejor a ambas 199: a) "Las limitaciones por razón de vecindad se basan en la idea de libertad e independencia de los respectivos fundos; las servidumbres colocan un predio en situación de vasallaje respecto de otro. b) Las limitaciones vecinales obedecen, en su esencia, a un afán de igualdad, equilibrio y reciprocidad primitiva, a diferencia de las servidumbres que comprimen el contenido de la propiedad sometiéndola a un gravamen y haciéndola depender de otra. c) De ahí que la relación vecinal incida sobre la propiedad para configurarla como una derecho normal, relativo y funcionalizado,mientras la servidumbre no configura o delimita el contenido ordinario de la relación dominical, sino que lo reduce en beneficio del predio dominante. Entraña una limitación excepcional y extrínseca de la propiedad ajena. d) Las limitaciones vecinales no suponen disminución del

198 Vid. prof. ALONSO PEREZ, M., ob. cit. p. 386. El art. 844 del C. civil italiano establece: "El propietario de un fundo no puede impedir las penetraciones de humos o de calor, las exhalaciones, los ruidos, las sacudidas y similares propagaciones derivadas del fundo del vecino si no superan la tolerancia normal, teniendo también en consideración la condición del lugar. En la aplicación de esta norma la autoridad judicial deberá contemplar las exigencias de la producción con los derechos de la propiedad. También podrá tener en cuenta la prioridad de un determinado uso". En el mismo sentido el artículo 684 del Cod. Civil suizo y el 1346 del portugués. El parágrafo 906 del C. civil alemán: "El propietario de una finca no puede impedir la penetración de gases, vapores, emanaciones, humo, hollín, calor, ruido, trepidaciones e inmisiones semejantes procedentes de otra finca, en tanto no entorpezca o sólo no entorpezca de una manera no esencial al aprovechamiento de su finca, o sea producida por un aprovechamiento de la otra finca que, según las circunstancias del lugar, es habitual en fincas de esa situación".

199 Vid. prof. ALONSO PEREZ, M., "Las relaciones de vecindad" en ADC, 1983, p. 365 y ss. 
patrimonio de quien las sufre, ni acrecimiento del que se aprovecha de ellas de ahí que no confieran derecho a indemnización, salvo cuando se incumplan y excedan el nivel de tolerancia permitido. Las servidumbres legales, por el contrario,al disminuir o reducir el contenido normal de la propiedad, demandan, en justa compensación una congrua indemnización en favor del dueño del predio sirviente. e) Los límites vecinales no se extinguen por el no uso, son imprecriptibles como "derecho común de la propiedad" -vieja idea de POTHIER- mientras las servidumbres legales no están exentas del régimen de prescripción, puesto que suponen derogación del derecho común u ordinario regulador del dominio. f) Las limitaciones vecinales protegen los intereses ligados a la buena convivencia y al uso tolerable de las fincas contiguas, pero sin atribuir a éstas un derecho real. Ya sabemos que las servidumbres constituyen, como recuerda Biondi, una categoría jurídica perfectamente definida como ius in re, que permite su reagrupación en un concepto general y en una determinada tutela procesal. Sólo en ellas y no en la relación vecinal, se distinguen perfectamente un fundo dominante y otro sirviente".

Las relaciones de vecindad son límites al derecho de propiedad en interés privado, y entre ellos cabe citar algunos artículos dados para casos particulares y concretos:

- deber que tienen los predios inferiores de soportar la caída de las aguas que descienden naturalmente de los predios superiores (art. 552 del C. civil).

- paso de materiales por finca ajena o soportar en ella la colocación de andamios y otros objetos (art. 569 del C. civil) ${ }^{200}$.

200 Hay división en la doctrina sobre la naturaleza de esa obligación. Unos autores configuran la norma como una mera limitación del dominio, y otros como permisiva de la constitución de una servidumbre temporal de paso. Los primeros se basan precisamente en el carácter meramente 
- recogida de las aguas pluviales en el suelo propio (art. 586 del C. civil).

- distancias relativas a luces y vistas (arts. 581-585 del C. civil).

- plantaciones y construcciones (arts. 589-592 del C. civil).

- persecución de un enjambre de abejas por suelo ajeno (art. 612 del C. civil).

- ramas y raíces del árbol vecino que se extienden a la heredad contigua (art. 592 del C. civil).

- paredes, edificios y árboles que amenazan caerse sobre la finca vecina (arts. 389-390 del C. civil) ${ }^{201}$.

Es necesario resaltar que aunque nuestro Código Civil denomina a estas situaciones servidumbres legales, se trata verdaderamente de límites, pues no suponen un gravamen de un fundo en beneficio de otro.

Otras veces, en cambio, el Código civil es consciente de la necesidad de que para el mejor disfrute de una propiedad es necesario gozar de alguna manera de la ajena, y en base a esta necesidad obliga a consentir el gravamen de la misma con una servidumbre en favor de la primera. Aquí nos encontramos ya con la existencia de un predio dominante, que es el que recibe la utilidad y un predio siriviente, que es el que ha de soportar la servidumbre, ello ocurre cuando por ej.

- el propietario quiere servirse del agua de que dispone y necesita pasarla por los predios intermedios (art. 557 del C. civil).

temporal de la relación, ya que falta entonces la perpetua causa para el establecimiento de la servidumbre.

201 Asímismo fuera ya del Código Civil, se recogen preceptos que tratan de garantizar las relaciones de vecindad; en la L.P.H. de 21 de julio de 1960 en su art. 7-3; en la LAU de 31 de diciembre de 1964, art. 114-8; en la Ley Catalana de 9 de julio de 1990 de la acción negatoria, inmisiones, servidumbres y relaciones de vecindad en sus articulos 34 y ss.; ya en el ámbito del D. Público art. 305 de la vigente Ley del Suelo aprobada por R.D. de 26 de junio de 1992 (art. 236 en la redacción del 76). 
- el que para dar riego a su heredad o mejorarla necesita construir parada o partidor en el cauce por donde haya de recibirla y que los dueños de las márgenes permitan su construcción (art. 562).

- el propietario de una finca enclavada entre otras necesita tener salida a camino público (art. 564).

- el propietario de una casa necesita el desagüe de las aguas pluviales que caen en su corral o patio, pues no tienen salida por su casa, a través de los predios contiguos (art. 588).

Aparte de los límites en interés privado, ya señalados, existen numerosísimos límites en interés público, que se encuentran dispersos en multitud de disposiciones contenidas tanto en el Código Civil (arts. 589, 389 y 390) como en diferentes leyes especiales ${ }^{202}$.

También se consideran límites y no limitaciones la situación de medianería, que origina una especie de comunidad de utilización, cabe dentro del marco de las relaciones de vecindad. Es calificada por el C. Civil de servidumbre legal pero verdaderamente ni es una servidumbre ni un caso de copropiedad.

Por el contrario, no serían límites, sino limitaciones que reducen el poder que ordinariamente tiene el dueño:

- Los derechos de tanteo y retracto: si el derecho de propiedad adoptado, es el definido en el artículo 348 del C.C., es factible plantear que

202 Así , entre otras , las establecidas en interes de la agricultura, en la Ley de fincas manifiestamente mejorables de 16 de noviembre de 1979, en la Ley de 15 de julio de 1952 sobre patrimonio familiar, en la Ley de Reforma y Desarrollo Agrariode 12 de enero de 1973 , derogada en su Titulo II del Libro Primero, en el Título III del Libro segúndo y el Títulol Vdel Libro Cuarto por la Ley 19/1995, de 4 de julio de Modernización de las Explotaciones Agrarias ; en interés de la vivienda y del urbanísmo se establecen una serie de límites y deberes que restringen la libertad del propietario, recogidos en la Ley de Solares de 15 de mayo de 1945, en la Ley de Arrendamientos Urbanos 30 de diciembre de 1994, en la Ley del Suelo, Texto Refundido de 26 de junio de 1992, derogado practicamente en su integridad tras la publicación de la sentencia del T.C. de 20 de marzo de 1997, sentencia que ha dado lugar a la Ley 6 / 1998, de 13 de abril, sobre régimen del suelo y valoraciones. 
la incidencia del tanteo y del retracto sobre este derecho, consista en limitarlo203.

Desde esta perspectiva, puede decirse que aquellos derechos de adquisición preferente, suponen unas barreras externas al poder del propietario, ante las que deben claudicar las facultades dominicales.

Esta visión general de los derechos de tanteo y retracto como cercenadores de parte del contenido de las facultades del propietario, es compartida por la jurisprudencia del Tribunal Supremo, en numerosas decisiones 204

-Las limitaciones administrativas, consistentes en la sujección parcial de una cosa a alguna utilización o uso en beneficio de la Comunidad, bien en utilidad directa de una cosa pública, bien en la de la colectividad. En nuestro Derecho "es imposible exponer todas las limitaciones administrativas, llamadas servidumbres legales de interés público, dispersas en multitud de leyes, y que tienen más adecuado desarrollo en el Derecho Administrativo"205.

También son limitaciones, las prohibiciones de enajenar, en cuanto suponen ciertas restricciones a la libre disponibilidad de la cosa por su dueño; así en laLey 14/ 1992 de 28 de diciembre de la CC.AA. de Aragón se regula estas restricciones en los arts.12 párrafos 1 y 2; art. 22 párrafo 1 y art. 40.

203 MOUTON Y OCAMPO, L., "Necesidad de la revisión del Código civil) (Instituciones que deben reformarse y agregarse)", R.G.L.J. tomo 113, Madrid 1908, pp. 433-463; ARIÑO ORTIZ, G., y CUETARA MARTINEZ, J.M., en La protección jurídica de los espacios naturales, Madrid, 1982, p. 114; COCA PAYERAS, M., Tanteo y Retracto, Función Social de la propiedad y Competencia Autonómica, Bolonia, 1988, pp. 151.

204 Vid. a modo de ejemplo la St. de 20 de marzo de 1929; St. de 8 de abril de 1942; St de 17 de diciembre de 1955; St. de 6 de marzo de 1971; St. de 29 de octubre de 1985.

205 CASTAN TOBEÑAS, Derecho Civil... ob.cit., p. 125. 


\subsection{DIFERENCIA CON OTRAS FIGURAS AFINES.}

Existen ciertas diferencias entre las limitaciones y las servidumbres. Como afirma CASTAN TOBEÑAS ${ }^{206}$, la servidumbre es una derogación del régimen normal de la propiedad (constituida por la libertad de los fundos), mientras que las limitaciones (impuestas por la ley a todos los predios que se encuentren colocados en determinadas condiciones), señalan los contornos normales del dominio.

Las limitaciones definen el derecho de propiedad, pudiendo afectar a cualquiera de sus facultades, tanto de goce como de disposición; en cambio, las servidumbres suponen un gravamen que afecta al goce o aprovechamiento del predio sirviente, por ello un retracto legal o una prohibición de enajenar constituyen limitaciones y no servidumbres.

Las limitaciones pueden afectar a la totalidad del derecho de propiedad, así la expropiación forzosa; en cambio, las servidumbres tan sólo gravan parcialmente tal derecho.

En razón a su duración; aquellas son indefinidas, éstas aunque perpetuas en principio pueden extinguirse por su no uso durante veinte años, artículo 546-2 del Código Civil.

Finalmente, las limitaciones pueden recaer sobre toda clase de bienes; en cambio, las servidumbres únicamente pueden gravar los bienes inmuebles.

Se ha discutido con insistencia la posibilidad de relación entre el derecho de obligaciones y el derecho de propiedad, discusión que tiene su base en la posibilidad o no de admitir un concepto obligacional derivado de

206 IBIDEM., p. 129; en el mismo sentido, SANTOS BRIZ, J., Derecho Civil. Teoría y Práctica, Tomo II, Derecho de cosas, Madrid, 1973, p. 131; MESSINEO, F., Manual de Derecho Civil y Comercial, Tomo III, ob.cit., p. 228; ALBALADEJO, M., Derecho Civil, Tomo III, Vol. 1ํㅡ, ob. cit., p. 219. 
una titularidad real con exigibilidad al propietario por ser titular del derecho de propiedad.

Aunque nuestro Código Civil no recoge expresamente, en la definición de la propiedad, el tema de las obligaciones del propietario, lo cierto es que las consecuencias de exigir obligaciones conectadas a un derecho real produce la figura conocida con el nombre de obligaciones "ob rem" o "propter rem".

Según la doctrina 207 los carácteres que concretan la regulación jurídica de este tipo de obligaciones se concretan en los siguientes:

1. Accesoriedad. Las obligaciones propter rem integran el contenido del derecho real y siguen su misma suerte. El nacimiento, transmisión y extinción del derecho real acarrea idénticas vicisitudes en la obligación real inherente.

2. Ambulatoriedad.La persona del deudor_y en su caso la del acreedor_será variable, pues depende de quien sea en cada momento propietario o titular de derecho real sobre la cosa.

3. Abandono liberatorio. El deudor ob rem puede eximirse de realizar la prestación señalada legalmente (v.gr. reparación y construcción del muro medianero art. 575; obras necesarias para el uso y conservación de la servidumbre realizada en el predio sirviente por los dueños de los predios dominantes art. 544; o por el dueño del predio sirviente art. 599; en materia de censos abonar el canon arts. 1625, 1631, 1659, $1664 \ldots$ etc), renunciando a su titularidad real.

4. Determinabilidad real. El deudor se individualiza o concreta por referencia a la propiedad, posesión o derecho real.

207 Vid. ALONSO PEREZ, en su Comentario al art 575 Código Civil, en Estudios del Centenario del Código Civil, vol. I, Ministerio de Justicia,Madrid, 1993, pp. 1468-1469 ; HERNANDEZ GIL, "Concepto y naturaleza de las obligaciones propter rem " RDP 1962, pp.850 y ss.; DE LOS MOZOS, Estudios Roca, II, pp. 331 y ss.; DIEZ-PICAZO, Fundamentos, II, pp. 58 y ss. 
5.Tipicidad. Al menos relativa, en el sentido de que la mayoría de las obligaciones "propter rem"son obligaciones legales, en las que sólo opera la autonomía de la voluntad cuando lo autorice un precepto legal.

6. Limitación fruitiva. Constituyen una limitación al goce y uso de las cosas objeto del derecho real.

7. Posible eliminación de la responsabilidad patrimonial universal, pues el incumplimiento específico de la obligación real, en las hipótesis legales en que se permita la renuncia liberatoria y el deudor haga uso de ella, impide responder ex art. 1911C.c.

Su tipicidad legal hace que en estas obligaciones no opere la regla inter partes del contrato (art. 1257C.C) y que el cambio del deudor no precise el consentimiento del acreedor (art. 1205 del C.c).

Además de los caracteres constitutivos de la obligación propter rem ordinariamente señalados por la doctrina, este tipo de obligación sólo existe cuando hay dos o más sujetos titulares de relaciones jurídicas sobre la misma cosa (ob eandem rem). Relaciones de comunidad (art. 395)208, vecindad sobre la misma pared medianera (art. 575), varios titulares que ejercen sus derechos sobre el mismo predio sirviente (art. 544), finca censida sobre la que el dueño directo y el censatario tienen sus correspondientes derechos (arts. 1625, 1631, 1659, 1660 del C.c). La concurrencia de diversos titulares ob eandem rem, sobre la misma cosa, aunque sea en concepto diverso, y por el hecho de ostentar un poder sobre aquélla ut dominus vel ut possessor, obliga a colaborar con los demás titulares y a contribuir, por tanto, a la conservación de la cosa disfrutada ${ }^{209}$.

208 Este precepto tiene su paralelo en el art. 5 de la Ley de Propiedad Horizontal, en el que no sólo se establece la cuota de participación como obligación para contribuir al sostenimiento de los gastos generales, sino que parece que todas las reglas relativas al uso, destino, instalaciones y servicios, gastos, administración y gobiernos, seguros, conservación y reparaciones, que forman el estatuto privado, poseen una cierta dosis de ambulatoriedad, en la medida en que, en cuanto obligaciones, se traslada a los nuevos propietarios de los pisos 0 locales, a quienes vinculan de forma directa.

209 Vid. ALONSO PEREZ, M., "La propiedad horizontal. Especialidades de su contenido como derecho", en R.D.P., febrero 1977, p.94. 
Dentro de las obligaciones propter rem, se citan también en el Código, aquellas obligaciónes que entran dentro de la responsabilidad objetiva, es decir, aquel tipo de responsabilidad que se conecta con la propiedad de una cosa o con la titularidad de un derecho real, y en la cual se prescinde, para determinar el sujeto responsable, del factor de la culpabilidad. Dentro de este tipo de responsabilidad se incluyen los supuestos contemplados en los artículos 1906-1907 y 1908 todos ellos del C. Civil 210 .

Este tipo de obligaciones, son reconocidas por distintos autores, si bien de forma diversa, bien se cataloguen como derechos reales, que como relaciones jurídicas obligatorias en cuanto que suponen prestaciones personales ${ }^{211}$, o como derecho de naturaleza mixta en razón a la debida naturaleza de obligatoriedad y de realidad ${ }^{212}$; incluso autores que adoptan una postura ecléctica al afirmar que pueden ser derechos reales o de crédito según la valoración que se conceda a los caracteres que integran el mismo 213 .

A modo de resumen de diferencias, se podría decir que la "limitación", afecta al derecho, la obligación a la persona. Ambas invaden la esfera personal aunque de forma diversa.La limitación actúa más bien en forma de restricción de facultades en orden al ejercicio del derecho de propiedad; las obligaciones vinculan, sujetan al propietario para que actùe en determinado sentido. Aquella tiene más bien una proyección objetiva, esta más bien una estructura personal.

\footnotetext{
210 Vid. ALONSO PEREZ, Comentario al art. 575 del C.c, ob.cit., p. 1469.

211 BARASSI, L., Propietà e Compropietà, Milano, 1951; BETTI, Teoría general del negocio jurídico, R.D.P. s.f., Madrid; MESSINEO, F., Derecho Civil y Comercial, Buenos Aires, 1954, Tomo II; HERNANDEZ GIL, F., Concepto y naturaleza jurídica de las obligaciones "propter rem". RDP, año 1962, pp. 858 y ss.

212 PUGLIATTI, S., La propietà nel nouvo diritto, Milano, 1954.

213 GIORGIANI, “II Diritto privato ed i suoi attuali confini”, Riv. Tri. Dir. e Proccedura civile, 1961. 
Asímismo y como consecuencia de la función social que la propiedad está llamada a cumplir, se le imponen al propietario una serie de deberes.

Las diferencias entre "deberes" y "limitaciones" descansan en la distinta postura de acción u omisión que ha de adoptar el propietario como titular del derecho de propiedad. Las limitaciones han tenido por antonomasia un contenido negativo de abstención, en cambio, los deberes lo tienen de actuación positiva de realizar una prestación de dar o de hacer acorde con su destino 214 .

También se ha considerado a los "deberes" como "previsiones estatutarias de carácter positivo"215. En cambio, otro sector de la doctrina, al referirse al contenido de los "límites" afirma que "a veces el límite consiste en que el propietario no puede hacer algo, otras en que tiene el deber de hacerlo quitándosele así la libertad de omitirlo"216.

Sin embargo, DIEZ PICAZO217 sostiene que "todo "límite" entendido como una privación o como una restricción de un contenido ideal, existe siempre que se impone un deber, de cualquier tipo que éste sea. Todo deber es una limitación de la libertad. La distinción entre límites y deberes con arreglo al carácter positivo y negativo del comportamiento del propietario (facere y non facere), tampoco parece convincente. Sería, dice, tanto como desconocer la categoría de las obligaciones negativas y de las prestaciones de abstención. Toda prohibición entraña un deber negativo. Son proyecciones distintas, dice, de un mismo fenómeno, de suerte que todo depende del punto en que se haya colocado la iniciativa y de quién sea la persona que la haya tomado. Si la iniciativa parte del propietario, la regla crea un límite, y si parte de los terceros, sean públicos o privados, la

\footnotetext{
214 Vid., CARRO MARTINEZ, A., "Los principios de la nueva Ley del Suelo", en Rev. de Estud. de la Vida Local (julio-agosto) 1956 p. 533.

215 MARTIN MATEO, El estatuto de la propiedad inmobiliaria, R.A.P., № 52, p. 101.

216 ALBALADEJO, M., Instituciones de Derecho Civil, op. cit., p. 66.

217 DIEZ-PICAZO,L., "Los límites del derecho de propiedad en la legislación urbanística", R.D.U. no23, 1971, p. 22.
} 
regla crea deberes. Por ello, estima dicho autor, que quizá fuese más exacto decir que "la situación de propiedad produce una serie de deberes que funcionan al mismo tiempo como límites del derecho".

Aunque las expresiones obligación y deberes parecen tener idéntico significado, y la Ley las utiliza como sinónimos, sin embargo, se han intentado diferenciar en base a la contraposición entre potestad y derecho subjetivo 218 .

La potestad es un poder abstracto y genérico, mientras que el derecho subjetivo emerge de una relación jurídica concreta, con un objeto específico y determinado. De la misma manera, el deber tiene un carácter abstracto y consiste en una limitación en virtud de la cual un sujeto se ve compelido a una omisión, a un pati, o a una prestación positiva de hacer o dar. La obligación, por el contrario, se refiere a un bien determinado y es correlativa o se corresponde con un derecho subjetivo ${ }^{219}$.

RODRIGUEZ ARIAS 220 , ha intentado diferenciar deberes $y$ obligaciones analizando los elementos que la componen:

- La obligación representa una situación jurídica subjetiva.

- El deber, una consideración objetiva.

Desde el punto de vista de la relación jurídica, la obligación tiene un origen voluntario; el deber necesario, con necesidad de medio para conseguir el fin.

218 Vid. DE CASTRO,F.Derecho civil...,ob.cit.,p.185.

219 CANCELLER FERNANDEZ, A., "El derecho y la obligación de edificar" Madrid, 1965, p. 237 y ss.

220 RODRIGUEZ ARIAS-BUSTAMANTE, L., Derecho de Obligaciones, Madrid 1965, p. 10. 
La obligación acusa un fuerte carácter individualista; el deber, un rasgo esencialmente social, ya que deriva de un orden general preestablecido en el seno de una comunidad de derecho.

La obligación se extingue al cumplirse la prestación; el deber no se extingue con el cumplimiento momentáneo de su fin, sino con la desparición de éste.

Y las cargas ¿como afectan al derecho de propiedad?. Tanto el límite como la obligación como la carga, tienen por función la de consentir la tutela concomitante de un interés diverso del del propietario, que generalmente será un interes público 221

La expresión "cargas" en términos generales parece significar tanto como gravamen, y en tal sentido, se refiere a ellas el artículo 1.483 del Código Civil; e igualmente con idéntico significado se menciona en la Ley hipotecaria a través de su articulado, artículos 225 relativo a las certificaciones de cargas; artículos 61,62 y 64 relativos a fincas refaccionadas; relativos a su liberación son los artículos 209 y 210; en todas estas referencias dicho término, se utiliza en sentido material de similitud a un derecho real que recae sobre bienes inmuebles.

Sin embargo del artículo 1214 del Código Civil, parece desprenderse más bien un significado adjetivo, de medio para obtener un fin, que de no realizarse no se produce éste, cuando dispone que "Incumbe la prueba de las obligaciones al que reclama su cumplimiento y la de su extinción al que la opone". Con ello el "onus probandi" aparece como una carga de quién pretende exigir o dar por extinguida una obligación. La doctrina moderna habla de carga "cuando el ejercicio de una facultad

221 Vid. MONTES, V., La propiedad privada en el sistema del derecho civil contemporaneo, Madrid, 1980, p. 253. 
aparece como condición para obtener una determinada ventaja"222, en parecido sentido la definen como, "la necesidad de satisfacer exigencias de índole positiva que incumbe a quien, aspirando a un determinado resultado práctico, tiene interés en la validez o en una precisa eficacia del negocio que realiza para alcanzarlo"223.

Para PUGLIATTI224, "la carga constituye ahora una categoría del deber jurídico, que tiene fisonomía propia, distinta de aquella otra categoría, actualmente clásica, de la obligación. La carga no implica sanción jurídica directa, sino que es condición para el logro de determinados efectos, de forma que si no se cumple, pierde los efectos útiles del acto; la obligación implica un deber de conducta para el sujeto, de forma que su incumplimiento acarrea la correspondiente sanciòn".

En nuestra doctrina, se ha considerado la carga "como contraprestación para obtener un beneficio"225; definición que se detalla más en GARCIA TREVIJANO226, cuando dice que "consiste en una subordinación de un interés propio a otro igualmente propio del mismo sujeto (o de otros que de él dependan) aunque de distinta naturaleza, de forma que si se quiere obtener un determinado efecto jurídico favorable, hay que actuar de determinada manera".

222 Vid. CARNELUTTI, Sistema de Derecho Procesal Civil, Buenos Aires, 1944, pp. 118.

223 Vid. BETTI, Teoría general del negocio jurídico, R.D.P. s.f. p. 86.

224 Vid. PUGLIATTI, S., La propietà... ob. cit., p. 39.

225 Vid.DIEZ-PICAZO, Fundamentos,III, ob.cit.p.81; DE LOS MOZOS, La obligación real, II, Madrid,1976,p.331. ; VALLET DE GOYTISOLO,Estudios sobre Derecho de cosas, Madrid, 1985; DIEZ-PICAZO y PONCE DE LEON, "Autonomia privada y derechos reales", RCDI, 1976,p.273; CASTAN TOBEÑAS, Derecho civil español común y foral, T.Il,vol.1º, Madrid, 1964;ALBALADEJO, Derecho civil III, Derecho de bienes, Vol.2º, Barcelona, 1989; BIONDI,en Le servitúe prediali, ob.cit.,p.109;GARCIA DE ENTERRIA, "Configuración jurídica de la propiedad urbana", Conferencia pronunciada en Jornadas de Derecho urbanístico, Salamanca, junio de 1973.

226 GARCIA TREVIJANO, J.A., Tratado de Derecho Administrativo, Edit. RDP, Madrid, 1964, p. 506. 
La carga se diferencia de la obligación en razón de que no existe sanción del mismo grado. Por ello la diferencia se produce en el campo de la exigibilidad de la conducta prevista. Como señala DIEZ PICAZO227, "Ios deberes jurídicos son directamente exigibles, con independencia de que por recaer en el terreno de la libertad puedan ser o no cumplidos "in natura". Las cargas son conductas necesarias, sólo requisito previo o presupuesto del acto del ejercicio de una facultad. El deber engendra una acción, una pretensión dirigida a reclamar su cumplimiento, pero inobservada la carga, permite liberarse de las consecuencias que origina el ejercicio del derecho. Aduce "ad exemplum" el que proporciona el artículo 1.796 del Código Civil, en cuanto a la conducta que exige el mismo al asegurado, de poner en conocimiento del asegurador el daño siniestrado en los plazos y a las personas señaladas, y de no hacerlo así pierde la acción. No existe obligación, dice, por cuanto el asegurador no puede exigir al asegurado su información, lo que ocurre es que la comunicación del asegurado es a modo de premisa de su propia pretensión".

En idéntico sentido GARCIA TREVIJANO228, admite tal carácter, al referirse a las normas de fomento que las establecen respecto a los administrados, quienes si quieren obtener los beneficios que aquellos otorgan, deben actuar en sentido determinado.

De "lege data", fuera ya del Código civil, en el ámbito de la propiedad del suelo, como veremos en un momento posterior, se observa una total equiparación entre las obligaciones y las cargas, dado que su no cumplimiento se sanciona, de igual forma en ambos supuestos, con la enajenación forzosa del bien afectado por las mismas, artículo 4.1 de la Ley 51/1962, de 21 de julio, sobre Valoración de Terrenos sujetos a 
Expropiación en Ejecución de los Planes de Vivienda y Urbanismo, cuando dispone que la declaración de incumplimiento de la obligación de edificar una finca, sin perjuicio de considerarse como carga real, iniciará inmediatamente el procedimiento de enajenación forzosa.

Igualmente, tal semejanza se desprende de los artículos 1 y 27.2 del Reglamento de edificación forzosa y Registro municipal de solares de 5 de marzo de 1964, en cuanto que se habla de la obligación en general de edificar, así como del carácter de carga real, a todos los efectos legales, de la situación de enajenación forzosa.

Es interesante hacer constar, cómo en un mísmo texto se produce una simbiosis entre el mundo de lo "obligacional" y el de lo "real", dado que el artículo 27 citado declara que el incumplimiento de la obligación de edificar se hará constar en el Registro de la Propiedad por nota al margen de la última inscripción, y que de no hallarse inscrito el inmueble, se extenderá anotación preventiva. Una vez más la publicidad registral ampara el principio de seguridad de tráfico de bienes, y al objeto de conseguirlo, se exige del Registrador comunique de oficio al Ayuntamiento los cambios de titularidad y las modificaciones objetivas de la finca que se inscriban.

De todo lo que llevamos dicho hasta ahora, podemos llegar al siguiente razonamiento, no cabe duda que los límites son instrumentos técnicos que, nacidos a la luz de la función social tratan de corregir el absolutismo de los derechos, y, en concreto, el poder discrecional otorgado tradicionalmente al propietario. Para paliar esta discrecionalidad, y partiendo de que no puede concebirse un poder absolutamente ilimitado, surgen innumerables limitaciones que, junto con las obligaciones y deberes, tratan de equilibrar el interés del propietario con otro interés, ya sea privado o público, que es también digno de tutela. 


\section{LIMITACION Y EXPROPIACION DEL DERECHO DE}

PROPIEDAD.

La necesidad de habilitar terrenos suficientes para atender a los intereses generales de la colectividad, impone a ésta el ejercicio del "imperium" por parte de la Administración Pública con el fin de conseguir aquellas extensiones necesarias en orden al cumplimiento de esos fines. Tales limitaciones afectan al "ius disponendi" del derecho de propiedad en el sentido de que exigen una necesaria disposición de su derecho al propietario. La imperativa transmisión del derecho de propiedad impuesta a su titular, el propietario, sirve de base a la presente limitación.

Tradicionalmente la expropiación forzosa ha sido considerada como limitación al derecho de propiedad que afecta al derecho de disponer, en tal dirección ROYO VILLANOVA ${ }^{229}$ cuando afirma, que la facultad de disponer tiene entre otras limitaciones, a) la de vender o no, b) la de vender a cualquiera, y c) la expropiación forzosa que obliga al propietario: $1^{\circ} \mathrm{A}$ vender el objeto de su propiedad, y $2^{\circ}$ A venderlo al Estado o a otra entidad o persona como representante de la colectividad que necesita de este medio para cumplir los fines de interés general".

Esta cesión forzosa a favor de la Administración, constituye el punto de partida que trata de asimilar la expropiación a una venta especial, venta impuesta y necesaria que lleva en sí la ausencia de libertad en su elaboración y por ende la de todo posible contrato. Por ello como dice VIGNOCH ${ }^{230}$, "ciertamente en el pasado, no dejó de considerarse la expropiación sino como una venta forzosa en la que la voluntad del Estado

${ }^{229}$ ROYO VILLANOVA, A., Elementos de Derecho Administrativo, Valladolid, 1955, citado por Castán Tobeñas en D. Civil, D. de cosas, ob. cit., p. 303.

230 VIGNOCHI, G.,'"L'indemnitá di expropiaziones" en JUS, de junio de 1961, fac. $2^{\circ}$ p. 294 , citado por Martín Gomero en Expropiaciones Urbanísticas p. 154. 
sustituía a la del propietario para determinar el traspaso del bien, dándose pie de esta manera a la tesis de la expropiación, como expropiación de la facultad de disponer; más a ello se opone el hecho de que el paralelismo entre la indemnización y precio viene imposiblitado por la naturaleza unilateral del "imperium" de la expropiación, por la carencia (prácticamente) de toda libertad contractual en la fijación del justiprecio y en los demás elementos de la relación, y por la diversidad de las causas respectivas de la compraventa y de la expropiación".

Por ello se precisa admitir que el verdadero sentido de la expropiación forzosa, según la orientación moderna, no es otro que el de un acto de Derecho Público derivado de la autoridad del Estado como representante de los intereses colectivos y sociales.

Idéntica posición adoptan en nuestra doctrina ESPIN CANOVAS 231 al señalar "que aunque se la ha considerado como una limitación del derecho de propiedad por la que el propietario no puede ejercitar libremente su facultad de disposición al tener que vender forzosamente al Estado, nos parece más acertada la opinión contraria que cree que la expropiación forzosa es algo más que una limitación de la propiedad privada, ya que para el expropiado produce la pérdida de su derecho. Se trata por tanto, de verdadera pérdida del derecho de propiedad para su titular, por causa de interés púiblico".

Para ALBALADEJO232, la expropiación constituye una causa de extinción de derechos y si se quiere es un límite a los mismos (en el sentido, no de que reduzca su poder actual, sino el de que eventualmente, puede suprimirse a su titular la facultad de no enajenarlo si no quiere, así como imponerle cierto adquirente). Queda claro, dice, que la expropiación no es 
una venta; no hay en ella contrato, ni acuerdo de voluntades, y la suma de dinero que proceda dar al expropiado, no es el precio sino una indemnización en metálico.

GARCIA DE ENTERRIA233, habla de límite intrínseco al derecho de propiedad, y no de invasiòn advenida exteriormente a tal derecho.

Indudablemente la puesta en relación de la utilidad pública y el interés particular, sobre los mismos objetos, producen una especial situación conflictiva de afectación de los mismos en uno u otro orden, y ello es lo que da lugar al nacimiento de la figura jurídica de la expropiación. "La protección jurídica dispensada al interés del propietario no ha de ser obstáculo para que prevalezca el interés público, siempre que esté debidamente comprobado y se ofrezca la debida compensación al primero" PUIG BRUTAU234.

Esta relación de intereses afecta al régimen jurídico de la propiedad y demás derechos patrimoniales, en cuanto que fijada la causa "expropiandi" legitima la medida de "privación" del derecho, o sujección o modificación del mismo a través de la necesaria "conversión" de aquellos en su medida de valor, bien "in natura" (cambios, sustituciones, permutas), o en moneda de curso legal, según justiprecio realizado a tal fin. Con ello la expropiación deriva a un caso típico de subrogación real, por causa de utilidad pública o interés social, en la que el propietario no pierde radicalmente la sustancia de su derecho, sino que tan sólo experimenta una transformación del mismo en la oportuna indemnización legal; hasta el

233 GARCIA DE ENTERRIA, E., Los principios de la nueva Ley de Expropiación Forzosa, Madrid, 1956, p. 23.

234 PUIG BRUTAU, Fundamentos de Derecho Civil, T. II, Barcelona, 1971, p. 421. 
extremo de que recaerán sobre ésta idénticos gravámenes que pesaban sobre la cosa expropiada, ROCA SASTRE 235 .

La figura jurídica de la expropiación forzosa por causa de utilidad pública, trasciende del "ius privatum" y se erige en figura prevalente dentro del "ius publicum"; recogida por el Código Civil como enajenación forzosa, se regirá por lo que establezcan las leyes especiales (art. 1456 C.c).

No hay que olvidar, que la Administración necesita de medios de todas clases en orden al cumplimento de sus fines, a menos que se inhiba de ellos, dejando de cumplir sus funciones, a costa incluso de su misma existencia. La obtención de medios materiales, se arbitra por la Administración Pública por distintos procedimientos: la confiscación, que supone la negación del derecho de propiedad que se absorbe por el estado sin indemnización alguna a su titular, aparece excluida de nuestro ordenamiento (sí se recogía en el Fuero de los Españoles); el comiso, medida sanción que tiene por base referirse a efectos cuyo tráfico se sanciona con su privación, particularmente por las leyes fiscales; la requisa, en cuanto que supone la intervención de la autoridad militar; la ocupación temporal, que supone la posesión por tiempo determinado; y la expropiación que como dice CARRETERO PEREZ"236, "constituye la privación singular de una titularidad patrimonial privada, consistente en la extinción o disminución de su contenido económico, acordada imperativamente por la Administración, por causa de interés general, compensada por una indemnización previa”.

235 ROCA SASTRE, A., Derecho hipotecario, Tomo II, Barcelona 1968, p. 719 y ss.

236 Vid. CARRETERO PEREZ, A., Comentarios a la Ley de Expropiación Forzosa, Madrid, 1966, p. 51. 
Se puede observar claramente el ensanchamiento habido en el ámbito de aplicación de la institución expropiatoria, que queda desbordada en sus moldes clásicos (tratarse de inmuebles referirse a transferencia de propiedad y tener por causa la utilidad pública) y en base a la Ley de Expropiación forzosa actual de 16 de diciembre de 1954, y su Reglamento de 26 de abril de 1957, se amplía su esfera de actuación, como señala MANZANEDO MATEOS y se manifiesta ${ }^{237}$ :

a) En la sujección a tal potestad expropiatoria no sólo de la propiedad, sino de cualquier derecho o interés legítimo de contenido patrimonial (art. 1, L.E.F.)

b) En la existencia de modalidades expropiatorias que no implican venta, sino otros derechos reales o incluso relacionados con su ejercicio (supuestos censos, arrendamientos, ocupación temporal o mera cesación en su ejercicio), y

c) En la causa "expropiandi" por interés social que expresa cualquier tipo de interés prevalente al individual, reconocida por la Ley ${ }^{238}$.

Esto tiene especial interés en el momento actual, a la hora de poner en relación los conceptos de limitación y expropiación del derecho de propiedad, por las especiales consecuencias en orden a la existencia o no existencia de indemnización caso de que su titular se vea privado de él en todo o en parte.

Por ello, cuando hablamos de la privación del derecho de propiedad por causa de utilidad pública cabe plantearse el siguiente interrogante ¿cuándo tiene el carácter de limitación y cuándo el de expropiación?. Admitir una u otra vía tiene particular relevancia en lo que a

237 MANZANEDO MATEOS, J.A., "Expropiaciones urbanísticas", en R.A.P. núm. 60, año 1969.

${ }^{238}$ Esta Ley de Expropiación Forzosa de 16 de diciembre de 1954 ha de entenderse afectada por lo dispuesto en los Títulos III y IV de la Ley 6/ 1998, de 13 de abril de, Régimen del Suelo y Valoraciones, y en los preceptos vigentes del Título V del Texto refundido de la Ley sobre el Régimen del Suelo y Ordenación Urbana de 1992. 
indemnización se refiere, y así surge los conceptos de "limitación constitutiva" y la limitación (expropiación), privación de derecho", una que configura los derechos y otra que los niega y extingue. Por ello, una es definidora del derecho, a través de las medidas legales que lo condicionan en orden a su extensión, contenido y ejercicio; y la otra supone la negación de un derecho ya existente o la mutilación de su contenido, con verdadero "sacrificio" para la persona de su titular. Una, el límite, no es indemnizable por cuanto que actúa como creadora del derecho de propiedad, la otra, la expropiación, sí lo es, por cuanto que niega a su titular el derecho de su pertenencia.

Como señala CARRETERO PEREZ239, "El límite es inmanente o institucional al Derecho, lo define al garantizar a su titular una gama de actos posibles que constituyen el contenido del derecho de propiedad. La limitación es una sujección general mediante la cual el Estado salvaguarda el interés general suprimiendo la libertad del propietario para utilizar como quiera su derecho. En cambio, la expropiación por constituir derechos reales administrativos sobre la propiedad privada, origina un poder concreto de la Administración sobre la cosa, por medio de una relación jurídica individualizada".

Cabría preguntarse, sí las espectativas forman parte del contenido de la propiedad, a efectos de indemnización, en el supesto de que la expropiación tenga lugar. La jurisprudencia del Tribunal Constitucional se pronuncia en contra, alegando que hay limitaciones que no son susceptibles de generar una obligación de resarcir al propietario afectado por ellas, por considerar que no suponen privación de propiedad, ni de bienes y derechos patrimoniales $^{240}$. Si esto es así, no son limitaciones porque configuran de

239 CARRETERO PEREZ, A., Comentarios a la Ley de Expropiación forzosa, Madrid 1966, p. 16.

240 En la sentencia 227/1988, de 29 de noviembre, en los fundamentos jurídicos 11 y 12 se refiere expresamente el Tribunal al derecho de propiedad cuando hay o no expropiación, y entiende que puesto que de aprovechamiento de aguas se refiere, ganados con anterioridad, su limitación temporal a 75 años no significa expropiación, puesto que se está configurando el 
nuevo un derecho, y si recortan facultades propias de un derecho configurado con anterioridad, llevaría aparejada la obligación de resarcir ${ }^{241}$.

Así, como indica el Tribunal Constitucional242, son esencialmente dos las notas que diferencian la expropiación legalmente configurada de cualquier otra intromisión en el derecho de propiedad no encuadrable en aquélla. La primera referida al objeto de la expropiación, que sólo puede recaer sobre derechos ya consolidados y en ningún caso sobre meras expectativas o previsiones de fututo. La segunda afecta a su alcance, que ha de circunscribirse necesariamente a la propiedad o a los derechos de uno o varios sujetos determinados o determinables sin que en ningún caso pueda tratarse de una regulación general con eficacia erga omnes.

dercho o delimitando el contenido de derechos patrimoniales. "En efecto, a diferencia del derecho de propiedad privada, no sujeto por esencia a límite temporal alguno conforme a su configuración jurídica general, es ajeno al contenido esencial de los derechos individuales sobre bienes de dominio público, garantizado indirectamente por la Constitución a través de la garantía expropiatoria, su condición de derechos a perpetuidad o por plazo superior al máximo que determine la Ley". Ni siquiera considera que exista dicha expropiación cuando la concesión que haya de obtenerse en caso de incremento de los caudales utilizados o modificación del régimen de explotación se extienda obligatoriamente a toda la explotación. En este supuesto la decisión de incrementar corresponde libremente al interesado, y, por tanto, "se trata de una nueva transformación voluntaria del derecho originario". En su fundamento juríco 7 el TC manifiesta que la Ley de Aguas no impone un sacrificio excesiva con la opción de demanialidad que en ella se acoge. Y, además, "la Ley respeta los derechos prexistentes en función del contenido efectivo o utilidad real de los mismos ...,limitándolos a los caudales totales utilizados, de suerte que cualquier incremento de los mismos requerirá la oportuna concesión. Pero esto no implica expropiación parcial de los mismos, pues con ello sólo quedan eliminadas las simples expectativas de aprovechamientos de caudales superiores que eventualmente podían obtenerse" vid. MORO ALMARAZ,en Medio ambiente y función social de la propiedad,RCDI, ํㅜ 617,1993,vol.II p.992, donde hace un análisis detallado de la citada sentencia así, como de la STC170/1989, de 19 de octubre, en cuyo fundamento jurídico $8^{\circ}$ intenta dilucidar si en la Ley de la Comunidad autónoma de Madrid 1/1985, de 23 de enero, del Parque regional de la cuenca del Manzanares, se produce una expropiación legal, cono afirman los recurrentes. A juicio del TC, no es así, para quien no existe expropiación en el sentido constitucional. La Ley realiza en los art. 14-22 "una configuración de los derechos existentes sobre dichos terrenos que no supone en si misma privación de propiedad alguna ni de bienes y derechos patrimoniales, sino sólo el establecimiento de las limitaciones generales y específicas que respecto de los usos y actividades hayan de establecerse en junción de la conservación de los espacios y especies a proteger".

241 Vid. MORO ALMARAZ, ob.cit., p.994 a 1010.

242 Vid. STC 41/1990, de 15 de marzo, f.jco.4; en el mismo sentido las SSTC 108/1986, de 26 de julio, f.jco.20; 99/1987, de 11 de junio, f.jco.6 a) y b), y 178/1989, de 2 de noviembre, f.jco.9.El Tribunal Constitucional sólo estima susceptible de expropiación, y por lo tanto indemnizable, la privación de bienes y derechos a que se refiere el art. 33.3 C.E. Asimismo, estima indemnizable, en el marco del art. 1.1 LEF la afectación de intereses patrimoniales legítimos, como las situaciones en precario, pero descartando siempre las meras expectativas. 
A modo de conclusión habria que decir que el problema de la propiedad, es un problema de límites, lo que se pretende es evitar que ésta constituya un entorpecimiento y una restricción de los intereses públicos, es decir, del bien común, cuyo control y tutela se confía a la Administración Pública, a través del principio de la "función social".

Así pues, la propiedad, que en su concepción individualista era simplemente un Derecho del titular, pasa a ser en la concepción social, un Derecho que crea obligaciones, y que ha de ser ejercitado en consideración no sólo a la utilidad del propietario, sino tambien a la utilidad general. Por tanto, no cabe hablar de un derecho de propiedad absoluto, los poderes del propietario se encuentran limitados. 


\section{CAPITULO QUINTO}

\section{LA FUNCION SOCIAL DE LA PROPIEDAD. SU CONSAGRACION EN LA CONSTITUCION ESPAÑOLA DE 1978.}

La función social no es algo nuevo en la propiedad moderna, pero, sin embargo, es a partir de esta Era cuando los autores comienzan a estudiar este tema y a hacerse preguntas como: ¿Cuál es el contenido que engloba el término función social?. ¿Qué significado tiene: subyace en su base una determinada ideología (socialista) o, por el contrario, no tiene nada que ver con ella?. ¿De qué forma incide sobre el derecho de propiedad y de qué manera lo afecta: lo anula o sólo configura su contenido?.

Estos interrogantes han dado lugar a que muchos autores que se han ocupado del tema, utilizaran términos distintos para designar una misma realidad.

En defintiva, uno de los grandes problemas del término función social es su indeterminación que ha dado lugar a su consideración como «cajón de sastre», donde han tenido cabida todas las fórmulas y términos empleados, si bien con una idea generalmente común: la subordinación (en mayor o menor grado) de los intereses individuales a la satisfacción de intereses generales ${ }^{243}$. A título de ejemplo pueden señalarse los escritos de COMPTE244, cuya obra influirá decisivamente en la conocida

243 LASARTE,C. en «Propiedad privada e intervencionismo administrativo», RGLJ, 1975,p. 143 la denomina "forzada viajera sin descanso".

244 COMPTE, A., Sisteme de politique positive, Paris 1892, T. I, pp. 156 y ss., quien ataca la visión mantenida de la propiedad como absoluta, «teoría antisocial y por tanto desprovista de justicia y realismo". 
construcción de la propiedad como función social elaborada más tarde por DUGUIT245 ; de GINER DE LOS RIOS246 o AZCARATE 247 en España; de IHERING 248 y de GIERKE 249 en Alemania, cuyos puntos de vista son, sin lugar a dudas, los que mayor relieve e influencia han alcanzado en la paulatina relativización del concepto individualista del dominio.

\section{INTRODUCCION:}

\section{La Constitución Española reconoce la propiedad privada pero, no}

hay una sola propiedad, sino propiedades, configura la función social (art. 33.2 C.E) como elemento estructural de la definición misma del derecho a la propiedad privada, incide sobre el interior del derecho subjetivo sobre su contenido, no siendo una mera limitación externa, por tanto, quiebra la concepción absoluta de la propiedad como derecho subjetivo de libre disposición señorio sobre el bien objeto de dominio reservado a su titular,

\footnotetext{
245 Vid. DUGUIT, L., Les transformations générales du droit privé depuis le Code Napoleón, Paris, 1912 (se cita la traducción especial Las transformaciones del Derecho (público y privado), Buenos Aires, s.f., especialmente, pp. 169 y ss.) Las mismas ideas seguían latiendo en su obra posterior Traité de Droit Constitutionnel, Paris, 1927 (3a. ed.), pp. 208 y ss.

246 GINER DE LOS RIOS, F., Resumen de filosofía del Derecho, Obras Completas, T. II, Madrid, 1926, p. 119, donde se sintetiza su opinión: «El más grave y trascendental de cuantos errores imperan aquí todavía es el de considerar el derecho de propiedad como una mera facultad muda, subjetiva y arbitraria, sin obligaciones correspondientes».

247 «La propiedad, de cualquier clase que sea, sobre todo la inmueble, aparte de satisfacer las necesidades de sus propietarios, ha de servir para cooperar a las de los demás, contribuyendo al mejoramiento colectivo». Esto quiere decir que la propiedad tiene que realizar, además del fin individual, un fin social.

248 Donde pueden leerse afirmaciones como: «Las tesis de los juristas y las ideas corrientes se ponen de acuerdo para admitir que el carácter esencial de la propiedad consiste en el poder ilimitado del propietario, y que toda restricción referente a éste dirige a la propiedad un ataque inconciliable con el espíritu de la institución. Entiendo que esto es un profundo error,...» (p. 249); no es, por consiguiente, exacto, decir que la propiedad según su concepción, supone el poder absoluto de disponer de las cosas.

249 GIERKE, O., Die Soziale Aufgate des Privatrecht, Berlin, 1889, pp. 23 a 25: « A la propiedad deben imponerse deberes sociales. Deberes de no abusar de ella, sobre todo; pero, lo que es más importante, también el deber de hacer de ella un recto uso. Al concepto romano de la propiedad como un concepto absoluto e ilimitado, debe yuxtaponerse aquel germánico, que piensa en la propiedad como un derecho relativo que contiene en sí mismo la propia limitación. La propiedad no ha de servir únicamente al interés egoísta del individuo, sino que debe ser orientada al interés de todos. Por el mismo motivo, todo el derecho inmobiliario deberá transformarse radicalmente, de modo que constituya un sistema especial, porque las normas que regulan la propiedad de los inmuebles no puede ser la misma que la que gobierna la propiedad de las cosas muebles. También en esto el criterio debe atenerse al interés social....».
} 
sometido únicamente en su ejercicio a las limitaciones generales que las leyes impongan para proteger los legítimos derechos 0 intereses de terceros, y el derecho de propiedad se configura y protege como un haz de facultades individuales sobre las cosas pero tambien, y al mismo tiempo, como un conjunto de deberes y obligaciones establecidas de acuerdo con las leyes, en atención a valores o intereses de la colectividad, es decir, a la finalidad o utilidad que cada categoria de bienes objeto de dominio está llamada a cumplir.

Por tanto, se ha pasado de una concepción absoluta a una concepción social del derecho de propiedad que exige del titular del derecho, como miembro de la sociedad, la utilización del bien en el sentido que más convenga a la colectividad.

\section{EL «DERECHO A LA PROPIEDAD»: RECONOCIMIENTO}

\section{CONSTITUCIONAL.}

En el párrafo 1del artículo 33 de la C.E, «se reconoce el derecho a la propiedad privada y a la herencia». Vamos a prescindir aquí de toda referencia al fenómeno sucesorio, sin dejar de apuntar su íntima conexión con la propiedad privada. La herencia es el patrimonio post-mortem, es una prolongación del Derecho de propiedad, prolongatio domini 250 .

Nuestra Constitución no reconoce el derecho de propiedad privada sino el derecho a la propiedad privada, lo que viene a significar que todo individuo tiene amparada constitucionalmente su pretensión de poseer bienes en calidad de propietario. Como afirma MONTES ${ }^{251}$, ello «implica que la propiedad privada se entiende aún como un bien o ventaja que ha de ser accesible a todos, por cuanto envuelve, incluso en el actual estado

250 Sobre la herencia en la Constitución de 1978, vid. LOPEZ Y LOPEZ, A.M., La garantía institucional de la herencia, Revista Derecho privado y Constitución, CEC, oㅜ 3,1994,p. 29-62. ${ }^{251}$ MONTES, V., La propiedad privada... cit., p. 152 nota 238. 
político-social, un valor de libertad, si bien de libertad económica». Con más o menos matices se muestra de acuerdo con esto la generalidad de la doctrina ${ }^{252}$.

Este reconocimiento que la Constitución otorga a la propiedad es distinto del efectuado por la Constitución italiana de 1942, que en su artículo 42 establece: «La propiedad privada es reconocida y garantizada por la Ley, la cual determina los modos de adquirir, de goce y los límites, al objeto de asegurar la función social y de hacerla accesible a todos» 253 .

De su lectura se deduce que el reconocimiento y garantía de la propiedad privada comienza a partir de la ley (ordinaria), de forma que ésta es la que determina ese reconocimiento y no la Constitución. No sucede así en la Constitución Española, donde es ésta quien reconoce la propiedad privada.

Pero ¿qué debemos entender por propiedad privada como objeto de «reconocimiento»?

La doctrina en este punto se encuentra dividida. Algún autor afirma que el artículo 33.1 «sólo contiene una garantía institucional y en modo alguno una garantía de las situaciones dominicales concretas»254.

252 Vid., entre otros, ESCRIBANO COLLADO, P., La propiedad privada... cit., p. 110; GARCIA PELAYO, M., Consideraciones sobre las claúsulas económicas de la Constitución, Estudios sobre la Constitución Española de 1978, Zaragoza, 1979, p. 35; BASSOLS COMA, M., Constitución y sistema económico, Madrid, 1985, p. 118; LASARTE, C., Curso de Derecho civil patrimonial, Madrid, 1987, p. 217; PEREZ LUÑO, A.E., Comentarios a las Leyes Políticas_dir. por Oscar Alzaga. Constitución española de 1978, vol. III, Valencia, 1980, pp. 411 y ss., GARRIDO FALLA, F., Comentarios a la Constitución, Madrid, 1985 (2a. ed.) pp. 698 y ss.; GARRIDO DE PALMA, V.M., «El jurista ante la propiedad privada», en Estudios en homenaje a Tirso Carretero, Madrid, 1985, pp. 245 y ss.

253 Vid. BARNES VAZQUEZ, Propiedad, expropiación y responsabilidad (La garantía indemnizatoria en el Derecho Europeo y Comparado), Madrid, 1996. Hace un análisis comparativo de esta cuestión en los capítulos 3 y 5 de la Parte I.

254 Con la denominada vertiente institucional u objetiva de la propiedad, se quiere hacer referecia a la propiedad como institución, a la existencia o pervivencia de ciertas categorias de bienes susceptibles de apropiación privada, aunque la Constitución no predetermina cuales, 
Otros, observan que «la garantía no se limita a la mera existencia del instituto jurídico de la propiedad»255, o ven garantizada «una vertiente personal del derecho» 256 .

Por último, son muchos los que se inclinan por considerar que, junto a la garantía institucional, en el precepto constitucional, son reconocidos y tutelados los concretos derechos subjetivos de propiedad 257 .

Esta última vía, será por la que discurra la jurisprudencia constitucional. El Tribunal Constitucional ha afirmado que en el artículo 33 «se contiene una doble garantía» del derecho de propiedad, ya que «se reconoce desde la vertiente institucional y desde la vertiente individual, esto es como un derecho subjetivo debilitado»258. Y aunque de este carácter de «derecho subjetivo debilitado» se desprende que «cede para convertirse en

vid. BARNES VAZQUEZ, Propiedad, expropiación y responsabilidad ${ }_{2}$ ob.cit.p. 31; LOPEZ Y LOPEZ, A.M., La Disciplina constitucional de la propiedad privada, Madrid, 1988, p. 42. Más matizadamente MONTES, V., La propiedad privada cit., que consigue en cierto modo su opinión al hilo de la STC 111/ 1983 de 2 de diciembre y PEREZ LUÑO, Comentarios a las Leyes políticas p. 411 y ss.En el àmbito del derecho comparado,la Constitución alemana ,identifica la vertiente de garantía institucional del derecho de propiedad con la pervivencia del dominio como institución, el Tribunal Constiticional Federal no ha declarado hasta ahora una norma inconstitucional por violar la garantía institucional de la propiedad,en el mismo sentido se pronuncia la Constitución francesa, vid. los capitulos III y IV de la primera parte del libro de BARNES, ob.cit.,pp.151 a 190.

255 ESCRIBANO, P., La propiedad privada, cit., p. 110.

256 BASSOLS COMA, Constitución y sistema... cit., p. 118.

257 Vid. ALZAGA, O., Comentario sistemático a la Constitución española de 1978, Madrid, 1978, p. 289; DE LOS MOZOS, «El derecho de propiedad...» cit., p. 130; DIEZ PICAZOGULLON, Sistema, III, cit., p. 156; ESPIN, Manual, II, cit., p. 94; GARCIA PELAYO, ob. y loc. ult. cit.; GARRIDO FALLA, ob. y loc. ult. cit.; GARRIDO DE PALMA, ob. ult. cit., p. 257; LACRUZ, Elementos, III-I, cit., p. 178.

258 Cfr. la STC 111/ 1983, de 2 de diciembre, f.j. $8^{\circ}$, cit., La misma doctrina se reitera en la Sentencia del Tribunal Constitucional $37 / 1987$ de 26 de marzo, sobre la Ley de Reforma Agraria de Andalucía, dictada para resolver un recurso contra la ley 3-7-84 del Parlamento andaluz; se dice así en el fundamento jurídico segundo de dicha sentencia: «... la propiedad privada, en su doble dimensión, como institución y como derecho individual, ha experimentado en nuestro siglo una transformación tan profunda que impide considerarla hoy como una figura jurídica reconducible exclusivamente al tipo extremo descrito en el art. 348 del Código civil. Por el contrario, la progresiva incorporación de finalidades sociales, relacionadas con el uso y aprovechamiento de los distintos bienes sobre los que el derecho de propiedad puede recaer, ha producido una diversificación de la institución dominical en una pluralidad de figuras o situaciones jurídicas reguladas con un significado y alcance diverso. 
un equivalente económico, cuando el bien de la comunidad...legitima la

expropiación», no equivale a negar el reconocimiento y la tutela del mismo.

Finalmente, al hilo de lo anterior había que decir que «la consecuencia más importante que está originando la penetración de la función social es la ruptura del concepto unitario del derecho de propiedad» 259 . Es preciso, por tanto, hablar de propiedades, no tanto por la diferente naturaleza de los bienes ${ }^{260}$, como por «el diverso significado que respecto de ellos toma la función social, y por el diverso juego de la misma en cada caso"261.

259 Cfr. HERNANDEZ GIL, La función social de la posesión, cit., p. 171. La tesis del pluralismo de la propiedad tiene su principal defensor en PUGLIATTI, S., en su obra: La propietá e la propietá «(con particolare riguardo alla propietà terriera»). Atti del Terzo Congreso Nazionale di Diritto Agrario, Milano 1956, p. 46 y ss. En nuestra doctrina vid. entre otros, BASSOLS COMAGOMEZ FERRER, La vinculación...cit., p. 48; BERCOVITZ, ¿Qué es la propiedad privada?, Barcelona, 1977, p. 52-53; CASTAN, La propiedad, cit., pp. 9-73 y ss. y 119; DE LOS MOZOS, «El urbanismo desde la perspectiva del Derecho Privado» en RDP (Abril) 1961 p. 296; DIEZPICAZO Y GULLON, Sistema, II, cit., pp. 109 y ss.;ESPIN, Manual, II, cit., p. 73; LASARTE, Propiedad privada... cit., pp. 148 y ss.; IDEM., Consideraciones previas al estudio del derecho de edificación. Pluralismo de la propiedad privada en Revista General de Legislación y Jurisprudencia (RGLJ) LXXII-1976 p. 25 y ss.; MONTES, La propiedad privada... cit., p. 142 y ss.; LOPEZ Y LOPEZ, La disciplina constitucional... cit., p. 39; SAINZ DE ROBLES, F.C. y DE LOS MOZOS, J.L., Limitaciones y modificaciones de los derechos reales inmobiliarios por razón de turismo», RDU, 1968, pp. 41 y ss. También en alguna sentencia del Tribunal Supremo aparece expresamente esta idea, por ejemplo, la Sentencia de 4 de noviembre de 1972 (R. 4692 ) en cuyo sexto considerando se dice: «si ya no hay propiedad, sino propiedades..., es porque... la propiedad queda condicionada a las exigencias políticas, sociales y económicas de la época». Pero aunque el pensamiento dominante es pluralista en este tema, no faltan defensores de la unidad conceptual de la propiedad por ejemplo, CONSTANTINO, M., Contributo alla teoría de la propietà, Napoli, 1967. Sobre todas estas cuestiones últimamente, resumen de larga dedicación al tema RODOTA, S., II terribile diritto. Studi sulla propietà privata, Bologna, 1981 (hay traducción española, con prólogo de DIEZ-PICAZO, Madrid 1986).

${ }^{260}$ Como queda expresado en la citada Sentencia de 26 de marzo de 1987 f.j. № 2 «... que se manifiesta en la existencia de diferentes tipos de propiedades dotadas de estatutos jurídicos diversos, de acuerdo con la naturaleza de los bienes sobre los que cada derecho de propiedad recae».

261 Cfr. DE LOS MOZOS, "El urbanismo desde la perspectiva del derecho privado" en R.D.P. ( abril ) 1961 p.296; LASARTE habla de "diferente importancia social de los bienes susceptibles de apropiación» en «Propiedad privada e intervencionismo administrativo» en R.G.L.J. (junio) 1975 p. 150.En parecido sentido BERCOVITZ ob. y loc. ult. cit.;ESPIN, ob. y loc. ult. cit. 


\title{
2.1. DISCUTIBLE CARACTER DE DERECHO FUNDAMENTAL DE
}

\section{LA PROPIEDAD.}

\author{
¿Es la propiedad un derecho fundamental?
}

Tradicionalmente, la propiedad venía siendo considerada como un derecho fundamental o un «derecho básico de la persona»262. Sin embargo, tras la entrada en vigor de la Constitución española de 1978, «la propiedad privada constituye un derecho de los ciudadanos, no fundamental, que es objeto de tutela exclusivamente a través del recurso de inconstitucionalidad de una ley o disposición normativa con fuerza de ley que no haya respetado el contenido esencial»263. En consecuencia, «la Constitución no habla ya de la propiedad como un derecho fundamental», sino, que lo sitúa entre los «derechos y deberes de los ciudadanos», con lo que parece apartarse de la idea "atributo de la personalidad», que era consustancial con la idea individualista y presupuesto del artículo 348 del C. civil»264.

Siguiendo esta última posición podríamos llegar a la siguiente conclusión:

262 Cfr. entre otros, DIEZ-PICAZO, L., Fundamentos de Derecho civil patrimonial, Madrid, 19, T. I, p. 43; PEREZ LUÑO, Comentarios, cit., p. 406-411; DE LOS MOZOS, J.L., El derecho de propiedad, cit., p. 138; GARCIA PELAYO, Consideraciones... cit., p. 32; Además también lo califican de Derecho fundamental la reciente Sentencia de la Sala 1era. del T.S. de 6 de julio de 1988 en su considerando octavo, cfr. Actualidad Civil, 1988, p. 2359; LOBATO GOMEZ, J.M., La propiedad privada del suelo y derecho a edificar, Madrid, 1989, p. 308 y ss.

263 Cfr. MONTES, V., La propiedad privada... cit., p. 161-162.

264 Cfr. MONTES, La propiedad privada, cit., pp. 170-171. En el mismo sentido BASSOLS, M., Constitución y Sistema económico, Madrid, 1985, pp. 109-110; ESCRIBANO, La propiedad privada, cit., pp.110-112, que se refiere a la prop. como «derecho de ciudadanía»; MARIN PEREZ, P., Derecho Civil, III, Madrid, 1984, pp. 71 y ss. que recoge los argumentos de la doctrina italiana. RUBIO LLORENTE, "La Constitución como fuente del Derecho», en la Constitución española como fuente del Derecho, vol. I, Madrid, 1979, p. 69, considera la propiedad uno de los ejemplos arquetipos del debilitamiento en nuestra Constitución de ciertos derechos clásicos por su aproximación a la categoría de las garantías institucionales. El derecho de propiedad, «expulsado de la Sección Primera del Capítulo Segundo del Título I, seguramente por la dificultad teórica de tutelarlo mediante el amparo, este derecho, que antes solía ser atendido como base o poco menos de todos los demás, ha dejado de ser entre nosotros, desde el punto de vista técnico, un derecho fundamental...» 
El Derecho de propiedad es un derecho más dèbil que los fundamentales de los artículos 14 a 29 de la C.E., con protección más débil. El Derecho de propiedad no es, en las rúbricas constitucionales de los derechos y libertades, uno de los «derechos fundamentales, y libertades públicas» (Sección primera del capítulo segundo, Título I) ${ }^{265}$, sino uno de los «derechos y deberes de los ciudadanos» (Sección segunda de idénticos capítulo y título). Sólo los primeros son susceptibles (art. 53.2 C.E.) de tutela (además del trato privilegiado en sede jurisdiccional ordinaria, procedimiento basado en los principios de preferencia y sumariedad) constitucional por la vía del recurso de amparo. El Derecho de propiedad no se protege por amparo (53.2 C.E) ${ }^{266}$. Es un Derecho constitucional pero no fundamental267 de ahí que se pueda expropiar, cosa que no puede hacerse con los derechos fundamentales. Además el Derecho de propiedad no se regula por Ley orgánica. Al hablarse literalmente en el artículo 81.1 de la C.E., de los «derechos fundamentales y de las libertades públicas» se está refiriendo única y exclusivamente a la Sección 1a. del cap. $2^{\circ}$ del Título I, cuyo contenido es el que ha de desarrollarse por Ley Orgánica. Para los derechos y deberes de los ciudadanos de la Sección 2a. basta la ley ordinaria (tanto estatal como autonómica) según se desprende del artículo 53.1 de la Norma fundamental268.

265 Sin perjuicio de que desde una perspectiva doctrinal o comparada, tal es el caso de la Constitucion alemana, y desde luego , supranacional, así, en el Convenio Europeo de Derechos Humanos y en el Derecho Comunitario, pueda ser considerado como derecho fundamental. Vid. BARNES, ob.cit., pp. 160 a 162 y el capítulo 2 de la citada obra.

266 Vid. STC 194/1991, fundamento jurídico 4.

267 Vid. REY MARTINEZ, La propiedad privada en la Constitución Española, Madrid, 1994 , defiende la postura contraria ,es decir, el carácter de derecho fundamental del derecho de propiedad.

268 En este sentido se manifiesta el T.C.: STC 76/1983 de 5 de agosto f.j. ㄲo2.

STC 111/1983 de 2 de diciembre f.j. oㅡ 8; llega a la conclusión de que la Constitución no exige una Ley Orgánica para regular el derecho de propiedad, a pesar de lo dispuesto en el Art. 81.1 con carácter general.

La Sentencia de la Sala 1a. del Tribunal Supremo de 6 de julio de 1988, por el contrario en su considerando octavo califica al D. de propiedad de D. fundamental. 
Aunque la expresión del artículo 53.1, «solo por ley», podría hacer pensar en una reserva de carácter absoluto, el reconocimiento de la función social de la propiedad permite que la ley habilite al poder reglamentario para prolongar su contenido ${ }^{269}$. Ahora bien, en ningún caso será admisible una deslegalización abierta o encubierta que defraude la reserva de ley, vaciando a favor del reglamento una materia que la Constitución ha querido preservar. Así lo entiende el Tribunal Constitucional al afirmar que «resulta, sin embargo, evidente que el artículo 33.2 de la propia Constitución flexibiliza la reserva de ley en lo que concierne a la delimitación del contenido de la propiedad privada en virtud de su función social, que debe ciertamente regularse por la Ley, pero también por la Administración «de acuerdo con las leyes» cuando éstas recaben la colaboración reglamentaria de aquélla. Prohíbe esta concreta reserva de ley toda operación de deslegalización de la materia o todo intento de regulación del contenido del derecho de propiedad privada por reglamentos independientes o extra legem, pero no la remisión del legislador a la colaboración del poder normativo de la Administración para completar la regulación legal y lograr así la plena efectividad de sus mandatos»270.

Por tanto, se regula la propiedad por Ley ordinaria, tanto estatal como autonómica, por Decreto-Ley y reglamentariamente, no es susceptible de amparo.

269 En este sentido, vid. BASSOLS, Constitución y sistema económico, cit., p. 124; DIEZ PICAZO, «Prólogo» a RODOTA, El terrible derecho, cit., p. 18; GARCIA DE GARRORENA MORALES, A., El lugar de la ley en la Constitución española, Madrid, 1980, pp. 66-67; MONTES, La prop. privada, cit., pp. 153 y 171.

270 Cfr. la STC 37/1987, de 26 de marzo, no 3, que sigue diciendo «remisión inexcusable, por lo demás, cuando, como es el caso arquetipo de la propiedad inmobiliaria, las características naturales del bien objeto de dominio y su propia localización lo hacen susceptible de diferentes utilidades sociales, que pueden y deben traducirse en restricciones y deberes diferenciados para los propietarios y que, como regla general sólo por vía reglamentaria pueden establecerse». No falta en este Sentencia (n.8 y n.9), por lo demás, la idea de la flexibilización de la reserva de ley en un nuevo sentido, al entender que opera no solamente respecto a la legislación estatal, que tiene atribuida competencia exclusiva en la materia (art. 149,1), sino que se extiende también a la legislación emanada de las Comunidades Autónomas, siempre que respete las condiciones básicas del ejercicio del derecho que se desprenden de la legislación estatal. 


\section{SIGNIFICADO Y ALCANCE DE LA FUNCION SOCIAL DE LA}

PROPIEDAD.

En el artículo 33.2 de la Constitución se dice que «la función social de estos derechos (propiedad y herencia) delimitarán su contenido de acuerdo con las leyes», la redacción de este artículo no es la más acertada. Parece deducirse que el legislador, para determinar cuál sea el contenido del dominio, ha de acudir a la función social y ello no es así. La redacción de este apartado del artículo 33, debería haberse hecho poniendo como sujeto de la oración a las leyes, de forma que a través de éstas el legislador determinará, en cada caso, el contenido del derecho de propiedad de acuerdo con la función social 271 .

Pero ¿qué significado tiene que la función social sea criterio para la delimitación del contenido del derecho de propiedad?. A este interrogante, no ampliamente tratado en la doctrina tradicional, se afirmaba que la función social era pura y simplemente un principio que justificaba las intervenciones administrativas a través de las limitaciones, en la esfera patrimonial de los particulares. De esta forma la función social afectaba siempre a la esfera externa del derecho.

Hoy se mantiene que el hecho de que la función social delimite el contenido del derecho de propiedad a través de la ley, significa que éste se funcionaliza incorporando a su definición el interés social, en el sentido determinado por la ley. Pero además ello es consecuencia de un largo proceso de penetración de la ley en la esfera de los derechos "civiles» de los individuos, no sólo con un objetivo de reconocimiento y garantía, sino con un alcance ordenador 272 .

271 En este sentido vid. BASSOLS, Constitución y Sistema económico, cit., pp. 119-120; MONTES, V., La propiedad privada... cit., p. 184; ESCRIBANO COLLADO, P., La propiedad urbana... cit., '. 133, quien no parece entenderlo así.

272 ESCRIBANO COLLADO, P., ob. y loc. ult. cit. 
Es la propia sociedad y en virtud de sus necesidades la encargada, por medio de la Ley, de establecer cuales serán las utilidades del derecho que deban cederse a la sociedad y cuales pueden permanecer en interés privado. La función social, por una parte, delimitará el contenido esencial del derecho privado pero, a su vez, está delimitada por dos causas: la de utilidad pública y la de interés social.

El primer interrogante que se nos plantea ante la fórmula del artículo 33.2 es el siguiente: ¿cómo actúa en concreto la función social ?. Es decir, se trata de determinar si actúa como un criterio delimitador de todas las situaciones de propiedad, $\underline{0}$, por el contrario si actúa como principio legitimador de la intervención del legislador en materia de propiedad.

La primera postura (función social como criterio delimitador) tiende a acentuar la importancia de la función social sobre la base de su idoneidad para operar directamente sobre el derecho de propiedad. Se expresa diciendo que «ha cambiado el esquema tradicional desde el momento en que el ordenamiento prevé que el ejercicio de las facultades no se dirija solamente a la satisfacción del interés (privado) del titular, sino que también tenga en cuenta las exigencias más generales de la propiedad en su conjunto. Ya no habrá, entonces, una atribución abstracta e incondicionada de facultades, sino una atribución para que el titular realice actividades o utilice la cosa en el sentido determinado por la Ley. Y así, ciertas facultades no se atribuirán, esto es, no formarán parte del contenido de la propiedad, otras exigirán para su ejercicio un conjunto de condiciones valoradas por el Estado y, finalmente, será obligatorio ejercitar otras facultades, de tal modo que el no ejercicio por parte del propietario traerá como consecuencia, una carencia sobrevenida de legitimación para la titularidad o para el ejercicio. Por todo ello, la función social no queda en la esfera externa del dominio, sino que penetra en su interior, toda vez que el mecanismo de atribución del derecho no se basa sólo y exclusivamente en 
el interés del titular, sino también, y sobre todo, en la conexión entre la posición del particular y su pertenencia a un grupo social273.

Esa es la idea central que se expresa a través de la fórmula «función social» de la propiedad. En definitiva, nos indica el texto constitucional que la propiedad no tiene un contenido apriorístico, sino que es un derecho diversificado cuyo contenido depende del interés público, de lo que exija en cada caso el principio de solidaridad, de las exigencias de la comunidad, todo lo cual se expresa con la fórmula función social de la propiedad. Y esta connotación legal de la conexión entre individuo y grupo social, entre interés de la colectividad e interés individual, configura en cada caso el contenido y el modo de ser de la propiedad»274. Por tanto la función social de la propiedad nos acerca a la idea de que el propietario no tiene un poder absoluto sobre la cosa, el ejercicio de las facultades que conforman la propiedad no se dirijen solamente a la satisfacción del interés privado del titular, sino también a la satisfación de exigencias más generales de la propiedad en su conjunto. «Por todo ello la función social no queda en la faz externa del dominio, sino que penetra en su interior, puesto que la atribución misma del derecho al titular tiene en cuenta no sólo su interés,

273 Vid. RODOTA, S., Note critiche... cit., 1296-97 y 1312. Poteri dei privati e disciplina della propietá, cit., 379. Vide nota 294, Voz Propietà (Diritto vigente) en Novissimo Digesto Italiano, Torino, 1976, p. 139. En nuestra doctrina ESCRIBANO COLLADO afirma que la propiedad es un derecho causalizado, en cuanto viene a constituir el fundamento de la atribución del derecho subjetivo. La diferencia fundamental que en la actualidad tiene el elemento funcional, frente al que para algunos autores tuvo con anterioridad, aparece concretada en el interés que incorpora. Hoy el derecho de propiedad ha dejado de ser un derecho egoísta, como proponían algunos autores. La función social ha introducido en la esfera interna del derecho de propiedad un interés que puede no coincidir con el del propietario, y que, en todo caso, es ajeno al mismo; interés social que, junto con el individual del titular del derecho, ambos inseparablemente, constituyen el fundamento de la atribución del derecho, del reconocimiento y garantía del mismo, La prop. privada...ob. cit., pp. 110 y ss.; RESIGNO, P., Per uno studio sulla propietà, cit., p. 44-45: la f. s. opera de modo prevalente aunque no exclusivo, allí donde en torno a los bienes económicos en propiedad se instaure una relación que solicita la colaboración de otro en la utilización de la cosa. Así, «social» quiere decir un particular modo de ser del individuo frente a los demás (relaciones de trabajo, concesión de derechos de goce, etc.)

274 Cfr. MONTES, La prop. privada, cit., pp. 196 y ss., siguiendo a un caracterizado sector de la doctrina italiana. 
sino sobre todo la conexión entre la posición del particular y su pertenencia a un organismo social « 275

En este sentido habría que decir que la propiedad no es en sí una función social276 en cuanto que no implica el deber jurídico de ejercitar una actividad dirigida a satisfacer directa y exclusivamente un interés público, sino que tiene una función social que cumplir, pues no debe entenderse como medio de tutela exclusiva de los intereses del propietario, sino también, como medio de actuación de un interés público, o de un interés extraño al derecho de propiedad, pero que goce de una especial relevancia social277.

Desde esta perspectiva, «la Constitución ha elevado a la categoría de principio general del derecho esta regla que se expresa en la fórmula «función social» de la propiedad, presentándola como una regla dotada de carácter básico, como soporte estructural del sistema, y con carácter general, en el sentido de que trasciende a un precepto, organiza y da carácter a muchos y es, además, una fórmula técnica del mundo jurídico. Se trata de lo que autorizadamente se ha llamado un principio político, un principio organizador de la comunidad social»278.

\footnotetext{
275 IDEM. P. 197

276 Cfr. PUGLIATTI, La propietà nel nuovo diritto, ob. cit., p. 141. Para una interesante y documentada reflexión crítica sobre el tema, RODOTA, II terribile diritto, cit., pp. 203 y ss.

277 Cfr. PUGLIATTI, La propiedad p. 44; BARASSI, L., Propietà e comproprietà, Milano, 1951 p. 288. En nuestra doctrina CASTAN, La propiedad y sus problemas... ob. cit., p. 79; RUIZ JIMENEZ, La propiedad, sus problemas y su función social, vol. II, Salamanca-Madrid, 1961. GITRAMA GONZALEZ, M., "Nuevo sentido de la propiedad», en Cuadernos de la Escuela social de Valencia, 1960; SANZ JARQUE, J.J., Más allá de la Reforma Agraria, 1970, que defiende las tesis de la funcionalidad social de la propiedad de la tierra; HERNANDEZ GIL, aplica el concepto de la función social, no sólo al derecho de propiedad, sino incluso a la posesión en La función social de la posesión, Madrid, 1980.

278 Cfr. MONTES, V., La prop. privada, cit., p. 198, de donde, entre otras cosas, pueden obtenerse consecuencias en orden a la extensión por analogía de las normas de carácter excepcional destinadas a realizar la f. s. de la propiedad, puesto que, al convertirse en principio general, hará caer la prohibición de la analogía. Esta misma opinión viene siendo sostenida en la doctrina italiana por RODOTA, Note critiche... cit., p. 1326; IDEM., II terribile diritto, cit., p. 316;
} 
La segunda postura, (función social como principio legitimador) tiende, en principio, a mantener intacta la estructura del derecho de propiedad, puesto que el reconocimiento de la función social no modifica sustancialmente ninguno de los elementos del poder reconocido al propietario. Viene entendiendo que el artículo 33.2 es un precepto sumamente genérico y de carácter programático que se dirige al legislador vinculando su actuación futura; en este sentido, estima necesario que la función social de la propiedad sea actuada por una ley concreta, mediante el establecimiento de los límites y deberes correspondientes 279.

Además, en general, estas opiniones siguen concibiendo los límites como algo que está fuera de la situación de propiedad, de la estructura interna del derecho del propietario, lo que comporta la presencia de un contenido esencial del dominio, como un a priori respecto de las modificaciones y de los límites 280.

No obstante, dada la ambiguedad con que está redactado el precepto hace que pueda ser interpretado desde ópticas completamente diferentes y aún, contradictorias. Si se profundiza más en el tema, puede verse cómo ambas ponen de relieve aspectos parciales del problema, pues la Constitución Española, permite ofrecer un cuadro en el que caben, convenientemente matizadas, ambas posturas.

RESIGNO, P., Per uno studio sulla propietà, cit., p. 44; PERLINGIERI, Introduzione alla problematica della propietà, Camerino, 1971, p. 123.

279 En este sentido se manifiestan, por ejemplo, DE LOS MOZOS, El derecho de propiedad... cit., p. 140; DIEZ PICAZO-GULLON, Sistema, III, cit., p. 156; ESPIN,_Manual, II, cit., pp. 95-96; LACRUZ, Elementos, III, 1ํ., cit., p. 178; LASARTE, Curso, cit., p. 228; TORRALBA, Lecciones, I, cit., p. 328.

280 RODOTA, Note critiche, cit., pp. 1314-1319; SANTORO-PASSARELLI, Propietà e lavoro in agricoltura, en lustitia, 1953, p. 171 y ss.

Comentando la Sentencia del Trib. Constitucional de 16 de diciembre de 1958, num. 78, adopta una posición semejante MAZZIOTTI, «Iniciativa económica privata, propietà privata e diritto del lavoro", en Giurisprudenza Costituzionale, cit., p. 1209 y ss., 1214. Para una exposición crítica de estas opiniones MONTES, La propiedad privada, cit., pp. 189 y ss.; y, en general, RODOTA, II terribile diritto, cit., pp. 327 y ss 
La función social del derecho, por su parte desplegará su eficacia normativa del siguiente modo:

El primer lugar, puede decirse que aunque desde una perspectiva general pueda pensarse que la función social «carece de valor técnico concreto y constituye un concepto jurídico indeterminado que pretende adecuar la titularidad dominical a las exigencias sociales»281, la Constitución española ofrece las pautas necesarias para conocer su contenido. No en vano la doctrina más autorizada establece una íntima relación entre el artículo 33.2 y los artículos 128.1 y $131.1^{282}$, y no son pocas las opiniones que la extienden a otros preceptos, especialmente a algunos de los contenidos en el capítulo III del Título I de la Constitución ${ }^{283}$. Por lo demás, este mismo camino es el seguido decididamente por el propio Tribunal Constitucional, que en su fundamento número 2 de la Sentencia 37/1987, de 26 de marzo, señala que «la incorporación de tales exigencias a la definición misma del derecho de propiedad responde a principios establecidos e intereses tutelados por la propia Constitución, y de cuya eficacia normativa no es posible sustraerse», haciendo referencia, en particular, a los artículos 128.1-40-45 y 130. Sólo en este sentido podrá decirse que la función social de la propiedad es un principio constitucional con valor normativo,que opera de forma inmediata, informando, además de

${ }^{281}$ Cfr. LASARTE, Curso, pp. 227-228. En parecido sentido MONTES, La propiedad privada, cit., p. 198, entiende que «la Constitución nada dice sobre qué otros criterios debe tener en cuenta la ley al establecer la función social»».

282 Cfr. BASSOLS, Constitución, cit., p. 123; DE LOS MOZOS, El derecho de propiedad..., cit., p. 139; DIEZ PICAZO-GULLON, Sistema, III, cit., p. 156; GARCIA CANTERO, La_propiedad en la Constitución de 1978, cit., p. 123; PEREZ LUÑO, Comentarios..., III, cit., p. 114-115; MONTES, La propiedad privada, cit., pp. 205 y ss.

283 BASSOLS, Constitución, cit., pp. 123-124; GARCIA CANTERO, G., La propiedad en la Consitución... cit., p. 123; PEREZ LUÑO, Comentarios, III, cit., p. 415; IDEM., Comentarios, IV, cit., pp. 263 y 292. En este sentido se pronuncia la Sala 4a. del Trib. Supremo en Sentencia de 10 de abril de 1985 (R. 2197), señalando que la nueva concepción de la propiedad «hoy se plasma en los artículos 33-45-46-47 y 53 de la Constitución». Vid. también las Sentencias de 21 de septiembre de 1985 (R. 5117), de 7 de febrero de 1986 (R. 1234) y de 2 de febrero de 1987 (R. 2043). 
la legislación positiva, la práctica judicial y la actuación de los poderes públicos.

En segundo lugar, el reconocimiento de la función social de la propiedad actúa como un principio que legitima al legislador ordinario para actuar de forma concreta los intereses generales, imponiendo al propietario de determinados bienes limitaciones y deberes que delimitan, definen o determinan el contenido del dominio, debiendo respetar, en todo caso, su contenido esencial. Esta idea, permite afirmar que la función social sólo puede ser actuada y concretada por el legislador que, como intérprete del interés general, debe delimitar el contenido del derecho mediante una ley ordinaria que regule su ejercicio en el marco de la garantía constitucional de la propiedad. Pero además, desde otra perspectiva, la función social de la propiedad sólo tendrá eficacia jurídica inmediata y efectividad práctica, en tanto haya sido concretada y desarrollada por las leyes, y de acuerdo con lo dispuesto en las mismas.

Por otro lado hay que decir que la relación entre delimitación y contenido esencial es básica porque la Ley debe regular la propiedad teniendo en cuenta su contenido esencial, previo a la Ley, que se inclina más hacia la faceta del interés privado, pero en tal regulación la Ley puede imponer límites y deberes que van a formar parte del contenido general (público-privado) de la propiedad pero que han de respetar ese contenido mínimo privado ${ }^{284}$. La intervención legislativa ha de dirigirse a asegurar la conexión entre el interés público y el interés del propietario, pero no a anular la propiedad privada, idea que hay que completar con la constatación de que «la propiedad privada, como situación jurídica, consiste

284 Vid. SERRANO ALBERCA, J.M., El derecho de propiedad, la expropiación y la valoración del suelo, Pamplona, 1995, p. 88. 
en la tipificación operada por el ordenamiento de una relación económica de goce o disfrute, 0 , si se quiere, de utilización de los bienes» 285 .

\subsection{EL CARACTER OBJETIVO DE LA FUNCION SOCIAL DE LA} PROPIEDAD.

Una vez aceptado que la función social trasciende el aspecto institucional de la propiedad privada, desplegando su eficacia sobre el derecho de propiedad, es preciso determinar sobre cuál de los elementos de la relación jurídica, sujeto u objeto, va a incidir.

Aún sin desconocer que siempre ha existido una distinción del régimen de los bienes por razón del interés público, y que el momento objetivo ha ido adquiriendo mayor peso a la conformación del material legislativo que integra el Derecho actual286, viene desarrollándose, una fuerte tendencia a dar relevancia a la función social como elemento normativo y como límite interno de la posición subjetiva del propietario287. Semejante noción excluye otras que, aun tomando como punto de partida el reconocimiento de la función social, «tienden a no modificar en ninguno de sus elementos la situación del sujeto propietario, refiriendo la función a la propiedad como institución o a los bienes que constituyen su objeto»288.

Sin embargo, si prescindimos de la idea de función social de la propiedad privada como institución, a la que se ha aludido, un camino que sigue recorriendo la doctrina es referir la función social «antes que a la

285 Vid. MONTES, V., La propiedad privada..., ob.cit., p. 204.

286 Vid. FINZI, E., «Diritto di propietà e disciplina della propietà», Riv. Dir. Priv. 1936, I, pp. 5-6. En distinto sentido PUGLIATTI, La propietà, cit., pp. 246, para quien el sujeto sigue siendo el término fundamental de todo fenómeno jurídico.

287 Cfr. RODOTA, II terribile diritto, cit., pp. 209 y ss.; NATOLI, La propietà, cit., pp. 178 y ss; GALLEGO ANABITARTE, Derechos fundamentales y garantías institucionales: análisis doctrinal y jurisprudencial, Madrid, 1994.

288 Cfr. RODOTA, ob. ult. cit., p. 227. 
propiedad como derecho, a la misma como bien, haciendo derivar de ello un vínculo externo al derecho de propiedad y, de ese modo, evitando prejuzgar su naturaleza de derecho subjetivo, reconocido y garantizado sólo en interés del propietario» 289 . En este sentido puede estimarse correcto decir que «la propiedad «tiene» una función social, cumple una función social: esto es, no es un derecho que pueda construirse como si estuviera en juego solamente el interés de un individuo propietario, como si la única «ley» que rige la utilización de los bienes fuera el interés del propietario. No es en suma, como acostumbra a decirse, un derecho «egoísta». La propiedad debe ser construida (esto es, debe delimitarse su contenido) de modo que se tenga en cuenta, la necesidad de utilizar los bienes también en interés de la colectividad. Acaso se podría, más justamente, hablar de función social de los bienes ${ }^{290}$ (esto es, de la utilidad social asegurada por los bienes). Lo que es cierto, es que la idea de función social justifica límites a la utilización «egoísta» de los bienes, y también la imposición al propietario de deberes, para asegurar su utilización conforme a los intereses de la colectividad»291, lo que daría lugar a pensar que la función social no se refiere al objeto sino al sujeto en cuanto que usa y dispone de los bienes.

Desde esta perspectiva se abre, como apunta GALGANO, «un nuevo terreno de reflexión sobre categorías jurídicas capaces de coordinar entre sí, en el uso de la riqueza, los intereses de los propietarios y los de los no propietarios, los intereses privados y los de la colectividad»292.

\footnotetext{
289 SANDULLI, A., «Spunti per lo studio dei beni privati d'interesse publico», Dir. Econ., 1956, pp. 56 y 55; TARELLO, G., La disciplina costituzionale della propietà, cit., p. 27.

290 En materia de distinción entre bienes y cosas vid. MONTES, Prop. privada... cit., p. 198 y ss.; DE CASTRO, Derecho Civil de España, cit., I, p. 469; DIEZ-PICAZO, L., Fundamentos del Derecho Civil patrimonial, cit., p. 121-126-162 y 174; PUGLIATTI, Beni e cose in senso giuridico, Milán, 1962, p. 27.

291 Cfr. ZATTI, P., Diritto privato (Diritto civile), Padova, 1983, p. 99.

292 Cfr. GALGANO, II Diritto privato fra codice e costituzione, cit., p. 155.
} 
A la vista de estas consideraciones de carácter general, no cabe duda que la Constitución española privilegia la funcionalización del aspecto objetivo de la relación propietaria, hasta el punto que, más que hablar de función social del derecho de propiedad, debiera hablarse de la función social de los bienes que actual o potencialmente constituyen el objeto del dominio 293 .

Esta idea, bastante difundida en nuestra doctrina, viene a considerar que, en tema de función social, debe atenderse, sobre todo, a los bienes, que son los que, en atención a sus especiales características y a su trascendencia social, determinarán la especialidad del dominio y demás derechos reales sobre ellos. En otras palabras, de función social ha de hablarse respecto de los bienes, y no respecto del derecho de propiedad 294 . $Y$ aunque no falta quien piensa que «afirmar que la función social la cumplen los bienes es tanto como desnaturalizar el fenómeno»295, esta idea se muestra como una de las más claras y precisas que aparecen articulando la disciplina de la propiedad privada en nuestra Constitución ${ }^{296 .}$

\footnotetext{
293 Esta idea la expresa ya GALGANO, F., en Diritto privato, Padova, 1981, p. 114-115. En relación al artículo 42 de la C.I., sostiene que la f. s. va referida al objeto del derecho de propiedad, no al derecho subjetivo como tal, pues las ideas de derecho subjetivo y función son antitéticas.

294 Vid. ESPIN, Manual, II, cit., pp. 95-96; PEÑA, Derechos reales, cit., pp. 101-102, 110-112, 132-133; LASARTE, Curso, cit., p. 228.

295 Cfr. MONTES, La propiedad privada, cit., p. 202; GONZALEZ GARCIA, La facultad de exclusión ${ }_{2}$ cit., pp. 158-159, aunque sin desconocer que en general son los bienes -por su especial naturaleza, por la importancia que ofrecen para la economía, por su escasez, etc.- los que determinan que los derechos, y en especial, el dominio, quedan específicamente vinculados a la función social». En parecido sentido, ESCRIBANO, La prop. privada, cit., p. 130.

296 Precisamente por ello algún autor italiano no ha dudado en buscar en la Constitución española la justificación positiva de la f. s. de los bienes, cfr. GALGANO, F.,_ll diritto privato fra Codice e Costituzione, Bologna, 1978, pp. 153-154; IDEM., «Intervento», Grisi dello Stato sociale e contemto minimo della propietà, cit., pp. 69-70, pues entiende que en ella «la ambiguedad de la fórmula viene superada refiriendo la función social, no al derecho de propiedad, que permanece como derecho subjetivo, sino a la riqueza, a los bienes, a las cosas objeto de la propiedad..., lo que significa que la función social de la riqueza es lo que justifica todo límite impuesto al derecho de propiedad, y todo deber impuesto al propietario».
} 
No es extraño, por tanto, que el propio Tribunal Constitucional haga suya esta idea afirmando que «la Constitución reconoce un derecho a la propiedad privada que se configura y protege, ciertamente, como un haz de facultades individuales sobre las cosas, pero también, y al mismo tiempo, como un conjunto de deberes y obligaciones establecidas, de acuerdo con las leyes, en atención a valores o intereses de la colectividad, es decir, a la finalidad o utilidad social que cada categoría de bienes objeto del dominio esté llamada a cumplir» ${ }^{297}$, aun sin abandonar la idea de que la función social es un elemento estructural de la definición del derecho a la propiedad privada, que forma parte integrante del derecho mismo 298.

Se podía decir, que son varias las razones que han contribuido a sustentar esta opinión, en primer lugar, una larga tradición que arranca de la propia Codificación civil y que se mantiene hasta la entrada en vigor del actual texto constitucional. Mucho más claramente aparece la idea, desde una vertiente distinta, en la Constitución de 1931, que subordina toda la riqueza a los intereses de la economía nacional. Las anteriores Leyes Fundamentales, sobre todo las leyes que tratan de actuar la función social de la propiedad en ellas reconocida, tampoco se apartan de este camino . No es extraño, por tanto, que la Constitución de 1978 se mantenga en la misma línea.

${ }^{297}$ Cfr. la STC 37/1987, de 26 de marzo, n. 2, aunque la idea se repite insistentemente a lo largo de toda la Sentencia. Vid., además del fundamento citado, in totum, los fundamentos 3,8 y 9, donde pueden leerse afirmaciones como las siguientes: «las características naturales del bien objeto del dominio y su propia localización lo hacen susceptible de diferentes utilidades sociales»; «el derecho a la prop. privada que la Constitución reconoce y protege tiene una vertiente institucional, precisamente derivada de la función social que cada categoría o tipo de bienes sobre los que se ejerce el señorío dominical está llamado a cumplir»; «la función social de la propiedad, determinada de acuerdo con las leyes, presupone la identificación de los fines de interés general que, sin perjuicio de la utilidad individual de su titular, están llamados a satisfacer los bienes objeto de dominio privado». En parecido sentido, Vid. STC 227/1988, de 29 de diciembre.

298 Así parece entenderlo la Ley 8/1984, de 3 de julio, de Reforma Agraria de Andalucía, que utiliza como principio inspirador de la idea de «función social de la propiedad de la tierra», según se desprende de su artículo 1ํ., y de los no 7 y 9 de su Exposición de Motivos. 
No son pocas las ocasiones en las que la Constitución utiliza la referencia al momento objetivo como medio para alcanzar la satisfacción del interés social o del interés general299.

En este sentido, la relación existente entre los artículos 33.2. y 128.1, pone de manifiesto el énfasis que en el texto constitucional se hace de la funcionalización de los bienes en orden a obtener la satisfacción de intereses supraindividuales sociales, colectivos o generales, no propios de su titular dominical. En efecto, la fórmula empleada por el artículo 128.1, subordinando al interés general «toda la riqueza del país en sus distintas formas y sea cual fuere su titularidad", con un sentido claramente objetivo, abarca todos los bienes económicos que constituyen la riqueza del país, prescindiendo del tipo de titularidad que sobre ellos recaiga y de cualquier valoración que de los mismos realicen los titulares de derechos sobre ellos. De otra parte, la conexión de la subordinación de la riqueza al interés general con el tema de la f. s. de la propiedad privada parece evidente, ya que en todo caso, se identifiquen los conceptos de «función social» e «interés general», o se considere la «función social» como un medio concreto para alcanzar el objetivo más amplio del «interés general», la función social ha de inspirarse en el interés general 300.

Esta circunstancia, que lleva a afirmar por sí misma la conveniencia de predicar la función social de los bienes y no del derecho, viene a encontrar refuerzo si se pone en conexión la idea central apuntada con los artículos 45.2, 46 y 47 de la Constitución, que funcionan como criterios para determinar el alcance concreto de la función social, pues

299 Antes de seguir adelante, queremos poner de manifiesto que los términos «función social», «interés social», «interés general», «interés público», «utilidad social» y otros similares, se reputan equivalentes y vienen siendo utilizados como intercambiables, a pesar de las posibles diferencias conceptuales existentes entre elllos.

300 Cfr. ESPIN, Manual, II, cit., p. 96. 
manifiestan una clara preocupación por la utilización y aprovechamiento de distintos bienes materiales en orden a su idoneidad para satisfacer intereses supraindividuales. Así, «la utilización racional de todos los recursos naturales», la conservación y el enriquecimiento de los bienes que integran el patrimonio histórico, cultural y artístico de los pueblos de España, y la «utilización del suelo de acuerdo con el interés general», se convierten en criterios sustantivos que permiten concretar la función social sobre determinados bienes de especial relevancia para el interés general.

Desde otra perspectiva, el artículo 33.3 se mantiene en esta misma línea al referir la causa expropiandi, directa y prioritariamente, al bien y no al derecho de propiedad ${ }^{301}$. Por ello precisamente, y al amparo de la idea de expropiación por causa de interés social que se contiene con carácter general, en el artículo 71 de la vigente L.E.F., se conecta la no utilización de un bien o clase de bienes en el sentido positivo de una determinada función social, con la privación del derecho de propiedad (o alguna de las facultades del mismo) que permite cumplir dicha función social. Este es el caso de la Ley de Fincas Manifiestamente Mejorables, de 16 de noviembre de 1979 , cuyo artículo 1ํo dispone: «La calificación de una finca rústica como manifiestamente mejorable, conforme a lo dispuesto en la presente Ley, implicará el reconocimiento del incumplimiento de la función social de la propiedad y producirá los efectos declarados en la Ley de Reforma y Desarrollo Agrario respecto a la expropiación forzosa, sin perjuicio de las modificaciones introducidas en la presente Ley»302.

301 En este sentido se ha dicho que «la aplicación de la expropiación forzosa por motivos de interés social indudablemente legitima la modalidad específica de las expropiaciones por incumplimiento de la f. s. de la propiedad, en virtud de las cuales la objetividad misma de la f. s. del bien justifica el cambio de titularidad por incumplimiento del dueño actual», cfr. BASSOLS, Constitución y sistema económico, cit., p. 127.

302 Véanse los artículos 1 y 2 de la L.R.D.A., así como el Título I del Libro IV que tiene por título Expropiación por causa del interés social. Con la entrada en vigor de la Ley de Modernización de las Explotaciones Agrarias de 4 de julio de 1995, queda derogada la Ley 49/1981, de 24 de diciembre, del Estatuto de la Explotación Familiar y de los Agricultores Jóvenes, y el Título lldel Libro Primero, el Título III del Libro Segundo y el Título IV del Libro Cuarto de la Ley de Reforma y Desarrollo Agrario, cuyo texto fue aprobado por Decreto 118/1973, de 12 de enero. Se 
También es el caso de la Ley de Reforma Agraria para Andalucía, de 3 de julio de 1984 , que con mayor claridad dispone en su artículo 3 que el incumplimiento de las obligaciones inherentes a la función social de la propiedad de la tierra facultará a la Administración Autónoma para acordar la expropiación del dominio o del uso de la finca...»303, expropiación que puede extenderse a la privación del derecho de propiedad o alguna de sus facultades «separables de la titularidad del propietario y enajenables a un tercero» 304 .

Si a esto añadimos que el artículo 33.2 no anticipa nada respecto a esta cuestión, pues ni refiere la función social a la titularidad, ni predica de forma clara la función social del derecho cuando alude únicamente a sus efectos delimitadores del contenido o, lo que es igual, del «conjunto de facultades atribuidas a la persona respecto al objeto de su derecho»305, ni hace referencia expresa a la función social como elemento determinante de los modos de goce o de adquisición del derecho, es fácil suponer que la Constitución no ha logrado sustraerse a la tendencia de confundir el derecho de propiedad con el objeto sobre el que recae, utilizando el término propiedad para referirse a ambos indistintamente ${ }^{306}$. Por tanto podríamos

modifica el artículo15 y el último punto del primer párrafo del apartado 5 del artículo 121de la Ley 83/1980, de 31 de diciembre, de Arrendamientos Rústicos .Se modifica , también el apartado 3 del artículo 28, y los artículos 32 y 35 de la Ley de Reforma y Desarrollo Agrario, cuyo texto fue aprobado por Decreto 118/1973, de 12 de enero.

303 Vid. también los no 9 y 10 de su Exposición de Motivos que se refieren a la expropiación forzosa por incumplimiento de la función social de la propiedad «(pudiendo ser en el sistema de la Ley del uso o bien de la propiedad, también de acuerdo con las modernas orientaciones en materia de propiedad, que ponen de relieve cómo lo más importante del Derecho subjetivo es el perfil del ejercicio, y no el de la titularidad pura»), y a la expropiación por causa de interés social «(donde los derechos del propietario quedan definitivamente sacrificados para la consecución de finalidades prioritarias para la comunidad»), así como su artículo 15 y, en general, su capítulo II titulado De la expropiación del uso y del dominio por incumplimiento de la función social de la propiedad de la tierra.

304 Esta posibilidad prevista expresamente en los artículos 3, 15, 20 y 28, como sanción al incumplimiento de la f. s. de la propiedad de la tierra, es perfectamente constitucional según entiende el T.C. en la Sentencia 37/1987, de 26 de marzo, n. 4, pues no priva al propietario de toda utilidad económica y, en consecuencia, no infringe el contenido esencial de la propiedad privada .

305 Cfr. DE CASTRO, Derecho Civil de España, Tomo I, Parte General, 3a. ed., Madrid 1984, cit., p. 586.

306 En este sentido, refiriéndose al artículo 42 de la Constitución italiana, TARELLO, G., La disciplina constituzionale, cit., p. 27, señala que «propiedad, de hecho, puede ser entendido 
leer la norma del siguiente modo: «la función social de (los bienes sobre los que recaen) estos derechos delimitará su contenido de acuerdo con las leyes», esta lectura encuentra un nuevo apoyo en el apartado tercero de dicho artículo cuando identifica «bienes» y derecho de propiedad sobre los bienes, a efectos de expropiación.

Por otro lado, el artículo 38 de la Constitución, al reconocer la libertad de empresa y, consiguientemente, la legitimación del uso organizado de los bienes productivos, propios o ajenos, encaminado a la obtención de beneficios, únicamente establece al ejercicio de la misma límites de orden objetivo «(las exigencias de la economía general y, en su caso, de la planificación)» que, en ningún caso, llegan a insertarse en el ámbito de poder del sujeto de la actividad económica. Además, existe una tendencia muy acusada a dotar a estos límites de un carácter social, en relación con los artículos 128 y 131 de la Constitución, y a establecer una especie de relación jerárquica entre la función social de la propiedad y la libertad de empresa ${ }^{307}$, que solamente puede ser entendida partiendo de la base de predicar la funcionalización social de los bienes sobre los que, simultaneamente, confluyen la titularidad dominical y la actividad empresarial.

como un vocablo que designa el derecho de propiedad o como un vocablo que designa los posibles objetos del derecho de propiedad», juzgando más adecuada la segunda lectura .

307 Sobre este particular puede verse la STC 37/1981, de 10 de noviembre, n. 2; la Stc 111/1983, de 2 de diciembre, n. 8; y particularmente, la STC 37/1987, de 26 de marzo, n. 5, en la que el Trib. Constit. no duda en afirmar que, «desde el punto de vista de lo que prescribe el artículo 38 de la Constitución, la f. s. de la prop., al configurar el contenido de ese derecho mediante la imposición de deberes políticos a su titular, no puede dejar de delimitar a su vez el derecho del empresario agrícola para producir o no producir, para invertir o no invertir», y que «la libertad de empresa que reconoce el artículo 38 de la Constitución no puede exonerar del cumplimiento de la función social de la propiedad, de lo que se sigue que las limitaciones legítimas derivadas de esta última no infringen en ningún caso el contenido esencial de la libertad de empresa». Afirmaciones éstas que trasladan los límites funcionales del derecho de propiedad a la actividad empresarial y que difícilmente pueden tener justificación fuera del contexto en que se enmarcan, que es, precisamente, el de la «función social que las fincas rústicas están llamadas a satisfacer». 
Por último, predicar la función social de los bienes y no del derecho de propiedad es, como veremos, la fórmula que mejor permite mantener el concepto unitario de propiedad, haciendo compatible la garantía de un contenido esencial del derecho, con la idea de la función social y con la existencia de diferentes tipos de propiedad dotados de un estatuto jurídico particular.

\subsection{INCIDENCIA DE LA FUNCION SOCIAL EN EL CONCEPTO Y} EN EL CONTENIDO DEL DERECHO DE PROPIEDAD.

Esta forma de concebir la función social permite reafirmar la profunda transformación que ha experimentado la propiedad privada en nuestro siglo y sacar las siguientes conclusiones: por un lado la existencia de diferentes tipos de propiedad dotados de estatutos jurídicos diversos y por otro la posibilidad de imponer al propietario deberes positivos

derivados de la función social de la propiedad.

El propio Tribunal Constitucional parte de que «la progresiva incorporación de finalidades sociales relacionadas con el uso o aprovechamiento de los distintos tipos de bienes sobre los que el derecho de propiedad puede recaer ha producido una diversificación de la institución dominical en una pluralidad de figuras o situaciones jurídicas reguladas con un significado y alcance diversos. De ahí que se venga reconociendo con general aceptación doctrinal y jurisprudencial la flexibilidad o plasticidad actual del dominio que se manifiesta en la existencia de diferentes tipos de propiedades dotadas de estatutos jurídicos diversos, de acuerdo con la naturaleza de los bienes sobre los que cada derecho de propiedad recae» (n. 2), pues estima que «la función social que 
este derecho debe satisfacer no es ni debe ser igual en relación con todo tipo de bienes» 308 .

En efecto, aunque la función social pueda considerarse un elemento estructural del derecho de propiedad ${ }^{309}$, lo cierto es que al venir directamente referido al objeto del mismo, sólo incidirá de forma refleja en su contenido, determinando, en su caso, los límites del mismo. Se mantiene, por tanto, como fundamental para definir el concepto del derecho de propiedad la idea de un poder del sujeto de carácter general y abstracto que se concreta en la atribución de un haz de facultades. Respecto de este núcleo de poder las limitaciones y deberes concretos, establecidos en base a la función social que según el ordenamiento jurídico el bien debe cumplir, actuarán como restricciones o condicionamientos, pero sin llegar nunca a suprimirlo 310 .

308 Cfr. la STC 37/1987, de 26 de marzo, n. 9 donde se continúa afirmando que carece de sentido «la exigencia de una regulación, necesariamente abstracta, de la función social -las funciones sociales, mejor- del dominio, realizada con carácter general y uniforme, pues sin duda resultaría altamente artificiosa», ya que «las características naturales del bien objeto del dominio y su propia localización lo hace susceptible de diferentes utilidades sociales» (n. 3). Igualmente el Tribunal mantiene que «la Constitución reconoce un derecho a la propiedad privada que se configura y protege, ciertamente, como un haz de facultades individuales sobre las cosas, pero también, y al mismo tiempo, como un conjunto de deberes y obligaciones establecidos, de acuerdo con las leyes, en atención a valores o intereses de la colectividad, es decir, a la finalidad o utilidad social que cada categoría de bienes objeto de dominio esté llamada a cumplir», por lo que rechaza la idea de que «la imposición de deberes positivos del propietario hagan irreconocible el derecho de propiedad como perteneciente al tipo constitucinalmente descrito" (n. 2).

309 En este sentido puede sorprender que el Tribunal Constitucional, en su Sentencia 37/1987, de 26 de marzo, n. 2, acepte la referencia a la f. s. "como elemento estructural de la definición misma del derecho a la propiedad privada», si no se repara en que está refiriéndose a su aspecto institucional. En efecto, esta idea se clarifica a continuación cuando se considera a la f. s. como «factor determinante de la delimitación legal de su contenido», refiriéndose esta vez a su carácter de derecho subjetivo, o, cuando en su fundamento octavo señala que «el derecho a la propiedad privada que la Constitución reconoce y protege tiene una vertiente institucional, precisamente derivada de la función social que cada categoría o tipo de bienes sobre «los que se ejerce el señorío dominical está llamado a cumplir».

310 Como señala MONTES, La propiedad privada ${ }_{2}$ cit., p. 185 , siguiendo seguramente a RODOTA, II terribile diritto, cit., pp. 225-226, operativamente la f. s. se traducirá en uno de estos tres supuestos: falta de atribución de terminadas facultades, complejo de condicionamientos para el ejercicio de las facultades atribuidas y obligación (o deber) de ejercicio de determinadas facultades. Pero en cualquier caso, deberá respetar siempre el contenido esencial del derecho de propiedad. 
Aquí se nos plantea el delicado problema de indentificar el derecho de propiedad, de averiguar si su concepto se encuentra recogido en algún precepto legal y de determinar cuál es el alcance del poder que confiere, y el haz de facultades o contenido en que éste se traduce. Lo que lleva a plantear nuevamente la difícil cuestión de determinar que deben entenderse por contenido esencial del dominio, esto es, de encontrar los rasgos característicos del derecho de propiedad, lo que, en definitiva, significa preguntarse si más allá de la pluralidad de tipos o estatutos dominicales definidos por la función social de los distintos bienes sobre los que recaen, hay una única estructura jurídica constitucionalmente garantizada que asume la función de elemento de agregación de las variadas formas que puede revestir el derecho de propiedad. Es algo así como ir a la búsqueda de la facultad última del dominio, del punto más allá del cual ya no hay propiedad ${ }^{311}$.

Si analizamos la normativa dictada en materia de propiedad se evidencia que, aunque la noción de propiedad debe tener en cuenta los diversos estatutos normativos, puede ser concebida en sentido unitario ${ }^{312}$, no sólo en base a la constatación de que al propietario le es garantizada la apropiación del bien de forma exclusiva, sino también en cuanto que dichos estatutos representan especificaciones de una estructura unitaria de la cual han surgido. Es decir, se puede afirmar que existe un concepto de propiedad unitario, lo que varía, de acuerdo con la función social asignada por el ordenamiento jurídico al bien objeto del dominio, es la extensión y el

311 MONTES, La propiedad privada, cit., p. 182. Vid. también, aunque desde otras coordenadas DE CASTRO, Derecho civil, I, cit., p. 655.

312 Sobre la existencia de una disciplina común de carácter genérico y unitario, aunque no dejen de hablar de propiedades en plural, insiste PUGLIATTI, La propietà, cit., p. 124; EI propio RODOTA, II terribile diritto, cit., p. 40, reconoce que «uno de los problemas centrales sigue siendo todavía el de la relación entre la realidad de los diferentes estatutos y la persistencia de las referencias a una noción unitaria de propiedad, no sólo en el lenguaje, sino en muchos de los materiales normativos componentes del ordenamiento (empezado por la Constitución)». 
número de los poderes que corresponden al propietario, esto es, el contenido concreto del derecho.

Esta unidad conceptual del dominio que aparece reflejada en el artículo 33.1 del texto constitucional, es la misma que se aprecia en el artículo 348 del Código civil, la misma que refleja el artículo 1 de la vigente Ley de Expropiación e incluso, la misma que late en los artículos 76 y 87 de la L.S. del 76, o en el artículo 2 de la L.R.D.A. así como en leyes posteriores vigentes, a pesar de que el contenido del derecho presente diferencias notables en unos y otros casos.

Sin embargo, a pesar del carácter unitario de la noción de propiedad implícito en la Constitución y no desmentido por ninguna de las normas citadas anteriormente, no se ofrece en ellas un concepto del derecho de propiedad.

Ello podría significar que no existe un concepto constitucional de propiedad, y que cualquier definición es aceptable si no está en contradicción con las previsiones constitucionales, en cualquier caso lo que no puede admitirse es que «la palabra propiedad haya sido llevada al texto constitucional como una palabra vacía, que el legislador ordinario pueda rellenar con el concepto que quiera»313. Si ello fuera así, el contenido esencial de este derecho vendría fijado por la propia ley dictada para delimitar y configurar su contenido, idea inaceptable, pues sería claramente contradictoria con lo dispuesto en el artículo 53.1, que impone a la acción del legislador el límite del respeto al contenido esencial.

313 Cfr. MONTES, La propiedad privada, cit., p. 170. 
El concepto de propiedad que consagra el artículo 348 del Código Civil, aparece como clave en la búsqueda de un concepto constitucional del derecho de propiedad privada, siempre que se interprete a la luz de la Constitución y no a la inversa. La idea de que la propiedad es «el derecho de gozar y disponer de una cosa» supone una atribución de poder a la persona para la satisfacción de sus intereses personales, y dota de sentido a la garantía del contenido esencial del dominio ${ }^{314}$. Otra cosa distinta es que el poder de goce o el poder de disposición puedan ser variados y modificados por las leyes en atención a la función social del bien objeto del dominio $o$, si se prefiere, que la atribución de estas facultades venga condicionada en aquellos casos en los que el bien tiene una función social que cumplir, de acuerdo con las leyes.

Sin embargo, el Tribunal Constitucional conectando con un determinado sector de la doctrina ${ }^{315}$, opta por rechazar la posibilidad de que el artículo 348 del Código civil sirva de base para determinar el concepto y el contenido esencial del derecho de propiedad, afirmando que «la propiedad privada, en su doble dimensión como institución y como derecho individual, ha experimentado en nuestro siglo una transformación tan profunda que impide concebirla hoy como una figura jurídica reconducible exclusivamente al tipo abstracto descrito en el artículo 348 del Código civil, que los recurrentes citan (sic) $)^{316}$ en apoyo de su alegato de inconstitucionalidad»317.

314 En este mismo sentido vid. últimamente con referencia al Derecho italiano, MANGLIAMELLI, S., La propietà privata nella costituzione. Giuffre. Ed. Milano, 1986. p. 92 y ss.

315 MONTES, La propiedad privada, pp. 217 y ss.

316 No faltan en esta postura ciertos prejuicios hacia la citada norma, pues, como puede comprobarse, los recurrentes para nada citan el artículo 348, sino que proponen como núcleo esencial del derecho de propiedad «la facultad de usar, disfrutar, consumir y disponer de la cosa o derecho sin más limitaciones que aquellas que se impongan mediante ley o no vayan más allá de lo que en cada momento se considere razonable por la sociedad». Sin embargo, es el Parlamento de Andalucía el que afirma que, «al contrario de lo que sugieren los recurrentes, el contenido esencial del derecho de propiedad no se deriva de lo dispuesto en el artículo 348 del C. civil, sino de lo que se desprende de un análisis sistemático de la Constitución, que precisamente se remite a la Ley (art. 33.2 y 3) para la determinación del rol, que en un momento histórico le corresponde $\mathrm{y}$, por ende, del preciso contenido que se le asigna. En consecuencia, el contenido esencial del derecho de propiedad... queda modulado por la 
Pero es curioso, que al lado de este rechazo de las posibilidades del artículo 348 del Código civil para integrar el concepto constitucional de propiedad, el Tribunal acude al Derecho preexistente para dar sentido a otros conceptos que sólo tienen razón de ser en relación con el concepto de propiedad privada, caso de la función social o de la expropiación forzosa ${ }^{318}$.

Esta aparente contradicción sólo se explica por la tendencia a convertir la idea de contenido esencial del dominio en un dato puramente económico, referido a la utilidad o al valor patrimonial que el bien tiene para su titular. Es decir, se viene a identificar el contenido esencial de carácter cualitativo con un contenido mínimo de carácter cuantitativo ${ }^{319}$.

Este viene a ser el camino seguido por nuestro Tribunal Constitucional en la tan citada Sentencia 37/1987, de 26 de marzo, apartándose, del propuesto de modo general en su anterior Sentencia 111/1981, de 8 de abril, que se refería a las facultades o posibilidades de actuación que integran el contenido del derecho. Por eso, aunque parece mantenerse una continuidad, y así se manifiesta por el Tribunal, la identificación del contenido «esencial o mínimo» del derecho de propiedad viene realizada en función de «salvaguardar la rentabilidad del

legislación específica a través de la cual nuestro ordenamiento jurídico viene a configurar la f. s. que a este tipo particular de propiedad le corresponde».

317 Cfr. la STC 37/1987, de 26 de marzo, n. 2, que más adelante añade: «debe rechazarse, por infundada, la pretensión de los recurrentes de identificar el contenido esencial de la misma atendiendo exclusivamente a lo que el Código civil, declinado en el siglo XIX, dispuso con carácter general en su artículo 348, porque tal pretensión no tiene para nada en cuenta las modulaciones y cambios que ha venido sufriendo desde entonces el instituto de la propiedad privada, en general, y de la propiedad agraria en particular». Puede verse, además, el fundamento octavo de la misma.

318 Vid. el n. 2 de la STC 37/1987, antes citada con referencia al concepto de f. s. de la propiedad agraria, que se define a la luz del artículo 2 de la L.R.D.A., de 12 de enero de 1973, y el n. 4, con referencia al concepto de expropiación forzosa que se llena de contenido mediante la referencia a la vigente Ley de Expropiación de 1954 y otras leyes especiales.

319 Vid. por ejemplo, ESPIN, Manual, II, cit., p. 97; y especialmente, MONTES, La propiedad privada $_{1}$ cit., pp. 154-160-165-170-179-205-208-211. 
propietario», o de impedir que se llegue a anular «la utilidad meramente individual» 320 .

Sólo desde esta perspectiva puede entenderse y asumirse que la fijación del contenido esencial del derecho de propiedad debe incluir necesariamente la referencia a la función social321, la identificación del contenido esencial con el contenido definido en cada caso de acuerdo con las leyes, o la posibilidad de tantos contenidos esenciales como propiedades legalmente tipificadas.

En resumen, y para concluir, aunque la función social va a conformar diferentes estatutos propietarios, no es un elemento que llegue a modificar la estructura interna del derecho de propiedad, sino el elemento que permite construir en torno a un núcleo predeterminado, las variadas formas de la propiedad. En este marco, el contenido esencial responde a un concepto que actúa como elemento unificador del derecho de propiedad, independientemente de su objeto, y representa un contenido genérico (un haz de facultades que puede resumirse en el goce y la disposición) referido al sujeto, mientras, la función social permite delimitar legalmente el alcance concreto de este contenido respecto a determinados bienes, dando origen a una pluralidad de propiedades, cada una de las cuales gozará de un contenido mínimo determinado por la utilidad económica que el bien debe reportar al propietario. Por esta razón la fijación del contenido esencial de la

\footnotetext{
320 En este sentido señala, en su fundamento cuarto, que «no sería constitucional una expropiación que, afectando parcialmente a algunas de las facultades del propietario reconocidas por la Ley, privase en realidad de todo contenido útil al dominio sin una indemnización adecuada a esta privación total del derecho, que puede, desde luego, medirse desde el punto de vista del aprovechamiento económico o la rentabilidad de la nuda propiedad o de las facultades que conserve el propietario tras la operación expropiatoria, teniendo siempre en cuenta que tal utilidad individual o tales facultades no pueden ser absolutas e ilimitadas, en razón de las exigencias de la f. s. de la propiedad».

321 Vid. COLINO GAREA,R., La función social de la propiedad privada en la Constitución Española de 1978, Barcelona, 1997, p. 201
} 
propiedad privada no puede hacerse desde la exclusiva consideración subjetiva del derecho o de los intereses individuales, sino que debe incluir igualmente la necesaria referencia a la función social, entendida no como límite externo a su definición, sino como parte integrante del mismo, por tanto, utilidad individual y función social definen el contenido del derecho de propiedad sobre cada categoría o tipo de bienes

La función social desde el punto de vista constitucional, se presenta como síntesis de intereses particulares y sociales, de tal forma que el legislador al determinar los diversos estatutos propietarios debe siempre asegurar la función social, ya que el derecho de propiedad se otorga para satisfacer un interés o utilidad social. El titular de un derecho no ostenta unos poderes ilimitados sobre los bienes de su propiedad, sino tan sólo aquellos que le son concedidos para atender la función social, función social que se descubre, como hemos tenido ocasión de analizar en el capítulo anterior, a través de los límites y limitaciones del derecho.

Seguidamente, vamos a estudiar, la importante proyección de la función social en el ámbito de la propiedad urbana y más concretamente en el sistema de compensación urbanística. 


\section{CAPITULO SEXTO}

\section{LA PROPIEDAD URBANISTICA : SU FUNCION SOCIAL.}

\section{INTRODUCCION}

La transcendental Sentencia del TC de 20 de marzo de 1997, ha venido a plantear, un nuevo modo de ver el urbanismo en nuestro país. El Estado carece de competencias para dictar una legislación urbanística básica, pero si puede ejercitar su competencia legislativa en materia de política económica, régimen jurídico de las Administraciones públicas y medio ambiente (art. 149.1 .13, 18 y 33 de la CE), sin contar que puede establecer las condiciones básicas del ejercicio del derecho de propiedad (art. 149.1 CE), tal como establece la DF única de la Ley 6/1998 . La cuestión es si en el ejercicio de estas competencias el legislador estatal se ha excedido de su ámbito propio y ha alcanzado el ámbito que corresponde a los legisladores autonómicos.

El fundamento 8 de la STC de 20 de marzo de 1997 ha delimitado el concepto de «condiciones básicas para garantizar la igualdad en el ejercicio del derecho de propiedad", como competencia estatal. Estas «condiciones básicas hacen referencia al contenido primario del derecho, a las posiciones jurídicas fundamentales (facultades elementales, límites esenciales, deberes fundamentales, prestaciones básicas, ciertas premisas o presupuesto previos...). En todo caso, las condiciones básicas han de ser las imprescindibles o necesarias para garantizar esa igualdad, que no puede consistir en una igualdad formal absoluta», a fin de no invadir las competencias autonómicas.

En el ámbito urbanístico se debe garantizar la igualdad «en las condiciones de ejercicio del derecho de propiedad urbana y en el 
cumplimiento de los deberes inherentes a la función social, pero no, en cambio, la ordenación de la ciudad» (f.jco. 9ํb). Teniendo en cuenta que el Tribunal Constitucional asimila a esto último «las normas que, en sentido amplio, regulan la actividad de urbanización y edificación de los terrenos para la creación de la ciudad» (f.jco.9ํ. b) in fine), es evidente que al Estado le queda un ámbito de actuación muy restringido.

El Tribunal diferencia las competencias urbanísticas administrativas (ordenación, planeamiento, ejecución, gestión y disciplina) de las que se relacionan con el estatuto jurídico del propietario del suelo. Sobre las primeras, reconoce una capacidad normativa plena a las Comunidades Autónomas y niega cualquier intervención al Estado, mientras que sobre las segundas, concluye diciendo que el Estado ostenta competencia para fijar las condiciones básicas que garanticen la tendencia a la igualdad en el ejercicio de los derechos y deberes de los propietarios, sin que por ello pueda establecer un régimen jurídico uniforme para todo el territorio ${ }^{322 .}$

En este sentido el Tribunal entiende que las CC.AA poseen una potestad normativa amplia, ya que, además de estar capacitadas para regular las disciplinas urbanísticas (ordenación de la ciudad), pueden

3221 Así queda recogido en el fundamento jurídico 7. a) de la STC de 20 de marzo de 1997, «condiciones básicas no en sinónimo de» legislación básica», «bases» 0 «normas básicas». El artículo 149.1.1ํ de la C.E, no ha atribuido al Estado la fijación de las condiciones básicas para garantizar la igualdad en el ejercicio de los derechos y libertades constitucionales, sino sólo el establecimiento de aquellas condiciones básicas que tiendan a garantizar la igualdad. El Estado tiene la competencia exclusiva para incidir sobre los derechos y deberes constitucionales desde una concreta perspectiva, la de la garantía de la igualdad en las posiciones jurídicas fundamentales, dimensión que no es, en rigor, susceptible de desarrollo como si de unas bases se tratara; será luego el legislador competente, estatal y autonómico, el que respetando tales condiciones básicas establezca su régimen jurídico, de acuerdo con el orden constitucional de competencias. Las condiciones básicas no equivalen ni se identifican tampoco con el contenido esencial de los derechos (art. 53.1 C.E), técnica cuyo objeto, consiste en garantizar el derecho frente a los eventuales abusos o extralimitaciones de los poderes públicos, en particular y en primer término, del legislador, cualquiera que éste sea, en su tarea reguladora. El contenido esencial constituye, una garantía constitucional en favor del individuo, algo a respetar por el legislador en cada caso competente, no para regular; no es, en definitiva, una técnica que permita determinar lo que al Estado o a las Comunidades Autónomas les corresponde. En términos positivos, pues, tanto el legislador estatal de las condiciones básicas, como el autonómico deben respetar el contenido esencial del derecho de propiedad (art. 53.1 C.E)». 
participar en la configuración del modelo estatutario del derecho de propiedad, respetando, siempre, las condiciones básicas que haya fijado de forma global el Estado.

En la nueva Ley 6/ 1998, de 13 de abril, sobre régimen del suelo y valoraciones ${ }^{323}$, el legislador estatal ha optado por un modelo de propiedad urbana opuesto al hasta ahora vigente, toda vez que este modelo se apoya en una base ideológica distinta, la que se centra en la idea de liberalización del suelo que permita incrementar su oferta, y en un título competencial específico: el art. 149.1.13 CE (Bases y coordinación de la planificación general de la actividad económica). Por esta razón, es preciso poner de manifiesto que la Ley 6/1998 viene a representar en el panorama del Derecho urbanístico español una transacción entre dos movimientos doctrinales: de una parte, la doctrina intervencionista, que considera el urbanismo como una función pública (ordenación urbana) y como un servicio público (urbanización), y de otra, la doctrina de la liberalización del suelo, para la que el urbanismo es más bien una actividad económica privada 324 .

La cultura urbanística española se nutre, desde la Ley de 12 de mayo de 1956, de la doctrina intervencionista ${ }^{325}$, que continua informando la Ley de 1975 (texto refundido del 76) y se agota en la Ley 8/1990 (texto refundido del 92).

\footnotetext{
${ }^{323}$ Las normas contenidas en esta Ley, son directamente aplicables, anulando las normas de las CC.AA. que estén en contradicción con ellas. Sin embargo, estas normas pueden ser desarrolladas o complementadas por la legislación autonómica. Tras la publicación de esta Ley, el régimen de las fuentes del derecho urbanístico es el siguiente:

- Ley 6/1998, de 13 de abril.

- Preceptos de la Ley del Suelo, TR de 1992, vigentes tras la STC 61/1997, no derogados por la Ley 6/ 1998.

- Legislación de las Comunidades Autónomas.

- Ley del Suelo, TR de 1976, legislación supletoria no expresa y reglamentos de esta Ley, cuya vigencia o no, deberá ser decidida por el aplicador del derecho en cada caso.

324Vid. LLISET BORRELL, F., El sistema urbanístico español después de la Ley 6/ 1998, Barcelona 1998, p. 23.

325 Desde una perspectiva científica la doctrina intervencionista ha sido defendida por PAREJO ALFONSO, L., en Reivindicación del Urbanismo, Liberalización del suelo al servicio del interés general, Madrid, 1997.
} 
La doctrina de la liberalización ${ }^{326}$ del suelo sale a la vida pública a través del Informe del Tribunal de Defensa de la Competencia de comienzo de la década de los noventa, pero no logra positivizarse, si bien tímidamente, hasta la Ley 7/ 1997, de 14 de abril, de medidas liberalizadoras del suelo y de Colegios profesionales, donde se suprime las categorías de suelo urbanizable, programado y no programado, y se reduce el porcentaje de absorción por la Comunidad de plusvalías urbanísticas al 10 por ciento como máximo.

La nueva Ley 6/ 1998, sin lugar a dudas, se apoya en la doctrina de la liberalización del suelo, pero mantiene la tesis de que el urbanismo es una función pública y un servicio público, sin perjuicio de la colaboración de los particulares en el planeamiento y en la gestión urbanística en términos semejantes a la regulación tradicional. Desde otro punto de vista, esta ley abre las puertas a una posible flexibilización del planeamiento, de estricta vinculación positiva en la legislación anterior (calificación urbanística) al admitir una simple vinculación negativa del plan que permite cualquier uso excepto los que declara incompatibles (art. 19.1 en relación con el art. 2.1). En esta línea, la definición del derecho de la propiedad queda configurada por la clasificación y no por la calificación, pues como puede observarse el art. 2.1 prescinde, al referirse a las facultades del derecho de propiedad, del término calificación, habitual en todas las regulaciones precedentes ${ }^{327}$.

\section{LA PROPIEDAD URBANISTICA.}

Como ya hemos estudiado, el derecho de propiedad, especialmente a partir de la entrada en vigor de la Constitución Española, no es un derecho absoluto, sino que vendrá delimitado por la función social

326 Esta doctrina ha sido mantenida entre otros por: ARIÑO, G y otros : El nuevo servicio público, Madrid, 1997, y por SORIANO, J.E., Desregulación , privatización y Derecho Administrativo, Bolonia, 1993, y La tercera desamortización, Madrid, 1996.

327 Vid. ROMERO SAURA, La calificación urbanística de los predios, Madrid, 1996 
que está llamado a cumplir, según establece el artículo 33.2 de la C.E. Estas limitaciones, que se ponen de manifiesto respecto de otros bienes, alcanzan su máximo exponente cuando se trata de la propiedad del suelo328 .

El urbanismo, en cuanto que supone la ordenación del territorio en su más amplio sentido, da la medida de la notable carga de función social que lleva en sí la propiedad urbanística. En este sentido, la Ley 8/1990, de 25 de julio, sobre reforma del Régimen Urbanístico y Valoración del Suelo, cuyo impulsor es el texto constitucional, supuso un cambio profundo en nuestra legislación urbanística, como así queda plasmado en el propio Preámbulo de la Ley, a pesar de la evolución ya detectada en este ámbito de la propiedad a través de las anteriores leyes del suelo. Su objetivo es limitar aún más el derecho de propiedad que recae sobre fincas urbanas, con objeto de solucionar los problemas actualmente existentes ${ }^{329}$, tales como combatir la inflación en este sector, acentuar el principio de igualdad, facilitar el acceso a la vivienda, y, en suma, acabar con la especulación del suelo. Esta Ley, ha visto su culminación en el complejo texto Refundido de la Ley del Suelo, de 26 de junio de 1992 330. Texto

328 Para un análisis de la propiedad urbana en el ámbito del Derecho Comparado vid. BARNES VAZQUEZ, en Propiedad, Expropiación y Responsabilidad, ob.cit., pp. 275 a 348, donde hace un estudio de la propiedad urbana en Alemania y en Francia.

329 A tales efectos es realmente significativa la Sentencia del TS de 5 de diciembre de 1994 Act.civil 255/ 1995, p. 658, la cual declara que la Ley del Suelo y las disposiciones urbanísticas en su caso imponen límites al derecho de propiedad, pero sin desconocer la titularidad dominical también protegida por la Constitución.

330 La LS Texto Refundido del 92 fue modificada por el Real Decreto-Ley 5/1996, de 7 de junio, de medidas liberalizadoras en materia de suelo y de Colegios Profesionales, que más tarde dio lugar a Ley $7 /$ 1997, de 14 de abril. Las modificaciones propuestas de la legislación urbanística están orientadas a incrementar la oferta de suelo con la finalidad de abaratar el suelo disponible así como a simplificar los procedimientos y a acortar los plazos vigentes. De acuerdo con el artículo 1, los Planes Generales de Ordenación Urbanística cuya tramitación comience tras la aprobación de este Real Decreto-ley contendrán una sola clasificación de suelo urbanizable. En el artículo 2, se modifica la cesión de suelo a los ayuntamientos situándola en el 90 por 100. El artículo 3 reduce los plazos de aprobación del planeamiento por los ayuntamientos y el artículo 4 , modifica la Ley de Bases de Régimen Local facilitando las aprobaciones de los instrumentos de planeamiento y de gestión urbanística. Finalmente decir que a los procedimientos ya iniciados antes de la entrada en vigor de este Real Decreto-Ley, según establece la disposición transitoria, no les será de aplicación el mismo, rigiéndose por la normativa anterior. Si bien, con la entrada en vigor de la Ley 6/ 1998 de 13 de abril, sobre régimen del suelo y valoraciones, como así queda expresado en la Disposición derogatoria única, queda derogado el Real Decreto Legislativo 1 / 1992, de 26 de junio, por el que se aprobó el texto refundido de la Ley sobre Régimen del Suelo y Ordenación Urbana, con 
refundido del 92 que ha quedado derogado prácticamente en su integridad por la Ley 6/ 1998 de 13 de abril, sobre régimen del suelo y valoraciones.

En diferentes párrafos de la exposición de motivos de la nueva Ley se exponen razones económicas justificativas de la necesidad de un cambio de orientación en la legislación urbanística (competencia como sabemos de las Comunidades autónomas). Estas razones económicas que ya estaban en la base de la Ley $7 /$ 1997, de 14 de abril, de medidas liberalizadoras en materia de suelo y de Colegios Profesionales, constituyen el fundamento de una nueva concepción de la propiedad urbanística.

La Ley de 1990 era decididamente intervencionista en las diferentes fases del proceso urbanístico. La Ley 6/1998 quiere, por el contrario, ser liberalizadora. Frente al intervencionismo se alza la necesidad de evitar la limitación de la oferta de suelo y la flexibilización de la actividad urbanística para que pueda adaptarse «una coyuntura económica cambiante, en la que los ciclos de expansión y recesión se suceden con extraordinaria rapidez»331.

Ya la Ley del Suelo del 56 modificó el concepto tradicional del dominio que recoge el art. 348 del Código Civil definiendo, en su art. 61, la propiedad como un derecho cuyas facultades se ejercerán « dentro de los límites y con el cumplimiento de los deberes establecidos en esta Ley, o en virtud de la misma, por los Planes de Ordenación, con arreglo a la

excepción de los siguientes preceptos: arts 104.3;113.2;124.1y124.3; $133 ; 134.1 ; 136.2 ; 137.5 ; 138 . b) ; 159.4 ; 168 ; 169 ; 170.1 ; 183 ; 204 ; 210 ; 211.3 ; 213 ; 214 ; 222 ; 224$ ;242.1

y242.6;243.1 y $243.2 ; 244.2,244.3,244.4 ; 245.1 ; 246.2 ; 255.2 ; 258.2 y 258.3 ; 259.3 ; 274 ; 276 ; 2$ $80.1 ; 287.2 y 287.3 ; 288.2 y 288.3 ; 289 ; 299 ; 300 ; 301 ; 302 ; 303 ; 304 ; 305 ; 306 ; 307 ; 308 ; 309 ; 310$; disposición adicional cuarta $1^{\circ}$ y $3^{\circ}$; disposición adicional sexta, y disposición transitoria quinta 1. Quedan asimismo derogados los artículos $1^{\circ}, 2^{\circ}, 3^{\circ}$, disposición transitoria y disposición final primera de la Ley $7 / 1997$, de 14 de abril, de Medidas Liberalizadoras en materia de Suelo y de Colegios Profesionales, derogación que queda justificada por la incorporación de sus normas en el nuevo texto legal, y se mantienen las medidas agilizadoras de la gestión urbanística que dan mayores competencias urbanísticas al Alcalde, como puede apreciarse en el texto que mantiene la vigencia del art. 4 y que se reproduce, como todo el derecho urbanístico estatal vigente en esta misma Ley.

331 Vid. apartado primero de la Exposición de Motivos de la Ley 6/ 1998, de 13 de abril, sobre régimen del suelo y valoraciones. 
clasificación urbanística de los predios « (asimismo queda plasmado en el art. 76 de la Ley del suelo de 9 de abril de 1976, en el artículo 8 del TR del 92, actualmente derogado y en el art. 2.1 de la nueva ley del suelo 6/1998). Es decir, que la función social necesita un medio de aplicación: las cargas, deberes, valoraciones, derechos y facultades, en su aspecto material, y las Leyes y Planes de Ordenación Urbana a que éstas se remiten en su aspecto formal, de lo contrario quedaría reducida a simple abstracción.

La propiedad urbanística dejó de ser un derecho absoluto sólo externamente limitado, y se convirtió en un derecho esencialmente limitado en su contenido. Sus límites y deberes establecidos por la Ley y por el Plan para garantizar su función social, pasan a ser los confines internos del derecho de propiedad. De esta forma en el régimen urbanístico de la propiedad, la posición del propietario de un solar afectado por el planeamiento urbanístico apenas puede identificarse con la suma de las facultades del art. 348 del C.c. El propietario del suelo ya no puede gozar y disponer de éste a su antojo sino que está vinculado al destino previsto en el plan e incluso en determinadas ocasiones tiene limitadas sus facultades de disposición (así por ejemplo en el ámbito de las parcelaciones y reparcelaciones). Tanto los límites como los deberes del derecho de propiedad, no representan una derogación del mismo, sino una delimitación ex-lege de su contenido, esto quedaba plasmado ya en el art. 70.1de la L.S del 56 al decir que la ordenación del uso de los terrenos y construcciones «no conferirá derecho a los propietarios a exigir indemnización, por implicar meras limitaciones y deberes que definen el contenido normal de la propiedad según su calificación urbanística».

Este principio general del derecho urbanístico reconocido en las Leyes del Suelo de 1956, 1976 y de 1992 queda ahora consagrado en el art. 2.2 de la nueva Ley del Suelo de 1998. Tal delimitación no indemnizable deriva de la configuración del derecho por la función social, y 
se complementa con el principio de distribución equitativa de los beneficios y cargas del planeamiento, que tienden a garantizar la igualdad entre los propietarios afectados, art. 5 de la Ley 6/ 1998 de 13 de abril.

Por tanto, la propiedad urbana continua siendo, en la Ley 6/ 1998, una creación del plan, y a partir del momento de la aprobación definitiva del Plan general se adquieren las facultades esenciales de este tipo de propiedad, así como los deberes que la misma comporta. Está claro que el ejercicio de las facultades de la propiedad urbana está condicionado al cumplimiento de una serie de requisitos objetivos, como la preexistencia de plan parcial y proyecto de urbanización para urbanizar, o que el suelo reúna las condiciones de solar para edificar. Pero esto no implica, como en la Ley 8/1990 y en el Texto refundido de 1992, que la propiedad urbana se escinda en una serie de derechos que se ganan o se pierden a lo largo del proceso urbanístico.

El contenido del derecho de propiedad inmobiliaria será en cada momento el que derive de la ordenación urbanística ${ }^{332}$, el cual, a diferencia de la propiedad común, es susceptible de modificación sin que ello de lugar, por lo general, a indemnización, salvo los supuestos que la Ley define (art. 2.2 de la LS de 1998)333.

332 En este sentido vid. sobre el carácter estatutario de la propiedad urbanística entre otros, MONTES, V. , La propiedad privada en el sistema del derecho civil contemporáneo, Madrid, 1980, p. 100 y ss. ; MARTIN MATEO, R. «El estatuto de la propiedad inmobiliaria», en R.A.P., no 52, 1967, p. 101 y ss. y 137 y ss.; MARTIN BLANCO, Derecho de propiedad ..., ob.cit., p.325-327; DIEZ PICAZO, L., «Problemas jurídicos del urbanismo», en R.A.P., no 43, 1964,p. 42 y ss; CARCELLER FERNANDEZ, A., Instituciones de derecho urbanístico, Madrid, 1984. p.97; LOPEZ PELLICER, J.A. Elaboración y gestión en el Planeamiento urbanístico, Madrid, 1983, p. 171-172; PAREJO ALFONSO, L., «La ordenación y la gestión urbanística: Un balance crítico», en Ciudad y Territorio, 1984.

333 En este sentido vid. la Sentencia de16 de noviembre de 1987 Ar. 9220 en cuyo f.j. n 5 establece: „Este carácter estatutario del derecho de propiedad inmobiliaria significa que su contenido será en cada momento el que derive de la ordenación urbanística, y siendo plenamente lícita la modificación del planeamiento, tal modificación no debe dar lugar, por regla general, a indemnización, dado que las facultades propias del dominio, en cuanto creación del ordenamiento, serán las concretadas en la ordenación urbanística vigente». En los mismos términos se pronuncia la STS de 27 de noviembre de 1987 Ar. 9325, en su f.j. $n^{\circ} 4$; la STS de 25 de noviembre de 1981 Ar. 5317, f.j. $n$ 3, señala: «nuestro Derecho Urbanístico...concibe las normas legales y de planificación como un auténtico estatuto jurídico de la propiedad inmobiliaria, que, excediendo del significado de simple cobertura habilitante de la intervención administrativa, define el contenido normal y condiciones de 
Este concepto estatutario de la propiedad urbanística basado en la idea de la función social y en el concepto de Plan, se caracteriza por configurar el dominio del suelo como un derecho planificado y como un derecho funcionalizado. Pero si bien es verdad que el Plan es el centro en torno al cual gira la propiedad urbanística conformando el derecho de propiedad, el contenido del derecho de propiedad urbanística está integrado por facultades de goce y disposición que son absolutamente independientes del Plan en cualquier clase de suelo, y el propietario conserva un ámbito de libertad que, por mínimo que quiera representarse, le es garantizado constitucionalmente ${ }^{334}$. Asimismo la funcionalización del derecho de propiedad del suelo ha de interpretarse en el sentido de que la satisfacción del interés reconocido al propietario debe producirse de tal modo que permita la realización del interés general, lo que quiere decir que la nueva concepción del derecho de propiedad radica en que esta institución no sólo está al servicio de los intereses del propietario (intereses individuales), sino también de otros intereses colectivos los cuales se satisfacen a través de la función social de la propiedad cuya tutela corresponde a la Administración pública. En el supuesto de que el propietario sólo persiga sus intereses individuales olvidándose de los colectivos, podrá ser compelido por la Administración a la satisfacción de la función social e incluso, podrá ser expropiado como sanción por incumplimiento de los deberes insitos en el derecho de propiedad 335

ejercicio de dicho derecho»; vid. también la STS de 12 de junio de 1985 Ar. 3217 f.j. oㅜ 2.

334 Vid. DE LOS MOZOS, Modificaciones del derecho de propiedad..., ob.cit., p. 18.

335 En este sentido, DIEZ PICAZO, en «Límites del derecho de propiedad en la legislación urbanística», RDU, 1971 , p. 26 , señala que " la propiedad no es otra cosa que una determinada manera de organizar la gestión y la explotación de los bienes económicos, porque el concepto de propiedad privada es una idea legal que encierra el reconocimiento de cierto modo de atribución a los individuos de facultades de gestión de los bienes y de explotación de los mismos con el fin de obtener de ellos su rentabilidad óptima y su mayor posible beneficio social». 
Las más importantes manifestaciones de la fuerza de la función social de la propiedad del suelo, en nuestro derecho urbanístico, incide de modo particular:

a) Clasificando el suelo, urbano, urbanizable y no urbanizable ( art. 7 de la Ley del 98) dándole al mismo una especial categoría y destino a cumplir, concediéndole aptitud para cumplirlo 336 .

b) Prohibiendo al propietario toda parcelación urbanística sin que previamente haya sido aprobado el planeamiento urbanístico exigible según la clase de suelo de que se trate (art.259.1 del T.R del 92 actualmente derogado y art. 96.1de la Ley del suelo del 76 que en la actualidad recobra vigencia).

c) Declarando indivisible las parcelas determinadas por el Plan como mínimas, al objeto de evitar la atomización de la propiedad y el minifundio consiguiente que impide darles el destino previsto (art. 258.1 a) del T.R del 92 actualmente derogado y art. 95.1.a) de la Ley del 76).

d) Imponiendo la edificación forzosa de los solares calificados como tal (art. 33 y 35 en relación con el art. 14 del T.R del 92) declarándolos en otro caso sujetos a enajenación forzosa 337 .

336 El fundamento jurídico 15 de la STC de 20 de marzo de 1997, ha reconocido la conformidad con la Constitución de la distinción, por norma estatal, de tres tipos de suelo (urbano, urbanizable y no urbanizable), a los efectos de definir un régimen jurídico propio de cada uno de ellos .En este sentido, LLISET BORRELL.F. en su obra El sistema urbanístico español..., ob.cit., p. 76, manifiesta que esta clasificación que recoge la nueva ley no sólo es idéntica a la de la legislación histórica, sino que sus categorías, vienen a ser una reproducción de las contenidas en la legislación precedente. En función del acercamiento a la vocación urbanística, considera, que cabe hacer las siguientes distinciones: a) suelo no urbanizable; b) suelo urbanizable no sectorializado; c) suelo urbanizable sectorializado; d) suelo urbano no consolidado y e) suelo urbano consolidado. El suelo no urbanizable y el suelo urbano consolidado son los dos polos que, en orden a la urbanización (prohibida y consumada, respectivamente), se comportan como propiedades inmobiliarias estáticas (fincas en cuyo dominio se destacan las facultades clásicas de usar, disfrutar y disponer más que los deberes propios de la función social). En medio de estos dos polos se localizan las otras tres categorías de la propiedad inmobiliaria dinámica. Estas categorías intermedias giran en torno de las cargas y deberes urbanísticos, cargas y deberes que han llevado a subrayar, en este tipo de propiedad, más los aspectos de la actividad urbanística que constituye su contenido ( solicitud de autorización para planificar, planificar, urbanizar, edificar), que los aspectos puramente dominicales según la concepción clásica de la propiedad.

337 Se trata con ello de evitar la retención de terrenos sin urbanizar ni edificar por parte de aquellos propietarios que persiguen una finalidad de especulación (Expo. Motiv. L.S del 56, III2.a), prueba de ello son las normas de edificación forzosa de solares contenidas en el 
e) Debiendo contribuir los propietarios a los gastos de la urbanización, en justa compensación a los beneficios que su ejecución habrá de reportarles; así como a la cesión de terrenos libres de gravámenes y costeamiento de obras del modo establecido en los Planes aprobados según Ley.

f) Haciendo de la expropiación, bajo su modalidad urbanística, el más frecuente sistema de actuación, sujetándola al sistema de valoraciones objetivas predeterminadas, y recuperando cuantas plusvalías pudieran derivarse de la aplicación del Plan (art.23 y ss. de la Ley de la LS de 1998) etc.

La propiedad urbana es obra del planeamiento ${ }^{338}$, el fundamento 7, «in fine» de la STC de 20 de marzo de 1997 dice literalmente que «en el campo urbanístico es la intervención del legislador estatal ex art. 149.1.1 C.E la que garantiza esa igualdad (»igualdad de todos los españoles») si se tiene en cuenta la inexcusable remisión al planeamiento y la disparidad de usos y contenidos susceptibles de apropiación que de aquí resulta».

No es que el planeamiento sea una exigencia constitucional pero sí que parece que el plan pueda ser considerado por el legislador estatal como un instrumento que, sin regularlo (la competencia para hacerlo corresponde al legislador autonómico) constituya un requisito imprescindible o el marco organizativo que posibilite el ejercicio mismo del derecho de propiedad 339 .

En este sentido, el legislador estatal establece las facultades urbanísticas del derecho de propiedad por remisión a las leyes, o, en virtud de ellas, al planeamiento (art. 2.1 de la Ley 6/ 1998) ${ }^{340}$.

Reglamento de Edificación Forzosa y Registro Municipal de Solares, R.D 635/1964 de 5 de marzo, así como los arts. 154 y 155 de la L.S..

338 Vid. LLISET BORRELL, F., El sistema urbanístico español después de la Ley 6/ 1998 de 13 de abril, Barcelona, 1998, p. 44.

339 Vid. Sentencia del TC 154/ 1988, en su fundamento jurídico 3.

${ }^{340}$ El papel de las Comunidades Autónomas en el complemento de las facultades urbanísticas es esencial, puesto que, aparte de poder completar la legislación básica, tienen competencia exclusiva sobre el planeamiento que es un instrumento fundamental 


\section{EL CONCEPTO DE PLAN Y SU INCIDENCIA EN EL DERECHO}

\section{DE PROPIEDAD .}

\subsection{SOBRE EL CONCEPTO DE PLAN.}

La Ley del Suelo considera al plan como la base necesaria y fundamental para ordenar el suelo; esta idea que aparecía ya plasmada en la Exposición de Motivos de la L.S. del 56, es compartida hoy de forma unánime por la doctrina ${ }^{341}$ y por la Jurisprudencia reiterada del Tribunal Supremo342.

De esta forma, el Plan aparece como «el eje en torno al cual gira la disciplina del urbanismo, como su elemento central y más característico, pues la Ley del Suelo confía a los Planes la tarea concreta de ordenar el territorio, coordinando la función pública del urbanismo con los derechos de los propietarios de los terrenos afectados. Es decir, por medio de los Planes la Administración pública desarrolla la parte más importante de las competencias que la Ley le atribuye en materia de ordenación urbanística, y

de la regulación de las facultades urbanísticas, en este sentido vid. la Ley 5/ 1999 de Urbanismo de Castilla-León, art.7; DL 1/ 1990 de Cataluña, arts. 113 y 129 y la Ley 10/ 1994 de Navarra. Art. 27.

341 Vid. entre otros CARRETERO PEREZ, «Naturaleza jurídica de los planes de Urbanismo», Conferencia inaugural del curso de la Sección de Práctica Jurídica del Colegio de Abogados de Valencia, octubre de 1969.Boletín del Colegio, no 80,p. 85; GARCIA DE ENTERRIA, Naturaleza jurídica de los Planes Urbanísticos, I.E. Admón. Local, Madrid,1966, p. 16; GARCIA TREVIJANO,J.A., Urbanismo y Suelo en el Derecho Español, p. 363;GONZALEZ BERENGUER, J.L., Teoría y Práctica del planeamiento urbanístico,_Escuela N. de Admón. Pública, 1969, p. 43; DIEZ PICAZO, L., "Problemas Jurídicos del Urbanismo», R.A.P., n43, 1964; GONZALEZ PEREZ, Comentarios a la L.S. I, p. 143 y ss., 508 y ss.; MARTIN BLANCO,J., "La penetración pública en la propiedad privada", R.A.P. 1972; SUSTAETA ELUSTIZA,A, Propiedad y Urbanismo, ob. cit. p.216 y ss..

342 En tales términos pueden verse las siguientes sentencias: St. de 17 de octubre de 1979 (Ar. 3891) y de diciembre de 1979 (Ar. 4173),que se refieren al plan como medio de articular el urbanismo y como instrumento definidor del contenido normal del derecho de propiedad. St. de 20 de septiembre de 1986 (Ar. 5279) que acepta un considerando de la apelada en el que se afirma resumiendo la postura del Tribunal, "que uno de los principios básicos establecidos por la antigua Ley del Suelo y Ordenación Urbana de 12 de mayo de 1956, plenamente aceptado y potenciado en la Ley de 2 de mayo de 1975 que modifica la anterior...es el de basar la actuación urbanística en la planificación». 
determina el conjunto de posibilidades de actuación que corresponden a los propietarios del suelo» 343 .

Definir el Plan, supone un análisis previo de su naturaleza así como de los elementos que lo componen, por esta razón nos parece conveniente hacer ciertas precisiones que nos permitan abordar de forma mas completa la incidencia del planeamiento urbanístico en la configuración del contenido normal del derecho de propiedad del suelo.

Para García de Enterría ${ }^{344}$, el plan tiene una doble incidencia sobre el administrado, bien al considerar al mismo, como totalidad en comunidad, o bien al considerarle como titular de parcelas ordenadas por él. Califica a los planes a modo de «tertius genus» entre norma y acto, dado que contienen reglas que se agotan en un periodo de tiempo determinado.

García Trevijano ${ }^{345}$ los considera como actos administrativos generales, no normativos, distinguiéndolos de los reglamentos, en cuanto que: «no necesitan habilitación legal; no tienen efecto erga omnes; ausencia de vacatio para su efectividad, necesaria siempre en los reglamentos, y en cuanto que los actos generales no pueden derogar a los reglamentos, dado que los ejecutan y son impugnables sólo directamente mediante recurso de reposición». Criterio al que se une González Berenguer ${ }^{346}$ al señalar que los planes de urbanismo no son actos-norma, y no son actos administrativos corrientes, en razón a su eliminación del mundo del Derecho y que no se notifican individualmente.

343 Vid. LOBATO GOMEZ, M., Propiedad privada del suelo y derecho a edificar, Madrid, 1989, p. 481.

344 Vid. GARCIA DE ENTERRIA, Naturaleza jurídica de los planes urbanísticos, Ciclo de conferencias sobre Urbanismo en el I.E Admón. Local, Madrid, 1966, p.85.

345 Vid. GARCIA TREVIJANO, J.A., Urbanismo y suelo en el derecho español, p. 363.

346 Vid. GONZALEZ BERENGUER, J.L., Teoría y práctica del planeamiento urbanístico, Escuela N. de Administración Pública, 1969, p.43. 
La tesis normativa es defendida por Diez Picazo ${ }^{347}$ al afirmar que «tiene un valor normativo inmediato y directo», deduciendo ello de los efectos de los mismos de carácter general y vinculante; son ejecutivos, su aprobación implica la declaración de utilidad pública así como la autorización para la ocupación de los terrenos a que afecta y exige como requisito sustancial la «publicidad».

La Jurisprudencia de nuestro Tribunal Supremo se pronuncia en esta materia en la sentencia de 8 de mayo de 1968 al decir que desde un punto de vista jurídico-administrativo, un Plan de Ordenación Urbana aprobado definitivamente merece la calificación de »acto administrativo general» productor de normas jurídicas objetivas, calificación que viene ratificada por la L.S. al conceder en su art. 223, acción popular para exigir ante los Tribunales Contencioso-administrativo la observancia de las disposiciones de esa Ley y de los planes de ordenación urbana y por ende autoriza la posibilidad de que aun faltando en su día la impugnación de los planes parciales, no obsta, para que se haga de los actos que se hayan producido en etapa de ejecución de aquél, de no ser conformes a derecho, y esto a tenor de lo dispuesto en el Núm. 2 del artículo 39 de la Ley de 27 de diciembre de 1956». De esta sentencia se desprende que la naturaleza de los planes de urbanismo resulta compleja e integrada por elementos normativos incorporados a un acto administrativo.

El propio Tribunal ha calificado a los Planes de disposiciones generales en otras sentencias.

Parece, por tanto, que no es nada convincente la postura de aquellos que definen el Plan como si se tratase de una norma; el argumento para distinguir una norma de una resolución administrativa suele ser que la norma se incorpora o integra en el ordenamiento jurídico, mientras que la resolución o acto administrativo no se integra sino que se 
agota con su cumplimiento. La norma se repite multitud de veces, en caso indefinido de supuestos, por ejemplo cualquier precepto del Código Civil; mientras que la resolución administrativa, el negocio jurídico, se agota en sí mismo. Esta es la doctrina dominante, que no es más que una variación de la clásica distinción norma=mandato abstracto y general, resolución=mandato concreto y singular ${ }^{348}$.

Aplicando esto al planeamiento urbanístico, habría que concluir que si hay un acto jurídico que se agota en sí mismo es el planeamiento; el plan regula de una vez por todas y con detalle la clase y el uso de cada predio, y esto no se vuelve a repetir más.

La doctrina dominante 349 mantiene que el Plan es una norma, pero con una argumentación defectuosa, una norma concreta-espacial que se agota con su cumplimiento, aunque ese agotamiento no le quita su cualidad de regla o norma, como lo prueba la existencia de normas o reglas singulares o concretas.

Este sector de la doctrina, al mantener que el plan es una norma porque se integra en el ordenamiento jurídico, está diciendo exactamente lo contrario de lo que resulta de los hechos, toda vez que el plan no se integra, sino que se agota con su cumplimiento y, por lo tanto, siguiendo su tesis se llega a la conclusión de que se trataría de una resolución y no de una norma.

En este contexto, una de las afirmaciones típicas que suele hacerse, como una consecuencia más del plan, es que sólo él genera o

348 Sobre esta cuestión vid., GALLEGO ANABITARTE, Plan y Presupuesto como problema jurídico en España. En torno al concepto de norma jurídica. Homenaje a Federico de Castro, 1979, pp.341 a 407.

349 Vid. GARCIA DE ENTERRIA, La ley del suelo y los principios del urbanismo, A.D.C, 1958, p.488. En el mismo sentido DE LOS MOZOS, El urbanismo desde la perspectiva del derecho privado, R.D.P.,1951, p. 206; REGUERA SEVILLA, La legislación urbanística y sus repercusiones en el Derecho Civil, Estudios de Derecho Privado. Edic. R.D.P., Madrid, 1962, p. 128; MARTIN BLANCO,J., Legislación urbanística y derecho privado, R.D.P., 1962, p. 16 y ss; CARCELLER FERNADEZ, A. Instituciones..., ob.cit.,p. 98 y ss. ; GARCIA DE ENTERRIA Y PAREJO, Lecciones ..., ob.cit., p.165 y ss. ; GONZALEZ PEREZ, Comentarios, I, p. 145 y ss. ; NUÑEZ RUIZ, Derecho urbanístico..., ob. cit., p. 175 y ss. 
crea las plusvalías al clasificar determinado terreno como urbanizable. Pero frente a este argumento puede afirmarse que la plusvalía se genera también, y de forma muy notable, sobre todo en los últimos años, en el mercado y la sociedad. Es cierto que el plan produce un efecto generador de plusvalías la mayoría de las veces al ser lo normal que el suelo afecto adquiera mayor valor; pero no es menos cierto que, incluso, y sin control posible alguno, el mercado y la sociedad marcan el precio de las cosas, con una gran diferencia entre el valor de adquisición y el valor de venta, que es, en definitiva, generar la plusvalía. Otra cosa es, que por ello, se genere el efecto especulación, que es distinto de la plusvalía derivada del planeamiento, sujeta a control, dada la intervención pública.

La importancia del Plan, en el contexto del ordenamiento urbanístico, a efectos del tema central de este trabajo es decisiva, ya que constituye la clave de todo el sistema de límites, limitaciones y deberes que el derecho urbanístico concreta al definir el contenido de los derechos de propiedad privada sobre el suelo afectado, y permite establecer los distintos regímenes urbanísticos del suelo conforme a la Ley del Suelo.

\subsection{INCIDENCIAS DEL PLAN EN EL DERECHO DE PROPIEDAD.}

Con la aparición de la Ley del Suelo en nuestro ordenamiento jurídico se opera una modificación muy sustancial del régimen jurídico de la propiedad del suelo. La nueva legislación urbanística inspirada en la concepción del urbanismo como una función pública, atribuida a la Administración 350 y articulada en torno a un nuevo instrumento de

350 Afirmación defendida por amplio sector de la doctrina y de la jurisprudencia. En el ámbito doctrinal vid. entre otros, ESCRIBANO COLLADO, La propiedad privada urbana..., cit. , p. 143 y ss.; FERNANDEZ RODRIGUEZ, Manual..., cit., p. 23 y 24; LLISET BORRELL, F., La actividad urbanística de los particulares, Madrid, 1975, p. 93 y ss.; MARTIN BLANCO, Derecho de propiedad...,cit., p. 40 y ss. ; TORRES LANA, La configuración jurídica del volumen de 
ordenación como es el planeamiento, introduce un cambio en la configuración jurídica del derecho de propiedad inmobiliaria que afecta al ius aedificandi. Ha significado trasladar a una decisión pública aquello que el propio artículo 350 del Código Civil reconocía al propietario.

Por ello se puede decir que la función pública del urbanismo ha hecho suyo el poder que tenía el propietario de fijar líbremente la utilidad y aprovechamiento de sus bienes, lo cual viene a significar, según opinan determinados autores ${ }^{351}$, no una pérdida absoluta de sus facultades, sino un reparto de las mismas entre el propietario y el ente público, de ahí que ni el propietario es libre de convertir suelo rústico en suelo urbano invocando las facultades que le corresponden como dueño de ese suelo, pues dicha conversión queda estrictamente reservada al Plan, ni la Administración pública puede hacerlo invocando el carácter de función pública del urbanismo en contra de lo dispuesto en un Plan de superior rango o de las normas materiales de la Ley del Suelo 352.

Esta calificación del urbanismo como función pública aparece plasmada de manera expresa en los primeros artículos de la Ley del Suelo del 92. Así, el art.1 define como objeto de la Ley «el establecimiento del

edificabilidad, ${ }_{2}$ Pamplona , 1975, p. 89 y ss.; GARCIA DE ENTERRIA, La Ley del Suelo..., cit., p. 492, IDEM Actuación pública y actuación privada..., cit.,p. 85; ENTERRIA Y PAREJO, Lecciones..., p. 97 y ss.; CARCELLER FERNANDEZ, Instituciones..., cit., p. 48; DE LOS MOZOS, El urbanismo desde la perspectiva del derecho privado,R.D.P., 1951, p. 209; LOBATO GOMEZ, Propiedad privada..., ob.cit.p.241 y ss. En el ámbito jurisprudencial pueden verse a título ejemplificativo entre otras las siguientes sentencias : St. de 1 de julio de 1964 (Ar. 3558); St. de 5 de diciembre de1964 (Ar. 5560); St. de 2 de mayo de 1973 (Ar. 2075); St. de17 de octubre de 1979 (Ar. 3891); St. de 4 de diciembre de1984 (Ar. 6520) y de 9 de febrero de 1985 (Ar.1007); St. TS de 14 de abril de 1992, RJ. 1992/ 3429 ; St. TS de 15 de abril de 1992 , RJ. 1992/ 4045.

351 Vid. LOBATO GOMEZ, Propiedad privada..., ob.cit., p. 476 y ss.; GARCIA DE ENTERRIA, Actuación pública..., ob. cit., p. 85; GONZALEZ PEREZ, Comentarios..., I, cit. ,p. 126; ESCRIBANO COLLADO, La propiedad privada urbana..., ob.cit., p. 139 entre otros.

352 En este sentido pueden verse las siguientes sentencias: St. de 22 de junio de 1986 (Ar. 5546); St. de 11 de septiembre de 1986 (Ar. 5962); St. de26de septiembre de1986 (Ar. 5990), donde se afirma que la clasificación de un terreno como suelo urbano «constituye un imperativo legal que no queda al arbitrio del planificador, sino que debe ser definido en función de la realidad de los hechos», añadiendo que «la definición con rango legal del suelo urbano constituye un límite a la potestad de planeamiento, tanto cuando ésta actúa ex novo como cuando opera por vía de revisión o modificación». 
régimen urbanístico de la propiedad del suelo y regular la actividad administrativa en materia de urbanismo» 353; incluye dentro de la actividad urbanística cuatro aspectos distintos: planeamiento urbanístico, ejecución del planeamiento, intervención del ejercicio de las facultades dominicales relativas al uso del suelo y edificación e intervención en la regulación del mercado del suelo (art. 2 y 3 ) concreta el contenido de la competencia urbanística en orden a cada uno de estos aspectos, en una larga lista de facultades que tendrá un carácter enunciativo y no limitativo, pues según establece el art. 3. 6 del TR del 92 »la competencia urbanística comprenderá cuantas otras fueren congruentes con la misma para ser ejercidas con arreglo a la presente ley», dejando así definidas las líneas maestras del «contenido concreto del urbanismo como función pública en nuestro derecho»354.

De otro lado, no está exento de polémica lo concerniente a la verdadera naturaleza del derecho a edificar y sobre su conexión al Plan, planteándose serias dudas por la doctrina sobre estos particulares. Al hilo de ello, se han suscitado dos planteamientos encontrados. Por una parte, surgen opiniones que siguen sosteniendo que el derecho a edificar, como contenido esencial de la propiedad privada, subsiste preexistiendo al Plan, es anterior a cualquier ordenación urbanística y por otro, se va a mantener

${ }^{353}$ En la nueva ley del suelo del 98 , a diferencia de la anterior, ya no se regula, como partes integrantes de la misma materia urbanística el régimen de la propiedad del suelo y la actividad administrativa en materia de urbanismo. Esta última se deja de lado por exigencias constitucionales y, en relación al régimen del suelo, el legislador estatal trata de no invadir la competencia autonómica sobre el régimen de la propiedad, dado que el Estado sólo tiene competencia sobre las condiciones básicas que tiendan a garantizar la igualdad de todos los españoles en el ejercicio del derecho de propiedad urbana. Dentro de las condiciones básicas que tiendan a garantizar la igualdad en el ejercicio del derecho de propiedad cabe situar, tal como ha declarado la STC de 20 de marzo de 1997, no sólo las facultades básicas del derecho de propiedad, sino también los deberes básicos de este derecho, si bien unas y otros podrán también ser objeto de regulación por el legislador autonómico. Por tanto no se trata de una relación entre bases estatales y desarrollo autonómico, sino que cada poder público operará su competencia exclusiva sobre su respectivo ámbito así, condiciones básicas que tiendan a garantizar la igualdad en el ejercicio del derecho de propiedad, el Estado, y regulación de los aspectos no básicos, la Comunidad autónoma.

354 Vid. GARCIA DE ENTERRIA- PAREJO, Lecciones..., ob. cit., p.98. 
que las posibilidades de edificación derivan de los planes. Se trata en definitiva de decidir si el derecho a edificar es una facultad inherente al dominio, necesitando a lo sumo un acto declarativo del poder público para poder ser ejercitado ${ }^{355}$, o si, por el contrario, se trata de una forma de aprovechamiento del suelo de la cual el propietario está privado, y que adquiere de la colectividad a través de un acto constitutivo de carácter administrativo.

La primera tesis, es decir, la de aquéllos que sostienen que el derecho de edificar, como contenido esencial de la propiedad privada, preexiste al plan al ser anterior a cualquier ordenación urbanística, encuentra su máximo exponente en la «ratio legis» del artículo 350 del Código Civil. El derecho del propietario a edificar sobre su terreno no es un

355 Esta postura era seguida con diversos y variados matices, por MARTIN BLANCO, J., EI tráfico de bienes inmuebles en la Ley del Suelo, Madrid, 1964, pp. 67 y ss., quien tras plantear el problema con total precisión, se inclinaba a considerar el derecho a edificar 0 facultas aedificandi como una facultad inherente a la propiedad inmobiliaria, pues «la licencia o permiso de construcción tiene un valor meramente declarativo y no es el Estado quien confiere al propietario el derecho a construir». Deja claro sin embargo, este autor, que esta inherencia no quiere decir que la facultas aedificandi puede ser ejercida sin más, porque, al contrario, su ejercicio se somete al cumplimiento de determinadas condiciones; por CHICO ORTIZ, en «El derecho de propiedad ante la nueva legislación urbanística» en R.D.U, no 33 p. 110 quien afirma que el propietario tiene siempre derecho a edificar, aunque su derecho se condicione a que el Plan califique su terreno de edificable y a que se cumplan las cargas y obligaciones impuestas por la legislación urbanística; por TORRES LANA en La configuración jurídica del volumen de edificabilidad, Pamplona, 1975 p. 140 y ss. En el mismo sentido se manifiesta SANCHO REBULLIDA, que en el prólogo de esta obra, p. 21, señala, respecto al ius aedificandi, que «no es una concesión administrativa al propietario, sino una parcial limitación legal de una facultad preexistente en el derecho de propiedad privada»; LOBATO GOMEZ, J.M, La propiedad privada del suelo y derecho a edificar, Madrid , 1989, p. 547; así mismo queda reflejado en «La disgregación de la propiedad inmobiliaria», ponencia sobre El sistema Económico en la Constitución Española p.725; o por SUSTAETA en su obra Propiedad y Urbanismo cit., pp. 342 y ss. que sigue considerando al derecho a edificar como elemento esencial de la propiedad del suelo, sin perjuicio de que tal derecho a edificar sea susceptible de mayores o menores limitaciones en orden a su ejercicio. En esta misma línea se encuentran, VALLET, J., Especulación del suelo, plusvalías urbanas y planificación territorial», Estudios sobre Derecho de cosas, Madrid, 1985 ( $2^{\mathrm{a}}$ ed. cumplida), T. I, pp. 386388; GONZALEZ PEREZ, Comentarios, I, cit., p. 637 rechaza la posibilidad de que sea el Plan quien otorgue al propietario las posibilidades edificatorias sobre el terreno objeto de su derecho y en su obra Informe sobre el Proyecto de Ley de Reforma del Régimen Urbanístico y Valoraciones del Suelo, Madrid, 1989, p. 43 y ss. mantiene que el ius aedificandi es inherente al dominio, y que la Ley incurre en inconstitucionalidad por vulnerar la garantía del contenido esencia del derecho de propiedad. 
derecho de configuración moderna, por cuanto ya aparecía expresamente regulado en la legislación de Partidas 356.

La libertad del dueño del suelo, en orden a la edificación, es el principio general y el punto de partida sobre el que se establece la disciplina del «ius aedificandi» en nuestra tradición jurídica, que va a quedar expresado en el brocardo «potest quis in suo ad libitum aedificare». Al lado de esta afirmación, de la libertad del dueño, surgen límites de diversa naturaleza357, que según la tradición del lus commune se van a articular como excepción al derecho que se afirma. Estos límites terminarán por consolidarse en torno a la competencia municipal ${ }^{358}$, hasta englobarse más tarde en un único instrumento normativo a través de las ordenanzas o estatutos municipales 359 , que van a producir lo que bien puede

356 Cfr. P. III, T. XXXII, L. 25a: «... Otrosí decimos que casa, o torre queriendo fazer de nuevo en lo suyo puedelo fazer dexando tanto espacio de tierra: fazie la carrera, cuanto acostumbraran los otros sus vecinos de aquel logar, o puedela alçar quanto quisiere guardandose todavia que no descubra mucho las casas de sus vecinos». Cfr. además la glosa a la Ley XXV de GREGORIO LOPEZ, "Quilibet in suo potest domun vel turrim aedificare, quantum voluerit extollere: dummodo vicini domum nimis son detegat», así como la glosa mucho, en la que se hace derivar la «libertas tollendi quantum vellet» del principio «quia solum est liberum usque ad coelum I. altius».

357 Así, nos encontramos con la prohibición de edificar siempre y cuando con ello «se descubra mucho la casa de los vecinos"; con el reconocimiento de la llamada servidumbre altius non tollendi a favor de las fincas de otros propietarios vecinos; con las limitaciones derivadas del statum vel consuetudo; Vid. en este sentido, DORAL, J.A., «Interés público y privado en la servitus altius non tollendi», R.D.P., 1968, p. 929; ESCRIBANO, La propiedad privada urbana, ${ }_{2}$ cit., pp. 39-40; CARRASCO PERERA, A., "lus aedificandi» y Accesión (La construcción en suelo ajeno en el marco de los principios urbanísticos) Madrid, 1986, pp. 34 y ss. y 41. También P. III, T. XXXII, L. $3^{\text {a }}$, titulada Como cada un ome puede vedar que non fagan casa ni edificio en las plaças nin en los exidos de la villa; LOPEZ GONZALEZ, I., Las licencias municipales de edificación y las técnicas de intervención administrativa en la propiedad privada, Sevilla, 1977, pp. 16 y ss.

358 En el artículo 32 de la Ordenanza de Intendentes y Corregidores de 1749 (Noviss. Recop., L. 2, T. XXXII, L. VII) se dispone como competencia de «las Justicias de las ciudades, villas y pueblos, se esmeren en su limpieza, ornato, igualdad y empedramiento de las calles y que no permitan desproporción ni desigualdad en las fábricas que se hicieren de nuevo y muy particularmente atenderán a que no se deforme el aspecto público, con especialidad en las ciudades y villas populosas».

359 El sentido de este profundo cambio se explica porque hasta la Ley de 1.956, el urbanismo no rebasa el ámbito municipal y se agota prácticamente en la obra urbanizadora de los espacios públicos (calles, plazas, etc.) y en la regulación de los aspectos estéticos e higiénico-sanitarios de la edificación. 
denominarse la «publificación de los límites de edificabilidad» ${ }^{360}$, con una regulación jurídica cada vez más especializada en esta materia, hasta llegar a nuestros días en que, ciertamente, se ha producido una evolución del fenómeno del urbanismo sobre el concepto absolutista de la propiedad.

En este orden de cosas, el artículo 350 del Código civil vigente, reproduciendo en sus términos el artículo 352 del Proyecto de Libro II del Código Civil de 1882, dispone que «el propietario de un terreno es dueño de su superficie y de lo que está debajo de ella, y puede hacer en él las obras, plantaciones y excavaciones que le convengan, salvas las servidumbres, y con sujeción a lo dispuesto en las leyes sobre Minas y Aguas y en los reglamentos de policía».

Efectivamente, la generalizada opinión de que el derecho a edificar es un derecho atribuido al propietario de un terreno se manifiesta mediante la afirmación de que «el dueño de bienes inmuebles, en fuerza de su dominio puede, por regla general, hacer con ellos lo que estime conveniente, y por lo tanto profundizarlos con plantaciones o elevar edificios sobre el suelo»361, pero se matiza al admitir que la Ley o las ordenanzas locales por razón de interés público o en beneficio de los vecinos, impongan límites o restricciones a este derecho, que pueden consistir o no en servidumbre 362 .

360 Cfr. CARRASCO PERERA, «lus aedificandi», cit., p. 37; LOPEZ GONZALEZ, Las licencias municipales, cit., pp. 16 y ss.

361 Cfr. GOMEZ DE LA SERNA y MONTALBAN, Elementos de Derecho Civil y Penal de España, $11^{\text {a }}$ ed., 1874, I, pp. 493.

362 Vid. en este sentido GOMEZ DE LA SERNA y MONTALBAN, ob. cit., pp. 526, 574 y ss. También AZCARATE, Ensayo sobre la historia de la propiedad, cit., T. III, pp. 48-49, diferenciando previamente «servidumbres» $y$ «limitaciones»; DOMINGO DE MORATO, D.R., El derecho Civil Español, I, Madrid, 1877 (2 $2^{\mathrm{a}}$. ed.) 
En este punto confluye la jurisprudencia del Tribunal Supremo que mantiene una línea muy similar pues, en la Sentencia de 6 de marzo de 1875, afirma que «la L. 25, tit. 32, p. 3, establece en favor del dueño de un solar el derecho a edificar a la altura que tenga por conveniente, con tal que no descubra mucho las casas de sus vecinos», y añade que "este derecho inherente al dominio sólo puede ser limitado por una servidumbre establecida sobre dicho solar con arreglo a las disposiciones legales, o por ordenanzas municipales que regulen la materia»363.

Por ello los intérpretes del Código vieron en este precepto, más que la definición de un principio general acerca de la extensión del dominio, las excepciones o restricciones a las que el ejercicio del derecho del propietario de un fundo debía someterse ${ }^{364}$, y así, la relativización de los pretendidos poderes absolutos del propietario sobre los bienes inmuebles se manifiesta en el intento de lograr un equilibrio necesario entre los poderes del propietario, los intereses de terceros y el interés público, en el ejercicio y desarrollo del ius aedificandi.

Es decir, el artículo 350 no sólo establece que el propietario puede edificar y las normas a las que ha de adecuar su actuación, sino que sólo él

363 Cfr. Sentencia de 26 de diciembre de 1874 . En el mismo sentido se manifiesta nuestro más alto Tribunal en Sentencia de 6 de marzo de 1875, que en uno de sus considerandos sienta las siguientes afirmaciones: «El derecho inherente al dominio que la Ley 25 , Tit. 32 , P. $3^{\mathrm{a}}$, concede al dueño para edificar a la altura que crea conveniente, con tal que no descubra mucho la casa del vecino, si bien está modificado por las Ordenanzas de los pueblos... debe ser respetado como un atributo de la propiedad»".

364 Vid. MANRESA, Comentarios, III, cit., p. 236, que aunque «parece a primera vista que este artículo viene a reafirmar más y más el derecho de propiedad», «lo que al fin hace es establecer límites a la propiedad de la tierra, pues si determina la extensión de la misma fija también los respetos que el propietario de un terreno ha de tener en cuenta y las limitaciones con que se puede usar de la superficie, de lo que está debajo y de lo que puede hacer encima de ella». En términos parecidos se manifiestan CHARRIN, A., «Extensión del derecho de propiedad», RGLJ, 1916, no 128 p. 276; SCAEVOLA, Derecho civil, VI, cit., pp. 498-499; SANCHEZ ROMAN, Estudios de Derecho civil, III, cit., p. 138; HERNANDEZ GIL, A., Dictámenes, Madrid, 1968, T. I. No está de acuerdo con esta apreciación generalizada CARRASCO, «lus aedificand»», cit., p. 43, que dice refiriéndose al artículo 350: «Este artículo no sólo, ni principalmente, contiene limitaciones al derecho que proclama. Tiene, sobre todo, un contenido «negativo». Dice cuáles son los únicos límites admisibles. Por tanto, es pecar de historicidad entender que este artículo es simplemente una limitación a la norma de alcance general del artículo 348». 
está, en principio, facultado para ello. Cumple así una función selectiva en el ámbito de la legitimación en el uso de una cosa y actúa como una técnica de defensa de la exclusividad del ius aedificandi365. Este precepto recoge un principio sobre el cual se organiza el régimen de la propiedad inmobiliaria en el sistema del Derecho codificado: el ius aedificandi es inherente a la propiedad del suelo.

Esta idea de que el propietario del suelo tiene, en principio, derecho a edificar en el mismo, al amparo de lo dispuesto en los artículos 348 y 350 del Código Civil, va a mantenerse sin fisuras en la doctrina y en la Jurisprudencia hasta la promulgación de la Ley del Suelo de 12 de mayo de 1956, reiterando que «el derecho del particular en estos casos no puede tener más limitaciones que las de orden legal, o sea, las que establezcan Leyes, Reglamentos y Ordenanzas que al presente rijan» 366.

En línea con la postura que acabamos de exponer de la jurisprudencia del Tribunal Supremo, pueden extraerse conclusiones similares, así, la Sentencia de 18 de enero de 1973 (R.350), que afirma en uno de sus considerandos que la facultad de edificar "dimana en principio del uso del derecho de propiedad de acuerdo con el artículo 348 del Código Civil y constituye la norma general «aunque» por necesidad y fortuna este derecho de propiedad no es absoluto, tiene limitaciones de carácter moral o social impuestas por el bien común...como sucede en materia urbanística» 367. La misma idea está presente en sucesivos

365 En este sentido se manifiesta CARRASCO PERERA, «lus aedificandi», cit., pp. 376 y ss., señalando que el artículo 350 y la regla «superficies solo cedit» cumplen idénticas funciones dentro del sistema: «consagran una atribución monopolística del «ius aedificandi» al propietario del terreno»; "cumplen conjuntamente una función de atribución exclusiva de la plusvalía de edificabilidad» y «desempeñan una función de justificación mutua».

366 Cfr. Sentencia de 5 de febrero de 1954 (R. 464).

367 Vid. S.T.S de 18 de enero de 1973 (R. 350) ; St. de 5 de mayo de 1965 (R. 2776 )y de30 de junio de 1975 (R. 3719), en las que se puede leer que " la facultad de edificar es inherente al derecho del dominio"; St. de 3 de noviembre de 1973 (R. 4322) ; St. de 6 de diciembre de 1980 (R. 4988)en la que se afirma «entre las facultades insitas en el derecho de propiedad, arts. 348 y350 del Código Civil se encuentra el ius aedificandi, principio que sufre 
pronunciamientos; así, la Sentencia de 21 de diciembre de 1974 que señala que «si, en efecto, el derecho a edificar en terreno propio constituye una de las facultades singulares del derecho de propiedad, de acuerdo con lo dispuesto en el art. 348 del Código Civil, y en las Leyes Fundamentales que reconocen el derecho a la propiedad privada «como un derecho condicionado a la función social», y en la Ley del Suelo que se ha inspirado en «este sentido social y funcional de la propiedad» se subordina al derecho de propiedad y a sus facultades en concreto, al servicio del bien común o de los intereses generales de utilidad pública, contándose entre ellas la de edificar»368; la Sentencia de 6 de julio de 1976, sienta que «sólo está legitimado para solicitar la licencia de edificación quien ostenta el ius aedificandi»369; mientras que para la Sentencia de 19 de enero de 1979 «la facultad que a todo propietario de terreno corresponde para realizar obras y edificaciones «ius aedificandi» no es más que una manifestación del genérico derecho de disposición (ius disponendi) propio del dominio, como derecho de gozar y disponer de una cosa, sin más limitaciones que las establecidas en las leyes (art. 348 C.c) y reglamentos de policía (art. 350 C.c), de lo que se deduce que la intervención administrativa en tal actividad, por razón urbanística, para velar por el cumplimiento de los planes de ordenación o en el ejercicio de las funciones propias de la policía de construcción, además de tener que ser congruentes con los motivos y fines que la justifiquen y con las restricciones estrictamente indispensables,

numerosas limitaciones, entre ellas las impuestas por las normas urbanísticas» ;St. de 13 de octubre de 1981 (R. 4148); St. de 9 de mayo de 1983 (R. 2920); St. de 15 de diciembre de 1983 (R. 6796) y St. de 24 de abril de 1984 (R. 2006) que consideran al «ius aedificandi» como «una manifestación de las facultades dominicales»; como «un genuino derecho de todo administrado»; como "un derecho preexistente» en el patrimonio del propietario del suelo; como un derecho que corresponde «a todo dueño de un solar»; la St. de 4 de octubre de 1982 (R. 6327) reconoce en suelo no urbanizable posibilidades de edificación; la St. de 19 de julio de 1984 (R. 4246) reconoce que, en caso de privación de este derecho al dueño de un solar, debe proceder indemnización ; la St. 23 de mayo de 1985 (R. 4121) indirectamente sostiene, que la facultad de cercar, que es por otra parte una manifestación de una genérica facultas edificandi del propietario, es inherente al dominio conforme a los art. 348 y 388 del Código Civil.

368 Vid. S.T.S. de 21 de diciembre de 1974 (5009).

369 Vid. S.T.S. de 6 de julio de 1976 (R. 4526). 
tiene siempre un carácter subordinado al expresado fundamental derecho de disposición, que es siempre la regla, mientras que la intervención o restricción administrativa es la excepción» ${ }^{370}$. Pero quizá sea la Sentencia de 21 de febrero de $1981^{371}$, la que más nítidamente recoge esta postura, intentando hacer compatible el «ius aedificandi» como contenido del dominio, con la configuración jurídica que del mismo hace la Ley del Suelo. Esta sentencia, en sus considerandos, sienta que «no se debe perder de vista que por mucho que se enfatice sobre la mutación sufrida por el derecho de propiedad en materia urbanística, hasta convertirse en un derecho de los llamados «estatutarios», su declinación en sus momentos de mayor esplendor, en los que le estaba permitido en su ejercicio, hasta el «ius abutendi», no puede llegar al extremo de reducirlo a un derecho inerme, totalmente sometido a cuantas prohibiciones y limitaciones tengan a bien adoptar las distintas autoridades administrativas, por rectas que sean sus intenciones; y no duden llegar a estos extremos porque la propiedad del particular sigue siendo algo más que una simple función social, puesto que conserva su núcleo primario de derecho subjetivo, uno de los principales de los que integran la constelación de los derechos de la personalidad, amparado en la cobertura legal que le proporciona el Código Civil (art. 348 - 349 y 350) y la propia Constitución española (art. 33) que, como consecuencia de lo dicho «al propietario no se le puede negar, en principio, el ejercicio del ius aedificandi, en cuanto constituye una de las facultades más genuinas de su derecho dominical; si bien, el moderno derecho urbanístico ha impuesto, sin desconocer tal derecho básico de la persona, una racionalización del uso y aprovechamiento del suelo, en función de las necesidades e intereses superiores de la colectividad; racionalización que parte de unas directrices e ideas básicas; contenidas en la Ley sobre Régimen del Suelo y Ordenación Urbana y que se 
completa, con todo un sistema de planificación, de desarrollo escalonado; sistema que tiene su remate en la fase de ejecución, con los controles preventivos que proporciona la técnica de la licencia urbanística; que la licencia, como acto de control preventivo, no es constitutiva, sino meramente declarativa de un derecho preexistente del administrado, ya atribuido por el ordenamiento urbanístico y por el derecho civil, la licencia no transfiere facultades, sino remociona límites, por lo que en su otorgamiento o denegación se ha de actuar dentro de la más estricta legalidad» 372 .

Incluso el propio Tribunal Constitucional, en su sentencia de 4 de julio de 1991, parece inclinarse por considerar el derecho a edificar inherente al dominio, al decir que « corresponde a los planes urbanísticos de acuerdo con la Ley delimitar el contenido del ius aedificandi que corresponde al propietario».

La segunda tesis, que defiende que las posibilidades de edificación derivan de los planes, encuentra su máximo exponente en García de Enterría. Según este autor, el paso fundamental dado por la Ley consiste «en privar a la propiedad de todas las expectativas ${ }^{373}$ urbanísticas y considerar éstas como derivadas directamente del Plan público, en lugar de entender que el plan debía reducirse a limitar las expectativas urbanísticas que sustancialmente emanasen de la propiedad misma» 374 .

372 El T.R.de la Ley del Suelo de 1992 , sin embargo, abandona este carácter de la licencia y le atribuye carácter constitutivo, en su artículo 33 dispone que «el otorgamiento de licencia determinará la adquisición del derecho a edificar», además el artículo 35 establece la extinción del derecho a edificar por incumplimiento de los plazos fijados en la misma, por otro lado el artículo 20.1.d. incluye la solicitud de licencia de edificación entre los deberes urbanísticos, y, los artículos 34 y 30.1 y 31.2 sancionan con la reducción del aprovechamiento urbanístico al propietario que no la solicita.

373 En relación con el tema de las expectativas el TC ha entendido que no forman parte del contenido del derecho, lo que viene a significar que no son susceptibles de indemnización, vid,St. 227/1988, de 29 de noviembre; St. 170/1989, de 19 de octubre y la St. 149/1990, de 4 de julio, que resuelve los recursos de inconstitucionalidad acumulados interpuestos contra la Ley 22/1988, de 28 de julio, de Costas.

374 Vid. GARCIA DE ENTERRIA, E., La Ley de Suelo y los principios del urbanismo, ADC, 1958, p. 501.; también recoge esta idea en su trabajo titulado Actuación pública y actuación 
Según este planteamiento, «se ha disociado el ius aedificandi de la titularidad dominical, en el sentido de que aquel derecho no dimana de esta titularidad, sino de una atribución pública de ordenación del suelo, atribución que determina, además la medida concreta en que ese derecho queda reconocido 375 .

En la misma dirección se encuentra Tomás Ramón Fernández ${ }^{376}$ que glosa el art. 87 de la L.S. de la siguiente manera:

«El derecho de propiedad del suelo no es ya un derecho potencialmente ilimitado, sino, más bien, un derecho encerrado en límites precisos que empieza por definir la propia L.S. y que terminan de perfilar los Planes de Ordenación. La Ley y los Planes no recortan, por lo tanto, un derecho que inicialmente tenga una extensión mayor, sino que definen cuál es en cada caso la extensión misma de ese derecho al precisar sus fronteras normales en función de la clasificación y calificación urbanística de los terrenos. Por eso, precísamente, porque se trata de definir los límites o fronteras y no de recortar algo previamente definido, es por lo que el artículo 87 establece que, la ordenación urbanística, no da derecho a indemnización, ya que la función de ésta es compensar justamente lo que se arrebata».

Parejo Alfonso, en esta misma línea, considera que el contenido del derecho de propiedad, por lo que se hace al aprovechamiento urbanístico del suelo, no es algo propio, insito en el derecho dominical, sino el resultado de una atribución positiva al mismo de la ordenación urbanística, en tanto que decisión pública. De este modo, es la ordenación urbanística la que define el estatuto del derecho de propiedad, confiriendo a

privada..., ob.cit., p.86 allí afirma que el ius aedificandi no es ya una facultad libre del propietario, es, en cuanto a su medida concreta, una estricta determinación del Plan, pues el Plan determina la existencia y el grado de aprovechamiento urbano, y este aprovechamiento no es objeto de una libre determinación del propietario: «es lo que el plan define y nada más lo que el plan define».

375 Vid. GARCIA DE ENTERRIA, Lecciones..., ob.cit., p. 415.

376 Vid. TOMAS RAMON FERNANDEZ, Manual de Derecho Urbanístico, Madrid, 1995, p. 104. 
éste determinados contenidos. En el derecho de propiedad del suelo sólo constan como facultades inherentes las típicas de la propiedad en general, es decir, las recogidas en el art. 348 del Código Civi. No así las que este cuerpo legal atribuía específicamente a la propiedad de la tierra en su artículo 350, porque este precepto quedó derogado en 1956 con la entrada en vigor de la Ley del Suelo»377.

En la misma línea otro sector de la doctrina ${ }^{378}$ afirmaba que es la ordenación urbanística la que define el estatuto de la propiedad, confiriendo a éste determinados contenidos; considera que el caso paradigmático de la propiedad vinculada es la propiedad urbana, el plan define el contenido del derecho de propiedad; su titular está obligado a ceder gratuitamente a la Administración parte de sus terrenos, con cargo a las plusvalías del proceso urbanizador, e incluso a soportar el cambio de su propiedad por otra.

En línea con la postura que acabamos de exponer, de la jurisprudencia del Tribunal Supremo, pueden extraerse conclusiones similares, así, la sentencia de 20 de septiembre de 1983 (R.5274), que tras sentar que uno de los principios básicos de la Ley del Suelo es el de basar la actuación urbanística en la planificación, afirma que «a través de esta instrumentación el ejercicio del «ius aedificandi» deja de ser una cuestión privada, para convertirse en una función social que la Administración debe tutelar y regular en forma reglada» ${ }^{379}$; la de 18 de enero de 1984 (R.133), que establece que «las tradicionales facultades del dominio se han ido disociando del derecho subjetivo de propiedad reflejado en los artículos 348 y 350 del Código Civil, hasta el punto de sustantivarse el ius aedificandi

377 Vid. PAREJO ALFONSO, L., Régimen Urbanístico de la propiedad y responsabilidad patrimonial de la Administración, pp.27 y ss.; en la misma dirección ESCRIBANO COLLADO,P., La propiedad privada urbana, Madrid, 1979, pp. 173 y ss.

378 Vid. BASSOLS COMA Y GOMEZ-FERRER. , "La vinculación de la propiedad privada por planes y actos administrativos», V Congreso Hispano-Italiano de profesores de derecho administrativo", Marbella, 1975, p. 85 y 116.

379 Vid. S.T.S. de 20 de septiembre de 1983 ( R. 5279 ). 
como contenido de una materia de competencia pública directa» ${ }^{380 ;}$ o la sentencia de 4 de diciembre de 1984 (6520), que mantiene que como consecuencia de erigirse el urbanismo en una función pública cuyo desarrollo define el contenido normal de la propiedad inmobiliaria, sienta las siguientes afirmaciones:

$1^{\circ}$ que en el suelo rústico o no urbanizable no figura «con carácter normal la facultad de edificar, y no figurando «con carácter normal la facultad de edificar, y no implicando ello ninguna indemnización, quiérese decir que esa ausencia ordinaria del ius aedificandi no es amputación de nada, de suerte que ese contenido de la propiedad, ligado a los aprovechamientos dictados por la naturaleza, será justamente el contenido básico de dicho derecho.

2 el ius aedificandi cuando ya aparece será, en consecuencia, una adición que el ordenamiento urbanístico otorga al contenido básico del derecho de propiedad.

$3^{\circ}$ una vez que el ordenamiento urbanístico ha incorporado al estatuto jurídico de un concreto suelo la posibilidad de edificar, el otorgamiento de licencia, en lo que ahora importa, es un acto rigurosamente reglado y debido, si se ajusta al ordenamiento urbanístico ${ }^{381}$.

Teniendo en cuenta este panorama doctrinal y jurisprudencial, en síntesis, las conclusiones relativas a si forma parte o no de las potestades de propietario fundiario el derecho a edificar, a nuestro juicio, serían las siguientes:

El ius aedificandi no puede quedar separado de la titularidad del predio o fundo. Esa separación no es defendible ni antes ni ahora. Esa concepción contribuye a la mala imagen del planeamiento, a sus 
determinaciones clasificatorias. Según el plan, lo que hoy es de una manera, mañana es de otra.

La única posibilidad de que el planeamiento sea el resultado, de una ponderación de intereses públicos y privados, es que el propietario del suelo no tenga sólo facultades agrícolas, ganaderas, cinegéticas etc. sino que tenga también facultades edificatorias, facultad que es contenido de su derecho de propiedad. Es decir, una cosa es el ius aedificandi, que en tanto que facultad genérica del derecho corresponde al dueño del suelo, y otra distinta es el aprovechamiento urbanístico del fundo que el Plan hace posible al ser éste la materialización de la facultad de edificar ${ }^{382}$.

\section{CONTENIDO URBANISTICO DE LA PROPIEDAD INMOBILIARIA Y LAS DISTINTAS FACULTADES QUE LO INTEGRAN.}

En el texto de la Ley del Suelo del 92, la propiedad inmobiliaria, como tal considerada, carece «a priori» de contenido urbanístico previo, aunque si se le reconoce una serie de expectativas «a posteriori» de orden urbanístico. De manera que mientras no se incorpore a un proceso urbanizador mediante la aprobación de un instrumento público, no existe contenido urbanístico alguno $\mathrm{y}$, por el contrario, cuando se tome esa decisión pública, el propietario ha de incorporarse definitivamente y sin excusas a las exigencias del Plan en el tiempo por él previsto.

382 Vid. LASO, J. L., Derecho Urbanístico III. La propiedad ante el planeamiento urbano, Madrid, 1982, pp. 30, 31 y 41 . El propio T.S. en alguna de sus sentencias apunta hacia una diferenciación entre las facultades del derecho de propiedad y el aprovechamiento urbanístico que puede comportar, vid. St. de 16 de marzo de 1982 (R. 2126), St. de 9 de mayo de 1983 (R. 2902), St. 19 de julio de 1984 (R. 4246) y St. de23 de mayo de 1985 (R. 4121). 
La Ley establece una escala gradual de posibles atribuciones al dueño en la medida en que va cumpliendo los deberes que la Ley califica de básicos 383 .

El artículo 20 del T.R. del 92 enuncia con carácter general, tanto para suelo urbano como para suelo urbanizable, el principio de la distribución equitativa de los beneficios y cargas, y proclama los deberes de cesión de terrenos, de costeamiento y ejecución de la urbanización, de obtención de la licencia de edificación y de edificación en los plazos establecidos. El cumplimiento de estos deberes determina la gradual adquisición de las facultades urbanísticas que se regulan en el artículo art. 23 del T.R. del 92, las cuales se van adquiriendo como contraprestación de los deberes y cargas que el propietario cumple a lo largo del proceso de urbanización y edificación ${ }^{384}$.

Sin embargo, la Ley del 92 confunde facultades con derechos y establece una escala, integrada por los derechos a urbanizar, al aprovechamiento urbanístico, a edificar y a la edificación. Pero aquí cabría preguntarse si se trata de verdaderos derechos o del ejercicio de facultades que, como tales, son inherentes a un derecho que no puede ser otro que el de propiedad.

La Ley no parece contemplar estas posibilidades de urbanizar de obtener el aprovechamiento urbanístico, de edificar o de patrimonializar la edificación como auténticos derechos subjetivos, pues ni permite su individualización con carácter general, ni su transmisión separada del

383 Cfr. comentarios a los artículos 1 y 2 . Sobre el régimen del subsuelo, NIETO, «El subsuelo urbanístico», REDA, núm. 66, pp. 187 y ss. y SAINZ MORENO, F., «El subsuelo urbano», RAP, núm. 122,1990 pp. 153 y ss.

384 Vid. LOBATO GOMEZ, J.M. «La disgregación de la propiedad inmobiliaria» en el libro de las XV jornadas sobre «El sistema Económico en la Constitución Española», Dirección General del Servicio Jurídico del Estado (Ministerio de Justicia)T.I, 1994, p. 721. 
dominio 385 ni siquiera la posibilidad de adquirirlos independientemente unos de otros. Sin embargo, considerarlos facultades supone referirlos a una situación de poder, supone entender que forman parte del contenido propio de un derecho subjetivo, lo que parece ser contrario a la filosofía de la Ley que los excluye del contenido del derecho de propiedad del suelo ${ }^{386}$ Si son derechos, como pretende la Ley, son independientes del derecho de propiedad porque nacen del cumplimiento de ciertos requisitos establecidos por la Ley aunque sólo pueden ser ejercitados por quien ostente la titularidad dominical del suelo.

De otro lado, no son derechos pertenecientes a la Administración que ésta cede al propietario, porque no se trata de derechos preexistentes, sino consecuencia de la concurrencia de ciertos requisitos que implican, aunque no siempre, el cumplimiento de deberes por el propietario. Si fueran derechos públicos cedidos por la Administración, esta cesión constituiría una concesión. No existe una titularidad pública previa del derecho, condición necesaria para que se pueda otorgar en concesión. El derecho a urbanizar, al aprovechamiento urbanístico, a edificar y a la edificación surge, ex lege, cuando se cumplen los requisitos legales, a favor del propietario del suelo y sólo de éste. Pero el derecho de contenido urbanístico no es un derecho personal sino un derecho por razón de la cosa, un derecho ob rem. Sólo el propietario de suelo puede disfrutar de este derecho, aunque esté sometido a la amenaza de su pérdida por incumplimiento de obligaciones, acompañada de la de la cosa que debe ser expropiada o enajenada forzosamente. Si esto es así, el llamado

385 Vid. LOBATO GOMEZ, «La disgregación...», cit. p 724, quien entiende que de esta afirmación general, hay que excluir el aprovechamiento urbanístico. En el mismo sentido, DE LA ESPERANZA RODRIGUEZ, A., "Los negocios jurídicos sobre el aprovechamiento urbanístico", Academia Sevillana del Notariado, T. VI, 1992, p. 37 y ss.

386 Vid. LOBATO GOMEZ, «La disgregación...», cit. p. 724 entiende que el problema sé complicaria aún más si se considera que algunos de estos derechos o facultades se articulan como autenticos deberes o cargas que se le imponen al propietario para consolidar y patrimonializar jurídica, económica y fisicamente los aprovechamientos urbanísticos derivados del planeamiento. 
derecho de contenido urbanístico, no es en realidad, más que una facultad inherente al derecho de propiedad que sólo puede ejercitar el propietario de suelo cuando cumple los requisitos legales.

Además, es igualmente incierto que para culminar el proceso de adquisición de facultades o derechos de contenido urbanístico, el propietario de suelo deba cumplir, siempre, las obligaciones de cesión, urbanización y equidistribución tal y como exige el artículo 20 del TR. El derecho a urbanizar «se adquiere» por la mera aprobación de un Plan según el artículo 24 del citado cuerpo legal, que puede ser de iniciativa pública o particular 387 y sólo la adquisición de ese derecho permite al propietario llegar a edificar. Asímismo, el derecho al aprovechamiento urbanístico "se adquiere» por la aprobación del Plan General en suelo urbano si los terrenos no están incluidos en una unidad de ejecución, según dispone el artículo 31 del TR. Basta el acto gratuito de la Administración de aprobar el Plan para que estos derechos los adquiera el propietario de suelo. No se cumple, por tanto, el artículo 20 del TR, pues el nacimiento de estos derechos, o mejor facultades, no dependen siempre de una prestación del adjudicatario como pretende citado artículo.

En realidad el proceso de adquisición gradual de facultades no existe en todos los casos. Lo que ocurre, simplemente, es que cuando se dan los requisitos que la Ley establece, un terreno puede ser urbanizado o edificado, aunque, ciertamente, el propietario, único beneficiario del ejercicio de aquellas facultades, puede verlas extinguidas si no las ejercita en los plazos que la Ley establezca ${ }^{388}$.

Pero este esquema de adquisición gradual de facultades urbanísticas condicionado al cumplimiento de los deberes urbanísticos en

387 Vid. LOBATO GOMEZ, «La participación privada en la formación de planes de ordenación urbana», RDU, 1989, p. 687 y ss.

388 Vid. DE LOS MOZOS, «Modificaciones del derecho de propiedad por razón de las actuaciones urbanísticas», ADC, 1980, p.6. 
los plazos establecidos y su consiguiente reflejo valorativo sólo debe regir allí donde la ejecución del planeamiento esté llamada a satisfacer demandas sociales efectivas.

Antes de la aprobación del Plan, ni siquiera puede hablarse de expectativas, con posterioridad a la aprobación ya cobran imagen las posibles expectativas que, en abstracto, se enumeran en el art. 23 TR. Pero cualquiera de ellas no existe en la realidad sino que se producen «gradualmente» en la medida que se van cumpliendo deberes urbanísticos según programa y plazos previstos por el propio Plan urbanizador389.

El cambio que se opera con la nueva Ley 6/1998 es el de devolver a la propiedad urbana su unidad, antes escindida en una serie sucesiva de facultades (derecho al aprovechamiento, derecho a edificar y derecho a la edificación). Las facultades de la propiedad vuelven a constituir un haz simultáneo sujetas a determinadas cargas y deberes. Dejan de ser un conjunto de facultades sucesivas de adquisición gradual a medida que se vayan cumpliendo los deberes y cargas en que se concreta la función social. Puede decirse que el propietario de suelo urbano y de suelo urbanizable tiene derecho, en principio, a convertir dicho suelo en solar edificable y, convertido en solar, tiene derecho a edificar, sin perjuicio de los deberes que en cada situación deba cumplir 390 .

El propietario de suelo, no limitado por la prohibición de urbanizar (limitación negativa que produce el Plan general) tiene, en esencia, la «facultas edificandi», si bien para ejercitar esa facultad de edificar está sometido a una serie de cargas sucesivas. Cumplidas estas cargas, el propietario puede solicitar la licencia de edificación que recupera su

389 Vid. MEDINA DE LEMUS, M., La propiedad Urbana y el aprovechamiento urbanístico, Madrid, 1.995, p. 223.

390 Vid. LLISET BORRELL, F., El sistema urbanístico..., ob.cit., pp. 54 y 55. 
carácter reglado, un tanto desnaturalizado en el TRLS de 1992 que la había convertido en una especie de concesión administrativa391 .

Por tanto en la nueva Ley del Suelo del 98, desaparece la distinción de las facultades-derechos a urbanizar, al aprovechamiento urbanístico, a edificar y a la edificación como momentos distintos de la propiedad urbana según la fase del proceso urbanístico en que se insertaba el dominio.

Es claro que la facultad de edificar no puede ejercitarse si, previa o simultáneamente, no se ha completado la urbanización, y que la facultad de completar la urbanización no puede llevarse a cabo si, previamente, no se ha aprobado el proyecto de urbanización, pero ambas facultades están ínsitas al derecho de propiedad, aunque la primera está condicionada al ejercicio de la última392 .

El aprovechamiento urbanístico 393 no es más que la delimitación del contenido económico de la propiedad urbana resultante del plan; define con arreglo al plan, el contenido de la propiedad, pero no es en si misma una facultad dominical como urbanizar o edificar. La facultad de edificar encuentra en el aprovechamiento urbanístico su medida. La facultad de urbanizar opera como condición del ejercicio de la facultad de edificar, pero no crea, como en la legislación anterior, el derecho al aprovechamiento, sino que, simplemente, lo concreta y hace posible su despliegue mediante la licencia de edificación y el hecho mismo de edificar.

391 Vid. la Sentencia del TS de 25 de febrero de 1991, Ar. 1385, en la cual se define la licencia urbanística como «un acto administrativo, de naturaleza reglada, mediante el cual la Administración actúa un control preventivo sobre la actividad de los administrados para asegurar que el aprovechamiento de los terrenos que se pretende llevar a cabo, autoriza simultáneamente la posibilidad de materializarlo.

392 Vid. LLISET BORRELL, F., ob.ult.cit., p.92.

393 En la nueva Ley del suelo del 98 , el propietario ya no adquiere un aprovechamiento urbanístico disminuido en un porcentaje del 15\%, sino que el aprovechamiento urbanístico es una facultad originaria de la propiedad, sin perjuicio de que exista la obligación de cesión de un determinado porcentaje de dicho aprovechamiento en un 10\% como máximo. En la legislación vigente esta cesión recupera la naturaleza de contribución en especie que corre a cargo del propietario y, a diferencia de la indicación de la STC de 20 de marzo de 1997, fija esta cesión no como un mínimo abierto a la competencia autonómica sino como un máximo, consecuencia lógica del giro impuesto por la nueva doctrina de la liberalización del suelo. 
La función social de la propiedad urbana no sólo impone la urbanización sino también la edificación. Por eso la Ley hace una remisión al planeamiento en orden a que éste imponga un plazo a la edificación de los solares resultantes de la urbanización 394

En clara manifestación de lo que antes se ha defendido, la Ley del Suelo produce una sustancial transformación en el derecho de propiedad 395 , como consecuencia de las actuaciones urbanísticas, de forma que su contenido se aleja, cada vez más, del esquema conceptual que contempla el artículo 348 del Código civil396 haciéndolo depender de la clasificación del suelo, la cual determina la atribución a los terrenos de las categorías previstas en la Ley (urbano, urbanizable y no urbanizable art. 9 de la LS del 98$)^{397}$ así como un régimen urbanístico concreto, determinado y distinto en cada caso, que define el conjunto de limitaciones, cargas y deberes que delimitarán el ámbito de ejercicio de las facultades del derecho de propiedad (art. 12 al 18 de a LS del 98 ). Además, como ya hemos señalado, la fijación del régimen urbanístico del suelo se remite a los Planes de Ordenación que tienen como misión especificar las determinaciones legales para sectores y fincas concretos, debiendo respetar en su elaboración las previsiones materiales dispuestas con

394 Conviene recordar que esta obligación aparece en los inicios de nuestra legislación urbanística y que, como norma supletoria, continúa recogiendo el TRLS de 1976 y el Reglamento de Edificación forzosa.

395 Sobre este aspecto, puede verse entre otros, ESCRIBANO COLLADO, La propiedad privada urbana, cit. p. 155 y ss.; SUSTAETA, Propiedad y urbanismo, cit. p. 272 y ss. ; ARNAIZ EGUREN,» Algunas consideraciones en torno al derecho de propiedad inmobiliaria, RCDI,1984, p. 61 y ss. ; BONILLA ENCINA, «Titularidades delimitadas. Delimitaciones en la propiedad urbana (acotaciones)», RCDI, 1971, p. 793 y ss.; CHICO ORTIZ, «El derecho de propiedad ante la nueva legislación urbanística», RDU, 1973, p. 87 y ss.; DE LOS MOZOS, »El urbanismo...», cit. p. 290 y ss. ; BASSOLS-GOMEZ FERRER, «La vinculación...», cit., p. 83 y ss. ; GARCIA DE ENTERRIA, «La ley del suelo...», cit., p. 493 y ss.; GARCIA DE ENTERRIAPAREJO, Lecciones, cit., p. 401 y ss.; MARTIN BLANCO, El tráfico de bienes inmuebles en la ley del suelo, Madrid, 1964, p. 70 y ss.; MARTIN MATEO, «El estatuto de la propiedad inmobiliaria», RAP, 1967, p. 166 y ss.; MONTES, La propiedad privada, cit. p. 119 y ss.; NUÑEZ RUIZ, Derecho urbanístico español, cit., p. 83 y ss.

396 Vid. DE LOS MOZOS, «Modificaciones en la propiedad...»,cit., p. 3.

${ }^{397}$ El art. 9 de la Ley del Suelo del 98 forma parte de la legislación básica del Estado y, por tanto, su contenido debe ser respetado por las Comunidades Autónomas que pueden completarlo pero no sustituirlo. 
carácter general en la legislación urbanística, sobre todo teniendo en cuenta que, a través de ellas, se trazan los límites y se marcan los cauces por los que debe discurrir la definición del contenido del derecho de propiedad del suelo de acuerdo con su función urbanística398.

La aplicación del planeamiento determina el deber de los propietarios afectados de incorporarse al proceso urbanizador y al edificatorio en las condiciones y plazos previstos en el planeamiento o legislación urbanística aplicable, así lo establece el artículo 12 de la LS del 98. Desde ese momento los propietarios afectados están sujetos a los deberes urbanísticos, cuyo cumplimiento les permitirá la sucesiva adquisición de las facultades urbanísticas.

Tanto los límites como los deberes no suponen una derogación del derecho mismo, sino una delimitación ex-lege de su contenido, art. 2.1 de la LS del 98, esta delimitación no indemnizable deriva de la configuración del derecho por la función social y se complementa con el principio de distribución equitativa de los beneficios y cargas del planeamiento, que tienden a garantizar la igualdad entre los propietarios afectados.

La nueva Ley del Suelo, instrumenta y señala la función social de la propiedad urbanística a través del establecimiento de cargas, deberes, limitaciones, valoraciones, derechos y facultades cuyo cumplimiento y ejercicio de unos y otros en la forma legalmente establecida conforman y aplican la función social de la propiedad urbanística. Es en el sistema de compensación urbanística donde el principio de distribución equitativa de las cargas y beneficios del planeamiento se lleva a sus últimas consecuencias, y es el equilibrio entre cargas y beneficios el que puede resolver con justicia la integración derecho de propiedad y función social. 
El sistema de compensación, cuando se dan los requisitos para el mismo, no confiere derecho indemnizatorio a los individuos que se ven afectados por él, todo esto permite configurar dicho sistema como límite del derecho de propiedad, lo cual legitima su estudio desde la perspectiva del Derecho Civil para clarificar instituciones jurídicas que por diferentes razones se han estudiado siempre desde otras ramas del derecho. Nuestro esfuerzo, a lo largo de este trabajo, se concentra especialmente, en el análisis de la proyección de la función social en el sistema de compensación urbanística. Para ello consideremos de vital importancia antes de adentrarnos en su estudio, tras establecer el marco general dentro del cual se inserta dicho sistema: propiedad urbanística, planeamiento y gestión urbanística, analizar jurídicamente la gestión urbanística, en cuanto vamos a profundizar en una forma o sistema de gestión urbanística privada, no sin antes hacer referencia a la regulación de los derechos (facultades) y deberes (limitaciones), que constituyen el contenido urbanístico de la propiedad, en la legislación autonómica ${ }^{399}$.

\subsection{CONTENIDO URBANISTICO DE LA PROPIEDAD EN LAS DIFERENTES COMUNIDADES AUTÓNOMAS}

El análisis de las Leyes autonómicas sobre esta cuestión tiene su importancia práctica, debido a que en muchos casos la Ley de Régimen del Suelo y Valoraciones desplazará a la legislación de las Comunidades Autónomas.

\footnotetext{
${ }^{399}$ Aquellas Comunidades Autónomas que hacen una remisión expresa en esta materia a los dictados del Texto Refundido de 1992 que contiene una concepción opuesta sobre derechos y deberes, en cuanto consagra la adquisición gradual de facultades, vendrán obligadas bien a una modificación legislativa, bien a aplicar la Ley de Régimen del Suelo y Valoraciones y con carácter supletorio el Texto Refundido de 1976.

Las Comunidades Autónomas que no tienen legislación específica sobre derechos y obligaciones aplicarán la Ley de Régimen del Suelo y Valoraciones y el Texto Refundido de 1976.

Finalmente, aquellas Comunidades Autónomas con legislación específica podrán establecer disposiciones complementarias sobre regulación de derechos y deberes siempre que no se opongan a las disposiciones de esta Ley de Régimen del Suelo y Valoraciones ni a los principios generales y básicos establecidos en ella.
} 
En todas aquellas Leyes autonómicas que han asumido el Texto Refundido de 1992 (Andalucía, Cantabria, Extremadura) los derechos a completar la urbanización y a edificar no están condicionados en su adquisición, por el cumplimiento de deberes, y por ello el art. 13 de la Ley de Régimen del Suelo y Valoraciones desplaza a los arts. 19 a 37 del Texto Refundido de 1992. El porcentaje del aprovechamiento urbanístico susceptible de apropiación (85 por 100 del aprovechamiento tipo) ha quedado desplazado en suelo urbano consolidado, por el 100 por 100 del aprovechamiento lucrativo y por el 90 por 100 en suelo urbano no consolidado. Son aplicables las técnicas de equidistribución del Texto Refundido de 1992, áreas de reparto, unidades de ejecución, las transferencias de aprovechamiento, etc., de tal manera que en el suelo urbano el aprovechamiento del 100 por 100 puede verse afectado por los efectos de estas técnicas de equidistribución.

Las Leyes autonómicas con una regulación específica contienen aspectos que han de entenderse como complemento de la legislación del Estado y otros que han de considerarse desplazados por el artículo 13 de la Ley del Régimen del Suelo y Valoraciones.

En Aragón, la Ley 5/1999, regula en el art. 16 los derechos de los propietarios en suelo urbano, remitiéndose al art. 13 de la Ley de Régimen del Suelo y Valoraciones. En suelo urbanizable, los propietarios tienen las mismas obligaciones que las establecidas en el artículo 18 para los propietarios de suelo urbano no consolidado, con la salvedad de que la cesión gratuita al municipio se referirá al 10 por 100 del aprovechamiento medio del suelo urbanizable delimitado o, tratándose de suelo urbanizable no delimitado, del sector. La cesión no comportará ninguna obligación municipal de participar en los costes de urbanización.

En Cataluña, el Decreto Legislativo 1/1990 regula los derechos de los propietarios en suelo urbano, el concepto de solar, las técnicas de 
equidistribución (arts. 113 y ss.), que son complemento del art. 13 de la Ley de Régimen del Suelo y Valoraciones. En suelo urbano el aprovechamiento susceptible de apropiación es el 100 por 100 sin distinción entre suelo urbano consolidado o no consolidado por la urbanización, porcentaje que está en los límites fijados por la Ley de Régimen del Suelo y Valoraciones, sin bien puede verse afectado por las técnicas de la equidistribución (art. 120.4).

En Castilla-La Mancha, la Ley 2/1998, los derechos urbanísticos del suelo urbano reconocidos en los arts. 50.1 .5 en relación con el concepto de suelo urbano, complementa el art. 13 de la Ley de Régimen del Suelo y Valoraciones. El porcentaje de aprovechamiento urbanístico susceptible de apropiación está sometido, en todo caso, a una cesión del 10 por 100 de la diferencia entre el aprovechamiento previsto en el nuevo plan y el preexistente, precepto incompatible con la Ley de Régimen del Suelo y Valoraciones. Los preceptos sobre las técnicas de distribución del aprovechamiento son complemento de la Ley de Régimen del Suelo y Valoraciones (áreas de reparto y aprovechamiento tipo, previstas en el art. 79)

En Castilla y León, la Ley 5/1999,en materia de derechos y deberes en suelo urbano y urbanizable se desarrolla el sistema definido en la legislación estatal (derechos a urbanizar y edificar, y deberes de urbanización, cesión, equidistribución y edificación) haciendo uso de la facultad otorgada a la legislación autonómica para modular las cesiones de aprovechamiento; estas se exigirán, en su cuantía máxima, en todo el suelo urbanizable (art. 19), y también en el suelo urbano de los Municipios mayores de 20.000 habitantes o que cuenten con Plan General de Ordenación Urbana (art. 17); de forma que los Municipios menores puedan en uso de su autonomía acceder a un más complejo régimen urbanístico, asumiendo los compromisos que conlleva un Plan General. 
En Galicia, la Ley 1/ 1997 establece los derechos en suelo urbano (art. 70). El porcentaje de aprovechamiento susceptible de apropiación en suelo urbano consolidado es el mismo de la Ley de Régimen del Suelo y Valoraciones (el 100 por 100) sin perjuicio de que este porcentaje pueda disminuir en virtud del principio de equidistribución mediante las transferencias de aprovechamiento o la reparcelación económica (art. 71). En suelo urbano no consolidado, el porcentaje de aprovechamiento susceptible de apropiación del 85 por 100 debe ser desplazado por el del 90 por 100 de la Ley de Régimen del Suelo y Valoraciones (art. 70.2.b)). Las técnicas de equidistribución, áreas de reparto y aprovechamiento tipo son complemento de la Ley de Régimen del Suelo y Valoraciones (art. 70.2)

En la Comunidad Autónoma de Madrid, la Ley 20/ 1997 regula las técnicas de las áreas de reparto y aprovechamiento tipo que son complemento para determinar el aprovechamiento en suelo urbano. El art. 8 establece que el aprovechamiento en suelo urbano consolidado, o lo que es lo mismo, no incluido en una unidad de ejecución, es el 100 por 100 del aprovechamiento tipo, o en su defecto el establecido en las ordenanzas. En suelo urbano no consolidado el porcentaje es el 90 por 100 de aprovechamiento tipo o medio. Se permite la equidistribución mediante las transferencias de aprovechamiento (art. 9) salvo en el caso de reforma del suelo urbano prevista en el art. 8.4. La Ley de Madrid establece unas cesiones adicionales en suelo urbano en el caso de expropiación que son inconstitucionales y los preceptos que las regulan deberán entenderse desplazados por los preceptos de valoraciones de la Ley de Régimen del Suelo y Valoraciones. En esta situación se encuentra la disposición transitoria $2^{\mathrm{a}}$ de la Ley 20/ 1997.

En la Rioja, la Ley 10/1998, de 2 de Julio, en materia de clasificación del suelo se produce una plena concordancia con la legislación 
estatal. Por lo que se refiere al suelo urbano y urbanizable, y dentro de los márgenes de la legislación estatal, se ha procurado ajustar las cesiones de dotaciones y de aprovechamiento a las características de los municipio de la región. Del máximo exigible a los municipios mayores de veinticinco mil habitantes, art. 11.3.c), (10 por 100 de cesión de aprovechamiento en suelo urbano no consolidado y en suelo urbanizable, y el 25 por 100 de la superficie del sector con destino a dotaciones), se desciende a los municipios con población situada entre mil y veinticinco mil habitantes, en que la cesión para dotaciones se reduce al 15 por 100 de la superficie del sector y la cesión de aprovechamiento de suelo urbanizable a la Administración actuante se sitúa en el 10 por 100 con posibilidad de reducción hasta el 5 por 100, a petición de los Ayuntamientos y previa autorización de la Comunidad Autónoma.

En Navarra, la Ley foral 10/ 1994 no distingue entre suelo urbano consolidado o no consolidado, sólo reconoce el suelo consolidado por la urbanización (art.7). Este precepto y el art. 13 sobre el porcentaje de aprovechamiento susceptible de apropiación en suelo urbano, han de entenderse desplazados por la Ley de Régimen del Suelo y Valoraciones. En este sentido, la Ley Foral 24/1998, de 30 de diciembre, tiene como objetivo adaptar el régimen de la Ley Foral 10/1994, de 4 de julio, al reducido porcentaje máximo de cesión establecido por la legislación estatal tanto para los suelos urbanos como para los urbanizables en todos los municipios, suprimiendo la participación en las cargas de urbanización de los aprovechamientos que corresponden a la Administración urbanística actuante en virtud del referido deber de cesión, modificando todos los artículos de la Ley Foral 10/1994,que hacen referencia al régimen de cesiones.

En el País Vasco, la Ley 11/1998 ha de entenderse desplazada en cuanto al porcentaje susceptible de apropiación en suelo urbano consolidado por la Ley de Régimen del Suelo y Valoraciones. 
En Valencia, la Ley 2/1997 ha establecido el mismo porcentaje de aprovechamiento que la Ley de Régimen del Suelo y Valoraciones, debiendo considerarse como complemento la Ley 6/1994 en cuanto a las técnicas de la equidistribución.

Aquellas Comunidades Autónomas que no contienen una regulación específica de los derechos a completar la urbanización y a edificar, en todo el contenido incluido en este ámbito, deberán aplicar la Ley de Régimen del Suelo y Valoraciones y con carácter supletorio el Texto Refundido de 1976 en lo que no se oponga a esta Ley.

\subsubsection{DEBERES DE LOS PROPIETARIOS EN SUELO URBANO.}

La regulación de los deberes del propietario en suelo urbano en la Ley de Régimen del Suelo y Valoraciones, admite un amplio complemento por la legislación de las Comunidades Autónomas.

Las Comunidades Autónomas de Andalucía, Cantabria y Extremadura han adoptado el Texto Refundido de la Ley del Suelo de 1992. El art. 20 de esta Ley establece los deberes legales para la adquisición gradual de facultades. Este precepto, no anulado por la Sentencia del Tribunal Constitucional 61/97, es incompatible con el art. 14 de la Ley de Régimen del Suelo y Valoraciones, razón por la cual estas Comunidades Autónomas deberán aplicar el art. 14 que desplaza al citado art. 20 del Texto Refundido de la Ley del Suelo de 1992. Estas Comunidades Autónomas deberán atenerse también al porcentaje máximo de cesión a la Administración, que en suelo urbano consolidado no existe y en suelo urbano no consolidado es el 10 por 100. No será tampoco aplicable el art. 27 del Texto Refundido de 1992, que establece un porcentaje de cesión del 15 
por 100 del aprovechamiento tipo del área de reparto del aprovechamiento medio o del permitido por el planeamiento. El Texto Refundido de la Ley del Suelo de 1992 será aplicable en todos los aspectos que se refieren a la fijación de las técnicas de la equidistribución (áreas de reparto, unidades de ejecución, aprovechamiento tipo, transferencias de aprovechamientos) y licencias de edificación con la limitación general de que en ningún caso el cumplimiento de deberes determine la adquisición de facultades.

Las Comunidades Autónomas de, Asturias, Canarias y Murcia, que no tienen una legislación específica sobre deberes, les será de aplicación supletoria el Texto Refundido de 1976. No obstante, el art. 14 de la Ley de Régimen del Suelo y Valoraciones se aplicará directamente y, en consecuencia, desplazará al art. 83 del Texto Refundido de 1976. El Texto Refundido de 1976 será aplicable en estas Comunidades Autónomas en todo lo que no se oponga a la Ley de Régimen del Suelo y Valoraciones al permitir moverse ésta entre un mínimo y un máximo. Estas Comunidades Autónomas deberán, en consecuencia, modificar su legislación en este punto, si quieren obtener cesiones en suelo urbano no consolidado.

En Castilla-León (Ley 5/1999) y en Aragón (Ley 5/1999), se regulan los deberes de los propietarios en suelo urbano, distinguiendo entre suelo urbano consolidado y no consolidado, complementando así el art. 14 de la Ley de Régimen del Suelo y Valoraciones excepto en lo relativo al porcentaje de cesión que en la Ley de Aragón se establece en el 15 por 100.

En Cataluña, el Decreto Legislativo 1/ 1990 en su art. 120 establece los deberes en suelo urbano sin distinguir entre suelo urbano consolidado y suelo urbano no consolidado. Pero puede considerarse complemento del art. 14. No establece cesiones a favor de la Administración en suelo urbano, pero esta determinación es compatible con la Ley de Régimen del Suelo y Valoraciones. El Decreto Legislativo 1/ 1990 es aplicable como legislación del planeamiento y en la regulación del deber de edificar. 
El art. 70 de la Ley 1/ 1997, de Galicia, regula los deberes en suelo urbano de forma complementaria y compatible con la Ley de Régimen del Suelo y Valoraciones, excepto en lo relativo al porcentaje de cesión (el 15 por 100), que ha de considerarse desplazado por la cesión de este art. 14 de la Ley de Régimen del Suelo y Valoraciones. Las técnicas de equidistribución previstas en los arts. 87 a 114 de la Ley 1/ 1997 son complementarias de los deberes de la Ley de Régimen del Suelo y Valoraciones y ponen de manifiesto cómo, a pesar del silencio de la Ley estatal, es posible establecer deberes complementarios, en este caso la equidistribución en suelo urbano consolidado. También regula esta Ley de Galicia el cumplimiento del deber de ejecutar la urbanización y edificar, que son complemento de la Ley de Régimen del Suelo y Valoraciones.

En Castilla-La Mancha, la Ley 2/1998 regula los deberes de los propietarios en suelo urbano (art.69), distingue entre suelo urbano incluido en unidades de ejecución, equivalente en parte al suelo urbano no consolidado y resto del suelo urbano (según el art. 45). Establece para el primer tipo de suelo la cesión del 10 por 100 que es compatible con la Ley de Régimen del Suelo y Valoraciones. La cesión para equidistribución en el resto del suelo urbano (art. 69.2.a).2), así como las técnicas y los instrumentos previstos para ello en la Ley, es compatible con la Ley de Régimen del Suelo y Valoraciones. Esta Ley 2/1998, de Castilla-La Mancha, establece con carácter general, unos deberes complementarios en el art. 51, que en general y con las precisiones sobre cesión en suelo urbano son compatibles con la Ley de Régimen del Suelo y Valoraciones. El último inciso del art. 51 exige el cumplimiento de estos deberes generales como condición del ejercicio de los derechos, no de su adquisición, con lo que ha de considerarse compatible con la Ley de Régimen del Suelo y Valoraciones.

En la Comunidad de Madrid (Ley 20/1997) no se regulan específicamente los deberes en suelo urbano y es, por tanto, aplicable 
directamente el art. 14 de la Ley de Régimen del Suelo y Valoraciones. Las cesiones son compatibles con las establecidas en esta Ley. En esta Comunidad se establece, para el caso de reforma urbana, el mantenimiento del aprovechamiento del planeamiento vigente, lo cual supone sensu contrario que el exceso de aprovechamiento deberá ser cedido. Ha de entenderse que en este suelo de reforma, si se trata de suelo consolidado, la cesión del exceso de aprovechamiento sólo es posible si es para equidistribución, pero no lo será si es cesión a la Administración. Las técnicas de equidistribución de esta Ley son compatibles con la Ley de Régimen del Suelo y Valoraciones.

La Ley foral de Navarra 10/1994 ha sido modificada en su art. 13 por la Ley 24/1998, de 30 de diciembre, estableciendo una cesión del 10 por 100 en suelo urbano incluido en unidades de ejecución, es decir, no consolidado. La cesión obligatoria y gratuita del 10 por 100 del aprovechamiento que se realice a la Administración actuante, tanto en suelo urbano como urbanizable, estará libre de cargas de urbanización, toda la cual será a cargo de los propietarios en proporción a sus aprovechamientos. Estas cargas de urbanización correspondientes al suelo cedido se considerarán integrantes del deber de costear la urbanización que corresponde a los propietarios afectados.

Las cesiones del 15 por 100 del aprovechamiento del suelo urbano previsto en la Ley 3/ 1997 del País Vasco, han de considerarse desplazadas por las cesiones previstas en el art. 14 de la Ley de Régimen del Suelo y Valoraciones.

Por último, la Ley 6/1994, de Valencia, es complementaria de la Ley de Régimen del Suelo y Valoraciones en cuanto al desarrollo y precisión de los deberes urbanísticos. El porcentaje de cesiones previstos en esta Ley ha 
sido modificado por la Ley 14/1997 (art.19) en el mismo sentido que la Ley de Régimen del Suelo y Valoraciones

\subsubsection{DERECHOS DE LOS PROPIETARIOS EN SUELO} URBANIZABLE.

El derecho a la transformación del suelo urbanizable no carecía de precedentes en la legislación del Estado y había sido regulada también por las Leyes autonómicas.

Los derechos en suelo urbanizable se configuran en la Ley de Régimen del Suelo y Valoraciones sobre los siguientes pilares:

- El derecho al uso rústico del suelo urbanizable dependerá de si se trata de suelo urbanizable de desarrollo inmediato o no. En el primer caso el uso rústico estará limitado conforme a las determinaciones del art. 17; en otro caso, será de aplicación lo establecido en el art. 20.

- El derecho a la transformación del suelo urbanizable incluido en ámbitos se desarrolla mediante planes parciales o instrumentos similares sin sometimiento a períodos cuatrienales. Los propietarios deberán tener preferencia en la iniciativa de la transformación mediante la formulación del planeamiento adecuado y también en la gestión que se desarrollará por un procedimiento similar al sistema de compensación. La Administración y otros particulares que manifiesten un interés legítimo pueden también formular el planeamiento de desarrollo de este suelo.

- El derecho a la transformación del suelo urbanizable no incluido en ámbitos se desarrollará a través de un instrumento similar al plan parcial que contendrá las condiciones para el desarrollo de este suelo. No se podrá exigir un programa de actuación urbanística y un plan parcial de desarrollo, ya que los propietarios tendrán la iniciativa del desarrollo sin concurso previo, si bien se podrá prever el desarrollo por la Administración bien 
directamente o mediante la convocatoria de un concurso. No se podrán programar las actuaciones urbanísticas privadas, pero sí las públicas. Para la gestión de este suelo se podrán emplear cualquiera de los sistemas de actuación, se podrá emplear la gestión pública a través de la expropiación directamente o con beneficiario, pero tendrá preferencia la ejecución directa del planeamiento por los propietarios.

- El derecho a la consulta deberá regularse con respecto a las condiciones mínimas establecidas en la Ley de Régimen del Suelo y Valoraciones.

Para comparar estos principios básicos de la Ley con la legislación autonómica distinguiremos diferentes tipos: En primer lugar, aquellas Comunidades Autónomas que no hacen referencia a estos derechos. En segundo lugar, aquellas Comunidades Autónomas que han vuelto a poner en vigor el Texto Refundido de 1992. En tercer lugar aquellas que contienen una legislación específica de los derechos en el suelo urbanizable.

En el primer caso se encuentran Asturias, Baleares, Canarias, Murcia y el País Vasco. En estos supuestos podrá aplicarse como legislación supletoria el Texto Refundido de 1976, modificado por esta Ley. No obstante, y dada la importancia en la materia, estas Comunidades Autónomas se verán obligadas a legislar de manera expresa sobre el ejercicio de estos derechos.

Aquellas Comunidades Autónomas que han puesto en vigor el Texto Refundido de 1992 se verán obligadas bien a dictar una legislación de desarrollo conforme a los principios de la Ley de Régimen del Suelo y Valoraciones, o bien a interpretar, conforme a estos principios, el Texto Refundido de 1992, lo cual implicará el desplazamiento de los preceptos de aquella Ley incompatible y la aplicación de las prescripciones expresas de la Ley de Régimen del Suelo y Valoraciones.

En este caso se encuentran Andalucía (Ley 1/1997), Cantabria (Ley 1/1997), Castilla-La Mancha (Ley 5/1997) y Extremadura (Ley 3/1997). 
Por último, aquellas Comunidades Autónomas que tienen legislación específica: Aragón, Castilla-León, Cataluña, Navarra, Galicia, Madrid y Valencia. El Decreto Legislativo 1/1990 de la Generalitat catalana seguía la distinción de la legislación del Estado del suelo urbanizable programado y no programado (art. 117). Daba la preferencia a la iniciativa privada en la formulación y ejecución de planes parciales en suelo urbanizable programado (arts. 25, 16 y 169) que establecía el mismo sistema de desarrollo en suelo no programado que la legislación del Estado de 1976. Cataluña se encuentra en una situación similar a la de aquellas Comunidades Autónomas que no habían promulgado una Ley especial en esta materia. La Comunidad Autónoma catalana se verá obligada a dictar una legislación que complemente los principios de la Ley de Régimen del Suelo y Valoraciones sobre este tipo de suelo, pues las normas del Decreto citado han sido, en gran parte, desplazadas por la Ley de Régimen del Suelo y Valoraciones. En parecida situación se encuentra Navarra (Ley Foral 10/1994, arts. 8 y 88). La Ley 9/1995, de la Comunidad de Madrid, confusa Ley, contiene un artículo, el 73, que debe entenderse desplazado por los preceptos de la Ley de Régimen del Suelo y Valoraciones, por ser contrario a los principios de esta Ley.

Pero los supuestos más singulares en la materia son la Ley $1 / 1997$ de Galicia y la Ley 6/1994 de Valencia. La Ley 6/1994 de Valencia estableció un sistema urbanístico diferente al Texto Refundido de 1992 entonces vigente. La clasificación del suelo en urbano y en urbanizable, se hace en esta Ley (art.9), en función de la idoneidad de los instrumentos de actuación urbanística que convenga al proceso urbanizador o edificatorio. Es suelo urbano aquel que el plan clasifique en función de que pueda edificarse. Es suelo urbanizable aquel que debe someterse al régimen de ejecución de actuaciones integradas porque no puede edificarse sin la previa urbanización. 
A primera vista podría pensarse que esta regulación no es conforme a la Ley de Régimen del Suelo y Valoraciones. Sin embargo, la clasificación del suelo urbanizable de la Ley valenciana es flexible y comprende los dos tipos de la Ley de Régimen del Suelo y Valoraciones (art.33). Su desarrollo mediante plan parcial y programa o sólo mediante programa, es compatible con los instrumentos de desarrollo previstos en la Ley. La figura del urbanizador es también compatible con la Ley de Régimen del Suelo y Valoraciones, y desde el punto de vista constitucional no es reprochable, si bien se puede convertir en la práctica en un instrumento para desplazar al propietario.

La Ley 1/ 1997, de Galicia, clasifica como suelo rústico susceptible de urbanizar (art.68) el suelo urbanizable, no incluía en ámbitos de la Ley de Régimen del Suelo y Valoraciones. Se trata, por tanto de una opción terminológica que sigue, no obstante, los criterios de la Ley. Su regulación concreta también es acorde con los principios básicos de ese artículo, así como el desarrollo mediante planes parciales (art. 21.2), la intervención de los particulares y la programación pública de actuaciones (art.15.2).

\subsubsection{DEBERES DE LOS PROPIETARIOS EN SUELO} URBANIZABLE.

Los deberes establecidos en la Ley de Régimen del Suelo y Valoraciones para este tipo de suelo son prácticamente los mismos que los correspondientes al suelo urbano no consolidado por la urbanización con la excepción del refuerzo de las estructuras de conexión. Son, por tanto, aplicables a este precepto los comentarios que hicimos en líneas anteriores. El deber de cesión de dotaciones es obligatorio, pero no gratuito, porque es compensable. La Ley de Régimen del Suelo y Valoraciones establece un mínimo que puede complementarse por las legislaciones autonómicas, sobre 
todo si tememos en cuenta el concepto amplio de dotaciones públicas. Sólo hay una limitación básica, que las dotaciones cedidas estén al servicio del ámbito. La fórmula de compensación de la cesión es competencia de las legislaciones autonómicas.

El deber de cesión de aprovechamiento puede oscilar entre un máximo (el 10 por 100) y un mínimo (0 por 100). Las legislaciones autonómicas no podrán superar el máximo, pero podrán obligar a que la cesión del suelo en el que se materialice el aprovechamiento sea urbanizado.

El deber de ceder los terrenos para sistemas generales, el deber de costear las infraestructuras de conexión, el deber de costear la urbanización y el de edificar necesitan del complemento de la legislación autonómica y del planeamiento.

Las Comunidades Autónomas de Andalucía, Cantabria y Extremadura, que han adoptado el Texto Refundido de 1992, deberán atenerse, en primer lugar, a los preceptos de la Ley de Régimen del Suelo y Valoraciones, razón por la cual tanto el sistema de adquisición gradual de facultades de aquella Ley como el porcentaje del 15 por 100 de cesión de aprovechamiento quedarán desplazados por los preceptos de la Ley de Régimen del Suelo y Valoraciones. Será aplicable el Texto Refundido de 1992 en todo lo que no se oponga al espíritu y a la letra de la nueva Ley y especialmente en todos aquellos preceptos sobre planeamiento, ejecución y gestión, incluidas las técnicas de equidistribución.

En aquellas Comunidades Autónomas que carezcan de legislación específica, será aplicable con carácter supletorio el Texto Refundido de 1976 (arts. 184 y concordantes), si bien el art. 18 de la Ley de Régimen del Suelo y Valoraciones se aplicará de forma directa y preferente (Asturias, Baleares, Canarias y Murcia). 
La Ley 2/1998, de Castilla-La Mancha, contiene una subdivisión del suelo urbanizable programado y no programado que no corresponde con lo establecido en la Ley de Régimen del Suelo y Valoraciones y que debe ser desplazado por los preceptos de la Ley estatal. No obstante, el art. 68, en cuanto establece deberes de suelo urbanizable programado, es complementario de la legislación estatal (art. 18 de la Ley de Régimen del Suelo y Valoraciones), que es aplicable directamente.

El régimen jurídico del suelo urbanizable establecido en la Ley 5/1999, de Castilla y León, y en la Ley 20/ 1997, de Madrid, es compatible y complementario con la Ley de Régimen del Suelo y Valoraciones. El Decreto Legislativo 1/1990 de Cataluña, establece en su art. 21 los deberes en suelo urbanizable que también son compatibles con el art. 18 de la Ley de Régimen del Suelo y Valoraciones.

La Ley 1/1997, de Galicia, en su art.72 establece el régimen del suelo urbanizable que es compatible con el art. 18 de la Ley de Régimen del Suelo y Valoraciones, con excepción del porcentaje de cesión, que no podrá exceder del 10 por 100.

Los arts. 11 y 21 de la Ley 10/1994, de Navarra, han de considerarse desplazados por el art. 18 de la Ley de Régimen del Suelo y Valoraciones complementada por el Texto Refundido de 1976.

Las Leyes 5/1998 y 20/1998, del País Vasco, son compatibles con el art. 18 de la Ley de Régimen del Suelo y Valoraciones.

La Ley del Suelo 6/1994,de Valencia, tiene una concepción diferente de los deberes del suelo urbanizable debido al sistema de gestión de este suelo. No obstante, las técnicas de equidistribución de la Ley valenciana y las cargas de la urbanización son compatibles con el art. 18 de la Ley de Régimen del Suelo y Valoraciones. Hay que tener en cuenta, además, que la Ley 14/1997 ha adaptado el porcentaje de cesión al 10 por 100 del aprovechamiento. 
CAPITULO SEPTIMO.

LA GESTION URBANISTICA: URBANIZACION Y EJECUCION

\section{INTRODUCCION}

Tras la publicación de la Sentencia de 20 de marzo de 1997, en esta materia también el Estado ha quedado privado de la más mínima capacidad de intervención.

La ejecución o gestión del planeamiento, queda definitivamente configurada como una faceta insita a la estricta competencia urbanística y, por lo tanto, autonómica en exclusiva.

Así se pone de manifiesto con la declaración de inconstitucionalidad por la negación de su carácter básico que recae sobre preceptos contenidos en el Capítulo I, Disposiciones Generales del Título IV del TRLS del 92, empezando por el que reconocía competencias de ejecución de los Planes al Estado, a pesar de que se ceñía a su "respectiva esfera de actuación” (art. 141TRLS): "Desde una interpretación sistemática, ha de partirse del dato de que el precepto alude a la ejecución de Planes de ordenación urbanística. Así las cosas, debe negarse la competencia del Estado para dictar una norma tal, ya que se trata de una determinación que compete establecer al Legislador autonómico, habida cuenta de que, en rigor, estamos ante la ejecución urbanística del planeamiento que se inserta sin dificultad en el ámbito material del urbanismo" (F.jco. 27.a).

Pese a ello, se deja constancia de que el Estado ostenta competencias sectoriales propias cuyo despliegue puede perfectamente 
incidir sobre la ejecución del planeamiento, del mismo modo que, en la fase previa de la ordenación misma, tales competencias pueden permitirle condicionar determinaciones del planeamiento territorial y urbanístico 400 .

\section{Afectadas por esa acepción expansiva del concepto de gestión}

urbanística, son insostenibles declaraciones que, aparentemente, podían haberse considerado "principales", según la terminología de la propia Sentencia. Así, la regla de la ejecución del planeamiento mediante unidades de ejecución delimitadas en cada área de reparto y la definición de sus posibles excepciones (art. 143 del TRLS) y el principio de que tales unidades de ejecución deben delimitarse del modo más favorable a la viabilidad de los deberes de cesión, equidistribución y urbanización (art. 144.1 TRLS) ${ }^{401}$.

400 Vid. el fundamento jurídico 27.a) in fine, donde queda plasmada esta idea: "Ello no empece, sin embargo, a que el Estado, en el ámbito de sus competencias, pueda esgrimir un título sectorial específico y distinto que le atribuya competencias de ejecución sobre otras materias que puedan resultar afectadas por el plan de ordenación, hipótesis por otra parte plausible habida cuenta del amplio alcance que los instrumentos de ordenación urbanística pueden albergar, al menos potencialmente, en relación con el uso del suelo, que excede, no sin frecuencia, de la ordenación de la ciudad en sentido estricto, para incidir sobre otras políticas sectoriales territoriales de la competencia exclusiva del Estado en virtud del art. 149.1 C.E (grandes obras públicas; ciertas infraestructuras; defensa y seguridad; etc.".

401 Vid. el fundamento jurídico 27.b) y c) de la Sentencia que establece en relación a este aspecto que: "...el Estado carece aquí de todo título competencial para prescribir que la ejecución se realice mediante unidades de ejecución y, menos aún, cuándo procede la actuación a través de esta técnica urbanística. El legislador estatal puede, como hace el art. 140 del TRLS no impugnado, establecer que la ejecución del planeamiento garantice la distribución equitativa de los beneficios y cargas entre los afectados, así como el cumplimiento de los deberes de cesión correspondientes y costeamiento de la obra urbanizadora, en la medida en que ello entronca con el estatuto básico de la propiedad urbana amparado en el art. 149.1.1을 C.E en los términos ya expuestos. Pero no le incumbe determinar el instrumento, el procedimiento o la forma en que ha de llevarse a cabo la ejecución del planeamiento, cuestiones estas que corresponden a la competencia urbanística autonómica, sin perjuicio de que, como hemos dicho (art. 94 del TRLS), pueda tomar como punto de referencia, sin sentar su régimen jurídico, las áreas de reparto o las unidades de ejecución para regular las condiciones básicas de las facultades y deberes urbanísticos que garanticen la igualdad. Desde esta perspectiva, en efecto, el art. 140 TRLS conecta con lo que ya ha dispuesto el art. 19 del TRLS, entre otros, que encabeza la regulación de los derechos y deberes básicos de los propietario, esto es, que la aprobación del planeamiento preciso según la clase de suelo determina el deber de los propietarios afectados de incorporarse al proceso urbanizador y edificatorio, en las condiciones y plazos previstos en el planeamiento o legislación urbanística aplicable. Desde ese momento los afectados quedan vinculados a los deberes urbanísticos básicos, cuyo cumplimiento les permitirá la sucesiva adquisición de las facultades urbanísticas (arts. 20 y 23 de TRLS, entre otros). Pero el art. 143 TRLS impugnado excede de la regulación de las condiciones básicas que garanticen la igualdad en el ejercicio de la propiedad urbana y en el cumplimiento de los deberes, también básicos, ex art. 149.1.1ํㅡ. C.E, cuando determina los supuestos en los que cabe establecer excepciones, sin que, para tal previsión normativa 
Hay una matización para el caso de que "sobre la ejecución del planeamiento incida un título competencial del Estado" pero planteada de una forma tan imprecisa que, una vez más, excluye cualquier virtualidad de la misma 402 .

Si se sostiene que el art. 143 TRLS, constituye la "concreta regulación" de las unidades de ejecución, es fácil intuir que la concepción que subyace en la doctrina del Tribunal Constitucional hace absolutamente inviable cualquier determinación del Legislador estatal con una mínima sustantividad en esta materia.

Teniendo en cuenta lo dicho anteriormente, preceptos de índole más concreta, como los relativos a consecuencias del incumplimiento colectivo de los deberes de ejecución en una unidad (art. 149.3 TRLS), reglas sobre las unidades excedentarias (art. 154.1 y 3 TRLS), atribución del aprovechamiento correspondiente a terrenos demaniales (art. 154.2 TRLS), reglas para la reparcelación (art. 166.1.a), c) y e)TRLS, efectos de ésta (art. 167 TRLS), liberación de expropiaciones (art. 174.2 TRLS e incumplimiento del beneficiario de ésta (art. 176 TRLS), estaban destinados a desaparecer.

Según establece el fundamento jurídico 28 en sus apartados a), c), d), e), f), g), y h), se estima que el Estado es incompetente para regular, en general, cualquier sistema de actuación, o para optar por concretos modelos o técnicas, entendiéndolo como facultad inherente a la competencia autonómica.

con pretensiones de norma básica, sean de aplicación los restantes títulos competenciales que invoca el Estado en la misma Disposición final única del TRLS.

402 El Alto Tribunal entiende que": resulta lícito, en aras de una mínima coherencia interna en lo que hace a la arquitectura básica de la propiedad urbana y como consecuencia de la peculiar naturaleza convencional de ésta, que el Estado tome como punto de referencia, como ha quedado dicho, las unidades de ejecución como fórmula para hacer efectivas las facultades y deberes urbanísticos y los principios básicos que la impregnan, pero no su concreta regulación como hace el art. 143 TRLS, que, en consecuencia, resulta contrario al orden constitucional de distribución de competencias"(F.jco.27.b) in fine). 
Sin embargo, el precepto según el cual la falta de ejecución del Plan imputable a la Administración permite a los propietarios permanecer en el proceso edificatorio (art. 150 TRLS) se considera que "completa el estatuto básico del régimen jurídico de la propiedad urbana y el precepto impugnado encuentra su cobertura en el art. 149.1.1ㅇ C.E” (F.jco. 28 .b).

\section{LA GESTION URBANISTICA.}

La gestión urbanística comprende toda la compleja actividad de dirección, promoción y coordinación de cualesquiera actuaciones urbanísticas. Es decir, su campo propio incluye desde la ordenación hasta la edificación ${ }^{403}$. En definitiva, la gestión urbanística comprende "las diversas actividades tendentes a concretar las indicaciones del planeamiento sobre los derechos de los particulares que se ven afectados por dicho planeamiento" 404 .

La titularidad de la gestión urbanística corresponde, con carácter general, a la Administración, según se desprende del propio artículo 141 de T.R. del 92 (artículo 114 de la L.S. texto refundido del 76); sin embargo, el ejercicio de esta función pública puede cederse a los particulares, "sin perjuicio de la participación de los particulares en dicha ejecución en los términos establecidos por la legislación aplicable".

Del propio artículo 4 del T.R. del 92 (artículo 4 de la L.S.), se infiere que no es cierto que toda actividad urbanística sea pública, ni que la

403 Vid. PAREJO ALFONSO, L., "La ordenación y la gestión urbanística : un balance crítico", en Ciudad y Territorio, núm. 59-60, 1984, pp. 41 a 54; CARCELLER FERNANDEZ, A. , Instituciones de Derecho Urbanístico, Madrid, 1984, p. 325; LOPEZ PELLICER, J.A., Elaboración y gestión en el Planeamiento urbanístico (Intervención de los particulares), Madrid, 1983, p. 115.

404 Vid. DEL POZO CARRASCOSA, P. , Aspectos Generales del Sistema de Compensación, Madrid, 1993, p. 32. 
ejecución de los Planes de Urbanismo sea competencia exclusiva de los entes públicos ${ }^{405}$, sino que existe una actuación pública y una actuación privada, conforme establecen los artículos 104 del T.R. del 92 (art. 52.1 de la L.S.T.R del 76) y 1.2, 8.3 y 24.1del R.G.U., que fomentan la iniciativa privada en la ejecución de los Planes y la participación ciudadana en todas las fases de la gestión del urbanismo406

Así, en el sistema de compensación, los particulares asumen la ejecución del Plan constituidos en Junta de Compensación, o por sí mismos cuando todos los terrenos pertenezcan a un sólo titular (artículo 157 del T.R., artículo 126 de la L.S.). El sistema tiene por objeto la gestión y ejecución de la urbanización por los mismos propietarios del suelo (art. 157.1 del R.G.U. ${ }^{407}$. Es un sistema de gestión, donde tratan de conciliarse los intereses particulares y generales en orden al desarrollo de las funciones que pretenden alcanzarse con el régimen legal de la propiedad del suelo.

En el sistema de cooperación sí corresponde la ejecución a la Administración (art. 162 del T.R.; art. 131.1 de la L.S.; art. 186 de R.G.U.), pero los propietarios podrán constituirse en asociaciones administrativas con la finalidad de cooperar en la ejecución de las obras de urbanización (art. 162.3 del T.R. del 92; art. 131.3 de la L.S.T.R del 76; art. 191 del R.G.U.), con las funciones que establece el art. 193 del R.G.U. ${ }^{408}$

405 Cfr. comentarios al artículo 4 de la L.S.T.R del 76 (art. 4 del T.R. del 92), y el Reglamento de Gestión Urbanística en su artículo 1.2.

406 Vid. MARTINEZ LOPEZ MUÑOZ, Derecho de propiedad y proyecto de Ley de reforma de la Ley del Suelo, en Derecho urbanístico Local, Madrid, 1992, p. 88 y ss.

407 Vid. entre otros, GARCIA DE ENTERRIA, "Actuación pública y actuación privada en Derecho urbanístico" ,en Curso de Conferencias sobre propiedad horizontal y urbanizaciones privadas, R.C.D.I., 1987, pp. 9 y ss.; CARCELLER FERNANDEZ, Reparcelación y compensación en la gestión urbanística, Madrid, 1980, pp. 14 y ss.; GONZALEZ BERENGUER URRUTIA, J. L., Gestión, financiación y control del Urbanismo, Madrid, 1979, p.583.; COSCULLUELA, "Teoria general de la gestión urbanística”, R.D.U., no53, pp.28 y ss.

$408 \mathrm{El}$ art. 193 del R.G.U., establece textualmente que "Serán funciones de las asociaciones administrativas de cooperación las siguientes: a) Ofrecer a la administración actuante 
Cuando se hubiera adoptado el sistema de expropiación, el Estado, las Entidades locales y las Entidades urbanísticas, podrán ejecutar los Planes de ordenación a través de concesión administrativa. Los particulares ejecutan la obra urbanizadora como concesionarios, cuando así se acuerde por el órgano competente, a través del correspondiente concurso, en cuyas bases se fijarán los derechos y deberes del concesionario (art. 211 y 212 del R.G.U.).

Resumiendo, se podría decir, que el sistema de expropiación implica una gestión estrictamente pública, pues supone "la desaparición de la propiedad privada en la superficie afectada", y "urbanización por el órgano gestor con arreglo a fondos públicos, siquiera éstos se obtengan en algunos casos mediante contribuciones especiales"409; el sistema de cooperación cabe decir que conlleva una gestión mixta, con protagonismo de la administración en la realización de las obras de urbanización; y el sistema de compensación, finalmente, es el caso típico de gestión privada, con los naturales controles administrativos, que será objeto de estudio en este trabajo ${ }^{410}$. Estos dos últimos sistemas implican el "mantenimiento de los propietarios genéricamente considerados en la propiedad del suelo, pero sobre la base de que procedan a un reparto equitativo del volumen

sugerencias referentes a la ejecución del Plan en el polígono o unidad de actuación de que se trate. b) Auxiliar a la Administración en la vigilancia de la ejecución de las obras y dirigirse a ella denunciando los defectos que se observen y proponiendo medidas para el más correcto desarrollo de las obras. c) Colaborar con la Administración para el cobro de las cuotas de urbanización. d) Examinar la inversión de las cuotas de urbanización cuyo pago se haya anticipado, formulando ante la Administración actuante los reparos oportunos. e) Gestionar la concesión de los beneficios fiscales que procedan. f) Promover con la Administración actuante Empresas mixtas para la ejecución de obras de urbanización en el polígono o unidad de actuación ". (En las letras a) y f) las referencias a polígono o unidad de actuación deben entenderse hechas a unidad de ejecución. La Ley de Suelo, T.R. del 92 utiliza el término "unidad de ejecución" para definir el ámbito que comprende una actuación urbanística, sustituyendo así, a los usados en la anterior legislación indistintamente como unidad de actuación o polígono.

409 Vid Exposición de Motivos de la Ley del Suelo de 1975, VI-6.

410 Vid. GONZALEZ SALINAS, J. para quien estos dos últimos sistemas, suponen "el mantenimiento de los propietarios sobre la base, no sólo del principio de igualdad entre ellos, sino, en especial, del cumplimiento de la doble carga urbanística de cesión de terrenos y mantenimiento de la urbanización", en Sistema de Compensación y terceros adquirentes de suelo, Madrid, 1987, pp. 38 y ss., 
edificable, cedan gratuitamente el terreno destinado a viales, parques y jardines, templos, centros docentes y culturales, y demás servicios de interés general y costeen las obras de urbanización correspondiente" 411

\section{LA EJECUCION DEL PLANEAMIENTO.}

Por más que la ejecución del planeamiento sea el contenido "normal e institucionalmente más propio de gestión" 412 , la actividad de ejecución es más amplia, de tal forma que la ejecución se configura como un conjunto de operaciones que tienden a cumplir dos finalidades básicas, la de reparto de los beneficios y cargas resultantes del Plan y la de creación física del equipamiento urbano, que permite la edificación de los terrenos. Abarca por tanto la dirección, promoción y coordinación de todas las actuaciones urbanísticas, la realización de las obras de urbanización e, incluso, el desarrollo de acciones inmobiliarias de construcción.

La ejecución es una potestad urbanística (art. 3.3 del T.R. del 92; art. 3.3 de la L.S.T.R del 76), cuyo ejercicio sólo se legitima en un Plan urbanístico. Por tanto los dos momentos básicos de la ordenación urbanística, gestión y ejecución, no son independientes, sino que están estrechamente relacionados entre sí, produciéndose de forma sucesiva, al precisar el segundo del primero.

La actividad de ejecución persigue la materialización de las determinaciones del planeamiento, consiste en la transformación de la realidad, tanto física como jurídica. La transformación de la realidad física se lleva a cabo mediante la realización de las obras que sean precisas; en

\footnotetext{
411 Vid. Exposición de Motivos de la LS,1975, VI-6.

412 Vid. COSCULLUELA, "Teoria general de la gestión...", ob.cit., p. 30.
} 
este sentido es el proyecto de urbanización el que define las obras a ejecutar, cuantifica su costo y posibilita su construcción. La transformación de la realidad jurídica supone acomodar la situación jurídico-civil previa de los derechos reales, a las exigencias de dichas determinaciones, lo cual se cumple a través de los llamados sistemas de actuación, compensación, cooperación o expropiación, que determinan el estatuto o régimen regulador de la totalidad de las operaciones que comporta la ejecución del planeamiento que se lleve a cabo ${ }^{413}$.

El artículo 144 del T.R. del 92 (art. 117 de la L.S.T.R del 76) establece que "las unidades de ejecución se delimitarán de manera que permitan el cumplimiento conjunto de deberes de cesión, equidistribución y urbanización de la totalidad de su superficie...". Por tanto el mecanismo que posibilita estas obligaciones de los propietarios es la unidad de ejecución. A efectos de ejecución del planeamiento se distinguen dos tipos de delimitación urbanística, el área de reparto y la unidad de ejecución, que obedecen a finalidades muy diferentes Las áreas de reparto tienen la misión de fijar el aprovechamiento tipo en cada una de ellas (art. 95 del TR). Las unidades de ejecución, la de constituir ámbitos territoriales dentro de dichas áreas, para efectuar en la ejecución del planeamiento el cumplimiento conjunto por todos los afectados, de los deberes de cesión, equidistribución y urbanización (arts. 143 y 144 del TR), excluyéndose en todo caso, según su régimen, los terrenos destinados para sistemas generales.

413 Vid. GARCIA DE ENTERRIA y LUCIANO PAREJO, Lecciones de Derecho Urbanístico, Madrid, 1981, p. 28. 


\subsection{AREAS DE REPARTO.}

La denominación áreas de reparto de cargas y beneficios que utiliza la Ley, no es la más acertada, dado que en realidad no se reparten ni cargas ni beneficios, no es otra cosa que ámbitos territoriales en los que se dividen los suelos urbano, urbanizable, y acto para urbanizar, a efectos de establecer el aprovechamiento tipo ${ }^{414}$, o susceptible de apropiación de cada una de las áreas de reparto, y que va a servir de base para concretar la facultad de apropiación y patrimonialización de la edificabilidad establecida por el Plan, entre los propietarios de suelo.

A cada parcela le corresponde un número de unidades de aprovechamiento. El aprovechamiento urbanístico es un contenido inherente a la propiedad urbana que corresponde al propietario. La obligación de ceder se produce como una contribución a posteriori que se materializa mediante los procedimientos de equidistribución establecidos por la legislación urbanística autonómica. Si bien en la legislación anterior esta cesión era la consecuencia de una reducción del aprovechamiento urbanístico cifrada en el 15 por ciento, en la legislación vigente recupera la naturaleza de contribución en especie que corre a cargo del propietario fijada en un 10 por ciento, no como un mínimo abierto a la competencia

414 El aprovechamiento tipo trata de hacer efectivo el principio de igualdad en la distribución de cargas y beneficios del planeamiento, garantizando a todos los propietarios de terrenos incluidos en una de las áreas de reparto un porcentaje del aprovechamiento de cada uno de ellos, cualquiera que fuere la situación de los terrenos, estuvieren incluidos o no en una unidad de ejecución; vid. art. 95 y ss. del T.R. del 92, preceptos que constituyen concreciones propias del contenido de los Planes Generales, cuya competencia, obviamente urbanística, corresponde a las Comunidades Autónomas (f.jco.25 c) de la STC de 20 de marzo de 1997); GONZALEZ PEREZ, Comentarios a la Reforma de la Ley de Suelo, reimpresión de la $5^{\circ}$ ed., Madrid, 1990.I, comentario al art. 84, así como la bibliografía que allí se cita,; MARTIN HERNANDEZ, 'El aprovechamiento tipo como componente de la gestión urbanística en el suelo urbano", R.D.U., núm. 118, pp. 29 y ss; BRUSILOVSKY y FRANCHINI , "Reflexiones sobre el cálculo del aprovechamiento tipo en suelo urbano" R.D.U., núm. 120, pp. 23 y ss. y PORTO REY, "Cálculo de los aprovechamientos tipo", R.D.U., núm. 120, pp. 105 y ss. 
autonómica sino como un máximo y, será el resultado de referir a su superficie concreta el 90 por ciento del aprovechamiento tipo que corresponda al área de reparto en que se encuentre. En este sentido el aprovechamiento apropiable ha de entenderse como un derecho, predicable del propietario del terreno o de la parcela, cuya titularidad se determina propter rem, en decir, por la pertenencia de una finca determinada 415 .

El sistema funciona de la siguiente manera: Una vez delimitada el área de reparto y concretada la totalidad de unidades de aprovechamiento que contiene, calificadas en función de su edificabilidad y usos, se obtiene un aprovechamiento tipo. El aprovechamiento tipo es el elemento esencial de las técnicas de equidistribución y puede ser considerado como "la posibilidad de utilizar o construir una superficie de suelo comprendida en un área de reparto correspondiente con una determinada intensidad 0 volumen edificable 416 ". Es la edificabilidad de un área del plan, es decir, los metros cuadrados que el plan permite construir de un uso lucrativo (vivienda, terciario, industrial, etc.) en un área determinada y que se calcula sobre los metros cuadrados de superficie total de dicho área excluyendo en suelo urbano las superficies para usos no lucrativos existentes (m2 de edificabilidad / m2 de suelo). Para hallar el aprovechamiento tipo se dividirá la edificabilidad total, una vez ponderada con los usos, por la superficie total del área, lo cual dará como resultado la cifra porcentual citada que será la medida del aprovechamiento urbanístico del área. El aprovechamiento urbanístico es la edificabilidad, para todos los usos, que corresponde a un determinado ámbito territorial según se establece en el plan de urbanismo, es la concreción del "ius aedificandi "417

\footnotetext{
415 Vid. ARNAIZ EGUREN, R., Registro de la propiedad y urbanismo, Madrid, 1995, p. 79.

416 Vid. Publicaciones ABELLA, La Ley del Suelo. Comentarios al Texto Refundido de 1992.

T. I, p.518

417 El concepto de aprovechamiento urbanístico ha sido profundizado por LASO MARTINEZ, J.L. y LASO BAEZA, V., en su libro titulado El aprovechamiento urbanístico. Madrid, 1995 allí eleva a categorías jurídicas conceptos hasta ahora poco estudiados. 
El aprovechamiento tipo es la base para calcular el aprovechamiento susceptible de apropiación privada o patrimonializable (aprovech.subjetivo) que es el que la ley reconoce al propietario para su parcela, con independencia del aprovechamiento real (aprovechamiento objetivo) de la misma418. Como sabemos no todo el aprovechamiento lucrativo pertenece al propietario. La función social de la propiedad impone que una parte de la edificabilidad, de la plusvalía, vaya a parar a la Administración. La nueva Ley establece que sólo el 90 por 100 del aprovechamiento lucrativo total de un área de reparto pertenecerá a los propietarios $^{419}$.

Este aprovechamiento patrimonializable se materializará, bien en especie, o bien mediante la compensación económica correspondiente. El aprovechamiento patrimonializable es, en resumen, el contenido urbanístico del derecho de propiedad ${ }^{420}$.

La ley 8/90 "hizo descansar el peso de la reforma en la fijación de un aprovechamiento tipo, que el propietario de suelo puede adquirir, con el cumplimiento de los deberes urbanísticos; ésta es la rentabilidad que se

418 Vid. La diferencia entre valor objetivo y valores subjetivos la plantea PAREJO ALFONSO, L., en Suelo y Urbanismo: El nuevo Sistema Legal, Madrid, 1991, p. 172 y la recoge MERELO ABELA, J.M. en su libro El Régimen Jurídico del Suelo...,cit.p.413.

${ }^{419} \mathrm{El}$ art. 27 del TR del 92, establecía que sólo el 85 por ciento del aprovechamiento lucrativo total de un área de reparto pertenecerá a los propietarios, si bien, es declarado nulo por la STC de 20 de marzo de 1997, entre otros con análogo contenido, por la rigidez del 15 por 100 , impuesto a todas las Comunidades Autónomas, pero mantiene la participación de la comunidad en las plusvalías. Esta participación se contempla en varios de los artículos mantenidos, en concreto en el 3.1.c) y en el 7, que reiteran la participación de la comunidad en las plusvalías que genere la acción urbanística de los entes públicos y en el art. 20.1.b), que la concreta en la cesión del aprovechamiento que excede del susceptible de apropiación privada. Lo que queda pendiente es el quantum, a determinar por cada Comunidad Autónoma dentro de un criterio mínimo que sí podría fijar el Estado, (f.jco.17.c) de la Sentencia).Por lo tanto, queda claro, que se mantiene el principio legal de la cesión de parte de las plusvalías urbanísticas y que ello es obligado a la vista del artículo 47 de la Constitución. Las plusvalías se generan normalmente a través del planeamiento y su ejecución, pero también en forma directa, como sería el caso de una Ordenanza que duplicara la edificabilidad de solares existente. $Y$ cabe añadir que esta cesión de plusvalías es la contrapartida urbanística de la indemnización por cambio de planeamiento con reducción de aprovechamiento, del artículo 237 de la Ley del Suelo, que continúa vigente.

420 Vid. SERRANO ALBERCA, J.M., El derecho de propiedad, la expropiación y la valoración del suelo, Pamplona, 1995, p. 281 y ss. 
garantiza al propietario por incorporarse al proceso urbanizador y edificatorio" 421 .

\subsection{LA UNIDAD DE EJECUCION: CONCEPTO, PROCEDIMIENTO} Y REQUISITOS.

El termino "unidad de ejecución” hace referencia al ámbito físico dentro del cual se realiza una actuación urbanística, a efectos de ejecución del planeamiento se concibe como una delimitación específica del suelo cuya finalidad es la aplicación de un determinado procedimiento o sistema de actuación, a efectos del cumplimiento conjunto de deberes de cesión, reparto (equidistribución) y urbanización ${ }^{422}$ así, el artículo 143 del T.R señala: "la ejecución del planeamiento urbanístico se realizará mediante las unidades de ejecución que se delimiten dentro de cada área de reparto...”. Este precepto ha sido objeto de impugnación, por cuanto el Estado carece aquí de todo título competencial para prescribir que la ejecución se realice mediante unidades de ejecución y, menos aún, cuando procede la

421 Vid. DELGADO-IRIBARREN NEGRAO, M. y BALLESTEROS FERNANDEZ, A. , Comentarios a la Ley sobre Reforma del Régimen Urbanístico y Valoraciones del Suelo , Granada, 1990,pp. 107 y ss.

422 Vid. GARCIA DE ENTERIA-PAREJO, Lecciones de derecho...,ob.cit., p. 35; MERELO ABELA, J.M, La reforma del régimen urbanístico y valoraciones del suelo, Madrid, 1991, pp. 80 a 82.; GONZALEZ SALINAS, J., Las plusvalías urbanísticas: sistematización del alcance del artículo 47 de la Constitución, en "Estudios sobre la Constitución española (Homenaje al profesor Eduardo García de Enterría), Madrid, 1991, p. 1819. La St. de 2 de febrero de 1990 (Ar. 968 ) sienta esta doctrina general: " De la normativa que es de aplicación al caso, se puede resumir que las operaciones urbanísticas en suelo urbano preferentemente deben practicarse por zonas poligonales y, sólo ante la imposibilidad de hacerlo así, a través de Unidades de Actuación_artículo 117.2 del Texto Refundido de la Ley del Suelo, aunque en cualquiera de estas modalidades los propietarios de los inmuebles radicantes en unas o en otras están obligados a "ceder gratuitamente a los Ayuntamientos respectivos los terrenos destinados a viales, parques, jardines públicos y Centros de Educación General Básica, al servicio del polígono o unidad de actuación correspondiente", bien entendido que la imposición y materialización de este deber, como la de los restantes derivados del planeamiento, se habrá de producir repartiendo de modo equitativo los beneficios y las cargas, mediante el procedimiento, de la reparcelación a que se refieren los artículos 97 y 117 de dicho Texto, según se previene en el 83 del mismo de cuya conjunción obligadamente se deduce...". 
actuación a través de esta técnica urbanística. El legislador estatal puede, como hace el art. 140 T.R. del 92 no impugnado, establecer que la ejecución del planeamiento garantice la distribución equitativa de los beneficios y cargas entre los afectados, así como el cumplimiento de los deberes de cesión correspondientes y costeamiento de la obra urbanizadora, en la medida en que ello entronca con el estatuto básico de la propiedad urbana amparado en el art. 149.1.1 ${ }^{\circ}$ C.E en los términos ya expuestos. Pero no le incumbe determinar el instrumento, el procedimiento o la forma en que ha de llevarse a cabo la ejecución del planeamiento, cuestiones esas que corresponden a la competencia urbanística autonómica, sin perjuicio de que pueda tomar como punto de referencia, sin sentar su régimen jurídico, las áreas de reparto o las unidades de ejecución para regular las condiciones básicas de las facultades y deberes urbanísticos que garanticen la igualdad. Pero el art. 143 T.R. del 92 impugnado excede de la regulación de las condiciones básicas que garanticen la igualdad en el ejercicio de la propiedad urbana y en el cumplimiento de los deberes, también básicos, ex art. 149.1.1ํㅡ.E., cuando determina los supuestos en los que cabe establecer excepciones, sin que, para tal precisión normativa con pretensiones de norma básica, sean de aplicación los restantes títulos competenciales que invoca el Estado en la misma Disposición final única del T.R del 92 (f. jco. 27. b) ).

Si no fuese posible la delimitación cumpliendo tales exigencias es cuando, en suelo urbano, se permite la actuación asistemática ${ }^{423}$,

423 Bajo el concepto de actuaciones asistemáticas en suelo urbano, se recogen los diversos supuestos singulares que afectan a parcelas incorporadas al proceso edificatorio y las que por su dispersión espacial, no entran a formar parte de Unidades de Ejecución, en las que las cesiones y aprovechamientos se rigen por normas específicas que tienden a equiparar los procesos redistributivos con los generales, siempre que ello sea posible. En conjunto se contemplan sujetos al proceso redistributivo la totalidad de parcelas de propiedad privada, con aprovechamiento nulo o lucrativo, permitiendo, en un primer momento, que mediante operaciones jurídico-privadas en todas concurra el aprovechamiento en términos materiales o monetarios que les corresponde, y si esto no fuera posible, por falta de voluntad o acuerdo entre propietarios, la Administración intervendrá como mediadora, imponiendo coactivamente las transferencias o adquiriendo y cediendo los excesos y defectos de aprovechamiento a 
(artículo143 apartado segundoTR). Es decir, en este caso, no es necesaria la continuidad del terreno que integra la unidad de ejecución, sino que se permite que las unidades de ejecución sean discontinuas (art. 144.2 del TR), a fin de hacer posible que la delimitación cumpla los requisitos 424 .

Por tanto la ley del Suelo permite que existan terrenos en suelo urbano, que queden excluidos de las unidades de ejecución, y en este caso están sujetos tan sólo al cumplimiento de sus deberes urbanísticos de cesión y equidistribución a través de las actuaciones asistemáticas, mediante la técnica de las transferencias de aprovechamiento (TAU) ${ }^{425}$, no existiendo mecanismos para distribuir la carga de urbanizar (cada propietario, sólo debe, en su caso, convertir su parcela en solar).

Es un instrumento impulsado normalmente a iniciativa de los propietarios que deben ejercer su deber de edificar.

Las transferencias de aprovechamientos urbanísticos se definen como aquellas técnicas jurídicas de aplicación en suelo urbano, no incluido en unidades de ejecución (art. 29.1. b TR), que permiten resolver en la forma prevista en los arts. 151.2, 187 a 191 y 194 a 196 TR, los eventuales desajustes entre el aprovechamiento real de una parcela y el patrimonializable por su titular, y conviene precisar que nunca son objeto de transferencia los aprovechamientos reales, sino los aprovechamientos

cada parcela, para que la propiedad ejerza su derecho a edificarla o su obligación de cederla. Vid. BLANCA BLANQUER,M., Derecho Urbanístico Actual, tomo II, Madrid, 1993, pp. 274 y ss. ,así como los artículos 187 b) y c); 188; 189.1 y el 192 del T.R. del 92.

424 Vid. LLISET, Nuevo régimen urbanístico, El Consultor de los Ayuntamientos,1990 p. 131; DELGADO IRIBARREN y BALLESTEROS, Comentarios a la LRRU, Granada, 1990, p. 106. 425 Vid. art. 188 del T.R. del 92. Las TAU no se contemplan en la L.S. en su redacción primitiva ni en la reforma de 1975, en cambio han venido aplicándose en la práctica desde 1978. La técnica consiste en permitir a los propietarios transferir los excesos del aprovechamiento tipo susceptible de apropiación a aquellos otros propietarios a los que el planeamiento no les permite obtener realmente el porcentaje del aprovechamiento tipo susceptible de apropiación; vid., en este sentido, GARCIA BELLIDO y ENRIQUEZ DE SALAMANCA, "Transferencias del aprovechamiento urbanístico", R.D.U., núm. 65, pp. 39 y ss. MARTIN HERNANDEZ, "El aprovechamiento tipo...,"ob.cit.,pp.79 y ss.; BLASCO TOLEDO, "La transferencia de aprovechamiento urbanístico: su aplicación práctica”, R.D.U., núm. 65 y ss. 
patrimonializables por razón de su imposible materialización sobre la propia parcela de que dimanan ${ }^{426}$. Son notas esenciales de esta técnica la voluntariedad de la equidistribución y la existencia posible de parcelas discontinuas.

Entre los procedimientos previstos para lograr ese ajuste figuran:

- Ios acuerdos entre los propietarios, de cesión o distribución de parcelas en las que el aprovechamiento permitido excediera del susceptible de apropiación, y el que se encuentre en una situación inversa.

- y la venta directa a la Administración actuante del aprovechamiento no susceptible de materialización ${ }^{427}$.

Los terrenos dotacionales que no se hubiesen obtenido a través de las TAUS, se obtendrán "mediante expropiación u ocupación directa" (art.199.2.b)).

La ocupación directa es una situación similar a las transferencia de aprovechamientos, pero aquí la iniciativa no pertenece a los particulares si no a la Administración.

EL artículo 203.1 TR entiende por ocupación directa la obtención de terrenos afectos por el planeamiento a dotaciones públicas, mediante el reconocimiento a su titular del derecho a integrarse en una unidad de ejecución con exceso de aprovechamiento real. Se trata de un acto unilateral de la Administración que supone para el dueño de los terrenos la necesidad de soportar la ocupación, sin que pueda oponerse a ello. Como tal acto de imperio, se asemeja a la expropiación, pero no es tal, no sólo

426 Vid. MERELO ABELA , J.M., "Ejecución del planeamiento: actuaciones asistemáticas", en la Revista Catastro, ํo 17 , p. 76.

427 Vid. GONZALEZ PEREZ, Comentarios a la Ley de Reforma del Régimen Urbanístico y Valoraciones de Suelo, Madrid,1991, p. 315 ; de la misma manera se encuentra regulado este aspecto en el art. 199.2. a) del T.R. 
porque la Ley las regula como dos formas diferentes, en preceptos también distintos, el 203 y 202 del TR, sino porque además, en la expropiación resulta indispensable el justiprecio de la finca expropiada, independientemente de que su importe sea abonado precisamente en dinero (art. 48.2 LEF), o se pague transmitiendo al abonado otros terrenos, como establece el TR para expropiaciones no motivadas por incumplimiento de deberes urbanísticos (art. 217 TR). En la ocupación directa, en cambio, no existe trámite de justiprecio, ni se valora la finca a expropiar. La Administración se limita a reconocer que el terreno ocupado tiene un determinado número de unidades de aprovechamiento apropiable (203.3.2.c TR), y se los entrega en una unidad de ejecución en la que puedan materializarse, por existir en ella terrenos con aprovechamientos lucrativos por exceso. Al no existir expropiación, el dueño de un terreno ocupado no pierde la propiedad del mismo por el hecho de la ocupación hasta que se le adjudiquen en propiedad una o varias fincas de resultado 0 reemplazo en la unidad de ejecución a la que se ha trasladado su aprovechamiento. El propio texto Refundido reconoce expresamente la titularidad de la finca al propietario, al concederle el derecho a ser indemnizado en los términos establecidos en el artículo 112 de la LEF por el periodo de tiempo que medie desde la ocupación de sus terrenos hasta la aprobación definitiva del instrumento de redistribución correspondiente. Con la aprobación definitiva del expediente reparcelatorio o compensatorio de distribución relativo a la unidad de ejecución a la que ha sido trasladado se produce la adjudicación 428

En suelo urbanizable, en cambio, no se admite la discontinuidad de los terrenos, aquí no se da otra alternativa que la de ejecución por unidades delimitadas con sujeción a aquellos requisitos que comprenderán terrenos continuos. Si no se cumplieran estos requisitos, estaríamos ante una delimitación contraria al Ordenamiento jurídico, y, por tanto, inválida 429.

${ }^{428}$ Para un estudio más detenido del tema vid. MEDINA DE LEMUS, M. La propiedad urbana y el aprovechamiento urbanístico, Madrid, 1995, p. 314 y ss.

429 Vid. GONZALEZ PEREZ, Comentarios, ob.cit. p. 1119. 
La unidad de ejecución ha de cumplir, en la ejecución del planeamiento, una compleja función, que va desde constituir el soporte físico de una actuación urbanística hasta servir de marco para permitir o hacer posible el "cumplimiento de los deberes de cesión, equidistribución y urbanización de la totalidad de su superficie conforme a lo que establezca la legislación urbanística aplicable" (art.144.1 del T.R. y el art. 117.2 a) y b) de la L.S.) ${ }^{430}$. Por esta razón, no sería posible la delimitación de unidades de ejecución con aprovechamientos excesivamente dispares en relación con el aprovechamiento del área de reparto (art. 145 del TR y 36.2.2RGU). Además es necesario que las unidades de ejecución, sean capaces de absorber los costes que la urbanización comporta ${ }^{431}$.

El procedimiento de delimitación del ámbito territorial en que se desarrolla la actividad de ejecución, podrá iniciarse, según establece el artículo 146.2 y el art. 38.1.c RGU, directamente por los propios planes; pero si no se contuviera en éstos, o se quisiera modificar la previamente establecida, se hace necesario desarrollar un sencillo procedimiento, previsto en el art. 146.2 del TR, que puede iniciarse, de oficio o a instancia de parte, y que comprende los trámites de aprobación inicial, información pública por plazo de 15 días y acuerdo de aprobación definitiva, una vez examinadas las objeciones presentada ${ }^{432}$.

430 Vid., NUÑEZ RUIZ, Ejecución de los planes de urbanismo, Madrid,1974, p. 202; CARCELLER FERNANDEZ, Reparcelación y compensación en la gestión urbanística, Madrid, 1980, pp. 20 y ss.; GARCIA DE ENTERRIA y PAREJO, Lecciones....ob.cit., pp. 35 y SS.

431 Vid. GARCIA DE ENTERRIA Y PAREJO, Lecciones...ob.cit., p. 504.

432 Vid. los artículos 146 y 83.2.b) del TR y 118.1 y 13.2.a) de la LS, así como el art. 38 del RGU . Asímismo queda recogido en la Sentencia de 31 de enero de 1992 en su f. jco. 4º(Ar. 1244). 
La delimitación de las unidades de ejecución ha de cumplir los requisitos legales, enumerados por el art. 144.1 del T.R. y 117.2 de la L.S y que vamos a exponer a continuación ${ }^{433}$ :

1ํ. Es necesario que la delimitación de la unidad de ejecución permita (en función de sus dimensiones) un equilibrio entre las cesiones de suelo que sean imputables al polígono y el aprovechamiento lucrativo realizable, cesiones derivadas de la exigencias del Plan y de los Programas de Actuación Urbanística (art. 144 del T.R. y art. 117.2.a) de la L.S.) ${ }^{434}$.

Para determinar esta capacidad de asunción de las cesiones de suelo, han de tenerse en cuenta dos datos: las dimensiones del polígono (hoy unidad de ejecución) y las características de la ordenación. Es decir, es preciso, por un lado, que la superficie, la extensión del terreno que constituya la unidad, sea suficiente para que, una vez detraídas las superficies de cesión gratuita obligatoria, el resto, lo que queda en propiedad de los particulares, sea asimismo suficiente para cumplir con el segundo requisito, la distribución equitativa de beneficios y cargas; y por otro lado, es preciso tener en cuenta las características de la ordenación de

433 En el ámbito jurisprudencial, la St. de 31 de enero de 1992 (Ar. 1244) en su considerando quinto, recoge estos requisitos: "El propio texto legal art. 117.2, fija los criterios materiales a los que debe atenerse la operación, estableciendo tres requisitos básicos de los que en todo caso, depende la validez de la delimitación, cuales son: A) Por sus dimensiones y características de la ordenación, sean susceptibles de asumir las cesiones de suelo derivadas de las exigencias del Plan y de los Programas de Actuación Urbanística. B) Que hagan posible la distribución equitativa de los beneficios y cargas de la urbanización, lo que comporta tanto la prohibición de delimitar polígonos o unidades de actuación contiguos a terrenos de cesión obligatoria y gratuita, sin incluir en los mismos la parte correspondiente de dichos terrenos (art. 117.4 de la Ley), como configurar polígonos dentro de un mismo sector cuyas diferencias de aprovechamiento entre sí, con relación al aprovechamiento del sector, sea superior al 15 por 100 (art. 36.2 del RGU). C) Que tengan entidad suficiente para justificar técnica y económicamente la autonomía de la actuación". La Ley, después de reforma de 1975, modificó la regulación de estos requisitos. Más que en función de las características del aprovechamiento, que era el criterio prevalente de la normativa anterior, se parte de la idea central de que haga posible la actuación urbanística dentro del principio de equitativa distribución de beneficios y cargas del planeamiento. Lo esencial, lo fundamental es que tengan entidad suficiente para justificar la autonomía de la actuación, de tal modo que, en atención a las cesiones obligatorias, sea posible la urbanización. Esta es la idea rectora de los requisitos exigidos en el número 2 del art. 144 del TR.

434 Vid. GONZALEZ PEREZ, Comentarios a la Ley de Suelo, Madrid, 1988, 1135 y ss. 
esa superficie, a fin de valorar hasta qué punto el aprovechamiento previsto en el Plan puede compensar las cesiones.

$2^{\circ}$ Como ya hemos señalado, la suficiencia de la unidad para asumir las cesiones ha de determinarse, en función de que el resto permita hacer realidad la distribución de beneficios y cargas de la urbanización. A estos efectos tiene gran relevancia el aprovechamiento tipo, debe procurarse que en cada unidad de ejecución se respete ese aprovechamiento, de esa forma se facilitará la actuación y se evitará tener que utilizar el mecanismo siempre complicado de las compensaciones. El art. 145 del T.R. y el art. $36.2^{\circ} 2^{\circ}$ del R.G.U delimitan un supuesto en el que no se cumpliría ese requisito, por lo que establece su improcedencia. Dice así: "A los efectos de hacer posible la distribución equitativa de los beneficios y cargas de la urbanización, no se podrán delimitar polígonos (debe entenderse por tal unidades de ejecución) dentro de un mismo sector cuyas diferencias de aprovechamiento entre sí con relación al aprovechamiento del sector sea superior al 15 por 100. Es decir, no es posible la delimitación de unidades de ejecución con aprovechamientos dispares en relación con el aprovechamiento del área de reparto.

3ํAㄹomás esa unidad de ejecución ha de hacer posible el cumplimiento del deber de urbanización de la totalidad de la unidad de ejecución, tanto en suelo urbano como en el urbanizable. Esta carga pesa sobre los propietarios afectados por una actuación, como requisito para la adquisición plena del derecho al aprovechamiento y como contrapartida por los beneficios derivados de la urbanización.

También, el artículo 186 hace referencia a la realización, por los propietarios afectados, de las obras de urbanización que garanticen su 
transformación en "solares" en el caso de actuaciones fuera de unidades de ejecución (asistemáticas).

Es preciso por tanto que la unidad tenga entidad suficiente para justificar técnica y económicamente la autonomía de la actuación urbanística $^{435}$. Este es un requisito no recogido expresamente en el T.R.; si bien, se deduce del propio art. 155436, hallándose previsto en el art.117.2.c) de la L.S del 76.

Los costes de urbanización a que se refieren los apartados a), b) y c) del párrafo 1 del art.155, habrán de ser sufragados por todos los propietarios afectados; para ello, se exigen dos requisitos generales :

1. Que estén previstos en los Planes y Proyectos. El Plan es el que determina el deber. De él deriva la carga de los propietarios.

2. Que sean de interés para el sector o área de actuación. En principio, habrá que estar al territorio de la unidad de ejecución. Los propietarios deberán costear todas las obras de urbanización que se realicen dentro del mismo. Pero puede que dentro del territorio de la unidad de ejecución, existan obras de urbanización que sean de interés general a varios sectores; por ejemplo, un parque urbano público general. En estos casos las obras serán sufragadas por los propietarios de terrenos situados en todos los sectores que resulten beneficiados 437 .

435 Vid. GARCIA DE ENTERRIA y PAREJO, Lecciones...,ob, cit., p.39: GONZALEZ PEREZ, Comentarios...,ob.cit., p. 1143.

$436^{\mathrm{En}}$ los gastos de urbanización que deben sufragar los propietarios afectados se comprenden los siguientes conceptos a tenor del art. 155.1 del TR: "a) El coste de las obras de vialidad, saneamiento, suministro de agua y energía eléctrica, alumbrado público, arbolado y jardinería, que estén previstas en los Planes y Proyectos y sean de interés para la unidad de ejecución, sin perjuicio del derecho a reintegrarse de los gastos de instalación de las redes de suministro de agua y energía eléctrica con cargo a las empresas que prestaren los servicios, salvo la parte que deban contribuir los usuarios según la reglamentación de aquéllos, sin perjuicio de la señalada en el artículo 30 de la Ley Reguladora de las Haciendas Locales. b) Las indemnizaciones procedentes por el derribo de construcciones, destrucción de plantaciones, obras e instalaciones que exijan la ejecución de los Planes. c) El coste de los Planes Parciales y de los Proyectos de Urbanización y gastos originados por la compensación y reparcelación. Art. 122.1 de la LS y arts. 59 a 61 del RGU.

437 Vid. GONZALEZ PEREZ, Comentarios.., I, ob.cit., pp. 1173 y 1174; GONZALEZ BERENGUER URRUTIA, J.L., Gestión, financiación y control del urbanismo, Madrid, 1979, 
Finalmente resta señalar, que caben dos posibilidades de llevar a efecto el cumplimiento de esta carga:

- que la urbanización la efectúen los particulares a su costa mediante la ejecución del Plan correspondiente por el sistema de compensación (arts. 157 y ss del TR; art. 126 y ss de la LS, cuestión objeto de estudio en este trabajo).

- o que la Administración ejecute las obras de urbanización con cargo a los propietarios en el sistema de cooperación (art. 162 y ss.; art. 131 y ss. de la LS); en este último supuesto, procederá la aplicación del art. 155.2 del TR, art. 122.2 de la LS. En el sistema de expropiación, no tiene sentido hablar del deber de costear la urbanización 438.

Los requisitos anteriores no son suficientes para que la delimitación de la unidad de ejecución se ajuste al Ordenamiento jurídico si no se cumple este tercero.

Dado que es obligación de los propietarios del suelo costear la urbanización, al delimitar la unidad de ejecución, debe tenerse en cuenta la obra de urbanización a realizar dentro de la misma, a fin de que el aprovechamiento de las superficies particulares permita a los propietarios soportar el coste de las obras.

En definitiva, la delimitación poligonal sólo es válida en la medida en que determine una actuación urbanística rentable ${ }^{439}$.

La actuación a través de estas unidades de ejecución constituye el sistema ideal para la realización de los principios informadores del Ordenamiento Urbanístico ${ }^{440}$.

pp. 677 y ss.; ORTEGA GARCIA, Los deberes o cargas en la legislación urbanística, Madrid, 1974, pp. 122 a 150.

438 Vid. LOBATO GOMEZ, Propiedad Privada ...,ob. cit., p. 527.

439 Vid , NUÑEZ RUIZ, Ejecución de los planes ..., ob.cit., p. 210; GARCIA DE ENTERRIA Y PAREJO , Lecciones ...., ob.cit., p. 41. 
Una vez delimitada la unidad de ejecución, la actuación urbanística exige la aplicación de una serie de procesos ordenados que se denominan sistemas de actuación.

\section{LOS SISTEMAS DE ACTUACION.}

\subsection{CONCEPTO.}

Toda actuación urbanística sobre un determinado espacio, se realiza a través de los denominados "sistemas de actuación"441. Son los cauces formales establecidos por el Ordenamiento Jurídico para la ejecución del planeamiento mediante unidades de ejecución ${ }^{442}$. Es decir, los sistemas de actuación engloban el conjunto de las distintas operaciones de la ejecución urbanística hasta la completa realización de la actuación urbanística (cesiones de suelo; distribución de beneficios y cargas mediante reparcelación o compensación, en su caso; realización de la obra urbanizadora) sobre un determinado espacio ${ }^{443}$. Contiene, por un lado, el

\footnotetext{
440 Vid. GONZALEZ SALINAS, J., Las plusvalías...,cit., p. 1824 , donde dice que " Si el sistema de actuación es el de expropiación, al quedar apartados los propietarios iniciales, no habrá beneficios ni cargas que repartir y el tema se centra en el justiprecio o valoración (urbanística en su caso ) de las propiedades comprendidas en tales polígonos ". Desde el punto de vista jurisprudencial la St. de 22 de mayo de 1980, sienta esta doctrina general : "Los actos de ejecución de los Planes Generales están sometidos por el artículo 104 de la Ley del Suelo de 1956 , al principio de unidad de actuación por polígonos", reiterando esta doctrina , la St. de 17 de octubre de 1985, confirma un considerando de la apelada, que dice : "Hay que recordar que, en principio, la acción urbanística debe realizarse por polígonos, que vienen a constituir una unidad cuya finalidad es la división del territorio a efectos de actuación urbanística. El polígono es , como recuerda la St. de 22 de mayo de 1980, la unidad que la Ley establece para la ejecución de los Planes de Ordenación. En el mismo sentido, la St. de 10 de junio de 1985 y la St. de 31 de enero de 1992 .

${ }^{441}$ En la Exposición de Motivos de la Ley del Suelo de 1975, IV- 5, se establece que los sistemas de actuación "son las distintas regulaciones legalmente previstas para ejecutar el Plan en cada polígono".

442 Vid. LLISET BORRELL, Nuevo Régimen urbanístico, Madrid, 1990, p.146.

443 Vid. LOPEZ PELLICER, J.A., Elaboración y Gestión en el planeamiento urbanístico, Madrid, 1983, pp. 155-156. en el mismo sentido GARCIA DE ENTERRIA- PAREJO ALFONSO, , Lecciones de Derecho Urbanístico, Madrid, 1981, p.512 quienes definen los sistemas de actuación urbanística, como "distintas técnicas para aplicar la plusvalía urbanística a la ejecución de la obra urbanizadora".
} 
régimen jurídico de la ejecución urbanística, en el sentido de determinar quién tiene la iniciativa y el protagonismo de la ejecución del Plan; y por otro, los mecanismos y criterios de distribución de los beneficios y cargas derivados del planeamiento 444 .

La Ley del suelo dedica a los sistemas de actuación los artículos 148 a 176. La mayoría de estos artículos sólo se aplican supletoriamente en las Comunidades Autónomas, si bien existen normas que constituyen legislación básica, así los arts.149.3, 150, 151.1 y 3, 166.1.a) y e), 167, 176,183 y 184.2; y son de aplicación plena las normas contenidas en los artículos $159.4,160.3,168,169,170.1,173,174.2$. Tras la publicación de la sentencia del T.C de 20 de marzo de 997, únicamente se mantienen en vigor los arts. 159.4, 168, 169, 170.1 y 183 al entender que el resto de los preceptos invaden la competencia autonómica en materia de urbanismo.

\subsection{CLASES DE SISTEMAS DE ACTUACION}

La Ley establece distintos sistemas en función del mayor o menor protagonismo de los propietarios en la ejecución del planeamiento ${ }^{445}$. Cabe distinguir entre dichos sistemas los que admiten la colaboración de la iniciativa privada, es decir, los de cooperación y compensación, y el de participación pública exclusiva que se manifiesta en el de expropiación forzosa, si bien con determinadas excepciones ${ }^{446}$. En el sistema de

444 Vid. DEL POZO CARRASCOSA, P., El sistema de Compensación Urbanística ${ }_{1}$ Madrid, 1992 , p. 31.

445 Vid. FERNANDEZ RODRIGUEZ, Manual de Derecho urbanístico, 9 ed. , Madrid, 1991, p. 156; GARCIA DE ENTERRIA Y PAREJO, Lecciones, cit., p. 515.

446 Vid. GONZALEZ BERENGER, quien en su obra Gestión, financiación y control del Urbanismo, Madrid, 1979, p. 371 y ss., hace una puntualización de estos supuestos, 
cooperación es preciso diferenciar dos aspectos distintos, por un lado la ejecución material de la obra de urbanización, la cual se lleva a cabo por la Administración actuante, siendo los propietarios de los terrenos incluidos en la unidad de ejecución los obligados a su financiación, en proporción a la superficie de tales terrenos y por otro el mecanismo a través del cual se lleva a cabo el reparto de beneficios y cargas entre los propietario, denominado Proyecto de Reparcelación, dicho proyecto se tramita por la Administración actuante, de oficio o a instancia de un porcentaje determinado de propietarios, y tiene por objeto:

a) Adaptar la descripción y características de las antiguas fincas incluidas en la unidad de ejecución a la nueva parcelación resultante del Plan.

b) Transmitir a la administración actuante las fincas de cesión obligatoria con destino a su afectación al dominio público y uso público (zonas verdes y viales). También serán objeto de cesión las fincas en las que se materializa el aprovechamiento urbanístico perteneciente a la Administración por ministerio de la Ley, en función del área de reparto en que se sitúe. Este conjunto de actos de atribución implica el nacimiento de una nueva titularidad no preexistente al proceso de ejecución.

c) Garantizar el deber urbanístico de financiar la obra de urbanización 447

Por lo que se refiere al sistema de compensación, en el que profundizaremos a continuación, simplemente adelantar aquí que esta modalidad de actuación se caracteriza porque la obligación de realizar la

diciendo que caben cuatro posibilidades,actuación privada en suelo privado (compensación) o se actúa públicamente en suelo privado (cooperación) o se actúa públicamente en suelo público (expropiación con ejecución por la Admón.) o se actúa privadamente en suelo público (expropiación actuada mediante concesión).

447 Vid. ARNAIZ EGUREN, R., Registro de la propiedad...,cit. p. 80 y 81, 
infraestructura urbana se imputa a los propietarios de los terrenos incluidos en la unidad. Los propietarios aportarán los terrenos de cesión obligatoria, realizarán a su costa la urbanización y, si son varios, se constituirán en Junta de Compensación ${ }^{448}$.

Por lo que se refiere al sistema de expropiación, se ha dicho que no estamos propiamente ante un sistema de actuación, pues éste nada dice sobre la gestión de la actuación urbanística una vez realizada la operación preliminar expropiatoria, por lo que más bien podría calificarse de sistema para la puesta en manos públicas de la totalidad del suelo, sujeto a la actuación para la realización de ésta por la Administración ${ }^{449}$.

\subsection{ELECCION DEL SISTEMA DE ACTUACION URBANISTICA}

De la lectura de los artículos 140 a 160 relativos a la "Ejecución del Planeamiento" y al "Sistema de Compensación", nos permite comprobar que no existen diferencias sustanciales respecto de la legislación anterior salvo una básica, que es la de que en todos los supuestos es la Administración quien elige el sistema de ejecución del planeamiento, que en la actualidad a quedado en entredicho tras la publicación de la STC 61/1997, recobrando su vigencia el art. 119.3 de la LS del 76.

El artículo 148 de Ley del Suelo del 92 establece que "las unidades de ejecución se desarrollarán por el sistema que la Administración elija en cada caso". Sin embargo, la antigua ley del 76, en virtud de la cual podían elegir el sistema de compensación los propietarios que representasen el 60 por 100 de la superficie del polígono o unidad de

448 Vid. BOUX REIG, Urbanismo y Derecho, Madrid, 1990, p. 176; BORREGO LOPEZ, EI sistema de compensación, en Derecho urbanístico local Madrid, 1992, p. 305 y ss.

449 Vid. en este sentido GARCIA DE ENTERRIA y PAREJO, Lecciones...,ob.cit. p. 55, en idénticos términos, PAREJO ALFONSO,L., Derecho Urbanístico, Instituciones básicas, Ed. Ciudad Argentina, 1986, p. 436. 
actuación (art. 119. 3 LS y 159-160 del RGU)450, hoy unidad de ejecución, recupera su vigencia.

En la Ley del 92 podían solicitarlo pero dicha solicitud "no vinculará a la Administración", pudiendo ésta denegarla sin que, por lo que se deduce en la Ley, tenga que razonar tal denegación (art. 149.2 LS), debiendo siempre la Administración elegir el sistema basándose en criterios técnicos y de viabilidad económica 451 .

Por el contrario la Administración sí deberá “justificar” el cambio de sistema cuando éste ya venía establecido con la Unidad de Ejecución (art. 149.1 de la LS) ${ }^{452}$.

${ }^{450} \mathrm{De}$ ahí se deduce que cuando la administración no había impuesto un sistema de actuación determinado en el propio plan o programa de actuación urbanística, sino que ello debía de realizarse en el expediente de delimitación del polígono, los particulares podían imponer a la administración el sistema de compensación de manera que ésta no podía oponerse a la gestión urbanística por este sistema, sin perjuicio de la potestad que la Admón. tenía y tiene, en determinadas ocasiones de imponer la sustitución del sistema de compensación (art. 156 y 183.1 del RGU), DEL POZO CARRASCOSA, Sistema de Compensación...ob.cit. p. 35; MARTIN BLANCO, La compensación...,ob. cit. pp. 117 y 118. En el ámbito jurisprudencial vid. las siguientes sentencias : St. 7 de marzo 1974 , reconoce que "la elección corresponde a la Administración en ejercicio de una facultad discrecional ; St. 22 enero 1962; St. 6 mayo 1968;Sts. 26febrero y 2 mayo de 1969; St. 29 diciembre 1972; St. 4 diciembre 1978; St. 31 octubre 1979 ; en análogo sentido las sentencias de 4 junio1980; 26 diciembre 1983 (Ar. 6416) así como la St. 10 junio 1985 (Ar. 4827) "en aplicación de la Ley del Suelo de 1976 si los propietarios del suelo representaban el 60 por 100 de la superficie del Polígono y éstos solicitaban la ejecución por el sistema de compensación la Administración estaba obligada a permitir que se ejecutara por este sistema". 451 Vid. St. de 4 de octubre de 1993, Ar. 7345 donde se establece que "El sistema de actuación que en cada caso se elija por la Administración actuante, depende esencialmente de la capacidad financiera pública y de gestión tanto pública como privada, teniendo en cuenta que generalmente en suelo urbano muy consolidado se tiende a utilizar el de cooperación". La elección del sistema de actuación ha de efectuarse en el Plan o en el Programa de Actuación Urbanística y, en su defecto, al delimitarse el polígono o unidad de actuación (art. 152.3 y 154 de R.G.U.; art. 146.2 del T.R.; art. 118.1 de la L.S.), siguiendo los criterios fijados en el art. 153 del R.G.U. donde se establece que "al determinarse el sistema de actuación, se deberá justificar su viabilidad en función de las necesidades medios económico-financieros con que cuenta la Administración, la posibilidad de colaboración de la iniciativa privada y las demás circunstancias que concurran en cada polígono.

452 La Administración pública, asimismo, podrá sustituir el sistema inicialmente elegido, no sólo en el supuesto de incumplimiento por los particulares de los plazos para cumplir los deberes urbanísticos cuando se hubiere elegido un sistema de gestión privada (art. 149.4 del TR), sino, en general, cuando se estime justificada (art. 149.1)Cfr. St. 23 noviembre 1984 (Ar. 6225); St. 23 mayo 1991 (Ar.5242);St. 30 enero 1990 (Ar. 937); St.26 diciembre 1991 (Ar. 361);St.10 diciembre 1991 (Ar.1411) entre otras. 
Por tanto, la determinación o elección del sistema de actuación, es una potestad pública, discrecional de la Administración. Esa discrecionalidad administrativa (potestad de la administración) tiene limitaciones, ya que está sujeta a las normas que regulan el procedimiento así como a los criterios para la elección del sistema de actuación.

A pesar de que un sector de la doctrina considera que estas limitaciones fueron prácticamente eliminadas por la $L R R U^{453}$, la redacción definitiva del artículo 149.2 del TRLS, permite entender que subsisten los criterios preferenciales de la normativa anterior ${ }^{454}$. En todo caso la normativa de la LRRU, que modificó la del texto de la LS del 76, supuso una ampliación de las facultades discrecionales que había limitado la reforma del 75, reforma que permitió afirmar que la elección del sistema constituía una actividad reglada en buena parte 455 .

El sistema de actuación se determinará en el Planeamiento general $o$ en el procedimiento para la delimitación de unidades de ejecución (art. 152.3 RGU). Una vez determinado el sistema de actuación para la ejecución del Plan en una unidad de ejecución, no quiere decir que Administración y particulares vengan obligados al mismo sin posibilidades

453 Vid. T.R. FERNANDEZ, Manual de derecho Urbanístico, Madrid, 1991, p.168 y LLISET BORRELL, en Nuevo régimen urbanístico, ob.cit. pp. 148 y ss. Si bien éste destaca que cada legislador autonómico podrá establecer una graduación de preferencias.

${ }^{454}$ Así lo entienden DELGADO-IRIBARREN y BALLESTEROS, en Comentarios a la LS, Granada, 1990, quienes afirman que "la Ley $8 / 90$ no ha modificado la preferencia de los sistemas de gestión, sino que ha graduado y concretado la posibilidad expropiatoria en caso de incumplimiento y efectuando puntuales habilitaciones para expropiar en supuestos de interés público prevalente. GONZALEZ PEREZ, J. Comentarios a la Ley del Suelo, (Texto Refundido de 1992). Sexta edición, Madrid, 1993, p. 1159, quien establece que la Administración resolverá según su más absoluta discrecionalidad, solo limitada por los principios generales del Derecho.

455 La reforma de la Ley del Suelo de 1975, permitió afirmar que la elección del sistema constituía una actividad reglada. En la misma dirección, vid, GONZALEZ BERENGUER, en Gestión, financiación y control del urbanismo, Madrid, 1979, p. 372, al decir que "hoy es evidente que ha desaparecido la discrecionalidad en orden a la elección del sistema" y GARCIA DE ENTERRIA Y PAREJO, Lecciones...,ob.cit., pp. 57 y ss. En parecidos términos, CARCELLER, Reparcelación y compensación en la gestión urbanística, Madrid, 1980, pp. 69 y ss.; PEREZ PASCUAL, E., Sugerencias a una futura Ley sobre urbanizaciones privadas, RCDI, no 578 (1987), pp. 9 y ss., y ABELLA, Reglamento de gestión urbanística (con la colaboración de Chorot y LLiset), Madrid, 1980, pp.399 y ss. 
de sustitución, sino que esta será posible, bien porque se considere justificada por la Administración (art. 149.1 TR) o bien por incumplimiento de los deberes de cesión, equidistribución y urbanización en el supuesto de que se hubiese fijado un sistema de gestión privada (art.149.3 TR). El efecto del incumplimiento será la sustitución del sistema por otro de gestión pública, así lo establece el art. 149.4, regla $1^{\circ}$, ahora bien, la regla $2^{\circ}$ del mismo número 4 reconoce a los propietarios que cumplan los requisitos que en él se señalan el derecho a conservar el derecho a adquirir el aprovechamiento urbanístico, siendo expropiados los restantes por el valor que establece el artículo 42.3. Por lo que en caso de que el incumplimiento de los deberes urbanísticos no fuese total, no procederá la sustitución del sistema de compensación, sino la expropiación de los derechos de los propietarios que hubiesen incumplido a favor de la Junta de compensación, que tendrá la condición jurídica de beneficiaria, (arts. 181 a 183 RGU). No obstante, del texto literal del número 4, regla 3o del art.149, parece desprenderse que en el supuesto de incumplimiento parcial la Administración puede optar por sustituir el sistema de compensación por el de expropiación, si bien en este caso las parcelas de los propietarios que conservasen el derecho a adquirir el aprovechamiento urbanístico será el correspondiente al 75 por 100 del aprovechamiento tipo del área de reparto, si se trata de suelo urbano, o el 50 por 100 , si se trata de suelo urbanizable (Art.32 TR), en lugar del establecido en el artículo 42.3 TR ${ }^{456}$.

Si la falta de ejecución del plan fuese imputable a la Administración actuante, los propietarios afectados conservarán sus derechos a iniciar o proseguir el proceso urbanizador y edificatorio ${ }^{457^{*}}$

456 Según este precepto, el aprovechamiento susceptible de apropiación se reducirá en un $50 \%$, cuando no se hubiera adquirido ese derecho en el momento de la notificación del incumplimiento Vid. GONZALEZ PEREZ,J., Comentarios...,cit., p. 1164

457 Vid. GONZALEZ PEREZ,J., Comentarios a la LRRU, Madrid, 1991, p. 279-280; DELGADO-IRIBARREN Y BALLESTEROS, en Comentarios a la LRRU, Granada, 1990 , p. 121 , señalan que lo establecido en este artículo "no quiere decir que cualquier retraso en la ejecución imputable a la Administración deje inerme a ésta ante futuros incumplimientos de los propietarios, sino que, por analogía con lo dispuesto en el artículo 140 del Reglamento 
Una vez hechas todo esta serie de consideraciones acerca de los diferentes sistemas de actuación urbanística, centraremos nuestra investigación en el análisis del sistema de compensación, al considerar a este sistema de actuación, y sobre todo teniendo en cuenta los objetivos de este trabajo, como modo o sistema de distribución de las cargas y beneficios entre los propietarios afectados para lograr la justa distribución de aquéllos (art. 3.1.b). La imposición de excesivas cargas no justifica la actuación de la función social de la propiedad, sino que es, o puede ser, ilegalidad, arbitrariedad o confiscación total o parcial de la misma.

El sistema de compensación, cuando se dan los requisitos para el mismo, no confiere derecho indemnizatorio a los individuos que se ven afectados por él (art. 6, 7 y 8 del TR y 76 y 87 de la LS del 76) lo cual permite configurar al sistema de compensación como límite del derecho de propiedad, es decir, como aquello que constituye el contenido normal del derecho de propiedad o el punto normal hasta donde llega el poder del dueño, o sea el régimen ordinario de restricciones a que está sometido tal poder ${ }^{458}$. No es sólo la configuración del sistema de compensación como límite del derecho de propiedad lo que legitima su estudio desde el punto de vista civil, clarificando, de esta forma, instituciones jurídicas que por diferentes razones se han estudiado prioritariamente desde otras ramas del derecho, sino la amplitud de su ámbito civil, ya que, a parte de incidir en la propiedad, utiliza conceptos civiles como adjudicación (art.157.3, 159.4), transmisión (art. 159.1), fiduciario, poder de disposición (art. 159.2) o aportación (art. 159.4)459 ; siendo, en todo caso, conscientes de la importante carga de Derecho Administrativo, o en general de Derecho Público que tiene la materia.

General de Contratos del Estado, los planes generales establecidos para el cumplimiento de los deberes urbanísticos deben entenderse ampliados por un plazo igual al tiempo perdido por causa de la actuación administrativa".

458 Vid. ALBALADEJO, Derecho civil, III, Madrid, 1995,p.257.

459 Vid. BADOSA COLL, F. En el prólogo al libro de DEL POZO CARRASCOSA, El sistema de compensación urbanística, Madrid, 1993 


\section{CAPITULO OCTAVO}

\section{EL SISTEMA DE COMPENSACION URBANISTICA}

\section{INTRODUCCION}

Como ya hemos puesto de manifiesto en líneas anteriores, la normativa, de la Ley del Suelo T.R. del 92, que regula este sistema de actuación urbanística, ha sido declarada inconstitucional, si bien lo impugnado a través de la interposición de los diferentes recursos no es el aspecto material de la regulación sino el carácter formal de precepto básico, de aplicación plena o supletoria que se otorga a la misma en cada caso a través de la Disposición Final Unica del TRLS del 92.

Así, desde la publicación de la sentencia del Tribunal Constitucional de 20 de marzo de 1997, las normas estatales que regulan estas cuestiones serán (aunque con derogaciones y alteraciones parciales como veremos en su momento), los preceptos de la LSTR del 92 que queden vigentes y como legislación estatal de aplicación supletoria el TRLS del 76, en la parte no derogada por el bloque de la constitucionalidad, por los Reales Decretos Ley 3/ 1980, sobre promoción de suelo y agilización de la gestión urbanística, y 16/1981, de 16 de octubre, sobre adaptación de planes generales de ordenación urbana y los Reglamentos de planeamiento, gestión y disciplina urbanística, todos de 1978, sin olvidar los de fecha más antigua: Reglamento de Edificación forzosa y Registro de Solares de 1964 y Reglamento de reparcelación de 1966. 


\section{CONCEPTO Y CARACTERES}

El sistema de compensación se regula en los artículos 157 a 161

del T.R del 92, de los cuales sólo se mantiene vigente el art. 159 en su

párrafo cuarto, razón por la cual nos veremos obligados a hacer una

remisión a los arts. 126 a 130 de la LSTR del 76, y concordantes del

Reglamento de Gestión (art. 157 y ss) ${ }^{460}$.Es el artículo 157.1 del RGU, el

que lo define mejor.

460 En la legislación de las Comunidades Autónomas son pocas las especialidades sobre sistema de compensación. En las líneas que siguen, a título ejemplificativo, vamos a señalar algunas de ellas. En Aragón la Ley 5/1999, de 25 de marzo amplía notablemente los sistemas de actuación, configurándolos directamente como formas de gestión de una actividad pública, la actividad urbanizadora. Se pone fin, así, en la Comunidad Autónoma, a la anterior distinción entre sistemas públicos y privados, complicada por la posibilidad de gestión de los primeros mediante formas directas o indirectas, de manera que terminaba dándose la posibilidad de sistemas públicos de gestión privada. En la Ley aragonesa, la urbanización es siempre una función pública, que se gestiona directamente por la Administración, en los sistemas de expropiación y cooperación (arts. 132 a 137), o indirectamente, por un urbanizador, propietario o no, aunque éste goza de una amplia preferencia en el caso de que decida ejecutar por sí mismo la urbanización, mediante los sistemas de compensación, ejecución forzosa o concesión de obra urbanizadora (art. 138 a 156). En Castilla-León la Ley 5/1999, de 15 de abril, en el título tercero aborda la gestión urbanística, es decir, el conjunto de procedimientos para la ejecución del planeamiento. Intenta aquí la Ley, reconociendo la gran variedad de las formas del desarrollo urbanístico, eludir un diseño que las predetermine, como ha sido habitual en la legislación anterior. Por ello se despliega a disposición de las Administraciones una pluralidad de sistemas, a fin de que no sea la rigidez procedimental un obstáculo a la ejecución del planeamiento, objetivo este preferible a la simetría de los mecanismos administrativos. Las formas de gestión que la Ley propone pueden agruparse en dos: para el suelo urbano consolidado, las actuaciones aisladas (arts.69 a 71), de sencilla ejecución; y para el suelo urbano no consolidado y el suelo urbanizable, las actuaciones integradas, que se desarrollaran mediante los sistemas siguientes: concierto, compensación, cooperación, concurrencia y expropiación (arts.72 a 92). Estas actuaciones aisladas reciben el nombre de sistemáticas en la terminología de 1992, dentro de ellas se incluye el sistema de compensación (arts.80 a 82), en el que se introducen ajustes, rebajando al 50 por 100 la superficie habilitante y se simplifica su normativa. Como nuevos sistemas se regulan dos: el concierto, disponible cuando se garantice la actuación solidaria de la propiedad (por ejemplo cuando haya un único propietario), y la concurrencia, en el que la empresa privada puede sustituir a una eventualmente renuente propiedad, a iniciativa del Ayuntamiento o de cualquier particular, pero en todo caso a través de un procedimiento selectivo, a cuyo término se adjudicará la ejecución de la actuación. El Adjudicatario, que obtiene la condición de urbanizador, no está obligado a ser ni a convertirse en propietario; se prefiere así fomentar la inversión en infraestructuras que forzar a la empresa privada a consumir sus recursos adquiriendo suelo. Como formas complementarias de gestión, se regulan el sistema de ocupación directa para la obtención de dotaciones urbanísticas públicas, los Proyectos de Urbanización para la ejecución material del planeamiento urbanístico y la celebración de convenios, figura cuya reglamentación incorpora elementos de seguridad jurídica como la definición de sus limitaciones o la publicidad, pero sobre la que no se ha querido normar en exceso para conservar su principal virtud, que es la flexibilidad. Son figuras de nueva presencia el canon y la garantía de urbanización, que amplían las opciones municipales para la ejecución del planeamiento. En Cataluña el Decreto 303/1997, de 25 de 


\title{
El sistema de compensación, es aquél de los sistemas legales de
}

\author{
actuación, que tiene por objeto la gestión y ejecución de la urbanización de
}

noviembre, por el que se aprueba el reglamento sobre medidas para facilitar la ejecución urbanística, establece en su art. 19 que las normas previstas en los artículos 2 al 14 y 16, sobre proyectos de reparcelación, serán aplicables a los proyectos de compensación, entendiéndose adjudicadas a título de adquisición originaria, además de las fincas de cesión obligatoria las que se atribuyan las empresas urbanizadoras que se incorporen a la Junta, así como las fincas resultantes que ésta se reserve con el fin de financiar la obra de urbanización. En relación con la adhesión de los propietarios a la Junta, una vez transcurrido el plazo legalmente establecido para la adhesión de los propietarios, la administración actuante podrá dejar sin efecto, previo acuerdo de la Junta de compensación, el expediente de expropiación iniciado al propietario no adherido, cuando éste haya solicitado su adhesión y satisfecho la parte proporcional de los gastos realizados con los intereses legales correspondientes, así como los que se hubieran devengado durante la tramitación del proyecto de expropiación, siempre que no se haya levantado aún el acta de ocupación. La Instrucción que regula aspectos orgánicos y funcionales del Registro de Entidades urbanísticas colaboradoras aprobadas por Orden de 5 de agosto de 1982, dedica a las Juntas de Compensación los artículos 9 a 17. La Ley del suelo de Cataluña, al refundir los textos legales vigentes, dedica al sistema de compensación los artículos 176 a 184. En Galicia merece destacar el art. 47 de la LSG 1/1997, al que está dedicado el sistema de compensación allí se establece que1. «La junta de compensación, dentro de los tres meses siguientes a la fecha de su constitución, redactará el proyecto de compensación. Formulado dicho proyecto, y previa audiencia de los afectados por plazo de un mes, se someterá a su aprobación, requiriéndose para adopción del acuerdo el de la mayoría de sus miembros que representen, a su vez, a las dos terceras partes de las cuotas de participación. Aprobado, se elevará a la Administración actuante para la aprobación definitiva dentro del plazo de seis meses, computados desde la fecha de constitución de la junta de compensación...». En la Comunidad de Madrid en la Ley 4/1984,de 10 de febrero, sobre medidas de disciplina urbanística señala en su art. 9.1 la preferencia del sistema de compensación, y en la Ley 9/1985, de 4 de diciembre, especial para el tratamiento de actuaciones urbanísticas ilegales en la Comunidad de Madrid, en su art. 17.1 remite a la LS en cuanto a la tipología y contenido de los sistemas de actuación urbanística. En Murcia, art.20.2 de la Ley 12/1986, de 20 de diciembre de medidas para la protección de la legalidad urbanística. En Navarra, la Ley Foral 10/1994, de 4 de julio de ordenación del territorio y urbanismo, simplificó al máximo la tramitación de los sistemas de actuación, en el que el proyecto de reparcelación adquiere la condición de instrumento clave en cualquier actuación privada. Los sistemas de actuación quedan configurados en cinco: compensación, cooperación, reparcelación voluntaria, en cuanto fórmula más simple de actuación, ejecución forzosa, sistema ya incorporado por la Ley Foral 7/1989, de 8 de junio, como sistema alternativo al de compensación con el que tiene ciertos puntos en común y expropiación. En la Comunidad autónoma Vasca la Ley 5/1998, de 6 de marzo de medidas urgentes en materia de régimen del suelo y ordenación urbana, en su art. 5.5 señala que las unidades de ejecución se desarrollarán por el sistema de actuación que la Administración elija en cada caso, pudiendo optar indistintamente entre los sistemas de compensación, cooperación o expropiación. En Asturias, la Ley 6/1990, de 20 de diciembre, sobre edificación y usos en el medio rural, en su art. 10 establece los criterios de obtención de «las dotaciones, servicios y sistemas de espacios libres de ámbito local que se sitúen en los núcleos rurales»; señala que se obtendrán por el sistema de expropiación, si bien se deja una puerta abierta a la aplicación de otros sistemas, como puede ser el de compensación. Finalmente en Baleares, en el Decreto de 4 de junio de 1987, de recepción de urbanizaciones por Ayuntamientos, señala en su art2 que en el sistema de compensación será la junta de compensación o el propietario o comunidad de propietarios de terrenos pro indiviso, quienes estarán obligados a ceder al Ayuntamiento las obras, bienes y servicios de cesión obligatoria y gratuita determinados en el Plan Parcial o Plan Especial; la Ley 10/1990, de 23 de octubre, de disciplina urbanística, en su Capítulo III, "De las urbanizaciones de iniciativa particular», recoge algunos aspectos referentes al sistema de Compensación. 
un polígono, o unidad de actuación (en la actualidad unidad de ejecución) por los mismos propietarios del suelo en régimen de solidaridad de beneficios y cargas 461 .

La doctrina ha elaborado diferentes definiciones del sistema de compensación coincidentes en sus rasgos esenciales con los preceptos legales que lo regulan. Así Nuñez Ruiz, ante el Proyecto de reforma de la Ley del Suelo del 76, afirma que el sistema de compensación «es un medio institucional de participación regulada de los propietarios para la ejecución de la urbanización de una unidad de actuación y, en su caso, de la edificación de los solares resultantes, mediante la constitución asociativa de la Junta de Compensación, que asumirá directamente la realización de estos fines que se determinen libremente en sus estatutos» $\$ 62$

También se ha dicho, que «por el sistema de compensación se da realidad al principio de la solidaridad de beneficios y cargas que debe existir entre los propietarios de un mismo polígono»463.

Martín Blanco ${ }^{464}$ considera que la ejecución de la urbanización, de la unidad de ejecución a costa de los propietarios es el objetivo esencial del sistema de Compensación, siendo la posible edificación de los solares resultantes, un fin meramente accidental, que aunque normalmente acompaña la actividad urbanizadora, no constituye un fin necesario ${ }^{465}$.

461 La particularidad de este sistema radica en el protagonismo de la gestión urbanística, que no es administrativa, sino privada, en el sentido de que_la ejecución del planeamiento, y con ello de la actividad urbanizadora, es asumida y realizada por los propietarios de terrenos afectados por la actuación, diferencia esencial con el sistema de cooperación.

462 Vid. NUÑEZ RUIZ, Ejecución de los Planes de Urbanismo, Madrid, 1974, p. 342.

463 Vid. PEREZ GONZALEZ, Revista de Estudios de la Vida Local, julio- agosto, 1965, p. 477.

464 Vid. MARTIN BLANCO, La Compensación...,ob.cit., pp. 93-94.

465 Señala como notas características del sistema de compensación las siguientes: a) la existencia de un substratum patrimonio real, consistente en suelo, terrenos y en su caso edificaciones. b) la unión de los propietarios de un polígono o unidad de actuación y los del suelo exterior al mismo ocupado para la ejecución de los sistemas generales. c) la solidaridad de beneficios y cargas del planeamiento que se ejecuta entre todos ellos. d) la gestión común de la urbanización mediante la creación al efecto de la Junta de Compensación con propia 
La gestión urbanística es privada, en el sentido de que la ejecución del planeamiento y con ello la actividad urbanizadora, es asumida y realizada por los propietarios de terrenos afectados por la actuación urbanística.

En el ámbito Jurisprudencial, no existe una definición del sistema de compensación formulado de forma explícita. La sentencia de 24 de diciembre de 1991 (Ar. 315 ), se expresa diciendo que «el sistema de compensación actúa como un todo armónico respecto del polígono«; así como la sentencia de 12 de marzo de 1991 (Ar. 1986) que dice «el sistema de compensación se incardina como uno de los métodos o instrumentos legales para la actuación urbanística, a fin de ejecutar los polígonos y unidades de actuación; en él los propietarios del suelo afectado se obligan, junto a la aportación de sus respectivas parcelas y terrenos de cesión obligatoria a la Administración actuante, a la ejecución de las obras de urbanización en los términos fijados en el Plan de Actuación Urbanística que se constituyen, por el procedimiento legalmente establecido, en Junta de Compensación que como órgano de naturaleza administrativa sujeto a la tutela de la Administración, con personalidad jurídica propia, previa inscripción en el Registro correspondiente de Entidades urbanísticas colaboradoras, con plena capacidad de obrar y de carácter corporativo, integrada además por un representante de esa Administración, por los propietarios del suelo exterior, pero ocupado para la ejecución y por las empresas urbanísticas que participan con los dueños de la tierra en la gestión urbanística, aprueba por el correspondiente procedimiento, las bases de su actuación, sus Estatutos y el proyecto de Compensación « 466

personalidad jurídica y plena capacidad. e) la finalidad de urbanizar los terrenos y, en su caso, de edificar los solares resultantes Vid. MARTIN BLANCO, La Compensación...ob.cit., p. 83. 466 En términos similares pueden verse las siguientes sentencias: Sentencia de 3 de marzo de 1989 (Ar. 1781) según la cual, el sistema de compensación «es aquel en el que los propietarios asumen mayor protagonismo, en cuanto a la ejecución de la tarea urbanizadora»; Sentencia de 11 de marzo 1989 (Ar 1968) que establece que «lo que importa es la voluntariedad del sistema de compensación, voluntariedad esta que se predica respecto de los propietarios en un doble sentido: a) sólo se aplicará el sistema si lo acepta una mayoría 
Este sistema, se caracteriza, como se deduce del art. 157.1 del T.R (art. 157 RGU y 126.1 de la LSTR del 76), porque tiene por objeto la asunción «ex lege» por dichos propietarios de las obligaciones de aportar los terrenos de cesión obligatoria ${ }^{467}$ y la de realizar a su costa de la urbanización ${ }^{468}$ Otra característica del sistema de compensación es la denominada «solidaridad de beneficios y cargas» consistente en que los propietarios participan y se distribuyen, entre todos, los gastos y cargas de la urbanización y los beneficios derivados en proporción a sus aportaciones (art. 157.1 RGU).

La primera nota, que caracteriza a este sistema es el suelo, comprendido en la unidad de ejecución, que ha de urbanizarse. El suelo es esencial, sin él no hay sistema de compensación. Es objeto de derechos

cualificada de propietarios - art. 119.3 del Texto Refundido- y b) ningún propietario puede ser obligado a incorporarse a la Junta contra su voluntad, de suerte que dentro de este sistema si algún titular de fincas del polígono no acepta su participación en ella se ha de acudir a la figura de la expropiación forzosa «; y continua diciendo «la Junta de compensación se caracteriza por la integración en ella de toda la propiedad del polígono: todos los propietarios son miembros de la Junta bien porque se han incorporado a la misma, bien porque la Junta ha adquirido, como beneficiaria de una expropiación, los terrenos de quienes no quisieron participar en ella art. 168 del RGU». Cabria añadir, en relación con el primer apartado, como ya hemos puesto de manifiesto en líneas anteriores, que el sistema de compensación ha sufrido un cambio respecto a la legislación anterior, en el sentido de que en todos los supuestos es la Administración quien elige el sistema de ejecución del planeamiento . Los propietarios que representen al menos el 60 por 100 de la superficie de la Unidad de Ejecución, podrán solicitarlo pero dicha solicitud «no vinculará a la Administración « quien resolverá adoptando el sistema de actuación que la misma elija en cada caso (art. 148.1 y 149.2 del TR); Sentencia de 30 de octubre de 1989 (Ar. 7478) establece que «es en el sistema de compensación donde aparece con mayor intensidad la participación de los propietarios dado que son ellos mismos los que asumen la carga no ya de costear la urbanización sino de llevarla a cabo por sí mismos; St. del TS de 24 de mayo de 1994, RJ1994/3907.Para un estudio más detallado del tema vid. DEL POZO CARRASCOSA, El sistema de compensación..., ob.cit. p.157 y ss.

467Vid. GONZALEZ PEREZ. Comentarios, II, Madrid, 1993, p.1195; GARCIA DE ENTERRIA Y PAREJO, Lecciones, ob.cit., p. 61; ORTEGA GARCIA, Los deberes o cargas en la legislación urbanística, Madrid,1974, p. 48 y ss.; DEL POZO CARRASCOSA, El sistema de compensación urbanística, Madrid, 1993, p. 37. MARTIN BLANCO, La compensación urbanística (principio y sistema), Madrid ,1985,p. 8y 40;NUÑEZ RUIZ, Ejecución de los planes de urbanismo, Madrid, 1974, p. 116 y ss.

468 Vid. LLISET BORRELL. La actividad urbanística de los Planes de Urbanización, Madrid, 1975, p. 230; GONZALEZ BERENGUER, Gestión, financiación y, control del Urbanismo, Madrid, 1979, p. 587 y ss; CARCELLER FERNANDEZ, Instituciones de Derecho Urbanístico, Madrid, 1984, p.344 y ss; GARCIA DE ENTERRIA y PAREJO, Lecciones..., ob.cit., pp. 61 y ss; DEL POZO CARRASCOSA, El sistema de Compensación, ob. cit., p. 37 
reales; es el título que otorga y legitima la posición jurídica de miembro de la Junta; señala la medida o contenido del derecho y obligación de cada titular, en función del valor de su aportación, tanto respecto de los beneficios y de las cargas como de la administración y gobierno de la Junta.

La aportación, a la Junta, de los terrenos de los propietarios afectados no implica necesariamente una transmisión de la propiedad de los mismos sino que se mantiene en manos de estos sujetos su derecho de propiedad privada, pero con la carga de transmitir a favor de la Administración el suelo de cesión obligatoria y gratuita, para viales, parques y jardines públicos, etc.; cesiones cuyo alcance varía, según la clase y categoría de suelo en que se actúe ${ }^{469}$. En relación con las cesiones, los propietarios no sólo habrán de cumplir la carga de ceder los terrenos de cesión obligatoria y gratuita, sino que, además, habrán de ceder las correspondientes obras de urbanización: arts. 179 y180 del RGU «la Junta de Compensación y la empresa que tenga a su cargo la ejecución de las obras de urbanización podrán ocupar a este fin los terrenos objeto de cesión hasta que finalizadas dichas obras sean recibidas por la Administración actuante».

La Administración, únicamente posee una labor de control y tutela mediante la aprobación de los distintos acuerdos, y de los Estatutos y las Bases de actuación de la Junta de Compensación (art. 157.2 del TR, art. 126.2 LSTR del 76) (documentos que estudiaremos a lo largo del trabajo).

La segunda nota que caracteriza a este sistema es la gestión y ejecución de la unidad de ejecución, es decir, urbanizar los terrenos y, en su caso, edificar los solares resultantes, a costa de los propietarios 470 (art.

469 Esta cesión obligatoria se establece en los mismos términos para el sistema de cooperación en el art. 162 y, son idénticas en ambos sistemas las cargas del propietario, vid NUÑEZ RUIZ, Ejecución de los planes de urbanismo, Madrid, 1974,p. 116 y ss.

470 En el sistema de compensación, tal y como se define en la Ley, es esencial la realización de la obra urbanizadora por los propietarios. En el sistema de cooperación, por el contrario, es la Administración la que ejecuta las obras de urbanización, con la posibilidad de constituirse asociaciones administrativas de propietarios, bien a iniciativa de éstos, o del propio Ayuntamiento, con la finalidad de colaborar en la ejecución de las obras de 
157.1 del TR, art. 126.1 de la LSTR del 76 y 157.1.2 del RGU), constituidos en Junta de Compensación, salvo que todos los terrenos pertenezcan a un sólo propietario. Esto se concreta en que la Junta es la responsable, frente a la Administración competente, de la urbanización completa de la unidad de ejecución, tanto en lo que se refiere a las características técnicas como a los plazos de realización, y de la edificación de los solares resultantes (art. 160.1 TR, art. 130.1 LSTR del 76 y 182 del RGU).

El hecho de ser los propietarios quienes ejecutan la urbanización, pone de manifiesto la doble carga urbanística ${ }^{471}$, por un lado las cesiones obligatorias y gratuitas de terrenos y por otro el responsabilizarse de los costes de la urbanización.

La tercera nota característica de este sistema es la anteriormente mencionada solidaridad, de beneficios y cargas, lo que significa, por un

urbanización, vid. GONZALEZ PEREZ, Comentarios al articulo 131.3 de la Ley del Suelo, II, p. 1246 y ss. (art.162 3 del texto refundido del 92); GONZALEZ SALINAS, Sistema de compensación...,ob.cit, pp. 54 y ss.; LLISET BORREL, La actividad urbanística de los particulares, Madrid, 1975, p. 230; GONZALEZ BERENGUER, Gestión, financiación y control del urbanismo, Madrid 1979, p. 587; FERNANDEZ RODRIGUEZ, Manual de derecho urbanístico, Madrid, 1991, pp. 169 y ss.; GARCIA DE ENTERRIA y PAREJO, Lecciones..., ob. cit., pp. 525 y ss.; CARCELLER FERNANDEZ, Reparcelación y compensación en la gestión urbanística, Madrid,1980, p. 87 y ss.; BORREGO, El sistema de compensación, en «Derecho urbanístico local» (dirigido por Boquera), 1992, pp. 309 y ss.; SASTRE, El sistema de compensación, «Jornadas sobre urbanismo y publicidad registral», Valladolid, 1988, pp. 87 y ss.

471 En la legislación urbanística, la función social de la propiedad se concreta en las cargas urbanísticas, las cuales forman parte del contenido de la propiedad urbana, así lo viene declarando reiterada jurisprudencia del TS de la que es ejemplo la Sentencia de 1 de febrero de 1982(sala $4^{\circ}$ )en la que se declara: "Que es debido a una estimación preferente de los intereses generales por lo que en la Ley del Suelo vigente (art. 87.1) se establece que la ordenación del uso de los terrenos y construcciones..., no conferirá derecho a los propietarios a exigir indemnización, por implicar meras limitaciones y deberes que definen el contenido normal de la propiedad según su calificación urbanística..., lo que constituye el principio básico del régimen jurídico de la propiedad en lo urbanístico: la regla general. Las excepciones a la misma se dan originando un derecho de los afectados por el cambio a indemnización, cuando la modificación o revisión de la ordenación de los terrenos y construcciones establecida por la planificación se produzca antes de transcurrir los plazos previstos para la ejecución de los respectivos Planes o Programas, o transcurridos aquellos, la ejecución no se hubiera llevado a efecto por causas imputables a la Administración; o bien, cuando las ordenaciones impusieran vinculaciones o limitaciones singulares que lleven consigo una restricción del aprovechamiento urbanístico del suelo que no pueda ser objeto de distribución equitativa ente los interesados (art. 87, nํํำ y 3); ; aparte de que los afectados tendrán derecho a la distribución equitativa de los beneficios y cargas del planeamiento en los términos previstos en la presente Ley (art. $87.1^{\circ}$ in fine)». 
lado, que la gestión ha de realizarse con distribución justa entre todos aquéllos de las cargas de urbanización (cesiones de terrenos y financiación de los costes de urbanización) y, por otra parte, ha de realizarse, asimismo una justa distribución de los beneficios de la ordenación, y en concreto, de los volúmenes edificables sobre el suelo de aprovechamiento privado, en proporción a las aportaciones de sus miembros.

El conjunto de operaciones para efectuar el reparto de beneficios y cargas, de modo proporcional a la aportación de cada miembro de la comunidad, constituye en lo esencial, una reparcelación (art. 164 TR) ${ }^{472}$, si bien en este sistema que estamos estudiando no se instrumenta de manera formal, sino meramente material, a través, como veremos más adelante, de las correspondientes bases de actuación y proyecto de compensación 473 .

Para que el reparto equitativo de beneficios y cargas sea proporcional a los terrenos aportados para el bien común, la comunidad de propietarios se constituye en Junta de Compensación, la cual será objeto de estudio en un momento posterior. Aquí, simplemente adelantar que dicha Junta se constituye con una doble finalidad, la de urbanizar, de acuerdo con el planeamiento, y la de repartir o equidistribuir, a través de un expediente llamado Proyecto de Compensación.

Hay que precisar, por tanto, que ni el término «compensación», ni el término «solidaridad», se emplean en el sentido que tiene en el Código Civil. El término compensación desde el punto de vista civil se emplea para designar una forma de extinción de las obligaciones, o de una clase de obligaciones (obligaciones vencidas, líquidas, exigibles, consistentes en dinero o cosas fungibles entre personas, por derecho propio, que son

472 Vid. GONZALEZ BERENGUER, «Esquema del sistema de compensación», RDU, ㄲo 61, p. 13.

473Vid. MARTIN BLANCO, La Compensación...,ob.cit.,p. 81 y ss. ; DELGADO IRIBARREN., El Sistema de compensación, XVIII Temas de Derecho Urbanístico, Oviedo, 1980,pp. 299 y ss.; GARCIA DE ENTERRIA y PAREJO, Lecciones..., p. 61 y ss. ; GONZALEZ PEREZ, Comentarios, II, ob cit.,pp1196; DE LOS MOZOS, "Sistemas de actuación urbanística», RDU, 1969, pp. 15 y ss.; GONZALEZ BERENGUER, Gestión...,ob.cit.,pp. 587 y ss.; NUÑEZ RUIZ, Derecho urbanístico, ob.cit., pp. 412 y ss. 
recíprocamente acreedoras y deudoras la una de la otra); o en el sentido más amplio de indemnización ${ }^{474}$.

En el ámbito del derecho urbanístico la palabra «compensación» es utilizada por la legislación urbanística en el sentido de igualar las cargas con los beneficios derivados del planeamiento o dicho en los términos del artículo 3.1.b) del TR, art.3.2.d) de la LSTR del 76, «impedir la desigual atribución de los beneficios y cargas del planeamiento entre los propietarios afectados e imponer la justa distribución de los mismos «. El concepto de solidaridad ha de entenderse, no en el sentido civil a propósito de las obligaciones art. 1144, que implica que a cada sujeto individual de una pluralidad puede exigírsele, o puede él exigir cuando la solidaridad es activa, la totalidad de la obligación, sino en el de participación equitativa de los propietarios en los beneficios y cargas de la urbanización, en proporción a sus aportaciones en la unidad de ejecución 475 .

\section{MIEMBROS INTEGRANTES DEL SISTEMA DE COMPENSACION.}

El principio general es que los integrantes del sistema y de la Junta de Compensación lo son «propter rem»476 es decir, por razón de su titularidad sobre los terrenos incluidos en la unidad de ejecución. Pero cabe también, la posibilidad de que determinados miembros integrantes de la Junta de Compensación, lo sean no por razón de su titularidad sobre los terrenos, sino por otras razones profesionales o de actividad (empresas urbanizadoras) o de tutela administrativa (Administración urbanística actuante) $)^{477}$.

474 Son de interés, a efectos comparativos los artículos 1195 - 1196 - 1201 del Código civil.

475 Vid. GARCIA DE ENTERRIA-PAREJO, Lecciones...ob. cit. p.61.

476 Vid. DIEZ-PICAZO, Fundamentos de derecho civil patrimonial, III. Las relaciones jurídico reales. El registro de la propiedad. La posesión. Madrid, 1995,p. 83 y ss; HERNANDEZ GIL, "Concepto y naturaleza jurídica de las obligaciones propter rem», RDP, 1962,p. 850;

477 Vid. MARTIN BLANCO, J., La Compensación..., cit. p. 121. 
Según establece el artículo 163.2 y 3 RGU, quedarán integrados en el Sistema y Junta de Compensación:

Los propietarios de terrenos que hayan aceptado el sistema, es decir, propietarios privados de suelo (personas naturales y jurídicas) incluidos dentro de la unidad de ejecución.

Las entidades públicas titulares, es decir, propietarios públicos de bienes incluidos en el polígono o unidad de actuación, ya tengan carácter demanial o patrimonial.

Los propietarios de suelo exterior al polígono, ocupado para la ejecución de sistemas generales, cuando hayan de hacerse efectivos sus derechos en la unidad de ejecución objeto de actuación por este sistema.

Un representante de la Administración actuante también formará parte de la Junta en todo caso (art. 158.4 TR).

Las empresas urbanizadoras que se incorporen para participar con los propietarios en la gestión urbanística de la unidad de ejecución. A diferencia de las incorporaciones anteriores (obligada 0 necesaria legalmente), la incorporación de las empresas urbanizadoras es facultativa.

\subsection{LOS PROPIETARIOS DE TERRENOS QUE HAYAN ACEPTADO EL SISTEMA.}

Como podemos ver la Ley del suelo del 92 en sus artículos 157.1 y 158.1(arts 126.1 y 127.1LSTR del 76), se fija en primer lugar, en los propietarios de fincas incluidas en la unidad de ejecución, cuya urbanización va a ser gestionada por el sistema de compensación.

En principio, lo que posibilita el ingreso en la Junta, evitando la expropiación forzosa de los terrenos objeto de su propiedad a favor de la misma, es la «aceptación formal» del sistema. 
Con anterioridad a la aplicación del sistema de compensación la legislación urbanística distingue entre la finca material como realidad física (art. 103.3 RGU), y la titularidad jurídica (art.103.4 RGU); es decir, la titularidad de los derechos y su posible reflejo en los títulos. Lo que se persigue con esto es buscar la concordancia entre la titularidad jurídica y la finca material.

En caso de discordancia entre la titularidad jurídica y la finca material, prevalecerá ésta sobre aquélla según establece el párrafo 3 del 103 RGU. Si la discrepancia se plantea en el orden de la titularidad de los derechos, la resolución definitiva corresponde a los Tribunales ordinarios (art. 103.4 RGU). Sin embargo, la discrepancia en cuanto a la titularidad no impide la aplicación del sistema de compensación, dado que la interpretación conjunta de los arts. 103.4 y 157.2 TR permiten afirmar que siempre que exista justificación de la titularidad del 60 por 100 de la superficie del polígono, se sigue adelante con la aplicación del sistema de compensación, aunque el resto de las titularidades sean dudosas 0 litigiosas, es decir, estén o no pendientes de un procedimiento judicial.

Por último decir que en función de lo establecido en el párrafo 5. del art. $103 \mathrm{RGU}$, las cuestiones de linderos podrán resolverse en el propio proceso de aplicación del sistema de compensación, si media la conformidad de los interesados.

Una vez que la aplicación del sistema de compensación esté decidido, lo que se pretende es su funcionamiento, y en este sentido el art. 172.a) RGU señala, que el proyecto de compensación debe contener «la descripción de las propiedades antiguas, según los títulos aportados, con las correcciones procedentes, y en defecto de títulos, según planos «; «el respectivo propietario, si fuera conocido»; cuestión que plantea el art. 103 RGU. Asimismo, el art. 161.3 RGU presupone las cuestiones del art. 103 RGU al señalar que el acuerdo de aprobación inicial de los proyectos de 
estatutos y bases de actuación se notificará a los «propietarios afectados», lo cual significa que la Administración tiene constancia de todos los propietarios susceptibles de integrarse en la Junta, tanto si se trata de propietarios indiscutidos como de propietarios cuya titularidad se esté debatiendo en un procedimiento judicial. La misma situación se produce en el art. 162.1 RGU.

\subsection{LOS PROPIETARIOS DE SUELO DESTINADO A SISTEMAS} GENERALES.

Como decíamos anteriormente, la legislación urbanística denomina «sistemas generales» a las obras de infraestructura en materia de comunicaciones, servicios etc. ${ }^{478}$. Estos propietarios cuyos terrenos han sido ocupados para la realización de obras de infraestructura, ven compensada la pérdida patrimonial que sufren, por una doble vía:

- Si ha tenido lugar la expropiación forzosa de esos terrenos destinados a sistemas generales (art. 71.2 RGU), el resarcimiento tiene lugar a través del pago del justiprecio que se hará en dinero, con lo cual estos sujetos ya no intervendrán en una ulterior fase de la gestión urbanística.

- O bien, otorgándoles un derecho de valor proporcional en un polígono distinto. Este derecho se concreta en la inclusión del sujeto en un procedimiento de reparcelación o compensación (arts. 201 y 203 TR) 479 , con lo cual según establece el art.85.1 RGU se le otorga el derecho a que se adjudique en propiedad, alguna de las fincas que resulten de ese proceso; adjudicación que se produce «mediante el reconocimiento a su

478 Vid. DEL POZO CARRASCOSA, ob. cit., p. 60.

$479 \mathrm{El}$ art. 203 fue objeto de impugnación. El motivo de la impugnación se resuelve en afirmar que su contenido es puramente de gestión urbanística y corresponde determinarlo a las Comunidades Autónomas. Si bien el Alto Tribunal entendió que el art.203 del TRLS del 92, en su totalidad se acomoda al orden constitucional de distribución de competencias. 
titular del derecho a integrarse en una unidad de ejecución con exceso de aprovechamiento real» (art. 203.1 TR), que es lo que se conoce con el nombre de sistema de «ocupación directa».

De esta forma, el art. 163 RGU, amplía el contenido del art. 157.2 TR, que solamente se refiere a los propietarios de la unidad de ejecución. Estos propietarios, a partir de la entrada en vigor del TR del 92, al derogar el art. $159 \mathrm{RGU}$, ya no se incluyen en el cómputo de porcentaje de superficie necesaria para solicitar la aplicación del sistema de compensación, pero sí deberán contribuir a los gastos de urbanización, en proporción a las parcelas adjudicadas 480

También pueden integrarse en la Junta de Compensación los titulares de cargas reales 481 sobre las fincas destinadas a sistemas generales cuando estas cargas queden liberadas; liberación que se produce cuando existe un acuerdo de reparto del aprovechamiento de la finca gravada, y se atribuye a sus titulares un determinado número de «unidades de aprovechamiento en proporción al valor de su derecho» (art. 54.2.1 RGU). A estos sujetos se les considera como copropietarios de la finca, juntamente con el antiguo propietario, y se les faculta para formar parte de la Junta de Compensación en la forma prevista en el art. 166.e)

480 Así, lo establecía el art. 51 RGU en su párrafo 3. Esta medida se mantiene en vigor, tal vez, para evitar que estos propietarios se enriquezcan injustamente y sobre todo si tenemos en cuenta que los arts. 151.2 y 203 TR, que son los que probablemente hayan justificado la derogación del art. $51 \mathrm{RGU}$, no se oponen explícitamente a ella.

481 Vid. DIEZ-PICAZO, Fundamentos, III, ob.cit.p.81y 82; DE LOS MOZOS, La obligación real, II, Madrid,1976,p.331. ; VALLET DE GOYTISOLO, Estudios sobre Derecho de cosas, Madrid, 1985; DIEZ-PICAZO y PONCE DE LEON, Autonomía privada y derechos reales, RCDI, 1976,p.273; LA CRUZ, Elementos III,1ํ, Barcelona,1988,p.15; CASTAN TOBEÑAS, Derecho civil español común y foral, T.II,vol.1ํㅡ. Madrid, 1982,p. 54;ALBALADEJO, Derecho civil III, Derecho de bienes, Vol.1ํㅡㄹ Barcelona, 1982, p. 17; BIONDI, en Le servitúe prediali, ob.cit.,p.109 entiende por carga real un gravamen que pesa objetivamente sobre un fundo, por el que cualquier propietario del mismo está obligado a realizar prestaciones positivas en favor del dueño de otro fundo, o de una persona determinada. En nuestro C.c el ejemplo más significativo pueden ser los censos (art. 1604 C.c.) CARNELUTTI, Sistema de Derecho Procesal Civil, Buenos Aires, 1944, p. 118.; GARCIA DE ENTERRIA, «Configuración jurídica de la propiedad urbana». Conferencia pronunciada en Jornadas de Derecho Urbanístico, Salamanca, 1973. 
RGU482. Si no se produce la liberación de la carga, es decir, «si en el momento de la ocupación los interesados no presentan convenio de reparto de las unidades de aprovechamiento»(art. 54.2.2 RGU), se atribuye la totalidad del aprovechamiento a la finca, aunque en la certificación se hace constar » la existencia de la carga o derecho no liberados y su titular».

\subsection{LAS ENTIDADES PUBLICAS COMO TITULARES DE BIENES} INCLUIDOS EN LA UNIDAD DE EJECUCION.

Como señala el art. 167.2 RGU, «las entidades públicas titulares de bienes incluidos en el polígono o unidad de actuación, ya tengan carácter demanial o patrimonial» integran con carácter obligatorio la Junta de Compensación (art. 163.2 RGU). Ese carácter obligatorio nace del hecho de ser titulares de terrenos, con anterioridad a la gestión por compensación. Estas entidades públicas como propietarias de suelo incluido en una unidad de ejecución están sujetas al deber de equidistribución por el procedimiento que la Ley establezca (art.154 TR, art. 122 LSTR del 76). En cualquier caso, no hay que confundir la situación de

482 Este precepto establece que «los cotitulares de fincas o derechos habrán de designar una sola persona para el ejercicio de sus facultades como miembro de la junta, respondiendo solidariamente frente a ella de cuantas obligaciones dimanen de su condición». Como dato comparativo, se podría añadir que, en el ámbito civil de la comunidad de bienes, a la hora de emprender actuaciones que conlleven actos de administración, gestión, aprovechamiento y disposición de la cosa, habrán de someterse a la opinión de la mayoría (arts 397 y 398 del C.c); en cambio cuando se trate de actos no de administración, sino de dominio que modifiquen el contenido del derecho real que cada titular ostenta sobre esa cosa común, por ejemplo, el pacto de indivisión de la cosa común, será válido, aunque no concurran todos los comuneros, y por tanto desplegará sus efectos, pero sólo lo hará sobre la esfera jurídica de aquellos comuneros que han sido parte en el mismo, independientemente de que representen la totalidad de las cuotas o simplemente un porcentaje de las mismas y ello porque: los comuneros que acuerdan la indivisión no pueden imponer ninguna obligación a terceros, aunque éstos sean copartícipes, ya que atentaría contra el art. 1257 del C.c; para un análisis mas detallado del tema vid. MORENO TRUJILLO, E., La indivisión voluntaria en las comunidades de bienes por cuotas, en Cuadernos de Derecho Privado, Barcelona, 1994, p. 133 y ss. En la ley de Propiedad Horizontal de 21 de julio de 1960, reformada por la Ley $6 / 1999$, de 6 de abril, se establece que para la validez de los acuerdos de la Junta de propietarios que impliquen aprobación o modificación de reglas contenidas en el título constitutivo de la propiedad o en los estatutos se requiere la unanimidad de todos sus miembros, para la validez de los demás acuerdos bastará el voto de la mayoría del total de los propietarios (art. $17.1^{\circ}$ y $\left.3^{\circ}\right)$. 
la Administración como sujeto de la Junta, en cuanto propietaria de terrenos antes del planeamiento y que son objeto de éste con la situación de la Administración que deviene propietaria de suelo como consecuencia de las cesiones obligatorias que los propietarios integrados en la Junta hacen a su favor, el suelo así adquirido se incorpora al patrimonio municipal del suelo. Estos terrenos los adquiere el Ayuntamiento a partir de la aprobación del proyecto de compensación (arts.172.b),c) y 179.1 RGU) ${ }^{483}$. La titularidad del Ayuntamiento sobre estos terrenos es una titularidad sobrevenida, que no puede legitimar la pertenencia del Ayuntamiento a la Junta 484 .

Esto que acabamos de ver, no es incompatible con el hecho de que el Ayuntamiento, según establece el art. 158.4 TR (127.4 LSTR del 76), tenga por imperativo legal un representante en el órgano rector de la Junta, con una función de control de la actuación de la misma. En el mismo sentido se pronuncia el art. 162.3 RGU.

\subsection{EMPRESAS URBANIZADORAS.}

El número 2 del art.158 del TR (art.127.2 LSTR del 76) admite, que «podrán incorporarse a la Junta las Empresas urbanizadoras que hayan de participar con los propietarios en la gestión de la unidad de ejecución». Como ya hemos indicado, su integración es facultativa no necesaria; rige el principio de voluntariedad en su incorporación a la Junta de Compensación.

${ }^{483} \mathrm{El}$ art. 159.3 TR, establece que «la transmisión a la Administración correspondiente, en pleno dominio y libres de cargas, de todos los terrenos de cesión obligatoria tendrá lugar por ministerio de la Ley con la aprobación definitiva del proyecto de compensación. LASO señala, en Derecho Urbanístico, Madrid, 1982,III, p. 145, que el proyecto sería el modo de adquirir la propiedad, mientras el Plan, el título de adquisición. En el mismo sentido, GONZALEZ SALINAS, J., ob. cit., p. 44.

484 Vid., DEL POZO CARRASCOSA, ob. cit.,p . 63. 
Esta incorporación puede realizarse en dos momentos diferentes: en el propio proceso de constitución de la Junta (art. 163.4.a RGU que señala que en la escritura de constitución deberá constar la relación de propietarios y, en su caso, empresas urbanizadoras); o una vez que la junta esté constituida en cuyo caso habrá de realizarse conforme a las previsiones de los estatutos (art. 165.2 RGU).

El art. 165.1 RGU no establece limitaciones temporales a la incorporación de empresas urbanizadoras, a diferencia de lo que hace el art. 158.1 TR (art. 127.1 LSTR del 76) en relación con los propietarios de terrenos incluidos en la unidad de ejecución los cuales si no se incorporan en las condiciones y plazos establecidos por el citado precepto, sus fincas serán expropiadas en favor de la Junta de compensación, que tendrá la condición jurídica de beneficiaria ${ }^{485}$.

Este «trato de favor « a la incorporación de empresas, se debe a que su ausencia no impide el proceso normal de la gestión urbanística. La incorporación de tales empresas una vez constituida la Junta requiere el acuerdo previo de los miembros de la misma titulares de derechos sobre las fincas de la unidad de ejecución. De esta forma, la incorporación de tales empresas sólo será posible si así lo prevén expresamente los estatutos de la Junta, estableciendo los requisitos y condiciones para la incorporación, art. 166. f) RGU486.

La función de estas empresas es la realización de las obras de urbanización que resulten de la aprobación del proyecto de compensación,

485 En este sentido establece el art. 158.1 TR que «los propietarios de la unidad de ejecución que no hubieren solicitado el sistema podrán incorporarse con igualdad de derechos y obligaciones a la Junta de Compensación, si no lo hubieran hecho en un momento anterior, dentro del plazo de un mes, desde la aprobación definitiva, a partir de la notificación del acuerdo de aprobación de los Estatutos y Bases de actuación de la Junta. Si no lo hicieran, sus fincas serán expropiadas en favor de la Junta de Compensación, que tendrá la condición jurídica de beneficiaria.

$486 \mathrm{El}$ art. 165.2 RGU establece que: «si la incorporación tuviese lugar después de constituida la junta, deberá realizarse conforme a las previsiones de los estatutos, y si estos no contuvieran determinación bastante al respecto, se precisará su modificación siguiendose el mismo procedimiento que para la aprobación de los estatutos». 
y para ello es necesario que la empresa haya aportado, de forma total o parcial, los fondos necesarios para realizar las obras de urbanización; aportaciones que son valoradas con arreglo a los criterios fijados en las bases de actuación, art. 167.1.d) RGU.

Esta incorporación a la Junta de la empresa urbanizadora, facilita la gestión urbanística, ya que no será necesario buscar otra empresa para la contratación posterior de las obras (art. 176.2 y 3 RGU), y no será necesario que la Junta realice un desembolso económico cuantioso, ya que la empresa puede recibir en pago terrenos resultantes de la compensación.

\section{CONTENIDO DEL SISTEMA DE COMPENSACION: LAS CARGAS Y DERECHOS DE LOS PROPIETARIOS.}

\subsection{LOS DEBERES Y CARGAS DE LOS PROPIETARIOS.}

Como vimos, cada vez es más acusada la tendencia que trata de superar la distinción entre servidumbre, limitaciones, deberes, obligaciones o cargas ${ }^{487}$, para establecer en su lugar la categoría única de las «cargas urbanísticas», como más adecuada a la nueva dinámica jurídica de la actuación urbanística, y como más conveniente para configurar jurídicamente, el lado pasivo o deber jurídico de las relaciones entrañadas en el sistema de compensación ${ }^{488}$ Sin embargo, la Ley del Suelo y el Reglamento de Gestión no han logrado esa configuración unitaria de las cargas urbanísticas sino que continúan utilizando esa diversidad de términos apuntados.

Nuñez Ruiz viene considerando a las cargas urbanísticas como «la contrapartida de la participación de los propietarios en la ejecución de los planes de urbanismo y su cumplimiento condiciona el mantenimiento de 
los propietarios en su propiedad « 489 . Señala este autor que no integran el derecho de propiedad en su situación actual, sino que delimitan el ejercicio normal del derecho de propiedad urbana, por eso estas cargas no son indemnizables, porque no son derechos que integren el patrimonio particular.

Las cargas urbanísticas son un derecho-deber ${ }^{490}$ de carácter patrimonial porque son intereses patrimoniales los que están en juego, corresponde al propietario y grava la finca afectada. Solamente en la medida que se cumple el deber (urbanizar, ceder terrenos, etc.)se tiene y mantiene el derecho de propiedad (participación en la gestión urbanística y en los beneficios derivados de ella). El incumplimiento de la carga, lleva consigo la pérdida del derecho para el titular de la carga (derecho-deber) a través del mecanismo de la expropiación forzosa, aunque su finalidad en este caso es sustituir o cambiar al sujeto o sujetos de la carga que no han cumplido por otros que cumplen para que la gestión urbanística, la ejecución del plan no se detenga; o incluso se puede llegar a cambiar todo el sistema de actuación, de compensación por expropiación forzosa.

Por tanto la carga urbanística, incluye dentro de su calificación a todos los deberes, obligaciones y limitaciones urbanísticas que puedan originarse en la urbanización de una unidad de ejecución, en cuanto derivadas de la ejecución de un Plan.

Las dos cargas urbanísticas que señala el artículo140 del TR (art. 120.1 LSTR del 76), efectuar las cesiones de los terrenos que se establezcan en la Ley y sufragar los costes de la urbanización son, dos aspectos de una sola carga: la afectación de los terrenos a la actuación urbanística una vez que tal actuación se concibe legalmente como ejecución del Plan de urbanismo. Dentro de esta afectación se integran y quedan comprendidas todas las obligaciones, deberes, limitaciones, 
compromisos, vinculaciones, etc., que desde el punto de vista de su ejecución y cumplimiento son tratados unitariamente, como cargas urbanísticas en cuanto son causa de un plan originador y legitimador de aquellas.

La carga urbanística se transmite ope legis, es decir su transmisión es automática por ministerio de la Ley y, propter rem por su relación con los terrenos sobre los que recae, así lo expresa también la sentencia de 7 de octubre de 1980. Este es el sentido del artículo 22 del

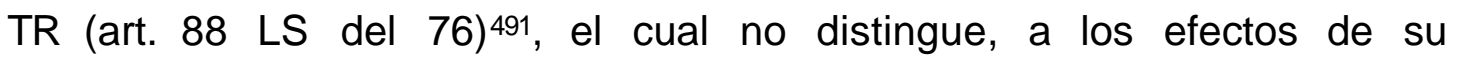
transmisión, entre derechos reales y obligaciones, ni entre cargas o gravámenes reales y simples obligaciones personales, ni entre derechos y obligaciones inscribibles o no registralmente. Todas las limitaciones, deberes y compromisos se transmiten por ministerio de la Ley con la enajenación de las fincas o terrenos, siempre que aquéllos tengan el origen y carácter legal urbanístico que el precepto señala ${ }^{492}$.

La carga urbanística es también oponible erga omnes, por su propia naturaleza y por la publicidad y generalidad con que está dotada como instrumento de aplicación de un Plan de urbanismo debidamente

491 El artículo 22 del TR establece al respecto que «la enajenación de fincas no modificará la situación de su titular en orden a las limitaciones y deberes instituidos por la legislación urbanística aplicable o impuestos, en virtud de la misma, por los actos de ejecución de sus preceptos. El adquirente quedará subrogado en el lugar y puesto del anterior propietario en los compromisos que, como consecuencia de dicho proceso, hubiere contraído con la Administración urbanística competente».

492 Por su contenido merece especial estudio la doctrina consagrada en la Sentencia del TS de 7 de octubre de 1980, en la que(recogiendo los Considerandos de la sentencia apelada y actualizando expresivamente la doctrina de otras sentencias) se declara que: «al consagrar el artículo 71 antiguo y 88 moderno con carácter estatutario el principio de subrogación real, es evidente que aquellas limitaciones afectan con trascendencia real a todo adquirente posterior, y si bien es cierto que parece atentar contra el principio de publicidad y seguridad de tráfico, no lo es menos que aquél se encuentra resguardado por la que se consagra en el artículo 43 de la derogada Ley y en el 55 de la vigente, y las limitaciones derivadas del urbanismo en manera alguna pueden ser catalogadas como las antiguas cargas ocultas...pues este principio de la subrogación real se da respecto de toda transmisión de bienes afectados por alguna función administrativa...y estas limitaciones han sido configuradas por la más moderna corriente civilista caracterizada como obligatio propter rem, que afectan al propietario de la finca por el mero hecho de serlo..., pues esta limitación en cuanto al destino no es más que una consecuencia de las limitaciones y prohibiciones, deberes, cargas y obligaciones que delimitan esa especial institución que es la propiedad urbanística». 
aprobado que tiene como características esenciales las de publicidad, obligatoriedad y ejecutividad (arts.131, 133, y 134 del TR).

Como deberes incluidos en las cargas urbanísticas cabe enumerar los siguientes:

Constituir, con los demás propietarios, la Junta de Compensación y realizar todos aquellos actos adecuados a tal constitución como son la redacción y aprobación de los estatutos y bases de actuación, elección y aprobación de los órganos o cargos rectores, inscripción en el registro de entidades urbanísticas colaboradoras etc.(art. 157 TR y 126 LS76).

Aportación de los terrenos e instalaciones a la gestión común (arts. 157 y 159 del TR, 126 y 129 LS 76), esta aportación puede hacerse con transmisión del dominio de los terrenos a la Junta y sin transmisión del dominio, manteniendo la propiedad los respectivos dueños. A este respecto, el artículo 159 del TR (art.129 LS 76) dispone que «la incorporación de los propietarios a la Junta de Compensación no presupone, salvo que los estatutos dispusieran otra cosa, la transmisión a la misma de los inmuebles afectados a los resultados de la gestión común».

Ceder obligatoria y gratuitamente 493 los terrenos necesarios, libres de gravámenes, en la proporción y con las finalidades señaladas por la Ley. En este sentido, las cesiones son verdaderas cargas urbanísticas, que recaen sobre la propiedad del suelo, que representan medios jurídicos técnicos para configurar el derecho de propiedad de acuerdo con la función social que éste debe desempeñar. Son objeto de cesiones que la Junta ha de efectuar, los terrenos que han de cederse gratuitamente con arreglo a la

493 Son muy diversas las opiniones doctrinales emitidas en materia de cesión de terrenos en este sentido, vid. entre otros, CARRO MARTINEZ, en Los principios de la nueva Ley del Suelo, en REVL, no88, 1956, p. 520; MARIN TEJERIZO, Las cesiones obligatorias en la Ley de Régimen de Suelo, en REVL. ํㅜ 88,1956, p. 571.; DE LOS MOZOS, El urbanismo desde la perspectiva del Derecho Privado, en RDP, 1961, p. 293; CARCELLER FERNANDEZ, Ejecución de los planes de Urbanismo, Barcelona, 1962, p. 57 y ss. y 87 y ss.; NUÑEZ RUIZ, Derecho Urbanístico Español, 1967, p. 271, 275 y ss. y en su obra Ejecución de los Planes de Urbanismo, 1974, p. 325 y ss. ; LOPEZ PELLICER, «La cesión obligatoria y gratuita de terrenos por razón de urbanismo", en RDU, 1977, nำ53, p. 47 y ss. 
clase de suelo sobre el que se actúa; la cesión gratuita a la Administración del 10 por 100 del aprovechamiento tipo y del exceso sobre el 90 por 100 de dicho aprovechamiento; las cesiones de terrenos para los sistemas generales, estas cesiones son onerosas, y la cesión de obras de urbanización e instalaciones (arts.159.3 del TR y 180 del RGU).

También, tienen que ejecutar y costear las obras de urbanización en la proporción establecida en los Estatutos y Bases de Actuación de la Junta. Estos costes de urbanización comprenden las obras de vialidad, saneamiento, suministro de agua y energía eléctrica, alumbrado público, arbolado y jardinería; las indemnizaciones procedentes por derribo de construcciones, destrucción de plantaciones, obras e instalaciones que exija la ejecución de los planes; el coste de los Planes Parciales y de los Proyectos de Urbanización (art.155.1 a) b) y c) y art. 122 de LS76).

Como la Ley permite la incorporación a la gestión común, de empresas urbanizadoras que aporten total o parcialmente los fondos necesarios para urbanizar en las condiciones que se determinen, en tal supuesto la obligación de atender al coste de las obras, por los propietarios, quedará sustituida por las contraprestaciones que la empresa haya de percibir por sus aportaciones a la gestión urbanística.

Además, tendrán que contribuir a los gastos de funcionamiento de la propia Junta (instalación, servicios, personal, honorarios técnicos y demás propios del funcionamiento de una empresa o sociedad urbanizadora que es lo que en este aspecto concreto es una Junta de Compensación), art. 154 del TR y 124 LS 76.

\subsection{LOS DERECHOS DE LOS PROPIETARIOS.}

Frente a las cargas a las que han de hacer frente los propietarios integrantes del sistema de compensación están los derechos que tiene todo 
propietario, así un derecho, de carácter previo, es el de oponerse al sistema de compensación, tal oposición lleva consigo la posible expropiación de los terrenos por la Administración urbanística actuante en beneficio de la Junta de Compensación.

Tienen derecho a solicitar de la Administración actuante que el pago de los costes de urbanización que deban ser sufragados por los propietarios afectados se efectúe en terrenos edificables cedidos gratuitamente y libres de cargas en la proporción que se estime suficiente para compensarlos (art.155.2 del TR y 122.2 L.S 76).

Pueden solicitar que las obras de urbanización se ejecuten directamente por la empresa urbanizadora incorporada a la Junta y que haya aportado total o parcialmente los fondos necesarios para urbanizar el suelo, en cuyo caso la compensación por tal aportación podrá satisfacerse en terrenos reservados a tal fin (art. 176 y 177 RGU).

Ejercitar su derecho de aprobar o rechazar el Proyecto de Compensación, previa audiencia de todos los afectados, bajo el necesario quórum para su aprobación por la Junta, de la mayoría de sus miembros que, a su vez, representen los dos tercios de las cuotas de participación (art. 174 RGU).

Tienen derecho a adquirir en plena propiedad y disponibilidad los solares resultantes que se le adjudiquen de acuerdo con las previsiones de las Bases de Actuación y del Proyecto de Compensación.

Participar en los beneficios que obtenga la Junta de Compensación como resultado de su gestión urbanística, una vez deducidos los gastos de gestión, urbanización, etc.

Podrán disfrutar con carácter permanente, de la exención del Impuesto General sobre Transmisiones Patrimoniales y del de Actos Jurídicos Documentados a favor de las transmisiones de terrenos que se realicen como consecuencia de la constitución de la Junta de 
Compensación por aportación de los propietarios y de las adjudicaciones de solares que se efectúan a favor de los propietarios miembros de dichas Juntas y en proporción a los terrenos incorporados por aquéllos (arts. 159.4 del TR. 122 LS 76 y 171 del RGU). Ejercitar y hacer valer cuantos otros derechos no enumerados vengan reconocidos por los estatutos y bases de compensación. Impugnar los acuerdos de la Junta de Compensación en el plazo y procedimientos previstos por el artículo 184 del RGU494.

Esto derechos y deberes que acabamos de enumerar conforman el contenido del sistema de compensación.

\section{LA JUNTA DE COMPENSACION.}

\subsection{INTRODUCCION.}

Una vez determinado el sistema de actuación, en el caso que nos ocupa, el sistema de compensación, se procederá a la puesta en marcha del mismo, mediante la constitución obligatoria de la Junta de compensación, salvo que:

a) todos los terrenos pertenezcan a un solo titular (art. 157.1 TR y 157.3, 173 y 174.2 del RGU)en cuyo caso el art. 173 RGU, dispone que: «En los supuestos de propietario único, el proyecto de compensación se limitará a expresar la localización de los terrenos de cesión obligatoria y de las reservas que establezca el Plan, así como la localización de las parcelas edificables, con señalamiento de aquellas en que se sitúe el aprovechamiento que corresponda a la Administración actuante».

Como estamos ante el sistema tipo de ejecución privada del urbanismo ${ }^{495}$. en este supuesto la urbanización constituirá una actividad

494 Vid. MARTIN BLANCO, J., La Compensación.., cit. p. 141 y ss.

495 Vid. GONZALEZ BERENGUER, Gestión, financiación y control del urbanismo, ob.cit. pp. 581 y ss. 
típicamente privada, sin intervención administrativa. Podrá contratarse libremente la ejecución de la obra urbanizadora, siendo responsable de las infracciones en que pudieran incurrir, el propietario o comunidad de propietarios.

Una vez terminada la obra de urbanización y vendida la totalidad o parte de las parcelas, si la conservación de las obras de urbanización y el mantenimiento de las dotaciones e instalaciones de los servicios públicos fuesen a cargo de los propietarios de los terrenos comprendidos en la unidad de ejecución, habrán de integrarse en una entidad de conservación (art.68 RGU), que será una entidad urbanística colaboradora ${ }^{496}$.

b) En el supuesto de que todos los terrenos pertenezcan a una comunidad pro indiviso tampoco es necesaria la constitución de la Junta:

Esta situación se equipara expresamente a la del propietario único (art. 157.3 RGU) a los efectos del sistema de compensación, si no existiese oposición por parte de ninguno de los condueños ${ }^{497}$. Si existiera oposición será preciso, para aplicar el sistema de compensación, constituirse en Junta de Compensación, con arreglo a las normas generales, entendiéndose que la exigencia del porcentaje de superficie quedará cumplida cuando concurra el 60 por 100 de las cuotas de interés en el proindiviso (art. 157.3.2 RGU), la solución es idéntica, en el caso de que aparezcan discrepancias entre los copropietarios una vez que esté en marcha la gestión urbanística por el sistema de compensación.

Por tanto, para poder hablar de Junta tiene que haber una pluralidad de sujetos.

496 Vid. GONZALEZ PEREZ, J. Comentarios al Texto Refundido de 1992, Madrid, 1993, p. 1195.

497 Vid. GARCIA DE ENTERRIA Y PAREJO, Lecciones p. 528, quienes consideran la equiparación de la comunidad pro indiviso al propietario único como un acierto, pues «esta exigencia de la unanimidad... viene dada por el régimen civil de la comunidad ordinaria de bienes, conforme al cual rige la regla de la mayoría sólo para los actos de mera administración y disfrute de la cosa común (art. 398 C.c) y la regla del acuerdo unánime para los restantes actos, es decir, para los de disposición y que impliquen alteración de la cosa (art. 397 C.C)». 
Ese carácter obligatorio de la constitución de la Junta deriva del hecho de que «sin la aprobación de la constitución de la Junta no puede aprobarse el proyecto de compensación; proyecto que se configura como título de adjudicación de las fincas resultantes (adjudicación de las fincas como ejecución del proyecto de compensación), que será objeto de estudio más adelante.

\subsection{NATURALEZA JURIDICA DE LA JUNTA DE COMPENSACION.}

El art. 158.3 del TR del 92 (art. 127.3 de la LS), señala que la Junta de compensación tiene naturaleza administrativa, personalidad jurídica propia y plena capacidad para el cumplimiento de sus fines 498 .

El RGU, en su art. 24.2, la incluye entre las entidades urbanísticas colaboradora 499 , a través de las cuales dice el art. 24.1 del RGU, los interesados participaran en la gestión urbanística.

498 El artículo 26.2 del RGU, sólo reconoce la personalidad desde la inscripción en el Registro General de Entidades Urbanísticas Colaboradoras. En consecuencia, podrá adquirir, poseer y enajenar los bienes de su patrimonio. Actuarán como fiduciarias con pleno poder dispositivo sobre las fincas pertenecientes a los miembros. Así lo dispone el art. 159.2 del TR, en esta dirección vid. GONZALEZ SALINAS, Sistema de compensación...,ob.cit., pp. 80 y ss.; MARTIN BLANCO, Dictámenes y estudios en derecho Urbanístico, Madrid, 1974, p. 388; ESPEJO y PEREZ DE LA CONCHA, Ejecución de Planes de Ordenación Urbana y Proyectos de Urbanismo, Madrid, 1970, pp. 242-243; LLISET, Naturaleza de las Entidades urbanísticas colaboradoras, REVL, 1975, pp. 693 y ss., y La fiscalidad en las Juntas de Compensación, RDU, núm. 53, p.69; GARCIA DE ENTERRIA y PAREJO, Lecciones de Derecho urbanístico, Madrid, 1981, p. 526; GARCIA GARCIA, La reparcelación y la compensación en relación con el Registro de la Propiedad, RCDI, núm. 576, pp. 1361 y ss; COSCULLUELA MONTANER, en «Teoria General de la Gestión Urbanística», en RDU, 1977, no 53; LOPEZ PELLICER y BUSQUETS CUEVAS, en Sistema de Actuación Urbanística: modelo de expediente y acuerdos para su publicación. I. El sistema de compensación, Centro de Documentación, Estadísticas y Publicaciones del I.E.A.L., p. 204; CARCELLER FERNANDEZ, en Reparcelación y Compensación en la Gestión Urbanística, Madrid, 1980, p. 222 y ss.

499 Vid. , entre otros, VILLAR PALASI, Sobre la personalidad y el acceso al Registro de las Entidades urbanísticas colaboradoras, RDU, núm. 43, pp. 13 y ss.; CARCELLER, El régimen de las Entidades urbanísticas colaboradoras según el Rrep, RDU, núm. 43, pp. 45 y ss.; FUENTES LOJO, Suma de la propiedad por apartamentos, Barcelona, 1978, II , pp. 1241 y ss.; UTRERA, La Junta de Compensación: su naturaleza jurídica y negocio jurídico de constitución, Revista de Derecho Notarial, núm. 109-110, pp. 157 y ss. Desde el punto de vista jurisprudencial vid. la St. de 13 de febrero de 1992 de la AP de Badajoz, Actualidad civil, 217/ 1993; St. del TS de 24 de mayo de 1994, f.jco.2o, RJ 1994/3907; St. de la A.P. de Pontevedra de 26 de junio de 1995, f. jco. 2ㅇ․ Actualidad civil 79/1996, marginal 118, entre otras , que abordan el tema de la naturaleza jurídica de la Junta de compensación. 
A pesar de esta calificación de la Junta, como entidad urbanística de carácter administrativo, la doctrina puso en duda que su naturaleza sea administrativa dada la confusión de intereses privados y públicos que en ella concurren 500 .

Pues, si bien es cierto que la Junta posee una vertiente privada o particular, en cuanto que las aportaciones de carácter patrimonial que realizan algunos de sus miembros integrantes de la junta (art. 159.4 del TR(art.129.3 de la LS) y 167.1.a), d), g), j) del RGU), van a constituir un «fondo común» sobre el que recae la actividad urbanizadora de la junta, siguiendo el principio de «solidaridad de beneficios y cargas» derivadas de la gestión urbanística(art. 157.1 del RGU)501, también tiene un fundamento de carácter público, en el sentido de que tiene por objeto la gestión y ejecución de una función pública502 en interés de toda la comunidad, como es la urbanización de una determinada unidad de ejecución (art. 156.1 del TR), siendo la junta responsable frente a la Administración competente, de la urbanización completa de la unidad de ejecución, y de la edificación de

500 Vid. BUSQUET CUEVAS, en La práctica del sistema de compensación, 1972, p. 84 dice: en el sistema de Compensación, la colaboración privada alcanza su máxima importancia, pues el ordenamiento jurídico al encomendar a los particulares asociados actividades urbanísticas de carácter público los integra en el esquema institucional del derecho urbanístico, con personalidad y plena capacidad jurídica, con arreglo a la Ley y a los estatutos «. Para TOMAS RAMON FERNANDEZ, las entidades urbanísticas colaboradoras tienen la naturaleza de entidades privadas, en Derecho administrativo, sindicatos y autoadministración, Madrid, 1972, p. 128.

501 Ello constituye un elemento más en la configuración del derecho de propiedad urbanística. En este sentido, la STS de 4 de octubre de 1983 (Ar. 5060) hace suyo un considerando de la sentencia de la Audiencia que establece: «Los expedientes de esta naturaleza (por ejemplo, el de constitución de la junta de compensación) forman gradualmente el último escalón de la Planificación Urbanística, participando, en consecuencia, de su carácter normativo y por tanto vinculante en su misión de delimitar el derecho de propiedad haciéndole cumplir la función social insita en el mismo». Sobre el tema de la gestión común y la «solidaridad de beneficios y cargas» puede verse la STS de 24 de noviembre de 1980 (Ar. 4596).

502 Sobre esta cuestión puede verse la St. de 11 de marzo de 1989( Ar. 1968 ) y la St. de 30 de octubre de 1989 (Ar. 7478), donde se expresa que: «la ejecución del planeamiento es claramente en nuestro ordenamiento jurídico una función pública, en la que los propietarios del suelo a urbanizar pueden asumir mayor, menor o incluso nulo protagonismo según el sistema de ejecución que se aplique». 
los solares resultantes (art. 160.1 del TR (art.130.1 de la LS) y 182 del RGU)503.

La Junta en tanto que persona jurídica, es la única que está legitimada para actuar frente a la Administración, pero también está legitimada para actuar frente a los propios miembros que incumplen y frente a aquellos propietarios que se niegan a aceptar la gestión urbanística por el sistema de compensación, pudiendo incluso solicitar su eliminación del sistema mediante la expropiación.

El fundamento de la existencia de la junta de compensación abarca las dos facetas, pública y privada, de manera conjunta, sin que sea necesario deslindar la una de la otra y dar prioridad a una sobre la otra; «aunque la finalidad última e inevitable es pública (urbanizar), la razón fundamental de la imposición del sistema está en el interés privado de los individuos afectados. Este fundamento privado, viene corroborado inicialmente por el hecho de que la junta se dota inicialmente de unos estatutos y redacta unas bases de actuación y un proyecto de compensación sin intervención inmediata y directa de la Administración, la cual intervendrá, en un segundo momento, en defensa precísamente del fundamento de tipo público, aprobados o no definitivamente dichos actos de la junta» 504

Esta dualidad de intereses público y particular505, se puede armonizar o bien acudiendo, aunque con carácter excepcional art. 305TR (236LS)506, a los «Tribunales y Juzgados del orden civil« (art. 9.2 LOPJ)

503 Pero además de esta relación entre junta y Administración de tipo funcional, se puede hablar también de una relación orgánica, dado que diferentes aspectos relativos a la junta, que iremos viendo a lo largo de este trabajo, permiten considerarla como englobada en la jerarquía administrativa por ejemplo, la aprobación de sus estatutos, la del proyecto de compensación, la prohibición de interdictos o los recursos contra sus actos.

504 Vid. DEL POZO CARRASCOSA, P., El sistema de compensación urbanística, ob. cit. p. 46.

505 Sobre la dualidad de intereses, vid. la St.de11de marzo de 1989 (Ar. 1968), F.jco. núm. 3. 506 Vid. GONZALEZ PEREZ, Comentarios, t. 3, p. 2331, reconoce esta posibilidad, aunque excluyéndola de las entidades urbanísticas colaboradoras por su "carácter administrativo». Asimismo, reconoce el carácter excepcional del acceso a la jurisdicción civil. 
bien a «los Tribunales y Juzgados del orden contencioso-administrativo» (art. 9.4 LOPJ), sin perjuicio de que en ellos se aleguen normas de Derecho civil y el órgano jurisdiccional se base, total o parcialmente, en ellas para resolver la cuestión planteada507, esta sería la vía normal ya que o bien la intervención directa de la Administración actuante o simplemente el propio cumplimiento de la finalidad urbanística, impondrán el acceso a la Jurisdicción Contencioso-Administrativa.

A partir de la promulgación del Reglamento de Reparcelaciones en 1966 se sostuvo que «ahora con más fundamento, puede decirse que las entidades urbanísticas colaboradoras no son sociedades civiles, ni mercantiles, ni asociaciones sometidas a la Ley General 191/1964, de 24 de diciembre»508. No son similares a las sociedades civiles reguladas en los artículos 1665 y siguientes del Código Civil509, porque si bien es verdad que tienen concomitancias con tales sociedades al referirse en algunos aspectos a derechos iusprivatísticos de sus componentes: «aportaciones de carácter patrimonial que realizan sus miembros», «equitativa distribución de los beneficios y de las cargas entre los mismos» etc., lo cierto es que cumplen primordialmente, funciones administrativas 510.

507 Este principio es admitido por la STS de 5 de octubre de 1987(Ar.8298), F.jco. 1. La cuestión litigiosa se refería a un aval en garantía del cumplimiento de una obligación entre una empresa y un ayuntamiento. La sentencia señala que, dado el carácter accesorio del aval, éste tiene carácter jurídico-administrativo a raíz del artículo 234 LS, pues también lo tiene el convenio principal. Pero lo importante, y lo que realmente tiene interés a efectos de nuestra argumentación, es que el Tribunal, a falta de normas especificas que regulen el particular, puede acudir a los ordenamientos civil o mercantil: "el aval configura un contrato accesorio del que garantiza y éste, en el presente caso, indudablemente tiene carácter jurídicoadministrativo, pues así lo prescribe expresamente el artículo 234 de la Ley del Suelo y, por tanto, sus contingencias han de decidirse en esta vía jurisdiccional, a las que consecuentemente han de someterse también las de aquél su accesorio, constituido precisamente como consecuencia de lo dispuesto en dicha normativa urbanística, y sin que para ello sea obstáculo legal el que en su decisión, y a falta de normas específicas que regulen el particular cuestionado, haya de acudirse a las contenidas en ordenamientos jurídicos de carácter civil o mercantil».

508 Vid. CARCELLER FERNANDEZ, Instituciones..., ob.cit., p. 267.

509 El artículo 1665 del Código Civil establece que «la sociedad es un contrato por el cual dos o más personas se obligan a poner en común dinero bienes o industria, con ánimo de partir entre sí las ganancias".

510 Vid., Sentencia de 29 de diciembre de 1987 (Ar. 9854). 
Tampoco, se les puede calificar como «asociaciones de interés particular «art. 35.2 de C. Civil511, puesto que no existe ánimo de obtención de un lucro partible. $\mathrm{Ni}$ tampoco pueden ser consideradas como «asociaciones de interés público» puesto que tienen limitada la libertad de integración inicial en la misma, se incorporan los propietarios con carácter obligatorio. Si la incorporación no se produce voluntariamente determina la expropiación, en beneficio de la Junta, de los propietarios que rechazan el sistema. En este caso la expropiación no tiene un sentido punitivo, la única finalidad es que un sector minoritario no obstaculice el hacer de la mayoría representada como comunidad real.

Esta libertad también falta en las transmisiones que de las fincas se realicen con posterioridad según el art.28 del RGU, el adquirente entrará a formar parte de la junta automáticamente, lo quiera o no.

No es posible incluirlas dentro del concepto de «corporación», ni de derecho público art. 35.1 del C.c., art. 114.8.1de la LAU y art. 15 de la Ley 12/1983, de 14 de octubre, del Proceso Autonómico512, ni en las de derecho privado (arts.35.1 y 993 C.c que habla de «corporaciones», en contraposición con el art. 994 del mismo cuerpo legal que hace referencia a los «establecimientos públicos oficiales»), la no inclusión dentro de estas entidades radica en la especificidad del sistema de creación de la junta, ya que a pesar de la limitación en cuanto a la libertad de integración tampoco se acerca a la «incorporación forzosa», propia de las corporaciones ${ }^{513}$.

Por todo lo que acabamos de decir, en la actualidad con la regulación que el RGU ha hecho de las entidades urbanísticas

511 El artículo 35.2 del C.c señala que : «las asociaciones de interés particular, sean civiles, mercantiles o industriales, a las que la ley conceda personalidad propia, independiente de la de cada uno de los asociados" son personas jurídicas .

512 Vid. DEL POZO CARRASCOSA, El sistema de compensación...,ob.cit., p. 47 y bibliografía allí citada.

513 Vid. COSSIO, Comentarios..., ob.cit., pp.833-834, donde señala que la nota distintiva de las corporaciones en relación con las asociaciones es la libertad de pacto, es decir, la incorporación forzosa; BAENA DEL ALCAZAR, en su obra Administración central y administración institucional en el Derecho español, Madrid, 1976, pp. 40-41, también considera el carácter forzoso como una de las características de las corporaciones. 
colaboradoras, en los artículos 24 al 30, nos pronunciamos por la naturaleza jurídico-pública514 de la Junta de Compensación, porque cumple fundamentalmente funciones administrativas de orden urbanístico.

La junta de compensación, tiene carácter administrativo y depende de la Administración urbanística actuante (art. 26.1 del RGU); estos dos aspectos resultan de la propia regulación legal de la junta de compensación. La calificación administrativa se contiene en el artículo 158.3 del TR; este mismo artículo, en su número 4, integra en el órgano rector de la junta un representante de dicha Administración, y en el número 5 establece que los acuerdos de la Junta de Compensación serán recurribles en alzada ante la Administración actuante.

Su constitución y liquidación, así como las modificaciones de sus Estatutos, requieren, para su eficacia, de un acto de aprobación administrativo (art. 27.1 .4 y art. 30.1 del RGU), y es en el registro donde se va a reflejar la vida y disolución de estas entidades art. 27.3 y 4 del RGU515.

Esta regulación de las entidades urbanísticas colaboradoras y, por tanto, de la junta de compensación como persona jurídico-administrativa no es discrepante, defiende García de Enterría516 , con la propia naturaleza de las cosas; «se está ante el fenómeno bien conocido de la atribución a los propios particulares interesados de la gestión de una función pública (la

514 Vid. GARCIA DE ENTERRIA y PAREJO, Lecciones..., ob.cit., pp. 532-533; CARCELLER FERNANDEZ, Instituciones de derecho urbanístico, Madrid, 1984, pp. 348-349; LOPEZ PELLICER, Elaboración..., ob.cit.,pp. 180-181.

515 Allí se establece, que «los nombramientos y ceses de las personas encargadas del gobierno y administración de la Entidad se inscribirán también en dicho Registro». «La modificación de los Estatutos requerirá aprobación de la Administración urbanística actuante. Los acuerdos respectivos, con el contenido de la modificación, en su caso, habrán de constar en el Registro".

516 Vid. GARCIA DE ENTERRIA Y PAREJO ALFONSO, en Lecciones de Derecho Urbanístico, vol. 2, Madrid, 1980, p. 340. Tal vez sea TOMAS RAMON FERNANDEZ, en Manual de Derecho Urbanístico, Madrid, 1980 quien plantea la cuestión que nos ocupa con mayor rigor. Para él, las Juntas de Compensación constituyen una figura típica de autoadministración, es decir, de gestión autónoma por los propios interesados de funciones inicialmente administrativas; lo que es un fenómeno característico del moderno Derecho Administrativo que se produce en muchos y muy diferentes sectores, bien bajo formas públicas de personificación, bien bajo formas privadas. 
ejecución del planeamiento) en régimen de autoadministración ${ }^{517}$, mediante la agrupación de los particulares en una organización corporativa, es decir, de base asociativa, sin perjuicio de las facultades de control de la Administración, en tanto que ésta no pierde en ningún caso la titularidad de aquella función y de las potestades a ella conectadas «.

Concluyendo, se podría decir que la Junta de Compensación es una entidad urbanística colaboradora de naturaleza administrativa ${ }^{518}$, sometida a la tutela de la Administración urbanística actuante 519.

La Jurisprudencia también ha optado por la tesis de la naturaleza jurídico-pública de la junta de compensación. Así lo establece la sentencia de 21 de octubre de 1987 y la de 29 de diciembre de 1987, en cuyo fundamento jurídico $2^{\circ}$ señala: «... ellas cumplen primordialmente funciones administrativas de orden urbanístico, y es este carácter el que las define de forma más acusada, en cuanto tienen como fin último la realización de fines urbanísticos que sólo se pueden reputar cumplidos cuando la corporación municipal a la que se hallan vinculados da por concluida la urbanización para cuya realización se constituyeron y recibe las obras ejecutadas, no pudiendo, entretanto, abandonar sus socios o componentes el ámbito de la misma, continuando hasta entonces sujetos a sus acuerdos y decisiones«.

La consecuencia más importante de este carácter jurídico administrativo es la fiscalización por los órganos municipales o urbanísticos

517 Como pone de relieve la St. de 11 de marzo de 1989: «mediante la constitución de la junta de compensación que da lugar a un supuesto de autoadministración, son los propietarios los que desarrollan la función pública de la ejecución del planeamiento en virtud de una delegación que hace de la junta un agente descentralizado de la administración, de suerte que aquélla tiene naturaleza administrativa -art. 127.3 del TR- en tanto en cuanto actúe funciones públicas «.

518 La naturaleza administrativa de la junta, establece la St. de 30 de octubre de 1989 (Ar. 7478), «no significa que toda la actuación de la junta de compensación esté sometida al Derecho administrativo: en la medida en que aquélla gestiona intereses propios de sus miembros sin ejercicio directo de funciones públicas, está sujeta al Derecho Privado. De ello deriva, pues, que al contratar - ejecución de obras, préstamos, ventas de terrenos, etc. - no ha de someterse a las formalidades propias del Derecho administrativo, pues todo ello tiene un carácter instrumental respecto de la finalidad última de la ejecución del planeamiento sin implicar el ejercicio directo de funciones públicas».

519 En este mismo sentido, vid, GONZALEZ PEREZ, Comentarios...,ob.cit., p. 1199. 
estatales o de las Comunidades Autónomas que llevan a cabo la gestión urbanística, con la posibilidad de recurso de alzada ante los mismos ${ }^{520}$. Así se expresa en el número 5 del art. 158 TR (art. 127.5 LS 76) y en el artículo 184 RGU.

González Salinas dice que la Junta es sujeto de la relación jurídico-administrativo que determina su existencia. La Administración ostenta una posición de tutela y, por tanto, arbitral, no sólo por la doble vía de alegaciones (por ejemplo, art. $174 \mathrm{RGU}$ ) y recursos (art. 158.5) que interpongan los propietarios minoritarios que acaban apoyando a éstos o a los órganos de la Junta, sino cuando la Junta solicita en su apoyo y beneficio la utilización de la vía de apremio administrativo o la expropiación forzosa (art. 160 TR y correlativos; art. 130 LS 76 ) ${ }^{521 .}$

\subsection{DERECHO A FORMAR PARTE DE LA JUNTA DE} COMPENSACION.

En principio, las Juntas de Compensación estarán integradas por propietarios que representen, al menos, el 60 por 100 de la superficie total de la unidad de ejecución 522 .

Según el art. 161.3 y 163.3 del RGU son propietarios afectados «tanto los de suelo comprendido en la unidad de ejecución como los de suelo destinado a sistemas generales ${ }^{523}$ que hayan de hacer efectivo su

520 Vid. CARCELLER, El régimen de las Entidades Urbanísticas Colaboradoras según el Rrep. , RDU, núm. 2, p. 64.

521 Vid. GONZALEZ SALINAS, Sistema de compensación .., ob.cit., pp. 80 y ss.

522 Propietarios de terrenos incluidos en la unidad de ejecución, sean particulares o entidades públicas (art. 158.1, 161.3 y 162.4-5del RGU).

$523 \mathrm{~L}$ a legislación urbanística denomina sistemas generales a las obras de infraestructura en materia de comunicaciones, servicios, etc. La Exposición de Motivos de la Ley del Suelo de 1975, en su apartado VI, párrafo $2^{\circ}$, los define y ejemplifica como «redes arteriales, grandes abastecimientos, etc.», y el artículo 68.2.d) TR establece que los Planes Directores territoriales de Coordinación realizarán «el señalamiento y localización de las infraestructuras básicas relativas a las comunicaciones terrestres, marítimas y aéreas, el abastecimiento de agua , saneamiento, suministro de energía y otras análogas» ; CARCELLER, Instituciones, ob. cit. p. 238, los define como: «los elementos integrantes de la estructura general de la ordenación urbanística (comunicaciones, espacios libres, etc. )o como el conjunto de 
derecho en dicho polígono o unidad de actuación». Este concepto no se predica de los titulares de derechos reales limitados, bien sean de goce o de garantía, sobre los terrenos citados ${ }^{524}$.

Esa situación de «propietario afectado» puede originarse en el propio Plan o a iniciativa de los propios sujetos.

En el propio Plan: A este respecto, el artículo 149.2 del TR (art. 119.3 LS 76) así como 157.2 y 158.1 RGU, establecen que, al igual que la normativa anterior, permite que los propietarios que representen al menos el 60 por 100 de la superficie de la unidad de ejecución, soliciten la adopción del sistema de compensación en el trámite de información pública del procedimiento regulado en el art. 146.2 del TR. Lo que suponía que la apreciación de aquellas circunstancias únicamente podía verificarse en el Plan o programa de Actuación.

Aquí se incluye todos los propietarios de la unidad, tanto los que aceptan el sistema de compensación como aquellos que lo rechacen.

\section{A instancia de los particulares interesados ${ }^{525}$ :}

De aquellos sujetos cuyos terrenos son susceptibles de formar una unidad de ejecución, cuando ni ésta ni, por tanto la aplicación del sistema de compensación están previstas en el Plan (art. 146.2 TR; 38.1.a) del RGU). Si bien todos los propietarios de la unidad de ejecución van a ser afectados por el sistema de compensación, solo los interesados van a tomar parte activa en la gestión urbanística por dicho sistema .

elementos que, ordenadamente relacionados entre sí, contribuyen a lograr los objetivos del planeamiento en materia de comunicaciones, servicios, espacios libres y equipamientos comunitarios, a nivel generalmente de ordenación supralocal».

524 Ello se pone de manifiesto en la propia legislación urbanística que habla siempre de «propietarios»(así se contempla en los arts. 157.2 TR (126.2 LS), 158.1, 161.3 y 162.4-5 RGU). La situación jurídica en la que quedan los titulares de estos derechos reales limitados 0 cargas que recaigan sobre las fincas incluidas en la unidad de ejecución, la analizaremos en un momento posterior.

525 Esta legitimación no se limita a los propietarios de terrenos en la unidad de ejecución (propietarios afectados) sino que debe reconocerse a todo el que tenga interés, según la norma general del artículo 31, LRJPA, (Ley 30/ 1992, de 26 de noviembre, de régimen jurídico de las administraciones públicas y de procedimiento administrativo común) más limitada que la legislación para promover Planes urbanísticos (art. 104 LS) . Cfr. Comentarios a este artículo, y CARCELLER FERNANDEZ, Reparcelación y compensación en la gestión urbanística, Madrid, 1980, pp. 23 y ss. 
Es la situación de propietario afectado, la que origina el derecho a formar parte de la junta de compensación ${ }^{526}$. Derecho éste, que podrá ejercitarse, no sólo en el proceso de constitución de la Junta (art. 166.e)RGU), sino también una vez constituida la Junta de compensación (art. 158.1 TR, art. 127.1 LS 76).

El momento del nacimiento de este derecho a formar parte de la Junta de compensación está en función del titular que lo solicite y según su fuente.

1. Así, en el caso de propietarios de suelo incluidos en la unidad de ejecución, sean particulares o entidades públicas (art. 163.2 RGU) ${ }^{527}$ y de los propietarios del suelo exterior a la unidad de ejecución ocupada para la ejecución de sistemas generales (art. 163.3 del RGU), la fuente del derecho a integrarse en la Junta de compensación es la Ley (art. 157.1 y 168.2.2 RGU), y el derecho nace en el mismo momento en que cada uno de esos sujetos mencionados puede calificarse como propietario afectado528.

Este derecho a formar parte en la Junta está presidido por el principio de igualdad entre sus titulares, en el sentido de que según establece el art. 166.e) RGU las condiciones y los requisitos exigidos «no podrán ser más gravosos para unos propietarios que para otros «, tendrán los mismos derechos y obligaciones los propietarios que se incorporen a la Junta como los miembros fundadores (art. 158.1 TR).

526 Vid. DEL POZO CARRASCOSA, P., El sistema de compensación, ob.cit. p. 54.

527 Las fincas de los que no se incorporen serán expropiadas en favor de la Junta de Compensación (art. 158 TR) que tendrá la cualidad de beneficiaria.

${ }^{528}$ En todo caso, el derecho a formar parte de la junta sólo será eficaz cuando el sistema de compensación sea viable, es decir cuando «los propietarios que representen al menos el 60 por 100 de la superficie total de la unidad de ejecución» estén de acuerdo en la aplicación del sistema de compensación (art. 149.2 y 157.3 TR así como el 158.1 RGU).Sino se consigue la voluntad de los propietarios que representan el 60 por 100 de la superficie del polígono, es nula la constitución de la misma. La St. de 10 de mayo de 1988 (Ar. 4448) desarrolla el procedimiento que se debe seguir para la constitución desde la solicitud hasta el inicio de su funcionamiento. Vid. el art. 157.2 de la LS sobre procedimiento. En idéntico sentido que la anterior, pero especificando que no se pueden excluir para computar el 60 por 100 las superficies edificadas, podíamos citar la St. de 7 de octubre de 1982(Ar. 6344). 
2. Al lado de los propietarios, podrán incorporarse a la Junta de Compensación las empresas urbanizadoras que hayan de participar en la gestión de la unidad de ejecución, así lo admite el art. 158.2 del TR y el art. 165 del RGU529. Su incorporación debe estar prevista expresamente en los estatutos de la Junta y su representación debe limitarse a una sola persona (art. 166.f RGU). El derecho a integrarse en la junta de compensación en este caso, es concedido por acuerdo de la propia Junta.

Los propietarios interesados son aquellos que teniendo el derecho a formar parte de la Junta de Compensación, acepten el sistema de compensación (art. 163.2 y 168.2.2 RGU). La consecuencia del no interés y por tanto de la no integración en la Junta, es la expropiación de los terrenos en favor de la Junta (art.168.2.1 del RGU). Estos conceptos no se aplican a las entidades públicas titulares de bienes incluidos en el polígono, las cuales, si bien no tienen obligación de solicitar el sistema de compensación, aunque la superficie de sus terrenos se incluirá en el computo de 60 por 100 necesario para la puesta en marcha del sistema (art. 157.2 TR), si están obligadas a integrarse en la Junta en el caso de que el sistema se aplique efectivamente 530 .

529 Vid. BUSQUETS, La práctica del sistema de Compensación, Madrid, 1972, pp.35 y ss.; LLISET BORELL, La actividad urbanística de los particulares, Madrid, 1975, pp. 230 y ss.; ESPEJO Y PEREZ DE LA CONCHA, Ejecución, ob.cit. p. 205. En el ámbito jurisprudencial la St. de 21 de enero de 1991 (Ar. 547) en el cuarto fundamento de derecho dice: «Respecto a la incorporación de unas empresas urbanizadoras en la Junta de Compensación sin cumplir con los requisitos exigidos en sus Estatutos, procede, conforme a lo expuesto en la sentencia apelada, declarar que tales empresas no fueron incorporadas a la Junta por su condición de urbanizadoras, como se desprende de la lectura del acuerdo municipal, correspondiendo a los demandantes acreditar, mediante la proposición de prueba en el expediente administrativo o en este recurso, que no tenían la condición de propietarios; que como prueba de un hecho negativo pudo hacerse exigiendo que se requiera a los demandados para que aportaran los documentos acreditativos de esa propiedad si lo que consta en el expediente administrativo no se estimare suficiente al efecto"».

530 Esto queda establecido en el art. 163.2 del RGU que distingue entre los propietarios personas privadas y los propietarios entidades públicas; los primeros según este precepto serán aquellos que hayan aceptado el sistema, no tienen esta consideración los segundos. «La Junta quedará integrada, según este precepto por los propietarios de terrenos que hayan aceptado el sistema, por las Entidades públicas titulares de bienes incluidos en el polígono o unidad de actuación, ya tengan carácter demanial o patrimonial, y en su caso, por las empresas urbanizadoras que se incorporen. 
En cuanto a las empresas urbanizadoras, no se las aplica esta noción de «interés», ya que no es posible la expropiación de sus bienes como mecanismo de facilitación de la gestión urbanística.

La integración efectiva en la Junta (art. 163.2 RGU) significa la aceptación definitiva del sistema de compensación por parte del propietario afectado. Este ingreso ha de hacerse según establece la legislación urbanística, «en el plazo límite de un mes tras la notificación a los propietarios afectados del acuerdo de aprobación definitiva, por parte de la Administración actuante, de los estatutos y bases de actuación de la futura junta. Si no lo hicieran, sus fincas serán expropiadas en favor de la Junta de Compensación, que tendrá la condición jurídica de beneficiaria»(art. 158.1 TR) . Esto quiere decir que los propietarios que no acepten el sistema de compensación quedan excluidos definitivamente de la posibilidad de intervenir en la gestión urbanística del polígono, con el objeto de no entorpecer el proceso urbanístico531. Además según establece el art. 36.1 RGU, «la ejecución se realizará siempre por unidades de actuación o polígonos completos» 532.

La incorporación a la junta de compensación puede producirse de forma voluntaria u obligada:

- Voluntariamente entran a formar parte de la junta todos los sujetos enumerados en el art. 163.2 .3 RGU excepto la Administración, por tanto:

531 Vid. FERNANDEZ, Manual, p. 161. señala: «la alternativa a la no incorporación voluntaria es la expropiación de los terrenos de los propietarios disidentes en favor de la junta constituida por la mayoría, lo que garantiza la posibilidad de llevar a término la ejecución del planeamiento en todo el polígono y evita el bloqueo del sistema por la minoría, a la que no obstante, no se perjudica en absoluto, puesto que se le abona el justo precio de sus propiedades».

532 A mayor abundamiento la St. de 26 de abril de 1988 señala en su F.jco. 4ㅇ que «la expropiación de los terrenos propiedad de quienes no se hubieren incorporado a la junta de compensación es uno de los efectos de la constitución de aquélla, efecto que se produce antes de la formulación del proyecto de compensación «y en su F.jco. 5 añade que « la Sala Territorial resolvió con acierto al afirmar la imposibilidad de aprobar un proyecto de compensación sin la previa expropiación de los terrenos cuyos propietarios no se han incorporado a la junta de compensación». 
- propietarios de terrenos incluidos en la unidad de ejecución

- propietarios de suelo destinado a sistemas generales

- y a las empresas urbanizadoras como lo ponen de manifiesto las expresiones «podrán incorporarse» (art. 158.1.2 TR y el art. 165.1 RGU) «su incorporación... si lo desean». En caso de que la incorporación no se realice, se procederá a la expropiación (Art. 158.1 del TR y 162.5 RGU).

De forma obligatoria la incorporación se produce principalmente, en el caso de la Administración, cuando sea titular de bienes incluidos en la unidad de ejecución. Esa incorporación de la Administración o de cualquier «entidad pública», como señala el art. 163.2 RGU, se produce por su condición de propietario de unos determinados terrenos, no teniendo nada que ver con la función de control y fiscalización que tiene la presencia obligada de un miembro de la Administración actuante en el órgano rector de la Junta (art. 158.4 TR) 533 .

Otro supuesto de integración obligatoria o automática en la Junta, es el que recoge el art. $28 \mathrm{RGU}$, el adquirente de una finca sujeta al sistema de compensación se entiende incorporado a la junta desde el momento de la transmisión.

La incorporación a la Junta de Compensación, puede tener una doble eficacia, según se deduce del art. 159.1 TR:

- Eficacia personal: Consiste en la posibilidad de intervenir en un proceso de gestión urbanística por el sistema de compensación. La actuación por el sistema de Compensación supone la realización de las obras de urbanización por los propietarios constituidos, cuando sean varios, en Junta de Compensación.

Pero hay que señalar aquí, que la cualidad de miembro de la Junta es « real», ya que está vinculada a la titularidad del bien que se ha

533 La Ley establece la necesidad de que forme parte del órgano rector de la Junta, en todo caso, un representante de la Admón. actuante, que será nombrado en el acto de aprobación de los Estatutos y de las Bases de actuación (art. 162.3 RGU). 
aportado (art. 28 RGU); por esta razón, los miembros de la Junta no pueden abandonarla hasta que se produce la urbanización, excepto en el caso de la transmisión de la finca, como señalábamos anteriormente.

- Eficacia real: Se produce cuando el ingreso en la junta lleva aparejada la transmisión a la misma de los inmuebles afectados a los resultados de la gestión común 534 .

Por tanto, si los Estatutos no establecen expresamente lo contrario, no existirá transmisión de la propiedad de los terrenos a la Junta. Los propietarios conservan el dominio sobre sus fincas, pero las facultades de disposición pasan a la Junta de Compensación, que las ejercerá libremente como fiduciaria535, con pleno poder dispositivo sobre las fincas pertenecientes a los propietarios. De esta forma, los terrenos siguen siendo propiedad de los miembros, que conservan la disposición de su propiedad, y podrán realizar actos de enajenación y gravamen, y el adquirente se subrogará en la condición de miembro de la Junta, con los derechos y obligaciones derivados de su Estatuto536.

${ }^{534} \mathrm{El}$ art. 159.1 TR dispone que la incorporación de los propietarios a la junta no presupone, salvo que los Estatutos dispongan otra cosa, la transmisión a la misma de los inmuebles afectados a los resultados de la gestión común.

535 Vid. en este sentido, NUÑEZ RUIZ, Derecho urbanístico español, Madrid, 1967, p. 313 al decir que con la incorporación de los terrenos se concede a la junta, "una especie de mandato común de carácter representativo». Y CARCELLER FERNANDEZ, «El régimen de las entidades urbanísticas colaboradoras según el reglamento de reparcelación», RDU, no 2, p. 60.

536 Hasta que se proceda a la adjudicación de las fincas resultantes, en esa fase intermedia, se podría decir, que conviven, de alguna manera, el poder de disposición de la Junta, en cuanto que podrá ejercer esas facultades de disposición como fiduciaria y el poder de disposición de los propietarios que se traduce en la realización de acto de enajenación y gravamen, si bien se les priva de las facultades de goce. 


\subsection{CONSTITUCION DE LA JUNTA DE COMPENSACION}

\subsubsection{LA INCORPORACION A LA JUNTA.}

Podrán solicitar la incorporación a la Junta, los miembros titulares de algún derecho sobre las fincas incluidas en la unidad de ejecución. Esta solicitud podrá hacerse antes de constituirse la junta (art. 157.2 y 158.1 TR, 157.1 y 2, 158.1, 162.5 y 163.1 .2 y 3 RGU). También es posible la incorporación a la Junta en el plazo de un mes, desde la notificación de la aprobación definitiva de los estatutos y las bases de actuación, por parte de la Administración actuante, art. 158.1 TR.

Finalmente existe la posibilidad de incorporación a la Junta, una vez constituida, dentro del plazo que la misma determine (art.163.5 RGU); de esta forma, «los propietarios o interesados que no otorguen la escritura podrán consentir su incorporación en escritura de adhesión, dentro del plazo que al efecto se señala»; es un supuesto de incorporación sobrevenida.

También podríamos hablar de la incorporación automática o «ex lege» a la Junta, tanto en el caso de la Administración, como propietaria de bienes dentro de la unidad de ejecución, como en el de los adquirentes de fincas incluidas en la unidad de ejecución, una vez que la Junta ya se ha constituido.

Excepto para las empresas urbanizadoras, la pertenencia a la Junta se determina en función de la titularidad de un sujeto sobre un derecho que recaiga sobre alguna de las fincas incluidas en la unidad de ejecución, o sobre terrenos destinados a sistemas generales, y que han sido imputados a la unidad de ejecución en cuestión. Esto significa que la posibilidad de pertenencia a la Junta se determina «propter rem» 537. Por 
esta razón, cualquier adquirente posterior de una finca sujeta a la gestión por compensación, cuando su transmitente formase parte de la misma, entrará a formar parte de la Junta desde que dicha transmisión se produce 538 .

Finalmente decir que la incorporación a la Junta se rige por el principio de igualdad, tanto en el momento de la constitución (art. 166.e RGU), como con posterioridad a la misma art.158.1 TR.

\subsubsection{PROCEDIMIENTO DE CONSTITUCION DE LA JUNTA}

Una vez transcurridos los plazos previstos en el art. 162.5 RGU, la Administración actuante requerirá a los interesados para que constituyan la Junta de Compensación, mediante escritura pública en la que designarán los cargos del órgano rector, que habrán de recaer necesariamente en personas físicas (art. 163.1 RGU) 539

En la escritura de constitución deberá constar (art. 163.4 RGU):

a) Relación de los propietarios y, en su caso, empresas urbanizadoras;

b) Relación de las fincas de las que son titulares;

c) Personas que hayan sido designadas para ocupar los cargos del órgano rector;

d) Acuerdo de constitución.

538 Así lo manifiesta el art. 28 RGU al decir que: «la transmisión de la titularidad que determine la pertenencia a cualquiera de los tipos de entidades urbanísticas colaboradoras llevará consigo la subrogación en los derechos y obligaciones del causante, entendiéndose incorporado el adquirente a la Entidad a partir del momento de la transmisión. En la misma dirección, STS de 28 de mayo de 1991 (Ar. 5243) F. jco. 1 y 2.

539 Este otorgamiento es el que constituye el verdadero acto de constitución de la Junta, vid. MARTIN BLANCO, ob. cit. , p.183. 
Los propietarios o interesados que no otorguen la escritura podrán consentir su incorporación en escritura de adhesión dentro del plazo que al efecto se señale (art. 163.5 RGU).

La copia autorizada de la escritura y de las adhesiones, en su caso, se trasladará al órgano urbanístico actuante, quien adoptará si procede, acuerdo aprobatorio en el plazo de treinta días (art. 163.6 RGU) 540.

Una vez aprobada la constitución, la Administración actuante elevará el acuerdo junto con la copia autorizada de la escritura al órgano competente de la respectiva Comunidad Autónoma, para su inscripción en el Registro de Entidades urbanísticas colaboradoras (art. 163.7 RGU).

La constitución de la Junta comprende las siguientes fases:

A) REDACCION DE LOS ESTATUTOS Y BASES DE ACTUACION DE LA JUNTA.

Una vez aprobado de forma definitiva el plan o programa de actuación urbanística, en el que se haya fijado como sistema de actuación urbanística el de compensación, los propietarios que representan al menos el 60 por 100 de la superficie total del polígono o unidad de ejecución, procederán a la redacción de los proyectos de Estatutos y de las Bases de actuación ${ }^{541}$.

540 Más que aprobación, de la constitución por el órgano urbanístico actuante, se trata como señala MARTIN BLANCO, en su obra, La compensación, ob. cit., pp. 249-257, de una homologación, constituyendo en este sentido una manifestación de la función tutelar del órgano urbanístico, careciendo de valor constitutivo.

541 La reforma del 75 modificó el sistema de la Ley anterior, no haciendo alusión alguna a la posibilidad de que sea el Ayuntamiento el que proponga las bases del sistema, como permitía el art. 126. c) en su primitiva redacción. Con arreglo al texto vigente, son los propietarios los que deben redactar los proyectos de bases y estatutos en la proporción señalada anteriormente. El artículo 161.2 RGU dispone que «la redacción de los proyectos de los estatutos y de las bases de actuación corresponderá a los propietarios interesados que reúnan el porcentaje de superficie que da lugar a la aplicación del sistema de compensación». En la misma dirección se pronuncian las siguientes sentencias: STS de 2 de noviembre 1985, establece, que según se dispone en el art. 126.2 de la Ley del Suelo, y correlativos 161y162 RGU, la redacción de los proyectos de estatutos y las bases de actuación 265 
El art. 158.1 RGU, establece un plazo de dos meses contado desde la aprobación definitiva del Plan que hubiese establecido el sistema de compensación, para que los propietarios que representen al menos el 60 por 100 de la superficie de la unidad de ejecución presenten el proyecto de estatutos y de bases de actuación. Si no lo presentan en ese plazo, la Administración actuante requerirá a los propietarios para que los presenten en el plazo de dos meses más (art. 158.1 RGU y 157.2 TR). Por tanto, el transcurso de este plazo sin que se presente el proyecto de estatutos y de bases de actuación no determina, automáticamente, la sustitución del sistema de compensación ${ }^{542}$ ' sino que es preciso el requerimiento de la Administración para poder optar por otro sistema (art. 158.2 RGU) ${ }^{543}$.

corresponde a los propietarios interesados que reúnan el porcentaje de superficie que permite la aplicación del sistema de compensación» así como la sentencia de 26 de diciembre de 1991 (Ar. 361 de 1992).

542 Así lo recoge la STS de 26 de febrero de 1985.

543 Vid. GONZALEZ SALINAS, J., Sistema de compensación..., ob. cit., pp. 127 y ss. En el ámbito jurisprudencial, STS de 26 de diciembre de 1991 (Ar. 361 de 1992) que en sus fundamentos de derecho quinto y sexto, establece: "Conforme al art. 158 del Reglamento de Gestión Urbanística, referido al sistema de compensación, el proyecto de estatutos y el de bases de actuación tiene que ser formulado por propietarios que representen al menos el 60 por 100 de la superficie total del polígono o unidad de actuación. Como en el caso que se enjuicia, según resulta de los antecedentes que quedaron indicados en el primer razonamiento, propietarios que representaban el 44,4 por 100 de la superficie de la unidad de actuación en cuestión manifestaron a la Administración municipal que no había acuerdo con los demás propietarios en relación con la presentación del correspondiente Proyecto de Estatutos y Bases de Actuación, resultaba inútil, al no poder alcanzarse el referido 60 por 100, el requerimiento previsto en el aludido artículo 158 del Reglamento de Gestión Urbanística, lo que impide entender que dicho art. se haya infringido en el caso que nos ocupa. Según resulta de los términos del mencionado artículo, antes indicados, para la presentación del proyecto de estatutos y el de bases de actuación sí es necesario que el mismo se formule por propietarios que representen al menos el indicado porcentaje del 60 por 100, pero para que la Administración proceda a la sustitución del sistema de compensación es suficiente, o bien, como expresa el indicado artículo, que no se hayan presentado los documentos expresados en el plazo previsto, o bien que, como ha ocurrido en el caso de autos, antes de transcurrir el mencionado plazo tenga conocimiento la Administración de que no se va a poder alcanzar el mencionado porcentaje del 60 por 100. Sexto, se refiere el art. $155 \mathrm{RGU}$ al cambio del sistema de actuación y en su párrafo segundo establece que «si el sistema estuviera establecido en el Plan o Programa de Actuación Urbanística habrá de analizarse la repercusión del cambio de sistema en el estudio económico-financiero". La parte apelante entiende que en el caso presente no se ha cumplido lo establecido en el referido párrafo segundo. La alegación que acaba de indicarse no puede ser acogida si se tiene en cuenta que si bien no aparece cumplido formalmente el requisito al que ahora nos referimos, la finalidad del precepto mencionado en relación a que no se proceda al cambio de sistema sin que se analicen las repercusiones económicas que puedan derivarse del mismo, sí aparece cumplida en el supuesto enjuiciado ya que en uno de los informes municipales emitidos en el expediente administrativo expresamente se indica 


\section{B) APROBACION INICIAL, POR LA ADMINISTRACION ACTUANTE DE LOS PROYECTOS DE ESTATUTOS Y DE LAS BASES DE ACTUACION.}

Una vez redactados los proyectos de Estatutos y de Bases de actuación, se someterán a la Administración actuante que decidirá acerca de la aprobación inicial (art. 161.1 y 3 RGU). Es esa aprobación la que inicia el procedimiento de Constitución de la Junta de Compensación 544

Aunque el proyecto se aprobara inicialmente sin alcanzar ese 60 por 100, podrá alcanzarse sucesivamente por incorporaciones de otros propietarios antes o después de la aprobación definitiva. Si se alcanza antes, en la aprobación definitiva habrá quedado subsanado el defecto inicial (STS de 9 de mayo de 1984); después de la aprobación definitiva también se puede subsanar el defecto si las Bases y Estatutos son asumidos por un 60 por 100 en los escritos de contestación o en los sucesivos de adhesión 545 .

El plazo para decidir sobre esa aprobación inicial es de dos meses desde la presentación de la documentación completa. Si transcurre ese plazo sin recaer acuerdo, la Comunidad Autónoma actuará por subrogación cuando así se solicite por los interesados, debiendo decidir en el plazo de dos meses contados desde la solicitud ante el órgano autonómico (art.157.2 LS).

como conveniente a los intereses municipales el cambio al sistema de cooperación dada la carga financiera que supondría la elección del sistema de expropiación».

544 Así queda puesto de manifiesto en el F. jco 2 de la STS de 19 de marzo de 1986 (Ar. 4578).

545 Vid. GONZALEZ SALINAS, Sistema de compensación, en , XVI Temas de Derecho Urbanístico, Oviedo, 1980, pp. 302 y ss. 
C) INFORMACION PUBLICA Y AUDIENCIA DE LOS PROPIETARIOS AFECTADOS.

La LS en su art. 157.2 y el RGU prevén un trámite que es, a la vez, de información pública y de audiencia y vista ${ }^{546}$

A los propietarios afectados, se los notificará la incoación del procedimiento personalmente ${ }^{547}$, evitando interpretaciones restrictivas de la necesidad de la citación personal548, haciéndose mención al Boletín Oficial de la CC.AA en que se publica el anuncio549' aunque estos medios de periódicos oficiales nunca pueden sustituir ni subsanar la notificación personal de los interesados 550 . Una vez notificados, en el plazo de 15 días podrán formular alegaciones y, en su caso, solicitar la incorporación a la Junta (art. 161.3 y 162.1 RGU).

También podrán formular alegaciones los propietarios interesados, durante el plazo de 15 días, contados desde la publicación en el Boletín de la Comunidad Autónoma (art. 162.2 RGU).

546 La STS de 2 de noviembre de 1985 dice: «Una vez presentado el proyecto, es sometido a información pública y comunicado individualmente a los propietarios afectados en un procedimiento cuyo protagonismo asume la Administración Pública, normalmente el Ayuntamiento, se sigue la tramitación hasta que, superadas las diferentes fases de aprobación inicial... se llega a la definitiva».

547 Vid STS de 8 de abril de 1.978 (Ar. 1568), al establecer la teoría general de las calificaciones dice que no es ésta «una mera cuestión formal, que no se trata de cumplir el trámite guardando unas simples apariencias sino de algo más profundo, porque el acto de notificación...desde el punto de vista del derecho de garantía del administrado....tiene sus propias exigencias que son fundamentales en cuanto sin ellas no existe la seguridad de que el particular haya quedado perfectamente enterado".

548 Vid. STS de 31 de octubre de 1.979.

549 Vid. STS de 23 de octubre 1991 (Ar. 8382).

550 Vid. la STS de 28 de octubre de 1.978 (Ar. 3985), que califica de situación de indefensión a la producida por falta de citación personal impuesta por el artículo 42 de la Ley del Suelo suficiente para decretar la nulidad del procedimiento y diciendo que la notificación no puede ser suplida por la publicación de anuncios, asimismo queda recogido en las STS de 6 de mayo de 1.977 (Ar. 3486), de 26 de febrero de 1.977 (Ar. 1605) y de 27 de febrero de 1.978 (Ar. 736). 


\section{D) APROBACION DEFINITIVA DE ESTATUTOS Y BASES.}

Transcurridos los plazos de alegaciones, mencionados anteriormente, la Administración actuante aprobará definitivamente los Estatutos y Bases de actuación con las modificaciones que procedieren en su caso y designará un representante en el órgano rector de la Junta (arts. 158.4, 127.4 LS 76 y art. 162.3 RGU).

Este acuerdo según los párrafos 4 y 5 del art. 162 RGU se publicará en el Boletín Oficial de la Provincia y se notificará a los propietarios afectados que no hubiesen solicitado la incorporación a la Junta ${ }^{551}$, constituyendo ello una auténtica audiencia de los interesados «y por tanto vinculante en su misión de delimitar el derecho de Propiedad haciéndole cumplir la función social insita en el mismo, a través de las limitaciones y obligaciones derivadas de la planificación, por lo que, y para lograr el necesario equilibrio con el reconocimiento de tal derecho de rango constitucional, se impone, como decíamos, la audiencia de sus titulares» 552 . para que puedan efectuarlo en el plazo de un mes, de forma que, si no lo

551 La notificación individual es esencial para la validez de la aprobación de los Estatutos y Bases, y si se han excluido de dicha notificación algunos propietarios de edificios o solares es nula la aprobación; así se expresa la St. del T.S. de 7 de octubre de 1.982 (Ar. 6344).

552 En el caso de que la notificación se haga a los titulares registrales y éstos no sean los propietarios verdaderos porque aquéllos hayan transmitido su propiedad, «la notificación se ha de considerar correctamente efectuada si se hizo al titular registral, y si una vez conocidos los verdaderos titulares se les concedió un plazo especial para que efectuaran las alegaciones que tuvieren por conveniente; pues es clara la voluntad del legislador de que en los expedientes instruidos a tales fines se oiga a los propietarios de las fincas afectadas 0 al menos se les de la oportunidad de ser oídos, arbitrando para ello el medio más eficaz e idóneo que ofrecen las normas procedimentales, constituido por la imposición obligatoria de la notificación o citación personal a los mismos de los diversos actos administrativos que vayan produciéndose en tales expedientes; imposición que pretende una auténtica audiencia de los interesados en cuanto a los Expedientes de esta naturaleza forman gradualmente el último escalón de la planificación urbanística participando en consecuencia de su carácter normativo y por tanto vinculante en su misión de delimitar el derecho de Propiedad haciéndole cumplir la función social insita en el mismo, a través de las limitaciones y obligaciones derivadas de la planificación por lo que, y para lograr el necesario equilibrio con el reconocimiento de tal derecho de rango constitucional, se impone, como decimos, la audiencia de sus titulares. No se trata por consiguiente, pese a la terminología de los textos legales de un simple acto de comunicación entre la Administración y los propietarios afectados, sino de una auténtica llamada a los mismos, cuya falta dada la transcendencia de estos expedientes, lo sumiría en un manifiesto estado de indefensión", así se plasma en la St. del T.S. de 4 de octubre de 1.983, ( Ar. 5060). 
hicieran, «sus fincas serán expropiadas en favor de la Junta de Compensación, que tendrá la condición jurídica de beneficiaria» (art. 158.1 TR).

Es posible la aprobación por silencio administrativo como queda puesto de manifiesto en el art. 157.2 in fine al establecer que «los Estatutos y Bases se entenderán aprobados si transcurrieran dos meses desde su aprobación inicial, sin que, por la Administración actuante, o por la Comunidad Autónoma, en caso de subrogación, se hubiera comunicado resolución expresa, supuesto en todo caso el cumplimiento del trámite de información pública».

La tramitación de las bases de actuación y de los estatutos es conjunta y simultanea, hasta la aprobación definitiva en ambos documentos por la Administración actuante.

La formulación de estos proyectos, constituye la primera actividad de los particulares interesados en que el sistema de actuación sea el de compensación. Por tanto, la redacción de los mismos es previa a la constitución de la Junta de Compensación (art. 157.2 TR).

\subsection{ORGANOS RECTORES DE LA JUNTA DE COMPENSACION.}

Por lo que a este punto se refiere, y teniendo en cuenta los objetivos de este trabajo, bastaría señalar que la legislación urbanística prevé la existencia de un plenario (art. 177.3 RGU) o pleno de la junta y de los denominados «órganos rectores» (art. 177.3 y 4 RGU), denominados también «órganos directivos» (art. 164 RGU) u «órganos de gobierno y administración« (art. 166.g), h) RGU.

Las competencias están distribuidas de la siguiente manera: 
La aprobación del proyecto de compensación es competencia exclusiva del plenario de la junta excepto en los casos de propietario único (art. 174.2 RGU), que es él mismo el que formula dicho proyecto y lo eleva a la Administración actuante para su aprobación. Una vez tramitado el proyecto, se elevará a la aprobación definitiva de la Administración actuante (art. 174.1 RGU).

Por lo que se refiere a la adopción de acuerdos por parte del plenario de la junta, el art. 29 RGU en su primera parte, señala que: «los acuerdos de las entidades urbanísticas colaboradoras se adoptarán por mayoría simple de cuotas de participación, salvo que en los Estatutos o en otras normas se establezca un quórum especial para determinados supuestos».

En el art. 166.g), se establecen especialidades para supuestos concretos, se habla de la posibilidad del voto proporcional al «derecho o interés económico de cada miembro» frente a la regla general del voto «individualizado» 553

Los «órganos rectores» de la junta de compensación ostentan la representación legal de la misma, de tal forma que las relaciones de la junta con el Ayuntamiento o la Administración actuante deben ser mantenidas sólo por el presidente o la representación legal de la junta o el propietario único554. La propia junta puede legitimar a los órganos rectores para que realicen actos de disposición individuales tendentes a la correcta ejecución y desarrollo del proyecto de compensación (art. 166. g) RGU).

\subsection{RESPONSABILIDAD DE LA JUNTA DE COMPENSACION.}

Según establece el art. 160.1 del TR «la Junta de compensación será directamente responsable frente a la Administración competente de la 
urbanización completa de la unidad de ejecución y, en su caso de la edificación de los solares resultantes, cuando así se hubiere establecido».

La Junta, responde del cumplimiento de las funciones que se le hayan asignado, y por tanto, de la «urbanización completa de la unidad de ejecución», así como de las restantes funciones que hubiesen establecido los Estatutos. Lo que supone la ejecución de las obras de urbanización y su conservación hasta su cesión a la Administración actuante.

La obligación de urbanizar555, lleva consigo la responsabilidad de presentar los proyectos de urbanización, para legitimar y concretar las obras, determinando el objeto de la relación obligatoria y el proyecto de compensación como instrumento para articular simultáneamente las cesiones de terrenos a la Administración y las aceptaciones de las nuevas parcelas a los gastos de la urbanización con la solidaria distribución de los beneficios y cargas del planeamiento 556

La presentación de ambos proyectos (compensación y urbanización) está sometida al cumplimiento de unos plazos, de este modo, en relación con el proyecto de compensación, aunque la cesión de terrenos a la Administración (Art. 179.2 RGU) no sea obstáculo para la ejecución de las obras, hay que tener presente la existencia de un plazo para la presentación del proyecto que las articula, y así poder disponer, real o financieramente, del suelo adjudicado557. Ese plazo puede establecerse en las bases de actuación o en el mismo planeamiento.

555 En cuanto a la obligación de urbanizar, el art. 182.2 del RGU dispone que: «la responsabilidad será exigible tanto en lo que afecta a las características técnicas de la obra de urbanización ejecutada como a los plazos en que ésta debió terminarse y entregarse a la Administración».

556 Vid. GONZALEZ SALINAS, J., ob. cit. pág. 98.

557 Vid. MARTIN BLANCO, J., señala al respecto en su obra La compensación....ob. cit. pp. 335 y ss., que aunque cuando el suelo de cesión obligatoria y gratuita una vez cedido mediante el proyecto de compensación pueda ser ocupado por la Junta para ejecutar las obras (art. 179.2 RGU), no resulta indiferente que, en tanto esa ocupación no sea necesaria, pueda la Administración utilizar o ejecutar sus obras sobre los mismos o disponer de los que integren el patrimonio municipal del suelo para las finalidades a que éste se afecta. 
Por lo que respecta al contenido del proyecto de urbanización, en lo que a las obras se refiere, se concretará en el plan o incluso en las bases de actuación como queda recogido en el art. 167.2 RGU, así como los plazos para la realización de las obras y para la presentación de dicho proyecto; sobreentendiéndose que se redactará con la antelación necesaria para que las obras puedan realizarse de acuerdo con los plazos previstos en el plan. Es en este contexto donde se concreta el incumplimiento de la obligación de urbanizar, que será exigible según establece el art. 182.2 RGU «tanto en lo que afecte a las características técnicas de la obra de urbanización ejecutada como a los plazos en que ésta debió terminarse y entregarse a la Administración». Aquí cobra sentido la aplicación del art. 182.1 RGU que establece que «la Junta de Compensación será directamente responsable, frente a la Administración actuante, de la urbanización completa del polígono o unidad de ejecución y, en su caso, de la edificación de los solares resultantes, cuando así se hubiese establecido, y de las demás obligaciones que resulten del plan de ordenación, de las bases de actuación o del presente Reglamento».

¿Qué ocurre si la Junta de compensación incurre en infracciones?.

A este respecto, el art. 183.1 RGU establece que «cuando en el ejercicio de sus atribuciones la Junta de Compensación incurra en infracciones que hayan de calificarse graves según lo preceptuado en la Ley, con independencia de la sanción económica que corresponda, la Administración podrá desistir de ejecutar el plan por el sistema de compensación y aplicar el de cooperación, e imponiendo en su caso, la reparcelación o el sistema de expropiación».

La Junta no sólo debe ejecutar la urbanización, sino que ha de hacerlo sin incurrir en infracciones urbanísticas, infracciones dice el precepto «que han de calificarse de graves»; y es que la Junta puede 
incurrir en infracciones en relación con la edificación y el uso del suelo, bien al edificar, bien al urbanizar (arts. 76-77-78 y 79 RDU) así por ejemplo:

a) realizando obras de edificación o urbanización en contra del uso que corresponde al suelo en el que se ejecuten, en cuyo caso serán sancionados con multa del 10 al 20 por 100 del valor de la obra proyectada.

b)realizando, en terrenos destinados por el planeamiento a uso público o de interés general o común, actos, obras o instalaciones que perturben gravemente dicho uso, la sanción será de multa del 10 al 20 por 100 del valor del suelo afectado, cuando el hecho que impida el uso o produzca la perturbación origine una situación permanente, y con multa del 1 al 5 por 100 de dicho valor, cuando se realicen con carácter meramente ocasional, o las instalaciones o actividades puedan ser objeto de legalización por el órgano administrativo competente.

c)realizando acto de uso del suelo que sean incompatibles o alteren la utilización prevista en el planeamiento, en cuyo caso le será de aplicación la sanción impuesta en el apartado b), dependiendo, asimismo del carácter permanente u ocasional de los actos de infracción.

d) Ilevando a cabo edificaciones con altura superior a tres plantas, donde no exista plan o normativa urbanística que lo autorice; o quienes edifiquen en solares enclavados en núcleos edificados en más de sus dos terceras partes con alturas superiores a la media de los edificios ya construidos, en cuyo caso serán sancionados con multa del 10 al 20 por 100 de su valor el exceso de edificación sobre la edificabilidad permitida por el Plan.

El hecho de ser alguno de los propietarios miembros quien individualmente hubiese cometido la infracción o en general obstaculizado la actuación, no podrá servir a la Junta para excusar su responsabilidad ante la Administración, ya que «la Junta integra solidariamente a todos los 
propietarios y responde directamente frente a la Administración actuante (art. 160.1 TR y arts. 182 y 183 RGU), debiendo haber utilizado los medios de que institucionalmente está dotada para imponerse y haber instado a su debido tiempo la tutela de la Administración para beneficiarse de la ejecución o expropiación» 558, pero como dice González Pérez ¿qué medidas podrá aportar la Administración Pública frente a la Junta en caso de incumplimiento?.

El art. 119 LS del 76 establecía la procedencia de la aplicación del sistema de expropiación, cuando la Junta de Compensación incumplía las obligaciones inherentes al sistema de compensación. El art. 149.3 TR remite a la legislación urbanística aplicable, y en defecto de dicha legislación se sustituirá, dice el párrafo 4, el sistema de gestión privada por otro de gestión pública ${ }^{559}$ en consecuencia, podrá acudirse al sistema de cooperación o al de expropiación, imponiendo en su caso la reparcelación (art. 183.1 RGU).

\subsection{RESPONSABILIDAD DE LOS MIEMBROS DE LA JUNTA DE} COMPENSACION.

Los propietarios de los terrenos de la unidad de ejecución deben aportar los terrenos de cesión obligatoria, realizar a su costa la urbanización y, en su caso, edificar en los solares resultantes (art. 157.1 TR). Si los terrenos fuesen de un solo propietario, tal obligación recaerá directamente sobre éste; si fuesen varios, deberán constituir la Junta de Compensación, que será la responsable directa ante la Administración del

558 Vid. GONZALEZ SALINAS, J., ob. cit. p. 49 y ss.; FERNANDEZ RODRIGUEZ, Manual de Derecho Urbanístico, Madrid, 1.991, p. 175 y ss.; GONZALEZ PEREZ, J., Comentarios...,ob. cit. p. 1.235; FERNANDEZ, T.R, Manual..., ob. cit. p. 160.

559 Para tratar de proteger los intereses de los propietarios no culpables del incumplimiento, el párrafo 4 del art. 149 TR en su regla segunda, reconoce a los propietarios que cumplan los requisitos que en él se señalan el derecho a conservar el derecho a adquirir el aprovechamiento urbanístico, siendo expropiados los restantes por el valor que establece el art. 42.3 TR; vid. GONZALEZ PEREZ, ob. cit. p. 1163. 
cumplimiento de la obligación. Por tanto, los propietarios responden ante la Junta y ésta responde directamente ante la Administración.

En caso de propietario único, desaparece la figura de la Junta de Compensación, con lo cual solamente existiría una relación de obligación directa entre el propietario único y la Administración. Puede incluso, como apunta González Salinas, que esa unicidad sea sobrevenida, como consecuencia de haberse quedado como único promotor uno de los propietarios que representen el 60 por 100, supuesto en el que también estarán legitimadas las expropiaciones a los propietarios no incorporados y no será necesaria la culminación del procedimiento en la constitución de la Junta 560

Dado que es la Junta la que ejecuta la urbanización con cargo a los propietarios, las obligaciones de éstos serán las de pagar las cantidades necesarias para realizar la urbanización. De ahí que el párrafo 4 del art. 160 TR, prevea especialmente el supuesto del pago de las cantidades adeudadas por los propietarios a la Junta.

En caso de incumplimiento por parte de los miembros de la Junta, la LRJPA en sus arts. 94 y 95, arbitra medios de ejecución forzosa para obligarles al cumplimiento. Como hemos dicho anteriormente que, con carácter general, la obligación del propietario consistirá en el pago de cantidades líquidas, la vía idónea de ejecución forzosa será el apremio sobre el patrimonio (art. 96. a) y 97 LRJPA), aunque también podrán utilizarse otros medios de ejecución forzosa cuando la obligación no sea pecuniaria (art. 301 TR) ${ }^{561}$ Además el párrafo 2 del art. 160 TR, nos dice que

560 Vid. GONZALEZ SALINAS, J. ob. cit. p. 94 y ss. En el mismo sentido, LLISET BORRELL, La actividad urbanística de los particulares, Madrid, 1975, p. 292; LOPEZ PELLICER, Elaboración y gestión del planeamiento, ob. cit. p. 203; GONZALEZ PEREZ, J., Comentarios...p., 1234.

561 De esta forma lo recogen los párrafos 2 y 3 del art. 301 TR al establecer que «los procedimientos de ejecución y apremio se dirigirán ante todo contra los bienes de las personas que no hubieren cumplido sus obligaciones, y sólo en caso de insolvencia frente a la Asociación administrativa de propietarios.

También podrán ejercer las mismas facultades, a solicitud de la Asociación, contra los propietarios que incumplieren los compromisos contraidos con ella». 
«la Ley habilitará a la Administración actuante para expropiar sus respectivos derechos en favor de la Junta de Compensación, que tendrá la condición jurídica de beneficiaria». Se establece, por tanto, la expropiación como mecanismo sancionador562.

No obstante todo ello, se establece una garantía en favor del propietario incumplidor, consistente en que no podrán instarse ninguno de los procedimientos señalados anteriormente hasta transcurrido un mes desde el requerimiento de pago efectuado por la Junta de Compensación (art. 181.3 RGU); lo que significa que, en cualquier caso y antes de ponerse en marcha los mecanismos coercitivos expresados, el propietario incumplidor tendrá la oportunidad de cumplir con las obligaciones en el plazo de un mes para las que se le haya requerido por la Junta de Compensación. Resulta patente, por tanto, que aunque el propietario incumpla, sino se le hace el requerimiento por la Junta y se le concede el plazo de un mes para el pago, no podrán ponerse en marcha los mecanismos expresados.

Además, y en relación al instrumento expropiatorio por incumplimiento, opera en favor del propietario una garantía más, por cuanto éste puede, en cualquier momento anterior al levantamiento del acta de ocupación, pagar las cantidades adeudadas a la junta, con los intereses y recargos que procedan, dando lugar a la cancelación del expediente expropiatorio (art. 181.4 RGU); lo que tiene su fundamento en el principio de proporcionalidad que impone que sólo debe acudirse a la medida expropiatoria en casos límites, ya que en los supuestos normales de incumplimiento del pago, el procedimiento de apremio resulta más adecuado para la finalidad perseguida 563 .

562 En el mismo sentido se expresa el art. 181.1 RGU.

563 Así se pronuncia la generalidad de la doctrina, Vid., entre otros, LOPEZ PELLICER, Elaboración..., ob. cit., p. 198, y «Costes y cuotas de urbanización y compensación» RDU, № 67, p. 97 y ss.; ABELLA, Reglamento de gestión urbanística, Madrid, 1980, p. 69; LLISET BORRELL, "Cuotas de urbanización», RDU, no 46, p. 64 y ss.; GONZALEZ SALINAS, 


\section{LOS ESTATUTOS DE LA JUNTA DE COMPENSACION.}

\subsection{CONCEPTO Y CONTENIDO.}

Los estatutos, son las normas constituyentes de la Entidad que definen su organización interna, su funcionamiento y régimen económicofinanciero, así como las garantías jurídicas correspondientes a los miembros de la Junta ${ }^{564}$. Son por tanto las reglas de organización y funcionamiento de la Junta; representan la estructura orgánica y funcional de la Entidad.

El contenido viene señalado en el art. 166 RGU, según el cual los Estatutos contendrán las siguientes circunstancias:

a) Nombre, domicilio, objeto y fines.

b) Organo urbanístico bajo cuya tutela se actúe.

c) Expresión del polígono o unidad de actuación que constituye su objeto ( unidad de ejecución).

d) Duración.

e) Condiciones o requisitos para incorporarse a la Junta, que no podrán ser más gravosos para unos propietarios que para otros. Los cotitulares de una finca o derecho habrán de designar una sola persona para el ejercicio de sus facultades como miembro de la Junta, respondiendo solidariamente frente a ella de cuantas obligaciones dimanen de su condición. Si no designaren representante en el plazo que al efecto se señale, lo nombrará el órgano actuante.

Cuando las fincas pertenezcan a menores o personas que tengan limitada su capacidad de obrar, estarán representados en la Junta de Compensación por quienes ostenten la representación legal de los mismos.

Sistema de compensación, ob. cit., p. 90; MARTIN BLANCO, La Compensación..., ob. cit. p. 482.

564 Vid. CARCELLER FERNANDEZ, A., Reparcelación y Compensación en la gestión urbanística, Madrid, 1980, p. 235. 
f) Condiciones o requisitos para incorporarse a la junta empresas urbanizadoras si expresamente se previera la posibilidad de su participación. Estas estarán representadas por una sola persona.

g) Organos de gobierno y administración, forma de designarlos y facultades de cada uno de ellos.

h) Requisitos de la convocatoria de los órganos de gobierno y administración, requisitos y forma de adopción de acuerdos, quórum mínimo y forma de computarse los votos, con expresión de los casos en que sean proporcionales al derecho o interés económico de cada miembro y aquellos otros en que el voto sea individualizado.

i) Derechos y obligaciones de sus miembros.

j) Medios económicos y reglas para la exacción de aportaciones que con carácter tanto ordinario como extraordinario pudieran acordarse.

k) Expresión de los recursos que con arreglo a la Ley sean procedentes contra los acuerdos de la Junta.

I) Normas sobre su disolución y liquidación.

\section{LAS BASES DE ACTUACION DE LA JUNTA}

\subsection{CONCEPTO Y CONTENIDO}

No hay en la Ley del Suelo ni en el Reglamento de Gestión una definición de lo que debe de entenderse por Bases de Actuación, se da por sabido el concepto limitándose a establecer que las bases de actuación serán aprobadas por la Administración actuante (art. 157.2TR y 126.2 LS 76), señalando las determinaciones que han de contener así como la redacción, tramitación y aprobación de las mismas (art. 167 RGU).

Las bases de actuación constituyen el mecanismo de fijación de los criterios que presidirán toda la actividad futura de la junta de 
compensación, esto queda reflejado en el art. 172 RGU, donde se expresa

que «de acuerdo con los criterios establecidos en las bases de actuación, la junta formulará un proyecto de compensación" 565 . Contienen un conjunto de reglas y criterios que, una vez aprobados por la Administración, constituyen normas de obligado cumplimiento para la Junta y sus integrantes con efecto inmediato sobre toda la dinámica de la Junta, empezando por el Proyecto de Compensación cuya validez y legalidad, exigen que esté formulado de acuerdo con aquéllas.

De ahí que sea indispensable la aprobación de las Bases de Actuación previamente al proyecto de Compensación (art. 157.3 TR y 172 RGU) puesto que es en las Bases donde se establecen las reglas para la redacción de dicho proyecto566. Si no se efectúa así, el proyecto de compensación es nulo567.

En relación con su contenido, señala Nuñez Ruiz ${ }^{568}$ que la generalidad de las Bases de actuación suele comprender:

565 Vid. MARTIN BLANCO, D., en su obra La compensación, ob.cit., p. 265-266, define las bases de actuación como «las reglas de incorporación o valoración de aportaciones, ejecución de la urbanización y liquidación de los efectos de la actuación urbanística de la Junta . Los Estatutos regulan la constitución y organización de la junta como persona jurídica y su funcionamiento jurídico como tal. Las bases de actuación regulan la actividad o actuación de la Junta en el orden económico preponderantemente con fuerza de obligar para el Ente y sus asociados, distribuyen los beneficios y cargas y contienen los criterios para efectuar el cálculo de aportaciones y adjudicaciones dentro, todo ello, del régimen jurídico que como garantía establecen los Estatutos».

566 En esta dirección, vid. , STS 7 octubre 1982 (Ar. 6344) que, a parte de los defectos de titularidad antes mencionados, existe otro de no menor importancia en la documentación presentada por quien solicitó la aprobación del Proyecto de Compensación, y es el de que, con total infracción de lo dispuesto en el art.112.2 de la Ley de 2 de mayo de 1975 (actual art. 126.1 del Texto Refundido de 9 abril 1976), se presentó y fue aprobado un Proyecto de Compensación sin las correspondientes Bases de Actuación elemento indispensable porque sin él no es posible conocer cuáles van a ser los criterios de valoración de las fincas aportadas, de los derechos reales o personales, de las edificaciones, de las fincas resultantes, las reglas para la distribución de beneficios y pérdidas, los supuestos de compensación a metálico, etc. (extremos que, hoy ya, se concretan en el art. 167 del Reglamento de Gestión), con lo cual se imposibilita a que los demás propietarios conozcan las consecuencias que se deducirán de su incorporación a la correspondiente Junta, y como, por ello ha de estimarse que dichas Bases de Actuación son un elemento esencial, su falta o ausencia vicia «ab origen» el acto de aprobación de dicho proyecto que, por esta razón ha de ser anulado.

567 Así lo establece la St. de 7 de octubre 1982 (Ar. 6344), F. jco. 17ํㅗㄹala: «Y como ha de estimarse que dichas bases de actuación son elemento esencial, su falta o ausencia vicia ab origen el acto de aprobación de dicho proyecto, que por esta razón ha de ser anulado».

568 Vid. NUÑEZ RUIZ, M.A., Derecho Urbanístico español, Madrid, 1966, p. 213. 
1ํ Terrenos que se aportan a la Junta y su valoración con arreglo a los criterios de tasación objetiva previstos en la Ley. La aplicación de estas valoraciones es obligada en el acuerdo de fijación de las bases de actuación, pues para el caso de no ser aceptadas por algún propietario que no hubiere solicitado el sistema servirá de justiprecio para su expropiación en beneficio de la Junta.

2 ํㅜㄹijación de la cuota de participación de cada propietario en proporción al coeficiente de valoración que le haya correspondido.

3ำ Repartición proporcional de los costes de urbanización. Las bases podrán señalar o exigir anticipos y garantías que aseguren el cumplimiento de estas obligaciones; posibilidad de sufragar los costes mediante la cesión gratuita y libre de cargas de terrenos edificables, previo acuerdo de la Junta con los propietarios en cuanto a su valoración.

4ํㅡㄹ Distribución equitativa o proporcional del volumen edificable.

5ㄴ La posibilidad de que se incorporen empresas urbanizadoras y el valor que haya de asignarse a sus aportaciones al objeto de su representación mediante cuotas de participación adicionales, es algo que corresponde acordar a la Junta de Compensación

El contenido de las bases de actuación (art. 167.1 RGU), se puede estructurar en tres temas generales 569 :

A) Criterios de valoración de todos los bienes que van a ser afectados por la actuación de la Junta de Compensación.

B) Criterios que han de regir la actuación urbanística de la junta.

C) Mecanismos de financiación de la actividad urbanística de la Junta de Compensación.

Las bases de actuación deben establecer, por unanimidad, criterios de valoración de todos los bienes, que de una forma u otra, van a 
ser afectados por la actuación de la Junta de Compensación570, de no ser así, la Junta adoptará los criterios establecidos para la reparcelación (art. 157.3 TR). Estos criterios de valoración, van referidos:

- a las aportaciones realizadas por los sujetos afectados (art. 167.1. a), b) y c).

- a los resultados de la actividad edificadora de la Junta (art. 167.1

i) RGU).

- y a las fincas resultantes en función del aprovechamiento de la unidad de ejecución (art. 167.1f) y g).

No obstante por acuerdo unánime de todos los afectados pueden adoptarse criterios diferentes siempre que no sean contrarios a la Ley o al planeamiento aplicable, ni lesivos para el interés público o de terceros.

Por lo que se refiere a las aportaciones, hay que entender por tal cualquier elemento patrimonial que vaya a ser utilizado para la realización de la gestión urbanística de la junta571.

No es necesario que se trate de aportaciones en propiedad ni de elementos incluidos en la unidad de ejecución, si tenemos en cuenta las aportaciones de las empresas urbanizadoras (art. 167.1. d) y 176.4 RGU), las cuales consistirán en aquellos elementos que se hayan pactado al permitir la incorporación de la empresa a la junta y el modo de realización de las obras de urbanización ${ }^{572}$. No cabe incluir aquí las aportaciones a la Junta, a que hace mención la letra j) del art. 167.1 RGU, «aportaciones bien en metálico, bien en terrenos o en industria, en su caso», puesto que dichas aportaciones contribuyen a la financiación de la actividad urbanística de la Junta de Compensación.

570 Según establece la STS 15 de julio de 1985 (Ar. 3917), Cdo. 1, las bases de actuación no deben contener valoraciones concretas de bienes determinados, dado que esto corresponde al proyecto de compensación.

571 Vid. DEL POZO CARRASCOSA, P. ob. cit., p. 75.

572 Vid. MARTIN BLANCO, J., ob. cit., p. 271-272. 
Los derechos incluidos en la unidad de ejecución y sujetos a valoración según se deduce del art. 167.1 a) y b) son: el derecho de propiedad y los derechos reales sobre las fincas, así como los derechos personales «que pudieran estar constituidos en razón de ellas».

La existencia de derechos reales limitados o de cargas (como puede serlo una servidumbre, una hipoteca etc.) sobre alguna de las fincas aportadas puede no alterar la valoración de éstas en la aportación ni la adjudicación que corresponda a la misma, pasando a gravar la finca adjudicada si son susceptibles de subrogación real y compatibles con el planeamiento o convirtiéndose en un crédito sobre la nueva finca cuando existiendo subrogación real y compatibilidad con el planeamiento urbanístico, la situación y características de la nueva finca fuesen incompatibles con la subsistencia de los derecho reales o cargas que habrían debido recaer sobre ellas ${ }^{573^{*}}$ Por tanto, dependiendo de las circunstancias en que se encuentren, podrá hablarse de extinción, o transformación, de esos derechos y cargas, de tal forma que cuando no tenga lugar la subrogación real (art.168.1), podrá acordarse la extinción de los derechos reales y cargas constituidos sobre la finca aportada corriendo a cargo del propietario que la aportó (es decir del propietario beneficiado por la extinción del derecho real), la indemnización correspondiente art. 168.1 del TR, lo mismo ocurrirá en aquellos supuestos en que se produzca la subrogación real, si existiesen derecho reales o cargas que se estimen incompatibles ${ }^{574}$ con el planeamiento (art. 168. 2 del TR). Estas

573 Vid. MARTIN BLANCO, J., La compensación..., cit. p. 269

574 En cuanto al ámbito de lo incompatible,» la terminología legal (derechos reales y cargas, art. 168.2TR; derechos o cargas art. 123.1 RGU) debe interpretarse en un sentido amplio de cualquier situación con trascendencia real. Sentido amplio que hace que la noción de compatibilidad o no, se aplique a: cargas y gravámenes, condiciones, sustituciones y demás derecho que afecten a las fincas aportadas (art.113.1.a) y b) RGU y a servidumbres y cargas, derechos de arrendamiento y cualesquiera otros (art. 99 RGU). Sin embargo, hay que tener en cuenta que la noción de incompatibilidad recaerá normalmente sobre derechos reales limitados por ejemplo una servidumbre de paso. La noción de cuando un derecho es incompatible nos la dan los artículos 98 y 99 del RGU. Por lo que se refiere a los derechos de arrendamientos que resulten incompatibles con la gestión urbanística por el sistema de compensación se extinguirán en virtud de la aprobación del proyecto de compensación(arts.99 y 98.2 RGU, ello 
indemnizaciones se considerarán gastos de urbanización, correspondiendo a los propietarios en proporción a la superficie de sus respectivos terrenos (art. 168.4 TR y 99 RGU).

Como criterio subsidiario a lo que determine la junta, la valoración de los derechos reales sobre inmuebles se llevará a cabo con arreglo a las disposiciones sobre expropiación, que serán las que determinen el justiprecio de los mismos (art. 64.1 del TR y 135 RGU) ${ }^{575}$ ' pero en la LEF en el art. 142 se produce una alteración en el orden de prioridades a la hora de aplicar los criterios de valoración al señalar que «la determinación del justo precio de los derecho reales sobre bienes inmuebles se practicará con arreglo a las normas de valoración señaladas por la vigente legislación del impuesto sobre derechos reales», con lo cual antepone al primer rango lo que la segunda parte del artículo 64.1 del TR establece como último criterio, es decir, lo dispuesto para el Impuesto sobre Transmisiones patrimoniales y Actos Jurídicos documentados.

Respecto de los criterios de valoración de los derechos constituidos sobre las fincas, según se desprende del art. 167.1.c) RGU, al exigir los «criterios de valoración de edificaciones, obras, plantaciones e instalaciones que deberán derruirse o demolerse», la valoración del derecho de propiedad, abarca los posibles deterioros de la misma. Si en el terreno existiese alguno de estos elementos no susceptibles de conservación 576 se valoran con independencia del suelo, esta

tiene como consecuencia la indemnización por resolución del contrato. El art. 60 RGU señala que las indemnizaciones debidas a los arrendatarios correrán a cargo de los titulares de terrenos y el art. 58 RGU establece la proporcionalidad a la superficie, es decir, que todos los miembros de la Junta deberán contribuir, como gasto de urbanización, a la indemnización debida por causa de los arrendamientos incompatibles. Vid. DEL POZO

CARRASCOSA, ob.cit.,p. 144 y ss.

575 El art. 135 RGU se remite al 64.1 TR al decir que « el justiprecio de las fincas gravadas con cargas, cuando la participación de los titulares de los derechos concurrentes con el del dominio en el contenido económico de aquéllas venga determinado taxativamente por las reglas a que se refiere el número 1 del artículo 64 del TR, deberá realizarse valorando por separado cada uno de aquéllos, para distribuirlo entre los interesados.

576 Dice a este respecto el art. 98.2 RGU que «se entenderá que no pueden conservarse los elementos mencionados: cuando sea necesaria su eliminación para realizar las obras de urbanización previstas en el plan, cuando estén situados en una superficie que no se deba 
indemnización será satisfecha a los propietarios interesados con cargo al proyecto en concepto de gastos de urbanización (arts. 58, 60 y 98.1 RGU) 577.

Las indemnizaciones resultantes serán objeto de «compensación» con las cantidades de las que resulte deudor el interesado por diferencias de adjudicación o por gastos de urbanización y de proyecto (art. 98.4 RGU).

Esto significa que la junta de compensación, no siempre tiene que realizar el pago en metálico, sino que se pueden arbitrar sistemas de «compensación» entre los individuos afectados y la propia junta.

Si la junta no ha establecido un criterio específico de valoración del terreno incluido en la unidad de ejecución, con carácter general, la valoración de ese terreno dependerá del aprovechamiento urbanístico aplicable al mismo.

Asimismo, las bases de actuación contendrán las reglas para valorar los inmuebles que se construyan cuando la Junta esté facultada para edificar y los criterios para la fijación del precio de venta a terceras personas (art. 167.1 i) RGU), con ello se pretende valorar los resultados de la actividad edificadora de la Junta; también, las bases de actuación contendrán, los criterios de valoración, de las fincas resultantes en función del aprovechamiento del polígono o unidad de ejecución (art. 167.1f) RGU), se adjudicaran las fincas a los miembros de la Junta en proporción a los bienes o derechos aportados (art. 167.1.g) RGU) 578 . Pero si los derechos no permiten la adjudicación independiente, puede ocurrir:

a) que no alcance el 15 por 100 de la parcela mínima edificable,

adjudicar íntegramente a su mismo propietario y cuando su conservación sea radicalmente incompatible con la ordenación, incluso como uso provisional».

577 Vid. ORTEGA GARCIA, Los edificios, cit., pp. 35-36.

578 Una vez valoradas las aportaciones del suelo y la de las fincas resultantes, como compensación a sus aportaciones, cada propietario recibe una finca independiente. 
en cuyo caso podrá sustituirse la adjudicación de parcela por una indemnización en metálico.

b) cuando alcance el 15 por 100 y cuando, no alcanzándolo, no se opte por la indemnización en metálico, se agrupará a los propietarios que se encuentren en este caso a fin de adjudicarles parcelas en «pro indiviso» 579 .

La adjudicación, con carácter general se hará en parcelas, no pudiendo obligar a los propietarios a aceptar una indemnización sustitutiva en metálico, salvo en los casos en que la Ley lo autoriza (como en el apartado 1.d) del 166 TR. El número 1, apartado f), párrafo segundo, establece que «las compensaciones económicas sustitutivas 0 complementarias por diferencias de adjudicación que, en su caso procedan se fijarán atendiendo al precio medio de venta de las parcelas resultantes, sin incluir los gastos de urbanización».

Las bases de actuación, deben también establecer los criterios que han de regir la actuación urbanística de la junta, haciendo mención al procedimiento para contratar la ejecución de las obras de urbanización y, en su caso, las de edificación (art. 167.1. e), en cualquier caso, la ausencia de esta mención no implica la nulidad de las bases de actuación ${ }^{580}$.

Además, las bases pueden contener reglas, acerca del momento en que pudiera edificarse sobre solares aportados o adjudicados por la Junta, por los propietarios o por las empresas urbanizadoras, sin perjuicio

579 Art. 94 RGU: «1. Cuando la escasa cuantía de los derechos de algunos propietarios no permita que se les adjudiquen fincas independientes a todos ellos, los solares resultantes se adjudicarán pro indiviso a tales propietarios. 2. Esta misma regla se aplicará, en cuanto a los excesos, cuando, por exigencia de la parcelación, el derecho de determinados propietarios no quede agotado con la adjudicación independiente que en su favor se haga. No obstante, si la cuantía de los derechos de los propietarios no alcanzasen el 15 por 100 de la parcela mínima edificable, la adjudicación podrá sustituirse por una indemnización en metálico. La misma regla se aplicará cuando los excesos a que se refiere el número anterior no alcancen dicho tanto por ciento. 3. Salvo lo dispuesto en el párrafo anterior y siempre que lo permitan las exigencias de la parcelación, la adjudicación de fincas independientes, al mayor número posible de propietarios, será preferible a la adjudicación pro indiviso, y esta última a la indemnización en metálico. En las adjudicaciones pro indiviso se procurará también la creación de comunidades del menor número posible de comuneros».

580 Así lo recoge la STS de 17 de octubre de 1990 (Ar. 8138). 
de la solicitud de licencia al Ayuntamiento en cuyo territorio se efectúe la actuación (art. 167.1. m) RGU) «así como las determinaciones complementarias que se consideren adecuadas para la correcta ejecución del sistema y de las obras de urbanización, incluso señalando las características técnicas mínimas que deben recogerse en los proyectos de urbanización que se redacten» (art. 167.2 RGU).

Las bases de actuación, deben prever así mismo los aspectos referentes a la financiación de la actividad urbanística de la Junta, tanto en relación a los miembros de ésta como en relación a terceros.

En relación a los miembros de la Junta el art. 167.1 RGU en diferentes apartados establece que las bases de actuación contendrán: «Forma y plazos en que los propietarios de terreno o titulares de otros derechos han de realizar aportaciones a la Junta, bien en metálico, bien en terrenos o en industria, en su caso» (apartado j). «Forma de exacción de las cuotas de conservación, si procediese, hasta la disolución de la Junta» (apartado n). «Reglas para la distribución de beneficios y pérdidas» (apartado k). Se prevé también, «supuestos de incumplimiento de las obligaciones de los miembros de la Junta de Compensación que darán lugar a la expropiación de sus bienes o derechos» (apartado h), en estos mismos términos, se pronuncia el art. 160 TR, distinguiendo, por un lado, la responsabilidad de la Junta de Compensación ante la Administración; por otro, la de los propietarios. La primera se regula en el número 1 del citado precepto y en los arts. 182 y 183 RGU; y la segunda, en los números 2,3 y 4 de este artículo y en el artículo 181, RGU.

Hechas toda esta serie de consideraciones en relación con los estatutos y bases de actuación habría que decir que la redacción de los mismos es previa a la constitución de la Junta de Compensación (art. 157.2 TR). Una vez constituida esta empezará a llevar a cabo sus funciones, que se concretan: 
1ํEn la elaboración del proyecto de compensación, que permitirá la justa distribución de beneficios y cargas del planeamiento (art. 172 a 174 RGU) y por tanto es aquí donde se materializa el principio de compensación urbanística como principio legal de «rango superior» ${ }^{581}$ entendido como norma de igualdad de trato en la distribución de las cargas y beneficios entre los propietarios afectados para lograr la justa distribución de aquéllos. Es ese equilibrio el que puede resolver la integración derecho de propiedad y función social. El exceso de cargas ya no sería función social.

2ํㅡ En la ejecución de las obras de urbanización (art. 175 y 176 $R G U)$, es decir, en llevar a cabo la edificación de los solares como carga urbanística. Se planifica el terreno para urbanizarlo y se urbaniza para edificarlo. La urbanización, por tanto, transforma fisicamente el suelo y habilita jurídicamente para construirlo, así la edificación es el resultado de haberse ejecutado las cargas de la urbanización.

En el sistema de compensación, la Junta lleva a cabo la urbanización, transforma fisicamente los terrenos y los convierte en solares, los cuales se adjudican a los propietarios integrados en la Junta para que con posterioridad sean edificados. La adjudicación de los solares y el momento de su edificación vendrán regulados por las Bases de actuación y de acuerdo con éstas y con los Estatutos, la edificación podrá llevarse a cabo por la propia Junta, por los propietarios, por las empresas urbanizadoras o por terceros adquirentes. En la base de todo ello está el Proyecto de compensación cuya aprobación definitiva desencadena todos los efectos necesarios para la transformación jurídica y física del suelo que lleva a la práctica de la ejecución del Proyecto o proyectos de urbanización.

581 Vid. MARTIN BLANCO, J., Texto Refundido de la Legislación Urbanística Estatal Madrid, 1994, p. 76 


\title{
CAPITULO NOVENO
}

\author{
EL PROYECTO DE COMPENSACION.
}

\section{CONCEPTO Y NATURALEZA DEL PROYECTO DE COMPENSACION}

El proyecto de compensación es la pieza básica para el funcionamiento del sistema de compensación y para la actuación de la Junta, de ahí la importancia que este documento tiene para el conjunto del sistema y para la regulación de los derechos y obligaciones de los propietarios de la Junta y de sus relaciones con la Administración urbanística actuante. Si los Estatutos, Bases de actuación y Título constitutivo de la Junta integran el proceso estático de formación de ésta, el Proyecto de Compensación abre la fase dinámica ${ }^{582}$.

Va a ser en este sentido la primera actividad de la junta de compensación la cual, redactará dicho proyecto aplicando los criterios establecidos en las Bases de Actuación (art. 157.3 TR y 172 RGU) ${ }^{583}$. Es un documento de carácter técnico y económico que contiene los aspectos concretos de la distribución de beneficios y cargas entre los propietarios de la unidad de ejecución ${ }^{584}$.

582 Vid. MARTIN BLANCO, J., La compensación..., cit. p. 285.

583 Así queda reflejado en la St de 2 de noviembre de 1985 (Ar. 5443) en los siguientes términos "...y ello porque según el artículo 171 del RGU, el Proyecto de Compensación se formula por la Junta de Compensación, de acuerdo con los criterios establecidos en las bases de actuación, en cuanto que tiene por finalidad, al modo de la reparcelación, determinar las parcelas edificables resultantes. Lo que viene a significar que, como exigencia lógica de la finalidad que está llamado a cumplir el proyecto de compensación, supone que la Junta, para poder formularlo, ha de tener a su disposición todos los terrenos integrados en el polígono de actuación" ; y en la St. de 5 de febrero de 1990 (Ar. 972) al decir que "... el proyecto de compensación que se impugna es la consecuencia lógica de las Bases y criterios establecidos para la Junta"

584 En este sentido se expresa BORREGO, El sistema de compensación, en "Derecho Urbanístico Local"(dirigido por BOQUERA), Madrid, 1992, p. 318; BOIX REIG, Urbanismo y Derecho, Madrid, 1990, p. 178; PARADA, Derecho administrativo, Madrid, 1991, III, p. 459 y ss. 
El proyecto de compensación es un procedimiento reparcelatorio de ahí que el art. 157.3 TR establezca que "para la definición de los derechos aportados, valoración de fincas resultantes, reglas de adjudicación, aprobación, efectos del acuerdo aprobatorio e inscripción del mencionado proyecto se estará a lo dispuesto para la reparcelación ", si bien admite que "por acuerdo unánime de todos los afectados puedan adoptarse criterios diferentes, siempre que no sean contrarios a la Ley o al planeamiento aplicable, ni lesivos para el interés público o terceros" 585 .

En su regulación reglamentaria, es un instrumento intermedio entre el Plan de Ordenación y el proyecto de urbanización ${ }^{586}$, que tiene por objeto expresar gráficamente con carácter vinculante, de acuerdo con las determinaciones del Plan de que depende y de las Bases de actuación del sistema de compensación, la localización y descripción de superficies y compensaciones que han de adjudicarse entre los propietarios para lograr el justo y equitativo equilibrio económico compensatorio entre los beneficios que les reportará la urbanización y su mantenimiento y conservación. Se producen por tanto, modificaciones en las fincas primitivas como consecuencia de la actividad urbanística.

Este carácter intermedio del Proyecto de compensación se pone de manifiesto examinando su contenido.

585 En los supuestos de propietario único al no tener que cumplir la función de distribución de beneficios y cargas, se limitará a expresar la descripción de los terrenos de cesión obligatoria y de las reservas que establezca el Plan, así como las parcelas edificables, con señalamiento de aquellas en que se sitúe el aprovechamiento que corresponda a la Administración (art. 173 RGU).

586 La finalidad del proyecto de urbanización es proyectar las obras que han de ejecutarse sin que pueda contener ninguna decisión o previsión de ordenación o planeamiento de otro tipo. La mera ejecución material de las obras de urbanización es una operación final de la actuación urbanística y también del sistema de compensación, pero la compensación es más que la ejecución de las obras de urbanización. 


\section{CONTENIDO DEL PROYECTO DE COMPENSACION}

El art. $172 \mathrm{RGU}$, establece las determinaciones que debe de contener587. La Sentencia de 12 de marzo de 1991 (Ar. 1986) señala que el proyecto de compensación "contendrá necesariamente: a) la descripción de las propiedades antiguas, con las precisas correcciones, según los planos, y expresión de sus cargas, gravámenes, condiciones y sustituciones y derechos que las afecten y la de las fincas exteriores al polígono ocupadas a propietarios que participan en el proyecto de compensación; b) la descripción de las fincas resultantes, incluyendo el 10 por 100 del aprovechamiento medio del sector y de cesión obligatoria a la Administración, titulares de las fincas adjudicadas y concepto de la adjudicación; c) localización de los terrenos de obligatoria cesión y reservas según el Plan; d) la superficie de parcelas que la Junta de compensación se reserva para su directa enajenación y sufragio de los gastos de urbanización y e) las compensaciones en metálico por diferencias en la adjudicación “.

El proyecto de compensación, describe de forma material las operaciones urbanísticas que han de realizarse, las cuales van encaminadas a modificar las fincas primitivas.

Por tanto, en función de lo visto hasta ahora, se podría sintetizar el contenido del proyecto de compensación en cuatro apartados:

a) Describe la situación inicial de las fincas antiguas, según los títulos aportados y en defecto de títulos según los planos, haciendo alusión

587 En relación con el citado precepto es obligado hacer las siguientes aclaraciones: en relación con la letra a) la referencia al polígono o unidad de actuación, debe entenderse hecha a unidad de ejecución, como ya hemos tenido ocasión de señalar en otro momento. En la letra b) la referencia a la Administración adjudicataria del 10 por 100 del aprovechamiento medio (el 10 por 100 del aprovechamiento tipo), debe entenderse hecha a la Administración actuante. En la letra c) la referencia a terrenos de cesión obligatoria y reservas debe entenderse hecha a terrenos afectos a dotaciones públicas, conforme a lo dispuesto por el art.205.1 TR. 
a todos los derechos que recaen sobre ellas, tanto personales como reales arts. 172.a) y 167.1.a) y c) del RGU); asimismo describe las fincas de aquellos propietarios (que participen en el proyecto de compensación) de suelo exterior al polígono que han sido ocupadas para la realización de sistemas generales ( art. 172 a) .2 RGU ).

b) El proyecto de compensación, debe determinar, para cada propietario que forme parte del mismo, "su derecho en el proyecto de compensación" (art. 172.a) RGU) o "derecho de los propietarios "en el resultado de la compensación (art. 177.4 RGU). Este derecho es un "derecho a la adjudicación en propiedad de las fincas resultantes" (art. 85.1 RGU, derecho que el art. 172. b) RGU califica como "el derecho que da lugar a la adjudicación" 588 que tendremos ocasión de estudiar con mayor detenimiento en un momento posterior. Con este fin, el proyecto de compensación va a determinar "el criterio utilizado para definirlo y cuantificarlo" (art. 172. a) RGU, criterio de proporcionalidad en atención a los bienes inicialmente aportados (art. 167.1 RGU y 157.3 y 166.1.a) TR.

c) Describe los terrenos que no han de ser adjudicados a los propietarios, de terrenos de cesión obligatoria (art. 20.1.a) y b), 27 y 159.3 TR y arts. 172.b) y c) y 179 del RGU) así como terrenos que la junta se reserva para enajenarlos directamente con el fin de sufragar los gastos previstos de la urbanización (art. 172.d) y 177.1 RGU) aquí el proyecto de compensación, actuaría como título de atribución a la junta del poder de disposición sobre estos terrenos.

d) Describe las fincas adjudicadas con sus cargas y gravámenes 589 indicando "los titulares a quienes se adjudiquen y concepto en que lo

588 Vid. St. de 31 de diciembre de 1985 (Ar. 6550) donde queda expresado que en el proyecto de compensación se deben adjudicar al antiguo propietario o aportante aquellos terrenos edificados que aporta y que son legalizables de acuerdo con el planeamiento.

589 Vid. CARCELLER FERNANDEZ, "Costes y Cuotas de urbanización y de conservación" RDU no 67 p. 90, dice que entre las cargas que afectan a las fincas resultantes, han de citarse las cuotas de urbanización, siendo extensivas en cuanto a la Administración. 
fueren" (arts 172. b) y 167.1g) del RGU), de ahí que el precepto citado, en su letra I) establezca las compensaciones en metálico si fueran procedentes por diferencias en las adjudicaciones 590 .

\section{TRAMITACION Y APROBACION DEL PROYECTO DE} COMPENSACION.

A raíz de la aprobación del TR de la LS de 26 de junio de 1992 al introducir en su artículo 157.3 un nuevo procedimiento de tramitación y aprobación de los Proyectos de Compensación distinto del establecido en el RGU en los arts. 172 a 174, aplicados hasta ese momento, se plantea el problema de cual va a ser en adelante la normativa aplicable, problema que se ve agravado aún más con la publicación del R.D. 304/1993, de 26 de febrero, por el que se aprueba la tabla de vigencias de los reglamentos de desarrollo del TRLS, entre otros el de Planeamiento y Gestión Urbanística, y que se aprobó al amparo del apartado 4 de la Disposición Final única del TRLS, que no ha derogado expresamente el art. 174 del RGU donde se regula expresamente el procedimiento de aprobación de los Proyectos de Compensación y que algunos entendían derogado tácitamente por el TRLS al establecer este texto legal un nuevo procedimiento de tramitación y aprobación de los Proyectos de Compensación asimilándolo a la figura de los proyectos de reparcelación.

Tanto la doctrina como la jurisprudencia, se encuentra dividida al respecto, así de una parte están los partidarios de considerar aplicable el procedimiento que para la aprobación de los Proyectos de Reparcelación

590 Vid. CARCELLER FERNANDEZ, ob. cit., p. 248 y ss. donde establece que la reglamentación más completa del proyecto de reparcelación (art. 82 y ss. RGU) puede ser utilizada con carácter supletorio para llenar las lagunas de la más reducida regulación del proyecto de compensación sobre cuya documentación guarda silencio el RGU, siendo aplicable por tanto la regulación de aquel. 
establece el TRLS en su art. 157.3591. Seguidamente vamos a exponer los argumentos alegados a favor de la aplicación prioritaria del art. 157.3 TRLS sobre la normativa contenida en el RGU:

a) Prioridad de la Ley sobre el Reglamento en el sistema de jerarquía de fuentes.

b) Los numerosos artículos de la legislación urbanística que remiten para cuestiones conectadas con los Proyectos de Compensación a las disposiciones que para esta materia se establecen respecto de los proyectos de Reparcelación, así los arts. 93, 178 y 186.4 del RGU y sobre todo el art. 157.3 TR que refunde todo lo dispuesto en los preceptos citados.

c) Los Proyectos de Reparcelación y los Proyectos de Compensación lo son de parcelación, además la prohibición absoluta del otorgamiento de licencias de edificación en la unidad de ejecución, hasta la firmeza en vía administrativa del acuerdo aprobatorio de la reparcelación (art. 164.3 TR y 186.4 RGU) se ha entendido por la doctrina extensible a los Proyectos de Compensación 592 .

Los trámites en líneas generales serían los siguientes:

1- Aprobación inicial por la Administración Actuante en el plazo de tres meses, sopena de subrogación por la Comunidad Autónoma.

591 Entre otros MARTIN RETORTILLO BAQUER, S., Prólogo al libro de GONZALEZ SALINAS, J., Sistema de Compensación... ob.cit., p. 25. GARCIA DE ENTERRIA y PAREJO ALFONSO. Lecciones de Derecho urbanístico... ob.cit., p. 75. En el ámbito Jurisprudencial cabe citar las siguientes sentencias: St. de 2 de noviembre de 1985 que considera que la actuación reparcelatoria equivale a la compensatoria, refiriéndose al contenido de fondo 0 sustancial de ambas instituciones; en el mismo sentido se expresa la St. de 24 de diciembre de 1991, y más recientemente la St. de 21 de octubre de 1992 cuando al referirse a los arts. 99.1.c) del TRLS de 9 de abril de 1976 y art. 95 del RGU, manifiesta que "... pues aunque estos preceptos se refieren al régimen jurídico de la reparcelación en sentido estricto podrían aplicarse a la compensación, que materialmente implica una reparcelación...".

592 La reparcelación y la compensación, han sido objeto de constantes comentarios doctrinales. Sobre la reparcelación en general, antes de la reforma de 1976, cabe citar a DIAZ MONTERO, Parcelaciones y reparcelaciones urbanísticas, Madrid, 1967, y a CORELLA MONEDERO, La reparcelación. Su naturaleza jurídica y práctica, Madrid, 1973. Tras la reforma de la Ley del suelo TR del 76 vid. MARTIN MARCOS JIMENEZ, Parcelaciones $y$ reparcelaciones y el Registro de la Propiedad, Madrid, 1976; GARCIA GARCIA, J.M., "La reparcelación y la compensación en relación con el Registro de la Propiedad", en RCDI, núms. 565, 567 y 576; FUERTES LOPEZ,M, Urbanismo y Publicidad Registral, Madrid. 1995. 
2- Información pública durante un mes con citación personal a los interesados.

3- Aprobación definitiva, bien expresa, bien tácita si transcurren tres meses desde que, hubiera finalizado el trámite de información pública sin resolución expresa.

En una segunda vertiente encontraríamos a los partidarios de entender que el art. 174 del RGU sigue plenamente vigente y que no puede entenderse derogado por lo dispuesto en el TRLS593 al que nos adherimos plenamente por diferentes razones que muy brevemente pasamos a exponer:

Si bien es verdad que ambos instrumentos urbanísticos (proyecto de reparcelación, para el sistema de cooperación y proyecto de compensación para el sistema de compensación) tienen prácticamente el mismo contenido, se rigen por idénticos criterios y persiguen la producción de los mismos efectos, no puede hablarse de su total identidad ya que cada uno de ellos es el resultado de un sistema de ejecución del planeamiento (compensación y cooperación), que aunque tienen los mismos objetivos y efectos en sus raíces y desarrollo son diferentes. El hecho de que el TR los distinga y diferencie es suficientemente probatorio de esta afirmación.

El segundo de los argumentos esgrimidos es la no derogación expresa por el R.D. 304/1993, de 26 de febrero, del art. 174 del RGU, como ha hecho con otros preceptos del mismo, unido al hecho de que incluso desde el punto de vista legal, se sigue manteniendo la diferenciación de la naturaleza de los dos sistemas de actuación, regulándose sistemáticamente

593 DE MIER VELEZ, J.L. El sistema de Compensación, Madrid, 1993, p. 15. Como representantes partidarios de este segundo posicionamiento cabe citar a GONZALEZ SALINAS, J., ob. cit., p. 54; GONZALEZ PEREZ, J., Comentarios..., ob. cit., p. 1210; en el ámbito jurisprudencial pueden verse las siguientes sentencias: St. de 13 de noviembre de 1984 (Ar. 6608), St. de 21 octubre de 1992 (Ar. 8042) que remite a las reglas establecidas en el RGU para la adjudicación de fincas a los miembros de la Junta una vez aprobado el proyecto de compensación. FERNANDEZ-FIGUEROA GUERRERO, F., "¿Nuevo procedimiento de tramitación y aprobación de los proyectos de compensación?". RDU. N: 134, 1993. p. 67 y ss. 
por separado en la Ley, y manteniendo ésta la vigencia de ambos, lo cual hace pensar que en ningún caso el legislador pensó en la identificación absoluta de los dos sistemas ni de los documentos necesarios (proyectos) para llevar a cabo sus objetivos.

Para la reparcelación el TR (art. 166) y el RGU (arts. 87 a 97 con las derogaciones parciales de los arts. 88 y 94) establecen los criterios que deberán utilizarse para la justa redistribución de beneficios y cargas, sin que sea necesaria la conformidad de la Administración actuante, criterios que no pueden ser modificados, salvo lo establecido en el apartado a) del art. 166 TR "los propietarios por unanimidad podrán adoptar un criterio distinto". Sin embargo en el sistema de compensación tanto al aprobarse las bases de actuación de la junta de compensación, como en el propio Proyecto de Compensación se pueden adoptar otros criterios distintos a los del TR aunque esos criterios del TR podrían calificarse como supletorios de los criterios que adopten los afectados 594 por la ejecución del planeamiento.

Aprobado el proyecto por la junta de compensación 595 por una mayoría de sus miembros que representen los dos tercios de las cuotas de participación (art. 174.1 RGU), y expuesto al público por término de 15 días 596 se elevará a la aprobación definitiva de la Administración actuante.

La aprobación definitiva, lleva consigo, por un lado la inscripción en el correspondiente libro registro del Ayuntamiento (art. 166.1 RPU) y por otro, la inscripción en el Registro de la Propiedad del acto firme de

594 Como ya hemos señalado en este trabajo, propietarios afectados lo son "tanto los de suelo comprendido en la unidad de ejecución como los de suelo destinado a sistemas generales que hayan de hacer efectivo su derecho en dicho polígono o unidad de actuación" (art. 161.3 RGU), mientras que los propietarios interesados (art. 161.2 RGU) son aquellos que teniendo el "derecho a formar parte" de la junta de compensación aceptan el sistema de compensación.

595 La St. de 21 de marzo de 1986 (Ar 2326) Fjco. 1, señala la independencia de los acuerdos de aprobación de los estatutos de la junta de compensación y del proyecto de compensación.

596 El plazo de un mes fijado por el art. 174 RGU hay que entenderlo reducido a 15 días si tenemos en cuenta el posterior art. 4 del RD Ley 3/ 1980, de 14 de marzo. 
aprobación definitiva (art. 174.3,4 y 5 RGU) cuyos efectos veremos seguidamente

Hay autores 597 que distinguen dos fases: una primera de tramitación ante la Junta de Compensación y una segunda ante la Administración actuante que se limitará a aprobarlo definitivamente, salvo objeciones. El trámite de audiencia a los afectados, previo a la aprobación, con mayoría cualificada, por la Junta de Compensación harían innecesario un trámite de información pública como ocurre con los proyectos de reparcelación ya que éstos no se ponen de manifiesto con anterioridad ni a los interesados ni a los afectados; por esta razón GONZALEZ PEREZ entiende que cuando el art. 157.3 del TR incluye la palabra "aprobación" está haciendo referencia a esta segunda fase del procedimiento de aprobación del Proyecto de Compensación sin que pueda significar una derogación del establecido en el RGU.

De todo lo que acabamos de ver se deduce que el procedimiento de aprobación de los Proyectos de Compensación sigue siendo el recogido en el RGU, cuyo art. 174 hemos de entender en vigor por no haber sido expresamente derogado ni por el TR ni por el R.D. 304/93 de 26 de febrero por el que se aprueba la tabla de vigencias de los reglamentos de desarrollo del TR y desde un punto de vista conceptual y de contenido sustantivo, por la propia "mens legis" y voluntad expresa del legislador al mantener los procedimientos de reparcelación y compensación por separado aunque reconocido expresamente con identidad en aspectos globales.

El procedimiento de tramitación ordinaria que el RGU establece en su art. 174 lo recoge la St. de 12 marzo 1991598, dicho procedimiento se desarrolla en tres fases

598 Vid. STS de 12 de marzo de 1991 (Ar. 1986) lo recoge en los siguientes términos: 
1. Una vez que el Proyecto de Compensación está formulado, se somete a audiencia de todos los afectados por un plazo de un mes (art. 174.1 RGU) durante el cual éstos pueden formular las alegaciones y sugerencias que consideren pertinentes.

2. Transcurrido dicho plazo, es aprobado por la Junta de Compensación con el quórum de la mayoría de los miembros que a su vez representen los dos tercios de las cuotas de participación (art. 174.1 RGU), con las alegaciones que, en su caso, se estimen.

3. Una vez aprobado por la Junta de Compensación se somete a aprobación definitiva por la Administración actuante.

Como el proyecto de compensación ha sido sometido a todos los afectados en el trámite de audiencia, en el que han podido formular alegaciones, no será necesario que ante la Administración actualmente se vuelva a repetir, de ahí que el art. 174.1 RGU, disponga que "el proyecto... se elevará a la aprobación definitiva de la Administración actuante"599.

Una vez aprobado definitivamente el proyecto de compensación, el órgano administrativo actuante procederá a otorgar escritura pública o expedir documento con las solemnidades y requisitos dispuestos para las actas de los acuerdos, con el contenido expresado en el art. 113.1 de este reglamento (art. $174.3 \mathrm{RGU})^{600}$, y se inscribirá en el registro de la propiedad, de conformidad a lo dispuesto en el art. 310 TR.

"Previa audiencia de los afectados por un mes, a la aprobación de la Junta de Compensación por la mayoría que deberán representar al menos las dos terceras partes de la propiedad y después será definitivamente aprobado por la Administración actuante con notificación a los interesados, otorgará su escritura pública con las menciones más arriba señaladas en cuanto a su contenido y la inscribirá en el registro de la propiedad que corresponda, incluyendo las operaciones jurídicas complementarias previamente aprobadas.

Igualmente la Junta de Compensación responderá de los costes de la urbanización incluyendo, entre otros gastos, el importe de Planes Parciales y proyectos de urbanización y reparcelación".

599 Vid. GARCIA DE ENTERRIA Y PAREJO, Lecciones de Derecho urbanístico, Madrid, 1981 , p. 539.

${ }^{600} \mathrm{El}$ art. 113.1 RGU, exige que contenga los siguientes extremos:

a) Descripción de las propiedades antiguas, según los títulos aportados con las correcciones procedentes, y en defecto de títulos, según planos. Se expresarán las cargas y gravámenes, condiciones, sustituciones y demás derechos que las afecten; el respectivo propietario, si 


\section{EFECTOS DE LA APROBACION DEFINITIVA DEL PROYECTO}

\section{DE COMPENSACION:}

\section{La aprobación definitiva del proyecto de compensación produce}

los mismos efectos jurídicos que la aprobación definitiva del proyecto de reparcelación (art. 174.4 RGU) 601 .

La expresión que utiliza el reglamento no es del todo cierta ya que la aprobación definitiva del proyecto de compensación desencadena una serie de efectos jurídicos y no jurídicos: urbanísticos, económicos etc. de ahí que la razón de utilizar esa expresión no es otra que la de remitirse a los artículos 122 a130 del RGU regulador de los efectos de la aprobación de la reparcelación aunque tampoco esta remisión es legalmente correcta, porque compensación y reparcelación van y pueden ir por caminos distintos de actuación. El propio artículo 73 del RGU, determina que no será necesaria la reparcelación, entre otros casos, cuando el plan se ejecute por el sistema de compensación602. Por estas razones parece conveniente

fuera conocido; la cuantía de su derecho en la reparcelación (en este caso compensación) y el criterio utilizado para definirlo y cuantificarlo. Cuando participen en la reparcelación propietarios del suelo exterior a la unidad se describirán también las fincas que les fueran ocupadas.

b) Descripción de las fincas resultantes, incluyendo, en su caso, aquellas en que se localice el aprovechamiento correspondiente al Ayuntamiento, titulares a quienes se adjudiquen y concepto en que lo fuese.

Se expresará respecto a cada finca la antigua a que corresponda o el derecho que da lugar a la adjudicación, así como las cargas y gravámenes, condiciones, sustituciones y demás derechos que las afectan por no ser incompatibles con el planeamiento.

c) Localización de los terrenos de cesión obligatoria y de las reservas que establezca el Plan.

d) Cuantía del saldo de la cuenta de liquidación provisional con que quede gravada cada una de las fincas adjudicadas.

${ }^{601}$ Nos está remitiendo al Capítulo VI del Título III del RGU, en concreto los arts. 122 a 130 RGU, de los cuales únicamente el art. 123.2 RGU ha sido derogado por el TR. Esta misma idea queda plasmada en el art. 157.3 TR al decir que: "Para la definición de los derechos aportados, valoración de fincas resultantes, reglas de adjudicación, aprobación, efectos del acuerdo aprobatorio e inscripción del mencionado proyecto se estará a lo dispuesto para la reparcelación". En esta misma dirección PAREJO ALFONSO, ob. cit., p. 425 señala que: "En tanto que la compensación no es materialmente... otra cosa que una reparcelación de régimen especial, es lógico que la aprobación del proyecto en que se instrumente aquélla produzca efectos propios de ésta".

602 Vid., MARTIN BLANCO, J., en Dictámenes y Estudios del Derecho Urbanístico, Madrid, 1970 , p. 347 a 354 , donde recoge la postura del actual RGU de no ser necesaria la reparcelación en la compensación, resumiendo este problema de la siguiente manera : "De 
interpretar el artículo 174.4 del RGU de forma y con el sentido adecuados para superar las inexactitudes e imprecisiones de su texto en una materia tan relevante como es la de los efectos de la aprobación definitiva del Proyecto de Compensación, dichos efectos no son otra cosa que, la apertura y comienzo de la faceta dinámica de la actuación urbanística de la Junta de Compensación. La ejecución material, propiamente dicha, del Plan comienza con la aprobación del proyecto. Constitución de la Junta y actuación de la misma son dos aspectos o momentos delimitados precisamente por la aprobación definitiva del Proyecto de Compensación. Es decir que el sistema de compensación comienza a funcionar con el Proyecto de Compensación, de ahí que haya de distinguir dos bloques de efectos que producen la aprobación definitiva del Proyecto de Compensación:

a) Los efectos jurídicos, económicos, urbanísticos entrañados por la ejecución del Plan de acuerdo con el Proyecto de Compensación que no es otra cosa que la puesta en práctica del conjunto de operaciones que conlleva la aplicación, al caso concreto y sobre el terreno de todas y cada una de las determinaciones del Proyecto, y la aplicación del juego de la subrogación real, cesiones, compensaciones, etc. .

b) y un segundo bloque de efectos de carácter jurídico-registral integrados por la inscripción del acuerdo aprobatorio del proyecto en el Registro de la Propiedad y por la inscripción en el libro-registro del Ayuntamiento.

Seguidamente vamos a ocuparnos del análisis de esos efectos, teniendo en cuenta que el efecto jurídico esencial conocido con el nombre de "derecho en la compensación" lo estudiaremos en un capítulo posterior, 
limitándonos en este momento al análisis de las cesiones obligatorias y gratuitas.

4.1 EFECTOS JURIDICO-ECONOMICOS: CESIONES OBLIGATORIAS Y GRATUITAS DE TERRENOS.

Todos los terrenos que, según la Ley, han de cederse obligatoriamente, se transmitirán al municipio por ministerio de la Ley. La Ley no exige que sean terrenos de cesión obligatoria y gratuita. Sin embargo, parece evidente que únicamente puede operar respecto de éstos, porque los de cesión onerosa requerirán el previo acuerdo sobre su valor o la tasación correspondiente. El artículo 179.1 y 2 del RGU, dispone que "el acuerdo de aprobación del proyecto de compensación producirá la cesión de derecho a la Administración actuante, en pleno dominio y libre de cargas, de todos los terrenos que sean de cesión obligatoria y gratuita según el Plan, para su incorporación al patrimonio municipal del suelo o su afectación a los usos previstos en el mismo, no obstante lo cual la Junta de Compensación y la empresa que tenga a su cargo la ejecución de las obras de urbanización podrán ocupar a este fin los terrenos objeto de la cesión hasta que finalizadas dichas obras sean recibidas por la Administración actuante" 603 .

${ }^{603}$ Asímismo queda recogido en la STS de 21 de enero de 1991 (Ar. 547): "Según lo dispuesto en el art. 179 RGU: "El acuerdo de aprobación del proyecto de compensación producirá la cesión de derecho a la administración actuante, en pleno dominio y libre de cargas de todos los terrenos que sean de cesión obligatoria y gratuita según el Plan, para su incorporación al patrimonio municipal del suelo o su afectación a los usos previstos en el mismo", cesión que se hace efectiva por ministerio de la Ley y en las condiciones que reglamentariamente se indiquen según prescribe el art. 128 LS de 9 de abril de 1976, sean cuales fueran los términos empleados en el acuerdo municipal, de naturaleza imperativa, o requerimiento amistoso dirigido a la Junta de Compensación, su cumplimiento daría lugar a una infracción manifiesta de esos preceptos, anticipando los efectos de la aprobación de un proyecto de compensación con posible lesión de los intereses y derechos de los partícipes en el expediente de ejecución de Plan Parcial; careciendo de fundamento legal la invocación de un interés social y utilidad pública basados en las dotaciones que procedía radicar en las parcelas objeto del requerimiento de cesión, ya que en ningún supuesto puede incidir ese interés cuando por un acto de la administración se vulnera o propone la vulneración de la Ley; 
En relación al significado de la cesión obligatoria y gratuita de terrenos en el sistema de compensación, la doctrina ofrece diferentes soluciones. De esta forma, se mantiene que las cesiones obligatorias de terreno son un medio de compensación de cargas y beneficios derivados de la urbanización. Lo que se pretende es que no haya enriquecimiento injusto para los propietarios, que no deben beneficiarse del incremento de valor que sus terrenos experimenten con las obras de urbanización, sin que tampoco exista enriquecimiento injusto para la Administración 604 .

En otras ocasiones se ha entendido que la cesión obligatoria de terrenos no es una figura expropiatoria sin indemnización, sino de un sistema de compensación que facilita la urbanización, sin lesionar intereses privados, sin perjuicio de los diversos matices que el sistema de cesión obligatoria presenta según el procedimiento utilizado por el Plan605.

También se ha defendido que la cesión obligatoria de terrenos por causa de urbanización puede estimarse como una limitación normal del dominio o como un daño especial, supuesto de la indemnización; en el primer caso no habría excepción alguna a la obligatoriedad de las cesiones, puesto que supondrían el normal uso de la propiedad, pero como las excepciones existen, hay que convenir que en ellas se da el daño especial, base de su tratamiento como expropiaciones 606 .

En opinión de Carceller Fernandez, se trata de una obligación de los propietarios de las fincas emplazadas en el sector que fuere objeto de la

sin perjuicio todo ello de que no puede estimarse incluida la cesión de terrenos a la Administración antes de la aprobación del proyecto de compensación en el art. 174.5 del RGU, pues no es equiparable una operación jurídica complementaria que sean del caso que no se opongan al proyecto de compensación o al Plan que se ejecute, con la cesión de unos terrenos con anterioridad a su aprobación, y por consiguiente sin conocer o no si esa cesión es conforme o no con el proyecto".

604 Vid. CARRO MARTINEZ, "Los principios de la nueva Ley del Suelo", en REVL, no 88, 1956,p. 520 .

605 Vid. DE LOS MOZOS El Urbanismo desde la perspectiva del derecho privado, en RDP, 1961 , p. 293.

606 Vid. MARIN TEJERIZO Las cesiones obligatorias en la Ley de Régimen de Suelo, en REVL, no 88,1956, p. 571 
urbanización, sin que quepa compensación, dado el carácter gratuito de la cesión, salvo en el supuesto excepcional de una cesión de terrenos viales en proporción superior a la establecida en la Ley607 .

También se ha dicho que es un supuesto de cambio del sistema de contribuciones especiales en el que de una contribución ex post, en dinero, se ha pasado a una contribución ex ante, en especie. En el sistema tradicional, para satisfacer el coste de la expropiación de los terrenos precisos para viales y zonas verdes (como los demás costos de la urbanización), la Administración debía resarcirse imponiendo contribuciones especiales por los aumentos de valor que la urbanización implicaba sobre los terrenos de la zona; en vez de ello, ahora, sin embargo, se impone directamente a los propietarios de esos mismos terrenos la obligación de cederlos para vialidad y parques, sobre los que se realiza la urbanización. En realidad, opina este autor, estamos de nuevo ante una figura que, no obstante su aparente extrañeza, responde a los puros principios de la contribución especial, de la que se ha suprimido con fines de eficacia el iter inutilis que era expropiación con indemnización por contribución dineraria impuesta a los propietarios del sector, para sustituirlo por el sistema directo de la cesión de los terrenos precisos 608 .

En opinión de González Berenguer, las cesiones son expresión del contenido normal del dominio sobre fundos urbanos... La Ley del Suelo es innegablemente el Estatuto de la Propiedad Urbana en España, el dominus fundiario tiene las atribuciones que la Ley le da y pensar en derechos naturales intocables es ingenuo... La cesión gratuita del terreno no representa sino una nueva determinación del contenido del dominio609

607 Vid. CARCELLER FERNANDEZ, Ejecución de los planes de urbanismo, Barcelona, 1962, p. 57 y ss. y 87 y ss.

608 Vid. GARCIA DE ENTERRIA, La ley del suelo y el futuro del urbanismo, Sevilla, 1958, p. 165;

609 Vid. GONZALEZ BERENGUER URRUTIA, Teoria y práctica de la ley del suelo, Madrid, 1964 
En otras ocasiones se ha defendido que la cesión obligatoria de terrenos no es una obligación, sino más bien un deber jurídico unido y objetivado al suelo urbano. El juego de beneficios y cargas hace de estas últimas una categoría jurídica distinta de las auténticas obligaciones, dentro de los deberes jurídicos: Si el propietario, quiere aprovechar los terrenos de su propiedad según el Plan, transformándolos desde el punto de vista económico-social de su utilización urbanística, debe ceder en compensación a las plusvalías los terrenos destinados a viales, parques y jardines públicos y demás dotaciones de interés general, asumiendo las cargas de urbanización. Es la contrapartida de esa actividad pública que la Administración le concede. Su incumplimiento no es que acarree una expropiación sanción, sino la recuperación plena de la actividad de gestión por la Administración sobre todo el polígono o limitada exclusivamente al propietario que incumplió las obligaciones y cargas. $\mathrm{Y}$ tal parece ser, el sentido en que se pronuncia la Reforma de la Ley del Suelo, aunque en aquélla no aparece clara la configuración jurídica de las cesiones de terrenos 610 .

Para Ortega García, la cesión gratuita de terrenos responde a los tres siguientes principios fundamentales: $1 \stackrel{0}{ }$ procede en base a un plan parcial y se trata de ejecución del plan, sea de nueva urbanización o de reforma interior, por lo que no se dan las cesiones en las nuevas obras de reposición o municipales ordinarias; $2^{\circ}$ Son compensación a los beneficios que la ejecución del plan ha de reportar y precisamente por ello han de guardar proporción con dichos beneficios; y 3ํㅡ Ha de regir la proporción entre propietarios, a fin de que la carga de la cesión sea debidamente repartida. Y sobre estos principios califica la obligación de cesión de terrenos como un deber jurídico611

610 Vid. NUÑEZ RUIZ, en Derecho urbanístico español, Madrid, 1967, p. 271 , 275 y ss. y en Ejecución de los planes de urbanismo, Madrid, 1974, p. 325 y ss

611 Vid. ORTEGA GARCIA, Los deberes o cargas en la legislación urbanística, Madrid,1974, p. 40 y ss 
Con posterioridad a la reforma de la Ley del Suelo de 1975, la doctrina sigue tratando estos problemas. Las cesiones gratuitas obligatorias, son entendidas como deberes en los que no se trata tanto de comprimir o de restringir las facultades dominicales del propietario, como de imponer ciertos deberes positivos de hacer, en virtud de la relación existente entre el dueño de la cosa (deberes ob rem); deberes que se asientan sobre la llamada función social de la propiedad, y estos deberes son calificados como cargas urbanísticas frente a las limitaciones 612 .

Esta tendencia a identificar los deberes con las cargas, defendida por diferentes autores como tendremos ocasión de comprobar, es de todo punto criticable dado que si bien las cargas benefician o perjudican a su titular y no tienen proyección sobre un tercero, los deberes se hacen en beneficio de un tercero.

En línea parecida con la argumentación anterior, se mantiene que la concepción social del derecho de propiedad por una parte otorga facultades a su titular y, por otro, le impone deberes o cargas. Entre estos deberes o cargas está la obligación que la Ley impone a los propietarios de suelo urbano y urbanizable programado de efectuar determinadas cesiones gratuitas de terrenos. Y esta obligación, sin perjuicio de su posible justificación en base a la concepción social del derecho de propiedad, se fundamenta, especialmente desde una perspectiva económica, en un principio que se fue gestando en la legislación del siglo XIX y del primer tercio del XX y que apareció ya plenamente consagrado en el Ley del Suelo de 1956: el de afectación de las plusvalías al coste de la urbanización. Principio de afectación de plusvalías al coste de la urbanización que, en síntesis, consiste en que la obra urbanizadora deberá costearse con cargo a las mismas. En consecuencia, y en los supuestos en que no se aplique el

612 Vid. CHOROT NOGALES, LLISET BORRELL y ARROYO GARCIA, en La Ley del suelo, Madrid, 1977, pp. 307, 317 y 321. 
sistema de expropiación, los propietarios deberán ceder determinados terrenos urbanizados resultantes, y con las plusvalías consiguientes, en cuanto no sean de cesión obligatoria y gratuita a la Administración. El principio se encontraba ya consagrado en le Ley del Suelo de 1956 y la Ley de Reforma, por su parte, lo mantiene plenamente, si bien pretende llevarlo a consecuencias más intensas al incrementar, como regla general, las obligaciones de los propietarios que, por otra parte, son superiores en suelo urbanizable programado que en suelo urbano; diferencia que es lógica, pues la plusvalía en el primer tipo de suelo es superior en cuanto supone normalmente la transformación de suelo que era inicialmente de carácter rústico. Y dado que el planeamiento incidirá de forma desigual sobre los propietarios, la aplicación del principio de afectación de plusvalías al coste de la urbanización exige la justa distribución de beneficios y cargas entre los propietarios 613 .

Para López Pellicer614 la cesión obligatoria y gratuita de terrenos constituye una carga de urbanización que, por ministerio de la Ley, han de soportar los propietarios de terrenos situados en un polígono o plusvalía derivada de la urbanización. Esta definición señala las principales características y naturaleza de este tipo de cesiones que son las siguientes:

a) Dentro del conjunto de determinaciones que configuran el estatuto jurídico del derecho de propiedad, la cesión obligatoria y gratuita de terrenos se configura como un deber legal y, más concretamente, como una "carga", cuyo cumplimiento por los propietarios del polígono o unidad de actuación urbanística afectados constituye un requisito que jurídicamente condicione la utilización o edificación del suelo, en cuanto que éste ha de reunir, para que sea susceptible de aprovechamiento

613 Vid. GOMEZ-FERRER MORANT, en "Régimen Jurídico del Suelo", en R.D.V., nº 55, 1977, pp. 43 y ss.

614 Vid. LOPEZ PELLICER, "La cesión obligatoria y gratuita de terrenos por razón de urbanismo", en RDV, 1977, no 53, p. 47 y ss. 
urbanístico privado, de los imprescindibles elementos y servicios públicos. Se trata de una carga de naturaleza real, por su objeto, cuyo cumplimiento constituye un requisito o condictio iuris, entre otros, para el ejercicio del derecho de edificar o utilizar un suelo que ha de estar debidamente urbanizado, derecho que de otro modo no puede ser ejercitado.

b) Más concretamente se trata de un deber o carga ex lege, que viene establecida directamente por la Ley, que como es sabido, constituye uno de los modos de adquirir la propiedad (art. 609 del C.c). En consecuencia cuando se den los requisitos legalmente establecidos, la Administración pública puede exigir su cumplimiento, incluso de modo forzoso si fuera necesario.

c) Las cesiones obligatorias y gratuitas de terrenos han de realizarse por los propietarios afectados por la actuación urbanística a desarrollar en un polígono o unidad de actuación, previamente delimitado por el plan que se trata de ejecutar 0 , de modo subsidiario, conforme al artículo 118 del Texto Refundido de la Ley del Suelo; y

d) Aun cuando las cargas de urbanización y, en particular, las cesiones obligatorias y gratuitas de terrenos a la Administración, son comunes a los diversos sistemas de actuación urbanística y, en consecuencia, proceda cualquiera que éste sea, como es lógico tales cesiones proceden y se desenvuelven normalmente cuando la ejecución de las obras de urbanización se efectuaban por el sistema de compensación o por el de cooperación.

Para Muñoz Machado, la cesión de terrenos es una técnica que sirve para recuperar para la comunidad las plusvalías producidas por el proceso de urbanización; no se trata de una expropiación; de una privación singular de la propiedad privada que hay que indemnizar, sino una fórmula de sustraer al propietario valores que no se deben a ninguna actividad suya, sino que pertenecen a la comunidad. Si no es, pues, una 
expropiación, ¿qué naturaleza jurídica tiene la cesión de terrenos? Por lo pronto, afirma este autor, parece evidente que no se trata de una simple limitación a la propiedad, puesto que los efectos de la misma no quedan, por ejemplo, en una simple declaración de inedificabilidad de los mismos (en el supuesto de que los terrenos se destinen a viales, parques 0 jardines), sino que supone una auténtica privación del dominio de los terrenos afectados y que, una vez cedidos, pueden, además, ser eventualmente utilizados $\mathrm{y}$ aprovechados para fines que implican la edificación. Parece evidente, por ello, que la cesión de terrenos es una prestación a que se somete ex lege a los propietarios de los terrenos, prestación que además surte efectos ope legis, o por ministerio de la Ley (art. 128 de la Ley del Suelo del 76). Y aún conceptualizada como una prestación impuesta ex lege se puede apurar la aproximación a su naturaleza jurídica considerándola como una contribución especial pagada en especie: hay aquí un beneficio especial para un sector de propietarios que no debe producirse, porque quebraría el principio de igualdad, a costa de que sea la comunidad, mediante sus contribuciones, quien sufrague las obras de urbanización o proporcione los medios necesarios para la instalación de servicios públicos; debe ser ese sector especialmente beneficiado el que pague; de aquí que la cesión de terrenos nos remita a la técnica de la contribución especial615 .

Para Tomas-Ramón Fernandez, las cesiones obligatorias y gratuitas de terrenos son deberes que definen en cada caso el contenido normal último del derecho de propiedad del suelo a partir de un contenido normal inicial, que es el que la propia naturaleza pone. Deberes cuyo cumplimiento está legalmente garantizado por vía expropiatoria que permite a la Administración desplazar al propietario incumplidor y buscar otro u

615 Vid. MUÑOZ MACHADO, “Apuntes de Derecho Administrativo 2”, Derecho Urbanístico, T. III, vol. $2^{\circ}$, Madrid, 1978, pp. 32 y ss. 
otros dispuestos a cumplir en su lugar. De forma que tales cesiones se justifican en cuanto compensaciones de la atribución de nuevos contenidos dominicales que el planeamiento realiza por encima de lo que la Ley considera el contenido normal inicial de la propiedad, es decir, el que la propia naturaleza pone 616 .

Teniendo en cuenta las diferentes manifestaciones doctrinales expuestas anteriormente, en nuestra opinión, las "cesiones de terrenos obligatorias y gratuitas", son cargas urbanísticas que, por ministerio de la Ley y a través de su especificación o determinación por un Plan legalmente aprobado, recaen sobre la propiedad de los terrenos comprendidos en un polígono o unidad de ejecución, imponiéndose en justa compensación por los beneficios derivados para aquéllos de la urbanización y cuyos efectos se producen plenamente, ope legis, por la ejecución del Plan.

Partiendo de esta noción y de su calificación como carga urbanística la figura que examinamos presenta los siguientes caracteres de legalidad, gratuidad, obligatoriedad, proporcionalidad, titularidad ob rem y eficacia ope legis.

La legalidad de la cesión obligatoria y gratuita de terrenos significa, que será ilegal toda cesión de este tipo que pretende imponerse al margen o fuera de las determinaciones de la Ley. La legalidad de la cesión se entiende en un doble efecto: por una parte, la cesión señalada en la Ley es mínima lo que significa que la Administración ha de exigirla necesariamente no pudiendo dejar de hacerlo; y, por otra, solamente son legales las cesiones para los fines expresa y concretamente señalados por la Ley lo que significa que la Administración actuaría ilegalmente si pretendiera ampliar o modificar los fines de la cesión señalados por la Ley.

616 Vid. TOMAS RAMON FERNANDEZ, Manual de Derecho urbanístico, Madrid, 1994, p. 87 y ss. 
La obligatoriedad de la cesión deriva de su imposición por la Ley; se trata de una carga ex lege cuyo cumplimiento puede ser exigido por la Administración a través de los medios de ejecución forzosa.

La libertad de cargas de los terrenos objeto de cesión.

La gratuidad de la cesión constituye su nota más típica diferenciadora de otros supuestos o figuras de cesión que se rigen por el principio de onerosidad.

La proporcionalidad de las cesiones es resultado de la necesaria equitativa distribución de las cargas urbanísticas entre los propietarios afectados. Tienen un doble sentido: de una parte las cesiones han de ser proporcionadas a los beneficios que se derivan del planeamiento; y de otra han de ser proporcionadas en su incidencia sobre los propietarios afectados.

En el primer aspecto, la Exposición de Motivos de la Ley del Suelo explica la imposición de las cesiones gratuitas de suelo como contrapartida de los beneficios del proceso de urbanización y como un componente más de la justa compensación que se exige a los propietarios por los beneficios derivados del proceso urbano. En este sentido es una aplicación concreta de la compensación urbanística. Si las cesiones obligatorias y gratuitas tienen su justificación porque son compensaciones de la concesión o atribución por la Administración de facultades que se otorgan al propietario a través del planeamiento, aquellas quedarían sin justificación cuando falte tal correlación cuando el Plan no otorgare beneficios o facultades o estos fueran desproporcionados o excesivamente inferiores a la carga de cesión.

En el segundo aspecto apuntado, la proporcionalidad de la cesión requiere que la carga de la misma sea distribuida proporcionalmente entre los propietarios afectados. Las técnicas del aprovechamiento tipo y de la reparcelación instrumenta tal proporcionalidad. 
En ambos casos no se produce ninguna modificación o alteración del Plan, sino que, simplemente la Administración asume la parte minorada de las cargas.

La titularidad ob rem de la carga de la cesión, supone la transmisión de la carga con la transmisión de la finca o terreno gravados por ella a través del mecanismo jurídico de la subrogación con arreglo al art. 88 de la L.S: "La enajenación de fincas no modificará la situación de su titular en orden a las limitaciones y deberes instituidos por esta Ley 0 impuestos, en virtud de la misma, por los actos de ejecución de sus preceptos y el adquirente quedará subrogado en el lugar y puesto del anterior propietario en los compromisos que hubiere contraído con las Corporaciones públicas respecto a la urbanización y edificación".

La eficacia de las cesiones obligatoria y gratuita se produce ope legis por ser una carga ex lege, que opera en cuanto a la transmisión o transferencia de los terrenos ministerio legis, con independencia y al margen de la voluntad de los propietarios cedentes (arts. 100, 128 de la L.S y 149 del RGU).

Por tanto, las cesiones son verdaderas y propias cargas urbanísticas, que recaen sobre la propiedad del suelo, que representan medios jurídicos para configurar el derecho de propiedad de acuerdo con la función social que éste debe desempeñar; función social que se concreta, en este caso, en la función social urbanística o función urbanística de la propiedad del suelo.

En el sistema de compensación urbanística, la carga de la cesión adopta sus propias modalidades.

Con carácter general las cesiones han de ser realizadas por los propietarios de terrenos afectados por la actuación urbanística. En el sistema de compensación, los propietarios de los terrenos comprendidos en el polígono o unidad de ejecución habrán de efectuar las cesiones, aun 
cuando dichas cesiones se llevan a cabo por la Junta de Compensación que se constituye como ente propio de dicho sistema. La Junta será la que señale los terrenos de cesión obligatoria y las reservas establecidas en el Plan mediante la aprobación del Proyecto de Compensación en que se localicen aquellas determinaciones; proyecto de compensación que, una vez aprobado por la Junta, habrá de ser sometido a la aprobación de la Administración actuante (art. 174 del RGU).

Son objeto de las cesiones que la Junta de Compensación ha de efectuar:

- Los terrenos que han de cederse obligatoria y gratuitamente con arreglo a la clase de suelo sobre el que se actúa, en este sentido la Junta de Compensación deberá ceder gratuitamente a los Ayuntamientos respectivos los terrenos destinados a viales, parques, jardines públicos y centros docentes al servicio del ámbito de desarrollo en el que sus terrenos resulten incluidos(arts. 14.2.a) y 18.1 de la nueva LS del 98.

- La cesión gratuita a la Administración del 10 por 100 del aprovechamiento del sector o ámbito correspondiente y del exceso sobre el 90 por 100 de dicho aprovechamiento. Estas cesiones vienen impuestas en los artículos 14.2.c) y 18.4 de la nueva LS del 98.

De acuerdo con los criterios establecidos en las Bases de Actuación, la Junta deberá formular el Proyecto de Compensación en el que deberá consignarse, entre otras determinaciones, la localización de los terrenos de cesión obligatoria y la descripción de las fincas resultantes que correspondan a la Administración como adjudicataria del 10 por 100 del aprovechamiento.

El Proyecto de Compensación deberá reflejar también las fincas resultantes y titulares a quienes se adjudiquen, que pueden ser, propietarios de otras fincas a quienes les correspondía un aprovechamiento cero o inferior al 90 por 100 que deben ser compensados con la 
adjudicación de terrenos edificables en el polígono objeto de la compensación.

- Además de las cesiones examinadas la Junta de Compensación deberá ceder, el suelo necesario para el establecimiento de los sistemas generales de ordenación del territorio. Esas cesiones se pueden llevar a cabo a través de modos diferentes: por convenio entre la Junta de Compensación y la Administración actuante; por expropiación forzosa por parte de la Administración a la Junta y por compensación, en este caso la Junta de Compensación afectada por la carga de cesión efectúa ésta y recibe, a cambio o en compensación, en otros sectores con exceso de aprovechamiento las parcelas con el aprovechamiento que corresponda a la superficie que ha cedido. Con lo cual la Junta de Compensación adquirirá unos terrenos fuera del ámbito del polígono o unidad de ejecución entrando así como titular propietaria de terrenos en otro polígono.

- La cesión de obras de urbanización e instalaciones. El art. 180 del RGU, con excesiva parquedad e indecisión, trata de desarrollar este supuesto de cesión en los siguientes términos: "La cesión de las obras de urbanización e instalaciones y dotaciones cuya ejecución estuviere prevista en el plan de ordenación y proyecto de urbanización aplicables se efectuará por la Junta de Compensación en favor de la Administración actuante dentro de un plazo no superior a tres meses, contado desde la recepción definitiva por la Junta". Una interpretación literal de estos preceptos lleva a la conclusión de que la Junta de Compensación tiene que ceder al municipio correspondiente todas las obras de urbanización instalaciones y dotaciones ejecutadas en el polígono o unidad de ejecución que constituye su ámbito de actuación. Porque todas han sido o han tenido que ser previstas necesariamente en el proyecto de urbanización aprobado y ejecutado, de acuerdo con las previsiones del Plan. 
Sin embargo esta conclusión que es válida para toda obra e instalación pública o con fines públicos que deben ser cedidas, puede no serlo para aquellas otras obras o instalaciones o dotaciones que tengan un carácter privado o que sirvan a determinados fines particulares respecto de los cuales entendemos que no existe la obligación de ceder a la Administración.

Todas estas cesiones, anteriormente mencionadas, llevan consigo un cambio en el carácter del bien cedido que de propiedad privada se transforma en dominio público municipal. Nos encontramos ante verdaderas transmisiones coactivas que operan ope legis por vía de compensación indemnizatoria, dando lugar a la extinción de toda clase de derechos reales y personales. $Y$ no se trata de adquisiciones que estén condicionadas por el tracto sucesivo, sino que operan con plena independencia de las titularidades sin perjuicio de las indemnizaciones que procedieran en favor de los propietarios.

4.2 EFECTOS DE CARACTER JURIDICO-REGISTRAL: INSCRIPCION DEL PROYECTO DE COMPENSACION EN EL REGISTRO DE LA PROPIEDAD Y EN EL LIBRO REGISTRO DEL AYUNTAMIENTO.

En la legislación anterior al TR y a la LRRU el mecanismo de acceso del Proyecto de Compensación al Registro se llevaba a cabo mediante una remisión a las normas que regulaban la reparcelación617. El art. 174.4 del RGU en su parte final establece que "La inscripción del acuerdo de aprobación del Proyecto de compensación por el órgano

617 Hoy en día esa remisión a las normas que regulan la reparcelación, carece totalmente de sentido, vid. DEL POZO CARRASCOSA, ob.cit.,p. 83 y ss; MERCEDES FUERTES, en Urbanismo y publicidad registral, Madrid, 1995,p.20 y ss.; CORRAL GIJON, J.M., La publicidad registral de las situaciones jurídicas urbanísticas, Madrid, 1996, p. 122 y ss. 
actuante, en el Registro de la propiedad se llevará a efecto de conformidad con lo establecido en el art. 114 de este Reglamento" 618 ' artículo que ha sido derogado por la tabla de vigencias del T.R. Este precepto por una parte determinaba cual era el título inscribible y su contenido y por otro como debía de efectuarse la inscripción.

El titulo inscribible según establece el art. 113.1 RGU lo constituyen la escritura pública o documento administrativo y en ellos se expresará además del contenido reglamentario, el acuerdo aprobatorio del órgano competente. El contenido, será el mismo del proyecto de compensación.

De acuerdo con lo establecido en el art. 114 del RGU la inscripción se llevará a cabo de la siguiente manera:

a) Se cancelarán las hojas regístrales correspondientes tanto a las antiguas fincas integradas o incluidas en la unidad de ejecución como a las fincas ocupadas para la ejecución de los sistemas generales, cuando sus titulares fuesen adjudicatarios en la unidad de ejecución con extinción de todos los derechos incompatibles con la ejecución del planeamiento. En el caso de fincas que se correspondan con otras resultantes, se hará constar en la nueva hoja registral que se abra, a la correlativa finca resultante.

b) Se abrirá una nueva hoja registral para cada una de las fincas resultantes adjudicadas, incluso de las que lo sean en favor del Patrimonio Municipal del Suelo o estén afectadas a cualquier servicio público.

c) En la inscripción de las fincas resultantes que se correspondan con otras anteriormente inscritas, se hará constar la hoja registral cancelada, en las restantes se practicará un asiento de primera inscripción . 
d) Se harán constar registralmente, los derechos reales que subsistan o se establezcan sobre las fincas resultantes, que no sean incompatibles con el planeamiento y especialmente la afección de las parcelas adjudicadas al cumplimiento de las cargas y pago de los gastos inherentes al sistema de compensación (art. 100.1.c) LS 76).

El acceso al Registro de la propiedad no es potestativo, sino que se establece imperativamente, como se contemplaba en la normativa anterior (art. 102, 114 y 174.4 RGU).

Se prevé el acceso al Registro de los actos de iniciación de los procedimientos por nota marginal y de los de aprobación definitiva mediante inscripción.

El art. 310 TR en su apartado 3 establece dos mecanismos de acceso al Registro, comienza diciendo este precepto que la inscripción de los títulos de reparcelación o compensación podrá llevarse a cabo:

a) bien "mediante la cancelación directa de las inscripciones y demás asientos vigentes de las fincas originarias, con referencia al folio registral de las fincas resultantes del proyecto, o bien,

b) mediante agrupación previa de la totalidad de la superficie comprendida en la unidad de ejecución y su división en todas y cada una de las fincas resultantes de las operaciones de reparcelación o compensación".

A partir de la aprobación del proyecto de compensación se pueden plantear tres situaciones distintas sobre una finca sometida al sistema de compensación.

- El art. 310.4.a) TR establece que si el título de compensación adjudicare la finca resultante al titular registral de la finca originaria, la inscripción se practicará a favor de este (atribución de la finca originaria a su titular registral).

- En los apartados b) c) y d) del art. 310.4 del TR contemplan el supuesto de atribución de la finca originaria a un adquirente posterior, 
aunque si bien es verdad con una redacción poco clara y en ocasiones defectuosa. Seria conveniente hacer una interpretación de los apartados b) c) y d), de lo contrario supondría una repetición de lo dispuesto en el apartado a).

El apartado b) viene a decir, que si el título de compensación no atribuyere la finca resultante al titular registral de la finca originaria, la inscripción se practicará a favor del titular registral actual.

El párrafo c) señala que "en el caso a que se refiere la letra anterior, se hará constar al margen de la inscripción o inscripciones de las fincas de resultado la existencia de los asientos posteriores que han sido objeto de cancelación, el título que los motivó y su respectiva fecha". De la redacción de este precepto se infiere que el término "posteriores" parece referirse a la inscripción de la finca originaria, y en ningún caso a la finca resultante, como parece entenderse de la redacción.

El párrafo d) señala que: "para la práctica de la inscripción de la finca o fincas de resultado a favor de los adquirentes de la finca originaria bastará la presentación del título que motivó la práctica de asientos cancelados posteriores a la nota (es decir, el título de compensación, art. 310.3 TR), con la rectificación que corresponda y en la que se hagan constar las circunstancias y descripción de la finca o fincas resultantes del proyecto, así como el consentimiento para tal rectificación del titular registral $y$ de los titulares de los derechos cancelados conforme al apartado b). Mientras no se lleve a cabo la expresada rectificación no podrá practicarse ningún asiento sobre las fincas objeto de la nota marginal a que se refiere la nota c)".

Por tanto, parece desprenderse de este confuso párrafo que, en el caso de que el adquirente de la finca originaria no hubiese llevado su adquisición al Registro, se necesita para ello, no solo "el titulo que motivó la práctica de los asientos cancelados posteriores a la nota" es decir, el título 
de compensación (art.310.3TR), sino también el consentimiento del titular registral y de los titulares de los derechos cancelados.

Pero, si el adquirente de la finca enajenada, sometido al sistema de compensación, hubiese llevado su adquisición al Registro, no tendría sentido condicionar, la inscripción de la finca resultante en su favor, a los consentimientos de los individuos que ya no tienen derechos sobre la finca mencionada, por tanto a este supuesto no seria de aplicación la regulación contenida en el art. 310.4.d) TR.

- Finalmente hay que decir que el art. 310 no contempla el supuesto de la atribución de una finca resultante diferente de la originaria, tanto al titular originario como al adquirente posterior. Tampoco se contempla el reflejo registral de las situaciones de copropiedad sobrevenida, ni la cuestión de los propietarios de terrenos destinados a sistemas generales. La realidad práctica nos demuestra que serán objeto de apertura de folio independiente con número propio, la peculiaridad radica en las situaciones de copropiedad, donde no se aplica la presunción de igualdad de la comunidad de bienes respecto a las porciones correspondientes a los partícipes (art. 393 del C.c), sino que, para que puedan inscribirse, es preciso que en la escritura de constitución se establezca la porción ideal de cada condueño con datos matemáticos que permitan conocerla indudablemente (art. 54.1 RH).

Según establece el art. 166 del RPU, con independencia de las inscripciones en el Registro de la Propiedad, anteriormente examinadas, habrá de inscribirse en el libro registro del Ayuntamiento, debidamente autenticado, el acuerdo de aprobación definitiva del Proyecto de Compensación, y en su caso, los acuerdos de revisión y modificación del mismo. También se inscribirán las resoluciones administrativas y sentencias que afectaren a dichos instrumentos urbanísticos. 


\section{CAPITULO DECIMO}

EL PODER DE DISPOSICION COMO MECANISMO DE ACTUACION DE LA JUNTA

\section{INTRODUCCION}

El proyecto de compensación constituye, "el título de adjudicación de las fincas resultantes de la gestión urbanística por el sistema de compensación" 619 , y lo es, tanto respecto de los miembros integrantes de la Junta (arts. 172 a) y b), 177.4, 167.1 g) y 85.1 del RGU) así como respecto de la Administración, el art. 129.1 de la LS establece que la transmisión a la Administración correspondiente, en pleno dominio y libre de cargas, de todos los terrenos de cesión obligatoria tendrá lugar por ministerio de la ley con la aprobación definitiva del proyecto de compensación.

Para otro sector de la doctrina, el proyecto sería el modo de adquirir la propiedad, mientras el Plan, el título de adquisición, con efectos y obligatoriedad en cuanto tal plan 620 .

Nosotros entendemos que si la incorporación de los miembro de la Junta no supuso la transmisión de la propiedad de los terrenos afectados, los solares resultantes que correspondan a cada propietario siguen siendo propiedad de ellos, con lo cual habrá de entenderse el proyecto de compensación como título de adjudicación y no como título de adquisición de la propiedad pues el Proyecto no otorga a los propietarios nada de lo que no tuvieran anteriormente, pero que pueden hacer efectivo a partir de ese momento.

En este sentido la legislación urbanística adopta la construcción privatista de la subrogación real, manteniendo sus dos notas características:

619 Vid. DEL POZO CARRASCOSA, ob.cit., p. 81; MARTIN BLANCO, ob.cit. p.75.

620 Vid. LASO, Derecho Urbanístico, Madrid, 1982, III, p. 145; en el mismo sentido, GONZALEZ SALINAS, Sistema de compensación, ob.cit., p. 44. 
por un lado la sustitución de una cosa por otra, y por otro la continuidad o permanencia de la misma titularidad o situación jurídica a pesar del cambio efectuado 621. Los efectos jurídicos que se derivan serían por un lado la desaparición de los antiguos objetos de derecho, incluso en los supuestos en que no se produzca una modificación de la línea poligonal que los delimita, pues en este caso se pasa del concepto de "terreno" al concepto de "solar" o "proyecto de solar", una vez que se haya realizado efectivamente la urbanización, se extinguen los derechos que recaían sobre dichos objetos de derecho; creación de las nuevas fincas resultantes así como de los nuevos derechos que recaerán sobre las fincas resultantes y adjudicación de las mismas a los miembros de la junta de compensación, éste es el efecto jurídico esencial conocido con el nombre de "derecho en la compensación", que estudiaremos más adelante 622

Lo cierto es que para que la Junta de Compensación pueda realizar sus funciones no es necesario que ostente un derecho de propiedad sobre los terrenos de sus miembros, pueden adquirir la propiedad por precepto expreso, pero sólo mediante él 623.

Solamente, si en virtud de disposición expresa en los Estatutos 624 , la incorporación determinó la transmisión a la Junta de los terrenos

621 Vid. entre otros ROCA SASTRE, "La subrogación real”, en RDP, abril 1949, pp. 281 a 304; MARIN PADILLA, M. Luisa, "La formación del concepto de subrogación real", en RCDI, 1975, p.1111; "El principio general de la subrogación real en los derechos reales de garantía y goce" en RCDI, 1978, p.1149 y 1207; LACRUZ BERDEJO, Elementos de Derecho Civil, I, vol. 3ㅜ, Barcelona, 1992, p. 103.

622 Vid. DEL POZO CARRASCOSA, ob.cit. p. 83.

623 En este sentido vid. NUÑEZ RUIZ, Derecho Urbanístico español, Madrid, 1967, p. 313, al decir que con la incorporación de los terrenos se concede a la Junta "una especie de mandato común de carácter representativo" y CARCELLER FERNANDEZ, en El régimen de las entidades urbanísticas colaboradoras, según el Reglamento de reparcelaciones, RDU, 1967, no 2, p. 60.

624 Los estatutos de la Junta de Compensación pueden prever que la incorporación a ella de los propietarios produzca la transmisión de la propiedad de las fincas a la propia junta, sólo en ese caso se produce la transmisión (art. 159.1 y 4 del TR así como el art. 171 del RGU) los cuales ratifican dicha transmisión al recoger la exención, de dichas transmisiones, del pago de dos impuestos (Impuesto sobre Transmisiones Patrimoniales y Actos Jurídicos Documentados y del Impuesto sobre el Incremento del Valor de los Terrenos de Naturaleza Urbana) característicos de la transmisión del dominio. Así mismo en el ámbito Jurisprudencial se pronuncia la St. de 27 diciembre de 1991 (Ar. 332) que establece que: “... la Jurisprudencia, desde la St. 28 Junio de 1975 (RJ 1975, 3097), viene atribuyendo a las mutaciones 
afectados, la adjudicación de los solares resultantes constituirá, también, una transmisión de dominio 625 . En este caso la titularidad dominical de los terrenos incluidos en la unidad de ejecución corresponde a la propia Junta y los socios participarán en ella en proporción al valor que las Bases atribuyan a los terrenos o aprovechamientos objeto de transmisión a favor de dicha Entidad.

Ahora bien, tanto en un supuesto como en otro, se dará la exención del Impuesto General sobre Transmisiones Patrimoniales y Actos Jurídicos Documentados, y no tendrán la consideración de transmisiones a efectos del impuesto municipal sobre incremento de valor de los terrenos. Unicamente se devengarán los impuestos cuando el valor de los solares adjudicados a un propietario excediera del que proporcionalmente corresponda a los terrenos aportados por el mismo (art. 171 RGU y 159.4 TR) 626. Al no tener la consideración de transmisión a efectos del impuesto municipal sobre el incremento del valor de los terrenos, no estará sujeto a este impuesto (art. 350 LRL) y por tanto no figura como exención en el art. 352 LRL.

El que la Junta se constituya sin aportación dominical de terrenos es el supuesto más frecuente y el que regula la legislación urbanística. La junta se constituye de tal forma que los socios conservan la titularidad dominical de los terreno. En este caso, el patrimonio de la Junta estará

dominicales en los planes de ordenación urbanística como consecuencia de una reparcelación o del ejercicio del poder de disposición plena que, con carácter fiduciario, ostentan las Juntas de Compensación formadas por los propietarios- la naturaleza de simple subrogación o modificación de la propiedad, que no implica, transmisión sujeta al Impuesto Municipal sobre el Incremento del Valor de los Terrenos; esa naturaleza subrogatoria y la actuación fiduciaria de la Junta de Compensación, está proclamada, respectivamente, en los arts. 100.1 b) y 129.2 del TR de la LS de 9 abril 1976, y aun cuando el último precepto permite en algunos casos transmisiones de dominio entre propietarios y Junta de Compensación, nunca en esos supuestos de transmisión es estimada como tal a efectos del Impuesto sobre Incremento del Valor de los Terrenos, pues así lo disponen expresamente los arts. 102.1 y 129.3 LS y 130 RGU de 25 de agosto 1978...". En el mismo sentido puede verse la St. 27 de mayo de 1988 (Ar. 3980) así como la St. de 8 de mayo de 1989 (Ar. 3745).

625 Aquí, nos encontramos con un principio puramente civil, como es el de la Autonomía de la voluntad, porque no impone una forma especifica de otorgamiento de estatuto, sino que estos se elaboran conforme a la voluntad de los propietarios.

626 Vid. LLISET BORRELL. "La fiscalidad en las Juntas de Compensación" RDU, no 53, pp. 77 y ss. 
constituido por las adquisiciones que lleve a cabo en nombre propio, aunque dichas adquisiciones se reducirán normalmente a las actuaciones expropiatorias, hay que tener en cuenta por otro lado las fincas de resultado que se reserve la junta, en los términos previstos en el art. 172. d) del RGU, con la finalidad de enajenarlas y de destinar el importe obtenido a sufragar gastos de urbanización (art. 177.7 del RGU).

Continua diciendo el art. 159 del TR que "en todo caso, los terrenos quedarán directamente afectos al cumplimiento de las obligaciones inherentes al sistema" y que "las Juntas de Compensación actuarán como fiduciarias con pleno poder dispositivo sobre las fincas pertenecientes a los propietarios miembros de aquéllas..."(art. 159. 2 del TR, art.129.1 de la LS) por tanto, los propietarios conservan la propiedad pero las facultades de disposición pasan a la Junta de Compensación, que las ejercerá libremente como fiduciaria.

Es ese poder de disposición, el mecanismo a través del cual, la Junta de Compensación lleva a cabo la gestión urbanística de la unidad de ejecución, así el art. 185 del RGU señala que la Junta tiene "facultad fiduciaria de disposición". De estas afirmaciones contenidas tanto en el TR art. 159.2 (art. 129.2 LS del 76) como en el RGU art. 185 se destacan dos aspectos:

El poder de disposición de la Junta y, la actuación de la Junta de Compensación "como fiduciaria".

Antes de estudiar cada uno de estos aspectos, es importante, a efectos de determinar esa actuación de la Junta como fiduciaria, analizar su relación con la institución del negocio fiduciario desde el punto de vista civil. Esta figura ofrece la peculiaridad de que no ha sido regulada por las leyes y de que carece de antecedentes en el Derecho común; si bien, sobre ella se han escrito importantes monografías ${ }^{627}$. Es una creación del pandectismo

627 Entre otros pueden verse los siguientes trabajos DE CASTRO, EI negocio fiduciario, Estudio critico de la teoría del doble efecto, en RDN, 1966, no 53-54, p. 7; JORDANO, El negocio fiduciario, 1959; Sobre negocio fiduciario, ADC, III, 1, 1950, p. 140; Propiedad 
alemán, que nace y se extiende apoyada en la concepción abstracta del negocio jurídico. El significado e importancia del negocio fiduciario depende en gran parte de la aceptación o de la negación de la teoría del doble efecto, que veremos seguidamente.

\section{NEGOCIO FIDUCIARIO: LA SUPERACION DE LA TEORIA DEL}

\section{DOBLE EFECTO.}

Para los pandectistas alemanes el negocio fiduciario628 producía el efecto real de transmitir la propiedad y, al mismo tiempo, en virtud del pactum fiduciae, la obligación de devolver la cosa al deudor si éste satisfacía la deuda. Esta visión deformada de la fiducia se introdujo en nuestro país y recibió el nombre de teoría del doble efecto.

El concepto del negocio fiduciario según la teoría del doble efecto "se caracteriza por su naturaleza compleja y por la confluencia en él de dos contratos independientes, uno real, de transmisión plena del dominio con su correspondiente atribución patrimonial, eficaz erga omnes, y otro obligacional, válido inter partes, que constriñe al adquirente para que actúe dentro de lo convenido y en la forma que no impida el rescate por el transmitente, con el consiguiente deber de indemnizar perjuicios en otro caso, o sea, restitución de la misma cosa o abono de su valor económico"629.

fiduciaria y negocio fiduciario, ADC, III, 4, 1950, p. 1259; Dictamen de los bienes trasmitidos fiduciariamente, ADC, XIX, 3, 1966, p. 619; GONZALEZ RODRIGUEZ, Nota sobre la fiducia en garantía. Bocetos jurídicos, AAMN, III, 1946, p. 370; NAVARRO MARTORELL, La propiedad fiduciaria. La fiducia histórica. Los modernos negocios fiduciarios, 1950; "Notas sobre la estructura y el concepto de negocio fiduciario", RDP, 34, 1950, p. 224; LIPARI, II negozio fiduciario, 1964; MESSINA, Negozi fiduciari. Introduzione e parte I, Scritti giuridici, I, 1948;CARIOTA-FERRARA, I negozi fiduciari, 1933; PUGLIATTI , Fiducia e rappresentanza indiretta, Precizioni in tema di venta a scopo di garanzia, Diritto civile, 1951, p. 201-333 y 335394;FUENTESECA, CRISTINA., El negocio fiduciario en la Jurisprudencia del Tribunal Supremo, Barcelona , 1997.

628 FERDINAND REGELSBERGER, es a quien el negocio fiduciario debe su nombre, en su estudio "Zwei Beiträge",según la autorizada afirmación de VON THUR, Der Allgemeine Teil des deutschen bürgerliches Recnts, 1918, II, 77, p. 186, núm. 2, a. Citado por DE CASTRO Y BRAVO, El negocio jurídico, Madrid, 1985, p. 381.

629 Entre los autores defensores de la teoría del doble efecto, y en consecuencia que mantienen que la causa fiduciae es transmisor de la propiedad se encuentran entre otros: NAVARRO MARTORELL, La propiedad fiduciaria, Barcelona,1950, p. 119; CARCABA 
Es decir, que el fiduciante transmite al fiduciario la titularidad dominical de su cosa o de su crédito de modo definitivo e ilimitado; el fiduciario será desde entonces el dueño, con todas las facultades de tal, frente al fiduciante y frente a todos. El fiduciante queda con un derecho de crédito contra el fiduciario, el correspondiente a la obligación de éste de utilizar la titularidad adquirida de modo que no contradiga la finalidad para la que se le ha confiado. Esta teoría ha sido sometida a revisión por De Castro ${ }^{630}$, el cual entiende que es una figura que no responde a la voluntad de las partes porque no es lo ordinario que el fiduciante haya querido transmitir la propiedad plenamente al fiduciario, pues quien hace una venta para garantizar al prestamista la devolución de lo prestado, quiere conseguir el préstamo y, porque no puede otra cosa, pasa por aquella imposición. Ni dice, ni cabe presumir que quisiera desprenderse definitivamente de su propiedad.

Por tanto De Castro con el ánimo de criticar la visión de los pandectistas recoge la posición de aquellos autores que conciben el negocio fiduciario de modo unitario con una causa propia denominada causa fiduciae, autores que encuentran su apoyo en el art. 1274 del C.c cuando alude a la causa de los contratos onerosos 631 . De Castro aborda el problema de la venta en garantía formulando las cuatro afirmaciones siguientes:

1. Señala que en la venta en garantía no puede encontrarse una causa onerosa ("A la entrega de la cosa confiada no corresponde el precio, que aquí no existe. Las obligaciones asumidas por el fiduciario no pueden

FERNANDEZ, M., La simulación en los negocios jurídicos, Barcelona , 1986,p. 58; DE LOS MOZOS, El negocio jurídico, Madrid, 1987, p. 477; O'CALLAGHAN,X., Compendio de Derecho Civil, Tomo I, Parte general, Madrid, 1992, p. 466.

630 Vid. DE CASTRO, El negocio fiduciario, ob.cit, p. 385 y ss. Por lo que se refiere, en concreto, a la "titularidad fiduciaria", vid. p. 419 y ss.

631 Albaladejo y Jordano se han adherido a la crítica efectuada por De Castro a la teoría del doble efecto. Pero es preciso destacar que esta posición no fue mantenida por estos autores hace algún tiempo, sino que admitieron la llamada teoría del doble efecto. En este sentido ALBALADEJO, M., en su obra El negocio jurídico, Barcelona, 1958, p. 225, admitió la validez del negocio fiduciario y afirmó que la atribución causal tiene por causa la causa fiduciae. El fiduciante, en su opinión, ostenta un derecho de crédito contra el fiduciario. A su vez, JORDANO BAREA, en El negocio fiduciario, Barcelona,1959, pp. 16 y 99-100 señalan que en los negocios fiduciarios, el fiduciario es dueño pleno y definitivo de la cosa. A su juicio la causa fiduciae es válida para transmitir la propiedad. En la actualidad la opinión de ambos autores ha variado sustancialmente en el sentido de rechazar esta primera posición. 
ser valoradas como contraprestación de la pérdida de la propiedad que sufriría el fiduciante... El fiduciante no ha recibido nada por lo que ha dado...").

2. De Castro afirma el carácter simulado de la compraventa ("...la venta, como contrato causal y no abstracto, requiere una causa. Al no haber precio, el negocio disimulado será el de garantía... El porqué y para qué del negocio fiduciario será entonces proporcionar al prestamista una seguridad más de cobro. Esta será la causa de la fiducia cum creditore").

3. De Castro, al aceptar la visión pandectista, niega que el negocio fiduciario pueda constituir una categoría unitaria ("... se descubre su carencia de propio sentido y su naturaleza de artificio empleado para servir resultados que caen dentro del ámbito de otras figuras jurídicas... habrá que negar que el negocio fiduciario constituya una categoría unitaria...”).

4. Por último, rechaza este autor la existencia de una transmisión de propiedad ("La transmisión de propiedad requiere un título o causa adecuada. El garantizar un cobro o el cumplir un encargo no son títulos que pueden justificar, respectivamente, una pérdida y una adquisición de propiedad, de modo pleno y definitivo").

Esta es la crítica a la visión pandectística efectuada por De Castro, donde parece identificar la visión pandectística como romana.

Por tanto, aunque los defensores de la visión pandectística632, conceden relevancia al conjunto de compraventa más obligación de devolver, hay un sector de la doctrina633 que entiende que es necesario

632 Vid. entre otros, GONZALEZ PALOMINO, La adjudicación para pago de deudas, A.A.M.N., I, 1943, pp. 255-256; GARRIGUES DIAZ-CAÑETE,J.,Negocio fiduciario en Derecho mercantil, Madrid, 1981,p. 85; SOLS LUCIA, A., El fraude a la ley. Estudio analítico del art. 6.4 C.c en la doctrina y jurisprudencia, Madrid, 1989, pp. 726-730; VIDAL MARTINEZ,J., La venta en garantía en el Derecho civil común español. Estudio jurisprudencial y ensayo de construcción doctrina, Madrid, 1990, pp. 184-230; NAVARRO MARTORELL, La propiedad fiduciaria, ob.cit., p. 119; CARCABA FERNANDEZ, M., La simulación en los negocios jurídicos, ob.cit., p. 58; DE LOS MOZOS, El negocio jurídico, ob.cit.,p. 477; O'CALLAGHAN,X., Compendio de Derecho Civil, ob.cit., p. 466.

633 Vid. entre otros FUENTESECA CRISTINA, El negocio fiduciario, ob.cit., p. 66; DE CASTRO, El negocio fiduciario, ob.cit., pp.423- 432; ALBALADEJO, M., " El Ilamado negocio fiduciario es simplemente un negocio simulado relativamente" en Actualidad Civil, no 36 , octubre, 1993, pp. 663 y ss.; JORDANO BAREA,J.B., "Mandato para adquirir y titularidad 
prescindir de la causa de la compraventa y atender a la causa del negocio disimulado, así tanto para la venta con fin de administración como para la venta en garantía la solución es la de reconocer un negocio simulado y configurar el disimulado como un mandato o una garantía. Por tanto, no es admisible la causa de transferencia ya que nada se transmite ni las partes tienen intención de hacerlo. Por ello, aunque se utilice la figura de la compraventa ésta constituye un negocio simulado, cuya causa no sirve, no es válida. La causa del negocio disimulado, que es la que hay que considerar, no lo es de transmisión. La voluntad de las partes será determinante para la configuración del negocio disimulado. Habrá que atender a lo querido por los interesados y averiguar si desean dar en garantía, en administración etc. En ningún caso efectuar una transmisión de propiedad. Es esta la opinión de quienes con mayor empeño han intentado destruir la teoría del doble efecto construida por los pandectistas alemanes.

Desde el punto de vista histórico, en Derecho Romano, las fuentes no permiten afirmar que el fiduciante transmitiese la propiedad de la cosa al fiduciario, sino que transmitía el ejercicio de la función de dominus fiduciariamente para el cumplimiento de una finalidad convenida (pactum fudiciae) que implicaba devolución de la misma cosa o venta de ésta si la deuda del fiduciante no hubiese sido pagada o garantizada. Este era el sentido de la causa fiduciae que no transmitía la propiedad porque para ello se requería una causa emptionis y el pago de un precio. La fiducia se constituía mediante una imaginaria venditio, es decir, una venta simulada que únicamente traspasaba la cosa bajo el poder o potestas (in mancipio) del accipiens el cual no podía usucapirla.

La fiducia clásica romana no implicaba una venditio porque la mancipatio era una forma solemne de transmitir un poder o potestas sobre las res mancipi, negocio abstracto, que puede tener diversas finalidades doctrina del profesor De Castro", A.D.C., 1983, pp. 1437 y ss. 
(emptionis causa, donationis causa, etc.) y cuando se realiza fiduciae causa no había precio efectivo sino simbólico (una moneda: nummo uno). Por tanto, el fiduciarius asume una función dominical fiduciaria, es decir, confiada en virtud del pactum fiduciae con finalidad de garantía. La causa fiduciae supone, precisamente, una entrega en confianza y no en propiedad.

El sentido de la mancipatio fiduciae causa y, por tanto, de la causa fiduciae consiste en que el accipiens (acreedor fiduciario) recibe la cosa, no por causa de venta sino como entrega de cosa confiada con una función de garantía y no como vendida. Podrá el acreedor fiduciario ejercitar la función de dueño que se le confía en el pactum fiduciae para el fin de garantía y devolver la cosa cuando cobre la deuda o venderla si no cobra. La causa fiduciae implica entrega en confianza y no en propiedad, es decir, para garantía y devolución, o, en otro caso, venta de la cosa 634 .

Concluyendo, ni en Roma ni en la actualidad es posible reconocer una transmisión de propiedad inherente a la causa fiduciae635 .

Seguidamente, partiendo de este concepto civil de negocio fiduciario, vamos a analizar la proyección del mismo en el ámbito de actuación de la Junta de Compensación, para ello partiremos del análisis del concepto de poder de disposición, sobre todo teniendo en cuenta que a la Junta se le atribuyen facultades dispositivas manifestadas en la cesión de terrenos a la Administración (art. 172.c) RGU), en la enajenación de los mismos para poder financiar la urbanización (arts. 172 d) y 177.1 RGU). Además puede incluirlos en el porcentaje del aprovechamiento urbanístico que corresponde a la Administración (art. 172.b) RGU); puede edificar (art.

634 Vid. FUENTESECA Cristina, El negocio fiduciario, ob.cit., pp. 67-68.

635 Desde el punto de vista jurisprudencial, el problema de si existe o no una transmisión de propiedad en el negocio fiduciario, queda suficientemente resuelto en el libro de Cristina FUENTESECA, El negocio fiduciario..., ob.cit., pp.96-180, donde intentando conseguir una versión global y rápida de todas las sentencias del Tribunal Supremo elabora un esquema en el que se recoge el contenido de cada fallo e indica si existe o no un pronunciamiento sobre el tema del negocio fiduciario, llegando a la conclusión de que el Tribunal Supremo no acude a la idea de transmisión de propiedad en la mayoría de las sentencias y aunque suele citar la teoría del doble efecto sólo lo hace de palabra sin que tal razonamiento sirva de fundamento del fallo y varíe el destino de los bienes. 
167.1.e) i) RGU; puede vender los inmuebles construidos a terceras personas (art. 167.1.i) in fine del RGU) .

\section{EI PODER DE DISPOSICION DE LA JUNTA}

La Junta de Compensación puede llevar a cabo la gestión urbanística del polígono gracias a la atribución a la misma del poder de disposición sobre las fincas incluidas en dicho polígono, por esta razón seguidamente describiremos de forma breve ese poder de disposición636, haciendo hincapié en aquellas cuestiones que serán de aplicación a los problemas derivados de la actuación urbanística de la junta de compensación.

La doctrina define el poder de disposición como la "legitimación para realizar la prestación con arreglo al tenor de la deuda concreta: para comunicar a otro el derecho o influencia sobre la cosa o conducta que constituye el contenido de la obligación"637; también se ha definido como una simple facultad caracterizada por atribuir un ámbito de posibilidades de actuación libre dentro del orden jurídico y por carecer de independencia por

636 La caracterización del poder de disposición, ha sido una cuestión ampliamente debatida por la doctrina, así, un sector doctrinal, mayoritario, representado, entre otros, por DIEZPICAZO, Fundamentos de Derecho civil patrimonial, T.III, Madrid, 1995, p. 839; LACRUZ BERDEJO, ob. cit.317, entiende que la "facultad de disposición jurídica tiene que ver con cada derecho subjetivo alienable: de ahí que, en principio, no se pueda disponer eficazmente de las cosas ajenas; también que tal facultad falte en algunas ocasiones, pese a ser los dueños personas plenamente capaces"; AGUILERA DE LA CIERVA, Actos de administración, de disposición y de conservación, Madrid, 1973, p. 157, defiende el poder de disposición como elemento integrante del derecho subjetivo. En este sentido, defiende CUENA CASAS, ob.cit., p. 490 que "un sujeto tiene poder de disposición cuando es titular del derecho que se pretende disponer, pero a ello no es obstáculo el que en determinadas circunstancias la ley legitime una adquisición de un no dueño, que sea el propio Estado el que opere la transferencia (en los casos de expropiación forzosa), o que eventualmente un titular de un derecho vea impedido el ejercicio de su facultad de disposición". Otro sector doctrinal, se pronuncia en favor de la autonomía del poder de disposición, posición que ha sido mantenida por: FERNANDEZ DE VILLAVICENCIO, "La facultad de disposición", ADC, 1950,p.1052; GOMEZ ORBANEJA, El ejercicio de los derechos, Madrid, 1975,p.66; BARASSI, I Diritti reali nel nuovo Codice civile, Milán, 1943, p. 425, entre otros.

637 Vid. LA CRUZ BERDEJO, Elementos de Derecho Civil. T. II, Vol. 1ํ1985, p. 192; en el mismo sentido BERCOVITZ en Comentarios al Art. 1160 C.c. Tomo XVI, Vol. $1^{\circ}$ p. 52 y ss. 
estar basados en una situación jurídica principal"638 ; o como "la legitimación que un sujeto tiene para actuar con eficacia sobre un derecho"639 .

Por esta razón, si la capacidad de obrar es requisito de validez de un acto, el poder de disposición lo es de eficacia, así queda reflejado en el art. 1160 de C.C, en el que la transmisión de un derecho sólo es eficaz, si el transmitente tiene la libre disposición del mismo.

La relación entre el sujeto del que se predica el poder de disposición y el objeto de la disposición puede ser de tres tipos:

a) Titularidad. El titular de un derecho en principio tiene la libre disposición del mismo, lo que le posibilita no sólo enajenar el derecho (arts. 480 y 1160 del C.C) sino también la creación de gravámenes sobre la cosa (arts. 597 y 1857.2 C.C). El poder de disposición debe ser suficiente para conseguir la eficacia de la transmisión de cada derecho concreto, de ahí que, cuando sobre un objeto determinado convergen varias titularidades 0 derechos la disposición sobre este objeto sólo será posible si el poder de disposición es suficiente. Por ejemplo en el art. 597.1 y 2 C.C la imposición de una servidumbre a un fundo indiviso sólo tendrá lugar cuando todos los comuneros hayan consentido, otros ejemplos los podemos encontrar en los arts. $96.4,595,596$ y 1377 C.C.

b) El poder de representación. Tanto el representante legal (arts. 162, 222 y 1259 C.C) como el voluntario (arts. 1259 y 1709) tiene poder de disposición sobre bienes de su representado, dentro del ámbito de la representación. Es precisamente este ámbito el que determinará el contenido de su poder de disposición (arts. 271, 272 y 1713.2 C.C). El representante ejercita el poder de disposición tanto en nombre como en interés ajeno, de su representado (art. 507 segundo apartado C.C).

El segundo componente del poder de disposición hace referencia a la aptitud del derecho para cambiar de titular o para ser gravado así, en

638 Vid. FERNANDEZ DEL POZO, "Derecho Real de uso y poder de disposición" en RCDI, 1988, pp. 85-106.

639 Así lo define DEL POZO CARRASCOSA, ob. cit., p. 99. 
determinados supuestos o bajo determinadas circunstancias se puede hablar de la posibilidad de disposición (arts. 1858 y 1874.2 C.C y 106.2 y107 L.H), y en otros casos de ausencia absoluta de poder de disposición (arts. 525 y 785.2 C.C y 26 y 108.2 y 3 L.H).

Trasladando este concepto civil de poder de disposición, que acabamos de exponer, al ámbito de la Junta de compensación y teniendo en cuenta que (salvo que se produzca alguno de los supuestos excepcionales, previsión estatutaria o expropiación que dan lugar a la transmisión de la propiedad a la junta) el propietario de una finca sujeta al sistema de compensación conserva su propiedad, en este supuesto, la Junta está legitimada para llevar a cabo diversos actos de disposición sobre dicha finca, incluso su enajenación a terceras personas no integrantes de la unidad de ejecución.

La Junta está legitimada, por la propia legislación urbanística, por las bases de actuación y el proyecto de compensación, para actuar en nombre propio y con eficacia jurídica sobre un derecho del cual no es titular de ahí que el proyecto de compensación permita que la Junta no sólo atribuya las fincas resultantes a sus propios miembros, sino que reserve superficies de parcelas para enajenarlas directamente con el fin de sufragar los gastos previstos de la urbanización" arts. 172. d) y 177.1 RGU640 . Esta

640 Así queda recogido en las siguientes sentencias: St. de 2 de noviembre de 1985 (Ar. 5443), según esta sentencia la actuación fiduciaria de la Junta se concreta en la posibilidad de disposición de los terrenos de los propietarios a través del Proyecto de Compensación, pudiendo incluso enajenar las fincas resultantes o reservarse parcelas, para con la enajenación de las mismas abonar los gastos de urbanización. "Para la aprobación del Proyecto de compensación han de hallarse los terrenos a disposición de la Junta de Compensación que si, por un lado, actúa como fiduciaria en pleno poder dispositivo sobre las fincas pertenecientes a sus miembros... por otro es beneficiaria de la expropiación en los casos en que ésta procede". La St. de 30 de octubre de 1989 (Ar. 7478) "... Y lo que en este momento importa destacar es que la Junta de Compensación actúa como fiduciaria con pleno poder dispositivo sobre las fincas pertenecientes a los propietarios que son sus miembros (art. 129.2 LS). Tal titularidad habilita a la Junta para disponer de las fincas mediante el proyecto de compensación, dentro del cual puede reservarse aquella superficie o parcela para enajenarlas directamente con el fin de sufragar los gastos de urbanización (arts. 172. d) y 177.1 del RGU)", y continúa diciendo: "Finalmente y dado que la parte apelante insiste en que la decisión impugnada se adoptó con su oposición será de indicar que la titularidad fiduciaria de la Junta no exige unanimidad para su actuación la Junta tiene personalidad jurídica, dado que habrá que estar a las reglas que al respecto establezcan los Estatutos art. 166. h) en relación con el art. 177.3 RGU-. Véase también la St. 19 de octubre de 1993 (Ar. 7368). 
legitimación para actuar con eficacia sobre el derecho de propiedad, no tiene su origen en una relación de titularidad, pues como ya hemos visto, salvo que en los Estatutos se disponga otra cosa, la junta no es propietaria, únicamente se le concede un poder de disposición 641 .

Tampoco tiene su origen en una relación de representación porque la junta no representa, en sentido estricto, a nadie, no tiene una autorización ni actúa por cuenta de ningún propietario concreto, sino que actúa en nombre propio en tanto que ente con personalidad jurídica propia. Ostenta una legitimación en nombre propio sobre bienes ajenos de forma que los actos de la junta sobre esos bienes se realizan para alcanzar los fines de la propia junta. Por tanto los intereses que persiguen la Junta y los propietarios no pueden identificarse ya que mientras que los propietarios tienen un interés en el mantenimiento y eficacia de sus respectivos "derechos en la compensación" (art. 177.4 RGU), la Junta tiene un interés distinto, que es la "gestión y ejecución de la urbanización de un polígono o unidad de ejecución" (art. 157.1 y 165 RGU) ${ }^{642}$.

\section{ALCANCE DE LAS FACULTADES QUE I NTEGRAN EL PODER DE DISPOSICION DE LA JUNTA DE COMPENSACION.}

Cuando la legislación urbanística habla de "facultad de disposición" (art. 185 RGU) se está refiriendo a una doble posibilidad.

- Por un lado a un poder de disposición material. En este sentido la actuación urbanística que lleva a cabo la Junta se traduce en una serie de actos de disposición material sobre las fincas incluidas en el polígono. Así la

\footnotetext{
641 Vid. art. 159.2 TR (129.2 LS) "la Junta tiene pleno poder dispositivo sobre las fincas pertenecientes a los propietarios miembros de aquéllas; así mismo la Ley le concede un poder de disposición hipotecaria sobre "las fincas pertenecientes a los propietarios miembros" art. 177.2 RGU en el sentido de que podrá concertar créditos con garantía hipotecaria de las fincas pertenecientes a los propietarios miembros para la realización de las obras de urbanización."

642 Vid. DEL POZO CARRASCOSA, ob. cit., p. 111.
} 
junta podrá alterar la forma de las fincas en aquellos casos en que no se corresponda la finca primitiva con la resultante (art. 122.3 RGU). De igual forma la Junta está legitimada para llevar a cabo la demolición de edificaciones, obras, plantaciones e instalaciones (art.167.1.c) RGU),e incluso está facultada para realizar nuevas construcciones (arts. 167.1.i) y 175 RGU).

Además, el propietario puede verse privado de la posesión de su finca si es necesaria la ocupación temporal de ésta para la ejecución de las obras sobre la finca en cuestión. Esta actuación de la junta no significa merma alguna de los derechos de los propietarios en el resultado de la compensación (art. 177.4 RGU), pero no permite la protección interdictal de los mismos (art. 185 in fine RGU) es decir, que los miembros de la Junta no podrán promover el ejercicio de interdictos cuando la Junta de Compensación ocupe bienes que sean precisos para la ejecución de las obras de urbanización, de conformidad con el plan que se ejecute.

- Por otro lado la Junta goza de un poder de disposición jurídico que está en función del sistema de compensación, de esta forma ese poder de disposición se proyecta en el ámbito externo y en el interno.

En el ámbito externo, este poder de la junta nace con la aprobación del proyecto de compensación, así la junta puede enajenar terrenos que se hubiese reservado, para hacer frente a los gastos de urbanización (art. 177.1 RGU), en este caso se trata de un poder de disposición sobre fincas que ya no van a ser adjudicadas a ningún miembro de la junta, ni siquiera en el caso de que la venta no llegue a producirse, pues el proyecto de compensación ya ha sido aprobado y de no enajenarse, será la propia junta la que decida el destino de tales fincas. Esta facultad de enajenar se entiende referida a las fincas resultantes, y no a las fincas originariamente aportadas, así se deduce de los artículos 172,d) y 177.1 RGU, que permiten la enajenación, para hacer frente a los gastos de urbanización, de los terrenos que se hubiesen reservado a tal fin en el proyecto de 
compensación, por ello, todos los gastos anteriores a la aprobación del proyecto de compensación serán financiados por las cuotas de los miembros de la junta o con las enajenaciones de los terreno que la junta haya adquirido en propiedad, no los que se hubiese reservado. En el mismo sentido se pronuncia el art. 185 RGU.

Por el contrario, la Junta no puede enajenar una de las fincas aportadas a la gestión por compensación, ni siquiera entendiendo que la enajenación estaría hecha bajo la condición suspensiva de la aprobación del proyecto de compensación. Lo que si podría hacer la junta con anterioridad a la aprobación del proyecto de compensación es crear y enajenar un "derecho en la compensación" por un valor determinado. Pero como veremos no se concreta sobre ninguna finca en particular.

Asimismo, la junta puede hipotecar (art. 177.2 RGU) y constituir otros gravámenes sobre las fincas pertenecientes a los propietarios miembros (art. 177.3 RGU). Esta posibilidad de hipotecar o de constituir gravámenes sobre fincas que pertenecen a los propietarios miembros de la junta, debe estar expresamente contemplada en el proyecto de compensación. La razón no es otra que al ser el valor de una finca hipotecada inferior al de una finca libre de tal carga, la libertad absoluta de la junta de constituir una hipoteca vulneraría el principio de reparto equitativo de los beneficios y cargas derivados de la urbanización. La ruptura de ese principio por desproporción en la imposición de excesivas cargas determinará la injusticia de éstas porque ese exceso se traduce en ilegalidad o confiscación total o parcial de la propiedad; es el equilibrio entre cargas y beneficios urbanísticos, el que puede resolver con justicia la integración derecho de propiedad privada y función social, pero en todo caso, serán los tribunales, en sus funciones de tutela del derecho de propiedad, los que determinen en qué medida la carga urbanística es o no aplicación justa y no extralimitada de la función social de la propiedad643.

643 Vid. MARTIN BLANCO, J. El texto refundido de la legislación urbanística Estatal, Madrid, 1994, p. 76. 
Esta circunstancia tiene un claro reflejo en el ámbito civil, si bien, la Ley hipotecaria no contiene un precepto expreso que determine quienes están legitimados para hipotecar, implícitamente se deduce del tenor literal del art.1857.3 del C.c donde se establece como requisito esencial "que las personas que constituyan la prenda o hipoteca tengan la libre disposición de sus bienes 0 , en caso de no tenerla, se hallen legalmente autorizadas al efecto". Es evidente que el término libre disposición, al que alude este precepto coincide con el concepto de legitimación, cabe por tanto que una persona esté legitimada para disponer de un derecho ajeno, pero tal legitimación no se basa en un poder de disposición. Por tanto la constitución de la hipoteca, no es un acto personalísimo, sino que puede realizarse mediante apoderado aunque con poder expreso (art. 1713 C.c). En el ámbito de la junta, su legitimación para concertar créditos con garantía hipotecaria va implícita en el poder de disposición que se le confiere.

En el ámbito interno, el poder de disposición se le atribuye a la junta desde el momento en que el propietario ingresa en ella, pero se concreta con la aprobación del proyecto de compensación, que es el instrumento de creación de las nuevas fincas resultantes y el título de creación de los derecho sobre dichas fincas. Este poder de disposición se centra en un proceso de extinción de los derechos antiguos sobre las fincas primitivas (art. 172.a) y en la correlativa creación de nuevos derechos sobre las fincas resultantes del proceso de compensación (art. 172. b) RGU).

Como manifestaciones de ese poder de disposición podíamos mencionar la posibilidad que tiene la Junta de conceder a cualquier propietario una finca absolutamente diferente de la originaria, en este sentido el art. 122.3 RGU establece que "cuando no haya una exacta correspondencia entre las fincas adjudicadas y las antiguas, el acuerdo constituirá un título de adquisición originaria a favor de los adjudicatarios y éstos recibirán la plena propiedad de aquéllas, libre de toda carga que no se derive del propio acuerdo". 
De igual modo, la junta tiene la posibilidad de obligar a la constitución de una copropiedad sobrevenida, posibilidad que queda plasmada en los artículos 94.1, 96.3, 122.4 y 167.1.g) RGU, este último precepto establece que las bases de actuación contendrán "las reglas para la adjudicación de fincas a los miembros de la junta en proporción a los bienes o derechos aportados, expresando los criterios de adjudicación en comunidad, si procediere", precepto que tiene su reflejo en el artículo 393 del C.c que preceptúa que el concurso de los partícipes, tanto en los beneficios como en las cargas, debe ser proporcional a las respectivas cuotas.

Asimismo, la Junta tiene la posibilidad de modificar, de forma sustancial, las condiciones del primitivo derecho de propiedad, en este sentido el art. 122.4 al decir que "esta misma regla se aplicará en los casos de adjudicaciones pro indiviso o con modificación sustancial de las condiciones de la primitiva titularidad", está poniendo de manifiesto por un lado, la posibilidad de modificar de forma "sustancial" las condiciones del primitivo derecho de propiedad y por otro lado la posibilidad de obligar a la constitución de una copropiedad sobrevenida.

De todo esto se desprende que, los miembros de la Junta siguen siendo propietarios de sus terrenos pudiendo disponer de su propiedad, si bien con las limitaciones que supone la incorporación a la Junta y la afección de los terrenos al cumplimiento de las obligaciones inherentes al sistema de compensación, lo que se hará constar en el Registro de la Propiedad por nota marginal que así regula el art. 169 del RGU644, quedando reducidas las facultades fiduciarias de la Junta, a la enajenación y a la constitución de

644 El art. 169 RGU establece que: "1. En cumplimiento de lo dispuesto en el art. 129 LS, (art. 159.1 TR) la afección de los terrenos comprendidos en un polígono o unidad de actuación al cumplimiento de las obligaciones inherentes al sistema de compensación se hará constar por nota marginal en el Registro de la Propiedad. 2. Dicha nota se extenderá a instancia de la Junta de Compensación, con aportación de certificación administrativa de haber quedado constituida la Junta de Compensación y de estar la finca incluida en el polígono o unidad de actuación. 3. La nota producirá los mismos efectos que señala el art. 102 de este Reglamento para las que en dicho precepto se disponen en el procedimiento de reparcelación". 
gravámenes sobre dichas fincas en los términos establecidos en el art. 177 párrafos 3 y 4 del RGU 645, por lo que, al carecer de patrimonio propio la Junta, serán las fincas de los propietarios miembros los bienes patrimoniales que acaben respondiendo de obligaciones contraídas e incumplidas por la Junta, ya que la incorporación de los propietarios, conlleva la de sus terrenos sin necesidad de transmisión patrimonial a la Junta.

\section{LA ACTUACION DE LA JUNTA DE COMPENSACION COMO} "FIDUCIARIA".

El artículo 159.2 del TR (art. 129.2 LS) dispone que "las Juntas de Compensación actuarán como fiduciarias con pleno poder dispositivo sobre las fincas pertenecientes a los propietarios miembros de aquéllas, sin más limitaciones que las establecidas en los Estatutos". La utilización en una norma urbanística de una figura civil como es la fiducia ha planteado numerosas dudas en la doctrina.

En términos generales, la doctrina rechaza la configuración de la situación descrita como una fiducia o negocio fiduciario 646 dado que cuando no hay transmisión de la propiedad de los inmuebles, a la junta de compensación, como es el caso que nos ocupa, no cabe hablar de "titularidad fiduciaria" de los terrenos por parte de la Junta, puesto que no es titular de ningún "derecho subjetivo" sobre los mismos ya que el derecho de propiedad sigue perteneciendo a los propietarios de la unidad de ejecución.

645 Del citado precepto se desprende que, ese poder de disposición en el ámbito externo sólo podrá ejercitarse si se produce un acuerdo expreso de la junta de compensación que permita la enajenación o la constitución de gravámenes sobre los terrenos que fueran reservados a ese fin en el Proyecto de Compensación o bien cuando esté previsto en los Estatutos que los órganos rectores de la junta puedan realizar dichos actos, "en cuyo caso se entenderá que actúan en representación de la Junta, sin necesidad de acuerdo expreso" (art. 177.3 RGU)

646 Vid. entre otros, GARCIA GARCIA. "La reparcelación y la compensación en relación con el Registro de la Propiedad" en RCDI 3a. parte, 1986, p. 1370. CASAS-MIRALLES en "La titularidad fiduciaria de las juntas de compensación": una forma de propiedad colectiva transitoria durante el proceso de urbanización, en Materiales IV Jornadas de Derecho Civil CATALA a TOSSA, Barcelona, 1988, p. 233 y ss. y LASO MARTINEZ, Derecho Urbanístico, III. La propiedad ante el planeamiento urbanístico, Madrid, 1982 p. 157. 
De ahí que haya que distinguir, en la facultad fiduciaria prevista en este artículo, dos modalidades de derecho diferentes. Por una parte, una facultad dominical fiduciaria que es la que correspondería a la Junta en el caso de aportación del dominio pleno de los terrenos en sentido estricto, lo que supondría que la Junta ostentaría una especie de propiedad fiduciaria y por otra la facultad fiduciaria en sentido propio, que es la que se atribuye a la Junta de Compensación en los casos en que la propiedad de los inmuebles incluidos en el proceso de equidistribución permanezca en poder de los propietarios. En relación a esta última se afirma que no se trata de una titularidad en sentido estricto, sino de una posibilidad normativa de actuación o facultad legal, que no supone titularidad alguna. Se atribuye una facultad dispositiva a una persona jurídica, en este caso la Junta, distinta del titular dominical, con la finalidad de facilitar su actuación, y simultáneamente, de permitir la gestión adecuada de un patrimonio afectado a un fin concreto, como es la realización de la urbanización de la unidad de ejecución. Puede suceder que la propia entidad, o sus socios, carezcan de medios iniciales para llevar a cabo esa tarea, lo que supone la necesidad de buscar otros medios de financiación.

Por otro lado, y como argumento en contra de la actuación de la junta como fiduciaria, habría que decir que la titularidad que ostenta la junta no es oculta, como sucede con la verdadera titularidad en el negocio fiduciario, sino que es una titularidad o poder de disposición que, legalmente previsto (se configure o no como apoderamiento) recibe adecuada publicidad registral en la inscripción de la Junta en su Registro647.

647 Vid. CASAS-MIRELLES, La titularidad, p. 233 y ss., quienes añaden que "La fiducia, en la legislación del suelo, no es un procedimiento indirecto y oculto puesto en juego por la autonomía de la voluntad para conseguir fines a menudo de dudosa licitud. La fiducia es aquí un instrumento que, públicamente, legitima la actuación del sujeto encargado de la ejecución del planeamiento. Es la solución equilibrada buscada para evitar tanto la necesidad de transmitir el dominio a la junta como la total falta de eficacia de ésta por carecer de una titularidad que legitime su actuación, de naturaleza dispositiva, sobre el suelo del polígono o unidad de actuación". 
Además, en ocasiones la situación de la Junta se ha reconducido a un mandato o apoderamiento, ligado a la finalidad de gestión de la junta, por el cual ésta puede disponer de las fincas aportadas 648 .

En este sentido, partiendo de la base de que no existe una "atribución patrimonial" a la Junta, lo que hace que no se pueda hablar de "titularidad fiduciaria" se podrían configuran las facultades dispositivas que confiere la Ley a dicha Junta como mandato o apoderamiento representativo o forzoso, por el cual ésta puede disponer de las fincas aportadas.

Por todo ello, entendemos que, lo correcto no es hablar de un patrimonio atribuido a la Junta con carácter fiduciario, sino de las limitaciones en la capacidad de obrar de su titular por razón del destino legal de los elementos que lo integran. Lo lógico es pensar que la Junta no puede llevar a cabo otros actos que aquellos encuadrados dentro de las propias finalidades previstas por el legislador para su constitución y subsistencia, y que se concretan en las obligaciones de ceder y urbanizar de tal forma que sus actos de enajenación o gravamen se destinen a financiar la obra de urbanización que constituye su finalidad esencial. La validez de tales actos exige el acuerdo del pleno de la Junta de compensación (art. 177.3 RGU), salvo que la constitución de gravámenes y la enajenación conste prevista en los Estatutos como competencia de sus órganos rectores, en cuyo caso se entenderá que actúan en representación de aquélla, sin necesidad de acuerdo expreso.

648 Vid. MARTIN BLANCO, La Compensación... ob.cit., p. 146 y ss., habla de "apoderamiento o mandato", en el mismo sentido, LASO, Derecho Urbanístico, III, Madrid, 1982 p. 153 y ss.; DELGADO IRIBARREN, El sistema de Compensación, en XVI Temas de Derecho Urbanístico, Oviedo, 1980, p. 306 nos habla de "apoderamiento forzoso, es decir, más que apoderamiento, sustitución en las facultades del propietario por ministerio de la Ley"; CHICO, en "Comentarios a la RDGRN de 12 de enero de 1984", RCDI, no 564, p. 1259 y ss., configura estas facultades dispositivas como mandato representativo"; CASAS-MIRALLES, La titularidad, ob. cit., p. 234 quienes añaden: "en cierto modo, podría decirse que la junta ha sido apoderada irrevocablemente por la ley. En sentido contrario a lo que acabamos de ver, se podría citar a GARCIA GARCIA, "La reparcelación y la compensación en relación con el Registro de la propiedad, en RCDI, no 576, p. 1368 y ss. que expresamente considera correcta la caracterización fiduciaria de la Junta. 
Habrán de ser los estatutos los que determinen la competencia o facultades, tipo de acuerdo, quórum necesario y demás circunstancias para que los actos dispositivos y de gravamen puedan ser válidamente realizados.

En cualquier caso, y con independencia de lo expuesto, aun cuando no estuviere previsto en los estatutos, la Junta, a través de sus órganos rectores, podrá poner a disposición de quienes ejecuten la obra urbanizadora las superficies sobre las que se vayan a ejecutar las obras y aquellas otras que sea necesario ocupar durante su realización, sin que ello signifique merma alguna de los derechos de los propietarios en el resultado de la compensación (art. 177.4 RGU).

La vinculación de los terrenos a la Junta, sin transmisión de dominio a ésta, como regla general y a falta de limitaciones expresas en los estatutos, no limita la disponibilidad o alienabilidad de éstos por sus propietarios, los cuales pueden establecer determinadas limitaciones 0 preferencias adquisitivas a favor de la Junta en los supuestos de transmisiones onerosas. En todo caso el adquirente por cualquier clase de título quedará subrogado en los derechos, obligaciones y cargas de que era titular el transmitente, habida cuenta de la titularidad propter rem y sin perjuicio de que se haga mención expresa de ello en el título de transmisión 649 .

Por otro lado, la no transmisión de la propiedad a la Junta tiene algunas ventajas: a) retener el dominio ante la eventualidad de que en el futuro, si se dieran circunstancias importantes, pueda dejarse sin ejecutar el Plan o revisar el mismo dejando la puerta abierta a la utilización de otro sistema de actuación; b) la no transmisión no constituye obstáculo para el funcionamiento práctico-legal y operativo de la Junta pudiendo actuar ésta con poder suficiente al efecto; y c) gozar de un trato fiscal más favorable.

649 Vid. MARTIN BLANCO, J., La compensación urbanística..., ob.cit., pp 151 y ss. 


\section{TRANSMISION DE LA PROPIEDAD DE LAS FINCAS A LA}

JUNTA.

Hemos visto que la incorporación de los propietarios a la Junta de compensación conlleva la de sus terrenos sin necesidad de transmisión patrimonial, sin embargo, los estatutos de la junta pueden prever la transmisión de la propiedad de las fincas a la misma (arts. 159.1 y 4 TR 129.1 y 3 LS, y 170 y171RGU).

La transmisión de la propiedad a la junta es una decisión que corresponde al conjunto de propietarios y que acordarán al redactar sus propios estatutos, lo que no obsta para que los estatutos puedan prever que esta transmisión de la propiedad se produzca para todos los integrantes de la junta o sólo para algunos de ellos. Esta posibilidad cuyo fundamento se encuentra en el art. 62 RGU, por aplicación analógica, puede tener lugar como cesión para pago de determinados gastos que puedan acordarse.

La atribución de titularidad dominical a la Junta puede tener también carácter colectivo y vinculante "salvo que los Estatutos dispusieran otra cosa". Lo característico en estos casos está en que estas Juntas de Compensación, al devenir propietarias, desde ese mismo momento, no necesitarán justificar su funcionamiento con facultades fiduciarias de disposición ex lege, sino que las fincas podrán ocuparse e hipotecarse porque son de la Junta. Es efectiva titular del suelo.

De igual forma, es posible la atribución a la Junta de la titularidad patrimonial, en el proyecto de compensación, aún no prevista en los Estatutos, en cuanto puede reservarse en el mismo proyecto suelo, en vez de adjudicarlo a los miembros integrantes de la junta (arts. 172.d), 174.1 y 177.1 RGU)650.

En el caso de los arts. 159.1 y 4 TR (129.1 y 3 LS), 170 y 171 RGU, la Junta de Compensación deviene propietaria plena y libre de los terrenos 650 Vid. GONZALEZ SALINAS, J., Sistema de compensación..., ob. cit., p. 85. 
aportados. Estos terrenos pasan a formar parte del patrimonio de la Junta de Compensación dejando de tener cualquier tipo de vinculación con el anterior propietario, y no tendrán la consideración de transmisiones a efectos del impuesto municipal sobre incremento de valor de los terrenos. El bien material aportado únicamente servirá como referencia para calcular la cuantía del derecho en la compensación.

Por lo que se refiere al aspecto formal, esta transmisión ha de documentarse en escritura pública (art. 170 RGU).

Además y según se desprende de distintos preceptos de la legislación urbanística, art.158.1 y 160.2 TR (127.1 y 130.3 LS), 168.2 y 181.1 RGU, la Junta de Compensación puede adquirir la propiedad de los terrenos incluidos en la unidad de ejecución en tanto que beneficiaria de la expropiación de los mismos, es únicamente beneficiaria de la expropiación651, lo que no significa que sea titular de la potestad expropiatoria, la cual corresponde, en este caso concreto del sistema de compensación, a la Administración actuante (art. 160.2 TR y 181.1.2 RGU).

Conviene señalar, antes de pasar a analizar los motivos que dan lugar a la expropiación en favor de la Junta, que la expropiación tiene lugar con anterioridad a la aprobación del proyecto de compensación ya que esa posibilidad de expropiar puede figurar en las bases de actuación art. 167.1 RGU y además si tenemos en cuenta lo dispuesto en el art. 178.1 RGU, tras la aprobación del proyecto, las fincas sólo quedarán "gravadas, con carácter real " al pago de las deudas que se hayan originado por la actuación urbanística de la junta, sin que se prevea en este caso la posibilidad de expropiación.

Esto quiere decir que la expropiación que insta la junta va dirigida al "derecho en la compensación", derecho que tienen todos los miembros de

651 Así el art. 3.1 LEF establece que: "La junta de Compensación es únicamente el sujeto que representa el interés público o social para cuya realización está autorizada a instar de la Administración expropiante el ejercicio de la potestad expropiatoria y que adquiere el bien o derecho expropiados". 
la Junta, pero si alguno de ellos, conservase un derecho de propiedad sobre alguna de las fincas aportadas, ese derecho de propiedad será también objeto de expropiación, por tanto si la Junta ha adquirido la propiedad de los terrenos durante el proceso de constitución de la misma, la expropiación solamente recae en el "derecho en la compensación ". Si la Junta no adquiriera la propiedad de esos terrenos la expropiación se extiende tanto al derecho de propiedad como al derecho en la compensación.

En el caso de los propietarios de terrenos exteriores al polígono, destinados a sistemas generales, la expropiación es "de su derecho en la compensación "pues no tendría sentido que lo hiciese la Junta de Compensación respecto de una finca que no está situada en una unidad de ejecución, además estos sujetos ya no son propietarios pues la Administración ya ha procedido a la ocupación de las fincas (art. 52 y 53 $\mathrm{RGU})$.

En el caso de las empresas urbanizadoras que se incorporan a la Junta el art. 167.1.g) RGU permite la adjudicación de fincas "a los miembros de la junta" y, en consecuencia, a las empresas urbanizadoras (art. 163.2 RGU) por tanto, cabe hablar para dichas empresas de un derecho en la compensación. El titular de la empresa urbanizadora recibe las fincas de resultado proporcionales a su aportación en concepto distinto del ordinario de subrogación real, es decir, a título de adquisición originaria. Como consecuencia las fincas adjudicadas deberán serlo en concepto de libres de cargas, en condiciones similares a las atribuidas al Organo actuante. Estas fincas adjudicadas pueden quedar afectadas o no a la obligación de urbanizar, circunstancia en todo caso que dependerá de los Estatutos de la Junta y de las condiciones establecidas para la incorporación de la empresa urbanizadora.

La expropiación a favor de la Junta de Compensación, puede tener lugar por dos motivos: 
- Como mecanismo para facilitar la actuación urbanística de la Junta.

En aquellos casos en que los propietarios no se hubiesen incorporado a la junta, ni inicialmente ni una vez requeridos para ello (art. 158.1 TR (127.1 LS) y 162.5 y 168.2.1 RGU), la expropiación constituye un medio de fomentar la incorporación del propietario de la finca a la junta. Pero además dentro de esta misma línea y según se desprende del art. 168.2.2 RGU también serán expropiados los terrenos de aquellos propietarios que no hubieran aceptado el sistema652 .

- Asimismo la expropiación puede tener lugar por incumplimiento, por parte de los propietarios, de una serie de obligaciones tanto de carácter legal (arts. 160.2 TR (130.3 LS) y 181.1 RGU), como impuestas por la propia junta (art. 167.1.h) RGU).

El cumplimiento de estas obligaciones, deberes o cargas está garantizado bajo amenaza de expropiación, incluso cuando el incumplimiento se refiere a los plazos para cumplir dichos deberes o cargas (art.181.1 RGU).

El objeto de la expropiación lo constituyen los respectivos derecho de los miembros de la junta que incumplen sus obligaciones, en este sentido los arts. 160.2 TR (130.3 LS), 167.1.h) y 181.1 RGU, nos hablan de la "expropiación de sus bienes y derechos".

652 La no adhesión a la junta trae como consecuencia ineludible la expropiación, así queda expresado en la St. de 2 de noviembre de 1985 (Ar. 5443) donde se establece que: "...como exigencia lógica de la finalidad que está llamado a cumplir el proyecto de compensación, supone que la Junta, para poder formularlo, ha de tener a su disposición todos los terrenos integrados en el Polígono de actuación; y esto presupone, a su vez, la expropiación de los bienes de quienes, como los recurrentes, no quisieron adherirse a la Junta, al hacérseles las oportunas comunicaciones al efecto"; St. de 11 de marzo de 1989(Ar. 1968)" ... dado que la no incorporación de los propietarios a la Junta da lugar a la expropiación forzosa de sus fincas, tan radical efecto exige que previamente se haya ofrecido a aquellos, "individualizadamente" la oportunidad de incorporación, a tal efecto nuestro ordenamiento ofrece hasta cuatro oportunidades distintas, arts. 158.1, 159.2, 162.1, 122.5 y 163.5 RGU”; St. de 16 de abril de 1979 (Ar. 1254) que tiene su base legal en la Ley del Suelo de 1956 pero cuya doctrina respecto a la expropiación de los no adheridos es hoy válida; St. de 9 de octubre de 1993 (Ar. 7165). 
Esta expropiación-sanción frente al incumplimiento de deberes por el propietario ha sido objeto de críticas $^{653}$, señalando como inconvenientes prácticos de esta alternativa los siguientes:

1ํㅡ El efecto de descapitalización del sector, ya que tal y como se practica la expropiación, supone la transferencia al propietario del valor monetario del bien expropiado. Si ese precio se reinvirtiera en el desarrollo del proceso urbano, este inconveniente no existiría, pero normalmente el precio de la expropiación será colocado por el expropiado en cualquiera otra inversión o sector, contribuyendo así a la descapitalización de un sector ya de por sí deficitario, ante las necesidades crecientes en los entornos urbanos.

$2^{\circ}$ La poca funcionalidad de la institución ante la debilidad financiera de las Administraciones municipales, pues frente a una situación generalizada de incumplimiento, poco es lo que pueden hacer las Administraciones municipales, si han de empezar por hacer frente a la carga financiera de las expropiaciones por incumplimiento de la función social de la propiedad .

En definitiva, la expropiación, colocada como alternativa de actuación pública frente a una actuación particular que no se pone en movimiento o que se desconfía de que logre unos resultados a la altura de las necesidades, debería regularse aquí con una flexibilidad de la que, en principio carece y debería estar acompañada de otras opciones que eliminen ese dualismo radical consistente en que o actúa el particular o actúa la Administración.

653 Vid. MORELL OCAÑA, L., "La Administración urbanística: sus rasgos peculiares ante la reforma de la Ley del Suelo", en RDU, № 33, 1973; MARTIN BLANCO,J., en El tráfico de bienes inmuebles en la Ley del Suelo, Madrid, 1985, pp. 181 y ss. , en La Compensación urbanística...,ob.cit., pp.167 y ss. y en "La especulación del suelo en la problemática general urbanística” en RDU, no 7, 1968, pp. 34 y 
Estos son en líneas generales los mecanismos de adquisición de la propiedad de los terrenos incluidos en la unidad de ejecución, por parte de la Junta de compensación, pero en este caso sería importante señalar que la propiedad que ostenta la junta es una propiedad transitoria, en el sentido de que cesa con las adjudicaciones de las nuevas fincas a los propietarios del polígono.

Por tanto, la propiedad de la junta no es una propiedad fiduciaria, sino una propiedad plena, la peculiaridad aquí viene dada no por el estatuto de la propiedad, sino por su titularidad, ya que la junta de compensación tiene una función determinada cual es la gestión y ejecución de la urbanización, función que puede cumplirse con las operaciones que realice sobre los bienes de su propiedad. 


\section{CAPITULO UNDECIMO}

\section{EL DERECHO EN LA COMPENSACION}

\section{INTRODUCCION}

El "derecho en la compensación", es un derecho de carácter personal y de contenido instrumental que tienen los miembros de la junta de compensación a que la propia Junta les adjudique, en el proyecto de compensación, un terreno de valor económico proporcional a la aportación realizada. En este sentido el proyecto de compensación tiene la función de concretar el derecho de los propietarios sobre los solares resultantes.

Por ello parece sostenible la tesis de que el Proyecto de Compensación es, en el plano de los derechos privados, un acto especificativo o distributivo de derechos que convierte los derechos derivados del Plan en derechos individualizados y concretos sobre solares determinados. Es el acto de adjudicación el que produce el efecto traslativo de la propiedad a través del mecanismo subrogatorio que más tarde analizaremos. Este efecto traslativo se produce, con las naturales variantes, tanto si el propietario aportó los terrenos en propiedad a la Junta o no y tanto esta aportación fuera el resultado de un convenio urbanístico de compensación o viniera legalmente impuesta, respondiendo así a la sustitución o subrogación que opera el cambio de cosa por cosa ya ex voluntate, ya ex necessitate 654 .

La legislación urbanística atribuye a los propietarios incluidos en el polígono o unidad de ejecución un derecho en el proyecto de compensación (art. 172. a) RGU) o derecho de los propietarios en el resultado de la compensación (art. 177.4 RGU). Así entre las determinaciones que debe contener el proyecto de compensación figura "la descripción de las fincas 
resultantes, incluyendo en su caso, las que corresponden a la Administración adjudicataria del aprovechamiento que le corresponda, titulares a quienes se adjudiquen y concepto en que lo fueren. Se expresará respecto de cada finca, la antigua a la que corresponda o el derecho que da lugar a la adjudicación..." (art. 172.b).

Se trata de un derecho de nueva creación que corresponde a los diferentes miembros de la Junta de compensación, no a los propietarios expropiados, (tanto los de terrenos incluidos en la unidad de ejecución como los de terrenos destinados a sistemas generales y cuyo desequilibrio patrimonial ha sido compensado mediante el pago de justiprecio). Se trata de un derecho que va unido a la cualidad de miembro de la junta, de ahí que "el derecho a la adjudicación en propiedad de las fincas resultantes" lo tengan también los propietarios de terrenos destinados a sistemas generales, que ya han perdido su derecho de propiedad; los propietarios de terrenos incluidos en la unidad de ejecución, en los casos que haya habido transmisión de la propiedad de aquéllos a la junta, y las empresas urbanizadoras, en los casos en que así se establezca.

Este derecho que da lugar a la "adjudicación de las fincas resultantes" (art. 172.b) RGU, tiene lugar con la aprobación del proyecto de compensación y se llevará a cabo de forma proporcional teniendo en cuenta los bienes o derechos aportados inicialmente (art. 159.4 TR, 169.1.g) y 171 del RGU) de forma que (para mantener ese criterio de proporcionalidad) se prevé la posibilidad de compensaciones en metálico para corregir las diferencias en las adjudicaciones de los distintos propietarios (arts. 167.1.c), 172.e) y 171 in fine RGU).

Una vez aprobado el proyecto de compensación y concretadas las adjudicaciones definitivas, se extingue ese derecho en la compensación. 


\section{CONTENIDO DEL DERECHO EN LA COMPENSACION}

El contenido esencial del derecho en el proyecto de compensación es un contenido económico determinado por las bases de actuación al fijar los criterios de valoración (art. 113. 1. a) y 167. 1. a). b), c) y d) RGU, por el proyecto de compensación (art. 113.1.a) y 172. a) RGU, y en el caso de los sistemas generales por la propia ley, al otorgar un determinado número de "unidades de aprovechamiento".

La adjudicación de terreno no es contenido esencial, sino la manera de satisfacerlo (art. 166.1.f) TR, tampoco sería contenido esencial la proximidad ente la finca "incorporada" y la "adjudicada" (arts. 166.1.g) TR y 95.1.2 RGU).

Ya hemos dicho que este derecho en la compensación va unido a la cualidad de miembro de la Junta de tal forma que, el adquirente de un terreno antes de que tenga lugar la aprobación del proyecto de compensación, se convertirá en titular de ese derecho a la vez que miembro de la Junta (art. 28 RGU y 22 TR (88LS)).

Por el contrario, si la junta de compensación, en ejercicio de su poder de disposición en el ámbito externo enajena una finca de un antiguo propietario, éste sigue siendo miembro de la Junta hasta que se complete el proceso urbanizador. El nuevo adquirente no pasa a incorporarse a la Junta puesto que ha adquirido un terreno resultante del proyecto de compensación $y$, por tanto, el derecho ya se ha extinguido.

El fundamento del "derecho en la compensación" varía según cual sea su titular:

- En el caso de propietarios de terreno incluidos en el polígono o unidad de ejecución (art. 157.2 RGU) el fundamento está en la titularidad de las fincas aportadas o derechos, que dan lugar a la adjudicación, de ahí que el art. 172.b) RGU establezca en relación con este aspecto, que en el 
proyecto de compensación deberá de expresarse la finca antigua o el derecho que da lugar a la adjudicación de cada una de las nuevas parcelas resultantes.

- Cuando se trate de propietarios de suelo exterior al polígono ocupado para la ejecución de sistemas generales (arts. 157.2 y 163.3 RGU) el fundamento es la ocupación de sus fincas sin que se haya aplicado el sistema de expropiación forzosa (arts. 71.2, 161.3 y 172.a) RGU y los arts. 210 y 204 TR)

- y en el caso de empresas urbanizadoras que se incorporen a la Junta, el fundamento de su derecho en la compensación está en función de su participación o de sus aportaciones en la gestión de la unidad de ejecución que realiza la Junta (art. 167.1.d) RGU, pero el derecho en la compensación de las empresas urbanizadoras vendrá configurado por los distintos criterios que presidieron la incorporación de la empresa a la Junta, así el art. 166.f) RGU establece que: "los estatutos de la Junta, contendrán condiciones o requisitos para incorporarse a la Junta empresas urbanizadoras si expresamente se previera la posibilidad de su participación...", criterios a los que se hace alusión también en los arts. 158.2 TR (127.2 LS) y 165, 166.f), 167.1.d) y 176.4 RGU.

\section{INSCRIPCION EN EL REGISTRO DEL DERECHO EN LA} COMPENSACION.

Cuando se trate de terrenos comprendidos en un polígono o unidad de ejecución, la existencia del "derecho en la compensación" se hará constar por nota marginal en el Registro de la propiedad según se deduce de los arts. 310 TR y 169 RGU. No cabe duda que la finalidad de estos preceptos es la de tratar de evitar uno de los problemas esenciales de la regulación anterior, dimanante de la escasez de efectos de la nota marginal a que se refiere el artículo 102 del RGU. La fuerza notificadora de la antigua 
nota era insuficiente de tal forma que la inscripción de cualquier título posterior a la iniciación del proyecto provocaba la imposibilidad no sólo de inscribir la finca de resultado a favor del titular inicial de la finca de origen, sino también la imposibilidad de practicar los asientos correspondientes al resto de las operaciones contenidas en el proyecto, lo que generaba toda clase de inconvenientes y perjuicios, no sólo a los propietarios implicados en el proceso, sino a los propios intereses públicos 655 .

La inscripción de las fincas de resultado, en el supuesto de que tenga lugar la agrupación previa de las fincas de origen, supone la realización de una doble operación, por un lado, la segregación de la finca instrumentalmente agrupada y por otro la adjudicación a favor de la Administración actuante y de los propietarios de las fincas de origen. Por tanto, el conjunto de datos registrales de las fincas de resultado deberá hacerse constar mediante nota al margen de la inscripción de la finca agrupada. Cada una de las fincas de resultado, incluidas las destinadas a dominio y uso público, deberá ser objeto de apertura de folio independiente con número propio, de tal forma que su inscripción refleje además la situación de las cargas trasladadas por subrogación real procedentes de la finca de origen aportada por el titular adjudicatario. Pensamos que aunque dichas cargas se hayan hecho constar en la finca formada por agrupación instrumental, la referencia a la finca de origen es esencial para concretar en el Registro la correspondencia entre aportación y adjudicación y, por tanto, el juego del principio de subrogación real.

En el caso de que no se practique operación previa de agrupación, la operación registral consiste simplemente en la apertura directa de folio independiente a todas y cada una de las fincas de resultado.

Tratándose de terrenos destinados a sistemas generales y de las cargas que sobre ellos recaigan, el "derecho en la compensación" queda reflejado en la "escritura de declaración o especificación de las unidades de 
aprovechamiento derivadas de su derecho" (art. 54.3 RGU), en la cual se hará constar el polígono donde tengan que hacerse efectivas. Esta escritura según el precepto citado "será inscribible en el Registro de la propiedad en el mismo folio de la finca ocupada". En este folio se inscribirán también las sucesivas transmisiones de todas 0 parte de las unidades de aprovechamiento, transmisión que se efectuará "conforme a lo establecido para la transmisión de bienes inmuebles (art. 54.4 RGU)" esta transmisibilidad parcial, puede ser extensible al caso de propietarios de terrenos incluidos en el polígono, lo cual podría dar lugar a una situación de copropiedad de la finca resultante según una interpretación conjunta de los arts. 28 y 166.e) RGU.

Esta inscripción se cancelará cuando tenga lugar la inscripción del acuerdo de aprobación definitiva del proyecto de compensación (arts. 54.4 y 174.4 RGU).

Esta constancia registral específica del "Derecho en la compensación" en el caso de terrenos destinados a sistemas generales tiene su razón de ser en la especial protección que se concede a los propietarios de esos terrenos a los que no se les ha aplicado el sistema de expropiación sino el sistema de "ocupación directa", lo que significa que se trata de una situación irreversible, con lo cual, la Administración, adquiere definitivamente la propiedad de los terrenos en cuestión cuando procedió a la ocupación de los mismos (arts. 201 a 204 TR, 52 y 53 RGU y 53 LEF).

El TR al sistema de obtención de terrenos, por parte de la Administración, destinados a sistemas generales denominado de "ocupación directa" (art. 203 TR) 656 , desde el punto de vista registral, le da un

656 Cuando se produce esta forma de actuación habrán de distinguirse en el inmueble ocupado dos elementos objetivos diferentes, por una parte, el suelo objeto de ocupación, despojado de contenido patrimonial, es decir, de aprovechamiento urbanístico apropiable, del que se apodera la Administración actuante, que queda facultado incluso, para su inscripción en concepto de dueña. Por otra, el aprovechamiento urbanístico apropiable que corresponde al titular del terreno ocupado, que se convierte en un elemento objetivo inmobiliario, susceptible de inscripción en folio independiente, en tanto tenga lugar su materialización en una parcela de resultado del expediente de equidistribución del que, en su momento, forme parte como una más de las fincas de origen. 
tratamiento especial al recogido en el RGU. Así en el folio registral de la finca afectada se inscribirá únicamente el derecho de la Administración adquirente del terreno (art. 203.5 TR). Simultáneamente a esta inscripción, se le abrirá al aprovechamiento urbanístico folio registral independiente al que se trasladarán las inscripciones de dominio y demás derechos reales vigentes sobre la finca con anterioridad a la ocupación (art. 203.6 TR).

En el caso de las empresas urbanizadoras, como miembros integrantes de la Junta de Compensación no será posible la constancia registral de su derecho en la compensación por falta de una finca que sirva de referencia.

\section{LA ADJUDICACION DE LAS FINCAS RESULTANTES}

\subsection{INTRODUCCION:}

La aprobación del proyecto de compensación constituye el título por el que se van a adjudicar las nuevas fincas resultantes. Por tanto tiene un doble efecto, por un lado extintivo en el sentido de que con dicha aprobación se extingue el "derecho en la compensación" y por otro creador ya que se materializa en la adjudicación de las fincas resultantes; de ahí que el art. 172.b) RGU establezca como una de las determinaciones que debe contener el proyecto de compensación, la descripción de las fincas resultantes expresando respecto de cada una de ellas la antigua a la que corresponda o el derecho que da lugar a la adjudicación, los titulares a quienes le son adjudicadas, si fueran conocidas y el concepto en que se realiza la adjudicación.

El contenido este precepto "se expresará respecto de cada finca la antigua a la que corresponde" no es del todo cierto ya que en ocasiones puede producirse esa correspondencia (art. 122.1 y 2 RGU en el ámbito de la reparcelación y al que nos remite el art. 174.4 RGU) donde la nueva finca o 
parcela entra en la misma situación jurídica de la antigua 657 "se mantiene la titularidad a través del mecanismo de la "subrogación real" de las nuevas fincas resultantes por las antiguas mientras que en otras ocasiones no se produce esa correspondencia física entre las fincas adjudicadas y las antiguas (art. 122.3 RGU), en estos casos, la aprobación del proyecto de compensación constituye un "título de adjudicación originaria de la propiedad" en favor de los adjudicatarios, que se concreta en la atribución de un derecho de propiedad nuevo sobre una de las fincas del polígono. Por tanto esa correspondencia de la que habla el art. 172.b) RGU "se refiere simplemente a la existencia de una base física sobre la que determinar la proporcionalidad de la adjudicación de la finca resultante, sin que sea necesaria la coincidencia" 658 . Este criterio de proporcionalidad tendrá como punto de referencia los bienes o derechos aportados inicialmente (art. 159.4 TR y 167.1. g) y 171 RGU).

4.2. SUJETOS ADJUDICATARIOS DE LAS FINCAS RESULTANTES:

¿Quiénes pueden ser sujetos adjudicatarios de las fincas resultantes de la gestión urbanística por el sistema de compensación?.

El sujeto adjudicatario es la Junta de Compensación como persona jurídica, la cual habrá de efectuar la adjudicación de acuerdo con las previsiones de los Estatutos, Bases y Proyecto de Compensación. Las adjudicaciones se establecen en el Proyecto de Compensación659.

Por aplicación analógica del art. 85.1 RGU "tienen derecho a la adjudicación en propiedad de las fincas resultantes":

1. Los propietarios particulares integrados en el sistema.

657 Vid. MARTIN BLANCO, ob. cit., p. 388-390.

658 Vid. DEL POZO CARRASCOSA, ob.cit., p. 128.

659 Vid. MARTIN BLANCO, La Compensación, ob.cit., p. 399. 
2. Los propietarios de suelo exterior a la unidad de ejecución que participen en el proyecto de compensación.

3. La Administración, en tanto que es propietaria de bienes incluidos en la unidad de ejecución.

4. Las empresas urbanizadoras que hubiesen hecho aportaciones.

5. La propia Junta de Compensación, cuando se reserve, en su caso, superficies o parcelas para enajenarlas directamente, con el fin de sufragar los gastos de la urbanización.

Sin embargo, en sentido estricto, se podría decir que los únicos propietarios que aportan los bienes sobre los que va a tener lugar la actuación por el sistema de compensación son los propietarios particulares integrados en el sistema y los de suelo exterior a la unidad de ejecución que participen en el proyecto de compensación. Ni las empresas urbanizadoras ni la Junta han aportado superficie alguna a la gestión por compensación pero a pesar de ello se les adjudican fincas al final del proceso porque así lo ha decidido la propia Junta de Compensación: a las empresas urbanizadoras como concreción de su derecho en la compensación, teniendo en cuenta los criterios que se referirán a su actividad, contrapartidas ofrecidas (arts. 158.2 TR (127.2 LS) y 165, 166.f), 167.1.d) y 176.4 RGU); y a la Junta, por e hecho de estar facultada para reservarse parcelas para enajenarlas y de esa forma sufragar los gastos de urbanización.

Situación distinta es la de los tres primeros supuestos. Es en estos casos donde el proyecto de compensación cobra verdadera importancia como título de adjudicación de las nuevas fincas resultantes. La eficacia del proyecto de compensación en este punto se concreta en que no se produce ninguna transmisión de fincas de unos propietarios a otros, sino una adjudicación.

La calificación como "adjudicación" significa que la junta tiene un papel decisorio, en virtud de su poder de disposición, en la atribución de las 
titularidades definitivas por medio del proyecto de compensación, sin que sea necesaria ninguna titularidad intermedia de la propia junta, en este sentido el art. 122.2 RGU utiliza la expresión "sin solución de continuidad" y el art. 122.3 RGU habla de una "adquisición originaria a favor de los adjudicatarios".

Esta forma de concretarse el derecho en la compensación a través de las adjudicaciones de fincas tiene un doble fundamento, así en los casos de propietarios de fincas incluidas en la unidad de ejecución, en la finca aportada, mientras que en el caso de propietarios de terrenos destinados a sistemas generales o en el caso de empresas urbanizadoras aquí la adjudicación, tiene su fundamento o bien en la titularidad de un determinado derecho que nace de la ley y del plan (propietarios de terrenos destinados a sistemas generales) o en la propia voluntad de la junta (en el caso de empresas urbanizadoras), arts. 113.1. b).2 y 172.b) RGU.

\subsection{ADJUDICACION DE LAS FINCAS RESULTANTES A LOS} PROPIETARIOS DE FINCAS INCLUIDAS EN LA UNIDAD DE EJECUCION.

\subsubsection{CRITERIOS DE ADJUDICACION:}

En el proceso de adjudicación de fincas resultantes a los propietarios de las fincas incluidas en la unidad de ejecución, se siguen dos criterios básicos, el de la proporcionalidad (art.171RGU) y el de mayor proximidad (art.95.1 RGU) aunque se admite también que los propietarios, por unanimidad, puedan adoptar criterios distintos, así como solicitar la conservación de la propiedad primitiva, que no sería objeto de nueva adjudicación en el caso de que se produjeran determinadas circunstancias (arts. 87, 89, 90 y $92 \mathrm{RGU}$ ).

Siguiendo el criterio de la proporcionalidad dice el art. 97 del RGU que "toda superficie, que con arreglo al plan, sea susceptible de propiedad 
privada, aunque no sea edificable, deberá ser objeto de adjudicación entre los propietarios afectados, en proporción a sus respectivos derechos en la reparcelación" (aquí habría que entenderlo referido a la compensación). Por tanto, es preciso que exista una justa proporción entre las fincas aportadas y las resultantes que se adjudiquen a cada propietario660.

Este criterio de la proporcionalidad con la superficie aportada tiene un límite y es que en ningún caso podrán adjudicarse como fincas independientes, superficies inferiores a la parcela mínima edificable 661 o que no reúnan la configuración y características adecuadas para su edificación conforme al planeamiento. Es decir, que cada parcela resultante, no sólo debe tener una superficie no inferior a la mínima exigida por el Plan, sino reunir, las demás características que el Plan señale para ser edificable.

Cuando la escasa cuantía de los derechos de algunos propietarios no permita que se les adjudiquen fincas independientes a todos, se les adjudicará un solar pro indiviso (art. 94.1, 96.3 y 167.1 g) RGU). Esta medida se aplicará también cuando "por exigencias de la parcelación" no sea posible adjudicar a un propietario determinado una única parcela resultante, en este caso se le adjudicará una finca en propiedad exclusiva y una cuota en la propiedad de otra de las fincas resultantes. Cuando la cuantía de los derechos de los propietarios no alcanzara el 15 por 100 de la parcela

660 De ahí que como dice la St. de 30 de enero de 1991 (Ar. 612): "La parte actora no ha practicado en primera instancia prueba alguna tendente a acreditar la lesión denunciada, a pesar de venir obligado a ello, art. 1214 C.C., limitándose a aducir la existencia del citado perjuicio, que la Sala de instancia ha admitido sin hacer razonamiento alguno sobre los criterios de valoración y adjudicación en que se fundamenta el proyecto reparcelatorio, así como sin tener en cuenta las especiales características, antes citadas, que concurren en el mismo, y sin más razonamiento que la invocación genérica de los preceptos antes mencionados. En esta situación, en la que no se ha acreditado el pretendido menor valor de la finca adjudicada con respecto a la aportada, debe necesariamente prosperar el recurso de apelación deducido, por cuanto la mera cita del art. 95 del RG es notoriamente insuficiente a los fines pretendidos, dado que el criterio de proximidad en la adjudicación que en el mismo se contiene no sólo sería predicable para el demandante, sino también para el resto de los propietarios afectados por el expediente." Es decir, que el criterio para enjuiciar la impugnación, radique en determinar si se ha roto aquella proporción.

$661 \mathrm{Si}$ tenemos en cuenta que uno de los fines de la compensación, es regularizar la configuración de las fincas, a fin de hacerlas aptas para su edificación, con arreglo al Plan sería absurdo que su resultado fuese crear fincas que no alcanzaran la superficie mínima, NUÑEZ RUIZ, "Régimen jurídico de las parcelas inedificables", RDU, n. 15, pp. 62 a 69. 
mínima edificable, podrá sustituirse la adjudicación por una indemnización en metálico662. Por tanto la sustitución de las parcelas primitivas por otras se lleva a cabo, bien mediante la adjudicación de fincas independientes, cuando no sea posible se llegará a la adjudicación pro indiviso, y sólo en último término se acudirá a la indemnización en metálico.

Teniendo en cuenta que en ocasiones las adjudicaciones no son proporcionales a los derechos aportados, la legislación urbanística prevé la compensación en metálico entre los afectados (art. 172 e) RGU). Se trata de ajustar las adjudicaciones siempre por defecto, procurando, cuando sea posible, que este defecto no rebase el 15 por 100 de los derechos de los adjudicatarios (art. 96.2 RGU). Salvo que viniese impuesto por exigencias de la edificación existente, con arreglo a los artículos 89 y 90 del RGU, no se harán adjudicaciones que excedan del 15 por 100 de los derechos de los adjudicatarios (art. 96.1 RGU).

El segundo de los criterios para adjudicar una finca resultante es el de la proximidad, se procurará "siempre que sea posible", que las fincas adjudicadas estén situadas en un lugar próximo al de las antiguas propiedades de los mismos titulares, art. 95.1 RGU663. El párrafo 2 del art. 95

662Asímismo queda plasmado en los artículos 93 y 96 del RGU. Según el art. 93 del RGU "1. No podrán adjudicarse como fincas independientes superficies inferiores a la parcela mínima edificable o que no reúnan la configuración y características adecuadas para su edificación conforme al planeamiento. 2. La superficie enclavada entre dos edificaciones que deban mantenerse podrá adjudicarse como finca independiente edificable aunque no alcance las dimensiones de la parcela mínima siempre que la diferencia no exceda del 15 por 100 de esta última y se cumplan las demás determinaciones del planeamiento. 3. Si se diera el caso de que el Plan no determine la parcela mínima edificable, ni pueda deducirse de su contexto, el propio Proyecto de reparcelación la establecerá razonadamente. 4. Cuando tratándose de edificación abierta, el Plan no contenga reglas de ubicación de los volúmenes, se tramitará y aprobará conjuntamente con el Proyecto de reparcelación un Estudio de Detalle en el que se determine la ubicación de los volúmenes en concordancia con los criterios de adjudicación."

En la misma dirección se pronuncia el art. 96 RGU: "1. Salvo que viniere impuesto por exigencias de la edificación existente, con arreglo a los arts. 89 y 90 de este Reglamento, no se harán adjudicaciones que excedan del 15 por 100 de los derechos de los adjudicatarios. 2. Por el contrario, se tratará de ajustar las adjudicaciones siempre por defecto, procurando, cuando sea posible, que éste no rebase el 15 por 100 de los expresados derechos. 3. La superficie adjudicable que quedare sobrante, como consecuencia de lo dispuesto en el párrafo anterior, podrá adjudicarse pro indiviso a todos los propietarios con defecto de adjudicación, con el fin de eliminar o reducir la cuantía de las indemnizaciones por diferencias de adjudicación."

663 A este respecto GONZALEZ PEREZ en Comentarios T.I., p. 1002 señala que "si en los supuestos en los que fuera posible la adjudicación en lugar próximo no se hiciera, el proyecto de reparcelación incurriría en infracción del ordenamiento jurídico y sería inválido". 
RGU establece una excepción a esta regla general, y es que este criterio de la proximidad no sería aplicable en el caso de que las antiguas propiedades estén situadas, en más del 50 por 100 de su superficie, en terrenos destinados por el Plan a viales, zonas verdes u otros usos incompatibles con la propiedad privada.

\subsection{EFECTOS DEL ACUERDO APROBATORIO DE} COMPENSACION:

El apartado b) del art. 167 TR (100.1.b) LS) establece que el acuerdo aprobatorio de la reparcelación (compensación) producirá el efecto de la "subrogación, con plena eficacia real, de las antiguas por las nuevas parcelas, siempre que quede establecida la correspondencia"664 . Según este precepto la función del título de adjudicación en que consiste el proyecto de compensación es la de mantener al titular de la propiedad, variando el objeto del derecho sobre la misma, con lo cual se conserva el derecho que se tenia anteriormente pero sobre un objeto diferente, por tanto siendo así, habría que entenderlo como una manifestación del concepto civil de subrogación real dentro del ámbito del sistema de compensación urbanística, sin embargo, al introducir en su redacción el término "correspondencia" (novedad respecto a la Ley del suelo del 76) entre la finca nueva y la antigua, hace que los efectos sean diferentes dependiendo de si se da esa correspondencia o no. Antes de pasar a hacer un análisis de este precepto, seria conveniente estudiar esta institución de derecho civil y su posible aplicación en el sistema de compensación urbanística.

664 En el mismo sentido se expresa el art. 122.1 del RGU. 
4.4.1 LA SUBROGACION REAL COMO INSTITUCION DE DERECHO CIVIL Y SU CONEXION CON EL SISTEMA DE COMPENSACION URBANISTICA.

La actividad urbanística en la ejecución del planeamiento determina cambios o mutaciones en el objeto de las relaciones jurídicas inmobiliarias. La sustitución o subrogación real se manifiesta en múltiples aspectos en el tráfico inmobiliario, jugando en tales casos su noción nuclear del mantenimiento o permanencia de la misma situación jurídica sobre la cosa o elemento patrimonial nuevos que reemplazan o sustituye a los anteriores 665 .

La legislación urbanística adopta la construcción privatista de la subrogación real, definida como "aquella figura en virtud de la cual la situación jurídica que en cierto respecto califica o afecta a una cosa determinada pasa a calificar o afectar en igual sentido a la otra cosa que haya reemplazado o sustituido a aquélla cuando la misma ha sido objeto de una enajenación o pérdida"666 . Por tanto subrogación significa sustituir a una persona o cosa, respecto de una misma situación jurídica determinada. Cuando lo sustituido es una persona, se habla de subrogación personal (activa o pasiva, o sea como titular o acreedor, o como gravado o deudor). Cuando lo sustituido es una cosa, entonces surge la subrogación real u objetiva.

La idea central de la subrogación real es el ocupar la misma situación jurídica, es decir, la subsistencia de una situación jurídica sobre un elemento patrimonial que sustituye o reemplaza otro elemento anterior.

Como notas características de esta institución podemos destacar: el cambio o sustitución de una cosa por otra y la permanencia inalterada de la

665 Vid. MARTIN BLANCO, J., La compensación urbanística...,ob.cit., p. 388.

666 Vid. ROCA SASTRE, R.M., "La subrogación real” en RDP, pp. 281 y ss. En este mismo sentido se pronuncian, entre otros, LACRUZ, en Elementos de Derecho civil, I, Barcelona, 1984, p. 103; MARIN PADILLA, M.L., "Sobre subrogación real", en RCDI, 1977,p. 1111 y en 1978, pp. 717 y 1149 y en 1980 , p. 1399. 
misma situación jurídica, notas que adopta la legislación urbanística, pues las permutas urbanísticas, la sustitución de fincas en la mecánica reparcelatoria o en el sistema de compensación, las indemnizaciones sustitutivas, etc., son supuestos en que se opera el cambio de unas cosas por otras. La relación jurídica de causalidad como fundamento legitimador del cambio se produce, unas veces de forma voluntaria a través del negocio jurídico concertado entre las partes; otras obligatoriamente por imposición legal a través, por ejemplo, de la expropiación forzosa.

En este aspecto, la intervención pública en el tráfico inmobiliario, matiza especialmente la nota obligatoria del cambio o sustitución de las cosas. En la actuación urbanística el principio ex necessitate, del que habla Roca Sastre (o sea cuando dicho cambio tiene lugar por virtud de un suceso o accidente de la naturaleza o hecho de tercero) domina el presupuesto de la subrogación real como consecuencia de la intervención de la Administración Pública que, adoptando la construcción iusprivatista de la institución la utiliza a sus propios fines imponiéndola por regla general, con carácter obligatorio, previa la adecuada conformación de aquélla a los fines administrativos públicos 667 .

La función de la subrogación real depende de la finalidad de cada una de las instituciones jurídicas en las que se inserta y del derecho que mediante ella se pretende conservar, tratando en todo caso de garantizar la perpetuación de las situaciones jurídicas preexistentes. La utilidad esencial de la subrogación real, en todos los supuestos, incluso en el ámbito de la gestión urbanística, radica en el mantenimiento del patrimonio del sujeto afectado, aunque si bien es verdad en la legislación urbanística para lograr esa finalidad no es indispensable el mecanismo de la subrogación real sino que se puede conseguir también por otras vías como es por ejemplo a través de la atribución con carácter originario, de una finca, supuesto que recoge el artículo 122.3 y 4 del RGU.

667 Vid. MARTIN BLANCO, La compensación urbanística...,ob.cit., pp. 388-389. 
Dado que no hay variación en el derecho, la subrogación real permite mantener los derechos o cargas que afectaban al antiguo objeto sobre el nuevo, esta situación también se produce en el ámbito de la legislación urbanística pero dentro de los límites que la propia legislación y el planeamiento le atribuyan así por ejemplo los arts. 168 del TR y 122.2 y 123.1 del RGU, prevén la extinción de esos derechos o cargas que resulten incompatibles con el planeamiento, y el art. 85.2 del RGU prevé la adjudicación a sus antiguos titulares de los derechos reales que subsistan. En todo caso se proclama así el efecto y característica jurídica esencial de la subrogación real: la continuidad de la titularidad o situación jurídica pues a pesar del cambio de las cosas, la nueva finca entra en la misma situación jurídica de la antigua.

El fundamento de esta sustitución de fincas en su vertiente urbanística está en el mandato legal, que tiene como finalidad la mejor ejecución de los planes de urbanismo. Especialmente para hacer realidad el principio de la justa distribución de los beneficios y cargas del planeamiento, entre los propietarios afectados.

En el ámbito de la legislación urbanística, como ya hemos señalado anteriormente, los arts. 167.b) del TR (art. 100.1.b)LS) y 122.1 RGU, admiten la subrogación con plena eficacia real de las antiguas por las nuevas parcelas, siempre que quede claramente establecida la correspondencia entre unas y otras, por el contrario los párrafos 3 y 4 del mismo artículo 122 RGU niegan la existencia de subrogación real cuando no haya una exacta correspondencia entre las fincas adjudicadas y las antiguas, por tanto, la aplicación de la subrogación real, depende de dicha correspondencia, la cual tiene dos manifestaciones distintas en el ámbito de la gestión urbanística. Así, en los artículos 113. b).2 y 172.b) del RGU la correspondencia va referida a la aportación que genera el derecho en la compensación, al establecer que el acuerdo de reparcelación y el proyecto de compensación deberán señalar, respecto de cada finca la antigua a la 
que corresponda o el derecho que da lugar a la adjudicación, en este último caso se refiere a los propietarios de terrenos ocupados por sistemas generales y a las empresas urbanizadoras; mientras que en los arts. 122.1 y 2 RGU se nos habla de correspondencia como continuidad, refiriéndose no ya a la propiedad sino a los derechos reales limitados que recaen sobre ella. Esta nueva vertiente de la correspondencia como continuación asimismo la recoge el art. 85.2 RGU.

Tiene que haber una continuidad o correspondencia física entre las fincas antiguas y las nuevas para poder hablar de subrogación real en el sentido de la LS y del RGU, sin embargo, y como dicen los arts. 122.2 y 71.3 del RGU) ello hará que "no exista una solución de continuidad en las titularidades sobre las fincas". Se trata, a pesar de todo, de derechos diferentes en el sentido de que el derecho anterior se extingue en virtud del proyecto de compensación al tiempo que crea un derecho nuevo. Por tanto, en este supuesto la subrogación opera con un doble efecto adquisitivo de la propiedad y derechos de las parcelas nuevas resultantes (en su mismo estado y condiciones art. 122.2 RGU) y extintivo de los derechos y cargas que resulten incompatibles con el planeamiento.

La existencia del proyecto de compensación es lo que hace posible hablar de una "no solución de continuidad" (art. 71.3 RGU) en el sentido de que el derecho anterior y el nuevo tienen el mismo contenido y recaen sobre el mismo objeto, esto queda puesto de manifiesto tanto en los arts. 185.1 en relación con el 122.1 y 85.2 del RGU) donde se utiliza los términos de “adjudicación” y de "adjudicatario", referidos a la subrogación real en el caso de perfecta "concordancia" de las fincas con el mismo titular, lo que significa que si el derecho se mantuviese, no sería necesario adjudicar, como en el art. 122.2 RGU que utiliza el término "quedarán referidas"668 lo que pone de

668 EI art. 122.2 RGU establece que "cuando opera la subrogación real, las titularidades existentes sobre las antiguas fincas quedarán referidas, sin solución de continuidad, a las correlativas fincas resultantes, adjudicadas en su mismo estado y condiciones, sin perjuicio de la extinción de los derechos y cargas que resulten incompatibles con el planeamiento." 
manifiesto que ha habido un cambio producido por el proyecto de compensación aunque la estructura y contenido del derecho antes y después sean idénticos.

Esta continuidad entre las diferentes titularidades sucesivas sobre el mismo objeto queda plasmada en el art. 92 RGU que señala en su párrafo primero que "no serán objeto de nueva adjudicación, conservándose las propiedades primitivas ${ }^{669}$, sin perjuicio de la regulación de linderos cuando fuese necesaria 670 y de las compensaciones económicas que procedan, las fincas no edificadas cuando concurran los dos siguientes requisitos:.."; y en su párrafo 2 señala que "tanto en este supuesto como en el del art. 90 de este Reglamento, los titulares que conservan sus propiedades primitivas tendrán la consideración de adjudicatarios a todos los efectos derivados de la reparcelación (compensación)”. Como podemos ver tanto el párrafo 2 del art. 92 como el art. 90.1 ambos del RGU permiten incluir a los primitivos propietarios dentro del concepto de "adjudicatario", incluso cuando se les atribuye la misma finca que aportaran.

De todo lo dicho hasta ahora en relación con la "correspondencia" como continuidad entre las fincas antiguas y las nuevas, se llega a la conclusión de que no cabe hablar de subrogación real en sentido técnico puesto que no ha habido variación alguna en el objeto. En este ámbito de la legislación urbanística, un propietario ve confirmado su derecho de propiedad mediante la extinción de su derecho de propiedad originario y la creación de un derecho con idéntico contenido y sobre el mismo objeto. Este sujeto nunca ha dejado de ser propietario de dicha finca, solamente ha cedido transitoriamente su poder de disposición sobre la misma671. En este caso, no se produce un efecto expropiatorio como contenía la normativa

669 No se produce el efecto de la subrogación real a que se refiere el apartado 1.b del art. 167. En estos supuestos los propietarios conservan las fincas primitivas. No se produce mutación dominical alguna, al igual que en las situaciones contenidas en los arts. 89 y 90 del TR.

670 Cuando una parcela no reúna la configuración adecuada para su edificación conforme al planeamiento, es lógico que se proceda a la regulación de linderos (art. 89 y 92 RGU).

671 Vid. DEL POZO CARRASCOSA, ob. cit., p. 139. 
anterior a la reforma de $1975^{672}$. Así, la sentencia de 17 de mayo de 1967 se pronuncia diciendo que el efecto expropiatorio de la reparcelación, respecto de las parcelas anteriores, se verifica mediante simultánea adjudicación de las nuevas. En realidad no existe expropiación, ya que a través de la expropiación como sistema de actuación urbanística (art. 134 y ss. de la LS), la Administración pública expropia la totalidad de los bienes y derechos incluidos en una unidad de ejecución 673 a fin de ejecutar las obras de urbanización. El ente público deviene propietario del territorio sobre el que se actúa, mediante el justiprecio que resulta de aplicar las valoraciones de la LS, realiza la urbanización y deviene propietaria de los solares resultantes que lanza al mercado. Por tanto mediante el acuerdo aprobatorio de reparcelación (compensación en este caso) se produce simplemente, según define el art. 122.1 RGU "una subrogación, con plena eficacia real, de las antiguas por las nuevas parcelas, siempre que quede establecida su correspondencia".

Cuando no haya exacta "correspondencia" entre las fincas adjudicadas y las antiguas (art. 122.3 y 4 del RGU), el acuerdo constituirá un título de adquisición originaria a favor de los adjudicatarios y éstos recibirán la plena propiedad de aquéllas, libre de toda carga que no se derive del propio acuerdo. Esta misma regla se aplicará en los casos de adjudicaciones pro indiviso o con modificación sustancial de las condiciones de la primitiva titularidad.

Estos dos supuestos que contempla el art. 122 RGU niegan la aplicación de la subrogación real, al establecer que es preciso que se de la "correspondencia" entre las fincas adjudicadas y las antiguas, para poder

672 Vid. MARTIN BLANCO, El tráfico de bienes inmuebles..., ob.cit., p. 208 y 209; LUCAS FERNANDEZ, "Naturaleza, fines y principios generales de la legislación urbanística", RDU, no 3, p. 33; CORELLA MONEDERO, La reparcelación su naturaleza jurídica y su práctica, Madrid, 1972, p. 82 a 84; BENAVIDES, "Algunas consideraciones sobre el Registro de la Propiedad y su papel en la política del urbanismo", RCDI, 1980, p. 166 y ss.

673 Vid. DE LOS MOZOS, "Sistemas de actuación urbanística", RDU, oำ11, p. 33 asimismo cfr. el comentario al art. 171 del TR en Comentarios a la LS texto refundido del 92 de GONZALEZ PEREZ, ob.cit,. p. 1324 y ss. 
hablar de subrogación real urbanística, sin embargo, el contenido de estos preceptos es criticable ya que si tenemos en cuenta el concepto civil de subrogación real sería perfectamente aplicable en este caso ya que en el ámbito civil no necesita que exista coincidencia entre la finca originaria y la resultante sino simplemente que haya un nexo de unión entre ambas, nexo que se da en el ámbito del sistema de compensación manifestado en las referencias continuadas que se hacen a las antiguas fincas, a las cuales se refieren las nuevas (arts. 167.1. g) y 172. a) RGU). Por tanto, no era necesario calificar al acuerdo (es decir a la aprobación definitiva del proyecto de compensación) como un título originario de adquisición de la propiedad.

Esta situación que describe el art. 122.3 del RGU sería también de aplicación a aquellos propietarios de suelo exterior a la unidad de ejecución destinado a la realización de sistemas generales y a los cuales no les ha sido aplicada la expropiación forzosa (arts. 71.2 y 85.1 RGU). Las parcelas que aportaron estos propietarios no forman parte de la unidad de ejecución a la que se refiere el proyecto de compensación, pero estos sujetos tienen un derecho a participar en las adjudicaciones, por tanto, en este supuesto, tampoco se da "una exacta correspondencia entre las fincas adjudicadas y las antiguas" (art. 122.3 RGU). Para estos propietarios el proyecto de compensación debería consistir en un título de adquisición originaria, produciéndose así una solución de continuidad en los derechos 674 , en cambio nada de esto establece el art. 71.3 RGU que dice así: "Las parcelas resultantes que se adjudiquen a los propietarios sustituirán a las primitivas, sin solución de continuidad en las respectivas titularidades, a todos los efectos".

La importancia del concepto "adquisición originaria" reside en el hecho de que al individuo que recibe una finca absolutamente diferente de la que aportó a la gestión por compensación (arts. 85.1, 71.2 y 122.3 del RGU),

674 Vid. DEL POZO CARRASCOSA, ob. cit., p. 141. 
la recibe en "plena propiedad" y "libre de toda carga que no se derive del propio acuerdo" (art. 122.3 RGU).

4.4.2 EFECTOS DE LA APROBACION DEFINITIVA DEL PROYECTO DE COMPENSACION RESPECTO DE LAS SITUACIONES JURIDICAS DE CARACTER REAL.

El Reglamento de Gestión Urbanística dedica a esta situación los artículos 123 y 125; y el Texto Refundido regula este aspecto en el art. 168, que es de aplicación plena según la Disposición Final única 2. Se establecen distintos supuestos en atención a las consecuencias de que no tenga lugar la subrogación o de que, aún existiendo subrogación, los derechos reales o cargas fueran incompatibles con el planeamiento o con la situación y características de la finca.

A) Cuando no tenga lugar la subrogación real (art. 168.1 del TR) el acuerdo de aprobación del proyecto de compensación producirá la extinción de los derechos reales y cargas constituidas sobre la finca aportada, y determinará el importe de la indemnización correspondiente al derecho o carga que se extinga, importe que tendrá que satisfacer el propietario que aportó la finca.

En el mismo sentido se pronuncia el art. 123.3 del RGU que recoge el supuesto de extinción de cargas y derechos incompatibles con el planeamiento sobre fincas respecto de las cuales no opera la subrogación real. También procederá la extinción en aquellos casos en que se de la subrogación real, pero cuando esas cargas y derechos sean incompatibles con el planeamiento (art. 168.2 TR).

Por tanto se producirá la extinción de los derechos y cargas cuando no tenga lugar la subrogación, y cuando los derechos o cargas se estimasen incompatibles con el planeamiento. Estos preceptos contemplan la extinción automática "ex lege" de esos derechos y cargas, posición un tanto extrema, 
como mantiene algún sector de la doctrina ${ }^{675}$, sobre todo si tenemos en cuenta que pueden darse casos de derechos reales que no lleven consigo la posesión de la finca, como es el caso de la hipoteca o del derecho de opción o el de retracto, lo cual nos lleva a la conclusión de que se trata de materia cuya regulación puede pactarse libremente por los propietarios integrados en la Junta de Compensación. Si nada han pactado, los derechos de servidumbres prediales y cargas, derechos de arrendamiento y cualesquiera otros que, por ser incompatibles con la ejecución del planeamiento deben extinguirse con el acuerdo de reparcelación (o de aprobación del Proyecto de compensación) serán regulados por lo dispuesto en el art. 98 del RGU676. Las indemnizaciones a los titulares de estos derechos por la extinción se considerarán gastos de urbanización y serán sufragados por los propietarios o por todos los miembros de la Junta en proporción a la superficie de sus terrenos (art. 58 y 60 del RG) 677 .

B) En el caso de producirse la subrogación real se mantienen los derechos que recaían sobre las fincas sujetas a la gestión urbanística por el sistema de compensación, de esta forma el art. 85.2 del RGU establece que: "los titulares de derechos reales que no se extingan con la reparcelación (en este caso compensación) aunque no se les mencione en el proyecto serán

675 Vid. MARTIN BLANCO, ob. cit., p. 397 y DEL POZO CARRASCOSA, ob. cit., p. 145.

676 Con arreglo a dicho artículo 98: 1. Las plantaciones, obras, edificaciones e instalaciones que no puedan conservarse se valorarán con independencia del suelo, y su importe se satisfará a los propietarios o titulares interesados, con cargo al proyecto, en concepto de gastos de urbanización. 2. Se entenderá que no pueden conservarse los elementos mencionados: cuando sea necesaria su eliminación para realizar las obras de urbanización previstas en el plan, cuando estén situados en una superficie que no se deba adjudicar íntegramente a su mismo propietario y cuando su conservación sea radicalmente incompatible con la ordenación, incluso como uso provisional. 3. La tasación de estos elementos se efectuará en el propio proyecto de reparcelación, con arreglo a las normas que rigen la expropiación forzosa. 4. Las indemnizaciones resultantes serán objeto de compensación, en la cuenta de liquidación provisional, con las cantidades de las que resulte deudor el interesado por diferencias de adjudicación o por gastos de urbanización y de proyecto.

677 La alusión a la "superficie de sus respectivos terrenos" que hace el art. 58 del RGU, debe entenderse hecha al valor de las parcelas adjudicadas conforme a lo dispuesto por el art. 166.1 f) del TR o, en caso de innecesariedad de la reparcelación, al aprovechamiento de las fincas, conforme al art. 163.1 TR. 
adjudicatarios en el mismo concepto en que lo fueren anteriormente, por aplicación del principio de subrogación real".

Como podemos ver, este precepto aplica el principio de subrogación real no sólo a la titularidad sobre las fincas sino también a los derechos reales que recaen sobre ella678. Esta situación también la contempla el art. 168.3 del TR en sus primeras líneas, pero ¿que ocurrirá si esos derechos reales o cargas que habrían debido recaer sobre las nuevas fincas fuesen incompatibles con las mismas?. El art. 168.3 establece que en este supuesto, las personas a quienes favorecieran esos derechos o cargas podrán obtener su transformación en un derecho de crédito con garantía hipotecaria sobre la nueva finca, en la cuantía en que la carga fuera valorada. Más que transformación, como apunta este precepto habría que hablar de sustitución de una carga por otra mediante la extinción de la primera por ser contraria al planeamiento (extinción ex lege) y la creación si lo solicitan los interesados, de un derecho de crédito por un valor análogo al de la carga que se extingue y garantizado a su vez, por una nueva carga o gravamen que se crea, la hipoteca.

Se podría decir que estamos ante un supuesto de subrogación real legal, en cuanto es la Ley del Suelo la que la establece, que opera sobre bienes singulares y concretos y en la que su efecto propio de trasladar a la finca nueva la situación jurídica (trasformada en derecho de crédito) existente sobre la finca antigua está condicionada al pago del crédito o justiprecio, representativos del valor de la carga extinguida679 .

La cuantía de este derecho de crédito vendrá fijada por el proyecto de compensación (art. $123 \mathrm{RGU}$ ). La Ley prevé la posibilidad de acuerdo entre las partes como mecanismo de funcionamiento de conservación de los derechos que recaen sobre fincas sujetas a la gestión urbanística. Si las partes estuvieran de acuerdo en la transformación en derecho de crédito y

678 Vid. MARTIN BLANCO, ob. cit., p. 395-396.

679 Vid. Idem. p. 396. 
en la cuantía de la indemnización, otorgarán la correspondiente escritura pública, que presentarán en el Registro de la Propiedad a fin de que se inscriba la hipoteca constituida en garantía del derecho de crédito.

En defecto de acuerdo entre las partes interesadas, cualquiera de ellas podrá acudir al Juzgado competente del orden civil para obtener una solución declarativa de compatibilidad o incompatibilidad de las cargas o gravámenes sobre las fincas nuevas 680 .

Si la sentencia se pronuncia a favor de la compatibilidad de las cargas o gravámenes sobre la finca nueva, la subrogación se produce plenamente y tales cargas o derechos quedarán referidos a las correlativas fincas resultantes adjudicadas. Registralmente se cancelará la nota en que se hizo constar lo contrario en el asiento correspondiente.

Si se pronuncia por la incompatibilidad de la carga con la nueva situación derivada del planeamiento no se opera la subrogación de aquella a la nueva o nuevas fincas respectivas, la sentencia deberá contener necesariamente un justiprecio de la carga considerada incompatible y ésta quedará transformada en derecho de crédito con garantía hipotecaria sobre la finca nueva681. Esta indemnización, correrá a cargo del titular de la finca beneficiada en este sentido el art. 168.2 del TR establece que "en los supuestos de subrogación real, si existiesen derechos reales o cargas que se estimen incompatibles con el planeamiento, el acuerdo aprobatorio de la reparcelación (compensación) declarará su extinción y fijará la indemnización correspondiente a cargo del propietario respectivo".

680 Con arreglo a la Ley del Suelo TR del 92 la compatibilidad o incompatibilidad de las cargas o derechos habrá que plantearla y solucionarla en el proceso civil declarativo ordinario que corresponda por la cuantía. En el texto primitivo de la LS del 56 se establecía que se decidirían por el trámite de los incidentes sin que fuera admisible apelación contra las resoluciones del Juzgado. Lo que fue suprimido por la reforma de 1975.

681 Vid. GONZALEZ PEREZ, Comentarios, ob.cit., p. 1318. 

CUMPLIMIENTO DE LAS CARGAS Y PAGO DE LOS GASTOS.

Ya desde la publicación de la LS de 1956, la obligación impuesta por la Ley a los propietarios incorporados al proceso urbanizador de colaborar con la Administración en la realización del equipamiento urbano que da lugar a la transformación del suelo en solares edificables, unida al deber de ceder gratuitamente a la Administración actuante las superficies que han de integrar dicho equipamiento, constituye la carga básica que la norma establece como pasivo del contenido económico de la propiedad urbana. Se trata de una obligación, o deber de hacer o de dar, cuya titularidad pasiva se identifica con la que corresponde al dominio y demás derechos reales sobre el inmueble, es decir, de las definidas civilmente como obligaciones propter rem.

Como consecuencia de lo establecido anteriormente, el artículo 22 del TR señala que: "la enajenación de fincas no modificará la situación de su titular en orden a las limitaciones y deberes instituidos por la legislación urbanística aplicable o impuestos, en virtud de la misma, por los actos de ejecución de sus preceptos. El adquirente quedará subrogado en el lugar y puesto del anterior propietario en los derechos y deberes vinculados al proceso de urbanización y edificación, así como en los compromisos que, como consecuencia de dicho proceso, hubiere contraído con la Administración urbanística competente”. Esta obligación, desde el punto de vista civil alcanza, no sólo al propietario de la finca de origen, sino a todos los titulares de derechos reales menores (derechos de servidumbres, arrendamientos etc.) o de facultades concretas sobre la cosa682 .

La vinculación de las fincas de resultado al pago de los gastos citados, inherentes al sistema de actuación correspondiente, aparece por primera vez en la legislación del suelo de 1976 y hoy lo recoge el artículo 682 Vid. ARNAIZ EGUREN, El registro de la propiedad..., ob.cit., p. 295-296. 
167.1.c) del TR 683 . Este precepto lo desarrolla el art. 178 del RGU, viene a decir que: "las fincas resultantes del acuerdo definitivo de compensación quedarán gravadas, con carácter real, al pago de la cantidad que corresponda a cada finca en el presupuesto previsto de los costes de urbanización del polígono o unidad de actuación a que se refiera, y en su día, al saldo definitivo de la cuenta de dichos costes". Esos costes de urbanización que deben ser sufragados por los propietarios afectados son los comprendidos en el art. 155 del TR (122.1 LS).

Es, por tanto, la propia parcela resultante, individualmente considerada, desde que se produce el acuerdo definitivo de compensación, la que con carácter real responde, de forma proporcional, de los gastos y de las cargas a que queda afecta. Es decir, es el propio acuerdo definitivo de compensación el que como efecto inherente al mismo, va a garantizar la efectividad de los gastos y las cargas de que cada parcela haya de responder ante la propia Junta.

La primera especialidad que ha de resaltarse, del efecto inherente antes mencionado, es que a diferencia de cualquier otro derecho real de garantía, que siempre es autónomo y dirigido a ese fin garantizador, y que precisa de una forma especial y fehaciente de constitución para que surta los efectos garantizadores del crédito que le son propios; en el caso que nos ocupa, es el mero acuerdo de compensación, nunca dirigido a ese fin garantizador 684 , aunque automáticamente se produzca ese efecto, el que por sí es bastante para determinar el carácter real de la garantía con que queda afecta cada parcela frente a los gastos y cargas que le correspondan.

Otra especialidad es la preferencia de citada garantía frente a cualquier otra y a todas las hipotecas y cargas anteriores, excepto a los

683 Vid. GONZALEZ SALINAS, J., Sistema de compensación..., ob.cit., p. 50. Esta misma idea queda reflejada en su obra, Régimen jurídico de la propiedad del suelo, en Tratado de derecho municipal, Madrid, 1988, II, p. 1839 y ss.

$684 \mathrm{Ha}$ de tenerse en cuenta, que el acuerdo de compensación tiene como finalidad principal la aprobación del proyecto, y que el carácter real que adquiere cada parcela es uno mas de los efectos que produce citada aprobación 
créditos a favor del Estado a que se refiere el número 1 del art. 1923 del Código Civil, y a los demás créditos tributarios en favor del Estado que estén vencidos y no satisfechos y se hayan hecho constar en el Registro, antes de adquirir el carácter real a que queda afecta cada parcela resultante (art. 126.2 del RGU).

Uno de los problemas que se plantea, desde un punto de vista técnico-juridico, es el relativo a que su encuadre en una figura jurídica de las que el Ordenamiento contempla no es posible, precisamente por las especialidades que presenta la figura que se estudia. Sin embargo, un importante sector de la doctrina 685 , parte de que la afección supone una hipoteca legal tácita de segundo grado con virtualidad para alterar el rango hipotecario, o de que ha de entenderse como un gravamen que afecta al conjunto de titularidades existentes sobre la finca686 .

Llama la atención sobremanera, si tenemos en cuenta la naturaleza jurídica de cualquier derecho real de garantía, con el que intentemos equipararle, el hecho de que tratándose de un efecto más de los que se derivan de la aprobación definitiva del sistema de actuación correspondiente, cumpla, mediante una afectación real, incluso con carácter preferente o privilegiado frente a otros créditos, la misma finalidad de garantía que la Ley atribuye a otros derechos reales (hipoteca, préstamo con garantía inmueble, etc.). Ha de reconocerse que esta equiparación de un efecto a un derecho real de garantía, no deja de ser muy singular.

685 Vid. GONZALEZ BERENGUER, J.L., Gestión , financiación y control del urbanismo, Madrid, 1979, p. 596 LOPEZ PELLICER, J.A. "Costes y cuotas de urbanización y de conservación" RDU, no 67, marzo-abril, 1980, p. 93.

686 Vid. GARCIA GARCIA. La reparcelación y la compensación...,cit., p. 94,quien no desarrolla su opinión, de forma que en la fase de ejecución lleva a cabo un tratamiento de la afección similar al que le correspondería en el caso de considerarla como un derecho real de garantía típico. 


\subsubsection{DIFERENCIAS Y AFINIDADES DE LA GARANTIA REAL}

CON OTRAS FIGURAS JURIDICAS.

\subsubsection{CON LA HIPOTECA ORDINARIA}

Si comparamos esta figura con la que en teoría le resulta más afín, esto es, con la hipoteca común u ordinaria, regulada en el art. 1.874 y siguientes del Código Civil687, encontramos no pocas diferencias. Una de ellas, que además, diferencia a la hipoteca de la mayoría de los demás derechos reales inscribibles, es el efecto constitutivo que tiene por el hecho de su inscripción en el Registro de la Propiedad; hasta el punto de ser indispensable, para que la hipoteca quede válidamente constituida, que el documento en que se constituya sea inscrito en el Registro de la Propiedad, conforme establece el art. 1.875 del Código Civil688. Sin embargo la inscripción no se precisa en la afección real, por cuanto su finalidad de quedar afecta la finca al pago de los gastos y las cargas se consigue por el mero hecho de la aprobación definitiva del proyecto; aunque lo cierto es, que éste también ha de ser debidamente inscrito, gozando por ello de los efectos del principio de publicidad registral. Se inscribe, el Proyecto con sus fincas, y éstas con sus cargas, pero esta inscripción no tiene efecto constitutivo en cuanto al nacimiento de la carga o afección real, ya que ésta, como se ha dicho, nace o se adquiere por el hecho de la mera aprobación definitiva del proyecto.

687 Con el fin exclusivo de ofrecer una noción descriptiva de la hipoteca inmobiliaria, vid. entre otros : MOXO en "Concepto unitario de la hipoteca" RDP, 1940, p. 58; COSSIO, Lecciones de Derecho Hipotecario, Barcelona, 1945; SANCHEZ ROMAN, Estudios de Derecho Civil, T. III , Madrid,1900; PLANIOL, Traite élémentaire de Droit civil, II, Paris, 1928 p. 861; VALLET DE GOYTISOLO, Estudio sobre Derechos de cosas y Estudios sobre garantías reales, Madrid, 1973;CHICO ORTIZ, J.M, Complemento del Derecho Hipotecario y su legislación, Madrid, 1974; Estudios sobre Derecho Hipotecario, T. I y II, 2o ed., Madrid, 1989; ROCA SASTRE, Derecho Hipotecario, $7^{\circ}$ ed. Barcelona , 1979 ;GARCIA URBANO, J.M "Crisis estructural del derecho real de hipoteca" en el libro, Homenaje a José María CHICO ORTIZ Colegio de Registradores de la propiedad y Mercantiles de España, Madrid, 1995, p. 787 y ss; BALLARIN HERNANDEZ,R. La Hipoteca ( Génesis de su estructura y función ), Madrid, 1980; CAMY SANCHEZ- CAÑETE, B., Comentarios a la legislación hipotecaria, vol I, 3e ed. Pamplona, 1982, p. 181 y ss.

688 Así se pone de manifiesto en las siguientes sentencias del Tribunal Supremo: St. de 14 de julio de 1933 (Ar. 1792) ; St. 21 de enero de 1943 (Ar. 17);St. 11 octubre de 1985 (Ar. 4738); St. 31 de octubre de 1986 (Ar. 6022) entre otras. 
Otra diferencia, no menos importante que aquélla, es la referida a la extensión, hasta la realización del bien trabado si fuera preciso, para cumplir la finalidad garantizadora que le es propia, toda vez que la hipoteca común sujeta directamente los bienes sobre los que recae al cumplimiento de aquélla (art. 1876 del C.c), aunque la finca se modifique o reforme en términos no exceptuados, cualquiera que sea su poseedor, quien por obligaciones personales no puede librarla de la responsabilidad a que está afecta por el derecho real, que permanece subsistente con el inmueble gravado, sin consideración a la persona que la disfruta 689 .

También se diferencian ambas figuras en los distintos sistemas de realización del bien inmueble afectado, mientras que en el supuesto de la hipoteca el bien inmueble se realiza bien mediante un procedimiento ejecutivo judicial sumario regulado en el párrafo $1^{\circ}$ del art. 129 de la LH en relación con el art. 131 de la $\mathrm{LH}$ y 225 a 233 del $\mathrm{RH}$, o bien a través del procedimiento ejecutivo extrajudicial regulado en el párrafo $2^{\circ}$ del artículo 129 de la LH en relación con los artículos 234 a 236 del $\mathrm{RH}$ ( para que tenga lugar este procedimiento es preciso que las partes se sometan a él expresamente), en el caso de la finca afecta al pago de los gastos y cargas urbanísticas, es la Junta de Compensación o el órgano de que se trate en cada sistema de actuación, la que, mediante la expropiación, puede hacer efectivos dichos gastos y cargas.

\subsubsection{CON LA HIPOTECA LEGAL TACITA.}

Como ya hemos señalado anteriormente, un sector de la doctrina mantiene que, esa afección real supone una hipoteca legal tácita con virtualidad para alterar el rango hipotecario.

En la hipoteca legal tácita690, la finca opera como garantía real de la parte proporcional que a su titular le corresponde en el pago de las

689 Vid. la S.T.S. de 28 de junio de 1.928; CJ., T. 184, núm. 73.

$690 \mathrm{El}$ artículo 158 de la L.H en su párrafo primero establece que "Sólo serán hipotecas legales las admitidas expresamente por las leyes con tal carácter". A su vez las hipotecas legales 
deudas generales por la actuación urbanística. Estas deudas se cuantifican cuando haya concluido la urbanización del polígono y, en todo caso, antes de que transcurran cinco años desde la aprobación del proyecto de compensación (art. 128.1 RGU). Se trata de deudas líquidas y exigibles entre cada uno de los adjudicatarios de fincas resultantes y la junta de compensación (arts. 127.4 y 178.2 RGU).

Tampoco parece correcto que la afección o carga real que analizamos se encuadre dentro de la hipoteca legal tácita por la finalidad que cumple esta figura en el tráfico jurídico691, y porque los efectos de ésta se contraen a la "anualidad corriente y la última vencida al efectuarse la transmisión del dominio de la finca"; habiéndose concretado en el mismo sentido que el significado de "anualidad de contribución" a que se refiere la hipoteca legal tácita a favor del Estado, las provincias y los pueblos ${ }^{692}$, desechando la tesis de que "anualidad corriente" haya de ser a efectos de operancia de tal privilegio la que corresponda al año natural en que se ejercite la acción administrativa de cobro, cualesquiera que sean las transcurridas desde que el tercero, protegido por los principios hipotecarios de prioridad y fe pública registral (arts. 17 y 34 de la LH), inscriba su derecho en el Registro de la Propiedad.

En definitiva, la hipoteca legal tácita, al igual que la carga real que estudiamos, representa una afección de los bienes inmuebles sobre los que recae, pero esta afección, en la hipoteca legal tácita, lo es en perjuicio de tercero, protegido por el principio de fe pública registral, y se produce en el momento en que éste inscribe su título, que es cuando entra en colisión el derecho que ha tenido acceso al Registro de la Propiedad con el privilegiado establecido a favor del Estado693, mientras que la carga o afección real surte

pueden subclasificarse en hipotecas expresas y tácitas según necesiten o no un acto especial de constitución.

691 Dotar de privilegio a los créditos del Estado frente a otros, o instrumento a través del cual se logra la preferencia o el privilegio de los créditos estatales frente a los de otros acreedores.

692 S.T.S. de 21 de diciembre de 1.979, RJ. 1979, 4448.

693 Así, S.T.S. de 23 de diciembre de 1.983; RJ. 1.983, 6998. 
efectos, con ese carácter real, desde que es aprobado el proyecto definitivamente, produciéndose por este mero hecho el efecto de crédito preferente (los gastos y las cargas de que cada finca responde de forma proporcional) frente a cualquier otra y a todas las hipotecas, excepto los créditos del Estado y tributarios referidos.

\subsubsection{CON EL CREDITO REFACCIONARIO:}

En ocasiones se ha considerado a esta garantía real como un crédito refaccionario 694 (el no anotado ni inscrito en el Registro), frente a lo que discrepamos porque un crédito refaccionario rompe el principio de "par conditio creditorum", porque su propia y especial naturaleza justifica el privilegio o la preferencia en la terminología del Código Civil. El crédito refaccionario exige que su origen sea un préstamo u otro contrato para obras de reparación, construcción o fabricación de la cosa, que esté en poder del deudor y que su importe se deba a persona distinta de él, que por su contribución al nacimiento o conservación de la cosa es lógico que cobre antes que otros acreedores, puesto que a él le deben la existencia de la garantía real695.

El crédito refaccionario deriva, por tanto, de un contrato de préstamo696, por el que se entrega a otro el dinero o materiales necesarios para la construcción, conservación o reparación de una finca, entregas que se van efectuando a medida que la construcción se va realizando, así pues, el elemento personal está integrado por el que presta y por el que recibe lo

694 Vid. CHICO ORTIZ, en Estudios sobre Derecho Hipotecario, T. II, ob.cit. p. 1317 y ss., quien define el crédito hipotecario como "aquel que hace surgir un crédito derivado de un contrato por cuya virtud una persona entrega a otra una determinada cantidad de dinero 0 materiales para que ésta lo invierta en la construcción, conservación o reparación de una cosa determinada".

695 Vid. S.T.S. de 21 de mayo de 1.987, RJ. 1.987, 3552; S.T.S. de 5 de julio de 1.990, RJ. 1.990, 5778.

696 Aunque no necesariamente en el sentido técnico-juridico que ha de darse a este contrato, sino también de aquellos otros que hayan contribuido por modo directo al resultado de una construcción, reparación, conservación o mejora del inmueble, según la S.T.S. de 21 de mayo de 1.987, RJ. 1.987, 3552. 
prestado. El acreedor refaccionario puede exigir que sobre la finca refaccionada se vayan anotando las cantidades que, de una vez, o sucesivamente, anticipare, siendo necesaria la presentación del contrato por escrito que, en cualquier forma, haya celebrado con el deudor (art. 59 de la LH) 697 .

Una vez definido el crédito refaccionario, que en definitiva no es más que una modalidad de contrato bilateral, sinalagmático, de garantía; vemos, sin hacer mayor esfuerzo, que esta figura contractual se aleja totalmente de la carga o afección real, coincidiendo únicamente en ambos casos el hecho de la no anotación en el Registro de la Propiedad para su efectividad en la finalidad garantizadora que ambos instrumentos cumplen; aunque justo es reconocérselo al crédito refaccionario no anotado ni inscrito que también goza de preferencia sobre los inmuebles a que la refacción se refiera, es decir, que la finca también queda afecta al crédito refaccionario (número 5 del art. 1.923 del Código civil); consideración que ciertamente no supone la creación de un gravamen real eficaz "erga omnes" (como ocurre en la garantía que se estudia salvo las excepciones que establece el art. 126 RGU), justo por no haberse verificado la inscripción registral ni haber siquiera procedido a su anotación, pero que lleva consigo la preferencia que, frente a otros posibles créditos existentes contra el mismo deudor, le conceden los arts. 1.922 y 1.923 del Código Civil698.

\subsubsection{LA PREFERENCIA DE LA GARANTIA Y LA ALTERACION}

\section{DEL RANGO HIPOTECARIO}

Otros dos aspectos que han de tratarse, siquiera de forma muy somera, son los relativos a la preferencia, y en consecuencia la alteración del rango hipotecario que supone.

697 S.T.S. de 10 de marzo de 1.973; RJ. 1.973, 906.

698 SS.T.S. de 11 de octubre de 1.894, 30 de diciembre de 1.896 y 21 de abril de 1.950; 'RJ. 1.950, 584; 26 de marzo de 1.976; RJ. 1.976, 1470; 21 de mayo de 1.987, RJ. 3552. 
Respecto a la preferencia de esta garantía, el art. 178.2 RGU se remite al art. $126 \mathrm{RGU}$, incardinado en la reparcelación, cuyo párrafo $2^{\circ}$ establece que: "esta afección será preferente a cualquier otra y a todas las hipotecas y cargas anteriores, excepto a los créditos en favor del Estado a que se refiere el número 1 del art. 1.923 del Código Civil y a los demás créditos tributarios en favor del Estado que estén vencidos y no satisfechos y se hayan hecho constar en el Registro antes de practicarse la efeccción a que el presente artículo se refiere".

Como vemos, se excepcionan, por un lado los créditos en favor del Estado a que se refiere el número 1 del art. 1.923 del Código Civil699, y por otro los demás créditos tributarios, por cuanto la Hacienda Pública ostenta prerrogativas legalmente establecidas, que son, entre otras, las contenidas en el art. 71 de la LGT, según la cual goza de prelación para el cobro de los créditos tributarios vencidos y no satisfechos en cuanto concurran con acreedores que no lo sean de dominio, prenda, hipoteca o cualquier otro derecho real debidamente inscrito con anterioridad a la fecha que se haga constar en el mismo derecho de la Hacienda Pública 700.

Sin embargo, la legalidad de este precepto ha sido puesto en tela de juicio en una doble vertiente: sosteniéndose que a través del mismo se introduce una hipoteca legal tácita 701 , y que supone una alteración del rango hipotecario.

La idea de que supone una hipoteca legal tácita trata de combatirse desde el hecho de la publicidad registral de que goza la aprobación del proyecto de compensación, o cualquier otra forma de

699 Este precepto, viene a decir que: "Los créditos a favor del Estado, sobre bienes de los contribuyentes, por el importe de la última anualidad, vencida y no pagada, de los impuestos que graviten sobre ellos".

700 Precepto que concuerda con el art. 16 de la Ley de Organismos Autónomos, conforme al cual tienen éstos prelación en concurrencia con otros acreedores excepto el Estado y los que sean de dominio, prenda, hipoteca o cualquier otro derecho real inscrito en el Registro Público para el cobro de las cuotas que le correspondan como consecuencia de la aplicación de sus recursos, esto es, de las tasas y exacciones establecidas.

701 Vid. GONZALEZ BERENGUER, Gestión...,ob.cit.,p. 396. 
actuación urbanística que también está sujeta a inscripción, al ser uno de sus efectos legales el de atribuir preferencia a los créditos generados por la actuación urbanística sobre bienes afectados por dicha actuación. Idea que a nuestro entender ha de rechazarse, por cuanto como se ha dicho antes, la afección de carácter real se produce por el mero hecho de la aprobación definitiva del proyecto, antes de que se inscriba y con independencia de que se inscriba o no. Otra cosa es que, a posteriori, el proyecto haya de inscribirse y que entonces la garantía real goce además de los efectos de la inscripción, por cuanto es lo cierto que cada parcela ha de inscribirse en folio independiente con número propio, donde han de hacerse constar los gastos y las cargas a que está afecta.

En cuanto a la alteración del rango hipotecario, ha de convenirse que, efectivamente, el art. 126 RGU altera el sistema de créditos privilegiados del Código Civil. Se produce un conflicto entre una norma reglamentaria del art. 126, y el carácter de norma jerárquicamente superior del Código Civil que el RGU no puede contradecir, por impedirlo el art. 1.2 del Código Civil, relativo al sistema de fuentes y al principio de jerarquía normativa702.

Este conflicto, que antes trataba de explicarse acudiendo a una interpretación forzada del art. 129.1 LS, en el sentido de que este precepto deslegaliza la materia al remitirse a su posterior desarrollo reglamentario, hoy ya no es posible conforme el tenor del art. 159.1 TR, que aunque recoge el contenido básico del art. 129.1 LS, sin embargo en la remisión que se hace al art. $310 \mathrm{TR}$, en modo alguno se trata ya de cuestión alguna relacionada con la preferencia de créditos.

702 Los principios de primacía de la Ley y de jerarquía normativa, implícitos en nuestro ordenamiento, fueron acogidos expresamente por la Ley de Régimen Jurídico de la Administración del Estado y hoy están proclamados en el art. 1.2 del Código civil, según el cual "carecerán de validez las disposiciones que contradigan otra de rango superior", e incluso la Constitución, que garantiza el principio de legalidad y la jerarquía normativa (cfr. art. 9.3) -RDGR de 26 de noviembre de 1.981, RJ. 1.981, 4744; de otro lado, el T.C. -SSTC. 27/1.981, RTC 1.981, 27; 99/1.987, RTC 1.987, 99; y 227/1.988, RTC. 1.988, 227, la seguridad jurídica es "suma certeza y legalidad, jerarquía y publicidad normativa, ...". 
Algunos autores, no obstante, mantienen la aplicabilidad del art. 126.2 RGU, pero ello ha de descartarse con arreglo a la legalidad estatal vigente 703 , aunque pueda mantenerse en algunas Comunidades Autónomas 704 .

\section{5.- AMBITOS DE RESPONSABILIDAD.}

La afección de las fincas resultantes, como garantía real de los gastos y cargas, generadas por la actuación urbanística en la Junta de compensación, nos introduce en los distintos ámbitos de responsabilidad, tanto de la junta como de sus miembros 705 .

A tal fin, la Junta tiene un patrimonio de responsabilidad integrado por los bienes aportados en propiedad y por los bienes "reservados" para hacer frente a los gastos de urbanización (arts. 172 d) y 177 RGU), con lo cual, como persona jurídica encargada de la gestión y urbanización, asume frente a terceros la responsabilidad del pago de las deudas generadas por la actuación urbanística como pone de manifiesto el art. 176.1 RGU al establecer que "las obras de urbanización que se ejecuten en el polígono o unidad de actuación por el sistema de compensación serán a cargo de la Junta".

703GONZALEZ SALINAS, Sistema..,ob.cit.p.228, señala, haciéndose eco de la argumentación de GARCIA GARCIA, La Reparcelación (2a. parte), p. 310: "Las dudas que ha planteado la legalidad de este precepto reglamentario podrían disiparse constatando que el art. 100 c) lo que establece es la "afección real de las parcelas". Puede entenderse este precepto no en el sentido de quedar afectada sólo la propiedad, sino la totalidad de los derechos y titularidades existentes sobre las fincas de procedencia y que se subroguen en las nuevas parcelas. Se da a entender que la afección, al recaer sobre la parcela, grava también otros derechos, además de la plena propiedad, porque (saliendo ya de la interpretación literal) tales derechos, en tanto se subroguen en las nuevas parcelas, también serán receptores de la plusvalía que fundamenta la carga del costeamiento de la urbanización que dicha afección garantiza. Y la única forma técnica de conseguirlo es precísamente anteponer dicha afección a esos otros derechos en su preferencia sobre el inmueble, es decir, alterar el rango hipotecario".

704 El art. 126.2 RGU puede ser aplicable en la Comunidad Autónoma de Cataluña, siempre que se interprete el art. 180.1 TRMU si forzamos la interpretación del art. 129.1 LS, en el sentido que se ha expuesto en el texto, deslegalización de la materia al remitirse a su posterior desarrollo reglamentario.

705 vid. GONZALEZ DEL POZO, El sistema de compensación...,ob.cit.,p. 154. 
Qué ocurriría, en el supuesto de que la Junta contrajera deudas frente a aquellas personas con las que ha contratado la realización de la urbanización de la unidad de ejecución. En este caso se suscita el problema de hasta qué punto cabe la traba de embargo sobre los bienes de los miembros integrantes de la Junta en la hipótesis de que se hubiese reservado el dominio de las fincas sobre las que opera el expediente. Para delimitar este supuesto, hay que partir de la base de que la Junta al no participar de las características de las sociedades mercantiles, sus miembros no actúan en régimen de limitación de responsabilidad por los actos de la entidad social, sino que responden con todo su patrimonio, conforme a lo dispuesto en el artículo 1911 del C.c. Por tanto, podría pensarse en la posibilidad de que el acreedor solicite la traba de embargo de dichas fincas en el supuesto de que la Junta incumpla las obligaciones de pago que asume. Esta cuestión fue objeto de un recurso gubernativo resuelto por la Dirección General de los Registros de 12 de 1984, en confirmación del criterio del registrador, que negó la práctica de anotación preventiva por aparecer las fincas inscritas a favor de persona distinta del embargado, que en aquel caso era la Junta, justificando su fallo en que no se había tomado la nota marginal que reflejaba la iniciación del expediente, de tal forma que del contenido de la Resolución parece desprenderse que, en el caso de haberse practicado dicha nota, no habría existido el defecto insubsanable dimanante de lo dispuesto en el artículo 20 de la Ley Hipotecaria706 .

Un importante sector de la doctrina 707 , trata de resolver esta cuestión en otro sentido. Entienden que de lo que no cabe ninguna duda es

706 El art.20 de la L.H dispone que " para inscribir o anotar títulos por los que se declaren, transmitan, graven, modifiquen o extingan el dominio y demás derechos reales sobre inmuebles, deberá constar previamente inscrito o anotado el derecho de la persona que otorgue o en cuyo nombre sean otorgados los actos referidos. En el caso de resultar inscrito aquel derecho a favor de persona distinta de la que otorgue la transmisión o gravamen, los Registradores denegarán la inscripción solicitada".

707 Vid. ARNAIZ EGUREN, en Registro de la propiedad..., ob.cit., p. 377-378; GARCIA GARCIA, Reparcelación y compensación ..., ob. cit. p.530. 
de que esta cuestión sólo tiene cabida en el ámbito del sistema de compensación, puesto que en la reparcelación la obligación del propietario se reduce al pago de los gastos de urbanización a favor de la Administración, de tal forma que ésta puede siempre proceder a su cobro directo al deudor por vía de apremio administrativo y sin que exista la titularidad pasiva interpuesta de otra persona jurídica. Por otra parte entiende este sector de la doctrina que difícilmente puede pensarse que la facultad fiduciaria de disposición de la Junta se considere como una titularidad que permita la traba directa por un tercero de bienes sujetos a esa posibilidad de actuación. En todo caso, lo único embargable sería esa titularidad en sentido estricto, nunca el dominio pleno de las fincas.

Lo cierto es que, los propietarios, por razón de su responsabilidad ilimitada en relación a las obligaciones dimanantes del proceso, están sujetos a su cumplimiento, en igual grado que la propia Junta. Por tanto, es posible el embargo de sus bienes. No obstante, la acción habrá de dirigirse contra todos ellos, sin que baste la tramitación del procedimiento ejecutivo exclusivamente contra la Junta, puesto que el hecho de que existan diferentes deudores en una misma obligación no permite la traba de embargo de los bienes de alguno de ellos, como consecuencia de una acción procesal dirigida contra otro. Otro de los argumentos alegados, en defensa de esta cuestión es que el principio de tracto sucesivo no puede alterarse en función de la mera existencia de la nota marginal de iniciación del expediente, ni aun con los efectos que a la misma señala el artículo 310.4 del TR. Por último parece evidente que la acción del acreedor, en orden al pago de la obligación contraida por la Junta, deberá dirigirse contra ésta y contra todos los propietarios, sin perjuicio de que la traba de embargo se ordene solamente sobre parte de los bienes.

Teniendo en cuenta lo señalado anteriormente, no cabe duda de que la calificación del Registrador en relación a los actos dispositivos de la Junta tendrá el carácter ordinario previsto en el artículo 18 de la Ley 
Hipotecaria, lo cual supone que deberá contrastar la validez del propio acto dispositivo en función de los criterios señalados. No se trata de actos administrativos, sino de negocios civiles generados en ejercicio de una actividad urbanística, respecto de los cuales no existe limitación alguna en el juicio de legalidad registral.

Otro sector de la doctrina 708 siguiendo un planteamiento opuesto al que acabamos de ver, entiende que la responsabilidad en la obligación o carga urbanística de compensación se agota exclusivamente en la realización del bien concreto aportado, con exclusión de los demás bienes o patrimonios del deudor. Asimismo defienden que los miembros de la Junta responderán frente a terceros de las deudas que ellos contraigan, así como de las deudas que contraigan con la junta; responsabilidad que en este caso de los miembros o socios queda limitada, únicamente, de forma individual, a los bienes y derechos que aportaron, lo que supone una exclusión o una excepción a la regla general de responsabilidad que se establece en el art. 1.911 del Código Civil, que consagra la responsabilidad universal patrimonial ("del cumplimiento de las obligaciones responde el deudor con sus bienes, presentes y futuros"), produciéndose, pues, una limitación de la responsabilidad de los miembros de la Junta por las cargas urbanísticas derivadas de la gestión por compensación. Esa responsabilidad limitada se justifica en virtud del principio de la distribución equitativa de los beneficios y cargas derivados del planeamiento. 


\section{BIBLIOGRAFIA.}

AA. VV. La reforma del Suelo de 1990, Valencia, 1991.

ABELLA ,J., Código Civil Español, Madrid, 1904 (5ee.).

AlbalAdejo GARCIA, M., Derecho Civil, T. III. Derecho de bienes, vol. I. Parte general y Derecho de la propiedad, 3a . ed. Barcelona, 1994.

Instituciones de Derecho Civil T. III, vol. 1ํㅡㄹ Derecho de Cosas, Barcelona, 1961.

- "Concepto, estructura y clases de posesión," RDP, 1962.

Curso de Derecho civil. De bienes. T. III, vol. 1ํ, Barcelona, 1982.

ALONSO PEREZ, M., "Las relaciones de vecindad" en ADC (Abril-junio) 1983.

- "La tutela del derecho civil frente a inmisiones molestas y nocivas" Estudios jurídicos en homenaje al profesor Aurelio Menendez, T II, Madrid, 1996.

- "La lucha contra las inmisiones molestas y nocivas:Especial consideración de los medios jurídicos-civiles (en defensa de los consumidores de medio ambiente, de salud y de bienestar), Recopilación de Ponencias y comunicaciones, Consejo General del Poder Judicial, Vol.II, Madrid, 1993.

- "Comentario a los artículos 571 a 579 del Código Civil" (De la servidumbre de medianería), en Estudios del Centenario del Código Civil, T.I . Ministerio de Justicia. Centro de Publicaciones. Madrid, 1993.

- "La propiedad en el Código Civil", en Historia de la Propiedad en España (S. XVXX), Centro de Estudios Registrales, Madrid, 1999, p.471 a 508.

ALPA, G., y BESSONE, M., Poteri dei privati e statuto della propietà, I Oggetti, situazioni soggetive, conformazione dei diritti; II Storia, funzione sociale, publici interventi, Padova, 1980. 
ALVAREZ CAPEROCHIPI, J.A., Curso de Derechos Reales. Propiedad y Posesión. Madrid, 1986.

- "Algunas consideraciones sobre la propiedad urbana como derecho a un aprovechamiento medio", RDP, 1981.

ALVAREZ GENDIN, S., "La teoría del interés mayor como causa limitativa de la propiedad privada" en RGLJ, 1929, Tomo 154.

ALZAGA, O., Comentario sistemático a la Constitución española de 1978, Madrid, 1978.

ARANGO RUIZ, V., Instituzioni di diritto romano, Padova, 1947, vol. I.

ARCHI. G., "Il concetto della propietà nei diritti del mondo antico". Rta. trimestrale di Diritto e Procedura Civile, 1959.

ARIAS BONET, "Dominio y utilidad pública en Derecho Romano". Est. homenaje a Don Nicolás Pérez Serrano. Edit. Reus, 1959.

ARIAS RAMOS, J.A., Derecho Romano, Madrid, 1974.

ARIÑO, G. y OTROS, El nuevo servicio público, Madrid, 1997.

ARNAIZ EGUREN, R., "Algunas consideraciones en torno al derecho de propiedad inmobiliaria", RCDI, 1984.

Registro de la propiedad y Urbanísmo, Madrid, 1995

ARTOLA, M., Antiguo Régimen y Revolución Liberal, Barcelona, 1978.

La burguesía revolucionaria (1808-1874). Historia de España Alfaguara ${ }_{2}$ vol. V, Madrid, 1879-1883. 
AZCARATE, G., Ensayo sobre la historia del Derecho de Propiedad y su estado actual en Europa, Madrid, 1879-1883.

Estado actual del Derecho de Propiedad en Europa Tomo III, Madrid, 1883.

BADOSA COLL, Ferran. Prólogo a la obra de DEL POZO CARRASCOSA, El sistema de Compensación urbanística, Madrid, 1993.

BAENA DEL ALCAZAR, Administración central y administración institucional en el derecho español, Madrid, 1976.

BALLARIN HERNANDEZ,R. La Hipoteca (Génesis de su estructura y función), Madrid, 1980

BARASSI, L., La propietà nel nouvo Codice Civile, Milano, 1943.

Propietà e compropietà, Milán, 1951.

I diritti reali nel nuovo codice civile, Milán, 1948.

BARBERO, D., Sistema de Derecho Privado, vol. II. Derechos de la personalidad, Derechos de familia, Derechos Reales. Traducción española de SANTIS MELENDO, Buenos Aires, 1967.

BARCELLONA, P., Diritto privato e processo economico, Napoli, 1973.

BARNES VAZQUEZ, J. La propiedad constitucional. El estatuto jurídico del suelo agrario. Madrid, 1988.

Propiedad, Expropiación y Responsabilida. La garantía indemnizatoria en el derecho Europeo y Comparado, Madrid, 1996.

BASSOLS COMA, M., Génesis y evolución del Derecho urbanístico español 18121956, Madrid 1973. 
- "Consideraciones sobre el Derecho a la Vivienda en la Constitución Española de 1978”, en R.D.U. octubre-diciembre, 1983 n. 85.

- "La vivienda como producto finalista de las ordenaciones territorial y urbanística", Ciudad y Territorio, ㄲo 80-2, 1989.

- "La Legislación urbanística de las Comunidades autónomas y el derecho de propiedad", R.D.U. núm. 116, 1990.

BASSOLS COMA, M., y GOMEZ FERRER, R., Las vinculaciones de la propiedad por planes y actos administrativos. Ponencia española al V Congreso Hispano-Italiano de profesores de Derecho Administrativo, Madrid, 1976.

Constitución y sistema económico, Madrid, 1985.

BAUDRY-LACANTINERIE, G., Precis de Droit Civil. Tomo III, 2a . ed. Paris, 1922.

BENAVIDES, "Algunas consideraciones sobre el Registro de la Propiedad y su papel en la política del urbanísmo", RCDI, 1980.

BERCOVITZ RODRIGUEZ-CANO, R.,¿Qué es la propiedad privada?,Barcelona, 1977. Comentarios al Código civil y compilaciones forales, dirigidos por Albaladejo, T. XVI,vol.Iㄴ, Madrid,1980.

- "Las bases de las obligaciones contractuales en el art. 149.1 de la Constitución", en Competencia en materia civil de las Comunidades Autónomas (Ponencias y comunicaciones a las jornadas de Granada, mayo de 1988), Madrid, 1989.

- "Las competencias de las Comunidades Autónomas en materia de Derecho Civil" en Primer congreso de Derecho Civil Vasco: La actualización del Derecho Civil, Oñati, 1983.

BETTI, E., Instituzioni di diritto romano,vol. I., Padova, 1947.

Teoria general del negocio jurídico, Edt. RDP, s.f., Madrid. 
BIONDI, B., Instituzioni di diritto romano, Milano, 1972 (reimpresión de la 4a . ed.). Le servitú prediali nel Diritto romano. Corso de Lezioni, Milano, 1954.

Servitú legali, "Seritti giuridici", vol. IV, Milano, 1965.

Las servidumbres (ed. española con anotaciones de GONZALEZ PORRAS) Madrid, 1978.

BLANCA BLANQUER, M. Derecho urbanístico actual, Tomo II, Madrid, 1993.

BLASCO TOLEDO, "La transferencia de aprovechamiento urbanístico: su aplicación práctica”, RDU, ํㅜ 65, 1979.

BOIX REIG, U., Urbanismo y Derecho, Madrid, 1990.

BONET Y SANCHEZ, L. Código Civil Español, T. II, Barcelona, 1890.

BONFANTE, P., Corso di Diritto Romano, T. II, La Propietà, 1ª parte, Milano, 1966 (reedición).

Las relaciones de vecindad, Traducción española de GARCIA VALDECASAS, A., Madrid, 1932.

Instituciones de Derecho Romano, 2a . ed. Madrid, 1959.

BONILLA ENCINA,J. "Titularidades delimitadas. Delimitaciones en la propiedad urbana", en RCDI, 1971 (julio-agosto).

BOQUERA OLIVER, "La limitación de la propiedad urbanística según la Constitución", en RDU, no 118, 1990.

BORREGO LOPEZ, El sistema de compensación, en Derecho urbanístico local, (dirigido por Boquera), Madrid, 1992. 
BRASSIELLO, U., La Propietà nella sua esenza e nella sua estensione, Milano, 1952. Propietà (Diritto romano), Novisimo Digesto Italiano, XIV, Torino.

BRUSILOVSKY Y FRANCHINI, "Reflexiones sobre el cálculo del aprovechamiento tipo en suelo urbano", RDU, nำ120, 1990.

BUSQUET CUEVAS , La práctica del sistema de compensación, Madrid, 1972.

CALVO SOTELO, J., La doctrina del abuso del derecho como limitación del derecho subjetivo, Madrid, 1917.

CAMY SANCHEZ-CAÑETE, B., Comentarios a la Legislación hipotecaria, Vol. I, Pamplona, 1982.

CAPOGROSSI COLOGNESI, L., La struttura della propietà e la formazione del "iura praediorum" nell'etá repubblicana, Milano, vol. I, 1969, vol. II, 1974.

CARBONIER, J., Droit Civil, Tomo III. Les biens. 9a. ed. Paris, 1978.

CARCELLER FERNANDEZ, A., El derecho y la obligación de edificar, Madrid, 1965.

Ejecución de los Planes de Urbanísmo, Barcelona, 1962.

Instituciones de derecho urbanístico, Madrid, 1992.

- "Costes y cuotas de urbanización y de conservación", RDU, nº 67, 1980.

-_Reparcelación y compensación en la gestión urbanística, Madrid, 1980.

- Teoria y práctica de la reparcelación, Madrid, 1969.

- "El régimen de las entidades urbanísticas colaboradoras, según el reglamento de reparcelaciones", RDU,nํ2, 1967.

CARIOTA-FERRARA, I negozi fiduciari, Padua, 1933.

CARNELUTTI, Sistema de derecho procesal civil, Buenos Aires, 1944. 
CARRASCO PERERA, A., CCJC, núm. 9, 1985, que comenta las S. T.S. 11 de junio15 de septiembre.

- "Ius aedificandi" y Accesión (La construcción en suelo ajeno en el marco de los principios urbanísticos) Madrid, 1986.

CARRETERO PEREZ, A., Comentarios a la Ley de Expropiación forzosa, Madrid, 1966.

- "Naturaleza jurídica de los planes de Urbanismo", Conferencia inaugural del curso de la sección de práctica jurídica del Colegio de abogados deValencia, 1969. Boletín del Colegio № 80.

CARRO MARTINEZ, A., "Los principios de la nueva Ley del Suelo" en Rev. de Estudios de la Vida Local (julio-agosto) 1965.

CASAS-VALLES y MIRALLES-GONZALEZ, "La titularidad fiduciaria de las juntas de compensación: una forma de propiedad colectiva transitoria durante el proceso de urbanización", en, Materiales IV Jornadas de derecho civil Catalá a Tossa, Barcelona, 1988

CASTAN TOBEÑAS, J., Derecho Civil español, común y foral. Tomo II, Derecho de cosas, vol. I, Los derechos reales en general. El dominio. La posesión. 12ª., ed. Madrid, 1982. También vol. II. Los derechos reales restringidos. 13ª. ed., Madrid, 1987.

- "La propiedad y sus problemas actuales", RGLJ,1962.

- Familia y propiedad, Madrid, 1956.

- "Familia y propiedad" ,RGLJ, septiembre de 1955.

CASTAN VAZQUEZ, "Notas para la reforma del título preliminar del Código Civil", en D.J, $1974, \mathrm{n}^{\circ} 4$.

- "El abuso del derecho en el nuevo titulo preliminar del código civil". Estudios sobre la reforma del título preliminar, Madrid, 1977. 
CHARRIN, A., "Extensión del derecho de propiedad", RGLJ, 1916, ㄲo 128.

CHICO ORTIZ,J.M., "El derecho de propiedad ante la nueva legislación urbanística" en R.D.U. no 33, 1973.

- "Comentarios a la RDGRN de 12 de enero de 1984 ", en RCDI, ํo 564, 1984.

- Complemento al Derecho Hipotecario y su legislación, Madrid, 1974.

- Estudios sobre derecho hipotecario, Tomos I y II, Madrid, 1989.

COCA PAYERAS, M., Tanteo y Retracto, función social de la propiedad y competencia autonómica, Bolonia, 1988.

COLINA GAREA, R., La función social de la propiedad privada en la Constitución Española de 1978, Barcelona, 1997.

COLMEIRO, M., Historia de la economía política en España. Tomo II, Madrid, 1863.

CORELLA MONEDERO,J.M. La reparcelación. Su naturaleza jurídica y práctica, Madrid, 1972

- La reparcelación en Derecho Urbanístico Local, Madrid,1992.

CORRAL GIJON,J.M.,La publicidad registral de las situaciones jurídicas urbanísticas, Madrid, 1996.

COSCULLUELA, J.M. "Teoria general de la gestión urbanística”, RDU,no 53, 1977.

COSTE-FLORET, La nature juridique du droit de propiété d'aprés et depuis le Code civil, Paris, 1935.

COSSIO, Lecciones de Derecho Hipotecario, Barcelona, 1945. 
CUENA CASAS, M.,Función del poder de disposición en los sistemas de transmisión onerosa de los derechos reales, Barcelona, 1996.

DE CASTRO Y BRAVO, F., Derecho Civil de España, Tomo I, Parte General, $3^{a}$. ed., Madrid, 1955.

- El negocio jurídico, Madrid, 1985.

- "El negocio fiduciario. Estudio crítico de la teoría del doble efecto", en RCDI, no 53-54, 1966.

DELGADO IRIBARREN, M., y BALLESTEROS, A., Comentarios a la Ley de Reforma del Régimen Urbanístico y Valoraciones del Suelo. Granada, 1990.

- "El sistema de compensación “, XVIII Temas de Derecho Urbanístico, Oviedo, 1980.

DE LOS MOZOS, Derecho Civil español, I, Parte General, vol. 1ํㅡ, Introducción al Derecho civil, Salamanca 1977.

- El derecho de propiedad y la Constitución de 1978, Propiedad, Urbanismo, Derecho comunitario europeo y doctrina de la Dirección General de los Registros y el Notariado, Madrid, 1986.

- "El urbanismo desde la perspectiva del Derecho Privado" en Rev. de Derecho Privado (abril), 1961.

- "Sistema de actuación urbanística", RDU, n111, 1969.

- "Modificaciones del derecho de propiedad por razón de las actuaciones urbanísticas" , ADC, 1980,T.XXXIII.

- El derecho de propiedad: crisis y retorno a la tradición jurídica, Madrid, 1993.

- La obligación real, II, Madrid, 1976.

Estudios sobre derecho de los bienes, Madrid, 1991.

DEL POZO CARRASCOSA, P. El sistema de compensación Urbanística, Madrid, 1993. 
DE MIER VELEZ, J.L EL sistema de compensación, Madrid, 1993.

DEMOLOMBE, Cours de Code Napoleon, Paris, 1845, T. 9.

- Cours de Code de Napoleón, IX. Traité de la distintión des biens. Tomo I, De la propietè. De l'usufruct. De l'usage et de l'habitatión, Paris, 1881.

DE VITA, La propietà nell'esperienza giuridica contemporanea. Analisi comparativa del diritto francese, Milan, 1969.

DIAZ MONTERO, Parcelaciones y reparcelaciones urbanísticas, Madrid, 1967.

DIEZ PICAZO, J.L., "Los límites del derecho de propiedad en la legislación urbanística" en RDU (mayo-junio) 1971.

- Estudios sobre la jurisprudencia civil, vol. II, Madrid, 1969.

- Fundamentos de Derecho civil patrimonial. Tomo II. Introducción. Teoría del contrato. Las relaciones obligatorias, Madrid, 1983 y T.III. Las relaciones juridico-reales.EI registro de la propiedad.La posesión. Madrid, 1995.

- "La autonomía privada y el derecho necesario en la Ley de arrendamientos urbanos", en A.D.C., 1956.

- "Algunas reflexiones sobre el derecho de propiedad privada en la Constitución", en el libro Homenaje al Prf. García de Enterria, Vol.II, Madrid,1991.

- "El abuso de derecho y el fraude de ley en el nuevo titulo preliminar de código civil y el problema de sus reciprocas relaciones", D.J, 197

- "Problemas jurídicos del urbanísmo", RAP. o 43, 1964.

DIEZ PICAZO, L., y GULLON, A., Sistema de Derecho Civil, vol. III, Derecho de cosas y Derecho Inmobiliario, Madrid, 1990 (7 $7^{\text {a }}$ ed.).

- Instituciones de Derecho Civil, vol. II, Madrid, 1978.

- Sistema de Derecho Civil, vol. II, Teoría general del contrato. La relación obligatoria en general. Las relaciones obligatorias en particular, $3^{\mathrm{a}}$. ed., Madrid, 1994. 
DI MAZO, G., Le base romanistiche del Codice Civile, Turin, 1950.

DOMINGO DE MORATO, D.R., El derecho Civil Español, I, Valladolid, 1868 y Madrid, 1877 ( $2^{\mathrm{a}}$. ed.)

D'ORS,A., Derecho Privado Romano, Pamplona,1974.

- Una introducción al estudio del Derecho, Madrid, 1963.

DUGUIT, L., Traite de Droit Constitucional. Tomo III, Paris, 1930.

- Les transformations générales du droit privé depuis le Code Napoleón, Paris, 1912, se cita la trad. esp. de Adolfo y Carlos G. Posada, Argentina, 1975 (Las transformaciones del derecho público y privado).

- Manual de Derecho Constitucional, 2a ${ }^{\text {a }}$ ed., Madrid, 1926.

- Le droit social, Le droit individuel et la transformations de l'Etat, Paris, 1908.

DUSI, Institucioni di Diritto privato, vol. I, $7^{\text {a }}$.ed. Torino, 1977.

EINAUDI, L., “Ordinamiento corporativo e propietà privata”, en Economía, 1935.

ENERIZ OLAECHEA, F.J., "En torno a la sentencia del Tribunal Constitucional sobre el Texto Refundido de la Ley del Suelo" en Actualidad Jurídica Aranzadi, № 289, 10 de abril de 1997.

ESCRIBANO COLLADO, P., La propiedad privada urbana, Madrid, 1979.

- "Función social y propiedad privada urbana", REDA, ํㅜ 6, 1975.

ESCRIBANO, T., “La propiedad y el artículo 348 del Código Civil español”, RDP, 1916.

ESPEJO Y PEREZ DE LA CONCHA, Ejecución de planes de ordenación urbana y proyectos de urbanísmo, Madrid, 1970. 
ESPIN CANOVAS, D., Manual de Derecho civil español, vol. II, Derechos reales, $6^{\text {a }}$. ed., Madrid, 1985 ( $7^{\text {a }}$ ed.).

FAIREN MARTINEZ (En las anotaciones a la obra de OURLIAC, P. y DE MALAFOSSE, J., Derecho romano y francés histórico. Tomo II. Los bienes. Barcelona, 1963.

- "El abuso del derecho", RDN, 1960.

FALCON, M., Derecho civil español, común y foral. 6a. ed., Barcelona, 1901.

Derecho Administrativo, sindicatos y autoadministración, Madrid, 1972.

FENET, P.A., Recueil complet des travaux prèparatoires du Code Civil, Paris, 1927 (reimpresión, 1970), en particular, T. XI, p. 115 a 134.

FERNANDEZ -FIGUEROA GUERRERO, F. “¿Nuevo procedimiento de tramitación y aprobación de los proyectos de compensación?” RDU, № 134, 1993.

FERNANDEZ RODRIGUEZ, T.R., Manual de Derecho Urbanístico, Madrid, 1994 "Reflexiones en torno al principio de igualdad en el ordenamiento urbanístico" en RDU núm. 65, 1979.

FERNANDEZ DEL POZO, "Derecho real de uso y poder de disposición”, RCDI, 1988.

FERNANDEZ DE VILLAVICENCIO, “La facultad de disposición”, en ADC, 1950.

FRESQUET, R. De Principes de l'expropiation por cause d'utilité publique a Rome et à Constantinople jusqu'á l'époque de Justinien. Des limitations apporteés par les lois au droit de propieté tant dans l'interet général que dans l'interet privé. Reune historique du Droit Français, Paris, 1860. 
FUENMAYOR CHAMPIN A., "La propiedad privada y su función social", Estudios de Derecho Civil en homenaje al profesor Serrano, Valladolid, 1965, T. I.

- La revocación de la propiedad, Madrid,1941.

FUENTES LOJO,J. Suma de la propiedad por apartamentos, Barcelona, 1978.

FUENTESECA, C., El negocio fiduciario en la Jurisprudencia del tribunal Supremo, Barcelona, 1997.

FUENTESECA, P., Derecho Privado romano, Madrid, 1978.

FUERTES LOPEZ, M. Urbanismo y publicidad registral, Madrid, 1995.

GALAN, "El bonum conmune y el derecho de propiedad según el pensamiento aquinatense", en RCDI, mayo, 1940, pp. 285 y ss.

GALGANO, F., // diritto privato fra Codice e Costituzione, Bologna, 1978.

- Diritto privato, Padova, 1981.

GALLEGO ANABITARTE, G. "Ideología y progresismo en la legislación hipotecaria del XIX", RCDI, 1986.

- "Plan y presupuesto como problema jurídico en España. En torno al concepto de norma jurídica" .Estudios jurídicos en homenaje al Prof. Federico de Castro, Madrid, 1976.

- Derechos fundamentales y garantías institucionales: Análisis doctrinal y jurisprudencial, Madrid, 1994.

- "Régimen urbanístico de la propiedad del suelo. Valoraciones. Expropiaciones y venta forzosa",RDU, № 134, 1993.

GARCIA BELLIDO Y J.J ENRIQUEZ DE SALAMANCA Y RUSSINES, "Transferencia del aprovechamiento urbanístico. Una nueva técnica para la obtención gratuita de los equipamientos en suelo urbano", en Ciudad y Territorio, №3, 1979.

- "Transferencia del aprovechamiento urbanístico", RDU, oo65. 
GARCIA CANTERO, G., "El Derecho agrario en la nueva Constitución”, en Rivista di Diritto Agrario, 1985.

GARCIA DE ENTERRIA, E., "Potestad expropiatoria y garantía patrimonial en la nueva Ley de Expropiación Forzosa", ADC, 1955.

- "Actuación pública y actuación privada en Derecho urbanístico",en Curso de conferencias sobre propiedad horizontal y urbanizaciones privadas, RCDI, 1987.

- "Dictámenes sobre legalidad de ordenanzas Municipales sobre uso del suelo y edificación” en R. de Administración Pública, n. 50, 1967.

- Los principios de la nueva Ley de Expropiación Forzosa, Madrid, 1956.

- "La Ley del Suelo y el futuro del Urbanismo", A.D.C., 1958

- "Configuración jurídica dela propiedad urbana", Conferencia pronunciada en Jornadas de Derecho urbanístico, Salamanca 1973.

- Naturaleza jurídica de los Planes Urbanísticos, EAL, Madrid, 1966.

- Legislación delegada, potestad reglamentaria y control judicial, Madrid, 1970.

- "El significado de las competencias exclusivas del Estado en el sistema autonómico" en Revista española de Derecho Constitucional, 1982.

GARCIA DE ENTERRIA y PAREJO ALFONSO, Lecciones de Derecho urbanístico, Tomo I, Madrid, 1989.

GARCIA DE GARRORENA MORALES, A. El lugar de la Ley en la Constitución Española, Madrid, 1980.

GARCIA GARCIA, "La reparcelación y la compensación en relación con el Registro de la propiedad", RCDI, ำ 576, 1985.

GARCIA GARRIDO, J.M., Derecho Privado Romano, I. Instituciones, Madrid, 1979. 
GARCIA GOYENA, F., Concordancias, motivos y Comentarios al Código Civil Español, Madrid, 1852.

GARCIA PELAYO, M., Consideraciones sobre las cláusulas económicas de la Constitución. Estudios sobre la Constitución Española de 1978, Zaragoza, 1979.

GARCIA SANCHEZ, A., Teoría de la inmissio, Madrid, 1975.

- Caracteres de las relaciones de vecindad predial en Roma, Madrid, 1975.

GARCIA TREVIJANO, J.A . "Tratado de Derecho Administrativo", RDP, Madrid, 1964.

GARCIA URBANO, J.M., "Crisis estructural del derecho real de hipoteca", en el libro Homenaje a José María Chico Ortiz, Colegio de Registradores de la propiedad y Mercantiles de España, Madrid, 1995.

GARCIA VALDECASA, La posesión, Madrid, 1987.

GARRIDO FALLA, F. El modelo económico en la Constitución Española, vol. I, Madrid, 1984.

- Tratado de Derecho Administrativo, Tomos I y II , Madrid, 1989 y 1992.

GARRIDO FALLA, F. y otros, Comentarios a la Constitución, 2a. ed., Madrid, 1985.

GASCON Y MARIN, J., Las limitaciones del Derecho de propiedad por interés público, Madrid, 1966.

- Comentarios a la Constitución, Madrid, 1985 (2ª . ed).

GAUDEMET, J. Le droit privé romain, Paris, 1974.

GIBERT,R.,La Codificación Civil en España, (1752-1889), La formazione storica del Diritto moderno in Europa, Vol. II, Firenze, 1973. 
GIERKE, O., Die soziale Aufgabe des Privatrecht, Berlin, 1889.

- La función social del derecho privado, Madrid, 1906 (trad. J.M. Navarro de Palencia).

GIORGIANNI, M.," II diritto privato e suoi attuali confini", en Revista Trimestrale di Diritto e Procedura Civile, 1961.

GITRAMA GONZALEZ, M., "Nuevo sentido de la propiedad" en Cuadernos de la Escuela social de Valencia, Valencia, 1960.

- "La corrección del automatismo jurídico mediante las condenas del fraude a la Ley y del abuso del derecho" en Curso Monográfico sobre la Ley de Bases para la modificación del Título Preliminar del C. Civil. Publicaciones del Ilustre Colegio de Abogados de Valencia y de la Academia Valenciana de Jurisprudencia y legislación. Valencia, 1975.

GOMEZ DE LA SERNA,P y MONTALBAN, J.M., Elementos de Derecho Civil y Penal de España, Madrid, 1881.

GOMEZ FERRER MORANT, R., Las zonas verdes y espacios libres como problema jurídico, Madrid, 1971.

GOMEZ ORBANEJA, El ejercicio de los derechos, Madrid, 1975.

GONZALEZ-ALEGRE BERNARDO, M., "Breviario sobre las relaciones de vecindad "en Libro homenaje a Roca Sastre, vol. I, Madrid, 1976.

- Las relaciones de vecindad, Barcelona, 1967.

- Manual de servidumbres $3^{a}$. ed., Barcelona, 1965.

GONZALEZ BERENGUER,J.L. La solución socializadora, única vía posible en la reparcelación y otros estudios sobre urbanismo y vivienda, Madrid, 1967.

- "Esquema del sistema de compensación", RDU, n 61, 1979. 
- "Una aproximación a la técnica del aprovechamiento medio", RDU, № 48, 1976.

- Gestión, financiación y control del urbanísmo, Madrid, 1979.

- Teoria y práctica del planeamiento urbanístico, Madrid, 1975.

GONZALEZ GARCIA, J., La facultad de exclusión del propietario, Granada, 1986.

GONZALEZ MARTINEZ, J., "Las relaciones de vecindad y la prohibición de los actos de emulación" en R.C.D.I., septiembre, 1928.

GONZALEZ PEREZ, J. Comentarios a la Ley de Reforma del Régimen Urbanístico y Valoraciones del Suelo, Madrid, 1991.

- Comentarios a la Ley del Suelo ( Texto Refundido de 1992) Madrid, 1993.

- Informe sobre el Proyecto de Ley del Régimen Urbanístico y Valoraciones del Suelo, Madrid, 1988.

Comentarios a la Ley del Suelo_(Texto de 1976), Madrid, 1988.

Nuevo Régimen del Suelo ( Decreto-Ley 5 / 1996, de 7 de junio), Madrid, 1996.

GONZALEZ RODRIGUEZ, "Nota sobre la fiducia en garantía". Bocetos jurídicos AAMN, III, 1946.

GONZALEZ SALINAS, J.,"Régimen Jurídico de la propiedad del suelo", en Tratado de Derecho Municipal, (dirigido por Muñoz MACHADO) Vol. II,Madrid, 1988.

- "Sistema de Compensación", en XVI temas de Derecho Urbanístico, Oviedo, 1980.

- Sistema de Compensación y terceros adquirentes de suelo, Madrid, 1987.

- "Las plusvalías urbanísticas: sistematización del alcance del art. 47 de la Constitución Española", en Estudios homenaje al Prof. García de Enterría, Madrid,1991. 
GONZALEZ ( Jerónimo), Estudios de Derecho Hipotecario y Derecho Civil, Madrid, 1948 (obras completas), 3 tomos.

GROSSI, P., Le situazioni reali nell'esperienza giuridica medievale, Padova, 1968.

- La propiedad y las propiedades (Un análisis histórico) Madrid 1992.

GUARINO, A., Diritto privato romano, Napoli, 1981 (6a. ed.)

GUILARTE ZAPATERO, Comentarios al Código civil y compilaciones forales, dirigidos por Albaladejo, T. XXIII, Madrid, 1990.

HATTENhAUER, H., Conceptos fundamentales del Derecho Civil, Barcelona, 1987 (trad. esp.).

HERCE VALLEJO, M. "Las compensaciones de aprovechamiento: Riesgos y limitaciones", en Ciudad y Territorio, ํo 3-4, 1983.

HERNANDEZ GIL, A., La función social de la posesión, Madrid, 1983.

- La posesión, Madrid, 1980.

- Dictámenes, Madrid, 1968, T. I.

- "Concepto y naturaleza jurídica de las obligaciones propter rem" en R. D. Priv. (octubre) 1962.

HERRERO GARCIA, M.J.,La Multipropiedad, Madrid, 1989.

HERRERO, S., El Código Civil Español, Valladolid, 1872.

IGLESIAS, J., Derecho Romano. Instituciones de Derecho Privado, Barcelona, 1982 ( $7^{\text {a }}$. ed.). 
IHERING, La posesión, trad.de Posada,2ed., Madrid,1926

IRTI, N., Dal Diritto civile al Diritto agrario, Milano, 1962.

- L'età della decodificazione, Milano, 1979, traduc. esp. de Rojo Ajuria, Barcelona, 1992.

- "Dal diritto civile al diritto agrario", en Revista di Diritto Agrario, 1961.

JORDANO BAREA, El negocio fiduciario, Barcelona, 1959.

- "Sobre negocio fiduciario", ADC, III, 1ํ, 1950.

- "Propiedad fiduciaria y negocio fiduciario", ADC,III, 4ํㅜ 1950.

- "Dictámenes de los bienes trasmitidos fiduciariamente", ADC, XIX, 3ํ, 1966.

KASER, M., "El concepto romano de la propiedad", AAMN, T. XVI, 1968.

- Römisches Recht als bemeinschaftsorduung, Tübingen, 1939.

LACRUZ BERDEJO, J.L., Elementos de Derecho Civil, I, Parte General del Derecho Civil, vol. 1ํ, Introducción, Barcelona, 1987.

- Elementos de Derecho Civil. Tomo III, Derechos Reales, vol. 1. Posesión y Propiedad, Barcelona, 1989.

- Manual de Derecho Civil, Barcelona, 1979

- Nociones de Derecho Civil Patrimonial e introducción al derecho, Barcelona, 1990.

- Elementos de Derecho civil, T.II,vol.I,Barcelona,1985.

LANVERSIN, J., La propiedad ¿una nueva regla de juego?, Madrid, 1976 (trad. esp.)

LASARTE ALVAREZ C., Curso de Derecho civil patrimonial, Madrid, 1990.

- "Propiedad privada e intervencionismo administrativo", en RGLJ (junio), 1975.

- "Génesis y constitucionalización de la función social de la propiedad", en Estudios Deusto (enero-junio), 1977. 
- "Consideraciones previas al estudio del derecho de edificación: pluralismo de la propiedad privada", en el volumen colectivo del $V$ Congreso hispano-italiano de Profesores de Derecho Administrativo, Madrid, 1976.

LASO GAITE, J. Crónica de la Codificación española, T. 4ํ, vol. 1ํㅡ, Codificación civil, I, Madrid, 1970.

- Derecho Urbanístico III. La propiedad ante el Planeamiento urbano, Madrid, 1982.

LASO MARTINEZ, J.L. "La reparcelación como instrumento para corregir situaciones de abuso de Derecho", RAP, № 73, 1974.

- Derecho Urbanístico, vol. III, Madrid, 1982.

LASO MARTINEZ Y LASO BAEZA, El aprovechamiento urbanístico, Madrid, 1995.

LAURENT, F., Príncipes de Droit Civil. Tomo VI. 2ª . ed. Bruxelles, 1878.

LEGUINA VILLA,J., "Las facultades dominicales de la propiedad forestal” en REDA, 1974.

- "Las Comunidades Autónomas" en La Constitución Española de 1978, Madrid, 1984.

LIPARI, I/ negozio fiduciario, 1964.

LLISET BORRELL, F., Nuevo Régimen Urbanístico, Madrid, 1990.

- La Ley del suelo. Comentarios al Texto Refundido de 1992. tomo I, Madrid, 1993.

- La actividad urbanística de los particulares, Madrid, 1975.

- "Naturaleza de las Entidades urbanísticas colaboradoras", REVL, 1975.

- "La fiscalidad de las Juntas de Compensación", RDU, no 53, 1977.

- "Cuotas de urbanización", RDU, № 46, 1976.

El Sistema Urbanístico Español (después de la Ley 6/ 1998), Barcelona , 1998. 
LOBATO GOMEZ, J.M., Propiedad Privada del suelo y Derecho a edificar, Madrid, 1989.

- "La participación privada en la formación de planes de ordenación urbana", RDU, ํo114, 1989.

- "La disgregación de la propiedad inmobiliaria", en el libro de las XV Jornadas sobre el sistema económico en la Constitución Española, Dirección General del Servicio Jurídico del Estado (Ministerio de Justicia) T.I, 1994.

LONGO CARO G., Corso di Diritto Romano. II diritti reali, Padova, 1962.

LOPEZ Y LOPEZ, A.M., La disciplina constitucional de la propiedad privada, Madrid, 1988.

- "La garantía institucional de la herencia", en Revista de Derecho Privado y Constitución,CEC, nº 3, 1994.

LOPEZ PELLICER, J.A. "El coste de la urbanización del suelo correspondiente al 10 por 100 del aprovechamiento medio de cesión obligatoria a la Admón." RDU, n. 96, 1986.

- Elaboración y gestión en el Planeamiento Urbanístico (Intervención de los particulares) Madrid, 1983.

- "Costes y cuotas de urbanización y de conservación", RDU, № 67, 1980.

- "La cesión obligatoria y gratuita de terrenos por razón de urbanísmo", en RDU,no 53, 1977

LUCAS FERNANDEZ, "Naturaleza, fines y principios generales de la legislación urbanística”, nํㅜ, 1980.

MALUQUER DE MOTES, C.J., "La codificación civil en España (síntesis de un proceso)", RDP, 1981. 
- La Fundación como persona jurídica en la Codificación Civil: De vinculación a persona (Estudio de un proceso), Barcelona, 1988.

MANGIAMELI, S., La propietà nella costituzione. Giuffre. Ed. Milano, 1986.

MANRESA, J.M. y NAVARRO,I. Comentarios al Código Civil Español, tomo III. 8 ed. , revisada y puesta al día por RICO PEREZ, Madrid, 1936.

MANZANEDO MATEOS, J.A.,"Las Expropiaciones urbanísticas”, RAP,nº60, 1969.

MARIN PEREZ, P., Derecho civil III, Madrid, 1984.

- Comentarios al Código civil y Compilaciones forales,T.VI, Edersa, Madrid,1980.

MARIN TEJERIZO, "Las cesiones obligatorias en la Ley de Régimen de Suelo", en REVL, nํ88, 1956.

MARTIN BERNAL, J.M., El abuso del derecho, Madrid, 1982.

- "Nuevas consideraciones valorativas en la teoría del abuso del derecho", ADC, 1979.

MARTIN BLANCO, J., El tráfico de bienes inmuebles en la Ley del Suelo. Madrid, 1968.

- Estudios sobre la Ley 8/1990 de Reforma del Régimen Urbanístico, Madrid, 1991.

- "La penetración pública en la propiedad privada", RAP, 1972.

- "El art. 56 de la Ley del Suelo y la recuperación por los propietarios de terrenos del ejercicio de las facultades dominicales", RDP, 1965.

- Las urbanizaciones privadas y su posible configuración jurídica, Ministerio de la Vivienda, Servicio central de publicaciones, 1973.

- La compensación urbanística: Principio y sistema, Madrid, 1985.

- Dictámenes y estudios en derecho urbanístico, Madrid, 1974. 
- El Texto Refundido de la legislación urbanística Estatal. Comentarios, concordancias, derogaciones y vigencias. Madrid, 1994.

- "Legislación urbanística y derecho privado", RDP, 1962.

MARTIN HERNANDEZ, P. "El aprovechamiento tipo como componente de la gestión urbanística en el suelo urbano. La experiencia madrileña”, RDU № 118, 1990.

MARTIN MARCOS JIMENEZ, Parcelaciones y reparcelaciones y el Registro de la propiedad, Madrid, 1976.

MARTIN MATEO, "El estatuto de la propiedad inmobiliaria" en RAP n. 52, 1976.

- "El municipio y la vivienda", Boletín Informativo del Patronato Municipal de la Vivienda, núm. 23.

MARTINEZ LOPEZ MUÑOZ, "Derecho de propiedad y proyecto de Ley de reforma de la Ley del Suelo", en Derecho urbanístico Local. Madrid, 1992.

MEDINA DE LEMUS, M. La propiedad urbana y el aprovechamiento urbanístico. Madrid, 1995.

MELERO ABELLA, J.M. Reglamento de gestión urbanística. Madrid, 1980.

- "La reforma del régimen urbanístico y valoraciones del suelo". Cuadernos de gestión social ํㅜㅅ, 1991.

- "Ejecución del Planeamiento: Actuaciones asistemáticas", Revista Catastro no 17.

MESINA Negozi fiduciario. Introduzione a parte I, Scrittigiuridici, I, 1948.

MESSINEO, F., Manual de Derecho Civil y Comercial. Tomo III. Personalidad, Familia. Derechos reales. Traducción española de SENTIS MELENDO. Buenos Aires, 1971. 
MESTRE, A., "Remarques sur la notion de propiété d'aprés Duguit", Archives de philosophie du droit, 1932.

MONIER, R., Manuel élémentaire de droit romain, Paris, 1947 (6ª ed.) T. I.

MONTES, V.L., La propiedad privada en el sistema del Derecho Civil contemporáneo. Madrid, 1980.

- Comentarios al Código Civil y Compilaciones forales, dirigidos por Albaladejo, Tomo V, vol.I, Edersa, Madrid, 1990, art. 348 y ss.

- Comentario del Código civil, editado por el Ministerio de Justicia, tomo I , art. 348 y ss.Madrid, 1991.

MORIN, G., La révolte du droit contra le Code, Paris, 1954.

- "L’oeuvre de Duguit et le Droit privé", Archives de philosophie du droit, 1932.

MORO ALMARAZ, M.J.," Medio ambiente y función social de la propiedad", En el Libro de las XV Jornadas sobre "El sistema económico en la Constitución Española", Dirección General del Servicio Jurídico del Estado (Ministerio de Justicia), T. I . 1994 .

MOXO, "Concepto unitario de la hipoteca" en RDP, 1940.

MUCIUS SCAEVOLA, Código Civil, IV, Madrid, 1949 (15 a. ed.)

NAVARRO MARTORELL, La propiedad fiduciaria. La fiducia histórica. Los modernos negocios fiduciarios, 1950.

- "Notas sobre la estructura y concepto del negocio fiduciario", RDP, nำ34, 1950.

NIETO, A. "El subsuelo urbanístico", REDA nํ6 ,1990.

NUÑEZ RUIZ, M.A. Derecho Urbanístico Español, Madrid, 1967. 
- Ejecución de los Planes de Urbanísmo, Madrid, 1974.

- "Régimen jurídico de las parcelas inedificables", RDU,no 15, 1969.

O'CALLAGHAN, X., Compendio de Derecho Civil III. Madrid, 1985.

OLIVER, Derecho Inmobiliario Español, Madrid, 1892.

ORTEGA GARCIA, A. Los deberes o cargas en la legislación urbanística. Madrid, 1974.

OURLIAC, P. y MALAFOSSE, J., Derecho Romano y francés histórico, T. II, Los bienes, Barcelona, 1963, (trad. esp.)

PARADA VAZQUEZ, Derecho Administrativo, tomo III, Madrid, 1992.

PAREJO ALFONSO, L., "La ordenación territorial: un reto para el Estado de las Autonomías" en Revista de Estudios de la Vida Local núm. 226

- "La ordenación territorial: un reto para el Estado de las Autonomías", R.D.U. núm. 105, 1987.

- "El urbanismo ante el Derecho", R.D.U. núm. 71, 1981.

- Régimen urbanístico de la propiedad y la responsabilidad patrimonial de la Administración (La alteración del planeamiento, la vinculación singular y la anulación de licencias) Madrid, 1982.

- "La ordenación y la gestión urbanística : Un balance crítico", en Ciudad y territorio, 1984.

- Derecho urbanístico: Instituciones básicas, ed. Ciudad Argentina, 1986.

- Suelo y Urbanismo : El nuevo sistema legal, Madrid, 1992.

- El nuevo sistema legal, Madrid, 1991

Reivindicación del Urbanismo. Liberalización del suelo al servicio del interés general, Madrid, 1997. 
PARTIDAS, Ley 1 , Título XXVIII, Partida $3^{\mathrm{a}}$.

Ley 25․ T. XXXII, Partida III. También Ley $3^{\text {a }}$.

PASQUAU LIAÑO, M., "Sobre la interpretación de los términos Legislación civil del artículo $149.1 .8^{\circ}$ de la Constitución" en Competencia en materia civil de las Comunidades Autónomas, Madrid, 1989.

PEÑA BERNARDO DE QUIROS, M., Derechos reales, Derecho hipotecario. Publicaciones de la Facultad de Derecho de la Universidad Complutense. Madrid, 1982.

PEREZ LUÑO, A.E., Comentarios a las Leyes Políticas dir. por Oscar Alzaga. Constitución española de 1978, III, Valencia, 1980.

PEREZ PASCUAL, E. "Sugerencias a la futura Ley sobre Urbanizaciones privadas", RCDI, no 578, 1987.

PEREZ SERRANO, N., "Constitucionalismo y Codificación" RGLJ, 1953 (núm. extraordinario del centenario).

PERLINGIERI, P., Introduzione alla problemática della propietà, Camerino, 1971.

PESET REIG, M., "Dos ensayos sobre la historia de la propiedad de la tierra", R.D.P., 1982.

- "Acerca de la propiedad en el Code" en RCDI (julio-agosto), 1976.

PLANIOL-RIPERT, Traité élémentaire de Droit Civil, T. II, 11 a.ed., Paris, 1928.

PORTO REY,E. "De la conservación individualizada del patrimonio inmobiliario a su rehabilitación integrada en el planeamiento urbano", RDU, no 109, 1988.

- "Cálculo de los aprovechamientos tipo", RDU, № 120, 1990. 
PUGLIATTI, S., La propietà nel nouvo diritto, Milano, 1954.

- La propietà e le propietà "(con particolare riguardo alla propietá tierriera)", Atti del Terzo Congreso Nazionale di Diritto Agrario. Milano, 1954.

- Fiducia e rappresentanza indiretta . Precizioni in tema di venta a scopo di garanzia, Diritto civile, 1951.

PUIG BRUTAU, J., Fundamentos de Derecho Civil, T. III, T. II, vol. I, Barcelona, 1987 $\left(4^{\mathrm{a}}\right.$. ed.)

PUIG PEÑA, F., Compendio de Derecho Civil. Tomo II. Derechos reales, 2ª. ed., Pamplona, 1973.

REGUERA SEVILLA, J. La legislación urbanística y sus repercusiones en el Derecho civil, Estudios de Derecho privado, Madrid, 1962.

RENARD, G., et TROTABAS, L., La fonction sociale de la propiété privée, Paris, 1930.

RESIGNO, P., "Per un studio sulla propietà", en Rivista de Diritto Civile, 1972.

REY MARTINEZ,F., La propiedad privada en la Constitución Española, Madrid, 1994.

RIVALLAND, J.M. Les charges d'Urbanisme. R. Pichon et Durand, Paris, 1969.

ROCA SASTRE, "La concepción del usufructo como pars domini", R.G.L.J., 1942. Derecho hipotecario, Tomos I, II y IV, Barcelona, 1979.

RODOTA, S., "Note critique in tema di propietà", en Rivista Trimestrale di Diritto e Procedura Civile, 1960.

- El terribile diritto. Studi sulla propietà privata, Bologna, 1990. (hay traducción española de al primera, con prólogo de DIEZ-PICAZO, Madrid, 1986.) 
- "Poteri dei privati e disciplina della propietà" en /l Diritto privatto nella società moderna, Bologna, 1971.

- Voce "propietà", T. XIV (Novissimo digesto italiano),Torino, 1967.

- La definizione della propietà nella codificazione napoleonica, Bologna, 1981.

RODRIGUEZ ARIAS, "El abuso del derecho" RDP, 1971.

RODRIGUEZ ARIAS-BUSTAMANTE, L., "El abuso del derecho en la historia y en la legislación comparada", en Revista Critica de Derecho Inmobiliario (marzo-abril), 1955.

- Derecho de Obligaciones, Madrid, 1965.

RODRIGUEZ, A., Los negocios jurídicos sobre el aprovechamiento urbanístico, Academia Sevillana del Notariado, T.VI,1992.

ROMERO SAURA, La Calificación Urbanística de los predios, Madrid, 1975.

RUBIO LLORENTE, "La Constitución como fuente del derecho" en La Constitución española como fuente del derecho, vol. I, Madrid, 1979.

RUGGIERO, R. Instituciones de Derecho civil , trad de la $4^{\circ}$ ed. italiana, vol. I, Madrid, 1929.

- Historia del liberalismo europeo, Madrid, 1944.

RUIZ DEL CASTILLO, C., "El concepto jurídico social de la propiedad y sus limitaciones" en Revista General de Legislación y Jurisprudencia, 1926.

RUIZ JIMENEZ, La propiedad, sus problemas y su función social, vol. II, Madrid, 1962. 
RUIZ-RICO RUIZ-MORON, J., "Las competencias de la Comunidad Autónoma Andaluza en materia de propiedad urbana", en Competencia en materia civil de las Comunidades Autónomas, Madrid, 1989.

SACCO, R., "Il sistema delle fonti e il diritto di propietà". Studi in onore a F. SantoroPassarelli, Napoli, 1972, T. IV.

SAINZ MORENO, F., "El subsuelo urbano”, RAP, núm. 122, 1991.

- La propietà, Torino, 1968.

SALA, J., Ilustración del Derecho Real de España, Valencia, 1803, T. I .

SANCHEZ CALERO, J., "Competencia de la Comunidad Autónoma andaluza en materia de propiedad" en Competencia en materia civil de las Comunidades Autónomas, Madrid, 1989.

SANCHEZ GONZALEZ, M.P., "Competencias de los Parlamentos autónomos en la elaboración del Derecho civil: Estudio del artículo 149.1.8ํㅜ de la Constitución" en A.D.C., 1986.

SANCHEZ ROMAN, F., Estudios de Derecho Civil, Tomo III. Derechos Reales. El Derecho de propiedad y sus modificaciones. $2^{\mathrm{a}}$. ed., Madrid, 1900.

SANTORO-PASARELLI, F., "Propietà privata e Costituzione", en Rivista Trimestrale di Diritto e Procedura Civile, 1972.

- "Propietà e lavoro in agricoltura", en lustitia, 1953.

- Voce "Propietà”, en Enciclopedia del Novecento V ,Roma, 1980.

SANTOS BRIZ, J., Derecho Civil, Teoría y Práctica. Tomo II, Derecho de cosas, Madrid, 1973. 
SANTOS DIEZ, R. El aprovechamiento medio como instrumento de gestión urbanística, Madrid, 1978.

SANZ JARQUE, J.J., Más allá de la Reforma Agraria, Madrid, 1970.

SASTRE, "El sistema de Compensación". Jornadas sobre urbanísmo y publicidad registral, Valladolid, 1988.

SCHULZ, F., Derecho Romano clásico, Barcelona, 1960 (trad. esp.)

SERRANO ALBERCA,J.M., El derecho de propiedad, la expropiación y valoración del suelo, Pamplona,1995.

SERRANO SERRANO, I. "La obligación de edificar en los planes de urbanísmo",. Conferencia pronunciada en Jornadas de Derecho urbanístico, Salamanca, 1973.

SEGURA GOMIS Reparcelación urbanística (una metodología de actuación), Madrid, 1986.

SIERRA BRAVO, R., La propiedad privada en la doctrina social de la Iglesia, Madrid, 1997.

SIMON SEGURA, F., La desamortización española del siglo XIX. Madrid, 1973.

SOLANS, J.A. "La reparcelación universal. Alegato para un retorno a los orígenes”, en Ciudad y Territorio, $n^{\circ}$ 3, 1974

SOLARI, G., Individualismo e Diritto privato, Torino, 1957.

SORIANO GARCIA, J.E., "Las facultades dominicales en la tercera Ley del Suelo". Estudios sobre la reforma de la Ley del Suelo, Madrid, 1991. 
Desregulación, privatización y Derecho Administrativo, Bolonia, 1993.

La tercera desamortización, Madrid, 1996.

SUAY RINCON, J., "La expropiación por incumplimiento de la nueva Ley del Suelo. Su carácter sancionador y sus consecuencias jurídicas”, RDU, 1991.

SUSTAeTA ELUSTIZA, A. Propiedad y Urbanísmo, Madrid, 1978.

TARELLO, G., La Disciplina costituzionale della propietà. Lezioni introduttive, Genova, 1973.

- La ideología della codificazione nel secolo XIX, Genova, 1971.

- Storia della cultura giuridica moderna, I. Assolutismo e codificazione del diritto, Bologna, 1976.

TOMAS Y VALIENTE, F., El marco político de la desamortización en España, Barcelona, 1977.

- "El marco político de la desamortización de Mendizábal y sus antecedentes", Historia agraria de la España contemporánea. Barcelona, 1985.

TORRALBA SORIANO, V., "EI Derecho civil desde la Codificación hasta el tiempo presente", R.G.L.J., 1975, I.

- Lecciones de derecho civil ,Tomo I, Barcelona, 1984.

TORRES LANA, J.A., La configuración jurídica del volumen de edificabilidad, Pamplona, 1975.

- "La edificabilidad de los terrenos y sus repercusiones en el tráfico jurídico inmobiliario",RCDI,no 506, 1975.

TROTABAS, L., “La fonction sociale de la propiété: le point de vue technique”, en RENARD-TROTABAS, La fonction sociale, de la propiété privée, Paris, 1930. 
UTRERA RAVASSA, C. "La Junta de Compensación : Su naturaleza jurídica y negocio jurídico de constitución", RDN, no 109-110.

VALLet DE GOYTISOLO, J., Panorama de Derecho civil, Barcelona, 1973. "Especulación del suelo, plusvalías urbanas y planificación territorial", en Estudios sobre Derecho de cosas, tomo I, Madrid, 1985.

VALVERDE Y VALVERDE, C.,Tratado de Derecho Civil, Tomo II. Parte especial. Derechos reales. Valladolid, 1936.

VATIER FUENSALIDA, C., "La elasticidad del derecho de propiedad en los planes de mejora ejecutados mediante arrendamiento forzoso en el Derecho Agrario Español", R.C.D.I., 1976.

- "Propiedad privada y Régimen del Suelo", RCDI, no613, 1992.

VILLAR PALASI, "Sobre la personalidad y el acceso al Registro de las Entidades urbanísticas colaboradoras", RDU, № 43, 1975.

VIOLLET, Histoire du droit civil francais, Paris, 1905.

WIEACKER, F., Storia del Diritto privato moderno, Milano, 1980 (trad. it.), vol. I.

- Historia del Derecho privado en la Edad Moderna. Traducción española de Fernández Jardòn, Madrid, 1957.

WEBER.A., "La protección de la propiedad en el Derecho Comparado", REDA, no 72 , 1991.

ZATTI, P., Diritto privato (Diritto civile), Padova, 1983. 